
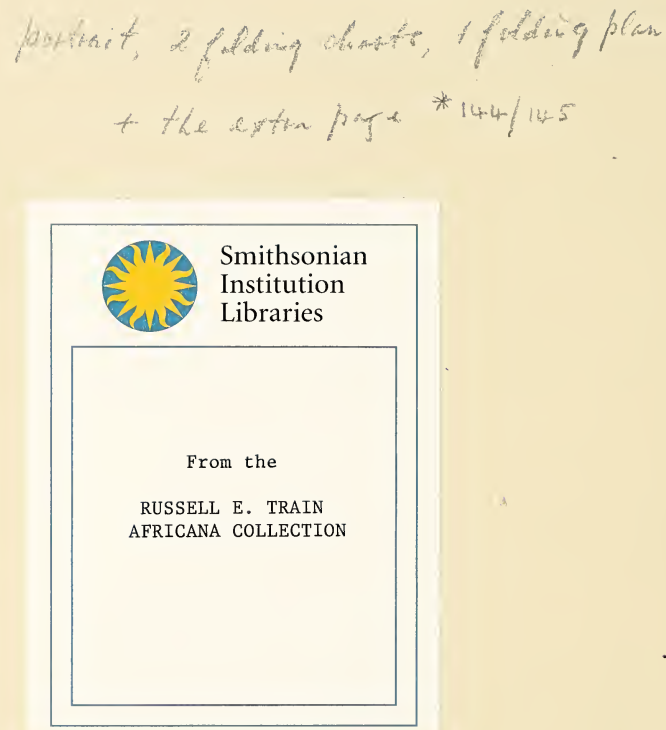





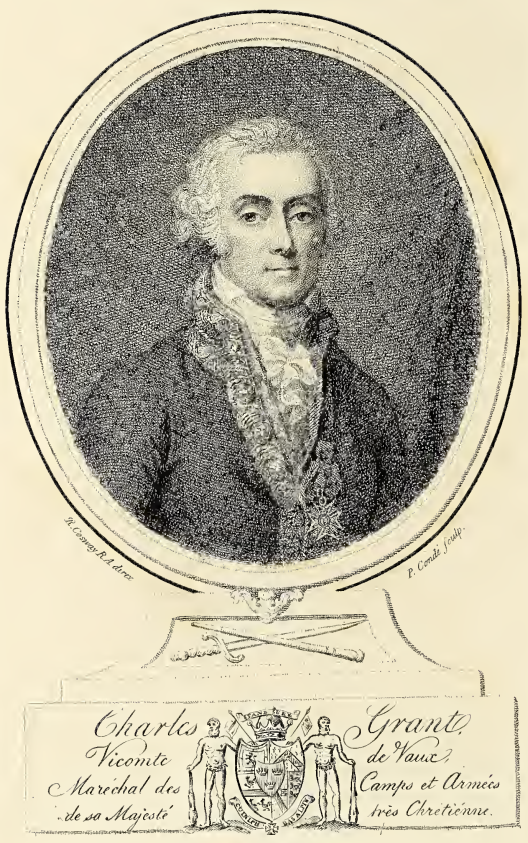


THE

\title{
HISTORY OF MAURITIUS,
}

\author{
OR THE \\ ISLE OF FRANGE, \\ AND \\ THE NEIGHBOURING ISLANDS; \\ FROM.
}

THEIR FIRST DISGOVERY TO THE PRESENT TIME;

COMPOSED PRINCIPALLY FROM THE PAPERS AND MEMOIRS OF

BARON GRANT,

WHO RESIDED TWENTY YEARS IN THE ISLAND,

BY HIS SON, CHARLES GRANT, VISCOUNT DE VAUX.

ILLUSTRATED WITH MAPS FROM THE BEST AUTHORITIES.

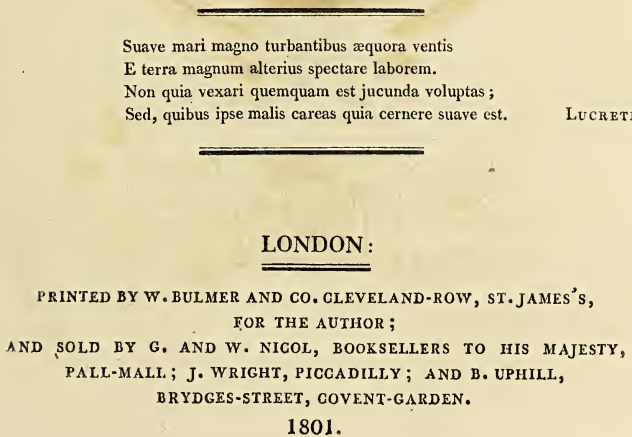




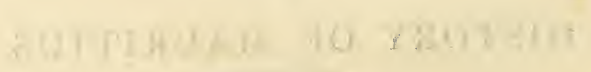

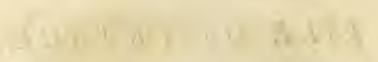

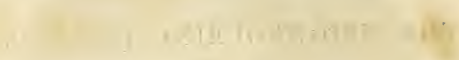

(20)

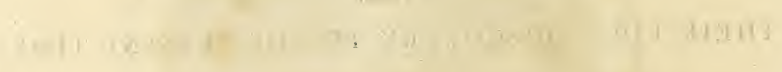

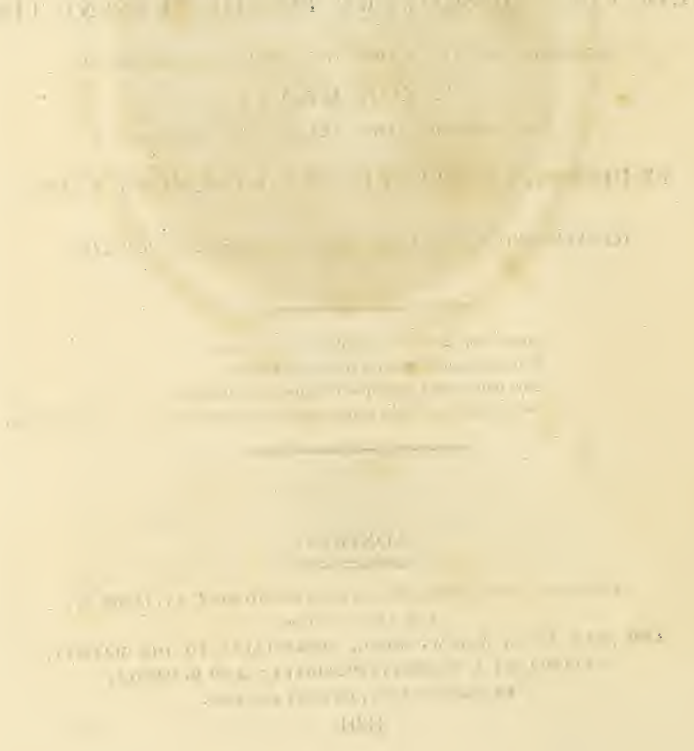




$$
\text { To }
$$

THE RIGHT HONOURABLE

\author{
H E N R Y D U N D S, \\ ONE OF HIS MAJESTY'S PRINCIPAL SECRETARIES OF STATE, \\ PRESIDENT OF THE BOARD OF CONTROL, \\ $d c_{0} d c_{0} b c$. \\ THIS \\ HISTORY OF MAURITIUS,
}

IS MOST RESPECTFULLY DEDICATED,

B Y

HIS MOST OBEDIENT,

HUMBLE SERVANT,

CHARLES GRANT,

Feb. 2, 180x.

Viscount de VAuX。 
$\checkmark$ mะ1. ...

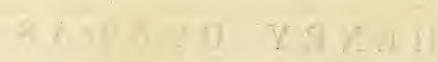

17 :

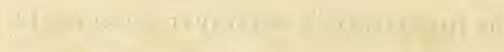

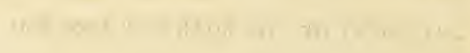

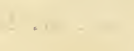

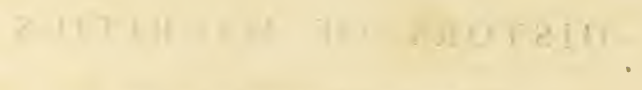

$$
\text { 근 }
$$

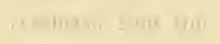

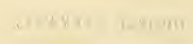

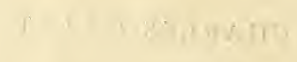

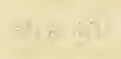




\section{LIST OF SUBSGRIBERS.}

\section{HIS MAJESTY'S LIBRARY.}

Admiralty, the Right Hon. the Lords Commissioners of, 12 copies

Agnew, Vans, Esq.

Allen, Mrs.

Anichkoff, —, Esq.

Arrowsmith, Mr.

Bathurst, Right Hon, the Earl of Bath, Right Hon. Lady

Breadalbane, Right Hon. the Earl of, Bredalbane, Right Hon. the Countess of

Belgrave, Right Hon. Viscount

Banks, Right Hon. Sir Joseph

Bellegarde, Viscount de,

Badenham, Charles, Esq.

Bedford, Gharles, Esq.

Bentinck, Governor

Berkeley, Robert, Esq.

Berkeley, Miss

Berkeley, Miss Jane

Boigne, General de

Bosanquet, Charles, Esq.

Bound, Miss

Bushby, William, Esq.

Cabell, William, Esq.
Cazenove, Charles Theophilus, Esq.

Chalmers, George, Esq.

Christin, F. H. Esq.

Cook, Rev. Thomas

Cosway, Richard, Esq.

Courtenay, Thomas, Esq.

Courtenay, Mrs.

Cox and Greenwood, Messrs. 2 copies

Gumming, George, Esq.

Dundas, Right Hon. Henry, 2 copies

Des Barres, Governor

Dundas, William, Esq.

Dunlop, William, Esq.

East-India Company, the Hon. the Directors, 40 copies

Edwin, Mrs.

Fawkener, William, Esq.

Flint, $\longrightarrow$ Esq.

Forbes, William, Esq.

Forbes, Mrs.

Forsyth, Mr. Isaac

Frazer, James, Esq. 
Glenbervie, Right Hon. Lord

Glynne, Lady

Gebhardt, A. G. Esq.

Gordon, James, Esq.

Grand, George Francis, Esq.

Grant, of Grant, Sir James, Bart. 8 copies

Grant, Lady, 4 copies

Grant, James Thomas, Esq. Patna, 2 copies

Grant, Major

Grant, Sir William, Solicitor-general, 5 copies

Grant, Charles, Esq. India House, 5 copies

Grant, Richard, Esq. 2 copies

Grant, Mrs.

Grant, James, Esq. 2 copies

Grant, Mr. John

Grant, Mr.

Grant, Mr.

Grant, William, Esq.

Grant, Henry, Esq.

Harrington, Sir John, Bart.

Hesketh, Sir Thomas, Bart.

Haldimand, Antony Francis, Esq.

Hawkins, Henry, Esq.

Hawkins, Antony, Esq.

Hollis, Mr. 6 copies

Johnson, Richard, Esq. Johnson, Samuel, Esq.
Jones, John, Esq. 3 copies

Jones, William, Esq.

Jones, Major

Lambert, Anthony, Esq.

Lane, Mr. Minerva Printing Office, 3 copies

Lee, Richard, Esq.

Lee, Richard, William, and E. Messrs. 2 copies

Lee, Mr.

Lennox, William, Esq.

Lewis, Rev. John

Montrose, His Grace the Duke of

Moira, Right Hon. the Earl of

Morton, Right Hon. the Earl of

Mackensie, Golin, Esq.

Meheux, John, Esq.

Menan, Mr.

Manning, William, Esq. M.P.

Morgan, Captain Charles

Morgan, Thomas, Esq.

Morgan, Miss

Neale, J. M. Esq.

Nicholls, John, Esq.

Portland, His Grace the Duke of

Pitt, the Right Hon. William

Pulteney, Sir James, Bart.

Parks, Captain, 2 copies

Paoli, General

Perinelle, Mr. 
Philipps, Mr.J.

Pollock, William, Esq. for his Grace the Duke of Portland's Office, and for himself, 3 copies

Powell, Mr.

Powell, Mr. James

Rivaz, Francis, Esq.

Rivier, Philip, Esq.

Roxburgh, His Grace the Duke of

Rose, George, Esq.

Rutherford, Captain

Spencer, Right Hon. Earl, 2 copies

Southwell, Right Hon. Viscount

Salisbury, Sir Robert, Bart.

Sutton, Sir Richard, Bart.

Salisbury, Mr.J.

Scott, David, Esq.

Shank, Captain
Stanley, Colonel

Symes, Lieut. Golonel

Thomas, Mr.

Thompson, Rev. Dr.

Towers, Gaptain, 8th Light Dragoons

Uphill, Mr. 24 copies.

Vaughan, Mrs.

Winchilsea, the Right Hon, the Earl of

Waddington, Mrs.

Walker, Mr. G.

Waring, John Scott, Esq.

Wheler, Mrs. Edward

Wheler, Rev. John, 2 copies

Williams, Mrs.

Windham, Joseph, Esq.

Wolff, George, Esq. 


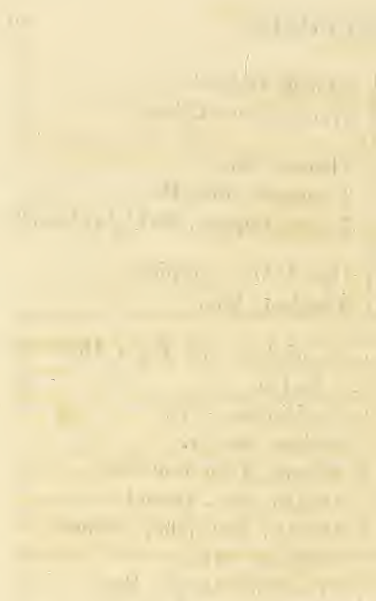




\section{G O N T E N T S.}

\section{GENERAL MAP OF MAURITIUS.}

\section{CHAPTER I.}

Observations on the Harbours of this Island, Page 1.-Exact Dimensions of it, 2, 3 . -Directions for making the Island by the Port Louis, 3, 4.-Directions for making the Island, by an English Navigator, 5.-Observations by Captain John Blake, 5.-Remarks Port Louis, 6.-Letter from Captain John Blake, respecting Port Louis, 7.-PLAN OR MAP OF PORT LOUIS, 8.-Details on the Isle of Tonneliers, and Fort Blanc, 10.-Port Bourbon, 12.-General State of the Air through the Year, 13.On the Climate of Mauritius, by M. le Gentil, 14.-Geographical Positions of the principal Points of the Island, and the Height of the Mountains, 16.-First Settlements in the Island by the Portuguese, 17 ; by the Spaniards, 19 ; by the Dutch, idem; by the French, 27.-List of the Governors of Mauritius, from the taking Possession of the Island by France, in 1715 and 1721 , down to the present Time, 29.

\section{CHAPTER II.}

The Soil, Page 32.-Natural Productions of the Island, 33.-Agriculture, according to M. Poivre, 34.-Trees natural in the Island, 36.-Trees and Plants, \&c. brought from the North Part of Madagascar, by M. Rochon, in the Year 1768 , 32.-Exotic Plants, brought into the Island, according to $\mathrm{M}$. de St. Pierre, 48.-The vegetable and fruciferous Plants, 50.-Garden Flowers, 51.-European Trees, 54.- Foreign ornamental Trees, idem.-FruitTrees, 55.-Marine Productions, -Fish, 57.-Shell-fish, 60-Madrepora, 63. -Ambergris, 64.-Native Animals, 65.-Animals brought into the Island, 69.

\section{CHAPTER III.}

Manners of the Inhabitants, Page 72.-Accounts of the Blacks, 74.-The Theory of the Island, and of its Caverns, 76.-Observations on the Isle of France, by M. le Gentil, R. Academician, concerning the Ground of the Island, of the Mountains, the Rocks, the Coasts, \&c. 12.-Luminous Globes, \&c. 90.-On the Agriculture of the Isle of France and Bourbon, by M. le Gentil, 92.-Iron Mines at Mauritius, 94.-Coffee, 95. -Nutmegs and Cloves, 98. 


\section{CHAPTER IV.}

An Account of the Island of Rodriguez, or Diego-ruis, Page 100.-Its Situation, according to the Admirals Cornish and Kempenfelt, idem.-Extract from the Voyage of le Guat and his Companions, relative to this Island, ro2.-Circumstances of their Arrival there, 103.-Their Establishment in this Island, 105.-Description of Rodriguez, 107.-The different Sorts of Trees of Rodrignez, 1 10.-Animals, 1 14.-Fish, $115 .-$ Birds, particularly the Solitaire, \&c. 117.-Inconveniences, 122.-Occupations and Employments of le Guat and his Companions there, 125.-Preparations for their Departure from Rodriguez, 127.- Their last Adieu to the Island of Rodriguez, 131.-Their Arrival at Mauritius, 133.- Their Residence on the Rock Island near the Coast of Mauritius, 138.Observations of le Guat on Mauritius, 142.-Description of the Bird called Dodo or Dronte, 144 .

\section{CHAPTER V.}

Historical Description of the Isle of Bourbon,-the Origin of its Establishment, Page 146.-An Account of the Governors from the Year 1664, till the present Time, 147 . -Extract of the Voyage of Rennefort in $1665,148 .-$ Voyage of M. de la Haye, in the Year 1670, 8c. 150.-Account of the Isle of Bourbon, from the Discovery of it by the Portuguese, 152.-Extract of the Narrative from M. Du Quesne, respecting this Island in 1690, 153.- Some Accounts of the Isle of Bourbon, by the Abbe Raynal, St. Pierre, Rochon, Poivre, Admiral Kempenfelt, 1'Abbê de la Caille, 155:-Observations on the Isle of Bourbon, by Admiral Kempenfelt, in the Year I $75^{8}$, I 59.-Observations on the Isle of Bourbon in $176_{3}$, by an Officer in the British Navy, $16_{3}$. - By Captain Castleton, of the Pearl, in $161_{3}, \imath_{64}$-Descriptions of the Hurricanes in the Isles of France and Bourbon, I71.-Idem, by M. Rochon, I72.-By M. Brunet, 175-Account of these Hurricanes in the two Islands, taken from the Memoirs of the Academy of Sciences, 1754, 176.-Extract of a Letter from Pondicherry, 1787 , taken from the Journals of the Isles of France and Bourbon, 180.-Account of the Volcano of the Isle of Bourbon, by M. Rochon, idem.-Description of the same, by M. Brunel, r8r.Observations on the Volcanoes of Vesuvius and Etna, to serve as a Comparison, 183.'The Agriculcure of the Isle of Bourbon, by M. Poivre, 186.

\section{CHAPTER VI.}

Letters of Baron Grant, respecting the Isle of France, Letter II. in I74I, containing, first, his Description of the Island, I89.-Secondly, Account of the Life and Operations of M. de la Bourdonnais, Governor of this Island, to the Year 1744, 196.

\section{CHAPTER VII.}

The Letters of Baron Grant continued, Letter III. in the Year 1742, concerning the interior State of the Island, Page 209.-Letter IV. in the Yeàr 1743, same Subject, 2I 2.Letter V. iv $\mathbf{7 4 4}$, same Subject;-Narrative of the Shipwreck of the St. Geran, and 
of Virginia, according to $M$. de St. Pierre, 214.-Letter VI. in the Year 1745 , containing an Account of the Grenville Family, 21 7. - Interesting Circumstances relative to Colonel Grenville, 219.

\section{CHAPTER VIII.}

The Letters of Baron Grant continued, Letter VII. in the Year 1746; containing some Account of the Island, Page 223.-A further Account of the Operations of M. de la Bourdonnais, 225.-Letter from M. Orry, Minister of the Navy, to M. de la Bourdonnais, 228.-Letter of M. de Bourdonnais to the Directors of the East India Company, in the Year 1746, 234.-Important Letter of M. de la Bourdonnais to M. St. Martin, Governor of the Mauritius, per interim, from the Isle Marotte in the Bay of Antongil, at Madagascar, 242.-Letter of M. de la Bourdonnais to M. Dupleix, 249.

CHAPTER IX.

The Account of the Operations of M. de la Bourdonnais continued, Page 253.- He makes the Siege of Madras, 257.-Capitulation of Fort St. George, and the Town of Madras, in the Year $1746,262$.

\section{CHAPTER X.}

Letters of the Baron Grant continued, Letter VIII. in the Year 1748, containing Observations on the Island, Page 282.-Third Epocha of the Operations of M. de la Bourdonnais, to his Death, 282 .

\section{CHAPTER XI.}

Letters of Baron Grant continued, Letter IX. in the Year 1749, containing Accounts of the Animals in the Isle of France, Page 295.-Hunting, 296.-Circumstances respecting theMaroon Negroes, Slaves, \&c. 297.-Arrival of M. David, who succeeded M. de la Bourdonnais as Governor-general, 298. - The Island threatened by Admiral Boscawen, 299.-IIl success of the latter, 300 .

\section{CHAPTER XII.}

Some Account of the Island of Madagascar, from the Observations of Admiral Kempenfelt, Page 301.-Curipus History of a Princess of Russia, at Mauritius, extracted from the Letters X. and XI. of Baron Grant, in the Years $175^{\circ}$ and $175 \mathrm{I}$, and from the Secret Memoirs of M. Duclos, 305 .

\section{CHAPTER XIII.}

Instructions for sailing to India by the Isles of France and Bourbon, Page 309.-An Account of the Winds that prevail in the Eastern Seas, 3r6.-A Memoir on the Archipelago, and the Dangers to which ships are particularly subject, to the North and NorthEast of Madagascar and Mauritius, by M. d'Après de Mannevillette, 318. 


\section{CHAPTER XIV.}

The Course by the East of Madagascar, during the Period that the South-west Monsoon prevails in India, extracted from M. d'Après, with important Surveys on the Coast of Madagascar, St. Marie, \&c. $33^{8}$.

\section{CHAPTER XV.}

The Course, on leaving the Isles of France and Bourbon, to proceed to India during the South-west Monsoon, Page 346.-The Course from the Cape of Good Hope to India, during the South-west Monsoon, passing to the East, and in sight of the Island of Rodriguez, 349.-Vyage to India, during the North-east Monsoon, $35 \mathrm{r}$.

\section{CHAPTER XVI.}

Extracts from the Registers of the Royal Academy of Marine, March, 1775, Page 353.On the Archipelago to the North and North-east of Madagascar, 356.-On the Chart of the Islands and Dangers situate to the North and North-East of Madagascar, between the fourth and eighth Degrees of South Latitude, and sixty-eighth and seventy-fifth of East Longitude, 357.-Introduction to a Chart of the Ethiopian Sea, $36 \mathrm{r}$.

\section{A CHART OF THE ETHIOPIAN ARCHIPELAGO.}

\section{CHAPTER XVII.}

Extract of the Life of M. D'Après de Mannevillette, Page $3^{6} 3$.

\section{CHAPTER XVIII.}

Letter XII. of Baron Grant, in the Year 1753, containing some Details on the Isle of France, 370.-Journal of the Voyage of Abbé de la Caille, from the Cape of Good Hope to the Isle of France; his Journey and first Operations in this Island, 371.-Brief Description of the Isle of France, by the Abbé de la Caille, 377.-Continuation of his Journal, 379 .

\section{CHAPTER XIX.}

Astronomical Observations made on the Isle of France, \&c. \&c. in the year 1753, by the Abbé de la Caille; extracted from the Memoirs of the Royal Academy of Sciences, Page 380.-Astronomical Tables of the Observations and $\mathrm{Calculations}$ respecting the Distances of the Tropics from the Zenith, by the Abbé de la Caille, 383,384 .-Observations on the Variation of the Needle, during the Course of three different Passages, in his Voyages to the Cape of Good Hope, and to the Isles of France and Bourbon, 385-Observations on the Latitude and Longitude, by the same, 386.-Observations of the Longitude of the Island of Madeira, by the Eclipses of Jupiter's Satellites, observed by M. Bory, Lieute- 
nant in the Royal Nayy, compared with those of the Abbe de la Caille, in the Isle of France, by M. de Lille; Extracts of the Memoirs of the Academy of Sciences, anno $1754,3^{87}$.

\section{CHAPTER XX.}

Extract of the Life of M. l'Abbé de la Caille, Page 390.

\section{CHAPTER XXI.}

Extracts from the Observations of M. le Gentil, Royal Academician, respecting the Southern Hemisphere, \&c. in a Series of Letters to M. de la Nux, Royal Academician, at the Isle of Bourbon, Page 398.-On the high Seas, 399.-Sea Birds, 400.-On the Voyage to China, 40r.-Navigation from the Isle of France to Cadiz, 404.- Inclination of the Needle of the Compass in the Indian Sea, 406.

\section{CHAPTER XXII.}

Extracts from the Letters of Baron Grant ; Letter XIII. relative to the Isle of France, Page 410.-Observations on India,-Pondicherry, 411 .

\section{CHAPTER XXIII.}

Extract of the Life of Hyder Aly Khan, \&c. Page 422.

\section{CHAPTER XXIV.}

Extracts from the Correspondence of Baron Grant, during the Years 1755, 1756, 1757, r758, I759;-Letter XI V. Page 440.-Letters XV. and XVI. - and Extract from General Lally's Instructions, given him by the French East India Company, 441.-Remarks on a Memorial of the French East India Company, delivered to the Count d'Aché, Chef d'Escadre, \&c. in the Year 1756, 443-On another Instruction to the Count d'Aché, in 1757,444 .- Instructions given by the Directors of the East India Company to the Governor of Mauritius and Bourbon, 24th of May, $176 \mathrm{r}, 445 .-$ Letters XVII. and XVIII. of the Correspondence of Baron Grant, 447.-Further Extract of the History of India, during the seven Years War, 448.

\section{CHAPTER XXV.}

Summary of the Life of Count de Lally, Page 455.- Journal of Expeditions in India, under the Command of Count de Lally, 456.-Report of the Siege and Conquest of Pondicherry, by the English, in the Year 1760,461 . - Condemnation and Execution of the Count de Lally, 462 . 


\section{CHAPTER XXVI.}

Observations of Admiral Kempenfelt on the Isle of France, in 1758, Page 464:-By M. Rochon, 470 .

\section{CHAPTER XXVII.}

An Account of the Isles and Sand Banks between the Maldive Islands and the Isles of France and Bourbon, by M. Rochon, Page 474.-Description of the Comora Isles, by Spilberg, \&c. $478 \div 48 \mathrm{r}$.

\section{CHAPTER XXVIII.}

Excursion of M. de St. Pierre in the Isle of France, Page 490.-Description of the great Cavern, 492. - Tour round the Island, \&c. 495. - Account of an Hermit, 501.-

- Commerce, Agriculture, and Defence of the Island, ibid.-Observations on the Isle of France, by the Abbé Raynal, 504.-An Account of the Isle of France, by Captain Munro, $5 \mathrm{Ir}$.

\section{CHAPTER XXIX.}

Observations on the Isle of France, by M. de Cossigny, who was Governor of this Island in the Year 1791 , Page 516.

\section{CHAPTER XXX.}

Conclusion of the Author, Page 522.-Abstract of Events that have happened in the Isle of France, up to the Year 1800, 524.-Proclamation of General Malartic, Governor of Mauritius, in January, 1798, 532.-Narrative of the Proceedings of Tippoo Sultaun's Ambassadors, in their Voyage to Mauritius, 535-537.-Circular Copy of a Letter from the Secret Committee of Directors, to the Government in India, November, $1798,547 .-$ Letters from General Bonaparte, at Cairo, to Tippoo Sultaun, in I799, 550.-The Governor-general (Lord Mornington) orders the Army of Coromandel and Malabar to assemble, \&c. 551.-Copy of a Letter from Lieutenant-general George Harris, to the Chairman of the Court of Directors, dated Seringapatam, 6th May, 1799, 553.-Capture of Seringapatam ; Death of Tippoo; Conduct of his Sons; Interment of the Sultaun, \&c. 554.-A Continuation of the late Events, which took place in the Isle of France, until 1800, 559.-Population and Military Force of the Isles of France and Bourbon in $1799,566 .-$ Expence of the Isle of France in 1798 , to be charged to the French Republic, 567.- The present State of Agriculture in the Isle of France, 568.Colonial Commodities which the Isle of France may produce in 1800, 569.-Actual State of the Commodities in 1800,570 .-Remarks on the Isle of France in $1800,57 \mathrm{I}$. 


\section{P R E F A G E.}

I PrEsent an History of the Island which gave me birth, to the Country that affords me protection. I shall only mention the Revolution in France, in order to observe, that the class of its people to which I belong, has had a full share of its miseries. I foresaw them all; and, being invited hither by the elder branch of my family in Scotland, I chose for my abode, the country which possessed a constitution, that I had openly proposed, while such propositions could be made, in my own.

I have endeavoured to alleviate my misfortunes, by literary pursuits; and having long formed the design of composing an History of the Isles of France and Bourbon, from the original materials which I inherited from my father, who had resided in the former of them during a period of twenty years, I have at length accomplished my purpose.

It may be said by some, that it is an indiscretion in me, to unfold the circumstances of these colonies, which have been, and, in some respects, still are, subject to the French Government; but it is not necessary, that this objection should be made to me, for I had long since made it to myself; and such a reflection had already delayed the publication of my work. I had flattered myself with the hope, that a general. peace, founded on the enlarged principles of public justice, would place every one in his former situation: but being at length persuaded, that a termination of the present calamities is distant, or at least uncertain, I no longer delayed my work, which, being purely historical, may be considered as belonging to all governments, and every age. 
In writing the history of a place, which is not without political interests, I had in view principally the advantages of my countrymen, the inhabitants of these colonies. I am well acquainted with the critical situation which they have for some years experienced: agitated by various civil commotions, they could scarcely be said to acknowledge any government; while the decree which abolished slavery, not only kept them in continual alarm for their property, but even for their personal safety; so that they were compelled to fortify their harbours, and prepare for resisting their mother country. Nay, dreading the execution of that decree, they had several times been on the point of applying to the protection of a foreign power. By their courage, prudence, and energy, they not only prevented the fatal effects which would have resulted from the fulfilment of that decree, and repelled the force which had been sent, in the time of Robespierre, to subject them to it, but had also delivered themselves from the armed and seditious banditti, who had threatened, more than once, to drench the island with blood. Under these impressions, I felt an additional motive to accelerate the publication of this work, from the hope I entertain, that the inhabitants of these colonies will thereby be no sooner known, than they will be found to deserve friends, as they have proved themselves superior to the attempts of their enemies.

I shall now proceed to lay before my readers, the plan of my work, and the arrangements which circumstances have obliged me to adopt in the order of it.

The description of the Isle of France is collected from my father's correspondence; the accounts given or communicated to me by my friends, as well as authentic papers which I have been permitted to examine, and the printed works of distinguished writers. I experience a sensible pleasure in unfolding the observations and important operations of those eminent persons who have acted their parts on the seas, 
and in the country whose history has employed my pen; though I cannot but lament; that from the nature of it, I am so limited in my accounts of them.

I have given to my narrative all the regularity which the nature of my materials would allow; and I follow the chronological order of events, without wandering from the geographical path. The subject possesses importance, as well as novelty; but I trust, that higher emotions than those of curiosity, will be gratified by it.

An author must ever feel some disadvantage from being a stranger in the country where he writes; but, from the peculiar circumstances in which I am involved, I am disposed to hope for that indulgence, of which I stand in great need.

The different quotations, will be found to produce occasional repetitions; but I am convinced, that a real advantage will result from it, by the accession of authorities which are produced by it. The history of islands so little known as those of France and Bourbon, may be considered, in a great measure, as places of new discovery; to obtain a knowledge of which, it is necessary to examine the accounts of every navigator who has successively visited them. Besides, each author whom I have cited, gives some specific information of his own, that has not been communicated by others.

As authenticity is the character which I wish, above all others, to attach to my work, I have preferred to let the authors whom I have quoted, speak literally for themselves; so that I ought, perhaps, as it was my first intention, to have given to this volume, the title of Memoirs for an History of the Isle of France, $\mathcal{E}^{2} c$. But it has been suggested by my friends, that the whole contains a sufficient degree of connection and interest to receive the title of an History, and I have submitted, as became me, to their suggestion.

If the historians of all ages had given nothing more than simple 
facts, supported by authentic documents, it would have been better for the world; the most important of all sciences, that of knowing the history of men and nations which have preceded us, would not then have been enveloped in obscurity and contradiction; but the desire - to shine as brilliant writers, a passion for the marvellous, a rage for systems, or prejudice in political and religious opinions, and other similar motives, have frequently rendered it impossible, in many works of great character, to separate truth from falsehood.

The general plan of this volume, which is more detailed in the table of contents, is as follows.

It begins by instructing the voyager in the mode of approaching the harbours of the Isle of France, which is accompanied with a general description of the place, the nature of the air, water, and soil, and the geographical positions. But before I enter upon a detail of these circumstances, and the branches of Natural History, which arise out of them, I give a succinct and chronological account of those persons who have been appointed to the government and superintendance of the Island, from its first colonial establishment, to the present moment.-I then proceed to give a particular history of the animal, vegetable, and mineral kingdoms: some account of the inhabitants, both white and black, succeeds, with their manners and customs; and is followed by a description of the beautiful scenery with which the Island is adorned.

I naturally introduce the reader, in the first place, to the Isle of France, which is the appropriate object of my History; but I suspend its historical narrative, in order to describe the Archipelago, with its various islands, that surrounds it: such as those of Bourbon, Rodriguez, \&c. all of which is so necessary to be known, to facilitate the navigation of those seas. I then return to the Isle of France, to describe its agricultural, maritime, and civil, establishments, as formed by M. de la Bourdonnais. I display all the various operations of that distinguished character, and his successors ; with the astronomical, geographical, and 
maritime observations of the learned professors and eminent navigators, whom my father successively knew during their official visits to the Island.-I then proceed to state and explain the connection of India with the Isle of France, in all its different epochas; which conducts me through a long succession of curious and interesting events, to the death of Tippoo Saib, which rendered England the mistress of Indostan.

Such is the nature of my work: nor shall I endeavour to deprecate criticism, by stating the difficulties with which I have struggled, in bringing this volume into the form which it now bears.-It would indeed, have been less liable to the censure of the critic, if I had written under more auspicious circumstances; and it would have been more deserving the attention of the politician and the philosopher, if I could have had recourse to the books and authentic papers, which are to be found in the libraries and public offices of Paris; but still, I am rather sanguine in the hope of its being generally acknowledged, that I have enlarged the acquaintance of Great Britain, and of the public in general, with a very important part of the Eastern world.

I add the following letter of my father, in order to authenticate his original design of collecting those materials, which form a very considerable part of this History. 
First Letter of the late Baron Grant to bis Fatber, on bis arrival in the Isle of France.

Isle of France, October 15, I740.

"After four months and an balf of a pretty successful voyage, I am at last arrived at the place of my destination. I avail myself of the first ships that sail for France to send you some news of me.

"I have here met with every thing equal to my most sanguine hopes. My uncle, who is in perfect health, received me in the tenderest manner, and shows me all possible kindness. We often speak of you, and you are never out of my thoughts, which, I flatter myself, you will most readily believe. I am never oppressed with sadness but when I think of the distance which divides us, the length of time which this separation may endure, and of the impossibility of receiving intelligence of you as often as I could wish.

" You will see, by my journal, that I had, altogether, an agreeable voyage.

" The description of the Island will follow my journal of the maritime observations of the voyage, * because the first objects which naturally present themselves on our arrival in a country, are those which belong to local situation.

"I shall afterwards begin its history, the events of which I shall place in chronological order, from the epoch of its discovery; and I shall renew my narrative on the arrival of Mr. de la Bourdonnais, of my friend Count 'de Rostaing, and myself, at the island: in short of all those who. have contributed to its settlement, as well as of the Isle of Bourbon.

"In the mean while, until I am better informed, I can assure you

* The journal and maritime observations are not printed in the present work, but may hereafter appear. 
that I am in a country, in every respect, delightful. I already perceive that no one is tormented here by law-suits, as in Normandy and elsewhere, and that whatever is possessed may be enjoyed in tranquillity.

"The climate is charming, and the society is very agreeable: but you must first be acquainted with all that formerly related to this little terrestrial Paradise, before you read what is actually passing in it, or what I may hereafter experience in common with the other inhabitants of it.

(Signed,) "Grant." 



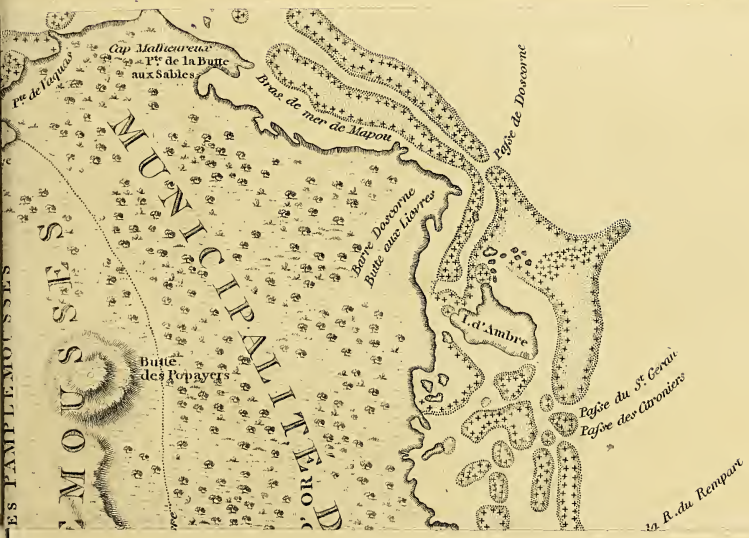






\section{HISTORY OF MAURITIUS.}

\section{CHAPTER I.}

Observations on the Harbours of tbis Island.-Exact Dimensions of it, according to the Geometrical Operations of Monsieur D'Apres, in 1751, and those of the Abbé de la Caille, in 1753.-Directions for making the Island, and sailing into its Harbours, according to the Account of Fobn Black, an Englisb Captain, and otberManuscript Fournals of Mr. Dalrymple and Mr. Parry, Ecc.-Particulars of the Forts of the Isle of Tonneliers, Fort Blanc, छc. whicb defend the Entrance of Port Louis, and the Town.- State of the Air tbrougbout the Year.Geograpbical Positions of the principal Points of the Island, and the Height of the Mountains. - Account of the several Settlements in it by the Portuguese, Dutch, and French.-The Governors, from the taking Possession of the Island by France in 1715 and 1721 , down to the present Time.

$T_{1}$

HERE are two harbours in this island. That to the south-east is called the Grand Port, or Great Harbour; and there the Dutch first established themselves; some vestiges of whose buildings are still visible. It is entered with great ease, with the wind right aft; but it is very difficult to get out by the same passage, as the winds are almost always in the south-east: there is, however, another entrance by which ressels might clear out with a leading wind, if a certain point of this passage, where there are not more than three fathom water, were cleansed and deepened; an operation which is very practicable, and would communicate a free enjoyment of all its other advantages. 
The lesser harbour, called Port Louis, is situated to the north-west, and it may be entered or quitted with a leading wind. It is situated 20 deg. 10 min. south lat. and 55 long. east of Paris. The larger harbour presents itself on arriving from the Cape of Good Hope, or from Europe ; whereas, to get to Port Louis, which is on the other side of the island, the circuit to be made is very considerable, as the current and the winds coming from the east, vessels find it absolutely necessary to bear away at least an hundred leagues, as high as the island of Rodriguez. A more particular description of these harbours will be given hereafter. *

The principal town, or, as it is sometimes called, the Camp, because the Dutch, at first, formed a camp there, is situated at the extremity of Port Louis, and at the opening of a valley which is about three quarters of a league in length, and eight hundred yards in breadth, and is surrounded by mountains, which nature has covered with verdure; but as the grass, in the dry seasons, is oftentimes set on fire by the Maroon negroes, this part of the mountains assumes an arid appearance, which has deceived some navigators into a belief that this island was unproductive and desolate. The circle of mountains which form the valley of Port Louis is broken into various parts : that which rises to the highest degree of elevation, is terminated by an insulated rock, called Le Pouce. This part is also covered with wood, and contains the source of a rivulet which runs through the town.

As to the town, or camp, it is composed of wooden houses, which have only a ground floor, on account of the winds and the heat. They are separated from each other, and surrounded with palisadoes. The streets are tolerably straight, and it were to be wished, that rows of trees were planted to render them cool. The soil about it is slightly sprinkled with rocks. The town has no regular fortification, but to the left of it in looking towards the sea, there is an intrenchment of dry stone, extending from the mountain to the harbour. On the same side is Fort Blanc, which defends the entrance; and opposite to it, on the other side, is a battery on the island of Tonneliers.

According to the measurement of the Abbé de la Caille, Mauritius, or the Isle of France, is ninety thousand, six hundred, and sixty-eight toises in circumference ;

* Port Louis, according to the observations of Mr. D'Apres de Mannevillette, in 1751 , is situated $20 \mathrm{deg} .9 \mathrm{~min} .40 \mathrm{sec}$. south lat. and $55 \mathrm{deg} .7 \mathrm{~min}$. $30 \mathrm{sec}$. longitude east of Paris. Cape Malheureux, which is the northernmost part of the island, is $19 \mathrm{deg} .58 \mathrm{~min}$. latitude, and the southernmost part is zo deg. $3 \mathrm{I} \mathrm{min.} \mathrm{These} \mathrm{observations} \mathrm{agree} \mathrm{with} \mathrm{those} \mathrm{of} \mathrm{the} \mathrm{Abbé} \mathrm{de} \mathrm{la} \mathrm{Caille.}$ 
its largest diameter is thirty-one thousand, eight hundred, and ninety toises from north to south; and twenty-two thousand, one hundred and twenty-four from east to west. Its surface coniains four hundred and thirty-two thousand, six hundred and eighty acres, at the rate of one hundred rods to each acre, and twenty-four feet to each rod. Thus, according to these calculations, the island is not more than thirtyone leagues in circumference, about eleven in length, and seven in breadth. The north-west part is level, and the north-east part entirely covered with mountains, from nine bundred to a thousand and fifty yards in height. The highest and most. remarkable of them is at the mouth of the Black river, and is called Peterbotte. It terminates in the form of an obelisk, crowned with a large square piece of rock, which no one has ever ventured to ascend. At a distance, this natural pyramid and its capital, resembles the statue of a woman.

The island is watered with upwards of sixty rivulets, some of which are destitute of water in the dry season; more particularly since so much wood has been cut down. The interior parts of the island are full of ponds, and are frequently refreshed with rain, the clouds being continually broken by the summits of the mountains, and the woods which cover them: this circumstance is extremely beneficial to the island, and is the cause of its healthiness and fertility.

A particular acquaintance with the harbours is essential to the knowledge of any maritime country. We shall, therefore, offer the instructions for entering Port Louis, which have been partly communicated by Mr. Dalrymple, who, in every thing which relates to the navigation and circumstances of the Indian seas, is superior to any other man.

"Proceeding from the east, the first land you make is a small island, west by south, provided you come by the latitude of $20 \mathrm{deg} .5 \mathrm{~min} .5 \mathrm{sec}$. Soon afterwards, you will see the north-east part of the principal island; then, keeping the same side, bear away boldly to the west, till you have the Isle Longue about three miles to the north-east, when the point you are to make, will be about a mile to the south : leave the latter at a convenient distance to the east; when, after having passed the two first points, direct your course to the body of the island, keeping, however, to the southwest of it, if you have a land breeze, but if the wind blows from the sea, keep more to the west, on account of the waves, which commonly bear towards the land. Then, leaving Fort Blanc to the right, steer into the port towards the south, or rather to the south-east, when you will be off the first buoy, which will be to the left of 
the entrance. Thus advanced, and when the point of the north west of the Island of Tonneliers is to the south east, you will be abreast the second buoy. From thence keep to the south-south-east, till the fort on the point to your right appears to the south-south-west; then proceed south-east by south, till the same fort is seen west by south, and the north-west point of the Isle of Tonneliers due east, and you will then be at the entrance of the harbour. You must then take care to slacken sail, having but a small space to run, and you will cast anchor in a good bottom of black mud, with small sea-weed and young coral, in four fathom water.

"The rest of the course for the entrance of the port is as follows: The fort on the point to the right must bear north-west by west half-west, Fort Bullocks, southwest by west; the first windmill to the right on entering, south-south-west; the second windmill on the little island, south by east; Fort Saint Barbe, south-east by south; the head of Peterbotte, south-east half south; the north-east angle of the wall of the magazines south-east half east ; the south-east point of the Isle of Tonneliers north half east; the redoubt of La Bourdonnois north-west, and the westernmost point of the Isle of Tonneliers, north-north-west.

"The bottom of the harbour, though it has, no great depth, is very level.

"During the time when we were moored in the harbour, which was from the $15^{\text {th }}$ June, ${ }_{175^{2}}$, old stile, to the 20 th of October following, we experienced frequent sea breezes for the space of five or six hours; and I have observed that the wind would remain sometimes in the east or north-west, for two or three days together without changing; and at other times there would be a sea breeze in the course of a fortnight. In such a circumstance, you may wait for a favourable wind to enter, by casting anchor in the Bay des Tortues, * in thirty or thirty-five fathom water, where, as soon as the point to be made, shall be to the north-east - Brows-bay, $1 \frac{x}{2}$ south-south-east, and the northern extremity of the Isle of Tonneliers, at about four miles, south-south-west: the westernmost land in view, south-west by west, you will be ready, on the first favourable breeze, to enter; and, while you, moreover, observe the directions already given, take care to make soundings

- The author of these observations is mistaken respecting the Bay des Tortues; he must mean the Bay du Tombeau, which is near it, and is situated between it and Port Louis. The anchorage is very good in the Bay du Tombeau, being from four to twelve fathom water. The Bay des Tortues has not sufficient depth or breadth. (Note of the autbor.) 
on both sides the vessel, the channel being very narrow at the entrance of the harbour."

On a chart of the harbour on the north-west, and the forts of the island of Mauritius, taken at $20 \mathrm{deg} .10 \mathrm{~min}$. latitude, and $54 \mathrm{deg} .55 \mathrm{~min}$. east longitude, from the meridian of London, the following directions for entering this harbour, were written by an English navigator.

"A fleet, arriving at the island of Mauritius, from Europe, must bear away at first, towards the south-east part, and then double it, so as have the east side well open: then proceed west by north, till you enter the track pursued by the Shrewsbury, a ship belonging to the East India Company, keeping at the distance of about two miles from shore. The Shrewsbury cast anchor in the road, in about eight fathom water; the flag-staff of the town, being south-east by south; and the extremities of the land from south-west by west to the north-east, at the distance of about three miles from the flag-staff. I found by several observations taken in the road, that the variation of the needle is from $15 \mathrm{deg} .17 \mathrm{~min}$. west. The island is situated in the latitude of the south-east trade winds: it is refreshed with frequent sea-breezes, which seldom fail blowing at the new and full moon from south to south-west for three or four days. If at this time a fleet should find itself near the island, it might, I think, safely run down the west side, keeping at a proper distance, as far as the entrance of the road; and without being incommoded with any battery; whereas, by entering on the east side, it would be obliged to pass before a chain of batteries. The pilot informed me, that a chain or boom had been lately fixed, to reach from the Isle des Tonneliers to the point of Fort Royal. On doubling the side of the road, I saw several poles in the water, with white flags arranged or planted on the edge of the shore; but fearing: some deception, I ventured to examine them during the night; but when I approached one of the flags, I found that it was fixed to a buoy, and the rope to which this buoy was tied, kept it floating two feet under the surface of the water, so that the flag seemed fixed in the sand at the bottom. On sounding I found eight fathom water."

The following observations were written on a chart of the island of Mauritius, and signed J. B. supposed to be Captain John Blake.

"The body of the island is situated $20 \mathrm{deg}$. $10 \mathrm{~min}$. south, $20 \mathrm{deg} .20 \mathrm{~min}$. It is about sixty miles in length, and forty-five broad;* is inhabited by the French, and

- Accórding to another copy of the same chart, the Abbé de la Caille determines the length of 
is their general rendezvous for refreshment for their ships, in going to, or coming from India. It is likewise appointed, from its convenient situation, to receive ships of war and privateers, for the purposes of refreshment, or refittal, \&c. as well as in time of war, to intercept or disturb the commerce of other nations to the East Indies. The town and the port in the north-west part of the island, form a magazine for all kinds of maritime stores and provisions, so that it may be considered of the same importance to the French in the East Indies, as Port Mahon is to the English in the Mediterranean; and it may hereafter become a dangerous place for the commerce of other nations engaged in the commerce of the East. It is a fine country, ornamented with trees of all sizes. The western parts, from Port Louis to the savannah, the country is mountainous and rocky, and is inhabited by goats and wild boars in great numbers. From Port Louis, stretching towards the east to the savannah, the country is very beautiful. In the environs of Flac, the country is level and without stones, watered by a great number of small streams.

"Port Louis is situated in about 19 deg. 50 min. south latitude, and is very discoverable from the mountain Peterbotte, towards which you must direct your course south-east by south, and enter the harbour by the Point Relief, bearing towards Peterbotte and the small point below it. It is not necessary to take soundings till you enter the channel, where you will find from forty, thirty, twenty, to nine fathoms water; when you may advance till it is necessary to be towed; and which cannot be avoided, as the winds generally blow from the land, and the channel is too narrow to admit of tacking. When you have once entered the upper part of the harbour, you are secure from the wind and bad weather, and in about four, or four fathom and a half water. You moor with the best bower anchor to east-north-east ; and small bower to the west-south-west, so as to ride between both to the south, south-east, which blow fresh in flurries. You also lay your stream anchor to the north-west, astern, to prevent your ship tending to the sea-breeze, as the harbour is narrow." J.B.

To the foregoing curious and instructive information, we shall add the following remarks.

The length of the channel, on entering Port Louis, from the first small white the island, from $20 \mathrm{deg}$. to $20 \mathrm{deg} .28 \mathrm{~min}$. south; so that the middle would be in $20 \mathrm{deg} .14 \mathrm{~min}$. south. From the observations of the Abbe de la Caille, the island is not of so great an extent as is here represented. 
flags, which have been placed there to mark out the passage, to the extremity of the harbour, is about a mile and three quarters. In the first part of the channel there is about eighty feet water; at one-third the length of it, between Fort Blanc, and the forts of the Isle of Tonneliers, there is forty-eight feet water; and in the remaining third of the channel, within the Isle des Tonneliers, near the bulk for careening vessels, there is sixteen, eighteen, and twenty feet water; and in the harbour, without the mole, before the powder magazine, there is from eight to fourteen feet water.

On the left side of the port, on entering, there is a natural bason called Le Trou Fanfaron. This bason, which is three hundred fathom in length, and sixty wide, is not more than eight or ten feet deep, on account of the earth or land which had been carried into it by the water, and on account of the coral banks which have grown there; but, as we shall state hereafter, according to the observations of M. de Tromelin, M. de Rochon, and others, this bason might be cleared out, and put into a condition to receive a considerable number of vessels, and to afford them the most perfect security, even against the effects of hurricanes.

We shall not enter at present into any further details respecting this harbour. The chart of the island, which forms an important part of this volume, and an account of the different points which will be given hereafter, will afford all the illustrations necessary to this branch of the general subject.

The tides are not very perceptible at this island. Those of the equinox rise three feet; the common tides rise at most but two feet two inches. It is always high water about noon, at the new and full moon. The winds also have a considerable influence on the tides; which are elevated by those of the west and north-west.

The following letter of Captain John Blake, of the ship Halifax, dated off Mauritius, the $19^{\text {th }}$ July, 1753 , respecting Port Louis, and the manner of entering it, forms a natural sequel to those which have preceded.

"It is a very convenient port, in which vessels may refresh and repair at a very small expence, and with the greatest expedition; this place being a magazine of all kinds of materials and provisions which a ship may stand in need of. Good beef costs but two-pence a pound, fish a halfpenny, and venison at the same price. Turtles are in great abundance, and are brought from Rodrigue Island, where, on that account, there is always a detachment of eight men. I mention this circum- 
stance, lest any of our vessels, passing near this island, and perceiving a building and smoke, may imagine that they are persons cast away, and lose their time, as I did, in the endeavour to get them off the island. The vessels which come here (to Mauritius), endeavour to put in there; and although our charts place the rocks that surround it at five leagues distance, it does not exceed more than two miles.

- "On the $2^{\text {th }}$ June, steering west-north-west, I discovered the Island Mauritius; fourteen leagues distant, baving $16 \mathrm{deg} .30 \mathrm{~min}$. west variation; I bore towards the north-east part of the island, until I had passed near the Round Isles, keeping two miles without the coast of the island, until I arrived at a mile's distance from the Coin de Mire. The French Captains told me, that the sides of this rock were so perpendicular, that a ship may approach near enough to admit almost of throwing a biscuit ashore. After I had passed this point, I bore away towards the land, south-west by south, and south-south-west, until I was near a ledge of rocks which run out before the long point, for about two miles from the shore, though they may be approached to at the distance of a mile without danger: I found no bottom with sixty fathom line, at the distance of two miles, after which there is no hazard. The town and the mountain of Peterbotte are then visible; the latter of which is very remarkable, and serves for the point of direction to enter the harbour.

"After having passed the ledge, which has just been mentioned, and keeping close to it, as the wind blows off shore, you may cast anchor in fifteen or twenty fathom water, though the bottom is not very good till you arrive near the port. I mention this circumstance, because if you sail during the night, the currents are so strong, particularly near the island, that they would carry the vessel to the leeward before it was day, and it would be absolutely necessary to bear away to the east, to regain the wind. There is no danger whatever between the ledge and the port : so that you do not get into less than twelve fathom water, you may sail by night as well as by day. Every vessel that arrives here, after having passed the ledge and drawn near the land, must hoist her flag and fire two guns. If in the night, the lantern must be lighted up, when a pilot comes on board, who brings vegetables with him, and steers the ship to the entrance of the port. The port captain then comes on board, with a boat, chains, \&c. to assist the ship in entering the harbour, and to moor it there, which he sees properly done before he quits the vessel. As the channel is very narrow, and the wind is generally contrary, it is frequently necessary to tow vessels 



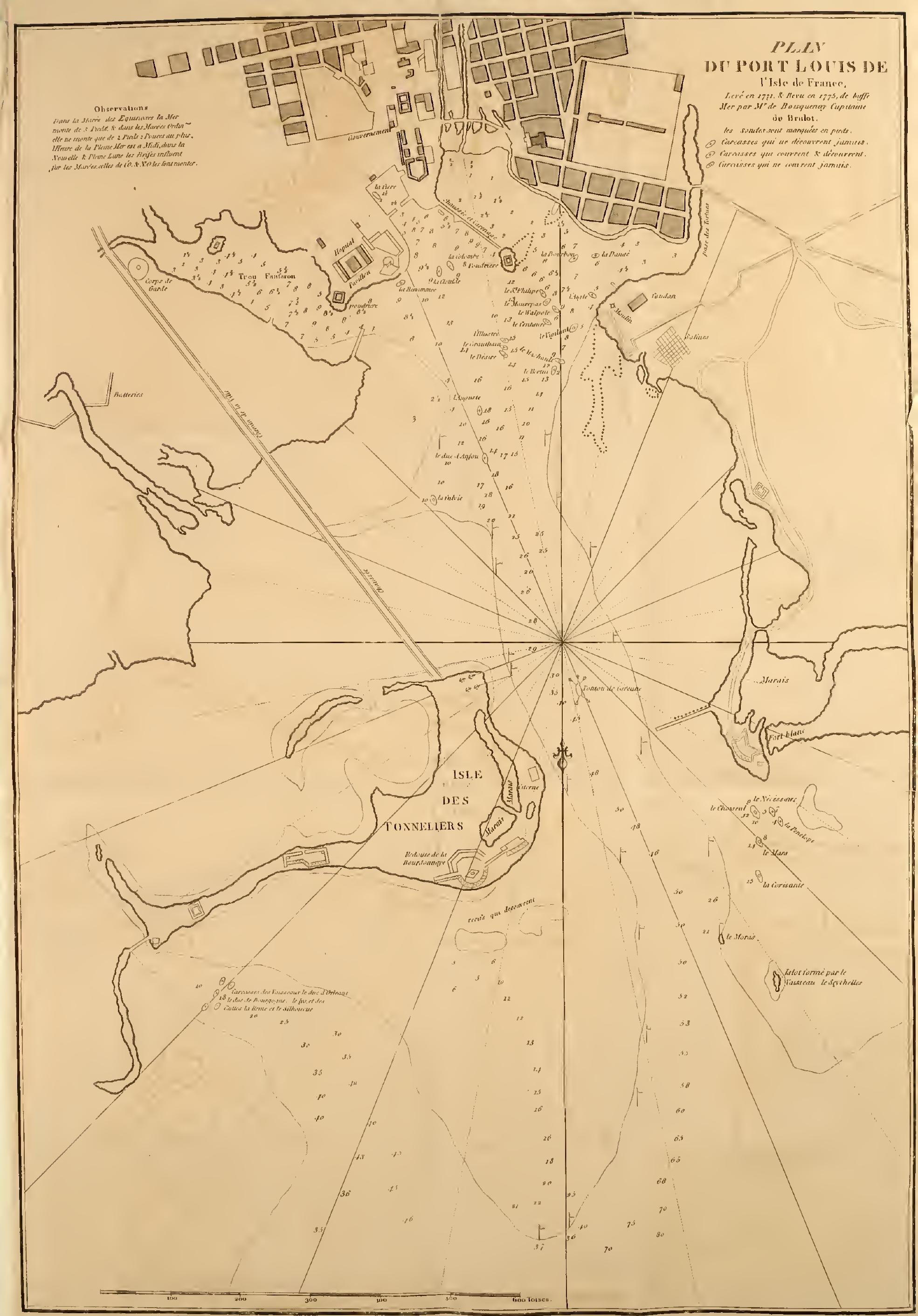



into the harbour, which, by means of long chains, is no difficult operation; and, in the course of the day, the vessel is moored. We had the good fortune to enter straight before the wind; but such a circumstance does not often happen. I must also observe, that, on the summit of a very high mountain, there is a very good light-house, as a guide to vessels that arrive by night, and in the day-time it displays a flag.

"The French always approach Mauritius between the Hanging Rock, which is called le Coin de Mire, and l'isle Longue, passing very near the Hanging Rock to avoid a reef, which stretches out two miles before l'isle Ronde. There is a good channel here, in passing which there is no danger. The French come within sight of land, as we did; they then touch at the Isles, reach the Hanging Rock, pass the reef off Long Point, and follow the same track which has just been described. No one on board my ship had been in this island, and our charts were very defective, making no mention of the passage between the isles; and as I was totally unacquainted with the navigation, I did not think it prudent to run any hazard; but I consider it as the surest and the best passage; although there is some difficulty in passing by the isles, from not discovering the land. But if the Hanging Rock should not be perceived in time to get beyond the reef off Long Point before night, it would be better to bear away to the east until morning, as there is no danger to be feared but which is perceptible. The vessel I command is the first English ship that has visited this island, since it has been in possession of the French; and I was received with the greatest civility."

It is necessary to communicate the following circumstances of the Isle des Tonneliers, at the entrance of Port Louis.

1. The redoubt, called le Bourdonnois, is bomb-proof, and is defended by at least thirty pieces of heavy artillery.

2. It is covered by a battery, which juts on the shore of the island, with a postern and a trench to communicate with it.

3. There is another battery to the left of the redoubt, with a covered way of communication.

4. About three hundred yards to the right, there is another redoubt or battery.

5. About two hundred and fifty yards still further to the right of the last, is another battery. 
6. A small battery at the east point of the Isle des Tonneliers, near a bridge, which communicates with another small and narrow island, at the extremity of which there is also a small redoubt.

7. There are two swamps behind the redoubt.

8. There are two reefs of rocks before the Isle of Tonneliers, towards the north, and facing the redoubt. They are extended to a sand-bank, which stretches out about two-thirds of a mile to the north, when there is about six fathom water, which diminishes on approaching the island.

9. But this bank does not extend itself, in the same manner, on the side of the island which borders on the channel at the entrance of the port, as it contains twenty-five fathom water; so that the largest vessels may pass through it.

10. It is but lately that a kind of causey has been erected to connect the Isle of Tonneliers with Mauritius.

11. There are several windmills round the harbour and the town.

12. In the midst of the channel, or of the port, between the Isle of Tonneliers and the town, a pontoon is fixed with anchors, in three fathom water, for carecning vessels.

Fort Royal, or Fort Blanc, on the point opposite the Isle of Tonneliers, contains thirty-five pieces of large cannon. The fire of this fort crosses that of the Isle of Tonneliers, in order to defend the entrance of the port. The breadth of the channel between the fort and the latter island does not exceed five hundred yards.

Fort Blanc is situated on a kind of island that stretches along the coast, with which it is connected by a bridge or causey, communicating with the narrowest part of a swamp, which separates it from the body of the island. This fort contains several covered batteries, and is flanked by others to the right and left. A mole has also been constructed, which stretches out into the sea, before, and to the right of the harbour.

In the middle space between Fort Blanc and the port or town, on the same side as the channel which forms the entrance, and at about six hundred yards from Fort Blanc, there is a small square fort, containing twelve eighteen-pounders. At the distance of five hundred yards from the latter fort, and near the harbour, begins a line of entrenchments, which stretches out as far as the mountain to the right of the 
entrance into the port, or to the west of the town. On the side of the channel, and before the entrenchments, are some salt-works. Within the entrenchment is the Bason des Tortues.

The extremie part of the harbour, before the great hospital, is defended by another fort, which is distinguished by a flag. It is likewise furnished with heavy artillery. The powder magazine is situate on a small island, which is connected with the shore, by a causey almost opposite the governor's house. This causey serves also for a quay; and it incloses a part of the great basin, where vessels enter to be careened. At the end of this causey, on the left, is a small inner basin for the refittal of vessels, and near it they take in their fresh water with the greatest convenience. Here also is the curious machine invented by M. de la Bourdonnois, by which vessels are lifted out of the water; so that they are cleaned and repaired with the utmost expedition.

The place of arms and the parade is before the governor's house; and behind the large buildings of the hospital is the Fort Sainte Barbe.

Unfortunately Port Louis is choked up in different places by the hulls of several vessels, which have been lost from an ignorance of the navigation, which is now so well known.* Many of these dangerous circumstances, however, no longer exist,

* The number of these hulls amounts to thirty-four. The names of the greatest part of them are still remembered; and their respective situations are marked in the chart of this port by $M$. D'Apres. They have been adopted, after him, by M. de Boisquesnay, officer in the French navy in 1775 , as well as by Mr. Dalrymple in 1793. - The names of these vessels are as follows:
a - La Renommée,
p - L'Illustre,
a a - Le Mars,
b - La Clotilde,
q - Le Grantham,
ab - La Corisante,
c - La Colomb,
$r$ - Le Desir,
d - La Pierre,
s. Le Machault,
a c - Le Moras,
e.- Le Bourbon,
t - Le Bertin,
ad - Les vaisseaux
f - La Danae,
u - L'Auguste,
- - Le Duc d'Orleans,
g - L'Aigle,
$v$ - Le Duc d'Anjou,
- Le Duc de Bourgogne,
h - Le St. Phillipe,
w - La Fulire,
- - et les flutes La Reine,
k - Le Maurepas,
x - Le Choiseuil,
1 - Le Walpole,
y - Le Necessaire,
rn - Le Centaure,
$z$ - La Penelope,
n - Le Vigilant, 
from the changes and settlements that have taken place; as well as from the cessation of the periodical hurricanes in the month of February, which have not happened for the last ten years : a very fortunate change, which has been attributed to the dimi. nution of the wood and the clearing the land.

The port on the south-east of the island, called Port Bourbon, is in 20 deg. $30 \mathrm{~min}$. south latitude. It has two entrances, but that to the west is by far the most commodious, on account of its depth, though it is rather narrow. It is necessary on entering to pass near the small island which is just off the shore; and, having doubled it, you must bear away to the east, to avoid the point of the reef to the west, and cast anchor in the basin in twenty or thirty fathom water. On entering the port you may distinguish the channel by the colour of the water; there being no danger which is not sufficiently apparent. The harbour is protected from bad weather by a reef of rocks, the greater part of which is visible at low water, and contains a small basin, in which vessels of any size may be careened. At the foot of the reef it is four fathom and an half water. It is, however, very difficult to get out of the harbour, from the stationary nature of the winds, which blow into the port, and when they change, are generally variable, with occasional breezes. There is, however, another channel, which, if it were cleared, would afford a practicable passage in all $^{2}$ weather; and were that necessary object accomplished, Port Bourbon would be the best in the island.

The general state of the weather throughout the year is as follows.

January.-Rainy and warm. Storms, which are sometimes accompanied with thunder, though by no means violent; and, as the tempestuous season approaches, all navigation is suspended till the month of April; when the fields become green, and the whole landscape assumes a more cheerful appearance.

February.-Violent gales of wind, and hurricanes, with thunder. These hurricanes, which, till the year 1789 , were constant in this month, have since that time entirely ceased : but the inhabitants hảve not a sufficient dependence on this circumstance, as to be wholly unprepared for them, in case they should return, and renew their former ravages.

March.-The rains are less frequent, the winds always in the south-east, and the heat moderate.

April.-The season is fine, and the grass begins to wither on the mountains. 
May.-Westerly and north-west winds; the season dry, but in the low grounds and the interior parts of the island, the air possesses an agreeable freshness.

June.-The winds are stationary at the south-east, from which point they very seldom vary. The rain falls in small drops.

July.-Wind in the south-east; strong breezes during the day, which subside at night, when it becomes calm. The rain falls in slight dropping showers; and the air is so cool as to require warm clothing. In short, it is now winter, if such an expression may be employed in a country where the trees never lose their leaves.

August. - It rains almost every day. The summits of the mountains are clad in cloudy vapours, which descend into the vallies, accompanied with gales of wind.

September.-The same weather and the same wind. It is now the time of harvest.

October.-The temperature of the air is somewhat warmer; though it is still fresh in the interior parts of the island. At the end of this month the corn is sown, and in four months it is reaped. It is sown again in May, and is ripe in September; so that there are two harvests in the course of the year.

November.-The heat is now very sensibly felt; the winds are variable, and are sometimes in the north-west. The rains are accompanied with storms.

December.-The heats increase. The sun is vertical, but the heat of the air is moderated by the rains, which destroy the rats, grasshoppers, ants, \&c. In short, the winds and rains produce the same beneficial effect, which other climates receive from the cold and frosts of the winter season.

M. le Gentil * gives the following account of the climate of this island, in his Voyage to the Indian Seas.

"There are four seasons in the island of Mauritius. The first begins in May, and is accompanied with south-east winds. At this time the island is subject to squalls and rain. The rains are in general very beneficial to the corn, though they sometimes injure it.

"The second season begins in September or October, at which time the southeast winds are succeeded by those of the north-west. The sun now approaches the zenith of the island, warms the atmosphere, and causes the rains and winds, which generally begin in December, when the third season commences, which extends to 
March. The fourth season then takes its turn, and lasts no more than six weeks. This is the dry season.

"This division of the year more particularly relates to the general cultivation of the island, than to any other circumstance; as, in fact, there are but two seasons, that of the winds from the south-east to south, and that of the winds from north-east to north. The two intermediate seasons are caused by the change in the air, which is a kind of monsoon, blowing from south-east to north-east. The south-east winds are strong and violent, but they are not dangerous to the shipping, as they never exceed a certain degree of force; on the contrary, the winds from the north-east to the north-west are weak and interrupted by calms. This is called the rainy, tempestuous, and hurricane season. It is, indeed, considered as the winter, though it is the hottest period of the year; and receives that denomination because, while it lasts, no ships venture out to sea, and the voyage to the Indies can only be made by a very long and circuitous course.

"The south-east winds give a certain freshness to the air, but while they blow, every thing ceases to vegetate, more particularly in those parts which are exposed to them. Hence it is, that trees and fruit seldom attain any degree of growth or perfection in the district of Pamplemouse, which is almost entirely cleared of its wood. Orange and lemon trees suffer the most from the south-east winds, as they require shelter. Those, indeed, which grow in the woods are flourishing and lofty, while such as inhabit the plain are shrunk or mutilated. This wind is so obnoxious to vegetation, that trees bear no fruit on the side that is exposed to it, while the opposite parts yield a comparative abundance. The tamarind, which possesses a more hardy nature, braves the malignity of the wind, and would therefore form a protecting shelter for the more tender fruit trees, which are planted in gardens; but it is of such a slow growth in this island as to be thought undeserving of any care or cultivation. The Dutch at the Cape of Good Hope shelter their fruit trees from this wind, by intersecting their gardens with thick planted lines or hedges of oak. In fact, there is no prospect of forming such a protection for the fruit trees in this island, but after a long course of years, as the growth of trees there is so very slow. The bamboo has, indeed, been planted for this purpose, but its roots spread to such an extraordinary distance around it, as to be injurious to the very trees it might be intended to protect.

"The nights are generally very fine, particularly in the season of the north-east 
HISTORY OF MAURITIUS.

15

winds. At this period, the sun rises with a serene aspect. At about ten $\odot^{\prime}$ clock small clouds appear, and continue to accumulate without any menacing appearance; they occupy but a small space, while their motion is almost imperceptible. A few drops of water fall from them, a certain sign of the rain which follows; for the sky is almost immediately, and so insensibly overcast, that it is impossible to perceive from whence the clouds have proceeded: at the same time the rain increases in such a manner, as to render it impracticable to see any object at the distance of an hundred yards. These rains continue about two hours, but fall only when the wind sets in from the sea. When these inundating showers cease, vapours arise from the sea, and are stopped by the mountains. On the contrary, during the season of the southeast winds, particularly in the evening, a small rain is seen to fall, though the sky appears without a cloud, and adorned with stars in full lustre. At the extremity of the harbour, rainbows are also produced by the moon; a pornomenton very seldom seen in our part of Europe." 
Table of the Geocraphical Positions of the most remarkable Points in the IsLE OF France, with the Height of its Mountains above the Level of the Sea, according to the Geometrical Operations de L'Aв BE de La CAILLe, made in the Year 1753.

Summit of the Isle of Serpents, called Parasol, or Small Round Isle

Summit of the Great Round Isle

Summit of le Coin de Mire

Point of Cannoniers

East point of the great Isle d'Ambre

Point of Roche

Foot of the flag-staff on the first discovery of the ships

Foot of the flag-staff of the Long Mountain

Front of the new church of Port Louis

Point of Flac

Foot of the flag-staff at the opening of Port Louis

Summit of the mountain called Peterbotte

Summit of the rock called Le Pouce

Point of the entrance of the Small River

Summit of the Piton de la Fayence

Summit of the mountain of the Corps de Garde

Point of the middle of the Isle

The Isle Roche, at water level, at the entrance of E. channel, P. Bourbon

Summit of the mountain Du Rampart

The highest point of the Three Mamelles

Summit of the mountain of Bamboo

Summit of the mountain of the Little Black River

Summit of the mountain of Port Bourbon

Flag-staff of Port Bourbon

Middle of Isle Marie Anne

Middle of the Isle du Passage

Point of the mountain of the Little Black River

Summit of the mountain of the port

Summit of the Morne du Brabant

Summit of the mountain de la Savanne

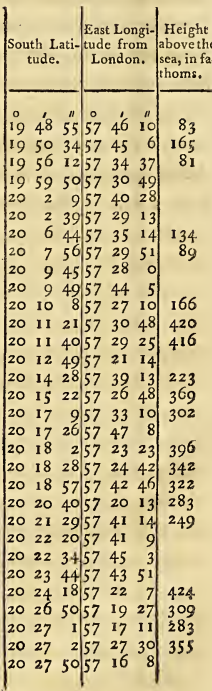

South-east point of the Isle 
To trace the origin of the islands of Mauritius and Bourbon, we shall give a biief sketch of several navigators who co-operated to their establishment.

1. Vasco de Gama, whose first voyage, in the years 1497,1498 , and 1499, was confined to the coast of Malabar, the discowery of Calicut, and the small island of Ankedives, on that coast.

2. After him, Don Emanuel fitted out a fleet of thirteen vessels to the same coast, under the command of Pedro Alvarez Cabral. He set sail in the month of March, in the year 1500. Cabral having stood out too far from the coast of Africa, and towards the west, by chance discovered the Brazils; after which he steered the same course as Vasco de Gama, and arrived on the coast of Malabar.

3. Vasco de Gama performed a second voyage towards this coast, in 1502 . He manifested more courage than humanity, and returned into Portugal, without having made any new discovery.

4. In 1503 , Don Emanuel sent three small squadrons; the first of which, commanded by Antonio de Saldagna, was destined to defend the entrance of the Red Sea : the two others, by Francis and Alphonso Albuquerque, were bound to the coast of Malabar. It was not here, however, that Alphonso first distinguished himself in the Indian seas. The early exploits of this famous man were confined to the Arabian and Persian Gulfs, and the coasts of the sea which separates the Peninsula of India from Africa.

5. In 1504, Alphonso Albuquerque being returned to Portugal, Edward Pacheco courageously sustained the interests of the Portuguese on the coast of India, in the war he had to maintain against the Zamorin of Calicut, in favour of the King of Cochin, their ally. He was well supported by Laurentio Moreno and others. But the discoveries of the Portuguese were not yet extended beyond Cape Comorin, nor across the Indian Ocean.

6. It was but in the year 1505 , that Don Emanuel determined to establish a Viceroy or Governor-general on the coast of India : this post was entrusted to Don Francesco d'Almeida, who held it from that period to the year 1509; when he was succeeded by Alphonso Albuquerque. Almeida never revisited his country, being massacred near the Cape of Good Hope by the Hottentots, on his return to Europe: It was in the first year of the government of Almeida, that the islands of Mauritius, Bourbon, Madagascar, and some others, were discovered.

Don Laurentio d'Almeida, son of the Viceroy; Don Pedro Mascaregnas, 
Tristan d'Acugnha, Diego Fernand Searez, and Ruy Pereira, Ruy Laurentio Ravasco, and others, were the first Portuguese gentlemen who immortalized their names, by the discovery of these islands, and several other important places: in the Indian seas, under the orders of Governor Almeida.

But it was under the great Albuquerque alone, when he was Governor-general of the Indies, in 1509 , that the astonishing discoveries and conquests of this nation were extended in a very surprising and glorious manner, by the valour of those eminent persons who commanded these extraordinary enterprizes. Among them are Francis Pereira Berredo, Sebastian Rodriguez, Fernando de Beja, John Serran, Pelagius Sala, Manuel de la Cerda, Christopher de Britto, Don Garcia de Morogna, Diego Mendez de Vasconcellos, Rabelo, Manuel d'Acugnha, Francis Pantoja, Gonzales Siqueira, and many others whom it is not necessary to mention.

1505. - Ruy Pereira was the first who, in part, discovered the island of Madagascar, and called it St. Laurentio, in the year 1505. - Fernandez Soarez discovered the south and west parts of it. Tristan d'Acugnha was sent there by Albuquerque to examine the coasts of it; and in 1510, John Serran and Pelagius Sala had the same commission.*

Finally, Don Pedro Mascaregnas, one of the first whom I have mentioned, discovered the Isles of France and Bourbon, under the government of Don Francis Almeida, in 1505 ; which important circumstance, being added to his former military exploits, obtained for him the honour of being afterwards named, by his court, Governor of Cochin.

1505.-Mascaregnas gave the name of Cerné to the Isle of France, without doubt, from the appellation of Cerna Etbiopia, which is given by Pliny to the island of Madagascar. But there is no reason to suppose that Pliny, or any of the ancient writers, were acquainted with this island; or that there had been any disco. very of it, previous to that made by the Portuguese, or of the other, now called the Island of Bourbon, and to which Mascaregnas gave his own name. At the same time, it has not appeared, from our inquiries, that the Portuguese made any settlements on either of these islands while they were masters of them,-a period that comprehended almost the whole of the sixteenth century. All they did, on

* I shall not follow the Portuguese throughout the career of their discoveries and conquests, as the history of them will belong rather to another work, which $I$ have already announced, and will form the eighth grand epocha of Navigation, since the origin of the world. 
their discovery of them, was to people them with some animals; with goats, monkies, and pigs.

1580.-In the year $15^{80}$, the Spaniards became masters of these islands: Philip the IId, King of Spain, having usurped the government of Portugal in this year, on the death of Henry of Portugal, became possessed, at the same time, of the Portuguese possessions in the Indian seas. The two islands which bore the names of Cerné and Mascaregnas, during the greater part of this century, had not yet experienced any of those advantages of which they were susceptible, nor were any settlements made on them; as the other conquests and discoveries of the Portuguese were too numerous and considerable to allow any attention to these objects.

These islands suffered the same neglect under the dominion of the Spaniards, which did not exceed a period of eighteen years. But if Portugal was not in a condition to maintain all its possessions, Spain, though a widely extended power, laboured under superior difficulties. She had to preserve, at the same time, her discoveries and conquests in South America, as well as those in the East and West Indies, whilst, in Europe, she could not quell the increasing efforts of her own rebellious subjects in Belgium. The consequences of that rebellion are well known; and Spain, by losing this essential part of her dominions, was forced, in the year 1598 , to abandon to the Belgic insurgents, or the Dutch, the whole commerce of the East Indies.

At this epocha, and even from the death of King Sebastian, Portugal was fallen into a state of confusion which had' brought on its ruin, and was the cause of her. passing, by degrees, under the dominion of Philip the Second. Accordingly, the Portuguese settled in the East Indies, considering themselves as deprived of their mother country, some of them assumed independence, others became pirates, and the rest entered into the service of the country princes, where many of them, from their superiority over the natives, became ministers or generals. They, however, acted without zeal for their general interests, which they sacrificed to their own individual objects; so that their separate enterprizes and conquests at length terminated in three distinct and hostile governments. They therefore lost their power, when the Belgians, or Dutch, actuated by a more humane and tolerating spirit, appeared in India, to dispute with them the empire of it.

The Dutch having revolted from, and maintained a successful war against, their 
King, Philip the Second of Spain, wêre, from subjects, elevated into sovereigns; and their first expedition, commanded by Cornclius Houtman, to the Indian seas, in the year 1595, laid the foundation of that power which they afterwards displayed there in $159^{8}$; a power, which they would have preserved entire, had not some very formidable rivals appeared in the English and French nations. At the latter period they had possessed themselves of the conquests made by the Portuguese, as well as the Spaniards, in the Indian Ocean, and consequently of the islands of Cerné and Mascaregnas. Admiral Van Neck was the first who landed on the Isle of Cerné, in $159^{8}$, when it proved to be uninhabited. He gave it the name of Mauritius.

If even this enterprize, which took place on the return of Houtman, were not connected with the former one, whose disgrace it was formed to repair, and whose pilots it employed, particularly Guzarate Abdul, whom the Dutch had brought from Java with that intention, it would be nevertheless necessary to give an account of it in this place, as it relates to the establishment of the Dutch trade at Bantam.

The importance of this object occasioned the equipment of a more considerable armament than the former. The number of vessels was doubled, and a whole winter was employed in the necessary preparations. On the first of May this fleet set sail from the Texel, under the command of Admiral James Cornelius Van Neck. The names of the vessels have been preserved, and were as follow: the Admiral's ship was called the Mauritius; the second, commanded by Wybrand Van Warwick, whose name has been celebrated from his conduct in subsequent expeditions, was the Amsterdam; and the six others received the denominations of the six provinces of Holland, Zealand; Gueldres, Utrecht, Friesland, and Overyssel. The whole equipage amounted to about $5_{5} 60$ men.

This voyage presents nothing more than the ordinary transactions of maritime life, until the month of September, when, having been separated in a violent storm, off the Cape of Good Hope, frve of them were driven towards the Isle of Madagascar. They doubled the Cape St. Julien, and, on the ${ }_{1} 7$ th, discovered the island, which the Portuguese had denominated the island of Cerné. The Dutch, knowing nothing of it but its name, ordered out two boats to reconnoitre the shore, one of which discovered the south-east port, which is sheltered from the winds, and appeared capable of containing fifty ships, with an excellent bottom. The seamen had broughs on board in the evening several large birds, and a great number of small ones, which 
had suffered themselves to be taken by the hand. They had also discovered a stream of fresh 'water, which flowed from the mountains; and, from their account, the island promised abundance of refreshments. The Vice-Admiral, Van Warwick, however, not knowing as yct that it was uninhabited, and not having time, from the sickly state of his peoplë, to make discoveries, ordered on the 20 th a large party to land, and to take such a station as would secure them from any sudden attack. On several succeeding days he ordered out boats to examine other parts of the island, to discover if it was inhabited. The parties continued to meet with great numbers of birds, who were all so insensible of danger, as not to make the least attempt to avoid the people that took them: they saw also large groves of cocoatrees. They discovered on the shore about three hundred weight of wax, which was impressed with Greek characters; near the same spot they also saw a hanging stage, the spar of a capstan, and a large yard, the remains of some unfortunate vessel which had been buried in the waves. They could not, however, find the least traces of human or quadruped inhabitants.-After having ordered public thanks to be returned to God, for having conducted them to such a fair and secure harbour, the Admiral named the island Mauritius, in honour of the Prince of Orange.

In the accounts of this voyage the following description is given of it.

They represent it as being situated $11 \mathrm{deg} .30 \mathrm{~min}$. south latitude, and that it is about 15 leagues in circumference.* The depth of the sea at the entrance of the harbour is about 100 feet. On every side lofty mountains present themselves to the view, which are clothed with trees of the finest verdure, and whose summits are frequently enveloped with clouds, or dimly seen through floating mists. The soil is stony, but at the same time so entirely covered with wood, that it was impossible to force a passage through it. The wood is in general black, like the finest ebony, or of a very fine red, or a deep yellow, having the appearance of wax. The Dutch took samples of these different woods to Amsterdam, where they were universally admired for their beauty. The palm-trees, of which there were great abundance, afforded to the fleet a very agreeable refreshment; the pith of them resembling in taste the flavour of a turnip. The extraordinary quantity of wood enabled the sailors to build very convenient huts, and the speedy recovery of the sick justified the opinion that the air was salutary. So abundant is the sea in fish, that one drag

* These observations are very erroneous. -The island is situated $20 \mathrm{deg} .10 \mathrm{~min}$. south, and is about 35 marine leagues in circumference; according to L'Abbé de Caille, M. D'Apres, \&cc. \& cc. 
of the net, took half a ton weight of fish. A thornback was taken of such a size as to furnish a ship's company with two meals.-The turtles were of such large dimensions that one of their shells was sufficiently capacious to admit of six men to take their seats in it.

Turtle-doves were in great abundance, and the sailors sometimes caught an hundred and fifty of them in an afternoon. The herons were wild, and when they were pursued, first perched on the trees, and then entirely disappeared. They saw very few geese; but the grey paroquets were innumerable. There was a very extraordinary bird of about the size of a swan, whose head was remarkably large, with a skin hanging from it in the form of a capuchin: three or four black feathers served it for wings; and about the same number, of a greyish colour, and which curled at their termination, composed its tail. Except the breast, every part was so tough, that the Dutch gave it the name of Walg-vogels, or disgusting fowl. Besides, the abundance of turtles made them less anxious about other food.

The Dutch commander ordered a board to be fastened to a tree, on which were sculptured the arms of Holland, Zealand, and Amsterdam, with this inscription in the Portuguese language: Cbristianos reformandos. A piece of ground was also inclosed with stakes of about four hundred fathom in circumference, which was planted and sown with vegetables and seeds, to make an experiment of the soil. Some hens, \&c. were also left there, that vessels which should hereafter stop at this island might find other provisions than the natural produce of it.

At this period the Dutch must be considered as masters of the island of Mauritius; but it does not appear that they ever occupied the island Mascaregnas, because it did not afford them a secure harbour. They had not even in the year 1601 , formed any settlement in the former of them, from the following circumstance, which is the most remote of any we have been able to collect concerning this island, since its discovery by the Portuguese.

On the 12 th of August, 1601, Hermansen determined to put into the island of Mauritius to get water and provisions, which began to fail. He had accordingly dispatched a yacht, called the Young Pigeon, to make díscoveries for that purpose. It was, however, a month before this vessel returned, when it had a Frenchman on board, whom it brought from this island, and who gave the following account of himself.

He had embarked in England some years before, on board a vessel which set 
sail in company with two others, on a voyage to the East Indies. One of these vessels was lost off the Cape of Good Hope; and the crews of the two which remained were so greatly reduced, that it was thought right to burn one of the ships, and to consolidate the two crews on board the survivor. Still, however, they were the prey of continuing sickness, till not a sufficient number of seamen remained to work the vessel, and she went ashore on the coast of Pulo Timon, near Malacca; where all the crew died, except himself, four Englishmen, and two Negroes. These forlorn people, therefore, had got possession of an Indian junk, with the extraordinary design of returning to England. The commencement of their voyage was successful; but the Negroes, alarmed at being so far removed from their own country, had conspired together to get possession of the vessel; their design, however, being discovered, they threw themselves into the sea, from despair, or the fear of that punishment with which they were threatened. After being tossed about by successive storms, they were at length driven to the island of Mauritius: but, unfortunately, at a moment when harmony was essential not only to their comfort, but almost to their existence, these wretched voyagers disagreed among themselves, before they had been eight days on the island. The Frenchman wished to remain there till it should please Heaven to send them relief; while the English insisted on putting out to sea, and determined to continue their voyage. They did not hesitate to execute their design; and the Frenchman was equally detormined: so his comrades hoisted their little sail, and left him to the solitude of this uninhabited spot: there he had passed near two years, sustaining himself with the fruit of the date-tree, and the flesh of turtles. In every thing that related to corporal strength, he was as vigorous as any seaman on board the Dutch ships; but his understanding appeared to have sustained a shock, which appeared very evident when he was pressed with a succession of questions, or when a conversation was continued beyond a certain period. His clothes had, by degrees, fallen from him, and he was found in a state that approached to nakedness.

It appears that in the year 1606 , and since that period, the Dutch sometimes put into this island, but there is no authentic reason to suppose that they really began to form settlements there till the year 1644. According to the information afforded by the voyage of Admiral Matclief, that naval commander put into the island of Mauritius, on the 1 st of January, 1606, where he met Admiral Vander-Nagen, who had a few weeks before set sail from Bantam. At that time the Isle of Mascaregnas had been abandoned by the Dutch. The first navigator who is related to have 
visited it since the foregoing period, was Captain Castleton, who commanded an English vessel named the Pearl: he touched there in the year 1613. It appears, at that time, that this island was uninhabited: though it is difficult to ascertain who were the first settlers of it. It is, indeed, generally believed, and the conjecture is certainly well founded, that they were some of those pirates who are known to have infested the Indian seas during this century.

In the collection of voyages undertaken by the Dutch, there are some which are no less interesting for their sentiments, than the curious circumstances which awakened them. That of William Isbruntsz Bontekoe is among the number; and such was its character for fidelity of narration, that Thevenot enriched his collection with it. This distinguished seaman commanded the ship the New Hoorn, which was sent to the East Indies in 1618 for commercial purposes. He set sail from the Texel on the 28 th of December, and on the $5^{\text {th }}$ of January following encountered a most furious and unrelenting storm, which lasted nineteen days, and it was not till the twentieth day, that the weather was sufficiently moderate to enable the crew to put the ship in a condition to pursue the voyage; in which they were materially assisted by two Dutch ships from Amsterdam, with whom they fell in, at a time when they were in great difficulty from the damages which they had received from the tempest. The New Hoorn was soon separated from them, but fell in again with them off the Cape de Verd Islands, when they agreed to pass the line in company; which they effected, after being becalmed for several weeks. After various dangers, disappointments, and difficulties, with a very sickly and dis-spirited crew, Captain Bontekoe arrived at length off Cape Mascaregnas, in seven fathom water. Although this situation was not altogether safe, from its vicinity to the shore, it was thought proper to anchor there, the sick men being so anxious to land; but in this expectation they were disappointed from the violence of the breakers. The long boat was therefore sent out to examine the island, and returned with a large quantity of turtle-doves, the sight of which inflamed the desire of the sick part of the crew to get on shore, which was afterwards effected, with every possible convenience their commander could afford them. They found plenty of wood-pigeons, which suffered themselves to be taken without attempting to fly away. Turtles were very easily taken; and the sick people, who were forty in number, found plenty of those refreshments which promised to restore them to health and strength.

The anchorage appeared to be so bad, that Bontekoe went in the ship's boat to 
discover a better; and, at about five miles from the ship, he found a bay with a sandy bottom. At a small distance within land he discovered a lake, the water of which had a brackish taste. He saw abundance of geese, pigeons, grey paroquets, and other birds. - He found twenty-five turtle-doves under a single tree, which were so fat that they could scarcely walk. If he caught a paroquet, or any other bird, and hurt it so as to make it cry out, those of its own kind would instantly fly about it, as if to defend it from further injury, and thus suffer themselves to be taken.

Having examined the bay, he sent an account of it to the sick people on shore, who willingly re-embarked, and the ship came to an anchor there in seven fathom water. Detachments of the crew were permitted to go on shore in search of refreshments, while others were employed in fishing the lake, in which they took carp, and a kind of salmon, which was very luscious and of a delicious flavour. They caught a bird which the Dutch called dod-aers; it has very small wings, and is extremely fat. They discovered also a rivulet of fresh water, which flowed from the mountains, and was pleasantly. bordered with trees. On the shore they found a plank, on which was engraved an account that Adrian Martin Blok, who commanded a fleet of thirteen vessels, had, on that spot, lost several boats and the sailors that manned them, on approaching the shore. Bontekoe, however, does not remark that the breakers were dangerous.

As the island was not inhabited, the sailors were free to wander over it, and to amuse themselves with fishing, shooting, or bird catching. They made wooden spits which served to roast the birds, and, by basting them with the oil of turtles, they were rendered delicious food. They discovered a second river, in which plenty of large eels were taken, which were well tasted. They also saw some goats, but those animals were so wild and swift that they caught but one, which was old, and whose horns were half eaten by worms. His flesh was not eatable.

With this abundance of refreshments the greater part of the sick were speedily and perfectly recovered, and but seven of them remained on shore till the departure of the ship, which was furnished with a large store of provisions, the produce of the island, which had been salted and dried. The birds, however, during the excursions of the ship's crew, had been taught all the wildness natural to them in the haunts of men.

Bontekoe took leave of this island with the design of touching at Mauritius, but the ship having fallen too low, they saw it only at a distance to the windward. 
Some of the crew not being yet recovered, and fearing, if the voyage was lengthened to Bantam or Batavia, that the alarming sickness which so many had escaped, might return, the Captain was determined to bear away for the island of Saint Maria, near Madagascar, and facing Antongil Bay. They accordingly arrived on the eastern side of the island in two fathom water. : The islanders, though less used to an intercourse with Europeans than the inhabitants of Madagascar, came on board with fowls, lemons, and a small quantity of rice; and made it understood by signs that they had cows, sheep, and other provisions. They had no other clothing than a small piece of cloth which passed round their middle : their colour was of a blackish yellow. Some of the ship's company went on shore to barter with them; when a small quantity of bells, knives with yellow handles, and glass beads, \&c. were considered as equal to the purchase of their cattle, sheep, hogs, water-melons, \&c. They carried their milk in large leaves laid one within the other, and which were so contrived as to contain it, as well as earthen vessels. Oranges and lemons, which were more peculiarly necessary for preserving the health of the crew, being scarce in this spot, Bontekoe determined to go, in an armed boat, to Madagascar, with such an assortment of articles as would enable him to return with a considerable quantity of the fruit he so much wanted. He accordingly entered a river, but could not proceed further than a league up it, from the over-arching boughs of the trees on either side of it, which hung down to the water. He saw no appearance of fruit or of habitations, and accordingly returned to his ship. On a succeeding day he was more fortunate, by extending his researches in the island before which his vessel lay at anchor. On a more distant part of the coast he found abundance of oranges, lemons, bananas, and rice; so that his crew regained the strength and lealth which they possessed on their departure from Europe. The natives of this island were idolaters, and the heads of bulls, elevated on poles, were the objects of their adoration.-Bontekoe's ship being refitted, he quitted the coast of Madagascar for the Straits of Sunda; but before he reached them, his ship unfortunately took fire and blew up; by which melancholy accident he was blown into the sea; but was taken up by the long boat, which had left the vessel, with a part of the crew; previous to the explosion, who, with their Captain, arrived at the Isle of Sumatra; from thence they obtained a passage to Batavia.

From this period to the year 1712 , when the Dutch evacuated the island of Mauritius, little is. known concerning this settlement, the administration of is 
government, or the different governors who have been sent there. We have been successful only in obtaining the names which follow.

In the year 1648 , Vander-Mester was the Dutch Governor of Mauritius. He is mentioned in a voyage to Madagascar, by the Abbé Rochon, as follows :

"Pronis, who had been commissioned to take possession of Madagascar in the ".name of the King of France, \&c. was a man of inferior talents. He added to his " other malversations, that of selling to Vander-Mester, then Governor of Mauritius, " the unfortunate Malegaches, who were in the service of the settlement; but it ex" cited the islanders to the highest pitch of indignation, when they found that among "these slaves there were sixteen women of the race of Lohariths."

According to Le Guat's account of the islands of Rodriguez and Mauritius, M. La Mocius was Governor of the latter, when he arrived at the former in the year 1690 . And, according to the same author, M. Rudolphe, or Rodolphe Deodaté, a native of Geneva, was Governor of Mauritius, when he was detained prisoner there during the years $1693,1694,1695$, and 1696 ; as will hereafter appear in the subsequent account of the island of Rodriguez.

Before we enter on the History of Mauritius under the French gove rnment, it is necessary for us to recur to the first settlement of that nation in the island of Mascaregnas, or Bourbon; as it was from the latter that the French came to establish themselves in the former.

The first appearance of an establishment at Mascaregnas was, according to the Abbé Rochon, in his work already mentioned, in the year 1657 , when M. de Flacourt, who was the first Director of the infant company of the Indies at Paris, arrived in that island. He mentions that M. de Flacourt was sent to Madagascar in the year 1648 , and consequently in the reign of Louis XIV. to consolidate there, the establishments already begun: but the French under his direction, in the southern part of that great island, having been attacked by the natives of the country, M. de Flacourt went with a part of them to settle in the island of Mascaregnas, in the course of the year $16_{57}$, when he gave it the name of the Isle of Bourbon; and hoisted the standard of France, in the very place where that of Portugal had already been elevated, as he had done at Madagascar.

The history and progress of the settlements formed in the island of Madagascar will have their appropriate place; though we may be previously obliged to mention it from its relative connection with the isles of Mauritius and Bourbon. We 
shall only observe in this place, that the first company which was established in France, with a view to make settlements in Madagascar, was not that which was erected by the famous Colbert, in $166_{4}$, but which served as a kind of superstructure to it.

The account given by M. de Flacourt of the reverses sustained by the French settlement at Madagascar, and the particulars of the establishment he had just formed in the island of Bourbon, with the wreck of that at Madagascar, induced the company to pay attention to the new object; a circumstance which caused the little colony to wear an increasing appearance. Since that period we bave little to communicate concerning this island, but a chronological statement of the governors who have presided over it to the present moment.

The population of the Isle of Bourbon having become considerable in 1712, an opportunity was offered of forming a French settlement on the island of Mauritius, which the Dutch had at this time abandoned. Accordingly a small number of French people landed there at this time, and changed its name to that of the Isle de France. It was not, however, formally taken possession of in the king's name till the year $1721 . *$

- The following account is taken from the Geographical Dictionary of M. de la Martiniere.-

" The Isle of France was called Mauritius by the Dutch, and is marked by that name, not only in all the ancient maps, but in those of M. de L'Isle. In $17^{21}$, the Chevalier Fougeray finding it advantageous for the French East India Company, took possession, fixed a pole in the ground of forty feet in height, decorated with a white flag, and to which was attached the following inscription :

Vivat Ludovicus XV. Rex Galliarum et Navare in xternum vivat.

Hanc ipse insulam suis dictionibus voluit adjungi, illamque jure vindicatam in posterum insulam francicam nuncupari.

In gratiam honoremque tanti principis, istud vexillum niveum extulit Joannes Baptista Garnier de Fougeray, Dux Navis dictx, le Triton ex Urbe San Maclovio oriundus, in minori Britannia, cum ipse huc appulerit, die 23 Septembris, eodem anno, in Galliam navigaturus. Des favente anchoras solirt."

Within a cannon shot of this place he set up a cross, on one side of whose transverse beam was 
The Dutch made their first settlement in this island on the south-east harbour, which is of the greatest extent; but having found it much easier to get out of the north-west port, they abandoned the houses which they had already built near the former, and where their tombs are still visible, to build others at the latter. At this time, the Dutch having possessed themselves of the Cape of Good Hope, and being anxious to put it in a state of defence, they by degrees transported thither all the troops they had at Mauritius; and, as has already been observed, in the year 1712, entirely abandoned it. But though the French maintained a preponderance in both these islands, their inhabitants, for a long time, consisted chiefly of adventurers of all nations, pirates, \&c. many of whom, as the only means of enjoying connubial comforts, had married the Negro women of Madagascar. It was not till the year ${ }_{1730}$, that the government and East India Company of France began to pay a serious attention to it, by sending engineers and other persons, properly qualified to form a regular establishment. But, in fact, the real founder of these two interesting colonies was $\mathrm{M}$. de la Bourdonnais, who was sent here, the first time as Governor-General, in $\mathbf{1} 734$.

Such is the origin of the French possession of these islands; and we shall now proceed to the more regular history of them.

The following chronological series of the Governors of the Isle of France, is extracted from the Journals of the Isles of France and Bourbon, which were printed in the former, in the years $1785,1786,1787$, and 1788 , \&c.

In 1715 , M. du Fresne, Captain in the naval service of the King of France, arrived at the north-west port, and gave the island the name which it now bears, of the Isle of France.

It was M. de Beauvilliers, Governor of the Isle of Bourbon, who sent a party from thence to take possession of the island of Mauritius.

inscribed-" Garnier de Fougeray of St. Malo, C. the Triton;" with the arns of France, and on the other side the following distich:

Lilia fixa crucis capiti mirare sacratæ

Ne stupeas; jubet hic Gallia stare crucem.

Anno 1721.

There appears to be a difference between the commanding officer mentioned in this account, and the person named in the list of governors for the year 1721: but it may be fairly presumed, from the resemblance of their names, that it is a mere nominal error; and that both accounts comprehend one and the same person; which the reader will immediately perceive as he proceeds, 
In $1721, M$. du Rougay began to form a settlement there; and M. de Nyou was named the Governor of it on the 11 th of October in the same year; and he arrived there in January, 1722.

M. Dioré, Lieutenant-Governor of the Isle of Bourbon, commanded in the interim at the Isle of France.

In 1722, a Provincial Council was established there.

On the 28 th of August, 1726, M. Dumar, who resided at Bourbon, was named Governor of both islands.

October 26, 1728, M. de Maupin was named Governor of both islands.

On the 1oth of November, 1734 , M. de la Bourdonnais was named GovernorGeneral of the two islands, and the Superior Council was established on his arrival, in 1735 .

M. de St. Martin commanded there during the expedition of M. de la Bourdonnais to the Indies, till ${ }_{1746}$.

In $1746, M$. David replaced $M$. de la Bourdonnais, at that time employed in an expedition to Madras.

In $175^{\circ}, \mathrm{M}$. de Lozier Bouvet, brother-in-law of M. David, commanded provisionally.

In 1755 , M. Magou, Commander-General of the two islands.

In $1759, \mathrm{M}$. Desforges Boucher, Governor-General.

In August, ${ }_{17} 64$, the administration of the island passed from the hands of the East India Company into those of the King.

July 14,1767 , M. Dumas, Governor of the two islands, and M. Poivre, Commissary-General of the Marine, executed the office of Intendant.

November 27, 1768, M. Steinaver succeeded M. Dumas.

June 6,1769 , the Chevalier des Roches, Governor-General.

August 21, 1772, the Chevalier de Ternay succeeded M. le Chevalier des Roches: and, on the same day, M. Maillard de Merle succeeded M. Poivre.

December 2, 1776, the Chevalier de Guiran la Brillanne was named GovernorGeneral.

November 17, 1777, M. Foucault was Intendant of these islands.

May 1, 1779, M. le Vicomte de Souillac, Governor-General.

July $4,1781, M$. Chevreau, Intendant-General of the two islands.

October 12,1785 , M. Motais de Narbonne, Commissary-General of the two islands. 
November 5,1787 , the Chevalier de Bruny d'Entrecasteaux, Governor-general. He was succeeded by General Conway, in $178 \mathrm{~g}$.

In 1791, M. de Cossigny was Governor, and was succeeded by M. de Chermont.

General Malartic is the present Governor, to which place he was appointed by his most Christian Majesty Louis XVI. in the year $\mathbf{1 7 9 2}$. 


\section{CHAPTER II.}

The Soil, and natural Productions of the Isle of France; Sbrubs, Plants, छீc.Its Agriculture.-Some Account of $M$. Poivre, Intendant of the Island, छsc. -Trees and aquatic Plants._-Trees, Shrubs, Plants, छ̇c. brougbt into the Island from the North Part of Madagascar, in 1768, by M. Rochon.-Herbs, Vegetables, and Flowers, introduced there-various other Sbrubs and Trees brougbt thitber.-Fruit Trees.-Marine Productions._Native and otber Animals of the Isle of France.

$T_{\text {HE }}$ earth is almost universally of a reddish colour, and mixed with ferruginous matter, which often appears on the surface in small orbicular shapes of the size of a pea. In the dry seasons the ground becomes extremely hard, particularly in the environs of the town. It resembles potters' earth, and when cut into trenches it is divided like lead with hatchets. After rain it becomes viscid and tenacious, but it is very fertile when cultivated; and the cultivation does not require extraordinary labour.

There is no real sand; and that which is found on the sea-shore is formed of the madrepore and shells, and calcines by fire. The ground is covered with rocks, from the size of a man's head to that of a large barrel. They are full of holes, at the bottom of which is an opening in the form of a lentil. Many of these rocks are in the shape of kidneys. In some places they appear in large masses; in others they are broken, but in such a manner as if they had suffered a separation, and been reunited. The mountains are formed of them, which, though parallel with one another, present themselves obliquely to the horizon. They are of an iron-gray colour, vitrify in the fire, and contain ferruginous matter; small pieces of very fine copper and lead have been extracted from them. In fragments of these stones are small crystallized cavities, some of which contain a very fine white down. 
The island produces three kinds of grass:-Along the sea-shore there is a thick elastic furf, whose herbage is fine, and the blade, which grows to a sharp point, is sufficiently strong, when dried, to pierce woollen cloth. In the hottest parts of the island the pastures are composed of a kind of dog-grass, ${ }^{*}$ that runs along the ground, and shoots forth small branches from its stems: though it is very tough, the cattle are fond of it in its verdant state. But the best grass grows in the more moist parts, and the windward situations of the island. It produces very large leaves, and is green and tender throughout the year.

The other herbs and shrubs possessed by the Isle of France are as follow :

A plant that yields a kind of pod, filled with a silky substance, of which, it is probable, some manufacturing use might be made.

A species of asparagus, armed with thorns, which shoots up to the height of twelve feet, and attaches itself to trees, in the manner of a bramble; but it does not appear that any attempts have been made to discover its qualities as a vegetable food.

A kind of mallow, with a small leaf, which flourishes most in the court-yards of houses, and by the side of highways.

A plant which bears a resemblance to the lily; is fond of marshy spots, and bears an odoriferous flower.

On walls and by the side of roads a tufted plant is frequently seen, whose flower resembles that of the common red single stock.

At the foot of the mountains near the town is found a vivacious sweet basil, whose odour is like that of the gillyflower. Its stem is ligneous, and an excellent vulnerary.

The Racquette, $t$ which makes a very formidable hedge, bears a yellow flower streaked with red; it is thick set with very sharp thorns, which cover its leaves and fruit. Of the latter, which is acid, no use is made.

The Veloutier grows in the sand on the sea-shore; its branches are covered with a down resembling velvet, its leaves produce a shining hair, and it bears bunches of flowers. At a distance this shrub emits an agreeable smell, which is not perceptible on a nearer approach to it.

There is a kind of plant, half bramble and half shrub, which produces, in bristled pods, a very smooth hard nut, of a grey. pearl-colour, and about the size of a musket ball. Its kernel is very bitter, and the blacks employ it in venereal complaints.

- Gramen caninitm. + Cactus cochenillifer, Linn. 
In those parts of the island which have been cleared, a shrub grows in great abundance whose leaves wear the form of an heart; its smell is grateful like that of balm, whose name it bears. It is employed to medicate baths.

The Fausse Patate runs along the shore, like rope-weed, with red flowers, in the form of bells. It delights in the sand.

In the very borders of the woods, a ligneous plant is found, called the basket plant, and tolerable thread is made from it: its leaves, which are small, when taken in barley water, are remedial for disorders in the breast.

There are a great variety of plants or shrubs comprehended under the name of Lianes, some of which attain the thickness of a man's thigh. They attach themselves to trees, to which they give the appearance of masts trimmed with rigging, while they protect them by their ligatures from the violence of the hurricanes. Nor can a tree, attached by them to the soil, be taken away after it is cut through, till these creepers are separated from it. The ropes made of their bark are stronger than those which are manufactured from hemp.

There are several shrubs whose leaves are like those of box.

There is also a spongy and thorny shrub, which has a large round leaf, and whose tufted flowers are of a deep red. Fishermen employ its stem, which is very light, instead of cork.

There is another very pretty wood, called Bois de Demoiselles: the leaf is indented like the ash leaf, and its branches are covered with sinall red berries.

According to M. Poivre,* who was appointed Intendant of the Isles of France

- M. Poivre was born at Lyons in 1719; and entered at a very early age into the Congregation of foreign Missions, who sent him to China. He travelled through several parts of that empire, and paid particular attention to the agriculture of it. On his return to Europe, the ship in which he was a passenger was attacked by a British ship of war, and, during the engagement, he had the misfortune to lose an arm, that was carried away by a cantion shot. This accident obliged him to renounce the ecclesiastical state : but the East India Company being well acquainted with his. activity and knowledge, selected him for the purpose of establishing a new branch of commerce at Cochin China. Having succeeded in this undertaking, he was appointed, by the Duke de Choiseul, Intendant of the Isles of France and Bourbon, in the year 1766; and in this situation, he fully answered the expectations of the French Minister. He encouraged among the inhabitants a spirit of agriculture, as well as a taste for the arts and other improvements. He sent to Madigasear for a supply of cattle and sheep to stack the island; he naturalized the tree that boars the bread-fruit; and, notwithstanding the many difficulties he had to encounter, succeecled in procuring plants of 
and Bourbon, during the administration of the Duke de Choiseul, in 1766, the Isle of France possesses a fertile soil, with brooks that are never dry in the hottest season, and water the island like a garden: nevertheless the harvest often fails, and the place is always, more or less, in a state of want. Since the government of $M$. de la Bourdonnais, which continued for twelve years, and who must be considered as the founder of the colony, since he introduced agriculture there, the inhabitants have wandered from project to project, and endeavoured to cultivate every kind of plant, but without persevering to secure success. Coffee, cotton, indigo, sugar canes, the pepper plant, the cinnamon tree, the tea plant, the mulberry tree, the cocoa, and the roucou,* have been cultivated in their turns, but without that knowledge and attention which is necessary to establish experiment. If they had followed the simple plan of their founder, which was, in the first instance, to secure a plentiful supply of bread, the island would, at this time, have been in a very flourishing state, abundance would have reigned, and the vessels which touched there would have found plenty of provisions and refreshments. The cultivation of corn, however, though neglected and ill understood, succeeds the best; and the land which is employed in tillage bears, in the same year, a crop of corn, and another of rice or

the nutmeg and cinnamon trees, which he flattered himself would hereafter furnish France with a very valuable article of commerce.-M. Poivre, after having exerted himself to the utmost, for the advantage of this settlement, returned to France, and died at Lyons, the place of his nativity, on the 6th of January, 1786 . The works which he published are sufficient to prove that he was a man of sound judgment and philosophic inquiry. They are, Ist. The Voyages of a Philosopher, which contain observations on the manners, arts, and agriculture of the people of Asia and Africa. 2d. A Memoir on the Preparation and dying of Silk. 3. Remarks on the History and Manners

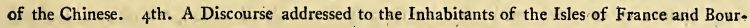
bon; with various manuscrips, which were collected by the Academy of Lyons, of which he was a member.

In order to enrich the colony committed to his care with the useful productions of other parts of the globe, he purchased of the old East India Company the large garden of Montplaisir, in order to cultivate and naturalize exotic plants. He undermined the ground in order to complete a radical destruction of the weeds; and, by his persevering spirit, the nutmeg and the clove, the reina, the bread-tree, and the dry rice of Cochin China, were introduced into this island. The care of cultivating and multiplying these valuable exotics: has since been entrusted to M. Ceré.

- Bixa Orleana, Lins. 
Indian corn, without ever lying fallow, or receiving manure, and with no great exertion of labour.

The Manioc, * which was brought from Brazil by M. de la Bourdonnais, and was at first cultivated by compulsion, is, at present, the principal resource of the colonists for the maintenance of their slaves. Their manner of cultivating it is the same as in America.

There were originally brought from Madagascar into this island considerable herds of cattle, and flocks of sheep; but since it has been discovered that more is to be gained, by individuals, from importing slaves than cattle, the latter have been neglected, and continue to be diminished; by the consumption of the island and the supply of vessels. Besides, the ground which has been prepared for pasturage has been so injudiciously disposed and mandged, that there is not sufficient herbage for the maintenance of the cattle. In different districts there is a yery fine grass, which shoots forth at the beginning of the rainy season, attains to the height of five or six feet, and arrives at its full growith in the space of three months, while that season lasts. At this time the colonists send their herds to graze on it, where they soon grow fat, but when the vegetation ceases it becomes dry and hard, so that the cattle cannot eat it. By a thousand accidents the dried grass is frequently set on fire, a circumstance which sometimes occasions a conflagration in the adjoining woods. During the remainder of the'year the flocks and herds are left to wander about the forests in search of a precarious subsistence.

The great error which has been committed in this island, and has proved most prejudicial to its agriculture, is the injudicious manner in which the ground has been cleared. The first settlers effected their purpose by fire; so that they opened large spaces of country, without leaving any intervals of wood, which could alone attrict the clouds to the new-formed fields. The rains are the best, and, indeed, the only manure in this island, and they confine their course to the forests, leaving unbedewed the tracts that are cleared. Besides, deprived of the surrounding woods, these fields have no protection against the violence of the winds, which often destroy an entire harvest: The Dutch, who had no woods at the Cape, have been careful to plant trees for the safeguard of their buildings. The Isle of France was covered with forests, and the inhabitants have destroyed them, in the cultivated parts.

* Jatropha Manihot, Limn. 
The greater part of the trees natural to this island have received their names from the arbitrary fancy of its inhabitants.

A large and very uncommon tree is found among the rocks, whose substance is as soft as the flesh of a turnip. It is called Mapou, or stinking-wood, from its offensive odour, and is considered as unwholesome.

The Bois de ronde is small, hard, and twisted; when burning it emits a lively flame: it is formed into flambeaux, and is considered as incorruptible.

Bois de Cannelle. The cinnamon wood, so called from a slight resemblance to the real spice tree of that name, is among the largest of the island. Its wood is useful in joinery work, and resembles that of the walnut tree, both in colour and veins. When first worked up it emits a fœid smell, like that of excrement, a peculiarity which it possesses in common with the flower of the cinnamon. Its seeds are enveloped in a red peal of a sour but very agreeable taste.

Of the Natte, there are two kinds : the one bearing a large and the other a small leaf. The carpenter finds it a very useful wood.

The Bois d'Olive, so called from a slight resemblance of its leaves to those of the olive tree, furnishes very durable timber for building.

The Bois de Pomme, is a red wood, in little or no estimation.

The Benjoin,* so called from its compact quality, is admirably calculated for the purposes of the wheelwright. It is very thick, and never splits.

The Colophane, + which yields a resinous juice, like that of the real rosin; is one of the largest trees in the island.

The fictitious Tatamaca, is very well adapted for building; it is of a very large size, and its trunk has been sometimes known to measure fifteen feet in circumference. It weeps a gum like that of the real Tatamaca.

Le Bois de lait. The milk-wood, so called from its milky juice.

Le Bois puant. The stinking-wood; which, though it emits an unpleasant odour, is excellent timber.

The Iron tree. $\$$ Its trunk is, as it were, blended with the roots; while from its sides a kind of small wing projects in the form of planks. Its wood is so hard as to turn the hatchet's edge.

The Bois de fougue, is a large creeping tree, whose bark is very tough: it also yields a milky juice, which is esteemed to be an excellent vulnerary.

- Benzonium,-Croton Benzoë, Linn.

+ Colophonia.

† Lignum ferri。 
The Fig tree, is of a large size; but neither its leaves or fruit resemble those of the same name so common in Europe. The figs are of the same shape, but they grow in bunches at the end of the branches. Its juice when dried becomes an elastic gum.

The Ebony tree. Its bark is white, with a large and stiff leaf, which is pallid beneath, and whose upper surface is verdant. Its heart alone is black, while its top is white. In a trunk of six inches square there is not more than two inches of ebony. The wood of it, in a fresh state, smells like human excrement, and its flower throws forth the odour of the clove : it produces a fruit like the medlar, full of a viscous juice, which is sweet, and of an agreeable flavour. There is also a kind of ebony, whose surface is white with black veins.

The Lemon tree does not produce fruit but when it grows in cool and moist situations. Its lemons are small, but full of juice.

The Orange tree loves the same damp soil, and its fruit is either bitter or sour. It abounds in the environs of Grand Port; but the China orange tree is rare, even in private gardens.

There is a kind of Sandal wood, though by no means common; its colour is of a greyish white, and it emits a faint odour.

The Vacoa, is a kind of small palm tree, whose leaves grow in a spiral form round the trunk. They serve to make mats and sacking.

The Latanier,* is a larger tree of the palm species; on its summit it produces leaves in the shape of a fan. They are used as coverings for houses: though but one is produced in the course of a year.

The Palm, (Palmiste $t$ ) is the most lofty of the forest; on its top it bears a bunch of palms, from whence proceeds a sprout, which is the only part that is esculent, and to obtain it the tree itself must be cut down. This vegetable, which is called a cabbage, is formed by young leaves rolled up together : it is very tender, and of an agreeable taste.

The Manglier, grows in the sea; its branches and roots twine along the sand, and are so interlaced that it is impossible to disembark where these trees grow. The wood produces a dye of a red colour. The greater part of them have but a very thin bark, and some of them nothing more than a slight skin; in which they particularly differ from those of the north, where considerate nature preserves them 
from the rigour of the climate, by clothing them with several coats. Their roots run generally on a level with the ground, and with them they cling to the rocks: they are low, and their tops are but thin of foliage: they are of a sturdy form; so that their native strength, when added to the plants to which they are attached, enables them to resist the hurricanes that root up the proudest trees of the forest.

The banks of the streams, which alternately wind in silence or impetuously rush through the woods, are covered with trees; from whence are suspended bunches of the Scolopendria, ${ }^{*}$ and flowers of the creeping plants. Among the rocks and in the shade, the mosses and capillary plants are seen to flourish. The fallen trunks of trees are covered with enormous fungi waved with different colours: there is, also, an infinite variety of ferns; and the common moss of Europe is here seen, but of a much larger growth. Instead of the reeds which we are accustomed to see on the sides of rivers, the songes grow in abundance along these streams; they are a kind of nymphea, and resemble the water-lily, so great an ornament to our tranquil pools.

To these we shall add a description of several trees, shrubs, and plants, which grow in the north part of Madagascar, and were brought from thence to the Isle of France, in the latter part of the year 1768 , by M. Rochon.

The Malao-manghit, is a tree whose bark is brown, the trunk straight, and its wood black; the sap is naturally white and milky, but when exposed to the air becomes red as blood. The leaves of this tree have a sweet and aromatic smell, and its fruit is a kind of nutmeg. The Malegaches suppose that it possesses the same virtues which we attribute to the true nutmeg.

The Rarabe. It is a wild nutmeg tree, and a much larger, as well as finer tree than the Malao-manghit. It produces a nutmeg that yields an aromatic oil, with which the Malegaches rub their bodies and anoint their hair. It is also employed to dissipate cold humours; and, taken inwardly, fortifies the stomach.

The Bachi-bachi. It resembles the Rarabe; though there is some difference in the fruit and leaves. This tree delights in elevated situations. The rind, the mace, and the nut; are all aromatic.

The Rharha-horac. It is the real wild nutmeg: its trunk is large and its branches bushy, and it flourishes in marshy situations.

The Founingo-mena-rubou. A large blue pigeon is very fond of the fruit of shis tree, and sows the nut in all parts of the islands.

- Ceterach aut Asplenium. 
Ravend-sara. Of all the various nutmeg trees in Madagascar, this more particularly attracts the attention of the botanist. The essence which is extracted from its leaves, possesses the united perfume of the clove, the cinnamon, and the nutmeg: they also produce an oil which is more esteemed than that of the clove, and it is preferred in culinary preparations, by the cooks of the Indies, to any other spice. It is a very precious tree, and loves a moist soil, though it is seen to flourish in a dry one: it grows to a large size, and its pyramidal head is well furnished with leaves. Its wood is white, hard, heavy, and without smell; but the bark sends forth a very powerful odour. The fruit of the Ravend-sara is of a globular form, flattened on its two extremities : its odour, as well as that of its shell, is not so strong as the perfume of the leaf, but is of a more delicate fragrance.

The Harame. It is the loftiest and largest tree of the country of Foule-pointe: its wood is white, but red at the heart. When it has attained its full growth, it sheds its exterior bark every year, which is of a greyish colour, and thick contexture. The trunk of this tree is smooth, and without any branches, but at its extremity, where it is well dressed with foliage, and the tuft which crowns it is a pleasing object. The least incision made in this tree procures an abundance of a white resinous and aromatic juice: the female Malegaches make a paste of it, which they consider as a very valuable cosmetic for the preservation of the skin. On burning this rosin, it dispenses perfume like that of incense. The fruit consists of a nut, whose outside skin alone gives an aromatic fragrance.

The Laben. This tree grows on the sea-shore, and consequently loves a sandy soil : it rises to a great height, and its wood is hard, of a reddish hue, and suited to the purposes of joinery. The fruit is of the size and shape of an olive, and its kernel is of a white colour and delicate taste.

The Fouraha. It is a very fine tree, and one of the most useful productions of hot countries. Except the teak, it is the best wood that the Indies afford for the construction of ships. It produces a balm of a green colour, which is a very excellent vulnerary. It is large, with spreading branches and tufted foliage; but the most remarkable circumstance belonging to it is its extraordinary height.

The Tevartna. This tree presents, amidst the wild irregularity of the forest, all the symmetry of art : it has all the appearance of having been clipped into the form of a pyramid, consisting of seven distinct stages.

The Huitchy. This is the most common tree in the forests of Foule-pointe; and, 
from the thick foliage of its top, is calculated to form avenues: it resembles the plumb tree, and rises to a similar height. Its wood is red, and may be used in joiner's work: its bark is very smooth and white, and its leaves, which are large, possess a very brilliant verdure.

The Fotersbé. It is among the largest trees of Madagascar; but its wood is fit only for fuel. There is another kind of it, which grows in swamps and marshy places. M. Flacourt describes it under the name of Voua foutra.

The Tanguem. It grows on the sea-shore, and its wood, which is hard and veined, is employed in cabinet and ornamental work. The Malegaches make a fatal use of its fruit, which contains a deadly poison. It is an undoubted Manchenillier.

The Antafara. This is known in the Isle of France by the name of the milk tree; its flower has the odour and figure of the jessamine. A slight incision produces, in great abundance, a caustic, milky juice.

The Assy. This is a fine palm tree, which grows to the height of ten or eleven feet; its trunk is impressed with the mark of its leaves, which it successively sheds. Its top is crowned with three or four rows of leaves, from four to five feet in length, and about an inch and an half broad, which resemble the leaf of the flax plant: they possess the consistence of palm leaves, and are manufactured into umbrellas.

The Tafoumonna. This tree is large and tufted; the bark is smooth, and the wood white. Its fruit is an acorn, like that of the oak; whose kernel has an aro. matic taste, with a slight flavour of turpentine.

The Hounits. It is a large and very fine tree; the bark is red, and the wood yellow. On an incision, a red juice issues from it of the colour of coral. From the bark of the root the Malegaches extract a fine red dye, by means of a common lie.

The Zavin-raven. It grows in marshy situations, rises to a moderate height, and is somewhat tufted: the trunk is covered with knots; the bark green, and the wood white.

The Lingo. This is a woody creeper, of about two inches in diameter, which ascends to the top of the highest trees : the wood is yellow, as well as the inside of the bark. The Malegaches employ the bark and root of this plant to dye the thread of their pugue of a red and yellow colour.

The Harongan. It rises to the height of fifteen feet, and grows in a sandy soil : its leaves are employed to dye hats and baskets. The rosin extracted from this tree is a kind of dragon's blood. 
The Tancarson. This is a wild vine, whose fruit is sour, but rather palatable, and esteemed by the natives. This creeper attaches itself to trees, and winds it self to the top of them : its root is diuretic. M. Flacourt, who has described several kinds of the wild vine, has not mentioned the tancarson.

The Taco. It is a kind of vine, like that which has been just described.

The Voua-lomba. . This is the fruit of a vine, which Europeans prefer to every other; it is called the Madagascar grape, and has a sharp taste. This plant dies every year; its root is a kind of igname. (Discorea opositi folia, Linn.)

The Anakuey. A sensitive plant.

The Aresou. A kind of elder tree.

The Tougnounan.

The Tafoumounam. An acorn fruit with a small white flower.

The Racoudrit. A green fruit in bunches.

The Uvangbiri. A plant with large square pods, which contain a bean that is an anti-hemorrhoidal.

The Tevarte. A shrub of a pyramidal form, that ascends in natural stages.

The Azambou. A fruit that has the appearance of a bunch of red flowers.

The Una-he taitchou. An eatable fruit.

The Sampan-leva. A fruit which grows in the form of a chaplet.

The Tchinghit. A bean, with a yellow flower.

The Lacca. A small berry, like a pepper-corn; the flower like those of the hazle nut.

The Voguindosong.

The Fanpechourou. A kind of lily, in the shape of a star. It announces the season of the whale fishery.

The Voua-hintchi.

The Fila v. equisetum arborescens.

The Voantlisan. A thorny tree, whose leaves are confined to its top.

The Tchusi-ovi. A kind of ipecacuanha seriploca.

The Jacuan. A species of almond: a tree without leaves, which emits a gum.

The Timbalave. A shrub with a white bell-flower.

The Ampalt. A round leaf, that files iron.

The Anghivi. A kind of bréde, whose red fruit is used to give a bitter, but agreeable, taste to the drink of the natives. 
The Azou-ranou.

The Farafer. (Plante parasite), with a long red flower in the shape of a hand, or a fork with five prongs.

The Vongo. A fine tree, whose fruit is called Vaassou voura. On incision, it yields a yellow juice.

The Vua-mitsa voi. An Aster.

The Tougouna-lein-tein. A kind of mint.

The Sanoang-matan-nahaurou. A kind of creeping asparagus.

The Ranga-zaa. A bulbous root, with a white flower.

The Tchilotou. A white tulip.

The Fifoutche: A tree, whose leaves resemble those of the mallow, with flowers round its trunk.

The Shira. A palm tree, from whose bark, when burned; an eatable salt is extracted.

The Raven-tongharts. A balsamic plant.

The Tanroujou. A kind of benjoin.

The Azou-ranou. A shrub, whose fruit has the flavour of cinnamon.

The Afatraha. A shrub, with an odoriferous bark.

The Vaing-bare. A plant, with an hairy, leaf and a white flower.

The Talate. Its leaf is thick and its fruit red, like that of the holly-oak.

The Jang. A tree that produces large bunches of flowers.

The Vua-tani. Its flower resembles that of the Lihoa of China.

The Vua-montueung. A plant, with a leaf like that of the tamarind, and its fruit resembles a bean.

The Vua-toutouc. A shrub, with red fruit, which is eatable, and has the flavour of the strawberry.

The Moulton-rongou. It has a resemblance to the rara; its leaf is small, and its fruit is of an oblong angular shape.

The Vouang-titirang. A kind of nut, whose outward shell is yellow and hairy。

The Voua-malim. A kind of Gousse d'houate.

The Voua-rougui. A kind of Manglier.

The Voua-tourindi. A large tree, which bears a small red flower in great bunches. The Ampali. It bears a large leaf, which polishes wood, and rubs off the rust of iron. The Joudi-fafal. Semper vivens. 
The Voua-severantou.

The Vouang-taé. Malum cidonium.

The Voua-futre. A kind of box tree, whose aromatic fruit is eatable.

The Enghi-panza. The lesser indigo.

The Enghi-bé. The large indigo.

The Vua-macaliong. A kind of taarin, from which oil is extracted.

The Sacaviro-ambon. A species of the Zedoaire.

The Vua fao. A kind of palm of Sagou.

The Ouvi-rombé. A creeper, whose leaf is small, and in the form of a heart with a very sharp point.

The Chifontsui. The leaf is small, and in pairs, like that of the small harame; its flower has four green leaves, which form a cup.

The Vua horda. A fruit, in the shape of a cucumber, and which smells like a quince.

The Sanguamou-batou. A plant, whose leaf has the same effect on fish as the coque du Levant. It must be bruised.

The Vaint-sombou. An herb, which has the same qualities.

The Sanga, sanga. The real papyrus.

The Vua-toudinga. A fruit like the pipar of China.

The Vua carabo. A kind of large flat chesnut, which grows on a creeping plant.

The Vua nantoula. It contains a large almond, of the same shape as the kernel of the sapotilla, but much thicker.

The Vouang-pin-lela : with leaves like the cinnamon tree, but without odour.

The Vua-tingui lé-pas. Fruit of a green colour, whose leafy bulb opens like the petal of a flower. The seeds are contained in a triangular pod.

The Anja oidy. A kind of heath, which grows to a considerable height.

The Vua tehirie. A kind of vacoua, with long and narrow leaves.

The Vua-khicason. A small fruit, like the ragoustah.

The Tehouti morou, or ranou: A plant, with a small husk.

The Vua-hia-vave. A creeping plant; with white female leaves.

The Vua nambouavon. A red fruit in bunches; with flowers of a violet blue, and whitish leaves. It is esteemed as a vulnerary.

The Vua-rhe. A kind of fig tree, whose fruit is excellent.

The Vua he taitson. 
The Varou. A kind of mallow.

The Lindern. A kind of palm tree, with the leaf of the seolopente.

The Angnan-rambou-lahe.

The Tongou hintchi.

The Harame; whose rosin partakes of the nature of ambergris.

The Chingolpont.

The Christala.

The Alut mandrout.

The Vangoni nangbona.

The Bakrang. A plant, with large buds.

The Ardouranga. A small plant, with vegetable flowers and red husk, like that of indigo.

The Vaguinang boua. A shrub, with a white hairy leaf, and white flower; the root is a fine vulnerary.

The Cani-prouti. A grass, with a large leaf; from whence the natives extract a juice, with which they paint their bodies.

The Chipoulou pouli.

The Adabou. A large tree.

The Ouoi-randra. An aquatic plant, with an indented leaf; the flower has two horns : the root is eatable.

The Tottlas. A kind of laurel, whose leaf and berry are aromatic.

The Voua-houda. A large fruit, like the mangue, of an oblong and cylindrical form; of a pleasant odour, with a ramified kernel, and leaves arranged opposite to each other.

The Mounou founace. A shrub, with a blue flower and a trefoil leaf

The Azou-minti. A very curious pyramidical shrub.

The Azou minti-be. A very fine tree, of the same form, with large leaves.

The Toucam-boudi. A small palm tree, with large leaves divided at the extremity.

The Fourangdra. A kind of winter cherry, with a triangular leaf, like that of parsley.

The Vua mandroucou. Bunches of flowers issue from its trunk, with spiral petals.

The Votia-mena. A sweet fruit, of a red colour, like that of coral; both the wood and leaves are red. 
The Mang. A tree, whose leaf is like that of the mallow, but larger and stronger: its flower is downy, like that of the ketmia, and of a red colour, like the rose.

The Angue-malou. A kind of aromatic bréde; its, flower is of a golden colour.

The Voulang-boudi-pouni. A red wood, which in time becomes black : it is used in dying.

The Tsimamasoo. A creeping plant, whose red flower is in the form of the jessamine.

The Manouquibonga. A shrub, with branches like those of the vine, and whose beautiful red flowers are ranged like an aigrette.

The Maan. A kind of veloutier, with leaves like the mallow.

The Sonmouterang. A downy flower.

The Lalong.

The Via foutchi. A woody creeper, whose fruit is inclosed in a cup, in the form of a star.

The Diti-azou. A fruit, which has the form of a small pear.

The Tavoutala. A small bulbous plant, of the orchis kind; its flower is of a greycolour.

The Chetchia. A kind of hieracium, with a yellow flower.

The Agnan rambou. Another hieracium, of a violet colour.

The Cutoubanda. A kind of pimpernel, which is applied to swellings.

The Nanton. A twisted tree, of two kinds, the large and the small leaf.

The Ampelang-thi-fouhe. Gentianella, with violet flowers.

The Campoudi. A kind of alsiné.

The Veloutier. Pithonia.

The Oubave. A tree, which produces a gum, like gum arabic.

The Bontou. A tree, whose root gives a yellow dye ; it grows on the side of water; and its leaf is thick and in pairs.

The Voai-morang. A shrub, whose bark possesses astringent qualities.

The Vuendrang. A kind of galenga.

The Afé. A large polipode, whose seed is eatable.

The Tabouronangat. Bethel.

The Voua-rozan.

The Voua-assim. 
The Ampelantghi. An agreeable plant, which grows to the height of twelve inches.

The Sondi-fa-fat. A plant, which is found on the sea-shore. The Malegaches rub their bodies with the leaves when they have suffered fatigue; and these frictions revive and refresh them: they pretend that its leaves are incorruptible. When medically applied, they are found to possess healing qualities.

The Vognin d'oseng. A plant, whose leaf resembles that of the lily; the time of its flowering marks the season fur the whale fishery: the prows of the piroguas, employed on that commercial service, are adorned with garlands of these flowers.

The Azimena. A very agreeable shrub, that grows to the height of four feet : its top is tufied, and its leaves are thick and of a fine green : its flower emits a very fragrant odour.

The Toulon gouala. A shrub, whose odoriferous leaves serve the Malegaches for pillows : it rises to the height of four feet, and its fruit is bitter, oily, and aromatic.

The Voua-azigné. This is the straightest and loftiest tree of Madagascar; its yellow, hard, and compact wood is employed in building houses, and forming the keels of the great piroguas. The resinous juice that flows from it is yellow, like amber, and of a glutinous quality, but without any șmell. The Malegaches extract from this valuable tree a clear oil, which, when fresh, is of an agreeable flavour: rice when mixed with it becomes a more delicate food; and this application of it is very common among the natives of the island.

The Fougmonnam. This tre grows on the summit of the mountains; its wood, which is weighty, and of a yellowish-bronze colour, is used for inlaying, and to make sagayes.

The Vohan silan. This tree attains the height of twelve feet; its trunk is straight, and covered with thorns, but without leaves, which form a thick tuft round its top: they are of a very fine green, are four inches and an half in length, and two and an half in breadth. The wood-pigeons are greedy of its fruit, which is of a very singular shape.

The Toulou. A shrub, which grows in a bushy form, in any kind of soil; the fruit is called the Mudagascar strawberry; it has a very agreeable flavour, and is esteemed by. Europeans, as well as by the natives.

The Voua-sévérantou. A shrub, which also grows in a bushy form, to the height of seven feet, and loves a sandy soil : its wood is white. 
The Chifont-fui. A beautiful shrub, whose trunk is straight and without any leaves, but those which adorn its round and tufted top.

The Finguere. A kind of wild fig tree, which, on incision, yields a milky juice, that, on coagulation, forms an elastic rosin; such as flows from the caout-choue: The Malegaches make torches, which burn without wicks, and afford a sufficient light, when they pursue their nocturnal fishery. Spirit of wine have no effect on this rosin, but it dissolves in ether or linseed oil; other fat and oily substances have also a considerable effect on it. This tree rises to the height of twenty feet; its leaves are eight inches long and four broad, and its fruit resembles a round fig, which is full of small grains : the Malegaches eat it with pleasure, though it is sour and caustic. This elastic gum is well known in Europe, and when used as bandages, probes, \&c. greatly facilitates certain chirurgical operations.

The Bagnets. A plant, from which the true indigo is extracted at Madagascar: this the natives perform by a very simple operation; they lay the leaves and the stem to soak in water, when the plant begins to flower; after putrefaction, the water becomes of a violet colour; and when it has attained a deep tint, the leaves and stems are taken out of it, and a certain quantity of oil poured into it; when the sediment has subsided the water is poured off; and the deposit, being dried in the shade, produces a fine indigo.

The Ravendras is not a muscadier, but, in the opinion of M. de la Mark, a proper species. It is the Bagato phyllum.

The Intchy, according to the same skilful botanist, is a basil hymenea.

The Antafara also, in his opinion, is among the genera of the Tabernamontana species.

The Filao is the Casuarina of Forster, and of Linnæus junior.

And, lastly, the Vua-tchirie is the Pandamus.

In the enumeration which has been made of the plants and trees of Madagascar, no notice has been taken of the following fruits, \&c. \&c.

The pine-apple, water melon, white pepper, and the banana; the saffron of the Indies, the great cardamum, the ginger, the veronica, the vesicaria, the pourpier, and the basil; the aster, the gentiliana, the bagnaudier, the veroche, and the papyrus of the ancients, called sanga-sanga, \&c. \&c.

Ambergris is found in the Isles of France, Bourbon, Rodriguez, \&c. and the shores of the former are covered with coral. 
The French caused the greater part of the plants, trees, \&c. hereafter described, to be introduced into the island. Some of the inhabitants have also made considerable contributions; among others, Messrs. De Cossigny, Poivre, Hermans, \&c. 1st. The reproductive plants, and which are, as it were, naturalized in the country. 2d. Those which are cultivated in the fields. 3 d. Such as are esculent, and belong

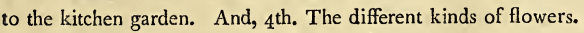

Among the wild plants, a kind of indigo grows in the plains near the town.

The Pourpier is a native of the country, and loves sandy places.

The Water-cress is found in the rivulets, where it was sown some years ago. The dandelion and wormwood grow freely among the rubbish, and in earth that has been moved. But, above all, the Molene* spreads its large and downy leaves, and shoots up its cluster of yellow flowers to an extraordinary height.

The Squine, (which is not the Chinese plant of the same name) is a grass, that grows to the height of the finest rye, and chokes up the other herbs by the quickness of its growth; but it must be eat while it is green, as it is too tough when dry to be used as food for any animal. It is green only five months in the year; and the black Maroons sometimes set fire to it, in defiance of the ordinances published against such a conflagration.

The Brette, whose name, in the Indian language, signifies an eatable leaf, is a species of morel. There are two kinds of them; the one called the Brette of Madagascar, whose leaf is somewhat thorny, but of a sweet taste, and a purgative quality. The other, which is in more common use, is served at table as spinage. It grows every where, and the water in which it is boiled is very bitter. The blacks moisten their manioc in it.

The plants which are cultivated are as follow:

The Manioc, of which there is another kind, called camaignoc, grows in the driest spots. It is a shrub, whose leaf resembles that of hemp; its root is as long, and as large as a man's arm; and, when grated, is made into cakes: three pounds of it are given to each Negro for his daily food. M. de la Bourdonnais procured it to be brought from the island of Madeira, and, as it quickly multiplies, is sheltered from the hurricanes, and gives a nutritious subsistence to the Negroes, is a most valuable plant.

The Maiz, or Indian corn, grows here to great perfection. It is a valuable grain, from its productive nature; though if it be kept long, the insect gets into it.

- Verbascum. 
Wheat also flourishes here, though it does not grow to a great height. It is sown by hand on account of the rocky soil; and is seldom kept more than two years. Although its flour is never very white, its bread is preferable to that produced by the flour of Europe, for long voyages.

The cultivation of rice is very successful; this grain produces more abundantly than the wheat.

The small millet yields a very plentiful harvest.

Oats succeed well in this island, but they are little cultivated.

The Negroes grow tobacco for their own consumption.

The fataque, is a grass with large blades, like those of a small reed: artificial meadows are made of it. It is a native of Madagascar.

Onobrycbis.

M. de St. Pierre mentions that attempts have been made to cultivate sainfoin, trefoil, flax, hemp, and hops, in this island, but without success.

\section{The culinary and fructiferous Plants.}

The greater part of the vegetables degenerate, and those who are curious in them, must annually obtain their seeds from Europe, or the Cape of Good Hope. The peas are tough, and without sweetness: the kidney-beans are hard; but there is a kind of them, which are larger and more tender, called the Cape pea. There is another kind, with whose vines arbours are formed. Horse beans are successful. There is also a kind of bean, whose pod is a foot in length; its grains are large, but are never eaten; and its branches are so luxuriant as to form verdant bowers.

The artichokes put forth large leaves, but produce small heads, which are very tough, unless the root has been well manured. Hedges are formed of them, as they are very thorny, and rise to a considerable height.

The Giromon is a small pumpkin. The cucumber is also diminutive, and less productive here than in Europe. The melon is in great estimation; and the Pasteque, or water-melon, is excellent: the climate is very favourable to it, as well as the soil, when improved by manure.

Gourds grow here to an enormous size, and are of great use, as they form the utensils of the Negroes.

The Bringelle, or Aubergine, is of two kinds: the one, which is a native of Madagascar, has a very thick bark, and produces a round and yellow fruit; the other, which is known in Europe, yields a blue fruit of the size of a large fig. 
There are two sorts of pimento; the one which is known in Europe, and the other which is natural to this island. It is a shrub, whose fruit is very small, and shines like grains of coral, on a foliage of the finest green. The Creols use it in all their ragouts; it is a very strong pepper, and burns the lips like a caustic: it is called the fiery pimento.

The Ananas, the finest of fruits, is known here; and the straw berry begins to multiply in cool situations: they however are not very productive, any more than the raspberry, whose fruit has degenerated. There is avery fine sort from China, which attains the size of cherries, and is very abundant; but it is neither sweet nor fragrant.

Spinage, cresses, sorrel, parsley, fennel, and celery, are of difficult cultivation: the beet, lettuce, endive, and cauliflower, are much smaller and less tender than they are in Europe. The cabbage, which is among the most useful vegetables, flourishes here. The pimpernel, purslain, and sage, increase here; but, above all, the cistercian, which is a long-lived plant.

Asparagus, carrots, parsnips, sassafrass, radishes, and turnip radishes, require cultivation; but as cattle are scarce, manure is proportionably rare. There is a kind of Chinese radish, which is successful. The red beet flourishes, but is very woody. The Pomme de terre, Solanum Americanum, is not larger than a walnut, from being ill cultivated : those of the Indies, called Cambar, weigh often upwards of a pound: its skin is blue, like a violet; but it is white within, and its taste very insipid: is affords a variety to the food of the Negroes. It multiplies considerably, as well as the potatoe, some kinds of which are preferable to the European chesnut. Saffron is used to give a colour to culinary, or cari, preparations, like the pistil in Europe. The ginger is not so hot as that of the Indies. The pistachio, which is not the fruit of the pistachio tree, is a small nut, that grows in the ground, in a rough shell: to be eaten, it must be roasted; but it is principally cultivated in order to extract a lampoil. This plant is a phenomenon in botany, as it is very rare indeed that oily qualities are found in those fruits which grow beneath the surface of the earth.

The mignionette, balsam, tuberose, larkspur, China-aster, and small pinks, all flourish as in Europe. The large pinks and lilies put forth abundance of leaves, but seldom bear flowers. Anemones, ranunculas, and the Indian rose, as well as the stock and the poppy, flourish in this island.

Among the more common flowering plants of Africa there is but one, which is the fine everlasting of the Cape; whose berries are large and red, like strawberries, and 
grow in bunches at the top of a stem, whose leaves resemble pieces of gray cloth. There is another everlasting, with purple flowers, which grows every where: a reed that does not exceed the size of a large hair, and bears a bunch of white and blue flowers, which, at some distance, appear to be floating in the air: it comes from the Cape; with a kind of tulip that has but two leaves, which stick to the earth as if they grasped it: there is a plant also from China, that sows itself: it has small flowers like a rose, each stem producing six or seven of them at the same time, all of which are variegated, from the deep red of bull's blood to the colour of brick.

The aloe flourishes here; from whose leaves may be drawn a medicinal gum, while their fibres are capable of being manufactured into linen: it grows on the rocks, and in places scorched by the sun. Some are covered with a strong and thick leaf of the size of a man's hand, and armed with a long spike : the stem rises from the centre to the height of a tree, that is covered with flowers which drop down aloes in their perfect state. There are others which are straight like large torches, with several sides, and covered with very sharp thorns; these are streaked, and have the appearance of serpents.

The rose tree is so easily propagated, that hedges are formed of it; but its flower is not close and fragrant as those of Europe : there are many varieties of them, and among others, a small kind from China, which bears flowers throughout the year. The jessamines of Spain and France are naturalized here. There are pomegranates with a double flower, but they are not very fruitful. The myrtle does not flourish here as in Provence.

The Asiatic, African, and American shrubs are, the Cassis, whose leaf is indented; but it does not resemble that of Europe. It is a large shrub, which is covered with yellow odoriferous flowers, in small tufts: they yield a bean which affords a black dye. As it is thorny, it is useful in forming hedges.

The Foulsapatte, an Indian word, which signifies the shoemaker's flower, from its depositing a black dye when rubbed on leather. This shrub has a fine green foliage, larger than that of the horn-beam, in the midst of which appear flowers, like those of the pink, and of a deep red: they are used in forming close hedges, and there are many varieties of them.

The Poincillade, which is a native of America, is a kind of bramble that bears clusters of yellow and red flowers; it is very beautiful, but fades in a short time. It yields a bean, and its leaf is divided like the esculent vegetables. 
The Jalap bears flowers in the shape of a funnel, and of a deep crimson, which only open at night: they smell like turpentine, and there are two kinds of them.

The vine of Madagascar is a creeper, of which bowers are formed, and bears a yellow flower; its leaves are downy, and appear to be covered with flour. There are several other kinds of flowering creepers in the gardens.

The Mongris, is a jessamine, whose leaf resembles that of the orange tree : there are both double and single ones, and they dispense an agreeable fragrance.

The Franchipanier, is a jessamine of another kind. This shrub grows in the shape of a stag's horn. From the extremities of the smaller horns there shoot out bunches of long leaves, in the centre of which are large white flowers, in the shape of a funnel, and have a pleasant odour.

The lilac of the Indies comes to perfection in a short time, and as quickly dies. It has an indented leaf of a very beautiful green; it bears sweet-smelling flowers, which change into berries: this shrub attains the height of a tree, and is of an agreeable appearance ; but, though its foliage is of a brighter green, its flower is less beautiful, than the lilacs of Europe, which do not grow here. That of Persia does not succeed here. There is also the laurel, the rose laurel, the Galet lemon tree; which is formed into hedges; its fruit is round, small, and very acid. The Palma: Christi grows every where, and its oil is a known vermifuge.

The pepper plant is a creeper, which twines like ivy; it flourishes, but bears no fruit. It is not known whether the tea tree, which has been brought from China, will naturalize itself in this island, as the Indian reed has done, which is of equal use in the Indies as the willow is in Europe.

The cotton tree grows, in the form of a shrub, in the driest situations; it bears a pretty yellow flower, to which a pod succeeds that contains the cotton. Its seed is given to promote milk in the breast.

The coffee tree is the most useful tree or shrub in the island. It is a kind of jessamine, with white flowers; its leaves are a fine green, placed in regular opposition to each other, and are like those of the laurel; its fruit is of a deep red, and separates into two beans. The trees are planted at the distance of seven feet from each other, and they are lopped at the height of six feet: they last only seven years : at three years they bear fruit; and the annual produce of each tree is estimated at a pound of berries. A Negro can annually cultivate a thousand pounds weight of 
it, independent of the berries necessary to his own subsistence. The inhabitants pretend that the coffee of this island is inferior only to that of Moka.

Among the European trees, the pine, the fir, and the oak, grow to a moderate height, when they decline. There are also cherry, apricot, apple, and mulberry trees; with the pear, the medlar, and the olive. The fig tree cannot boast of its fruit; nor does the vine succeed in this climate: it produces grapes, but they do not ripen at the same time, and yield nothing for the vintage. In Europe, the fruit of the same tree attain their ripeness, in a great degree, at the same time; here they ripen successively; which occasions an uncommon variety in the taste of the fruit, gathered at the same moment from the same tree: it would probably be otherwise if it were left to its natural growth. The vine grows, in hot countries, in the midst of woods, where it twines itself round the trees which serve to shade it: this circumstance proves, that if it were introduced into more shady places, it might succeed in this island. The peach tree produces fruit, in a moderate abundance, and of an agreeable taste; but the stone does not separate.

The trees in this island are in a perpetual state of vegetation; and it might be a beneficial practice if they were planted deeper in the earth, in order to check their growth: they should be preserved from the heat here, as they are protected from the cold in the northern parts of Germany. The European trees shed their leaves in the cold season, which possesses here the warmth, and is accompanied with as much humidity as the spring in the moderate parts of Europe.

The foreign ornamental trees are, the Laurel, which flourishes here, as well as the Agathis, of which there are several kinds. Its leaf is indented, and intermixed with bunches of white airy flowers, which are succeeded by long, leguminous pods. The Chinese frequently represent them in their landscapes.

The Polche is a native of India; it has a tufted foliage, whose leaf is in the shape of an heart: it is useful only for the shade it affords. It produces an unprofitable fruit of a ligneous substance, and in the form of a medlar.

The Bambou, appears at a distance like our willows. It is a reed that shoots up to the height of the loftiest trees, and puts forth branches covered with leaves, like those of the olive tree : they are formed into avenues; and as the wind passes through them it produces a ceaseless murmur. Their uses are various and well known. 
The Attier, whose triangular flower is of a solid substance, has the taste of the pistachio. Its fruit resembles that of the pine tree; when ripe, it is filled with a white, sweet cream, has the fragrance of the orange-flower, and is full of black kernels. It is a grateful fruit, but very heating.

The Manguier is a very fine tree, which the inhabitants of India represent on their painted silks; it is covered with flowery branches, like the Indian chesnut tree : to them succeeds a quantity of fruit, in the shape of a very large flat plumb, covered with a rind that smells like turpentine. The fruit has an agreeabie thind vinous taste, and if it were not for its smell, might be said to equal the finest fruits of Europe: it is probable that a very pleasant drink might be extracted from it. It is generally loaded with fruit in the hurricane season, which occasions the loss of the greater part of it. It grows on the sands, and even in the sea.

The Bananier grows every where, but has no wood: it is nothing but a tuft of leaves, which rise in columns; and expand, at the top, in broad bands of green, which have the appearance of satin. At the end of a year, there sprouts forth from the top a long cluster bristled over with fruit, in the shape of a cucumber. The fruit, which is mucilaginous, has an agreeable taste, and the Negroes are very fond of it: it is given them on festivals, and they reckon their time by the course and number of Banana feasts. Its leaves resemble silk girdles; its cluster falls down for several feet, and its violet-coloured head resembles that of a serpent : this circumstance may have been the cause of its being called the fig tree of Adam. This fruit lasts all the year, and there are many kinds of it, some of the size of a plumb, and others as long as a man's arm. Linen may also be made of the fibres of this plant.

The Gouyanier bears a strong resemblance to the medlar tree; its flower is white, and its fruit smells like bugs. It possesses an astringent quality; and is the only fruit which breeds maggots.

The Jam-rose, is a tree which affords a fine shade, though not of a lofty growth; its fruit emits the fragrance of a rose bud, and is of a sweetish taste.

The Papayer is a kind of fig tree, without branches; it grows fast, and shoots up like a column, with a capital of large leaves: its fruit, which is like a small melon, grows out of its trunk, which is of the substance of a turnip. Its seed has the taste of cresses. The female Papayer only bears flowers; they are of a form and smell as agreeable as those of an honeysuckle.

The Badamier seems to have been formed for the purpose of giving shade. It 
grows in the form of a pyramid ranged in several separate stories: its foliage is fine, and it yields a few almonds, that have an agreeable taste.

The Avocat is a handsome tree, and yields a pear which incloses a large kernel: the substance of this fruit is like butter, which when seasoned with sugar and lemonjuice, it is a pleasant eatable, though of an heating quality.

The Jacq is a tree of a beautiful foliage, and bears a monstrous fruit, which is the size of a large pumpkin, whose rind is of a fine verdant colour, and entirely shagreened. It is full of grains, whose coats, consisting of a white, glutinous, and sweet skin, are alone eaten. It smells like rotten cheese, and is a powerful stimulant.

The Tamarind has a very fine top: its leaves are placed in regular opposition to each other, and close in the night. Its pod affords a mucilage, which makes a pleasant and cooling beverage. It has perpetuated itself in the woods.

There are several kinds of orange trees, one of which bears an orange called by distinction the Mandarine. A large kind of Pamplemouse, an orange of a red colour and an indifferent taste: and a lemon tree that bears a large fruit, which yields but little juice.

The Cocoa tree has been transplanted hither. It is a kind of palm tree that flourishes in the sand, and one of the most useful trees in the commerce of India: it serves to give oil, and fibres for cables. It is said that at Pondicherry each cocoa tree annually produces a pistole. It delights so much in the vicinity of salt water, that salt is thrown into the hole in which the fruit is planted, to facilitate the open: ing of the bud. The cocoa appears to be designed to float in the sea, from its hairy coat, which keeps it above the water, and the hardness of the shell, which is impenetrable to it. This palm is the inhabitant of the southern shores, as the fir is the prevailing tree of the north, and as the date is the pride of the arid mountains of Palestine. Not long since it was discovered that a crab took up its abode at the foot of the cocoa tree: nature has provided it with a long claw, terminated by a nail, with which it draws out the substance of the fruit, through the holes at its extremity. This animal is found on the Island of Palms, to the north of Madagascar, which was discovered in 1769 , by the shipwreck of a vessel named L'Heureux, that perished in its voyage to Bengal. This crab served the crew for food.

There has lately been discovered, in the island of Sechelle, a palm tree that bears double cocoa nuts, some of which weigh more than forty pounds. The Indians 
attribute to it very extraordinary virtues: they suppose these trees to be a production of the sea, because the currents sometimes throw them on the coast of Malabar. They call them marine cocoa nuts. This fruit when stripped of its hair, mulieris corporis bifurcationem, cum natura et pilis representat. Its leaf, which is in the shape of a fan, is large enough to cover the half of a hut. But, in the usual proportionate dispensations of nature, this tree does not bear more than three or four of these enormous nuts; while the ordinary cocoa tree bears thirty or forty: their taste is much the same. Marine cocoas have been planted in the Isle of France, and begin to shoot.

There are also some curious trees, as the date, which seldom bears fruit; the palm which is called the Araque, as well as that which produces the sago; the $\mathrm{Ca}$ nificier and the Acajou, both of which yield flowers, but without fruit; the cinnamon tree, of which avenues have been made, resembles a large pear tree, both in size and foliage; its small clusters of flowers and its cinnamon have an aromatic odour. There was but one cocoa tree in the island in the year $176 \mathrm{~g}$.

It is long since the Ravinerara, a kind of nutmeg from Madagascar, has been planted here; as well as the Mangoustans and the Litchis, which produce the finest fruits in the world; the varnish tree, that yields an oil capable of preserving cabinet work; the tallow tree, whose seed is covered with a kind of wax; a tree from China, which yields small lemons in clusters like grapes; the silver tree of the Cape; and, lastly, the Teak, so well known for its service in the construction of vessels.

\section{Marine Productions.}

There is a great variety of fish in the seas that surround the Isle of France.

Whales are often seen to windward of the island, particularly in the month of September, which is the season of their copulation: they are then frequently observed to poise themselves perpendicularly in the water, and approach the shore: they are very inferior in size to those of the North. They are never caught, though the Negroes are not unacquainted with the art of harpooning them, because those people are engaged in more useful and less perilous occupations. The flesh of these whales is like that of the ox.

The Vicille, is a blackish fish, like a cod, both in shape and taste. It is sometimes poisonous, as well as several other kinds, which, however, are easily known: Those 
who accidentally eat of them are seized with convulsions, which sometimes end in death. In such circumstances their skin falls off in scales. In the island of Rodriguez, which is not more than an hundred leagues distant from hence, the fleet under Admiral Boscawen lost, by the eating this fish, upwards of fifteen hundred men, which occasioned the expedition to fail against the Isle of France. It is supposed that these fish acquire their poisonous quality by eating the branches of the madrepore. The poisonous fish, however, may be known by the blackness of their teeth, or by throwing a piece of silver in the kettle in which they are boiling, which becomes black if they are impregnated with deleterious juices. It is, however, a very singular circumstance, that this fish is never unwholesome to the windward of the island. It is therefore an ill-founded opinion that the madrepores communicate this poison; because the island is surrounded with banks of coral. Others attribute it to the fruit of some poisonous tree which falls into the sea; but this opinion is no better founded than the former; since, among other reasons, the island does not produce any fruit that could produce such a pernicious effect. There is also one kind of wood-pigeon, whose flesh taken as food occasions convulsions: but, as it is a bird of passage, and as this fish is found in every part of these seas, this fatal quality may be acquired on the neighbouring coasts of Madagascar or Africa.

In the number of these suspected fish are several of a whitish appearance, with a wide mouth, and a large head; such as the Captain, and the Carranque. The flesh of these fish is not remarkably good; and those which have a rough bone on the palate, are supposed not to be dangerous.

There are sharks, but they are never eaten.

In general, the smaller the fish are, the less danger there is in eating them. The roach is much larger than, but very inferior to that of Europe: it is considered as wholesome, as well as the mullet, which is very common.

There are pilchards and mackerel, which differ little in appearance from those known to Europeans.

The Poule d'eau, a kind of turbot, is the best fish of these seas: its fat is green.

There are white rays, whose long tails are covered with sharp-pointed bones; and otters, whose skin and flesh are black; the sabre fish, so called from their shape; the moon fish, speckled with different colours; and the purse fish, whose skin is marked with the meshes of a net. There are other fish like our whiting, of red, 
yellow, and violet colours. There are also the perroquet fish, which is green, with a yellow head, and white hooked beak; they swim in shoals, as the birds, from whom their name is derived, fly in flocks.

The armed fish is small and of a very whimsical shape : its head is like that of the pike, which bears on its back seven bony bristles as long as its body, the prick of which is poisonous: they are united by a pellicle that resembles the wing of a bat. It is marked from its mouth to its tail with brown 'and white stripes, like a zebra. There is a fish which is square, like a trunk, whose name has been given to it, and is armed with two horns like a bull : there are several kinds which never attain to any considerable size; as the porcupine fish, bristled over with long prickles, and the polypus, which crawls in the swamps, with its seven claws armed with airholes : it changes its colour, spouts forth water, and endeavours to defend itself against any one who attempts to take it. These strange fish are found in the ledges and reefs of rocks, and are seldom if ever applied as food.

The fresh-water fish are better than ours; and appear to be of the same kind as those which are taken in the sea. Among these the best are the lubin, the mullet, and the carp; the cabot, that lives in the torrents formed by rocks, to which it adheres by means of a concave membrane, and very large and delicate shrimps. The eel is a kind of conger; there are some from seven to eight feet in length, and of the thickness of a man's leg; they retire into the holes of the rivers, and sometimes devour those who are so imprudent as to bathe there.

There are lobsters, or Langoustes, of a prodigious size, though their claws are comparatively small; they are of a blue colour marbled with white. There is a small kind of them, of a most beautiful form; they are of a sky-blue colour, with two small claws, divided into two joints, which are like a knife whose blade turns back into the handle. It seizes its prey as if it were maimed.

There is a great variety of crabs; the following are the most remarkable : a kind, rough with tubercles and prickles, like a madrepore; one which has on its back the impression of five red seals; another, whose claws terminate in the form of an horseshoe. There is a kind also which is covered with hair, is entirely unprovided with claws, and sticks to the sides of ships: there is also a gray crab, with a smooth indented shell, on which appear several whimsical and irregular figures, that are exactly similar on each crab. There is another, whose eyes are placed at the termination of two long tubes', like telescopes. When it does not employ them, it lays them in 
grooves along the side of its shell The sea spider is a crab with red claws, of unequal length. There is also a crab, whose shell is three times larger than itself; thus it appears to be covered as with a large shield, and when in motion its feet are not visible.

In many places along the sea-shore, at a few feet beneath the water, are found great numbers of Boudins, red and black. When they are dragged on shore, they emit a thick, white, and flimsy matter, which is transformed in a moment into a parcel of loose glutinous threads. This animal is supposed to be the enemy of the crabs, among which it is found. Its slime is calculated to embarrass their claws, which are not able to lay hold of its elastic coat, or cylindrical shape. The sailors give it a very gross name, which may be rendered in Latin by mentula monacbi. The Chinese esteem it very much, and consider it as a very powerful stimulant.

There may be ranked also among the shell-fish, a shapeless, soft, and membraneous mass, in the centre of which is a single flat bone, somewhat bent. In this species the common order of things seems reversed, as the animal is without, and the shell within.

There are several kinds of Oursin (Ecbinus marinus): the blue Oursin, with long prickles; in the water its two eyes shine like grains of lapis lazuli; and, among many others, there is one which resembles the bottom of an artichoke.

Of the various snails some remain fixed to the rocks, with an incrusted shell; and others wander about whose shell is smooth and shining. Among the former is the Boucbe d'Argent simple, which, when cleared of its incrustation, exceeds burnished silver in beauty: the Boucbe d'Argent epineuse; the Boucbe d'Or, whose shell is yellow; the river snail, whose black skin conceals a fine rose colour, striped with points d'bongrie: the Persic or Panama Conch, which affords a liquor that gives a purple dye; a long snail, whose mouth is marked with black spots; and several others.

Among the wandering snails are, the fluted Nerite, the smooth Nerite, with red, gray, and black streaks, in all directions: there is a great variety of them. The harp snail, the most beautiful in shape and colour; the same with the addition of prickles; a snail similar to one which is seen in the Azores, that yields a purple juice; and many others.

There is in the Isle of France a smooth and flat Lépas,-the Star Liepas, and 
the Lepas fluviatilis, which, like the other shells found in the rivers of this island, is covered with a black skin; the Oreille de Mer, whose inside is empearled, and a kind of white shell, whose bourellet is still more rounded.

The vermicular, (the Serpula of Linn.) which is nothing more than a white pipe, is supposed to be a fragment of the Arrosoir, (the Serpula penis), a large kind which winds across the madrepores. The Cornet of St. Hubert, a small white vermicular, in a spiral form, and divided into separate partitions, like the nautilus; the Nautilus papyraceus, and the common Nautilus, whose section forms such a fine volute.

Among the Rouleaux, (Conus, Linn.) is a common olive; (Voluta, Linn.) a beautiful olive, which resembles the shades of a velvet of three colours; the black is most esteemed; there are some of five inches in length; a small olive more open; and the common Rouleau, with red spots. These three kinds have an upper skin covered with hair; the Drap d'or; the Tonnerre, whose shell is very small, striped in zig-zaig; the Poire; the Rouleau covered with skin like the Poire, whose mouth has an hollow slit, and is of a fine scarlet; the Ear of Midas is incrusted, but it is of a beautiful lustre; the Grand Casque of a pale yellow colour; the white Casque spotted with purple, and is very small; the Scorpion, covered with skin, and has seven fangs; and, lastly, the Araignée, a large and fine shell, whose lips are of a violet colour, and has a mouth decked with prickles.

Among the Porcelaines, (Cypræa, Linn.) there is a common kind of a reddish brown, à dos d'ane; another, which is spotted like a tyger, and the Carte de Geograpbie, which is rare. There is also the $E_{u} u$, or the egg of a milk white, whose mouth is red and yellow. The Lievre, (Lepus,) of a fine dark red colour, and the Olive de Rocbe, Voluta, whose shell is very brittle.

Among the $V i s$, the common speckled $V i$ is is very long; there is another equally beautiful, whose spiral form is accompanied with a moulding; the Enfant en Maillot, more swelled; another equally large called the Culotte de Suisse, whose colours and lustre are very fine; a small $V i s$ with a kind of beak, with an hole pierced in it: another à dos d'âne, that is also pierced; the fuseau blanc, which is rare; the fuseau with red spots; the maritime Mitre, marked with the same spots; the Mitre fluviatilis, which is covered with a black skin.

It is a singular circumstance, that all the univalves are turned from left to right, the shell being placed on its mouth, and the point towards the person who regards it. Exceptions from this general rule are véry rare. If it were asked, by what law 
their volute always turns to the same side? it may be answered, by the same law which makes the earth turn from the west to the east. In that case, the sun may be the efficient cause, as it is of their colours, which increase in beauty as we approach nearer to the line.

The Scorpion, which has very long claws, increases its shell every year. Its old claws become useless, and it forms new ones. It may be asked, what it has done with the old ones? In the same manner the Porcelaine has a thick mouth, which is formed in such a way, that it cannot augment its revolutions on itself, if it does not succeed in destroying the obstacles to its opening. It is not improbable, that these animals possess a liquor capable of dissolving the walls of the roof, which they wish to enlarge, and if this dissolvent exists, it might be employed for the stone in the bladder, and to destroy those glutinous humours, which resemble the prima materia of shells.

Among the Bivalves, are the common Oyster which adheres to the rocks, and is of so rude a shape, that it is necessary to employ an hammer to open it: it is good to eat; a kind which is called the leaf, on account of its form; a gray oyster which sticks to the sides of ships, and whose shell is beautiful and elastic: this is very rare. The pearl oyster is white, flat, thick, and very large; it is found at a greatdistance from land, and is the same as that in which pearls are found; another pearly oyster which is still flatter, and of a deep violet colour; it attaches itself by means of threads, like the muscle. It is very common at the south-east port, and is found at the mouths of the rivers. Its pearls are of a violet colour.

The oyster called la Tuillée, is by no means uncommon; it is of the same kind as those, which serve as holy-water pots in the church of Saint Sulpice. It is perhaps the largest shell fish of the sea. There are to be seen of them, at the Maldivian Islands, which require the strength of two oxen to drag them along. It is a very curious circumstance, that this oyster is found in a state of petrifaction on the coast of Normandy.

There is also a kind of oyster which is very small, and of a grey colour, that resembles, in shape, a Polish saddle; the thorny oyster, which is found in the beds of coral, and the Pelure d'oignon, or onion peel, of which we have seen only some detached shells.

There are three kinds of muscle, which are neither curious nor common: they resemble, in shape, the dail of the Mediterranean, and are found among the 
madrepora: there is also a white muscle, with an elastic shell, which incorporates itself with the sponge; it is an intermediate gradation between two kinds.

The Hacbe d'armes is of the muscle kind, and is formed like a battle axe, with the hatchet on one side, and a point on the other; it is covered with asperities, and opens with a simple elastic plait.

Among the cockles, is the Arcbe de Noe, whose extremities rise like the poop of a vessel; the Cout de Bouf, one side of which is irregular; the Corbeille, whose flutings blend with eacb other; the Rape, whose stries, or gutters, are formed by arches which cross one another; a common cockle, with a slender shell, the inside of which is tinged with a deep blue; another sort, which is very beautiful and scarce, and marked on the outside like embroidery; the Peigne, and the Manteau ducal, of a fine Aurora colour.

There is every appearance, that the shell fish have their hostilities as well as other animals, as the shattered remains of them are continually found on the shores; and those which are taken in an entire state, are always pierced in different parts. There is a snail, armed with a sharp tooth, with which it wounds the shell of the muscle. It is found in the straits of Magellan, and is called the armed Burgau.

To obtain fine shell fish, they must be taken alive. Those, whose covering is clear, live on the sand, where they take refuge in stormy weather: others cling to the rocks: the muscles take abode among the branches of submarine plants, where they do not multiply in a great degree : if they were to spawn on the rocks, as in Europe, the hurricanes would destroy them.

There is much variety in the hinges of the shells of fish, which the artisan might imitate with advantage. The oyster has but little leather, which incorporates with the stony substance: the muscle has a strong elastic skin: the bacbe d'arme has but one fold: the cour, if regular, has some small teeth at its hinge, which lock in one another; and if one of its sides extends, the hinge increases on the side where the weight preponderates, and the teeth which form it have a porportionable strength. An admirable principle of geometry is visible in their curb.

The Isle of France is entirely surrounded with the madreporæ, which are stony vegetations, in the form of plants and shrubs. They are in such abundance, that the rocks are entirely formed of them.

They may be distinguished by those which do not spring from the earth, and those which are attached to it. 
Among the first are the Cbampignon, which appears to be composed of leaves; the Plumet, which is of the same kind; the Plumet, with three and four branches, and the Cerveau de Neptune.

A mong those which decorate the bottom of the sea, and which appear to hold to the earth by their roots, are the Cbou-fleur; the $\mathrm{Cbou}$, whose leaves and appearance resemble very much that of the garden vegetable of the same name: it is of a large kind, as well as a madrepora, in a spiral form, and which is very brittle; another, which resembles a tree in its bark and branches, a very pretty kind, which is called the Gerbe, that seems to be formed of several clusters of ears of corn; the Pinceau, or the pink; in the centre of each segment, a small quantity of green is remarkable; a common kind, forming a tuft like the Reseda, with its conic flowers; a very pretty one, which grows in the form of an island, with its shore and its mountains; another, which resembles a congelation; a kind, whose foliage branches out like the fingers of the human hand; the Bois de Cerf, whose branches are detached and brittle; the Rucbe a Miel, a shapeless mass, whose surface is regularly perforated with holes; a coral of a pale blue colour; withinside it is of a darker blue, and a coral, distinctly marked with black and white, which has something of the nature of the red coral, that has not yet been found here. Here are also several coralline vegetations of various colours, which are so brittle, that they cannot be conveyed to Europe.

Among the Litbopbites, there is a plant resembling a long straw, which has neither foliage, knots, or blossoms; there is also a vegetation, like a small forest of trees, whose roots are very much interwoven, and each of them has a small bunch of leaves. The substance of this lithophite partakes of the nature of wood, and burns like it in the fire; it is, however, in the class of the madreporæ. There are also three kinds of marine stars, which do not suggest any particular remark.

It is no longer doubted, that the madreporæ are the work of an infinite number of small animals, although they bear an exact resemblance to trees, by their appearance, stem, branches, and mass, and even by their flowers, which display the same colour as the blossom of the peach tree.

Ambergris was formerly found on the coast, and there is even a small island to the windward which bears its name. 


\section{Native Animals.}

- According to the Abbé de la Caille, monkies were brought into the Isle of France by the Portugueze. The Monkey of this island is of a moderate size, with hair of a reddish-grey colour, and rather thick. It has a long tail, and is gregarious. These animals frequently venture to plunder the houses of the inhabitants; on which occasion they place sentinels on the rocks and in the trees; and when they perceive the dogs and hunters coming in pursuit of them, they set up a cry, and the whole of this curious party decamps. It climbs the highest mountains, and reposes above the precipices, on the smallest projections. It is the only quadruped of its șize that exposes itself in such a situation.

It is supposed, that formerly the Flamingo (Phænicopterus) was common in this island, but at present the number is reduced to a very few. It is a large handsome sea bird, whose plumage is an intermixture of black, white, and rose colour.

There is a considerable number of Corbigeaux, which are considered as the best game of the island: it is very difficult to shoot them.

There are two sorts of the Paille en Cul (the Phaéton æethereus of Linn.); the one of a silver white; the other having the beak, claws, and rump, red. Although it be a sea bird, it builds its nest in the woods. The English call it the Tropic Bird.

There are several kinds of Parroquets, with a gray capuche : they are of the size of a sparrow, but can never be tamed. They are good to eat.

The woods produce Blackbirds, which at the call of the hunter come to the end of his gun. They are considered as game.

We shall now mention an animal of a very singular nature, which $M$. de Buffon calls the great Bat of Madagàscar.

It is about a foot in length, from its posterior extremity to its beak, and its wings stretch to about four feet; it has large canine teeth, consisting of four in the upper, and as many in the lower jaw. Its muzzle is black and sharp; its ears large and bare; its talons are hooked, large, and compressed : it has no tail. These bats are of different colours; some of a bright red, others brown, and some are almost black. They resemble the common bat in their interior conformation, the shape of their wings, and the manner of spreading them when they fly. When these animals repose, they cling to the tops of the highest trees, and hang with their heads downwards. At other times, they fix themselves upon animals, and even upon man himself. They 
feed indifferently on fruit, flesh, and insects. They are so fond of the juice of the palm tree, that they sometimes intoxicate themselves with it, so as to fall to the ground. Their horrid shrieks are heard, during the night, in the forests, at the distance of two miles, but they retire at the approach of day. Nothing is safe from the ravages of these destructive creatures; they equally destroy the wild and domestic birds, whenever they have an opportunity; and they will sometimes attack the human kind, by seizing and tearing the visage. It is very probable, as $\mathbf{M}$. de Buffon has observed, that the ancients borrowed their idea of the harpies, from these terrible animals. The Indians consider them as a palatable article of food, particularly in certain seasons of the year, when they are full of fat: and even some of the French people, both in this island and the isle of Bourbon, have brought themselves, in this particular, to follow the Indian example. The Negroes, however, hold them in the greatest horror; and no consideration whatever could induce them to have any other concern with these noxious creatures, but to destroy them; for which purpose they employ uncommon dexterity. It has often happened, that persons have been attacked, while asleep, and bled to death by them, as they are powerful and subtle bloodsuckers; so that it is really dangerous to slumber in the open air, or to let them enter into an house during the night.

There is a kind of hawk, called the Chicken eater, which is said to feed on grasshoppers. It dwells on the sea shore, and discovers no appearance of alarm at the sight of man.

Formerly there was great plenty of turtles on this coast; but at present they are very much diminished.

The sea shore is full of holes, which are inhabited by great numbers of Tourlouroux, which are a kind of amphibious crab, that dig under the earth like a mole. They run very fast, and when they are in danger of being taken, present the points of their claws, with which they make a kind of ringing noise. They are of no use whatever.

Another very singular amphibious animal, is the Bernard l'bermite (Cancer Beruhardus, Linn.), a kind of lobster, whose hinder part is without a shell; but nature has instinctively taught it to lodge that part in any empty shell it can find. They are seen running about in great numbers, each of them carrying its borrowed house, which when incommodious, from its being too small, it changes, as opportunity serves, for one that is more capacious. 
The most noxious insects of the island are the Locusts, which are well known for the injury which agriculture receives from them.

There are several kinds of caterpillars, some of which, as that of the Citronnier, are very large and beautiful.

There is also a nocturnal butterfly, which bears on its corselet, a death's head (the Atropos, or tête de mort.) It frequents, and flies about, the interior apartments of houses.

The Centipede (centpieds, scolopendre), is frequently seen in obscure and humid situations. It is not improbable that this insect was designed to kecp man from unwholesome places. Some of these insects attain the length of six inches, and ants have been seen to seize their legs, and to drag them along like a piece of timber.

The Scorpion inhabits the same moist places; its bite is not mortal, but it produces a fever, which is cured by rubbing the affected part with oil. This insect is the only one in the island, that is noxious to man; but it is become much lis's venemous than formerly.

There are bees which produce excellent honey.

There is a kind of insect that resembles the ant in appearance, nor is it less sagacious in forming its abode. These creatures make a sad havock among the trees, and timber, whose wood they pulverize, and with the dust form arches of about an inch in breadth, over which they pass and repass. These insects, which are called Carias, and are black, will sometimes over-run the whole timber-work of an house : They will make their way into trunks, and other pieces of furniture, in the course of a night. The most certain remedy against their depredations, is to rub the places which they frequent, with garlick.

There are three kinds of Cancrelas (Blatta Indica), a kind of beetle. One of them is of a flat shape and a gray colour, but the most common is of the size of a may-bug, and of a reddish-brown colour. This Cancrelas, or kakerlaque, is a Coleopterous insect, which soils and destroys every thing. It is called Ravet in the Antilles; though the Cancrelas of the Isle of France is larger than the Ravet of St. Domingo, but is equally troublesome by piercing the water-casks in ships, and making holes of two inches in circumference.

It has for its enemy a kind of beetle, or green fly, which is very active and light ; and whose touch alone renders it motionless. The beetle then drags it along till it finds a chink to deposit its victim, it then lays an egg in the body of the Caicrelas, 
and abandons it. This touch, which some have supposed to be a charm, is the puncture of a sting, whose effect must be very prompt, as that insect is of a very hardy nature.

In the trunks of trees is found a large worm with claws, which gnaws the wood: it is denominated a Moutouc. Not only the black, but the white inhabitanis, consider it as palatable food. Pliny observes, that it was a favourite dish at the first tables in Rome, where it was the custom to fatten it with flour. 'Those were highly esteemed and preferred, which were found in the trunks of the oak. It was called Cossus.

The kinds of flies which are common with us, are to be found here. The gnat, called Moustique, or Maringouin is very troublesome, as in every place which it frequents: its hum is very loud. This gnat is black, spotted with white. Gauze curtains, which are called mousticaires, are employed as preservatives against it during the night.

On the banks of rivulets are seen the insects called Demoiselles (Libellula), which are of a fine violet colour, and whose head is like a ruby. This is a carnivorous insect, and feeds on butterflies.

There is a small beautiful Lizard about four or five inches. in length, with very lively eyes, which is to be found in the houses. It crawls up the walls, and even along the glass of the windows. It feeds on flies and insects, for which it will lay in wait with extreme patience. It lays small round eggs about the size of a pea, which are white spotted with yellow. Some of them are rendered so familar as to take sugar from the hand. They are very innocent, and as they destroy the insects, are considered as beneficial domestic associates. There is a kind of them which inhabit the woods, and is extremely beautiful; being of an azure colour inclining to green, with crimson streaks on the back, which resemble Arabic characters.

But a more formidable enemy to the insects is the Spider.-Some of these are as large as a nut, with long legs covered with hair. Their webs are so strong, that small birds are taken in them. They destroy also wasps, scorpions and centipedes. The mild temperature of this climate, so much desired by the inhabitants of Europe, is favourable to the propagation of insects which devour fruit. But the fruits of these Southern countries are clothed with such thick rinds, hard skins, and aromatic barks, as the orange, the lemon, \&c. that there are very few kinds in which the fly can deposit its worm. Many of these insects also are in a continual state of hostility, as 
the centipedes and the scorpion. The Formicaleo lays its snares for the ants; the green fly stings the cancrelas; the lizard pursues the butterfly; the spider prepares its nets for every insect that flies; and the hurricanes which formerly arrived every year, destroy both the pursuer and the pursued.

\section{Animals brougbt into the Isle of France.}

Foreign fish have been even brought to this place. The Gourami comes from Batavia. It is a fresh-water fish, and is esteemed to be the best in the Indies. It is like the salmon, but more delicate. Here are also the gold-fish from China, which lose their beauty as they increase in size. These two species multiply in the pools. Several ineffectual aitempts have been inade to transport frogs. hither, which cat the eggs which the Moustique deposits on the stagnant waters.

A bird has been brought from the Cape which is extremely useful: The Dutch call it the Gardener's Friend.

It is of a brown colour, and the size of a large sparrow. It feeds on worms, caterpillars, and small snakes. . But it not only eats them; ; it also provides a store for its future wants, by hanging them up on the hedges; and if deprived of its liberty; will contrive to suspend a portion of the meat which is given to it, on the wires of its cage.

The Martin has multiplied very much indeed, in this island. It is a kind of Indian starling, with a yellow beak and claws. It scarcely differs from that of Euröpe but in its plumage, which is less spotied, It has the same warble, the same aptitude to articulate words, and the same actions. : It counterfeits other birds, and settles on animals to pluck their hair; but it is most remarkable for its greedy consumption of grasshoppers. They always go in pairs ; and at sunset asssemble in thousands, on certain trees which they prefer. After a general warbling, the whole flight goes to rest; and at break of $\mathrm{d}_{\lambda y}$ they disperse in pairs through different parts of the island. This bird is not eatable.

Several couple of Ravens had been let loose in the woods, to destroy the rats and mice, of which there remain but three males. The inhabitants accused them of devouring their chickens.

It is not possible to pass over the mischief occasioned by the Cape Bird, a kind of small singing bird which is very melodious. They were at first brought here from curiosity, but some of them escaped into the woods, where they have greatly! 
multiplied. They subsist on the fruits of the harvest, and the government has set a price on their destruction.

There is a very pretty Tom-tit, whose wings are dotted with white spots; and the Cardinal, whose head, neck, and belly, at a certain season of the year, are of a bright red; the rest of its plumage is a fine pearl colour. This bird comes from Bengal.

There are three kinds of Partridge much smaller than ours, and their cry resembles that of a hoarse cock. They roost, during the night, on the trees, as in other hot countries.

The fine Pheasant of China, and Pintades, have been let loose in the woods. Geese and wild ducks have also been introduced to the pools of water; there are also tame ones, and among others the Manilla duck, which is very beautiful. There are our European fowls; a kind of African fowl, whose skin, flesh, and bones are black; and another sort from China, the male of which is remarkable for its courage.

Many of the inhabitants derive considerable advantage from their poultry, on account of the scarcity of meat. Pigeons succeed very well here, and they are the best fowl of the island. Two kinds of turtle doves, as well as hares, have been brought hither.

In the woods, there are goats, wild hogs, and deer, the latter of which have multiplied in such a manner, that a squadron of ships has been victualled with them. Their flesh is excellent, particularly in the months of April, May, June, July, and August. The flocks which have been domesticated have never multiplied.

Among the domestic quadrupeds, there are sheep who loose their wool, goats which thrive, and cattle which come from Madagascar, and have a large wen on their necks. The cows give very little milk, and their calves degenerate.

There is sometimes a total want of butchers' meat; but the inhabitants have a resource in pork, which is better than that of Europe; it does not, however, make good salt meat, which proceeds from a defect in the salt. The female pig is very subject, in this island, to produce monsters.

Horses are very dear; a common one will cost an hundred pistoles. They fall away at the port, on account of the heat. They are never shod, though the island is full of rocks. Mules are very scarce here; and the asses are small and rare. The ass might become the most useful animal of the country, as it would ease the labour of the Negroes. 
Some time ago two very fine wild asses, male and female, of the size of a mule, were brought from the Cape. They were streaked on the shoulder like the zebra of the Cape, though there is a considerable difference between them. These animals are of a nature that cannot be tamed.

Cats have degenerated here; the greater part of them are thin and emaciated, nor do the rats discover any very great apprehension of them. Dogs are much more effectual in destroying these noxious animals; but in the course of time they lose their hair and their scent. It is said, that they are never known to go mad in this island. 


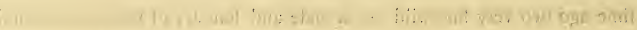

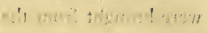

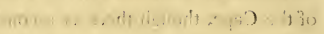
, : 114.,

\section{CHAPTER III.}

Manners of the Inbabitants.-Account of the Blacks.-Theory of the Island, and its Caverns.-Some general Observations on the Isle of France, by M. le Gentil. -Luminous Globes, E̊c.
\end{abstract}

$T_{\mathrm{HE}}$ Isle of France was an absolute desert when Mascaregnas discovered it. The French who first established themselves there, were certain planters from the Isle of Bourbon, who brought with them simplicity of manners, good faith, an hospitable disposition, and an indifference for riches. M. de la Bourdonnais, who may, in some degree, be considered as the founder of this colony, brought some workmen along with him. When, however, he had rendered this island interesting by his labours, and it was thought convenient as a staple for their commerce of the Indies, persons of all conditions settled in it.

The agents of the Company, who possessed all the principal employments in the island, exercised too much of that financial disposition, which is discouraging to those who are employed in cultivating the earth. The whole of the public establishment was at their disposal; they, at the same time, controlled the police, the civil administration, and magazines of the island; some of them cleared the land and built houses, all of which they disposed of, at a very high price, to those who had ventured hither, in hope of advancing their fortune. There was consequently a great outcry against them; but the power was in their hands, and complaint was of no avail.

Several persons in the marine service of the Company settled here. They had long complained, that while they encountered dangers and suffered fatigues in support of the East Indian commerce, others acquired the honours and emoluments of it. As this settlement was so near to India, a sanguine hope of advantage from fixing in it nimated their mind, and they became its inhabitants.

Several military officers of the Company arrived here; they were very respectable 
persons, and some of them distinguished for their birth. They could not imagine that an officer would debase himself so far as to receive ordẹrs from a man who had formerly been a clerk in an accompting-house, though he might condescend to receive their pay. Nor did they like the sailors, who are rather too peremptory in their manners. On becoming inhabitants, they retained their original disposition, and consequently did not advance their fortunes.

Some of the King's regiments put in here and made some stay; while several of the officers, allured by the beauty of the climate and the love of repose, were induced to establish themselves in the island: but every thing was at the disposition, and submitted to the power of the Company.

The inhabitants were also increased by the arrival of some missionaries of the order of St. Lazarus.

To complete the settlement of this island, some merchants with small capitals arrived, and found it without commerce.' These people augmented the abuses of money jobbing, which they found already established, and employed themselves in, forming petty monopolies : they soon became obnoxious, and acquired the name of Banians, or Ferws. On the other hand, they affected to despise any particular distinctions of the inhabitants, and were fond of propagating the opinion, that, after having passed the line, a general equality prevailed.

Such was the situation of this colony when it was ceded to the King in the year 1765 .

One part of the inhabitants, who were attached to the Company from gratitude, beheld, with pain, a royal administration; while the other part, who had so long looked for the favour from a new government, seeing it principally occupied in plans of economy, were proportionably chagrined and disappointed.

The soldiers furnish a considerable number of workmen, as the moderate heat permits the white people to work in the open air ; though they have not been rendered so beneficial to the colony as they might have been, in a more enlarged disposition of their capacities.

Though the seafaring people are always going and coming, they have, nevertheless, a considerable influence on the manners of the colony. Their policy is to complain alike of the places which they left, and of those at which they arrive: they have always bought too dear and sold too cheap, and think they are ruined if they do not gain an hundred and fifty per cent. 
An hogshead of claret costs five hundred livres, and every thing else in proportion. It is scarce credible, that the merchandize of Europe is dearer here than in India; and that Indian commodities fetch a higher price here than in Europe. The maritime people are so necessary to the inhabitants, that they are held in great consideration.

The greater part of the married people live on their plantations; and the women seldom visit the town, but when they are tempted by a ball, or are called to perform some essential duties of their religion. They are passionately fond of dancing; and no sooner is a ball announced, than they come in their palanquins from every quarter, as the roads will not admit of wheel carriages.

The women have but little colour, but they are well made, and, in general, handsome. Nature has given them a considerable portion of wit and vivacity; and if their education were not neglected, their society would be very agreeable : they are very fond mothers; and if they ever fail in fidelity to the marriage vow, it is too often owing to the indifference of their husbands, or to the Parisian manners which have been introduced among them. Their ordinary dress is fine muslin, lined with rose-coloured taffetas.

They possess, in a great degree, the more estimable domestic qualities; they seldom or never drink any thing but water, and their cleanliness is extreme. Their children are never confined in swaddling clothes, but run about almost as soon as they are born; they are often bathed, and allowed to eat fruit at their own discretion. As they are left entirely to themselves, and are uncontrouled by the superintendance of education, they soon become strong and robust, and their temperament advances in proportion. The females are sometimes married at eleven years of age.

There are about four hundred planters in this island, and about an hundred women of superior rank, not more than ten of whom live in the town. On firing the evening gun at eight o'clock, every one retires to his own habitation.

\section{The Blacks.}

Of the population of this island, we must consider the Indians and Negroes as forming a considerable proportion.

The first are from the coast of Malabar, and are a very mild and gentle people: 
they come from Pondicherry, and let themselves out for a certain number of years. They are almost all of them workmen, and occupy a suburb which is called the Black Camp; they are of a deeper colour than the islanders of Madagascar, who are real Negroes, have the features of Europeans, and their hair is not woolly : they are sober and economical. Their head is dressed with a turban; and they wear long dresses of muslin, with large gold ear-rings, and silver bracelets at the wrists. There are some who enter into the service of the rich and titled inhabitants, as pions; a kind of domestic, which answers to the character of an European running footman : his peculiar distinction is a cane in his hand, and a dagger at his girdle. It were to be wished that there were a greater number of the inhabitants of Malabar established in this island, particularly of the cast of husbandmen.

At present, Madagascar furnishes the Negroes which are destined to cultivate the land in the Isle of Bourbon. The common price of one of them is a barrel of gunpowder, a few muskets, some pieces of cloth, and, above all, a certain proportion of piastres. The dearest of them costs about fifty crowns of France.*

These people have neither so flat a nose, or so dark a complexion, as those of Guinea; some of them are only brown; while others, as the Balambous, have long hair: nay, others of them have fair, and even red hair. They are dexterous, intelligent, and have a sense of honour and gratitude. The greatest insult which can be offered to one of these people, is to speak disrespectfully of his family; they are far less sensible to personal injuries. In their own country they work up various articles, with equal ingenuity and industry. Their zagaye, or half-pike, is very well forged, though a couple of stones form their hammer and their anvil. The linens which their women weave are very fine and well dyed; these they cast around them in a graceful form, and the manner in which they arrange their hair produces a pleasing headdress; it consists of curls and tresses very tastefully blended with each other, and is the work of the women. They are passionately fond of dancing and music; their instrument is the tantam, which is a bow fixed to a gourd, from whence they draw a soft harmonious sound, with which they accompany the airs that they compose. Love is the general subject of them, and the girls dance to the songs of their lovers: the spectators beat time and applaud.

They are very hospitable. A black who is on a journey, enters without previous ceremony, or being known to the owner, into any hut which suits his convenience;

- In 1768. 
and those whom he finds in it most willingly share their meal with him. Nor is it their custom to ask from whence he comes, or whither he is going.

Such are the qualifications and manners with which they arrive at the Isle of France. They are all disembarked with no clothing of any kind, but a strip of linen round their loins. The men are placed on one side of the beach, and the women with their children on the other. The planters then examine them, and make their purchases accordingly. Brothers, sisters, friends, and lovers, are now separated, and are led away to the respective plantations to which they are destined. Sometimes, in the paroxysms of their despair, they imagine that the white people are preparing to eat them, that they make red wine of their blood, and gunpowder of their bones.

Their manner of life is as follows : at day-break, the smacking of a whip is the signal that calls them to their work : and they then proceed to the plantation, where they labour in a state of almost entire nakedness, and in the heat of the sun. Their nourishment is ground maize boiled in water, or loaves of the manioc; and a small piece of cloth is their only covering. For the least act of negligence, they are tied hand and foot to a ladder, when the overseer gives them a certain number of strokes on their back, with a long whip; and with a three-pointed collar clasped round their necks, they are brought back to their work. It is not necessary to describe the severity with which these punishments are sometimes inflicted. On their return to their habitations in the evening, they are compelled to pray to God for the prosperity of their masters.

There is a subsisting law in favour of slaves, called the Code Noir; which ordains that they shall receive no more than thirty strokes at each chastisement; that they shall not work on Sundays; that meat shall be given them every week, and shirts every year: but this law is not observed.

The Negroes are naturally of a lively disposition, but their state of slavery soon renders them melancholy. Love alone seems to allay their pain : they exert themselves to the utmost in order to obtain a wife; and, if they can choose for themselves, they always prefer those who are advanced into a state of womanhood, who, they say, make the best soup. They immediately give them all they possess; and if their wives live in another plantation, they will undertake the most difficult and dangerous journies to see them. On such occasions they fear neither fatigue nor punishment. Parties of them sometimes meet in the middle of the night, when they 
dance beneath the shelter of a rock, to the mournful sound of a gourd filled with peas.

The discontented Negroes generaliy fly for refuge into the woods, where they are pursued by detachments of soldiers: when they are taken, they are punished with great severity; and the third offence of this kind is followed by death.

Religion is, indeed, sometimes employed to alleviate the evils of their situation. Some of them are occasionally baptised: they are then told that they are become the brethren of the white people, and that they will go into paradise; but it is not an easy matter to persuade them, that the Europeans will ever prove their guides to heaven.,

It is not for us to discuss, in this place, the subject of slavery; on which very able writers have differed, and with which volumes have been filled. That discipline, and sometimes a severe one, may be necessary in the management of plantations, cannot be denied, and that the owners sometimes exercise their power with unnecessary rigour, must also be acknowledged; at the same time it would be ridiculous to assert that, because a white man is the master of a plantation, he must be cruel, and because a black man is a slave, he must be wretched. We shall conclude this subject with some remarks of the late Admiral Kempenfelt, made by him in the year $175^{8}$.

"The slaves of Madagascar are the most inclined to desert from their masters. Many of them, incited by the love of liberty, have retired into the most inaccessible woods and mountains, and, forming themselves into bodies, attack the plantations in which they have been slaves. The mischief they occasion is sometimes very destructive, both to the plantations, as well as to those who inhabit them. When they are impelled by hunger, neither domestic or wild animal, not even the monkies escape them. They also make a kind of short spear or javelin, which they throw to a considerable distance, and with great dexterity. Many, on their desertion, have put out to sea in canoes which they have stolen, and have trusted to the mercy of the waves, in order to regain their native island of Madagascar; and it is known that some of them, by the force of the currents, and the favour of the winds, which generally blow that way, have arrived there, having been recognized by French people who had seen them at Mauritius.

" Many of the black Maroons have been taken and destroyed by the detachments of troops that are sent after them; they are still, however, numerous, and from the 
ferocity of their character, the subject of continual alarm to the planters who live in the vicinity of the forests which they inhabit. When they are taken, they are punished with the greatest severity; but what appears perhaps to be a cruel treatment, is the effect of dire necessity, as the French are naturally humane; and if very severe examples were not made, they would not live in safety. It is indeed well known, that many inconveniences have resulted from the indulgence of the planters, particularly in granting liberty to the favourite slaves; so that it has been absolutely necessary to abridge that power, and to limit freedom to those alone who have saved the life of their master."

\section{The Theory of the Island, and its Caverns.}

On a first inspection of the surface of the Isle of France, there is every reason to imagine, that it has undergone some violent shock; and that all the stones which are found on it have been thrown out of a volcano; or that they have proceeded from some general explosion in the island, which has occasioned the disorder wherein they now appear. Such is the general opinion in the island; but it is not from an inspection of the exterior soil alone, that a right judgment can be formed of the early state of the Isle of France.

When the causeys were made which serve to pass the ravines at the entrance of Moka and the Plains of Willems, a rampart was thrown up to the right and left, in the adjoining highlands, from twelve to fifteen feet in height, and the earth that was taken from them served to form the upper part of the causeys. On digging to raise these ramparts a reddish earth presented itself, intermixed with blocks of stones of different sizes, but almost all of them round. These stones are not solid, and are very brittle; and their grain is the same as that of the hard stones which are found in other parts of the island: they are enveloped in a kind of hard crust, of the same co. lour as the ground from which they were extracted. Every part of the island contains these stones in great abundance; some of them are of an enormous size. When the surface of the lands have been cleared, fresh ones alway's appear after a succession of rains ; particularly in those parts where the land descends, as on the Plains of Willems.

These stones are formed in the ground, and harden there as in a quarry: they cannot be broken or worked but by gunpowder and the hammer; they are withal 
very porous, and covered with small holes of little depth, whose cavities are filled with a kind of crystalization.

The source of the Rampart river is in a mountain which cannot be less than twelve hundred feet in height. The woods, which are beautiful towards the bottom of it, diminish in its ascent, and at the top dwindle into young trees and shrub-wood. There is the fountain-head of the river, which falls a few feet in the form of a cascade, into a small bason. The water issues from the ledge of an horizontal rock which rests on a thick bank of earth of a greyish-white colour, and of a consistence to be cut with a knife, but does not harden in the air. It is covered with an infinite number of small black spots, which have the appearance of coal, but are, more probably, particles of ferruginous matter.

In a valley at the foot of the same mountain there is very excellent stone for building, which appears to be of the same nature, or at least to have the same grain as the earth that is at the top : it is pierced also with holes, and is full of the black particles; from whence it may be concluded, that these stones are formed in the bosom of this mountain, that the substance was originally as soft as that of the earth, and that the rains and torrents having worn away one part of the mountain, these rocks have been carried down into the valley.

At the foot of the mountains of Villebague, on the road which leads to a deep bottom called Nicoliere, stones of the same kind are seen in the channels formed by the rain; they are in an half-hardened state, and have been uncovered by the impetuosity of the torrents. These stones, which are of about two or three pounds weight, are easily broken; and the more so, as by being exposed to the air, they are already cracked; they are covered, as well within as without, with spots of different dimensions, for the most part of a bluish cast; which are, without doubt, particles of iron ore.

The same cause which has formed and hardened all these rocks in the earth, has formed and hardened those which are so numerous in all the rivers of the island. These rocks, that continually interrupt the course of the rivers, appear as if they had been artificially heaped upon one another.

This effect is remarkable in an hundred parts of the island, but principally in the river of Pamplemousses on quitting Villebague, which is a plain, considerably elevated above the district of Pamplemousses. This river is very much inclosed, and consinues to be so for the distance of a quarter of a league, while the ground sinks in 
that length from two hundred and fifty to three hundred feet, which forms a considerable declivity. In this extent of a quarter of a league, the bed is from sixty to eighty feet beneath the surface of its banks; and, like the other rivers, is full of rocks which have fallen to the bottom of the precipice. The river is no more than ten feet broad beneath these frightful ramparts, which afford an intermediate space of three hundred feet at their summits. On each side, on these precipices, there are rocks, many of which are half bare, while others appear to have so slight an hold, as to awaken the expectation that the next moment will precipitate them to the bottom. During three parts of the year these rivers may be crossed by stepping from rock to rock.

Besides the rocks or stones which are formed in the bosom of the earth, large banks or ranges of them are very frequent, whose clefts are filled with a crust of earth which is very hard, and generally ferruginous; a sufficient proof that the form of the island has not been effected by any violent concussion of the earth. These banks are of a different thickness from eight to ten feet, and seldom more. It is a range of this-kind which interrupts the river between the Reduit and the plains of Willems. The stream flows over it, and then precipitates itself in a fall of more than sixty feet, forming a magnificent cascade. The river of the plains of Willems, as well as that of Moka, have similar falls. Immediately after these three cascades, which are almost upon the same line, and all of them within the space of half a league, the three rivers unite to form one stream, which is called the Great river.

The banks of stones exactly correspond to each other on both sides of the river; they are from eight to ten feet thick, and have no other inclination than that of the ground which supports them. In these ravines may be distinguished three or four banks of the same kind, one above the other, and separated from each other by beds of earth of an equal thickness, which contain other rocks, like those which have been already mentioned, that cover the surface of the island.

There is likewise a very remarkable example of these beds of horizontal rocks, in the plain that leads from the port to the Royal battery. This plain is covered with stones from the foot of the mountain of the Decouverte, Here also is obtained the stone which is used in building,

In the same plain, on the road from the port to Moka, facing the right side of the first river, and on the top of the declivity, at some hundred paces from the brink, there is an horizontal bed of large rocks, about one hundred fathom long, 
and composed of two ranks of enormous rocks, placed on each other, which resemble the artificial foundation of some vast edifice. They are likewise split in a perpendicular manner, and the clefts seem to have been filled with some kind of cement, This range had certainly been covered with earth, like those which are found in the neighbouring plain, between the port and the Great river: but, from its elevated position, the torrents have, by degrees, carried away the ground that covered it into the neighbouring ravine.

About half way between the plantation, in which the forges are established, and the Bay of Turtles on the shore, at about a league from the sea, is a frightful solitude. It consists of a large open country, whose surface is parched, barren, and rocky, with horizontal banks of stone which are level with the earth in some places, and in others only present their points, \&c. Numerous spots of this kind seem to militate against the opinion, that the island is nothing more than various beds of matter, heaped upon one another.

Over the Rampart river, on the road leading to Flacq, about three leagues from Port Louis, is a bridge which was constructed in 1770, and certainly does not announce the progress that has been made in the construction of bridges and causeys within the last fifty years: but the object which more particularly engages our attention in this place, is a ledge of rocks beginning at this bridge, and stretching along the sands in the road of Flacq. At the bridge the river takes a bold meander, which forms a kind of peninsula or isthmus. To the right, in going to Flacq, the bank is interrupted and divided by the course of the river, which is not more than from twenty-five to thirty feet wide at the bridge; so that it has the appearance of having been cut away to give a free current to the water. It is the more remarkable, as this bank, which is ferruginous, is of the greatest hardness: the two beds of stone, also, exactly correspond with each side of the river. This bank is formed of beds from one to two feet in thickness; it rests upon the ground, and is a little inclined towards the water, which proves that it has given way on that side. In some parts the ground beneath has been carried away, and has formed what appears to be the hollow entrances of a cavern. A little farther onward are to be seen some portions of the same bank, which, having been broken off above, have probably fallen into the river. Continuing the road to Flacq, at sixty or eighty fathom from the bridge, this bank is like the upper part of a large vault, from thirty to forty fathom broad: it stretches out very far to the right and left, and 
loses itself in the woods. It cannot be doubted that this vault, for it is certainly made by the hand of nature, rests on a bed of earth, and that this bed in the course of time being carried away by the water, a cavern will remain in its place: perhaps the cavern already exists. In fact, at the mouth of this same river at the distance of two or three leagues, there are several caverns of great depth. A great part of the road which leads from the river of the rampart to Flacq, is formed on beds of rocks : in some places it appears to be hollow, and resounds beneath the horses' feet.

A part of the plantations in the highlands of Flacq, are absolutely horrible, from the quantity of rocks which they contain. There are also plots which consists only of one single rock, some parts of which are rather more elevated than the others, and have the appearance of flag-stones. The low plantations, which are nearest to the sea shore, have fewer rocks, and a better soil, which is maintained at the expence of the highlands, whose earth is carried off by the waters, and spread on the lower grounds.

So many facts and circumstances, and many others of the same kind, which are visible to every eye, seem to contradict the opinion of volcanoes in the island, and an universal change in the state of it.

\section{Observations on the Isle of France, by M. le Gentil.}

M. le Gentil also delivers the following opinion. "They say in the country, that "volcanoes have pervaded every part of it. If however, there have been any volca" noes in the Isle of France, the part which I saw had been preserved from them; for " what must have been the force and explosion that could have shattered it as a mine " would have done, and have lifted up enormous rocks from its bowels, to scatter " them about upon its surface; while this same force should have suffered them to " remain in their horizontal positions, an hundred feet deep or upwards, in the " ravines, as well as in many other parts?"

Volcanoes never fail to leave traces of their ravaging power; such as calcined and melted stones, pumice stones, lavas, cinders, \&c.; but none of them are to be seen in the Isle of France. The mountain's are in general indented with points like the comb of a cock. Those which are flat on the summits, present the appearance of a pavement, and no signs of a funnel are to be seen in any part. These mountains have been covered with earth and trees; but at present their summits are almost entirely naked. The same change has taken place with respect to them, which is 
now operating on the mountain of Moka; and every year the ravaging progress of the hurricanes and rains, in despoiling it of its ground and trees, is visible. During the heavy rains, these naked places are lost in waterfalls of a transient nature, which form agreeable objects. It is thus that the mountains called Trois Mamelles, Pieterbot, \&c. have been deprived of their earthy covering. It may indeed be said, that pumice stones have been found in the Isle of France ; but this circumstance may be easily explained. The only spot where they are to be seen, is on the windward side of the island, towards the isles of Amber, which have isles of coral, and are consequently open. It may therefore be reasonably supposed that these pumice stones come from the volcano in the Isle of Bourbon, and are driven to the isles of Amber by the winds and currents ; in the same manner as in India, those extraordinary cocoa nuts have been brought, whose origin has not been known more than fourteen years.

As a last resource, the partizans of volcanoes throw themselves into the caverns, which they insist have been the mouths of the volcanoes, that have produced the present appearance of the island; but, on visiting them, they seem to be nothing more than quarries of stone, originally resting upon earth, which has abandoned them. They now sustain themselves like vaults formed by human labour; and the proof is, that all these quarries are situated on gentle declivities. Some of them are to be seen on the plains of Willems, \&c.

The most difficult circumstance to explain in these quarries are the parapets that crown them, which are of equal breadth and height; particularly on the cavern of Piton de la Decouverte, in the plantation of the late $M$. Le Juge, first in rank in the supreme council. Immediately before the entrance of it, there is a kind of cylindrical opening, about twenty paces diameter, and worked in the rock like the coating of a well. This hole may be twelve feet in depth, and its stones are whole and entire, a proof that they have not suffered the operation of fire: the descent into this hole is by an easy declivity, which consists of a rude mass of rocks and earth, and immediately faces the entrance of the cavern, from whence the same declivity passes under a kind of arcade, and descends eight or ten feet. A large cave succeeds, from seventy to eighty paces wide, and from twelve to fifteen feet in height. It presents a fine vault formed with free stones of an enormous size, through which the water filters in every part: the ground, that is of black hue, is consequently soft; and the drops of water, which mark the place where they fall by a 
small hole, lose themselves in the earth. Though the ground possesses sufficient consístency to bear a man, a stick of five feet long may every where be plunged into it with the greatest facility. There is a small hole at the extremity, through which it would be impossible to pass without the assistance of the creeping plants and shrub-wood which grow about it : by clinging to them, a person may draw himself through it. Through the greater part of this cavern there is, on both sides of it, a parapet wall, that rather inclines from its perpendicular, and is from three to four feet in height. This cavern must have been formed by a sinking of the ground, and probably has been deeper than it is at present, as the rains which enter it, always bring something with them.

These parapets are the more remarkable in the caverns, as the mountains them. selves appear also to possess them. On examining the bottom of the river Lataniers, near the plantation of the priests, which is among the mountains, it is perceptible that these steps, or parapets, rise from the bottom of the river up the mountains, and extend along the chain of them. The Long mountain, that lies to the left, has them also. They are likewise apparent in the mountains that form the bay called Ance Courtois, which is traversed to go to the quarter of Moka. These small banks have a slight inclination; and all these mountains resemble, in their united shape, the foot of a goose, as they surround Port Louis: The highest of these mountains, according to the measurement of the Abbe de la Caille, is upwards of two thousand four hundred feet above the level of the sea. They are blocks of very hard stone, whose substance appears somewhat different from that of the rocks of quartz, which have been already mentioned as being formed in the earth. A piece of the stone, taken from this mountain, being thrown into the furnace of a workshop established on the spot, and withdrawn in an almost liquified state, produced a grain of lead, about the size of a large pin's head. In every other respect this mountain appeared, like all the others, a kind of scbisteuse stone, ${ }^{*}$ in horizontal, vertical, and shelving beds, in whose interior parts are found small crystals. This rock is very hard, and its parts equally tenacious. The undermining it with gunpowder had very little effect, as it probably found a vent through clefts in the beds, which though apparently well united, are not without many imperceptible, as well as visible openings, which offer a sufficient passage for the air. Aqua fortis being poured on a piece of this stone, caused an effervescence in several parts.

(Hist. Nat. Mineralog.) Schistus, saxum sissile, lapis sissilis : a kind of slate. 
This rocky mountain is in the first place covered with a thin crust, which is easily removed; but the most singular circumstance of it is, that the upper part is covered with a bed of vegetable earth, from two feet and an half to three feet thick, which likewise encloses round stones, similar to those already mentioned as covering the face of the island. This bed of earth appears to form a rich soil, which affords a plentiful nourishment to the beautiful trees that spring from it.

The top of the mountain of Pouce forms a level, which is steep on every side, and is not less than a league and an half in circumference. This piece of ground has a very gentle declivity on the side of the Ance Courtois, and then rises insensibly to the foot of the Pouce, which possesses a much higher elevation, and is an entire rock. This level spot is covered with very fine wood, as has already been noticed. A road has been begun on this mountain, to shorten the road from the port to the quarter of Moka, which is directly behind it.

On this flat there are three small and very shallow rivers, which, running over the bare rock, fall into the Ance Courtois. Very little labour on the side of the port; would render this spot an impregnable situation, which might be defended by stones only.-M. de la Bourdonnais, the founder of the Isle of France, had projected to form it into a redoubt, or secure place of retreat. The small rivulets which water it would be an invaluable resource, as an enemy could not turn their course; and if the streams should not be sufficiently abundant, reservoirs might be contrived to remedy the deficiency. Great care also should be taken of the woods, which protect these rivulets from the heat of the sun, and prevent them, probably, from being frequently dried up, as they appear to be supplied by the rains and moisture of the situations. Besides, if the woods were to be cleared away, there would be danger of losing the soil, which, no longer connected and kept together by the roots, \&c. would slide off into the Ance Courtois.

The way from the interior part of the harbour to this spot, is through fragments of the mountain, confusedly intermingled with large pieces of rock, and across hillocks which are formed by them.

The soil of the Field of Mars, and at the extremity of the harbour, is composed of a bed of rich clay mixed with flints; beneath which, it is probable, there are the same kind of rocks as are seen in the town, and at the entrance of the plain.

Two small rivers which traverse this plain, skirting the mountain of La Decouverte, discover that the earth in this part has no solidity, being composed only of 
flakes of flint, and a kind of clay, but in a small quantity. In the vast plain of the Field of Mars there is a course of clay, almost on the surface, and mixed with gravel. After having passed the Little mountain, on a level with the Field of Mars, it appears again. In some places it is without any mixture; and stakes of eight or ten feet in length may be easily thrust into it, without meeting any resistance. It is what some call quaking earth.

It continues to be mixed with gravel as far as the river of Lataniers, and even beyond a small brook, when the ground rises. It may also be perceived, after having turned the Long mountain, to the foot of Pieterbot. Lastly, it may be traced in the way to the Great river in the Ance Courois. It is again perceived on approaching the bottom of the mountains; from whence it may be inferred, that the mountains at the extremity of the harbour, those of La Decouverte, the Little mountain, the Long mountain, and even Pieterbot, rest on a bed of clay.

In the district of Moka, clay is again found at the foot of the mountain of the same name. In the environs of this place is the first cascade, which has been already mentioned; and as the two other cascades are on the same line, and on the same level, it is probable that it is the same bank of clay which these three rivers have met with, and which they have carried along with them and destroyed, in these places; by the violence and force of their torrents.

All these facts clearly demonstrate that the Isle of France, as it exists at this day, is not the immediate effect of a volcano.

In the Isle Bourbon there is a volcano, which, however, occupies only a very small part of it; but, notwithstanding this volcano, it must be acknowledged, that from the quarter of St. Denis to the point of St. Gilles, there appears the same kind of conformation as in the Isle of France. The quarter of St. Denis, which is flat and level, presents a very singular arrangement, which must be long posterior to the first effects of the volcano upon this island, if it should ever have undergone any change from them.

This curious arrangement is perceptible at the river St. Denis, whose banks are steep, and which has not less than from fifty to sixty feet depth above the scite of the town. Its banks consist of beds of rocks horizontally placed on each other, and are covered with a dry, sandy earth, which produces a kind of coarse grass.

The sea shore is lined with large pebbles, which the waves carry off and throw back again with great force, accompanied by a stunning noise. It is also 
remarkable, that under this horizontal bed of rocks, and on a level with the river, is another bed of pebbles, like those which are seen on the sea coast, and at the bottom of the river. On examining the foot of the mountains of St. Paul, in the way to the point of St. Gilles, which is more than half a league, all the rocky shelves rest on a bed of flints or small round stones, which, with a small mixture of sand, form a solid body. The sand of St. Paul is nothing more than the dust of the round stones and pebbles with which this part of the island abounds; but the most remarkable circumstance is, that all this side is perpendicularly cut, and very elevated in certain places; and that the section exposes the different beds of stones, all of which are inclined to the horizon. The point St. Gilles is a kind of cape; and here it evidently appears, that the beds of stone are not horizontal; but, on tracing them for a considerable length, they seem to have the same inclination as the slope of the mountain, which cannot be less than nine or ten degrees. The same inclination is perceptible in the road from St. Denis to St. Paul. This road crosses the mointains, which may be from four to five hundred fathom in height. They all of them stretch from the middle of the island in various branches, which are visibly the effects of torrents. Three of these branches are very steep, and the vallies between them are on a level with the sea. It appears, in the course of this journey, that the beds of stones are not horizontal, but inclined towards the sea; and this inclination is nearly the same as that of the mountain.

According to M. de la Nux, in all the ravines or hollows, called rivers, the shelves of rock possessed a certain degree of inclination. In short, it is a singular circumstance, that the inclination of these rocky beds being given at the point of St. Gilles, from nine to ten degrees, and the distance of this point to the middle of the island, being likewise given, the height of the island is rather correctly ascertained, according to the measurement of $\mathrm{M}$. de la Nux. It may surely be allowed as a reasonable conjecture, that some subterraneous fire, or some other powerful cause, may have forced from the bottom of the sea the block of stones called the Isle of Bourbon.

The Isle of France, and the Isle of Bourbon, seem to have originated from the same cause, as they do not bear the least resemblance to Madagascar. That island may be supposed originally to have formed a part of Africa ; but the Isles of France and Bourbon do not appear to have belonged to any continent. The districts of St. Denis and St. Paul, which are two plains that extend to the foot of the mountains, may have been formed, since this epocha, of the broken parts of the highlands, 
and the pebbles which the sea may have thrown up. The soil of St. Paul seems to be thus composed, of pebbles and of sand. This kind of dyke has so little solidity, that the sea broke in upon it, - in several places, in the hurricane of ${ }_{1746}$, and threatened to swallow up the whole of that quarter of the island. At certain times, when the sea runs very high, and the bar swells, it beats upon the shore with such tremendous violence, that each time the surge dashes on it, and particularly near the point of St. Gilles, the ground receives a shock, which is very perceptible to any one who may be standing on it. These convulsive motions of the bar at St. Paul, even in the finest weather, cannot be attributed to any known cause; but it is not improbable that subterraneous fires may promote them. On the recession of the waves from the shore, a person standing there, feels the effect of a sudden and warm vapour passing over his face.

The hospital of Port Louis is situated on a bank of coral, where there are, also, the foundations of a citadel, designed by M. de la Bourdonnais. This bank surrounds the island, at the distance of about a quarter of a league from the shore, except off the steep parts of it, where the rocks prevail.

At the hospital, this bank is upwards of ten feet above the level of the sea, and it appears to be every where of the same height to windward, as well as to leeward of the island, viz. from the Little river to la Flacq, which is nearly a third part of its circumference.

In the plain of Port Louis, called the Camp, at less than a quarter of a league from the bank of the hospital, there are several wells, from forty to fifty feet in depth. In digging them, nothing was found buf a bed of flints, and a kind of clay which contained talc and lenticular stones, in a great measure resembling those which are found in the quarries of Montmartre. These wells, which-sink nearly to the level of the sea, did not produce any coral, nor is any found in the elevated parts of the island; nor have shells been discovered there, which are so abundant around the foot of the island. All its surface and ravines consist of earth, or a vitrifiable sand; and the mountains are masses of rocks, covered with a thin bed of earth, equally vitrifiable. Thus, there is no appearance whateyer that the sea has covered the Isle of France, since it would have left some evidences of such a circumstance, and none are to be found. The bank of coral, which has already been mentioned, being formed by the sea, it is evident that these shores are full of Polipieres (poliprius). 
There are two kinds of these banks of coral; the first consists of rays or vermicular tubes, so fine and compact, that they form a body as hard as stone: it is the immediate work of the polypiers. The second does not appear to be the immediate work of these animals, as the parts that compose it are irregularly connected, like the grès (lapis arenceus), which they resemble in their arrangement; but, being calcinable, are of a very different nature. These coral stones appear to be composed of nothing more than very fine calcinable sand and broken shells. They are, without doubt, formed by the waves of the sea, which, by beating upon the corals and madreporæ which it nourishes, reduces them to a very fine sand, whose particles it then drives on shore; and having cemented them by means of a certain juice which it mixes with them, a very hard stone is formed, that is employed in building. The second kind is composed of the first, but it affords a larger portion of lime from an equal quantity. The bank of the hospital is almost entirely of the first kind : this bank is about eighty fathom wide, and one hundred and forty in length; it stretches out between a small arm of the sea to the right, and the port to the left, and is about ten feet higher than the sea. The ascent to it, from the port, is by an easy slope. Here the forges of the port have been erected. This kind of cape is composed of large rocks of quartz, from four to five feet high, which rest on a bottom of reddish sand. This sand, or earth, which is of the same nature as that of the island, when put in aqua fortis, does not produce any ebullition. The bank of coral, which is about four or five feet thick, rests immediately upon one of rock. The same circumstance is visible at the powder mill, near the hospital.

The Isle of Tonneliers is, also, nothing more than a bank of coral and shells, about half a league in length, and half a quarter of a league wide. There are at Flacq two large plains of this kind, which stretch out to the right and left of the port of that name, if it may be allowed that title. These plains are partly covered over with a short- grass : there are others, also, near the Great bay, and the Little river. It is proper to observe, that these plains are generally overflowed by the hurricanes, and several of these banks are perpendicularly cleft. The same circum. stance is also observable between Port Louis and the Great river.

Besides these plains or banks of coral, which the sea seems to have formed and abandoned, the island is almost entirely surrounded with reefs, which generally extend half a league in the sea. At high water they are covered; but when it is low, there is not more than a foot and half of water over the whole space which 
they occupy; and then a passage is practicable over many parts of them. Nothing can be more agreeable than the parties of pleasure among them, when the sea is tranquil, and the weather is fine; as they represent a forest of coral of all colours, whose stems appear above the water. At the same time the polypi are seen to come from their cells in the form of plumes, and various fish of the most beautiful colours also present themselves to the view : the bottom is likewise decorated with oursins * of different kinds and hues; though they are found in still greater numbers in the recesses of the coral.

After gales of wind and hurricanes, the shores are strewed with the remains of the madrepora, $\uparrow$ filled with these oursins, and an infinity of fragments of other kinds; and the sea rises in such a manner, and so suddenly, on the edge of these reefs, that vessels may range along them to get into port.

The reefs are nothing more than coral, or madreporæ, worked in the sea by the polypi, and form a considerable steep or perpendicular bank, which is continually augmenting, either by the labour of those animals, or the power of the sea, which, in its boisterous state, covers it with fragments of the same substance, which it has broken off from their beds, or forced up from its own depths. The particular spots which the billows have reached during the hurricanes, are evident from the beds of fragments which the sea has left on withdrawing itself to its natural limits. Indeed, there is every reason to conclude, that hereafter a dry passage will be obtained to. the very brink of the reefs of the Isle of France; as the foot of the island will be prolonged in such a manner, that the space now under water will become plains, like those which have been already described.

The Isles of Amber, to the windward of the Isle of France, are also a considerable mass of coral, which the sea formerly cast up, and afterwards abandoned, as in the Isle of Tonneliers. There is no doubt but these islands and plains of coral rests on a base of vitrifiable sand and rock of quartz, which may be supposed to be a prolongation of the Isle of France; and that, from the inclination of its beds, it has proceeded, as well as the Isle of Bourbon, from the bottom of the sea.

\section{Luminous Globes, छீc.}

Luminous globes are occasionally seen at Port Louis; which, being surrounded by very high mountains, that check the course of the winds, are consequently

- Echinus marinus.

$\uparrow$ Coralla stellata. 
calculated to promote these aerial fires. M. Gentil saw one of this kind, the 1 st of December, 1760 , at the height of about eiglteen degrees from the extremity of the port. It was full twenty minutes in diameter, and divided instantly into two small pyramids, or flames of fire, which remained nearly at the same height, while a small detached portion of it descended some degrees lower. The whole passed off without explosion, and lasted at most five or six seconds, with a very luminous effect during its passage.

On the 11 th of June, 1762 , at three quarters of an hour after sunset, another of these fiery meteors was seen in the environs of the zenith, which was larger in appearance than the sun or moon, and surrounded with flaming hair. It passed on with considerable rapidity to the south east, and was extinguished without any explosion, behind the top of the mountains, dragging after it a tail like that of a sky rocket. It was about thirty seconds in its passage.

\section{The following Letter was addressed by $M$. Fortin, to Mr. Abrabam, at the Isle of France.}

"Y You must have perceived the meteor that appeared yesterday evening, and I send you the result of my observations.

" I was sitting before my house, when two flashes of lightning, immediately succeeding each other, and of a fiery red, struck my eyes so forcibly, that I imagined some part of my buildings had taken fire. I arose immediately, and not-seeing any appearance about me that justified my alarm, I turned my eyes towards the sky, when I perceived two small clouds of smoke, like those produced by bombs when they burst in the air. I hastened instantly to my pendulum, when I observed that it was six o'clock, nine minutes, and about fifteen seconds. I then returned as hastily to examine these small clouds. Some time after, two claps rapidly succeeded each other, like two very loud reports of a cannon, which notwithstanding appeared to proceed from a great distance; they reechoed afterwards in the air for a moment. I ran instantly to the clock, and found it to be six o'clock, thirteen minutes, and about four seconds. So that allowing for the time in going to and returning from the clock, the total duration of this phœenomenon was three minutes and forty-five seconds, which appear to give a great distance.", 
The following Account of the Isles of France and Bourbon, bas been given by M. le Gentil.

"There are, properly speaking, no diseases in the Isle of France; that is to say, in the plantations; for at the north-west port, the scurvy sometimes makes its appearance. The south-east one, on the contrary, is very wholesome, and persons afflicted with scorbutic complaints are sent there in order to be cured. The inhabitants however prefer the smaller and less healthy, to the other, which is among the finest harbours in the world.

"The Isle of France may, therefore, be considered as a very happy climate; and the Isle of Bourbon seems to be still superior for the salubrity and softness of the air : nor have I ever known a place in which affability, social cheerfulness, or hospitality, were more prevalent than in the Island of Bourbon.

" The lands in the Isle of France bear a larger proportion of annual produce than those of France; they do not however lay fallow, nor are they manured. They appear very dry, poor, and arid; and the vegetables draw all the nourishment from the water and the air. In fact, with a certain quantity of water and proportion of heat, the most sandy soil will become productive; which is proved by those small rocky islands scattered through the seas of the torrid zone, and covered with woods of the brightest verdure. The land of the Isle of France is of a dark red, and mixed with ferruginous matter. The sand of the ravines and rivers is the sand of a mine; that of the sea-shore is calcareous; and in the year 1770 , the Governor, who had been persuaded by a private person then inhabiting the island, that he would produce crystal glasses equal to those of France, some advances were made towards such a manufacture. The object of such a branch of commerce would be to supply the Indies.

(") The manioc flourishes in the Isle of France, and the finest grow at Pamplemousses, and the Long mountain : it remains eighteen monthș in the ground before it is fit for use, and then it is as thick as a man's leg.

"The maize is very successful : it requires a considerable quantity of water and heat, so that the season of the north-east wind agrees with it the best. The district of Flacq, which is a quarry of rocks, produces the finest. Such a soil is not favourable to corn; the inhabitants, therefore, clear away the smallest stones, and plant maize in the places which they occupied, where it is found to luxuriate, and grow 
to the height of from eight to ten feet. Though it generally requires a large portion of moisture, any great quantity of rain is not necessary to it in this quarter, as the dews are very abundant; and rocks, which keep the earth from becoming dry, preserve the soil in the requisite state of humidity, so that the crops never fail; and unpromising as the soil is, the inhabitants look for two, and sometimes three harvests in the course of the year:-such is their wealth and their commerce. A certain portion of it they pour into public magazines; with the rest they nourish their slaves, barter for corn, and feed their hogs and poultry, with which they traffic. They have every convenience that is to be derived from water, as Flacq is a kind of archipelago, on account of the various branches of water that intersect it. This quarter also possesses, in the low grounds towards the sea, some parcels of ground which is proper for the cultivation of rice ;" and M. le Gentil adds, that, in his time, "it was that part of the island which supplied the Company's magazine with such a necessary article." The plantations which are more exposed, and have none of these rocks, do not succeed so well in the growth of maize.

"In the Isle of Bourbon the crops are very generally abundant, and its corn approaches in quality that of France, though its situation is between the tropics; but its' soil possesses a great degree of elevation.

"I saw," continues M. le Gentil, " on my return from Pondicherry, in the year 1770 , in the Isle of Franice, under the cultivation of the Curate of Pamplemousses, a small corn field, which wore a very fire appearance, was of an equal height of about three feet, and, according to the declaration of the ecclesiastic, had, in a former year; yielded fifteen fold.

"At Flacq, the corn generally produces twenty fold, and sometimes thirty in fresh ground; but no more than ten in that which has been in a long and successive state of tillage. But to ensure such a produce, there must be a concurrence of favourable circumstances; the rats and the birds must be checked in their devastation; the rain must fall in that degree of moderation as not to beat down the crop; and it must be preserved from the mildew.

" The small quantity of corn which is grown in the Isle of France appears, at first, to be rather extraordinary, as the mode of cultivation is superior to that of Europe. There it is sown, and here it is actually planted, on account of the rocks, which will not allow the use of the plough, and more hands are consequently necessary; but the land is never relieved by a fallow, or sustained by manure. 
"M. de la Bourdonnais, whose views in settling the Isle of France were purely commercial, wished to introduce silk-worms and indigo. It is probable that cotton was brought into this island by that distinguished person.

"I have met with people," continues M. le Gentil, "who have pretended that the iron of this island is of no value; but I differ in opinion from them, as I have samples of it which justify my dissent. It cannot indeed be denied that it has a very moderate sale in the Indies, when compared with that which is exported from France; but that proves nothing more than its inferiority to European iron, without confirming the depreciating opinion of $\mathrm{it}$. Besides, the mode of extracting the metal from the earth, and the subsequent process to purify and render it malleable, must, in a great measure, influence its final value. The following experiment, however, will determine the qualities and nature of the iron found in this island.

" The masts of vessels being made in Europe of a light wood, the circles of iron which are applied to strengthen and support them, sink into it. In the Isle of France, the wood which is employed to splice the masts is extremely hard, and not only resists, but, from its elasticity, breaks the circles of European iron. Those made of the iron of the Isle of France, employed in the French vessels during the last war, and worked at the forges of Mr. Herman's, were the only hoops of this kind that resisted, and remained firm. This circumstance appears to be decisive in favour of the iron of this island. It has been said, and many have believed, that the whole of this island is iron. There is certainly some iron there, but not equally abundant; and the forges have been erected where the ore is the least prevalent. It is by washing the earth that the mineral is obtained; and some time since it was brought to the gate of the kiln, on the side of which the Patouillard is established, in a fine plain. These works were, for some time, successful from the advantage of a favourable vein, but they have since been abandoned, though the plain has not been completely raked. A small portion of mineral was, however, found in $177^{\circ}$, and that was fetched from more than the distance of half a league from the kiln : besides, the mineral was poor, was found in veins or furrows of little length, and but few feet under ground. I know not," says M. le Gentil, " if the excavation sunk to more than eight feet, after which was a bottom of rock, and a kind of soft, sandy stone, which was good for nothing. The mine at Pamplemousses, if it deserve that title, is not rich, and seems to be furnished with what mineral it contains by the force of the rains, which wash it down from the highlands into the plains. 
"It has been said, that one hundred pounds weight of this mineral will give fifteen pounds of wrought iron; but $\mathrm{M}$. le Gentil saw, that nine thousand pounds of mineral gave from fifteen hundred to two thousand two hundred pounds of cast iron. This is about twenty per cent.; but these fifieen hundred, or two thousand two hundred pounds of cast iron, did not give half that quantity of wrought iron; consequently this mine did not produce more than ten pounds of wrought iron for each hundred of mineral.

"At Villebagne the mine appeared to be more abundant; but it is the distance of a league from the forges, in very elevated spots, and intersected by ravines and precipices. In the still more elevated parts, such as the military quarter of Nouvelle Decouverte, the mines appeared equally productive; but if Villebagne is excepted, these spots give but little encouragement to establish forges, as there is not sufficient water to answer all their demands: nor is it probable that the proprietors of the forges will ever go two or three leagues from Pamplemousses among frighful mountains, and where there are no roads, to rake up the ground, in order to bring iron to their furnaces; besides, these mines are, as it were, on the surface of the earth. The East India Company had set apart, for these forges, an extent of wood of ten thousand acres, called the Reserves: they then imagined, that, by making regular falls in these lofty woods, they would shoot forth again the following year, and that the young trees being left untouched, would replace the larger ones. But how many generations will pass away before this fine forest is reproduced? as, according to the opinion of M. le Gentil, the woods once cut down, in the Isle of France, do not grow again; so that the forest which is appropriated to maintain the fire at the forges of Mondesir, will soon be transformed into a vast desert. In the year 1.770 , the people belonging to them were obliged to go a league and an half to fetch charcoal, and every year will proportionably increase that distance : so that the mutual decrease of wood and mineral, will insensibly bring on the decay of this branch of commerce.

"Coffee is a valuable production: it is planted in the Isle of Bourbon at six feet distance. One foot is supposed to give about four pounds; nevertheless a tree is not expected to produce more than a pound of coffee; so that a plantation which possesses fifiy thousand feet of coffee, does not yield more than fifty thousand pounds of it; and for every thousand feet a Negro is necessary for its cultivation. The Company has, for a long time, fixed the price of coffee in the Isle of Bourbon, for which it gave eight pence per pound: so that a planter possessed of fifty thousand 
feet of coffee, was secure of the annual profit of twenty thousand livres; which is a very considerable revenue in a country where all the necessaries of life are produced in so great abundance, and are so excellent; such as cattle, kids, poultry, vegetables, \&c. The articles principally wanted are wine and clothing, and there is plenty of coffee to barter for them; which must consequently be a leading object of commerce.

" The coffee-tree is a native of hot countries, but it does not flourish equally in them all, and from that circumstance proceed its different qualities. The best coffee is from Arabia; that of Martinico and the Isle of Bourbon is the next in estimation; while that of Java and Ceylon is very inferior. Those last places are nevertheless nearer the line; and the heat should be consequently greater there, than in that part of Arabia where the coffee-tree flourishes. Moka being in thirteen degrees and an half of latitude, may possess a degree of heat equal, perhaps, to that of Java and Ceylon; but the heat of Moka does not determine that of Arabia, and no coffee is to be found within fifteen leagues of that place. Betelfaquir, which is twenty-five leagues to the north north-east of Moka, is the market where it is purchased; and Moka, which is situated in the midst of burning sands, that produce nothing but date trees, and are; never watered by rain, is the port from whence it is exported to foreign countries. In the mountains of Arabia there are occasional rains; and it is by a judicious management of the water derived from them, as they are not very abundant, that the Arabs invigorate the cultivation of their coffee. They arrange their plantations round the mounaains in a spiral form, and place their trees at a small distance from each other, and just below the reservoirs of water, by which they are enabled to water them as occasion may require, by the means of small channels or trenches. At Ceylon and Java the rain is too frequent; for though coffee requires a freshened and moist soil, a too great abundance of rain is fatal to it.

"Although it is very hot at Moka during the summer months, it is rather cool in the winter : it must, consequently, be cold in the mountains where these plantations of coffee are situated; as in this part of Arabia the mountains rise before each other in the form of an amphitheatre.

"The Arabs, to prevent the impoverishment of their land, surround the grain of coffee as soon as it is planted, with a small parapet of stone or pebbles, which protects the foot of the tree. Nor do they mutilate the trees, but let them grow to the height which nature has assigned them, which is from twenty-five to thirty-five feet. 
"The natives of this country do not value the coffee that grows in the plains; it is a large berry which is not esteemed in Arabia. In proportion as the country recedes from the sea and rises into heights, the coffee increases in value. It is really cold in the mountains, and there the best coffee is produced. Great heat, therefore, is not the only cause of the superior quality of coffce.

"It freezes even at Senan, * the capital of the states of the Iman, about fifteen degrees of north latitude, where the pools are covered with ice. M. le Gentil cannot ascertain whether there are plantations of coffee in this country, though he has been informed that the coffee tree is found in the gardens of that city, which is situated on a very high mountain. There is, however, a kind of coffee which bears the name of Senan, that is in great estimation, and large quantities of it were formerly purchased by the East India Company.

"Some of the inhabitants of the Isle of Bourbon, residing in the district of St. Paul, had carried their coffee plantations to the utmost possible height; in fact, some of them were in an elevated situation four hundred fathom above the level of the sea. At this height there is neither snow or ice; and the thermometer never sinks lower than within six degrees of the freezing point: the soil, however, was good; nevertheless the proprietors, in the year 1766 , destroyed all these plantations, because the trees put forth but few branches, and the knots, which were at too great a distance from each other, yielded but a small quantity of fruit, which was large and spongy, and seldom came to maturity : for even in the lower parts, the harvest, instead of being gathered in the months of July and August, was necessarily deferred to February, so that the proprietors of land found the cultivation of corn to be much more profitable. This difference may proceed from the nature of the soil, the winds, and particularly from exposition. It has been already observed that the Arabs, in their mode of cultivating the coffee tree, let it attain its natural height, while in the Isles of France and Bourbon, they keep it down in a thicket of no greater height than seven or eight feet. This method is attributed to the circumstances of the climate, and to preserve the trees from hurricanes, which have not so much power over them in their mutilated state. It is also well known that this tree exhausts the ground in which it is planted, so that a coffee plantation

- Or Sanaa (see the Dictionary of M. de la Martiniere), or Sana, the capital of the Iman in Arabia Felix, $15^{\circ} 20^{\prime}$ latitude, more than 100 leagues from Moka, in the mountains. See a Journey in Arabia, by Niebur. Tom. 1. 
scarcely lasts from fifteen to twenty years; and when the trees are become fruitless and perish, it cannot be renewed in the same spot, at least in this island, and fresh ground is required: a circumstance which sufficiently proves, that this tree greatly exhausts the ground in which it is planted. The inhabitants of the Isle of Bourbon, therefore, resolved to plant cotton, which grows in the old as well as in the new plantations.

" The nutmeg has been also brought into this island; but whatever attention may be paid to its cultivation, it will be very inferior in quality to that of the Molucca Islands. This nut requires an arid, spongy soil, composed of cinders, lavas, and volcanoes, with a very hot atmosphere and frequent rains. The Molucca Islands possess these qualities so necessary to the perfection of this tree, which, from a want of them, will not succeed in the Isle of France.

"It was brought there in the year 1770, in consequence of an expedition in which M. Veron was engaged, who died at his return. The nuts, however, which were then principally distributed among the inhabitants, were of the bastard kind, large and oblong, which are the growth of Manilla and the Philippines; and hence it is that the Spaniards boast of possessing the nutmeg in those islands : but this kind is not to be compared with that of the Moluccas, which is small and round, very few of which have been brought to the Isle of France.

" $M$. le Gentil however mentions, that the inhabitants of the Isle of France spared no labour or expence in the cultivation of this valuable spice, and that a subsequent expedition took place to the Moluccas, for the purpose of procuring more of the best kind. He also adds, that the nutmeg which was shewn at the Academy in the year 1773 , as the produce of the Isle of France, was judged by the persons employed to examine it, to be the true commercial nutmeg.

" The cloves which were produced at the Academy, from the Isle of France, were smaller than those of the Moluccas.

"The Mangoustan (Garcinia, Linn. gen. No. 594) the first of fruits, in the opinion of all those who have tasted it, is a native of the eastern coast of India, from whence young plants were brought to the Isle of France in the years 1754 and 1770 , but in so bad a state, that it is not probable this tree will succeed in this colony. The soil in which it grows at Malacca is very rich and strong, as well as swampy, during three parts of the year. It is also very hot there, with heavy falls of rain; so that the mangoustan grows very quick, and in a superior form. On 
the contrary, the soil of the Isle of France is light and sandy; nor is it so hot or so much watered as the peninsula of Malacca. This great difference therefore in the soil and climate, sufficiently explains the cause why this tree, notwithstanding the great attention paid to it, has not succeeded in this island.

M. le Gentil appears not to entertain any very confident hopes that the cocoa tree will flourish in the Isle of France. He speaks of it in the following manner.

"When I quitted the Isle of France in 1766, the cocoa tree of Madame Le Juge was already of a promising appearance: on my return in 1770 , after an absence of four years, and having seen the cocoa trees at the Philippines, I was not satisfied with that of the Isle of France, nor of the progress it had made during my absence. It was very short, when compared with the trees I had seen at Manilla: it seemed also to have the symptoms of old age, and of a premature decay. It had indeed yielded cones of a fine appearance, but they never became perfectly ripe: it is natural therefore to suppose, that the cocoa tree will not flourish in the Isle of Erance." Such is the nature of this tree, and that of the Jaca (the Tijaca marum of the Hort. Malab.), that they both bear fruit along their thickest branches, and not at the end of them, and sometimes on their trunks, and in their roots. This latter operation of nature is a symptom of their approaching decay. They begin by bearing fruit on the thick branches, then on the trunks, and lastly on the roots. As they advance in age the fructification approaches to the roots, and when the latter become the seat of it, the tree is verging on a state of decay. This circumstance induced M. le Gentil to determine, that the cocoa tree which he saw in the Isle, was advancing to a state of premature old age. 


\section{CHAPTER IV.}

An Account of the Island of Rodriguez, or Diego Ruys._Its Situation, according to the Admirals Cornish and Kemponfelt.-Extract from the Voyage of $M$. le Guat, relative to this Island.-Circumstances of bis Arrival tbere.-The Mode of Life adopted by bim and bis Companions. - Natural History, Animal, Vegetable, and Marine Productions. - The interesting Departure of M. le Guat, छ'c. from thence for the Island of Mauritius; their Arrival there; with their Reception, and subsequent Treatment, छेc.

$T_{\mathrm{HE}}$ Island Rodriguez being particularly connected with the Isle of France, the following account, containing a relation of the first remarkable events which happened there, naturally presents itself, as an appropriate link in the chain of our narration.*

This island, according to Admiral Kempenfelt, is situated 19 deg. 13 min. latitude, and the variation of the needle is 10 deg. $13 \mathrm{~min}$. W. It is about twenty-six miles long, and twelve broad, possessing a mild climate. The country is mountainous, and in many places full of rocks and large stones, which cover the surface; though there are others in which the soil is excellent, and calculated to produce fruit trees and vegetables of every kind: the garden of the French Governor is full of them: he has also plantations of rice, peas, and tobacco ; but the best production of the island is the land turtle, which is in great abundance. Small vessels are continually employed in transporting them by thousands to the Isle of Mauritius, for the service of the hospital. Sea turtles are also very plentiful; the sea cow is often taken, and there is an abundance of fish of various kinds. It is however necessary to observe, that such as are caught beyond the reefs in deep water, are poisonous; while those which are taken in the more shallow parts are excellent; particularly the Pierre bas, the red and grey mullet, and a fish that resembles a whiting, and which the French call Mort au chien.

- This island must not be confounded with that of Diego Rayes, which is but one degree north from the equator, and $88 \mathrm{deg}$. long. east from Ferro; nor with that of Diego Garcia, which is situated between the $7^{\text {th }}$ and 8 th deg. south latitude, and 87 long. 
Vessels may enter the port with safety, from the end of May to the beginning of December; the other months are subject to very dangerous hurricanes.*

On the northern side of this island there is a bay that affords excellent anchorage, and a secure shelter for ships of all dimensions. There are also ample supplies of wood, and excellent water may be obtained with the greatest facility. $t$

It is high water at the new and full moon, at three quarters past twelve at noon; N. by E. and S. by W. The spring tide rises from four to five feet perpendicular height, and the common tides seldom more than a foot. There are different points of land which direct a safe steerage into the north-west channel, but that of the north-east has not the same advantages. The principal point of view for the former is, first, the French Governor's house, or rather that of the superintendant, appointed by the Governor of the Isle of France, to direct the cultivation of the gardens there, and to overlook the park of land turtles. Secondly, the park of land turtles, which is on the sea-shore facing the house. And, thirdly, the mountain called the Sugar Loàf, which rises above the Oven valley. In this road there is excellent anchorage in sixteen fathom water; there is also abundance of fish, turtles, and sea cows, with cabbage trees, lemon trees, \&c.

The bottom of the road, as well as that of the sides of the vallies, is sand, the same as that which covers the shore. The whole island is covered with mountains, woods, and rocks.

There are two entrances into this bay: that of the north-west is the best, the channel being the largest and deepest. That of the north-east is sufficiently deep, since there is, in every part of it, from five to ten fathom water; but there is not sufficient breadth between the reefs of rocks, which lie from one to four fathom beneath the water. This bay presents to the view one spacious opening; but the centre of it is occupied by a large oblong bank of sand and rocks, of about eighteen hundred fathom in length, and eight hundred broad, which stretches across the opening. This bank, however, is covered with a shallow sea, from one and an half to

- Isle Rodriguez was more subject to hurricanes than the Isle of France.

$+T^{\prime}$ is account is given according to a plan of this port taken in 1761 , and made by order of Admiral Cornish, who was then cruizing near this island, by the late Admiral Kempenfelt; which plan was entrusted to me by the Lords Commissioners of the Admiralty, with the gracious permission to employ it for the illustration of this work. I am under similar obligation to one of the zery respectable Directors of the East India Company. (Note of the Autbor.) 
ten fathom water, but it would not be safe to pass over it. The north-east passage is between the end of this bank and the Bay Aux Requins; it is about nine hundred fathom wide; but there are ten or twelve shelves of rocks in various directions, from one and an half to four fathom beneath the water, which, in fact, narrows the channel on this side to a breadth of an hundred fathom, and cannot be distinguished on the surface of the water, as there are no buoys, nor any guiding points of view on this side of the island. The north-west entrance, which is about a thousand fathom broad, affords a channel, whose breadth is about four hundred and fifty fathom, with from ten to sixteen fathom water; but there being also four" shelves of rocks on one side, and three on the other, dispersed through the whole space, from two to four fathom beneath the surface, the superior advantage of this entrance arises from commanding certain points of view, which serve as beacons, and ascertain a secure and certain track for vessels to enter into the bay.

This bay, which is upwards of four thousand fathom in length, and three thousand broad, affords an excellent anchorage, as has been already observed, in from ten to eighteen fathom water. The bottom of the bay consists of a large sandy flat, intermixed with rocks, which is dry at low water; and to the left of it is the small island called the Diamond, which is opposite to a creek of the same name; and another islet, called by the English, Booby island. This flat is surrounded by rocks, which rise from banks of sand. By the side of Diamond island is another bay called Oyster bay, which is the most considerable outlet of this road. To this succeeds the bay of the Oven valley, where the guard-house of the French superintendant is placed. It was entrusted in the year 1740 , to a Negro family. The Oven valley, which contains the house and gardens of the French Resident, is a peninsula : to the north of it is the Great bay, on whose shore is the park of turtles: to the west and south-west is the Oven bay; and it is bounded on the east by a river, into which ships enter to take in fresh water; they also take in water from the brooks that cross the neighbouring valley, called Norfolk valley. Still more to the left is another fine valley, called Watson's valley, which is the most convenient place for procuring wood. There is nothing between this valley and the Bay des Requins, which completes the enclosure of the Great "bay, but two small vallies, called the Dove valley, and the Little valley.

When M. du Quesne, in the year 1690 , prevailed on the Dutch government to send a frigate, in order to form an establishment in the Isle of Bourbon in favour 
of the refugee protestants of France, some of them gave the following account of that island, where howeyer they did not land, as they unexpectedly found that the French were in possession of it.*

"We very clearly discerned a pleasing variety of woods, rivulets, and plains, covered with the most charming verdure; and if our eyes were delighted with the pleasing prospect, our sense of smelling was not less gratified, as a most grateful odour from the orange and lemon trees, with which the island abounds, was wafted to us, though we were at some distance from the shore; and some of us were as much refreshed by it, as if we had actually landed there."

The account which has been published of this island by M. du Quesne, does not indeed mention this circumstance; while M. Delon has not only confirmed it, but attributes the peculiar priviledge of this island, in not being infested with serpents or venomous animals, to the powerful effects of the numerous odoriferous flowers with which it is covered, whose fragrance operates as a poison to them. He even declares that he has himself verified this opinion by actual experiment.

The adventurers from Holland were so much delighted with the first view of the Island of Bourbon, that they were affected with a proportionate disappointment when circumstances compelled them to proceed, without landing there, to the Isle of Rodriguez, where they found indeed more resources than they had any reason to suppose, but which were not unaccompanied with sufferings and misfortunes. One of these adventurers, $M$. le Guat, has left a relation respecting this island, of which we proceed to give the general circumstances.

\section{Circumstances of their Arrival at Rodriguez.}

"On a Saturday morning, being the $25^{\text {th }}$ of April, 1691 , we perceived land, which was the little Island of Diego Ruys, or Rodriguez: we approached very near it, by the east point, bearing away to the south. It seemed to be difficult of access, on account of the breakers, that stretch far out into the sea, and with which it is surrounded. At first we perceived neither port or bay, nor any spot which promised a convenient landing. Towards evening we threw out the lead, and found a bottom of rotten rock, at three leagues from the land: here we cast anchor, and remained till Monday the 27 th. We employed that and the following day in examining the exterior of the island, in order to discover some accessible spot.

* M. du Quesne had been induced to believe that the French had, at this time, abandoned the Isle of Bourbon. 
" On the 28 th, about four o'clock P. M. we observed an opening, which had the appearance of answering to our wishes, but night coming on, we stood a little out to sea, and lay to till break of day : about eleven o'clock in the morning, on the 2gth, we were becalmed, a circumstance which threatened considerable danger, as a rapid current was evidently carrying us among the rocks, which stretched out more than a league into the sea. In short, we approached so near them as to cause the most serious alarm, when a favourable wind fortunately sprung up, and saved us from approaching shipwreck. We doubled the cape towards the north point, and at noon the boat was hoisted out to go in search of some inlet. In the evening we sailed towards the north-east point, and the long-boat made a signal to inform us that they had found an anchorage. As we were upon rock, in no more than eight fathom water, we were continually obliged to take soundings. At length, however, we anchored in nine fathom, in a sandy bottom, having been towed thither by the long-boat. The following day, being the 3 oth of April, at an early hour in the morning, we cast anchor in nine fathom, with a similar bottom, and were sheltered from the east and south-east winds, which predominate in this country.

"The island had a very inviting appearance, both at a distance, and on our near approach to it. This little new world seemed to us a seat of delight; though we did not see so many birds as appeared on the shore of the Island Tristan; nor was the air so perfumed with flowers as when we passed the Isle of Bourbon, about a month before. But the aspect of this island was so delightful, that we could scarce satisfy ourselves with gazing at the little mountains of which it is composed, covered as they were with large and beautiful trees. The rivulets, whose course we could discern as they sunk into the vallies, after expanding in various branches over a considerable space of country, which I shall not call either a plain or forest, though either denomination might be applied to it, flowed immediately before us into the sea.

"These scenes brought to our recollection the famous Lignon, and the various enchanting spots which are so agreeably described in the Romance of M. d'Urfé. But other, and more important considerations soon arose in our mind. We admired the secret and extraordinary operations of Providence, which, after having permitted us to be ruined in our country, and to be cruelly driven from it, had at last suffered us to dry up our tears in this earthly paradise to which we had been conducted, and where it depended upon ourselves alone to be rich, free, and happy; by employing our tranquil life in the calm enjoyment of what we possessed, in glorifying the 
Author of all good, and advancing our final salvation. We were all of us occupied in such delightful meditations, when the long-boat was hoisted out to take us on shore. As there was a general eagerness to quit the ship, I did not press forward; and the boat being full, I remained behind. In the evening the captain returned, and gave me an account of the wonders which he had seen; but he chose to indulge himself in a strain of exaggeration, which was contradicted by a very early experience. He spoke of animals and fruits which have never been seen in this island; though he brought with him several birds which were fat and well tasted; and I made a very agreeable repast on these new and unknown viands. The next day, May 1, 1691, I joined my companions on shore.

"This island, which is called Diego Rodrigo, or Diego Ruys, or Rodriguez, is situate in the nineteenth degree of south latitude, and about twenty leagues in circumference.

\section{Their Establisbment in the Island.}

6. We established ourselves to the NNW. of the island, in a fine valley, and near a large brook of excellent water: but it was not till we had examined every part, that we preferred the spot, of which I shall now give the description.

"A small river that rises near the middle of the island, and about four or five thousand paces above the scite of our huts, forms, by falling from rock to rock, a succession of cascades, basons, and pieces of water, that would adorn the gardens of a prince. In warm and dry seasons it receives but little water from its source; but, at all times, the tide keeps it full to the spot where the land begins to rise. This side of the river is, in general, less elevated than the other, and is sometimes inundated by the rains that accompany the hurricanes.

"Pierre Thomas, one of our pilots, determined to inhabit a small island formed by the brook. He accordingly built his hut, made his little garden, and threw a couple of bridges over the branches of the stream. During any inundation he used to roost in a tree; and always made his situation pleasant to himself, as well as agreeable to his companions. He sang, played upon the flute, and was the only person among us who smoked tobacco. When his stock was exhausted, he supplied it with the dried leaves of certain trees in the island. The hut nearest to this island was that of M. de la Haye. He was, by profession, a goldsmith, and had constructed a forge, so that he was obliged to make his house somewhat larger than the rest.

"The huts were from ten to fifteen feet square, according to the fancy of the 
builders. The trunks of the lataniers formed the walls, and the leaves of the same tree covered the roofs. The huts were at some distance from each other; and a palisade inclosed our gardens. Near the water was the town-house, where our little republic used to assemble to deliberate principally concerning the affairs of the kitchen. This building was twice the size of the others. Here our food was prepared; and under a large tree beside the hut we used to eat it. This tree spread its thick branches over us, and defended us from the heat of the climate. It was in the trunk of this tree that we scooped a niche, as a receptacle for those memorials which I shall particularize in a future page.

"On the other side of the water, exactly opposite to the building which we called the public hotel, was the public garden. It was a spot of fifty or sixty feet square, surrounded by a palisade about six feet high, and formed in such a manner as to prevent the smallest tortoises from passing through it.

"The hut of M. le Guat was situate between two flower gardens, and rested against a large tree, which protected it on the side of the sea. This tree yielded a fruit, which bore some resemblance to an olive, and whose kernel was a favourite food of the parroquets.

"A little lower, and nearer the water, was the abode of M. de la Case.* This brave man, who is at present in America, had been an officer in the troops of Brandebourg, and knew what it was to live in tents.

" On the other side of the rivulet, between the little island and the public garden, M. Testard erected his habitation : his sad fate will soon be related, and the most sincere regret which will ever accompany the remembrance of that amiable and gallant man.

" M. M. B***le and Boyer inhabited the same dwelling, which they had erected at a small distance from the brook, and nearer to the sea. The latter of them died in this island, and his ashes repose there. The epitaph which was inscribed on his distant tomb, declares our opinion of his excellence. The former still lives. When we were at this island he was not more than twenty years of age; but, while he possessed the vivacity natural to his period of life, he had the composure, mildness, and discretion of a more prolonged experience. He had received a good education; and the advantages he had derived from it he was ready to communicate to all around him. It was principally to his inventive genius that we were enabled to

* The names of La Case, and Testard, continue to be well known in the Isles of Madagascar, France, and Bourbon. 
construct the vessel, which will be hereafter mentioned, as well as to succeed in the manufacture of hats, which proved so useful to us. I shall also remark, that, excepting Pierre Thomas, and R. Anselin, who were of a low origin, we were, all of us, superior to want, and had not thrown ourselves from despair on a desart island, or from not having a place where to rest the soles of our feet. Many of the party were persons of good family, and some property; but as this colony of M. du Quesne made some noise, and we were young, healthy, active, and without any incumbrances, the spirit of enterprize induced us to make this voyage.

"The trees which were scattered about our little town, were the remains of a much larger number, which we thought proper to clear away. This was no very difficult task, as the soil is very light, and the roots 'easily separated from it. When we had finished our humble habitations, the captain of the frigate, who had remained fifteen days in the road, bade adieu to us, when he had provided the necessary refreshments. He did not however think proper to leave every thing which had been designed for us : nor did we fail, in our letters to Holland, to give him the character which he deserved; but, as we were afterwards informed, he very discreetly did not deliver them to the persons to whom they were addressed.

"He however left us a quantity of biscuit, with fire-arms and ammunition, tools for agriculture, saws, hatchets, and the necessary implements for building; some household utensils, mills, fishing nets, and linen; besides, each individual had his own baggage and private stores. The medicine chest by some inadvertence, as may be supposed, was not brought on shore.

"Pierre Thomas, who has been already mentioned, had quarrelled with the captain, and being afraid of returning with him, wished to remain in the island; so that he would have repaired the loss of one of our companions who died at sea, near Mascaregnas; but the captain, on the very eve of his departure, came on shore, and took away two of our companions, Jacques Guignies and Pierrot, so that the whole of the little colony consisted of no more than eight persons.

\section{Description of tbis Island, and of its Natural Productions.}

"When the ship was gone, and we were all of us recovered from our fatigues, we made a tour round the island, to discover if it afforded a more eligible spot than that which we had chosen; but though there were several situations equally convenient, there was not one which equalled that which we had selected, in point of beauty; we therefore adhered to our first choice. 
"As soon as we had cleared as much ground as was necessary for our principal garden, we sowed our seeds, of which we had great abundance, and of various kinds; but those which were brought from Holland were spoiled by the sea air, as we had omitted to put them in bottles, and seal them close: we had, however; procured others at the Cape of Good Hope. There came up but five plants of the common melons, and no more of the water-melon; three of endive, the same number of wheat, with some artichokes, purslane, radishes, mustard, stocks, and trefoil. The stocks grew to be of a considerable size, but they did not bear flowers, and in a short time they all perished. The radishes were all destroyed by the worms before they were in a state to be eaten; but the melons required a very small degree of cultivation, and produced fruit of an uncommon size and exquisite flavour; and though eaten to excess, did not produce any unpleasant effect. They were in a continual state of production throughout the year; but we found from experience, that those which were planted in the shade, succeeded better than such as were entirely exposed to the sun. Among the five water-melon plants there were two kinds, the red and the white; and they sometimes grew to such a size, that the whole party found one of them too much for one repast. When we mixed a few ashes with the earth in which they were sown, they produced an uncommon quantity, and acquired an higher degree of flavour. The artichokes grew most luxuriantly, but they yielded a very small fruit ; indeed we were disposed to suspect that they were of an inferior kind. The endive, purslane, and mustard, exceeded our expectations; but we could not, by any cultivation in our power, deprive them of a bitter taste. Of the three grains of wheat which were sown, we could preserve but one plant. That however put forth more than two hundred stems, and encouraged us to expect a proportionable harvést : but the plant soon degenerated, and at length produced a kind of tares : a circumstance which caused no common disappointment, as it deprived us of the pleasing prospect of obtaining bread.

"It is not however to be concluded, that the change of wheat into tares is a natural consequence in this island, because such a degeneration often happens in Europe; on the contrary, it may rather be supposed to have arisen from the inconsiderate manner in which the seed was sown.

"The air of Rodriguez is very pure and wholesome; and, as a proof of it, not one of us was sick during the two years we remained there, notwithstanding the great difference of climate and mode of nourishment. The worthy man whose remains we left behind us, lost his life in consequence of violent fatigue. The 
heats of the summer are very much moderated; as, at eight o'clock in the morning, a light north-east or north-west wind constantly rises, and gives such an agreeable freshness to the air, and such a temperature to the hottest season, that the whole year appears to be one continual spring or autumn; as it is never too cold to forbid the pleasure of bathing. The nights are mild and refreshing. It rains but very seldom; at least we never experienced rain but for a few weeks after the hurricane, in the months of January and February. Within an hour after the rain has fallen, the ground is sufficiently dry to admit of walking. The dews, which are abundant, supply the place of showers; and as for thunder, which is sometimes so tremendous in various parts of Europe, it is never heard in this tranquil abode.

" The island, as it has been alreadý observed, consists of a succession of hills of various and pleasing shapes, which are covered with flourishing trees, whose perpetual verdure offer the most pleasing scenery; and being seldom embarrassed with underwood, form delightful groves; which, while they afford a most refreshing shade, break the views, some of which embrace a large extent of ocean, into pleasing and magnificent prospects. The vallies that serpentine between the hills possess the finest soil in the world: it may be said to be entirely composed of decayed trees and leaves, which, being reduced to a kind of compost, are washed by time down the sides of the hills to enrich the vallies beneath them: this soil being very light, requires little or no culture, and is pregnant with fertility.

"The vallies are shaded with different kinds of palms, the ebony, and various other trees, whose branches and foliage do not yield in beauty to those of the finest trees in Europe. In the bottom of these vallies there are streams of limpid water, which are plentifully supplied from perennial springs in the middle of the island; and had the course of these rivulets been expressly directed by the hand of art to water this little country, they could not have been contrived with better effect. But to their beauty, may be added the utility they afford to the spot, which they at once refresh and adorn. Seven water-falls may be seen at the same time tumbling down from the rocks into as many basons, and uniting to form one delightful stream.

"These waters abound with eels of a very extraordinary size and exquisite taste. Some of them were so large, that one was: a heavy burthen for two men. As the streams are not deep, and perfectly transparent, these monstrous fish, which are seen crawling along the bottom, may be easily struck with an harpoon; though there was no occasion to employ any other means to take them than the hook; as the 
bait was no sooner thrown into the water than they instantly seized it. They have sometimes indeed been shot, with the ordinary ammunition of the sportsman.

"The vallies, which are fertilised by these beautiful rivulets, insensibly widen as they approach the sea, till they extend sometimes into plains of two thousand yards broad, whose soil, to the depth of eight or ten feet, possesses the most fertile qualities : they are also covered with those delightful groves which have been already mentioned, beneath whose shade, in the noon-tide of the hottest season, the air possesses a most agreeable and enlivening freshness. The trees shoot up their tufted tops to the same height, and interlacing their branches with each other, form a sucsession of leafy canopies which blend, as it were, into a large platform of neverfailing verdure; while the stems, like so many strait and lofty pillars, at once support and nourish it: an unrivalled example of the architecture of nature. At the same time the greatest part of the trees which adorn this little paradise, are not less useful to the service, than gratifying to the senses of man. The different kinds of palm tree, are so many astonishing magazines to supply the necessaries of life : their fruit is excellent; while the juice which flows from their trunks is, without any preparation, a very delicious and salutary beverage. : The leaves of some of them are esculent, and of a grateful taste; while others bear a resemblance to linen and silken stuffs. These wonderful trees abound in every part of the island, and it may be expected that some account should be given of them.

\section{Of the different sorts of Trees.}

"Palm trees, of which there are more than thirty kinds, have been so frequently described, as to render a minute account of them superfluous : it may be proper, however, to give some general account of those which we found in the Isle of Rodriguez. They are in general about thirty or forty feet in height; their trunk is strait and without leaves, but covered with a kind of sharp scales, which are somewhat raised at the point: others have a smooth bark. At the upper part of the trunk grow the branches of palm leaves, which hang around like so many plumes of feathers: beneath these branches grow long clusters of fruit, which is green, and of the size as well as the shape of an egg : it is known by the name of date. In the centre of this large leafy plumage, and on the summit of the trunk, grows what is called the cabbage: it is not visible; as the branches rise all around and overtop its situation. It is composed of tender leaves, which adhere closely to each 
other, and form a mass like that of a cabbage. It is about two feet in height, and of the same thickness as the trunk. The large outward leaves of this mass are white, sweet, supple, and strong: they may be used as goat skins, when skilfully dressed; or linen, or satin, or napkins and towels; such is their various utility. The membranes or leaves of the heart are tender and crisp, like that of a lettuce: it may be eaten raw, and tastes like a nut; and forms an admirable ragout, when dressed with the fat and liver of the land turtle.

"The nectar of this island is the palm wine, so well known throughout the Indies. There were two modes employed to obtain it: we sometimes made an hole, about five inches diameter, in the trunk of the tree, at the height of about six feet, and a vessel being suspended under it, was soon filled with this pleasant liquor: at other times the cabbage was scooped out of the tree; by which operation a cistern was formed on the top, from whence two or three times a day the juice might be drawn. Either way the liquor was equally good; but in order to spare the trees, the first method is the best; as after the reservoir, formed by the removal of the cabbage, has furnished its liquor for about a month, the tree becomes so exhausted as to decline and die. But the incision, if not made too deep, is not attended with any fatal effects: the liquor will not however flow from one aperture more than four days, when the tree must be left to recover its strength: besides, if a very large wound should be made, it may weaken the trunk to such a degree as to disable it from resisting the hurricanes.

"The Latanier (Corypha umbraculifera, Linn.) is placed by botanists in the class of palm trees. In the Isle of Rodriguez this tree has a strait trunk, formed, as it appears, of a succession of large rings of equal thickness, with a smooth bark. At the top there is cabbage similar to that which has been just described; at the bottom of which several large leaves shoot forth, whose stalks are six or seven feet in length. These leaves are strong and thick, and resemble an open fan; some of them are eight feet in diameter, so that they form an excellent covering for houses : they may also be shaped into hats and umbrellas. The stalk, which is hollow, is four fingers broad, and upwards of an inch thick, and rather round on the sides: the extremity of it, which springs from the tree, and in a great measure embraces it, presents a large and concave shape, which is sometimes more than a foot in diameter, is about the thickness of a crown piece, and was made to serve the purpose of plates and dishes. The exterior rind of this stalk may be employed for ropes, and the fibres 
of the interior one will serve as a sewing thread. It appears indeed that it might be woven into linen, if the filaments were properly prepared. The wine drawn from the latanier does not differ, either in the taste or other qualities, from that of the palm tree: but it is necessary to apply it to immediate use; as on the third or fourth day it begins to be sour, and on the seventh or eighth it acquires as sharp an acid as the strongest vinegar, without any change in its colour.

"The dates of the latanier are of a larger size than those of the palm tree; but as there was plenty of better things, such as flesh, fish, fruits, \&c. we abandoned the dates to the doves and other birds, of which a future description will be given.

"Around the lower part of the cabbage of the latanier, and between the stalks of its large leaves, there grows a kind of cotton of a light lemon colour, which is known throughout the Indies by the name of Capoe, of which we made excellent matrasses: this cotton may be spun and employed to every purpose of the weaver, \&c. We should indeed have endeavoured to manufacture the capoe, as well as the fibres or filaments of the leaves of the lataniers, into some kind of useful fabric, but we were well furnished with linen and cloth; and the air withal was so mild, as to render our clothes in a great measure unnecessary.

"This island also produces several other kinds of wholesome fruit trees: that which bears a species of pepper, is about the size of a plumb tree, and has a leaf like that of the jessamine; the fruit grows in small bunches, and served to heighten our culinary preparations.

"The sea having brought some cocoa nuts to our shore, whose germ began to appear, we planted one of them some months after our arrival, and when we quitted the island it had risen into a tree of four feet in height.

"There is every reason to conjecture that these cocoa nuts, which sometimes weigh five or six pounds, and are thrown upon the coast of this island without suffering the least injury, come from the Isle St. Brandon, which is from sixty to eighty leagues to the north and windward of Rodriguez. The sea never brings any thing but on that side; ' which justifies the opinion, that we were indebted for these presents to the currents, as well as to the wind and tide. It is very probable, that in the hurricane season, the whirlwind may have blown these fruits from the Isle St. Brandon to a considerable distance in the sea, when they became subject to the course of the waves.

8s. There is alsa in the Isle Rodriguez the Indian Fig tree (Ficus indica), its 
branches extend in a circular form, and are so thick as to be impenetrable to the solar rays. Some of these trees are so large that two or three hundred persons may take shelter under them: this circumstance arises from the peculiar property of the branches, which bend down to the earth, take root there, and form a progeny of stems that, by shooting forth new branches, compose this vast extent of shade: the inbabitants of the East hold this tree in great veneration, and frequently erect their pagodas beneath it.

"According to Boulaye le Gout, this tree is called the sacred Kasta, and is held in such high estimation by the devote'es, because their god Kan is said to have diverted himself with playing the flute beneath the umbrage of its wide spreading branches. The same author adds, that the inhabitants do not venture to rob it of a single leaf, from the apprehension that death will inevitably follow within a year of such a violation. He also refers his reader to what Herodotus and Quintus Curtius have written concerning it. Tavernier also mentions, that it is called Lul by the Persians; but that the Franks gave it the name of Banian, because the penitent Faquirs and Banians perform their devotions within its bowers. M. de Rochefort calls it Pareturier, in his natural history of the Antilles. According to his description, the leaves of its young branches are like those of the quince, the upper part being green, and the under part whitish and downy : they are the favourite food of the elephants. Its fruit consists of small figs of the same size as those of Europe, but not so well tasted: they are of a red colour both within and without. The natives of the country where this tree grows make some kind of dress of the bark. "1: "The Kasta of the Isle of Rodriguez has a leaf the size of an human hand: it is thick, and resembles the shape of an heart, like that of the lilac, and to the touch, is soft as satin. The flower is white, and emits a pleasing odour; the fruit is round, its colour red, and of the size of a small plum. Its skin is hard, and contains small seeds like those of our figs. It is not unwholesome, but its taste is insipid : it is the common food of the bats, who roost in great numbers among the tufted branches of the tree.

"The wood of the trees in this island is, in general, very hard; that which we employed in building our huts, became full of worms within a few weeks after it was cut down; but if it is left to soak during a month in the sea, the worm cannot enter it.

r There is a tree which, from its fotid smell, we called the stinking wood: it 
is the most serviceable of any other for carpentry; but, from its obnoxious qualities, little use could be made of it.

"This island does not produce any kind of tree, shrub, plant, or herb, that is of the growth of Europe, except purslane, which is found in the vallies. We sowed some of it, which was brought from the Cape of Good Hope, and it proved to be exactly the same as the native purslane of the island.

\section{Animals.}

There are no four-footed animals at Rodriguez; but rats, lizards, and land turtes. Of the latter there are three different kinds; and some of them are so large as to weigh an hundred pounds. Their flesh is wholesome, and not unlike our mutton, but more delicate. The fat, which is white, does not congeal, and is never known to cause an indigestion : we considered it as superior to the finest butter of Europe : it is alse sovereigit remedy for sprains, sheumatism, and similar complaints. The liver is a most delicious food, and is very large in proportion to the animal, as it is equal to one-third of the whole weight of the flesh. The bones are solid, and consequently without marrow.

"These furtles lay their eggs in the sand, with/which they cover them; when they are left to the slow operation of being hatched by the sun. They are perfectly round, like billiard balls, and are not larger than those of our common fowls. The shell is soft, and the interior part is excellent food.

"There is such an abundance of these land turtles, that they are sometimes seen in flocks of two or three thousand. They collect together towards the evening; in the coolest places they can find, and in such close array, that the spot which they have chosen seems to be paved with their shells. 'It has been observed that some of them constantly take their post at a small distance from the main body, as if to perform the duty of centinels: but the utility of this arrangement is not readily comprehended, as the turtle possesses no means of active defence, or the least capacity to save itself from danger by flight.

"There are also sea turtles' in great abundance; and some of them have been taken that weighed upwards of a quarter of a ton. They lay, their eggs in sandy places near the sea, and always in the night : they deposit them in an hole about three feet in depth, and a foot broad; and the largest lay about two hundred in the short space of two hours: having covered them with sand, they leave them to be 
hatched by the heat, which effects the purpose at the end of six weeks. The young ones, at their birth, are not larger than chickens; and, on coming out of the shell, hurry instantly to the sea. We sometimes diverted ourselves with carrying some of them to the distance of a quarter of a league within land; when, being placed on the ground, they took the strait road to the sea. At this period they walk or crawl faster than when they are grown to a larger size. The frégates (sula fregata) and many other birds destroy them in such numbers, that not a tenth part escapes from such voracious enemies: but as the turtle lays every year from a thousand to twelve hundred eggs, the multiplication is not easily calculated.

"These eggs are not so grateful a food as those of the land turtles; neither is the flesh so delicate. The eggs of both, however, are of the same shape; and the white is so soon desiccated, that the egg may be properly said to contain nothing but the yolk.

"The liver of the sea turtle has scarcely any taste; but the smell is rancid; and it excites an unpleasant sensation in the stomach for a considerable time after it has been eaten.

"These animals feed on the herbs that grow at the bottom of the sea, and are never seen on shore but when they lay their eggs. Previous to that operation, they remain nine days in a state of coition.

"Their fat, after it has been once melted, remains in a liquid state. Its taste, as well as that of the land turtle, is very grateful to the palate, and a most excellent article for culinary purposes.

i " The sea turtle will: live upwards of a month without eating, provided it has discharged its eggs, and is dashed, from time to time, with pails of sea water. Its blood is cold.

\section{Fish.}

"The Lamentin, or sea cow, (trichechus manatus, Linn.) is also found in great abundance in the seas that surround this island, and appears in large herds. . Its head resembles that of a hog, with a less pointed snout. It has no fins, but in their place two paws. The body is thick ás far as the navel; and the tail has this peculiarity, in common with the whale, that the breadth of it is horizontal, when the animal is laid on its belly. Its blood is warm, and its skin is rough, hard, and of a blackish hue. A small quantity of hairs is scattered over it, though they are 
scarcely perceptible. Its eyes are small; and two holes which it opens and shuts at pleasure, may be denominated its gills and ears. $\Lambda$ s it seldom shews its tongue, which is not large, many have asserted that it has none. It has grinders, and even tusks, which appear as in a wild boar, but it has no fore teeth. Its gums are very bard, and with them it tears up and browzes upon the grass at the bottom of the sea. Its flesh is excellent and wholesome, and resembles that of the best veal. The largest of these animals are about twenty feet in length.

" The females have breasts like those of a woman. Some mention that it has two young ones at a time, and that it suckles them both together, supporting them at its basom with its paws; but as. I never saw it embrace more than one, I am inclined to believe that the former account is erroneous.

"6 This extraordinary nurse seems to verify the description of the prophet Jeremiah, in his Lamentations, ch. iv. ' Even the sea monsters draw out the breast; they ' give suck to their young ones; but the daughter of my people is become cruel, like 'the ostriches in the wilderiess.'

"This fish is taken with great ease. It feeds in flocks like sheep, not more than three or four feet from the surface of the water; and when we: went into the midst of them they did not quit their station, so that we could take which we pleased, either by shooting them, or dragging them by main force on shore; though the latter mode would employ three or four men to effect it. We sometimes found three or four hundred of them feeding together, and so little disposed were they to avoid us, that we often touched their breasts in order to select the fattest. By tying a rope round the tail, they were dragged out of the water; and as the flesh of the smaller ones is the most delicate, our fishery was confined to them. The fat is firm, and well flavoured; and neither in its appearance or taste can the flesh be distinguished from that of butcher's meat. This animal dies immediately on losing a little blood.

" Our discovery of its being an inhabitant of these seas, arose from our finding a dead one on the shore, some months after our arrival in the island. We did not however observe that it was amphibious ; indeed, it is to be doubted whether it is able to drag along its unwieldy shape on the land.

" A large number of other kinds of fish inhabit the surrounding seas ; all of which, excepting oysters and eels, are different from those of Europe:

"Sea-eels were easily caught with a linè, as well as those of the fresh water, 
From the breakers to the lend, there are large spots that are covered at high water, and remain dry when the sea withdraws itself. In this space, there are ditches or hollows formed by the sea, which, as they always remain full of water, retain large quantities of fish. In these pools a line may be employed with ease and pleasure; beçause these waters being very clear, the fish are seen coming hastily to seize the hook, around which arises a kind of combat for the bait; so that in a very short time an abundance of them may be taken.

"About a thousand yards from our habitations there was a creek which is full at high water, and at the mouth of which we used to lay a net, so that when the sea had retired there remained many different kinds of fish, and in great numbers, which were easily taken. There was also another creek on one side of our village that abounded in oysters, which stuck to the rocks. We often went to breakfast there on this delicious shell-fish; which also procured us an excellent ragout, when blended with the cabbage of the palm trees, and the fat of turtles.

\section{Birds.}

" The most remarkable bird in this island is the Solitaire, so called because it is never seen in flocks. The plumage of the males is gray intermixed with brown; their feet and beak resemble those of the turkey, though the latter is rather more crooked. They have scarce any tail, and their hinder part is covered with feathers in such a manner as to give it a round appearance. They are taller than the turkey; and have a straight neck, somewhat longer in proportion than that bird when it erects its head. They have a black and lively eye, but are without crest or top-knot. They never fly, as their wings are not sufficiently strong to sustain the weight of their bodies; and they employ them principally as the means of attack or defence, or to call to one another. For this latter purpose, they turn round twenty or thirty times with great velocity; when their wings, being outspread, the motion produces a noise which resembles that of a kestril; and may be heard at the distance of an hundred yards. The bone of the pinion enlarges at the extremity, and forms, under its feathers, a small round lump like a musket ball, which, with the beak, forms its principal defence. It is very difficult to catch it in the woods, but in an open space it is easily overtaken. From March till September these birds are very fat; and when young, yield a well flavoured meat. The males sometimes weigh between forty and fifty pounds.

"The hen is a most beautiful bird. - Some of the females are white; and others 
brown. They have a kind of band, resembling what is called a widow's peak, at the top of the bill, which is of a tan colour. They take great care to keep their feathers in a nice state of arrangement, and to clean themselves with their beak. The feathers that cover the thighs are curled at the end, so as to have the appearance of shells; and, as they are very thick, produce an agreeable effect. They have two projections on the crop, which are formed of feathers whiter than the rest, and curiously represent the bosom of a woman.

"These birds walk with so much stateliness and grace, as must excite the admiration of all who behold them; and they have often been indebted for their lives, to their pleasing appearance. Though they appear rather of a familiar disposition, when they are left to themselves, it is impossible to domesticate them. Whenever they are taken, they shed tears without making the least noise, and obstinately refuse all kind of food; so that they soen die from the want of nourishment. Their gizzard is always fourd to contain a brown stone, of the size of an hen's egg, and of a rugged exterior: it is flat on one side and round on the other, and is very heavy and hard. This stone appears to be born with them, as they are found to contain it when quite young: besides, the channel that passes from the stomach to the gizzard is much too narrow to afford a passage for it. We made use of this stone, in preference to any other, to sharpen our knives.

"This bird builds its nest upon an heap of palm leaves, which it raises about a foot and an half from the ground for that purpose. It lays but one egg, which is larger than that of our European goose. The cock and hen both sit on it in their turns; and the time necessary for hatching extends to seven weeks. During the whole period of incubation and nourishing the nestling, which is not capable of supporting itself for several months after its birth, the parent birds do not suffer any of their kind to approach them : the hen reserving to itself the right of driving away the intrusive females, and the cock exercising his office, of guarding the privileged spot against male intruders. Each calling the other, as occasion requires, to perform the duty assigned it.

When the young bird is in a state to maintain itself, the parents continue their union. We often remarked, fabulous as it may appear, that, within a few days after the young one has quitted the nest, a troop of thirty. or forty of the old ones. brought another of the same age to the spot; where the former with its parents. joined the troop, and they all proceeded to some retired place; when the elder birds retired in pairs, and left the two young ones to themselves. As we frequently 
followed them on these occasions, I vouch for the truth of this extraordinary circumstance, which we observed with equal surprise and satisfaction.

"The Gellinottes (gallina rustica) are fat during the whole year, and of a delicate taste : they are of a light-gray colour, and there is very little difference in the plumage of the two sexes: they take such precaution in secreting their nests, that we could never discover any of them; and consequently did not taste their eggs. They have a red border round the eye; and their beak, which is straight and sharp, is also red, and about two inches in length. They were seldom able to fly, their fat rendering them too heavy for such an exertion. If any thing red is presented to them, it irritates them so much that they instantly attack it, and in the heat of their fury they are readily taken. The bitterns also which we found in the island were as fat and palatable as well fed capons, and more easily caught than the gelinottes.

"The pigeons are somewhat smaller than those of Europe : they are of a slate colour, and always in a fit state for the table: they perch and build their nests on trees. They are so very familiar that, allured by the melon seeds, we seldom sat down to dinner without being attended by a considerable number of them. We accordingly caught them at our pleasure. They however never build their nests on the main island, but on the trees in the small islets near it, in order, as it may be supposed, to avoid the rats, which are so abundant in the former, but never pass over into the latter.

"The Fous, the Frégates, the Pailles en queue, and some other sea birds who live solely on fish, make their nests on trees; but the ferrets and some others, lay and hatch their eggs on the sand in the islets, which are the habitation of the pigeons. The flesh of these birds has a rank taste, but their eggs are excellent. The fous come in the night to repose in therisland; and the frégates, who possess a superior power of flight, watch for their arrival on the tops of the trees, when they rise up to a great height and pounce upon them like an hawk, but not with a view to kill them, but to make them disgorge the contents of their stomach. The fou, when it is struck, seldom fails to cast up the fish it has in its craw, which the frégate catches as it falls : there is sometimes a contest between these birds, but the frégate, which is more bold, active, and vigorous, seldom fails of obtaining its object. It is of a blackish colour, of the size of a duck, with wings of an extraordinary length. It is a bird of prey, with characteristic talons, and a beak six inches in length, which is crooked at the point. The old males have a piece of red flesh, that resembles a cock's-comb, under the neck. 
" The fou is so denominated, because it lights upon ships, and suffers itself to be taken : its back is of a chesnut colour, and its belly white : the beak is pointed, very thick towards the head, and notched on the sides; its legs are short, and its feet are like those of the duck, and of a pale-yellow.

"The Paille en queue is about the size of a pigeon, and entirely white; it has a short and. strong beak, and a feather in its tail, about a foot and a half in length, from whence it takes its name. These birds waged a curious war with us, or rather with our caps: they used suddenly to attack us behind, and snatch them from off our heads; so that we were obliged to carry sticks, in order to defend ourselves against these extraordinary hostilities; but we could never discover the use to which these thievish birds applied their booty, or whither they carried it. The ferret and the pluto will be described among the birds of the Isle of France,

"In the Isle of Rodriguez there is but one kind of small bird, and it resembles the canary bird: we however never heard it sing, though it was so familiar as to perch on a book at the moment we were reading it.

: 4 There are green and blue parroquets in great abundance, which are of a moderate size : the flesh of the young ones is as delicate as that of young pigeons. There are also sea larks and snipes, and a very few swallows.

"The bats fly about during the day like other birds; they are as large as a pullet, and each wing is about two feet in length. They never perch, but hook themselves to the branches of trees by their feet, with their head hanging downwards; and as their wings are also furnished with hooks, they do not readily fall to the ground when struck, but remain attached to the boughs : indeed, when seen at some distance enveloped in their wings, they have the appeatance of fruit rather than of birds. The Dutch at the Isle of France considered them as a delicate food, and preferred it to that of any other fowl. We however could not bring ourselves to eat them. They carry their young, of whicl they have always two, wherever they go, and never quit them till they are able to fly.

"The palm trees and lataniers are covered with lizards about a foot in length, whose beauty was a frequent object of our admiration: : they are black; gray, blue, green, and red, and of the most brilliant tints. Their common food is the fruit of the palm tree. They are not in the least obnoxious; and we found them so familiar, that they: used to come and eat the melons, not only on the table, but from our hands. They are the prey of birds, and particularly of the bitterns: when we threw them down from the trees with a pole, the latter used to run to the spot 
and swallow them up before us, notwithstanding our utmost endeavours to obstruct their voracity.

"There is also a nocturnal lizard, of a grayish colour, and a very unpleasing shape : it is as thick and as long as a man's arm, and its flesh is not unpalatable: it is fond of the latanier.

"A quantity of salt may be collected from the holes of the high rocks on the coast, sufficient to supply the island if it were inhabited in every part. The sea water is driven into these cavities by the force of the waves, and the sun, that universal chemist of nature, converts it into salt.

"The sea also brought yellow amber, and ambergris : we found a large piece of the latter, of whose name and qualities we were altogether ignorant, and which was the cause of all our subsequent misfortunes, as will be hereafter related. We also found large quantities of bitumen, which we denominated amber, though it might more properly be considered as jet.

"This island produces a flower of a most agreeable odour: it is white as the lilly, and resembles in shape the common jessamine: it grows chiefly on the trunks of trees which are so decayed as to have become a kind of earthy substance; the fragrance of these flowers is perceptible at the distance of an hundred yards.

"The air of Rodriguez is obnoxious both to lice and fleas, an effect which we practically experienced after our landing on it : neither are there any of those stinging flies and other small insects, that in many places are so troublesome, or rather so insupportable, during the night*.

"In the small islands which have been already mentioned as the asylums and breeding places of the pigeons, there is an infinite number of sea-birds. Their flesh is neither palatable nor wholesome, but their eggs possess both those qualities. These birds are so numerous, that, when they take their flight, the air is sometimes darkened by them.

" They hatch on the sand, and so near to each other that they are in absolute contact, though of different kinds : they were so fearless of us that they would not move from before us, till they were forced from their situation. They lay three times in the course of the year, but never produce more than one egg at each

* This is the more extraordinary, as musquitoes are very troublesome in the Isle of France: this difference probably proceeds from the large quantity of wood-land there. 
period; a circumstance which is unknown among the birds of Europe. Some additional peculiarities belonging to them will be mentioned hereafter.

\section{Inconveniencies.}

" Having related the advantages and beneficial productions of this island and its environs, we shall now mention those circumstances which were unpleasant, and attended with inconvenience.

"There is a small fly, which, immediately on our landing, surrounded and covered us : so great was their number that it answered no purpose whatever to kill them: they do not sting, but when they settle on the face they occasion a troublesome itching. At sunset they retire to the trees, and reappear at sunrise ; as they love shelter and a gentle air, we had no sooner cleared a tract of land, than thè wind, having a more free course about our huts, drove them into the woods, and freed us from their persecution within the extent of our plantation; but we were sure to meet them when we enlarged our walks beyond it.

"There is also a larger $\mathrm{fly}$, which, unfortunately for us, had sufficient strength to resist the wind, and proved extremely troublesome. Its belly is full of live worms, which it deposited on our meat; and even let them fall on us as they flew : the only means of preserving our food from this insect was by steeping it from time to time in sea water. Coverings or safes might indeed have been made, by weaving the filaments of the latanier leaf for that purpose, but such a contrivance did not occur, when it might have been so serviceable to us.

"We were also persecuted by rats, which are like those of Europe, and in great numbers : they not only ate the seed we sowed, but used to gnaw whatever they found in our huts. The Americans have snakes which seem to have a natural hostility to this vermin. Cats also wage continual war with them; but we had no other assistance than that of the owls, and our own traps: we hawever contrived in a great measure to banish them, though they occasionally returned to torment us. The most expeditious and certain method to reduce them would be, by scattering poisoned food : the island being small they would soon be destroyed, nor would any inconvenience arise from such a mortality, if it were to take place previous to the establishment of the colony.

"The land crabs were also among our enemies; and from their prodigious numbers it would be almost impossible to destroy them, as well as from the difficulty 
of forcing them out of their holes. They inhabit the lower parts of the island, where they dig in the earth till they come to water: their den is spacious, with several outlets; and they have the precaution to wander but very seldom to any considerable distance from them. They continued, however, to ravage the produce of our garden, both day and night; and even to burrow beneath the fences which had been formed to protect it. The back, or shell, is round, about four inches in diameter, and of a dingy red. This animal moves in every direction, upon eight claws, which rise about three inches from the ground; and it has, in common with every kind of crab, two large indented claws of unequal size; that of its right side, being larger and stronger than that on the left. When it is in motion, its mouth cannot be perceived, as it is beneath its body; but its eyes are like those of the crabs in France and England, the one rising an inch above the other, on the extremity and forepart of the shell.

"It instantly retires on its being approached; but as it always pursues the stones which are thrown at it, sufficient opportunities are given to strike it. It is, however, imprudent to risque the being pinched by it. It frequently cleans its hole; and, having heaped up the offensive ordure, removes the whole, by pressing it with its claws to its belly : a reiteration of this labour soon completes the cleanly office.

"Some time previous and subsequent to the full moons of July and August, these crabs proceed by thousands, from all parts of the island, to the sea, laden with eggs. Great numbers might be destroyed at these periods; and we have sometimes killed upwards of three thousand in the course of an evening, with our sticks, without producing any visible decrease.

"In the second year of our abode in the island, the project was adopted of sowing seeds in the places which these creatures inhabited, in order to keep them away from the gardens; at least till our plants were grown to such a size as to defy their inröads. The precaution was also taken to sow the seeds of plants that we wished to cultivate, in those spots which the crabs did not frequent : these were elevated situations, with a rocky bottom, and at a distance from the brooks.

"The sea-crabs are much larger, as well as a more wholesome food, than those of the land; and their flesh is more easy of digestion. There is another kind of these animals, which in the, Antilles are called Tourlouroux: they are nearly of the same shape as those which have been just described, but somewhat less. They may be said to be amphibious, as the tide fills their habitations twice a day. 
"The hurricane, to which this island is subject in the months of January or February, is a most formidable enemy. We twice experienced the horrors of it. This furious wind generally, springs up after mild weather, and even after a calm. Its extreme violence lasted during the space of an hour; when we saw several large trees laid prostrate, and our own huts shattered to pieces. The sea was in a most terrible state of agitation, and, raising its billows like mountains, drove them against the shore with such impetuosity, that they seemed to threaten its: existence. The heavens were confounded with the earth; the air thickened, and covered us with darkness; while the clouds, rolling over each other, dissolved in such streams of rain, that the fine and fertile vallies exhibited a general inundation, whose torrents bore down every thing before them. The animals instinctively preserved themselves from the fury of the storm, by taking refuge in the holes of the mountains; they soon however reappeared, as the weather, in a short time, reassumed its serene and pleasant state. The last of the two hurricanes which we experienced at Rodriguez, was much more terrible than the former: in the midst of its greatest violence, there was a sudden calm, and extraordinary stillness, which induced us to think that it was passed away; but it soon returned with a renewed and aggravated fury. It entirely destroyed all our gardens, by overwhelming them with a deluge of salt water; but as the soil was not injured by that circumstance, our first occupation, on quitting the recesses of the yocks, where we had taken shelter, was to sow our seeds, as we had already done.

"The last enemy with which we had to contend, was the green caterpillar, which always succeeds the hurricanes. These reptiles greatly annoyed us, from February to April, by eating our melons; of which they would not leave a single leaf. Experience, however, at length taught us to keep the plants covered between sunset and sunrise; by which precaution they were at length preserved. As this vermin did not touch either endive or purslane, it may be reasonably presumed, that there are other herbs and vegetables which would be unpalatable to them.

" There are also small scorpions in some parts of the island; but they are by no means dangerous, as we were stung by them without any other inconvenience than the sensation of being pricked by a pin.

"When we bathed in the sea, or waded in it for the purpose of fishing, we were often surrounded by shoals of sharks, some of which were of a large size, without receiving the least injury from them. When we were upon the fatal rock of the 
Isle of France, which will be particularly mentioned hereafter, we saw, an hundred times, a pack of hounds swimming after a stag in the sea, and in parts which abounded with sharks, without the least interruption; nor did any accident happen to us though we continually bathed there. There is every reason to conclude, that the sharks of these parts are of a different kind from those which frequent other seas; where they are described and known to be of a most dangerous and ravenous nature.

\section{Their Occupations and Enjoyments.}

"Our occupations, during our abode in the island, were not, as it may be imagined, very important, but it was necessary to do something. The repair of our huts, and the cultivation of our gardens, employed one portion of our time, and walking engaged another. We often went to the southward of the island, which we crossed in all directions; and sometimes made the tour of it; nor is there a single spot that we have not frequently visited. Neither the high mountains, nor the lesser hills, are without verdure, though they are very rocky; but there is from two to four feet depth of earth above the rock. At the same time large and straight trees are seen to arise between the crags; nor could we discover the earth that nourished them. At a distance, this circumstance gives a more advantageous idea of the island than it deserves, because it encourages a conjecture, that it contains a deep and excellent soil.

" There are few or no places in the island which are not easy of access; and in every part there is plenty of provision and water. If no kind of fowl is visible, to strike a tree with force, and hollow aloud, will occasion them instantly to hasten to it, when they may be easily struck down with a stick or a stone. It was by the following accident that we discovered this singular circumstance. As we were one day rambling about at a distance from each other, it became necessary for us to. shout very loud, in order to collect the company, when we were astonished to see the birds flying. and coming from all parts round about us; so that a single discharge of our pieces was sufficient to procure us plenty. The land turtle is likewise to be found every where; and the air is so mild and temperate, that there is no reason to apprehend any inconvenience from sleeping beneath the canopy of heaven. Shelter, however, is easily obtained, and a few leaves of the latanier may at any time be contrived to afford it.

os Besides our little journies, we seldom failed to take our evening walks, One of 
them possessed so much beauty as to deserve a particular description: it extended along the sea-shore to the left of the rivulet: it consisted of a natural avenue of trees, which was as straight as if it had been planted with a line: it run parallel with the sea, was about twelve hundred paces in length, and might be continued for seven or eight miles. One side of this charming spot presented a vast expanse of ocean, whose tide, rolling over the breakers, at the distance of about a league, produced a confused but pleasing murmur : the other side offered a view of the most delightful vallies, which wore the appearance of beautiful orchards in the mild and rich season of autumn, and were bounded by a fine range of hills, that closed the prospect.

"Among the great number and variety of trees which nature has lavished on this spot, there is one which deserves particular attention for its beauty, grandeur, and the symmetrical arrangement of its magnificent branches: their extremities are every where tufted in an extraordinary manner, while its large and thick foliage drops around almost to the ground; so that on whatever side this fine tree is approached, a very small part, if any, of its trunk is perceptible. Within its shade there are branches that appear like timber work, expressly contrived to support the large tufts of foliage, which, spreading around form a kind of natural pavilion, the freshness of whose umbrage is inexpressibly grateful. The fruit, however, is of a sour, unpleasant taste, not unlike that of a ripe quince; but there is no reason to suppose it unwholesome: it graws in clusters, and appeared at a distance like the fruit of the anana. The leaves, which are of a fine green, have so short a stalk that they seem to be attached to the tree itself: the largest are four or five inches broad at the upper part, and terminate in a point, their length being about fifteen inches; while the fruit, which is of different colours, according as it is more or less advanced to maturity, appears between them. The whole presented an astonishing object of vegetable grandeur and beauty.

"In this solitary situation we amused ourselves with chess, trictrac, bowls, and skittles. Hunting and fishing, from their facilities, did not deserve the name of occupations : and to vary our amusements, we sometimes did not disdain to instruct the imitative faculties of the parroquets, which are so numerous in this island.

"During the last year we were often occupied in building the boat, whose history will be given hereafter; and we lengthened out our day by the aid of our lamps, which were supplied with the oil of turtle. We employed burning-glasses to light our fires. 
"As we had flesh and fish in abundance, with herbs, roots, fruit, and palm wine, there was no reason to apprehend any inconvenience from a dearth of provisions : on the contrary, we were nourished with very, wholesome and even luxurious food, which never occasioned the least sickness or indigestion, though we were without bread: the captain had, indeed, left two large barrels of biscuit, which was principally employed in thickening our soup.

\section{Preparations for their Departure from Rodriguex.}

"We had already been more than a year in this island, when we became uneasy that no vessel had arrived there; nor were we free from alarm, that a portion of the best part of our lives might be passed in this unprofitable solitude: it was at length resolved among us that, after having waited for news from M. du Quesne during two whole years, we should do our utmost to get to the Isle of Mauritius, as vessels arrived there every year from the Cape of Good Hope.

"That island is not more than eighty leagues from Rodriguez, though, in our situation, it was natural to consider it as a very long passage ; but as the wind blew. regularly on that quarter, it was determined that we should instantly build a boat in the best manner in our power; and if there was any probability of its being capable of service, attempt the voyage.

"The undertaking appeared to be pregnant with difficulties, but not altogether impracticable : we were, indeed, to construct a large boat, without intelligent workmen, and with few tools. Besides, we had neither pitch, tar, ropes, anchor, or compass : in short, a thousand other obstacles presented th zmselves to the reflection, and filled us with alarm. It was, nevertheless, resolved to set about the work, and if we did not lose our labour, to proceed on the voyage. Accordingly, without apprenticeship or experience, we, in an instant, became carpenters, rope makers, sailors, \&zc. and proceeded to employ our united efforts to forward the important object we had in view. The sea had fortunately thrown upon the shore a large square oak beam of sixty feet in length, which was sawed into planks; but as the saw broke three times in performing this office, and was also handled with little skill, they were of unequal thickness, and altogether indifferently shaped.

"Our bark was twenty-two feet long at the keel, six broad, four deep, and round at both ends: we were provided with a small quantity of nails; and Jean de la Haye, the goldsmith, who had some instruments of his trade along with him, forged others, as well as some useful iron tools : he had also contrived 
to mend the saw. Old linen was employed for the purpose of caulking; anå the kind of jet, which has been already mentioned, when mixed with the native gum of the place, dissolved in turtle oil, served as pitch. We twisted the fibres of the latanier leaves into ropes, which were of sufficient strength, but defective in pliancy; and they frayed also, in a short time, when employed in running work. A piece of rock which weighed about an hundred and fifty peunds, served for an anchor; and we formed a sail as well as we could. Thus, by the joint contribution of our in. dustry, the boat was completed; and, by our united strength launched into the water.

« For our stock of provisions, a sufficient quantity of dried lamentin was prepared; and several barrels were filled with water; we also took the biscuit that remained; and furnished ourselves with plenty both of land and water melons, the latter of which may be kept for a considerable time.

"We were so fortunate also, in a general search for whatever might be of use, as to find a small solar quadrant, which, though of a very inferior kind, we flattered ourselves might be useful in our projected expedition : when, however, the boat.was launched, we discovered that it did not 'obey the rudder, and we were under the necessity of supplying its place with an oar.

"The day fixed for our departure was Saturday the 1 gth of April, 1693, because it was near the full moon, when the state of the tide would enable us to pass the breakers, and we should possess light through the greater part of the night. These breakers surrounded the island, with the exception of two openings which gave access to it.

"When we arrived at Rodriguez, we perceived on the bark of several trees the names of certain Dutchmen who had landed there some years before, and had left the date of that circumstance; we accordingly determined to follow their example, and consequently wrote a brief account of our history in French and Flemish; particularly specifying the date of our arrival, the time of our abode, and the day of our departure; this document was inclosed in a phial, which was placed in a niche cut in the trunk of a large tree, beneath whose shade we used to take our meals, and which we believed to be proof against the violence of the hurricanes.

"At length the day of our departure arrived, and after having implored the divine assistance and protection, of which we appeared to be in great need, we embarked about noon with our provisions and our property: the weather was fine, and the wind favourable; and though the boat was, as may be supposed, of an 
imperfect construction and wretchedly equipped, we were animated with the mose sanguine hope of succeeding in our expedition. We reckoned, indeed, if the fine weather continued, and the kind of monsoon, which has already been mentioned, prevailed, that, according to our calculation, founded on the information of the captain and sailors during our passage, we should arrive in two days and two nights at the Island of Mauritius.

"We accordingly departed, with the animating hope that we should soon find ourselves among the inhabitants of the world. The space between the island and the breakers was soon passed : but we relied too much on our good fortune; for, instead of endeavouring to make our way through one of the openings already mentioned, we passed over the breakers, and the boat unfortunately struck one of their points in its passage; but, as we scarcely felt any shock, we flattered ourselves that no mischief would ensue: we were however deceived; for a leak soon appeared, and the water gained so rapidly upon us, that we instantly determined to regain the land. In the mean time the boat was filling, the helm was of no use, the wind blew us away, and fear prevented us for some time from employing any means of preservation. At length, however, the love of life instigated us to exertion; and by employing the oars, and having a leading wind, the breakers were soon repassed; but about thiry paces beyond them the boat sunk. If this event had taken place but a quarter of an hour before, we must inevitably have perished : the boat, however, did not overturn, and we remained upon its deck, in not more than three feet water. As the sea began to ebb, and being not more than half a league from land, we determined to wait till the water was sufficiently lowered for us to drag our chests on shore.

" This task was at length completed, but with great pain and difficulty, and we were obliged to return to the boat several times, in order to effect it: though much of our cargo was lost, we preserved those articles which were most necessary to us. On the following day we contrived to recover our boat, and drag it on shore.

"The greatest loss, however, that we sustained, was in the death of Isaac Boyer, which was occasioned by the extreme fatigue he underwent on this unfortunate occasion. He was the strongest and most vigorous person among us; but, worn out by the exertions he had made to recover the boat, and the articles it contained, he laid himself down, naked as he was, on the scorching sands, an indiscretion which 
brought on a fever, attended with delirium; and as we possessed no medicines, or indeed any medical skill, the sick man was left to the operations of nature, which, after some little struggle, was overpowered by the disease. He died in the twentyninth year of his age; and beneath the shade of a palm-tree, his remains were religiously deposited

"Though the grief which we felt for the loss of a friend, who was equally useful and dear to us, was such as the occasion merited; and though our first undertaking was attended with such unpropitious circumstances, it was immediately proposed to make another attempt to leave the island, even in such a brittle bark as ours, and boldly to brave once more the winds and the waves. It was determined, however, to profit by former misfortunes, and to employ a greater degree of precaution. It was said that the boat would be strengthened by its repairs, and that buoys might be placed to ascertain a better and less dangerous passage through the reefs. It was also suggested that we should quit the island at the moment of spring tide, with a view to pass over the rocks, if it should not be practicable to follow the track marked out by the buoys.

"I thought, with my companions, that it would be terrible indeed to be confined for the rest of our days, in an island of the Antipodes; but at the same time it did not appear to me possible that a mișerable gondola, such as we had made, would be capable of sustaining so long a passage, especially as we had not the necessary equipments. I had, indeed, opposed the first design; and was still more averse to forward the second. I represented in strong terms, but accompanied with gentle manners, the necessity of giving a greater degree of consideration to the design which was meditated. I praised the courage of those who were the most forward in prometing the project, and assented to some of their reasons; at the same time I requested them to reflect, that it would be a miracle if we escaped from a second wreck. I added, that experience should have made us wiser: that this impracticable scheme had already cost the valuable life of one of our companions; and that we ought to consider such an event as a warning to continue the exercise of our patience. I proceeded to observe, that the assistance which we expected might be on the sea, and that it might arrive at the moment when we were the sport of the waves, or gorging the monsters which inhabit them. We were, I said, in a situation where we wanted nothing that was necessary to sustain life; at the same time we might prepare large fires on the elevated spots of the island, to invite any passing vessel to 
come to our assistance : and to aid us in such a project, the latanier afforded its cotton, and the turtle its oil. Other arguments might have been used, but those which I had already employed did not receive a favourable attention.

"We are losing time, exclaimed one of the most determined among us, and we have had enough of prosing; so follow me, my friends, and let us think of the readiest means to quit this irksome solitude. At this summons, every one rose up as if it. had been uttered by an oracle; and nothing was now thought of but to prepare for the voyage. I ventured to make additional propositions, and thereby gained some little time; but, at length, it was resolved that we should embark on the day of the full moon.

"As nothing worse could happen to me, than to live and die alone in an island at the extremity of the world, I resolved, though not without some degree of hesitation, to depart with my adventurous friends.

\section{Their Adieu to the Island of Rodriguez.}

" The appointed day being arrived, we bade adieu to this charming island, and embarked once more in our miserable boat, on the 21 st of May, 1693. At first we were obliged to use our oars, there being little or no wind, in order to gain, with more exactness, the course marked out by the buoys; so that we passed the breakers without any accident: but in a few moments afterwards one of our oars broke, in consequence of a powerful effort made to escape from the rapidity of the current, which threatened us with no common danger; at the same time the calm rendering the sail useless, it appeared to be impossible for us to escape shipwreck. At length however a gentle breeze sprung up, which, with the assistance of our remaining oar, just preserved us from destruction. There was also another point about two leagues distant, towards which the current, that overpowered the wind, was driving us: but as we had by this time contrived to mend the broken oar, we employed it so effectually as to eseape this second danger. It was very fortunate, indeed, that we were able to restore to its practical use this instrument of our deliverance, as the rapidity of the current continued to demand our utmost exertions to resist it. The sea broke with a fearful impetuosity against the rocks which were the objects of our alarm; and night coming on, redoubled our apprehensions and our toil. To complete our misery, the sea sickness, which was occasioned by the agitation of our little vessel, so entirely overcame us, that we were, in a great 
measure, deprived of all power of exertion. The chief promoters of this enterprize were now convinced of their folly and presumption, and there was not one of them who did not anxiously wish to regain the island: but such attempt was altogether impracticable. In this lamentable situation did we remain from eleven at night till two in the morning; in which time, we concluded, that all the points were passed, and that we had gained the open sea, as we no longer heard the noise of the breakers. We had hitherto depended on our oars, but we now claimed the assistance of our sail, and began in some degree to recover ourselves. The next day the wind was variable, and the six following days it was in our teeth; a very extraordinary circumstance in these seas. The meat which had been dressed for the voyage we were obliged to throw overboard, as it became full of maggots; and our whole dependence, as to provisions, was some dried lamentin and water melons. In the early part of the voyage we had taken the precaution to content ourselves each day with two or three ounces of this food, in order to prolong to the utmost our miserable existence, if we should be so unfortunate as to miss the Island of Mauritius. Indeed, it was by a kind of miracle that we at length reached it.

"The wind, which had never ceased to be adverse till the morning of the eighth day of our navigation, was succeeded by a violent tempest. The weather was perfectly serene till noon, when the heavens became obscured; and the rain fell during four hours in such abundance, that it would have filled the boat in a very short time, if we had not laboriously and unceasingly exerted ourselves to empty it. This rain, however, was not accompanied by any violent wind; but as the night came on the wind increased; and the small glimmering of light that remained was succeeded by profound darkness.

- "The tempest increasing, we were obliged to lower our principal sail ; and, as it was impossible to keep in a light, having neglected to contrive a lantern previous to our departure, we were no longer able to consult our little compass; we therefore lost our course, and could do nothing more than bear before the wind with the foresail. The darkness did not always remain the same, and the vane was sometimes percep. tible; though that was now of little consequence. The greatest danger seemed to arise from the construction of the boat, which was only decked at one end: but those of us who had taken the lead in planning the expedition, could never be persuadẹd that it would not be accompanied with favourable weather and gentle gales. All attempts to find a reckoning was vain, and this night was alarming beyond 
description. The hurricane that had overtaken us between the Cape of Good Hope and Mauritius, was terrible indeed ; but we were then under the conduct of experienced sailors, and in a vessel that was capable of resisting it. It is not necessary to detail the particular circumstances of our situation : we were all of us convinced that our last hour was at hand: and it was even proposed to leave the boat to itself, and to wait approaching death with the resignation that became us. But this proposition of despair was soon over-ruled; and it was ageeed that we should exert the utmost efforts to our last moment. We accordingly recovered some degree of resolution; and several prepared themselves to swim when the boat should sink, and to add a few more painful morments to their existence. Though the state of extreme weakness in which we now were, might be naturally imputed to the toil we had undergone, to the want of food, the solicitations of sleep, which it was impossible to gratify, and the alarms which we could not suppress, it was, I doubt not, very much increased by the secret reproaches which we thought against each other and ourselves, for presumptuous confidence, or timid submission. But whatever irritating feelings agitated our minds, they were never suffered to be realized in words; and we encouraged each other in the language of fraternal affection. Thus were we placed between life and death.

\section{Their Arrival at Mauritius.}

"When the sun began to whiten the horizon the winds abated their fury; the sky became clear; and the light. unfolded to is a lofty cape, which was the Isle of Mauritius. If I omitted the particular description of our late situation, from my incapacity to give an adequate idea of its horrors, I certainly shall not attempt to display our present sensations. Our strength seemed to be renewed by our joy; and about five o'clock in the evening of the $2 g^{\text {th }}$ of May, and the ninth of our voyage, we arrived in a small bay in the Island of Mauritius. We were taken up a pleasant river by the tide, and disembarked in a very agreeable spot, at the foot of an hill which was covered with large and flourishing trees. It would be superfluous to describe our condition; but sleep, which we could now enjoy without apprehension, and such refreshments as could be obtained without much exertion, re-established our strength; and in the course of a few days we proceeded to discover the inhabited parts of the island.

"With this view we pursued our course along the coast; and, after a voyage of five days, during which we always slept on shore, we arrived at the Black River; 
where we found a few small houses inhabited by Dutch families, who received us with great kindness. These people had cleared as much land as was necessary for them, in a very pleasant valley. They had the greater part of our plants in their gardens, as well as those of India; and they cultivated a considerable quantity of tobacco. Their yards were filled with poultry, which proved a great luxury to us after our long abode at Rodriguez. The cottages of this little colony were covered with the leaves of the latanier, as our luts had been; but they were larger and more elevated, because this island is less exposed than Rodriguez to the fury of hurricanes.

" These good people live, in a great measure, by hunting, and they have dogs for that purpose. After we had remained aboùt a month with them, five of our party were commissioned to give notice of our arrival to the Governor. The place of his residence, which was called Frederick Henry, was situated on the south-east side of the island, at the distance of twenty-eight miles from the place where we had taken our temporary abode. The name of the governor was Rodolpho Deodati, a native of Geneva. While our deputies were gone to wait upon him, he himself arrived at the place where we were, in the course of his annual tour round the island. I was no sooner informed of this circumstance, than I went with my companion who remained with me, to demand his protection, which he immediately promised in the most obliging manner. After he had heard our history, both he and his attendants considered our sorry bark with astonishment, and expressed their surprise at the rashness of our enterprize. He promised to send us an anchor, which we should find in passing to the North-west Port, as it might be serviceable to us in going to the Lodge; the name given in these islands to the habitation of the governor, in whatever form it may be constructed. He also assured us in the most civil terms, that we should want for nothing; and added, that we might indulge the pleasing expectation of a vessel, which would arrive in a short time.

"In consequence of these kind expressions, which he frequently repeated, we departed from the Black River, where our deputies had rejoined us, and happily arrived at the North-west Port; but we found no anchor, as the Governor had promised, nor could we obtain the necessary instructions: for instead of our being informed how we might continue our voyage to the Lodge, we were told that we must carry our baggage to Flacq, a small village which contained the Company's garden, and was about eight leagues from thence. As this fatiguing journey appeared to be inevitable, we resolved to undertake it ; and accordingly transported 
our property thither in the course of eight successive journies, through woods in which there was no regular path, and where we frequently lost our way.

"When we arrived at the Lodge, we found the surgeon of our vessel, whose name was Clas, and Faques Guiguer, one of our small company of pilgrims, who has been already mentioned, and whom Valleau, our captain, had taken from us at Rodriguez. He had his reasons, which I shall not stop to develop, for taking the latter from us, as well as for leaving both of them afterwards at the Island of Mauritius. They related to us the following history:

"The Captain Valleau had no sooner weighed anchor off Rodriguez, than he opened all our letters, and having read them aloud to the ship's company, threw them into the sea. Two days after his arrival at Mauritius, an, English captain, with his crew, arrived there in a small sloop, having escaped from his ship, which had struck upon a sand-bank near Rodriguez. This man proposed to Valleau to accompany him to the wreck, with the hopes of enriching themselves with some of the valuable merchandize which it contained : the latter agreed to the proposition, and a secret engagement was ratified between them. Valleau, who was accountable to the Commandant of Mauritius, who was then M. Lamocius, for his actions, in order to cover his design, represented to him that the eight adventurers at Rodriguez might be reduced to the greatest distress, and that it would be an act of charity to send them certain necessaries and accommodations, of which he presented an ample description. The Commandant, to whose attention the Governor of the Cape of Good Hope had warmly recommended us, fell readily into the snare; and by his orders Valleau's vessel was laden with deer, calves, goats, hogs, fowls, and fruit; in short, with abundance of every thing produced at Mauritius; and which, if they had arrived, would have made an Eden of our island. The waves, however, were our avengers; and he was for several days severely buffeted by them, without being able to get to the wreck; and the stock of provisions, of which he may be said to have robbed us, was all he got by his villainy.-I shall now return to our own history.

"Jean de la Haye, the goldsmith, having a considerable quantity of professional tools, which were very heavy, and consequently incommodious to take about with him, was induced to dispose of a part of them to a person of the same profession whom we met at the North-west Harbour. Among his tools was a piece of ambergris, of about six pounds in weight, which had been found at Rodriguez, and has 
been already mentioned. De la Haye having asked the goldsmith what it was, the latter quietly replied that it was a gum, which was employed as tar at Mauritius; that great quantities of it were found in certain trees, and that it was of little or no value : De la Haye, therefore, very cheerfully threw it into the bargain that had been made between them : he, however, kept a few small pieces as objects of curiosity.

"The following day some one having informed him that this pretended gum was real ambergris, this circumstance produced a very sharp and angry dispute between the two artisans; and De la Haye thought it right to apply to the Commandant for justice; when it appeared, in the course of various discussions of the subject, that he had applied to his own advantage whatever ambergris he could collect, though the India Company laid an exchusive claim to it, and had absolutely ordained, that whoever found any of it should immediately cede it, at a fixed price, to their agents, for their sole advantage. The Commandant, therefore, was alarmed at the probability that this history might reach Batavia by our means, and that the Company would not only make him render an account of his peculation, but punish him with great severity for the commission of it: he accordingly meditated our destruction; and as a preliminary step to his design, he committed our boat to the flames, and distributed our sails, which were made of fine holland, among his huntsmen.

" He began to mark his discontent by lodging us in an hut, and supplying our table with the remains of what had been served to the servants of the Company. In a short time after, he forbade us to go further from our hut than the distance of a thousand paces: he also deprived us of the servant which had remained with us, by employing him in the service of the Company; and, as he had already engaged the other in his own service, we were now reduced to five persons.

" This conduct, so opposite to his former friendly behaviour, caused us to look forward with apprehension to the consequences that might follow : but as there are in all societies certain characters, who are more impatient and uneasy than the rest, those of that temper among us, La Case and Testard, formed a project to seize a small sloop belonging to the Company, and take refuge at Mascaregnas, now the Isle of Bourbon, which is not more than forty leagues from Mauritius: but as they had every reason to imagine that the rest of us would firmly oppose such a stratagem, they concealed it so successfully, that we entertained not the least suspicion 
that they even meditated such an expedition. But as the execution of their enterprize required some assistance, they applied to a soldier in the service of the Company, who had complained to them of the Commandant's conduct towards him, and proposed that he should be of the party: the soldier instantly communicated to the Commandant the proposition which had been made to him; though he added at the same time, that the three comrades of the two delinquents were entirely innocent and ignorant of the plot.

"Several weeks passed on without any appearance of suspicion on the part of the Commandant; though all our actions were strictly observed without any distinction. At length, during the night of the $15^{\text {th }}$ of January, he sent a body of soldiers to bring all of us before him. On this occasion he began by declaring, that he had no accusation against me and two of my companions; and then proceeded to question the others : they at once avowed the truth; adding withal, that our boat, which had been wantonly burned, was a superior vessel to that of which they had formed the design to possess themselves; and that they intended to leave a sufficient sum of money for the payment of it: which declaration the soldier himself confirmed. Nevertheless we were all of us, the innocent and the culpable, conducted to a dark prison, and put in a kind of stocks, which compelled us to remain in a recumbent posture. The only difference in the treatment of us appeared the following day, when our two accused companions were punished with an additional load of iron fetters.

"We remained in this state two days and two nights, when my two innocent companions and myself were delivered from it. On quitting the prison we were conducted to the Commandant, who, after insulting us with declarations of his good-will towards us, made many insidious promises of the kindness he would shew us, but without one consolatory word respecting the injuries which he had done us. The first act of his kindness was to order us to be guarded day and night; and it was immediately followed by a seizure of every thing we possessed, except our clothes, bedding, and a few books. We were then put on board a boat, together with our accused comrades, who were brought in their shirts and with the fetters on their legs, totally ignorant of our future destination. It proved, however, to be a barren and frightful rock, of about two hundred paces long, and half that space in breadth, where it was almost impossible to walk, as the surface consisted 
of deep holes, and pointed stone : though we could, indeed, sometimes pass into two neighbouring islets *.

\section{Their Residence on the Rock Island.}

" Here we were placed, without any covering but a wretched hut situated on an elevation, close to the breakers, within two paces of the sea, and in the hurricane seasons: it was also in a state of ruin, and had already served as a prison for criminals, who some years before had been banished thither.

"Here we remained near three years; at least those of us who survived that period. Thus, like the flying fish, we no sooner escaped from the pursuit of one enemy than we fell into the maw of another.

"We had remained near three months in this miserable condition, when on the $15^{\text {th }}$ of March, 1694 , we saw a Dutch vessel, called the Perseverance, come to an anchor before the island, which according to the laws of the country, should have transported us, whether we were criminal or innocent, to Batavia, or the Cape. But we learned from our purveyors, that we must not expect to depart in that vessel : it was therefore resolved by my two comrades and myself, who were not in a state of accusation, to risque every thing in order to get to the island while the officers who commanded the Dutch vessel remained there, that we might make our complaints, and relate our sufferings in their presence. We accordingly made a raft of sea-weeds, which was floated by two water barrels attached to its extremities; and $\mathrm{B}^{* * *}$ and De la Haye, my two companions whose innocence had been acknowledged, and who were better swimmers, as well as more capable of bearing fatigue than myself, hazarded the passage on this kind of flying bridge: in twelve hours they reached the land.

"They instantly proceeded to the lodge of the Commandant, and they found the officers of the vessel with him. In their presence they gave the history of the cruel treatment which they had received; and demanded to be sent away, according to the general orders, and customary practice of the company; and, in the mean time, claimed that treatment and protection which, as innocent men, they deserved.

* This islet appears to be that of Marianne, situated about two leagues from the fort of the south-east port, where the Dutch Commandant then resided. 
"Deodati, at the same time that he repeated his belief of our innocence, and lamented our sufferings, could not, he said, act in a more lenient manner towards us; for as we were all Frenchmen, and associated together, he could not place a confidence in one more than in the other. The officers appeared to entertain a favourable opinion of us, but they had no right to interfere in our behalf, nor the power to afford us the least protection. We however indulged the hope that they would report our situation to their masters.

"Thus ended this bold, hazardous, and fruitless embassy; my companions were ordered again to the stocks; and, on the following day, were brought back to the island, with an absolute prohibition, on pain of exemplary punishment, to quit it: and to prevent all possibility of attempting it, we were now supplied only with one barrel of water at a time, and which had but one bottom.

" The officers of the vessel were, nevertheless, correctly informed of our history and condition, by a circumstantial account which my two comrades contrived to communicate to them; and in which they were earnestly supplicated to make known our situation to our relations in Holland, that they might employ the means necessary for our deliverance.

"These gentlemen paid us an humane visit on our rock, in order to satisfy themselves concerning the contents of the memorial which had been presented to them. They were soon convinced of the cruelty with which we were treated, execrated the barbarous injustice of the Commandant, and solemnly promised that they would do every thing in their power to procure us relief: they also sent us three hundred pounds weight of rice, some white biscuit, and several bottles of Spanish wine and brandy; a treasure which we carefully concealed from the rapacious inquiries of Deodati. The officers having informed us, that though they could not take an active part in getting us on board their ship, they were ready to receive us, if we could contrive, by any means of our own, to reach it. With this encouragement we made another raft, but the winds and the currents being unpropitious, we were compelled to return; and, in a few days after this attempt, we had the inexpressible mortification to see the vessel depart without us.

"The Commandant, being on the eve of marriage with the daughter of an old inhabitant of the island, was influenced, by the good humour which the approaching event occasioned, to give orders that I should be removed from my desolate abode: but I was not permitted to see him, and I could do nothing for my 
companions. I received, however, great benefit myself from the little voyage, and the change of air. To add to the distress of those whom I had left, and whose health and strength had yielded to the miseries of their situation, a violent hurricane, which shook the most solid buildings, tore up large trees from the earth, and destroyed the harvest in Mauritius, blew away, like so much straw, their wretched habitations from the rock, and they had no other shelter but such as its cavities afforded them.

" It may not perhaps be an unamusing relief to the curious mind, to be informed of the personal circumstances and employments of the exiles of the rock.

"As we did every thing in our power to counteract our melancholy, one of us, who had a great deal of ingenuity and fancy, suggested the idea of making hats of the leaves of the latanier, $\pi$ s there were some of those trees in one of the adjoining islets, to which we had access at the full and new moon. This employment did not merely serve to amuse, but became the cause of procuring us relief; for these hats were considered as such a flattering present, that they purchased the good will and gratitude of those who brought us our provisions: and when the inhabitants of the island saw these productions of our toil, they were so delighted with them, that in return for such as we could present to them, they contrived to convey to us various kinds of refreshments, which proved of the greatest utility and comfort.

"In our situation it was natural for us to look to fishing as an aid to our subsistence; but all application for any remnants of our fishing tackle being treated with neglect, we were only able to contrive a kind of harpoon with a pole and a large iron nail, with which, however, we were sufficiently successful in the holes or trenches on the shore, that served as traps for the fish when the sea retreated from them. But our fishery had well nigh cost us our lives. It happened that in one of our fishing parties, we caught, or rather killed, as we thought, an immense eel, which weighed upwards of sixty pounds; and, as we bore it away in triumph, each of us considered himself a St. George, the conqueror of the dragon. We found its flesh, however, not only hard but nauseous; and it was fortunate that we were so soon disgusted with it, or we should have been irrecoverably poisoned. Instead of an eel, it proved to be a marine serpent (the Murena), whose deleterious qualities are so well known to naturalists, but of which we were altogether ignorant. We all, indeed, suffered severely from the very little we eat of this serpent, and it was a month before I recovered from the effects of the small morsel which reached my stomach. 
"But as if we were not sufficiently wretched beneath the tyrannic barbarity of Deodati, an accident happened which, by giving him an opportunity to affect new suspicions against us, threatened us with still more alarming effects of his vengeance: a fire had broke out in the fort, and, till the real authors were discovcred, the Commandant had entertained, or at least pretended to entertain, a suspicion that we were concerned in the mischief. The man who brought us our provisions gave the following account of this event.

"The Commandant having been informed that a Negro had committed some thefts in his kitchen, condemned him to receive the chastisement connected with that offence, which was very severe. The miscrable culprit, alarmed at the sufferings with which he was threatened, took to flight, after having plotted a design, with one of his comrades and two Negro women, to set fire to the fort: they accordingly executed their fatal scheme, but were not so fortunate as to escape: they were shortly taken, when the two men suffered the rack, and the women were hanged. A very singular circumstance attended this execution, and as it was related to us by a person of the most incontestible credit, I shall venture to repeat it.-One of these wretched criminals, it seems, had possessed a most inordinate passion for play, which predominated on the scaffold, where he was about to suffer a most painful death. He there entreated, with the most earnest solicitation, that some one of the assistants, on this awful occasion, might, as an act of charity, be permitted to throw dice with him for a few minutes, and that he should then suffer the sentence of the law without regret. If he had any secret motive for his conduct, it was known only to himself; but be that as it may, no one was disposed to be of his party; and he appeared to lament the refusal more than his fate.

"About this time two English vessels came to an anchor in the road of the northwest harbour, but as it was more than twelve leagues from our rocks, we knew nothing of their arrival: as the Commandant, with his usual precaution respecting us, had prohibited, under very heavy penalties, the communication of such an event to us. We were indeed informed afterwards, that one of the Captains of these vessels having been made acquainted with our detention, was so sensibly affected with our situation, that he had determined to relieve us, and had actually prepared a boat to fetch us away, when the weather interposed to prevent this act of humanity; besides, it must have gone round one half the island of Mauritius, in order to have reached us. 
"On the 5 th of September, 1696 , the vessel called Suraag, arrived with a special commission to take us to Batavia. Our generous friends, the officers of the Perseverance, did not neglect to present our letters and memorials to the Directors-General in Holland, and such was the effect which was produced by them. The Commandant continued his injustice, his insolence, and his cruelty to the last, and added to the long catalogue of complaints which we were already prepared to make against him, when we should arrive in Batavia."

\section{Observations of Le Guat on Mauritius.}

We shall add the following remarks of M. le Guat on the Island of Mauritius, which are not only curious from their early date, but may be considered as a part of its history.

"Ships may come to an anchor in three principal places: at the fort, ${ }^{*}$ in the soutbeast river, and the north-west haven.

" The Company maintains, at the fort, a garrison of about fifty men; and there are about thirty or forty Dutch families dispersed in different parts of the island.

After the fort had been burned down, it was rebuilt with stone, and furnished with twenty brass cannon.

"The soil of this island is almost every where of a reddish colour, and generally good; but in the neighbourhood of the south-east fort it is unproductive. It is a matter of some difficulty to get out of the south-east road, although there are two openings, as a certain wind is necessary, which does not often blow; and profound calins are very frequent in these regions. The other two roads are tolerably commodious.

"The island produces ebony trees, both black and red: the black is the hardest wood; indeed the soldiers who are employed to saw ebony, can finish twenty feet of the red in as short a time as twelve of the black; which is considered as a day's labour.

"There are oranges both sweet and sour, an abundance of lemons, and divers kinds of trees which are fit for the purposes of building and carpentry. At a quarter of a league from the fort is a forest of lemon trees; and in its neighbourhood, as well as in several other places, there are plantations of tobacco, which is extremely pungent. The sugar cane is also successfully cultivated; the extract of it, which is called arrack, is very strong, and indeed unwholesome when it is new. The anana and 
banana, both excellent fruits, are in great plenty. : There are also cocoa trees, palm trees, the lataniers, and several kinds of fruit trees.

" There is a kind of shrub which is called Stront-boom, that possesses very poisonous juices; the largest part of its trunk is in the middle; the wood is soft, and its leaf, though somewhat larger, resembles that of our willow. I never saw its flowers or its fruit. Both the wood and the bark contain a strong and violent poison, which is said to defy all remedy. On passing one day through the woods, I by chance broke off a small twig, and put.it, without reflection, into my mouth, and though I threw it away instantly, and without having, apparently, swallowed an atom of it, I very narrowly escaped death. During twenty-four hours I suffered the sensation of being throttled, and my throat was swelled to such a degree, that I breathed with the greatest difficulty. The method employed to discover the poisonous from the salutary fruits in this island, is to present them to a monkey, and his acceptance or refusal at once determines their wholesome or obnoxious qualities.

"In the middle of the country, in a plain surrounded by mountains, there is a wood which it is very dangerous to enter. The branches of the trees are so thick, as well as so interlaced with each other, that they entirely obscure the sun: the whole forming an inextricable labyrinth, and without affording any fruits to support the unfortunate wanderer who might be lost in it. A former Commandant of Mauriius, and his attendants, remained in this forest upwards of four days without tasting food, when they fortunately discovered an opening, by which they were preserved from the fate that threatened them. The other woods may be penetrated without difficulity, and some of them are extremely pleasant.

"On each side of the rivers there are, frequently, small vallies, whose soil is excellent. Some parts of the country are also level, particularly in that district which is called Flacq, or flat country; which is the residence of the greater part of the colony. The India Company has established a large garden there, which contains the greater part of our European plants that can be cultivated with success in this climate.

"It is from this garden that the Company derives both roots and fruit for the supply of the garrison, the Negroes, and other persons whom it maintains in the fort. A boat is regularly sent twice a week to the Great river, to transport these necessaries, which are brought in waggons from Flacq : this conveyance is attended with considerable expence, as it is a distance of eight leagues, at least, from thence to the fort; but the soil round the latter place is so barren, that it is incapable of being 
made productive, and the water is impregnated with saltpetre. There is a certain part of the island which is called the burnt country, because the trees which formerly covered it were consumed by fire: many of them however have recovered, though that district is one entire rock.

"The potato succeds in every part of the island, and forms the common food of the inhabitants. It serves them as bread, in the same manner as among the common people of Ireland. When rice is wanted it is purchased of the Company; though there are situations, both as to soil and water, which are very well adapted to the cultivation of that grain. The inhabitants however are too idle to pursue that beneficial agriculture.

"The cows yield but little milk. That animal in Holland will give six times the quantity of those in Mauritius : their flesh also is very inferior to ours; but the difference arises, probably, from a total inattention to pasturage in this island. There are also wild cattle, which are indigenous; at least they were found there by the Dutch in the last century. There are also wild horses, which are sometimes killed to provide food for the dogs. The two different species of animal which have just been mentioned, are subject to a kind of falling sickness, of which they frequently die, especially when they are young.

"This island was formerly full of geese, wild ducks, moor-hens, gallinas, and land and sea turtles; but they are now become rare. The lamentin, and other marine animals, have also removed farther from the coast, since they have been disturbed by its inhabitants. We frequently saw large flights of herons, and many of those birds which are called giants, from the elevation of their head, which is about six feet; their legs and neck are both of great length, while their body is not larger than that of a goose. They are entirely white, except in one part beneath the wing, which has a red tinge; they have the beak of a goose, but more pointed; the claws are separated, and very long: they feed in marshy spots, and are frequently caught by dogs, as they require a considerable time to rise on the wing: they bear a great resemblance to the ostrich. We saw one of them at Rodriguez, which was so extremely fat that it could not move with sufficient agility to escape us. But as that was the only one we saw on that island, we were disposed to believe that it was driven thither by the violence of the wind. It is a very palatable food.

" The rats are very numerous, and a large supply of cats is necessary to exterminate them. 


\section{The Dronte, Dodo, छ̊c.}

There is found also in this island, the Dronte, Raphus (Brisson, Mochr; Dodo, Edwards,) which is a species of itself, though some have supposed it to belong to that of the ostrich.

It commonly inhabits the Island of Mauritius, so celebrated for the beautiful ebony wood which it produces. It is a very stupid animal : its size and figure is between that of the turkey and the ostrich; it is taller than the swan; its head is long, large, and shapeless; its feathers rise to a point on the forehead, and grow around the beak and on the face, in the form of an hood, from whence it has obtained the name of the hooded swan; its eyes are black and large; its beak, which is strong, and of a considerable size and length, is both pointed and hooked, and of a pale blue colour; the neck is long, fat, and curved; the body is large and round, and covered with gray feathers, which are as soft as those of an ostrich; its wings are short; its legs are thick, long, and of a yellow colour; it has four claws, three before and one behind; it does not fly, and is very slow in its progress when it walks : the flesh is covered with fat, and is at the same time so nutritious, that three or four of these birds are sufficient to glut an hundred people. Stones are generally found in the stomach of this animal. Lightness and activity, says M. Buffon, are attributes common to birds, but the Dronte has no claim to these characters; . on the contrary, it appears to be expressly formed to give an idea of the heaviest of organized beings.

Size, which, in animals, generally pre-supposes strength, in this particular instance produces nothing but weight. The ostrich, the tomjou, and the casoar, are not more capable of flying than the Dronte; but they are very swift of foot; whereas, the Dronte appears to be borne down by its own weight, which it can scarce bear along. It answers, amongst the birds, says M. Buffon, to the slotb among the quadrupeds. It may be said, indeed, to be composed of brute inactive matter, in which the vivyfying particles have been omitted: it has wings, but they are too weak, and too short, to lift it into the air; it has a tail, but it is both disproportioned and out of its place. It may be actually taken for a tortoise, covered with feathers; and nature, by furnishing it with these useless ornaments, seems as if she wished to add the embarrassment to its natural weight, the awkwardness of its 
motions, to the inactivity of the mass, and render its lumpishness more disgusting, by forcing upon the observation that it is a bird.

This bird is no longer found in the Isle of France; nor in those of Bourbon, Rodriguez, and Sechelles. It must now be placed among those species which have existed, but have been destroyed by the facility with which they were taken. No hope can now be entertained of finding them, but on the shores of uninhabited islands.

This is the bird which is named the Giant by le Guat, p. 144 . 
"There are neither lice, fleas, toads, or frogs, at Mauritius; Rodriguez was also free from them, as well, I believe, as every other island in these seas.

"Hurricanes were formerly frequent, as well as violent, in this island; but that which I have already mentioned, and from whose fury we suffered so much additional misery on our rock, was the only one which had been experienced during the course of the last twenty years. There are, however, at certain seasons, very violent winds, accompanied with torrents of rain.

"It is a singular circumstance, if it be true, as I have heard it universally affirmed, that when an hurricane visits Mauritius, it always happens on the $g^{\text {th }}$ day of February: this is declared by the inhabitants as an indubitable fact.

"The seed-time is in the rainy season, which lasts five or six weeks. The climate is wholesome, though the heats are sometimes extreme. The fine season generally continues from June to February."

N. B As the extract from le Guat, on the Island of Rodriguez, may perhaps be found long, I think proper to explain my motives on the subject.

The residence of le Guat and his companions in that island, being the sole event which furnishes us a sort of historical description, it was necessary to mention it. By attachment to truth and justice, I could not do better than to let the author speak himself; knowing that this manner, which has been adopted in Anarcharsis, \&c. offers more interest to the reader. However, it has cost me more labour than if I had written the whole in my own way; because I have been obliged to correct the style, and to shorten it in every part, which seems to me tedious, prolix, and often of erroneous systems: besides, he places Rodriguez at two hundred leagues from Mauritius, whereas it is not half, as I make him say, \&c. \&c. \&c.

I wish the knowledge I present of this island, may be sufficiently convincing of the advantages which may be reaped from it, that it should no longer remain useless to humanity. 


\section{GHAPTER V.}

Historical Description of the Isle of Bourbon.-Origin of its Establisbments.-An Account of the Governors from the Year 1664.-The successive Voyages tbither -Descriptions of it by Reynal, Rocbon, St. Pierre, Poivre, Admiral Kempenfelt, La Caille, and the Captain of an English Sbip.-Account of the Hurricanes, by Brunel and Bernier, Eंc.-History of the Volcano, by M. de Commerson, Rocbon, and Bruncl; and a Comparison of it with those of Mount Etna and Vesuvius.-State of its Agriculture, by M. Poivre.

1505. $\mathrm{F}_{\text {rom }}$ the discovery of the Isle of Bourbon by Mascaregnas, in 1505, to the year 1598 , when the Dutch possessed themselves of it, + it does not appear that the Portuguese had formed any establishment there, nor even that their navigators had approached it. The Dutch themselves, at this latter epocha, had only touched at the Isle of France.

1613. After the Portuguese, the English captain, Castleton, appears to be the first who had visited this island, in ${ }_{16} 6_{3}$ : he left it as he found it, absolutely desert.

1618. Bontekoë came to an anchor off the coast of this island in 1618 . It'was then without inhabitants; but he found a plank there, on which an account was inscribed, that Admiral Martens Blok, commanding a fleet of thirteen ships, had lost a boat with several sailors on this coast. +

1664 . From this period, 1618 , to 1657 , according to Rochon, or to $166_{4}$, according to Rennefort, we have not been able to discover that any voyager had touched at the island of Mascaregnas.

1665. It was in this year that M. Flacour, director of a French Company, took possession of it, and gave it the name of the Isle of Bourbon, which it still retains. He left there but very few inhabitants, as will be seen hereafter.

* According to an incription found at St. Paul, at Mascaregnas, and mentioned by le Guat, the Portuguese took possession of that island in the year 1545 .

+ See the second voyage of the Dutch to the East Indies, by Vanneck.

+ Chapter I. page 24. 
An Account of the Governors of the Isle of Bourbon; extracted from the Fournals of the Isles of France and Bourbon, wbich were printed at the former, in the years $1785,1786,1787$, and 1788; and from the Voyages of Flacour, of Rennefort, de la Haye, छ'c.

As no settlement had been made at the Island of Mascaregnas either by the Portuguese or the Dutch, M. de Flacour, governor of the Island of Madagascar, took possession of it in the year $16_{57}$, in the name of the King of France, and denominated it the Isle of Bourbon. He left there nine men and three women, and appointed a man named Payen to be their commander.

In $166_{5}$, Rennefort touched at the Isle of Bourbon, in his voyage to Madagascar, with three vessels, the Taureau, the la Vierge de bon Port, and the l'Aigle Blanc. These vessels left the Sieur Renaud with twenty artisans under his orders. He possessed this little command till June, $16_{71}$, when M. de la Haye relieved him. This Renaud, who was one of the first clerks of the India Company, established in $166_{5}$, may indeed be considered as the first governor of this island; and he it was who formed the four principal establishments, which actually subsist, under the names which he gave them, viz. St. Paul, St. Denis, St. Mary, and St. Susanna.

In 1671 , M. de la Haye, who commanded a ship in the king's service, took possession of it also in the name of his Majesty Louis XIV; and conferred the command on M. de la Hure, who died suddenly.

M. de Florimond, lieutenant in the king's service succeeded him, and died also in a short time.

In 1673 , M. Nuger.

In 1675 , Father Hyacinthe arrived there, to exercise the functions of a priest, and arrogated to himself the rights of a governor.

In 1678 , M. Drouillard followed his example, though he had only the title of agent.

In 1689, M. de Vaubulon arrived in the character of governor; and in the same year M. le Cours succeeded him.

In June, 1701, M. de Villiers was governor.

From 1704 to $1708, \mathrm{M}$. de Chalainville.

From 1710 to 1715 , M. de Parat.

From 1715 to $1721, M$. de Beauvilliers.

In 1722, M. Desforges Boucher. 
In 1723 , the Superior Council of the Island established.

Oct. 8,1726 , M. Dumas was appointed director-general of the Islands of France and Bourbon.

In 1735 , M. de la Bourdonnais succeeded him.

In 1738 , M. Dumont, director of the Isle of Bourbon, was replaced by M. du Guerty.

In 1746 , M. de Lozier Bouvet; and M. Bellier per interim.

In $1767, M$. de Belle-Combe was commandant, by order of the king, at the Isle of Bourbon, and M. de Cremont commissary of marine.

In $1773, \mathrm{M}$. de Steinaver.

In 1776 , M. le Vicomte de Souillac; and in $177^{8}$ the Marquis de Courcy, in the place of M. de Cremont.

In 1779, the Count de St. Maurice succeeded, per interim, to the Viscount de Souillac.

In 1781 , the Baron de Souville.

In 1784 , M. de Motais de Narbonne succeeded the Marquis de Courcy.

In 1785 , M. Dioré succeeded the Baron de Souville; and M. de Chanvallon replaced M. de Motais de Narbonne.

The governors general, since the year 1787 , have been the Chevalier de Bruny d'Entrecasteaux, General Conway, M. de Cossigny, and M. de Malartic. The latter was named governor-general in $179^{2}$, and has retained his appointment to the present time, though he was nominated by the king.

M. Dupuy succeeded M. de Narbonne as intendant-general, and has also kept his situation.

Since the arrival of M. de Malartic, as governor-general, the Isle of Bourbon has been successively governed by Messrs. Chermont, Duplessis Vigoureux, Roubaut, and G. M. Jacob, who is the actual governor.

\section{Extract from the Voyage of Rennefort, in $166_{5}$.}

"When the orders, which were deposited with Messrs. de Beausse, de Montaubon, and de Rennefort, were opened off the Cape of Good Hope, the president, surprised to find that Merchants were named members of the Council, was anxious to arrive the first at Madagascar. Those who were embarked in the three other vessels, having lost sight of the admiral, no longer thought it necessary to remain in company; but 
having agreed upon Mascaregnas as a place of rendezvous, according to the tenor of orders, took their different courses, and soon lost sight of each other. The Taureau arrived there the ninth of July; the La Vierge de bon Port cast anchor four days after in the same road; and the Aigle Blanc arrived at the same time, at the eastern side of the island. As there was not any one on board the latter vessel who had ever been on shore in this island, six of the passengers undertook to reconnoitre. it, and, having ascended a mountain in order to take a view of the country, perceived the two other vessels, and hastened to that part of the shore which was the nearest to them. A boat was accordingly dispatched to the Aigle Blanc, to inform the captain of this circumstance; who immediately weighed anchor and joined his companions.

"The Isle of Mascaregnas is situated between twenty-one and twenty-two degrees of south latitude; is of a round figure, and sixty leagues in circumference. The sick who were landed there, recovered in a very short time, from the purity of the air, and the excellence of its refreshments. The turtle doves, the wood pigeons, and parroquets, were so far from being alarmed at the sight of man, that they flew about him with such familiarity, as to suffer themselves to be taken without any exertion. Cattle and goats were seen in great numbers. Hogs also were in great plenty, and fed on the land turtles, which were seen crawling about in every quarter. The sea turtles visited the shore during the evening, and were easily taken. The birds, indeed, were frightened from their familiarity, by the indiscretion of those who very idly amused themselves with discharging their pieces; but the land animals were inexhaustible, as well as the fish, which were found in pools, or inhabited the beautiful rivers that flowed through the island. Almost all the trees wept benzoin, and other precious gums: they are very lofty and fit for building; but their wood is extremely hard, and so heavy that it cannot be employed in the construction of vessels, particularly as it splits when dry.* The soil is so rich as to be made capable of producing two harvests in the year; and the water, which is excellent, does not nourish any venemous and mischievous animal. Ambergris, coral, and the most beautiful shells in the world are found upon the coast.

"One half of this island was formerly consumed by fire, which has left very

* That is not exact: it has been known since, that there are trees in these islands which are proper for the construction of vessels, as has been proved by experience. Some frigates, privateers, and merchant ships, have been built at Mauritius at different times. 
dreadful proofs of its violence. The anchorage is not good off any part of the island; nor are hurricanes unfrequent. When they arise, trees are torn up by the roots, houses are blown away, and if the ships are not driven on shore, they are sunk by its fury.

" There were two Frenchmen on that side of the island where the three vessels cast anchor. Their little habitation was situated near a cascade, which fell from a large rock, and in the midst of plantations of tobacco, roots, and garden herbs. They had formed an enclosure, which contained hogs and goats, not only for their own convenience, but to sell to strangers who might touch at the island and could not spare time to procure them by hunting. This arrangement had some time before proved very useful to them, when a large English ship, called the Charles, commanded by Captain Barker, stopped at the island to take in water. They then exchanged their animals for brandy, oil, vinegar, and cloths, of which they stood in great need. One of these Frenchmen was named Louis Payen, and had passed three years in this solitude, after having lived twice that period at Madagascar; the other seemed to act in the capacity of a servant. Besides the two Frenchmen, the island was inhabited by ten Negroes, seven men and three women, who had been sent from Madagascar. They had revolted against the Frenchmen, and retired into the mountains, where they were beyond the reach of fire-arms. Six soldiers were sent in search of them; but they remained secure in the inacessible parts of the mountains.

“ These ships left at Mascaregnas the Sieur Baudry, a merchant, who was sick, and the Sieur Renaud, one of the principal clerks of the India Company, with twenty artisans under his direction."

\section{Voyage of $M$. de la Haye to the East Indies, in the years 1670 and ${ }_{16} 6$. $^{*}$}

" M. de la Haye was governor of St. Venan and colonel of a regiment of. infantry, when he was appointed by the king to the command of a squadron which was the most considerable that had been hitherto sent from France to the Indies. It consisted of five ships of war, a dispatch frigate, and three vessels armed en fute, which carried two thousand and fifty men. It received orders, not only to stop at Madagascar and the Isle of Bourbon, to declare M. de la Haye governor-general in the name of the king, but to visit all the French establishments in the Indies.

* It was published at Paris, in 1698, in 12 mo. under the title of Fournal des Grandes Indes. 
"M. de la Haye arrived at Madagascar, and, after passing six months in that island, proceeded with the whole fleet to the Isle of Bourbon.

" He found four plantations already established in this new colony, by fifty subjects of France, under the direction of the Sieur Renaud, in the name of the East India Company. On the 15 th of May, ${ }_{1} 6_{51}$, he declared his commission and appointment, in the name of the king; and the first act of his authority was to substistute, in the place of the former governor, a reformed captain of infantry, named de la Hure, with full powers over the four plantations, which had already been severally denominated St. Paul, St. Denis, St. Mary, and St. Susanna. The three latter were situated in the finest part of the island, between Cape St. Bernard, and the river St. Susanna; though this district extends much farther, being at least fifteen leagues in length, and four in breadth. The parts which had been cultivated, proved abundantly fertile : the corn, rice, and various kinds of roots and esculent plants were very șuccessful; nor were the vines, which had been planted about two years, less flourishing; but the grapes were devoured by the birds before they were ripe. Vessels came to an anchor off St. Denis, the only place in the fine part of the country where there there was a convenient landing; while the inhabitants of St. Mary and St. Susanna experienced considerable difficulty in transporting their commodities.

"St. Paul was the first plantation which the French had formed in the Isle of Bourbon; and the former governor had made it the place of his residence. It is situated at the foot of a mountain, at the distance of about two leagues from the sea. The intermediate space forms a fine plain, which is watered by a pool that opens towards the sea; and, in order to prevent it from overflowing in the rainy season, a channel has been cut, which at that period is capable of receiving a boat. Vessels ride more secure on this side of the island, because it is less exposed; and the two points which stretch out, form a kind of bay. The river of St. Gilles is bounded on one side by one of these points, which is called the Gallet. The place appeared to be commodious for a plantation; but it is so entirely covered with stones that it cannot be cleared. The writer observes, that with little trouble this river might be opened, which at its mouth is three fathom deep, with a rocky bottom.*

"The bulls and cows which M. de la Meilleraie had left there, thirty-five years before, were greatly multiplied, but in a less proportion than the hogs and goats. All these animals were become so wild, that it was absolutely necessary to

* This work has been since accomplished. 
employ hounds in taking them. The inhabitants had already remarked, that each kind of animal had its season. That of the hogs and goats began in the month of June, and lasted till January. The pigeons descended from the mountains in the month of November, and were excellent to the month of May, when they again sought their retreats: these animals were indeed equally good throughout the year, but at particular seasons they found in the flat countries certain food which served to fatten and render them more delicate."

\section{Account of the Isle of Bourbon, from the Discovery of it by the Portuguese.*}

"The Isle of Bourbon was without inhabitants, and consequently without cultivation, but the coast abounded in fish; and land turtles were every where seen of a prodigious size. In the early part of the settlement the colonists lived on fish, turtle, rice, potatoes, and yams. They denied themselves butcher's meat, as it was of the utmost importance that they should increase their cattle and sheep.

"As soon as the season became favourable, they planted sugar canes, and sowed corn. The first harvest surpassed their hopes; and this little colony was considered as established, with an assurance of encreasing prosperity. The life of the ancient patriarchs does not offer a more faithful picture of that happiness which is always inseparable from man, when he lives under a serene and fruitful climate, in a state of labour and innocence.

"The inhabitants of Bourbon extracted a fermented liquor from the sugar cane, a process which they had learned from the islanders of Madagascar. It is preferable to the best cyder of Normandy, though it will not keep twenty-four hours after its fermentation.

" The small number of cattle and sheep, which had been transported from Madagascar to Bourbon, encreased and multiplied. These animals found in the woods, with which this island is covered, a shelter from the burning sun of the torrid zone. They fed on a succulent grass, and appeared to take delight in the extensive savannais, whose productions are similar to those of the island from whence they came.

"When the inhabitants had secured the means of subsistence, by a right system of agriculture, a principal and fruitful source of the riches of man, they entertained

- As it is our object to make this account of the Isle of Bourbon as complete as possible, we shall add all the information that could be obtained, subsequent to the period of Baron Grant. 
as opinion that coffee might, in the course of time, become a useful branch of commerce between them and Europe. In 1718 , they procured from Moka and Ouden some young plants of the coffee tree: nor were they deceived in their speculation; and the Isle of Bourbon became a productive settlement to the East India Company.*

\section{Extract from the Narrative of $M$. du Quesne, respecting the Isle of Bourbon, in 1690 .}

" This charming island, which is in the twenty-first degree of south latitude, has an advantage, in common with a great part of the countries which are not remote from the line, that the heat is moderated by certain regular and refreshing winds.

" It is, however, a peculiarity of this spot, that some of its numerous springs are pure and wholesome, while others are medicinal and purgative. The brooks, or rather small rivers, which water the plains, are so full of fish, that some travellers have declared it to have been a matter of difficulty to wade through them. There are several lakes, and one in particular, whose sources are so abundant as to supply the waters of seven considerable rivulets which meander through a wide extent of fertile country.

"I shall not enlarge on the beautiful shells which cover the shores, nor on the coral and ambergris which are found on them; it is of more importance that the sea abounds in fish, and that the turtles, which it supplies in great plenty, are wholesome and delicious food. The land turtles are among the riches of the island: their flesh is delicate, and their fat is superior to butter for culinary purposes. There are sea turtles which weigh upwards of five hundred pounds: those of the land are not so large, though some of them would be an heavy load for a strong man. Their oil, for their fat, which never congeals, may be considered under that denomination, is an excellent remedy for various disorders. The turtle is very longlived; and it has been observed, that in the course of twenty years it does not encrease more than a few inches.

" The forests are not so thick but they admit of an easy passage; and their shade does not prevent the fruits from ripening. There are cedars and ebony trees in great abundance, and others that answer every purpose of the carpenter. There are also palm trees, fig trees, lataniers, orange and lemon trees, as well as the acajou,

* M. Rochon. 
or mahogany tree, of different kinds. There are at least twenty other species of tree, whose fruit is wholesome, delicious, and of great variety. There are also the aloes, indigo, sugar canes, cotton, the anana, the banana, tobacco, the potato, the pumpkin, land and water melons, cucumbers, and an hundred other plants, fruits, and roots, which grow every where, and without cultivation, even on the mountains. Turkey corn, or maize, millet, rice, wheat, barley, and oats, are also experimentally known to flourish there; and a twofold harvest of these grains may be annually gathered. All the plants and herbs of our European gardens have been cultivated there with great success. As the grapes are excellent, the inhabitants may look to the time when they will drink good wine of their own growth: nor is there any reason to doubt that they might naturalize, in this island, the greater part of the fruit-trees of our continent.

" The horned cattle, hogs, and goats, which were transported thither by the Portuguese, have multiplied in such a degree, that they are seen in large herds and flocks in the forests. It would not therefore be an unreasonable expectation that deer, sheep, and the other animals which are seen in the same climates, would procreate and increase in this island.

"Among the birds that are common there, I shall enumerate the partridge, the turtle dove, the wood pigeon, the snipe, the blackbird, the thrush, the goose, the duck, the bittern, the moor-hen, the parroquets, the egret, the booby, the frégate, the sparrow, and a great number of small birds. There are also several kinds of birds of prey, and sea birds. There are bats as large as our fowls, which the inhabitants consider as an addition to their tables. The giant and the dodo* are large birds of an extraordinary height, which frequent the rivers and the lakes, and whose flesh is like that of the bittern. The partridges are grey, and about half the size of ours. The male sparrow has a red throat, whose colour, in the coupling season, becomes more brilliant : but though these birds embellish nature, they are very hostile to the farmer, as they come in clouds to devour the grain that has been sown, and it is necessary to employ every means for their destruction.

"There are also snails, and flies which are very troublesome: and lastly, there are hurricanies; which, though they are not so furious as those of the American

- I believe that in this description, as well as in those of Le Guat and others, the great bird which they call Giant, and Solitaire, is the same; it is the Dodo, or Dronte, of Buffon. See page 117 . 
islands, are dreadful visitants. These terrible storms arrive but once in a year, and always at the same period; nor do they exceed twenty-four hours in duration. Preparations are therefore made, and precautions employed, which in a great measure baffle their violence. And, after all, it may be observed, that for one bad day, there are three hundred and sixty-four which are genial and serene."

\section{Some Account of the Isle of Bourbon.}

This island is much less known than the Isle of France, because it has no port; it is nevertheless as populous as the latter, and furnishes more corn than is necessary for the consumption of its inhabitants.

The Abbé de la Caille, from correct astronomical observations, has placed the Isle of Bourbon in twenty degrees fifty-one minutes south latitude, and fifty three degrees ten minutes east longitude, from the meridian of Paris.

It is about thirty-five leagues to the leeward of the Isle of France: nor does it require more than one day to pass from the latter to the former, while it will sometimes employ a month to return; because the winds blow, and the currents run, almost always from the south-east; though, in general, the voyage is performed in fifteen days.

"The Isle of Bourbon has, at a distance, a globular appearance, and is an huge mass of lofty mountains. It is said to be cultivated to the height of eight hundred fathom; and three inaccessible peaks, which are situated in the middle of the island, are supposed to possess an elevation of upwards of three thousand two hundred yards. *

"A beautiful sky, a pure air, a delicious climate, and wholesome waters, have however collected a numerous population of strong and courageous men, distributed in nine parishes, of which St. Denis is the principal; as well as the residence of the governor, of the administration, and supreme council.

"Many years have not passed away since these men were celebrated for a spirit of candour, equity, and moderation, worthy of the primitive ages. The war of 1756 produced some alteration in their manners, though without materially affecting their morals. These virtues were the more remarkable, as they were maintained in the midst of twenty-six thousand one hundred and sixty-five slaves, according to the calculation made in $1776 .+$

- Reynal.

+ At present there are at least forty-eight thousand slaves in this island.

$\mathrm{X} 2$ 
"At the same period, the colony reckoned fifty-seven thousand eight hundred and fifty-eight animals, not one of which was engaged in the service of agriculture, except two thousand eight hundred and ninety horses, which were employed for different purposes; the rest were reserved for the sustenance of the inhabitants.

"At this time the produce of the harvest rose to five millions four hundred and forty-one thousand quintals of corn; to three millions one hundred and ninety-one thousand four hundrẹd and forty tons of rice; to twenty-two millions four hundred sixty-one thousand and eight barrels of maize. The principal part of these productions was consumed in the island itself; the remainder formed a supply for the Isle of France.

"The colony at that period cultivated for the mother country, eight millions four hundred and ninety-three thousand coffee plants, the fruit of which is inferior only to that of Arabia ; each tree producing two pounds of coffee. This produce, however, is diminished since the cultivation has been carried on in an open country; since the planters have been under the necessity of continuing their plantations in an exhausted soil, and since the insects have attacked them.

" The shores of this island are very steep, and the sea is continually throwing up large pebbles; so that it is impossible for the canoes to approach land without being destroyed. *

"The difficulty of landing at St. Denis has occasioned the erecting a kind of bridge, which projects into the sea, by which the boats are enabled, though with considerable inconvenience, to reach the shore. There are no inns or places of public accommodation at St. Denis, or indeed in any other part of the island; and strangers are indebted to the hospitality of those with whom they have commercial connections. $t$

"The breeze, which comes always from the south-east, rises at six in the morning, and continues till ten at night. In the month of November it blows equally throughout the twenty-four hours.

"The distance is seven leagues from St. Denis to St. Paul. The mountain of St. Denis is passed by a transverse road, paved with pointed stones. The native horses of the country are employed on these journies, which are very strong and safe, though they are never shod. At two leagues from St. Denis is the Grande Cbaloupe: it is a valley, formed by two very steep mountains that run parallel with each other; 
and the bottom of it is an awful solitude, where an eternal calm reigns, though the wind blows fresh on the mountains. *

"At two leagues from St. Paul there is an extensive sandy plain, that reaches to the town, which is built in the same manner as St. Denis, and consists of large regular spaces surrounded with hedges, in the middle of which is an habitation; so that these towns have the appearance of large villages. St. Paul is situated on the bank of a lake of fresh water, which might with great ease be converted into an harbour.

"The India Company had at Bourbon a custom-house, and a Governor, who was very circumspect in his conduct towards the pirates. It so happened that the Viceroy of Goa came to an anchor in the road of St. Denis, and was invited to dinner by the Governor; but he had no sooner landed, than a piratical vessel of fifty guns moored alongside, and took possession of it. The Captain then came on shore, invited himself to dine with the Governor, placed himself at table between him and the Viceroy, and informed the latter that he was his prisoner. When the wine and good cheer had brought the sailor into good humour, M. Desforges; the Governor, demanded at what sum he would fix the ransom of the Viceroy: ' I must have,' answered the pirate, 'a thousand piastres.'- ' That is too little,' replied M. Desforges, ' for a brave man like you, and a person of high distinction like him : demand more, or nothing.' ' Well then,' said the generous corsair, 'I give him his liberty.' The Viceroy immediately re-embarked and set sail, equally grateful to the address of the Governor and the liberality of the pirate.

" Since that period, the number of inhabitants has increased, and agriculture has flourisled. At present there are sixty thousand slaves, and five thousand white inhabitants. $t$

"This island, which is better cultivated than the Isle of France, depends, never-

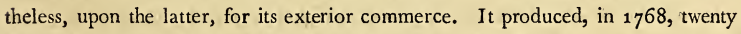
thousand quintals of corn, and the same quantity of coffee, without mentioning rice and other productions, which are consumed within itself. Herds of cattle are not uncommon. The King pays fifteen livres for an hundred weight of corn, and the inhabitants sold the quintal of coffee for forty-five livres in piastres, or seventy livres in paper.

"There is nothing worthy of observation at St. Denis but an inclosed stone * St, Pierre. + Idem. 
redoubt, which is too far from the sea ; a battery in front of the government buildings, and a drawbridge. Behind the town is a large plain, which is called the Camp de Lorraine. *

"The soil is more sandy at Bourbon than in the Isle of France; it is intermixed, for some distance from the sea, with the same round pebbles which cover the shore; a circumstance that justifies the conjecture that the sea has, in this part of the island, retired from the land.

"An old man, aged upwards of fourscore years, informed us, that he was one of those who took possession of the Isle of France when the Dutch abandoned it: twelve Frenchmen landed there in the morning for that purpose, and in the afternoon of the same day an English vessel anchored off it with the same intention; but it arrived too late.

"The manners of the ancient inhabitants of the Isle of Bourbon were distinguished by their simplicity : the greater part of the houses were without fastenings, and a lock was so rare as to be an object of curiosity : they frequently kept their money in turtle-shells, and placed them over their doors. They clad themselves in blue linen, but disdained both shoes and stockings, and lived on rice and coffee : they received few or no articles from Europe, and were content to live without luxury, so that they could live free from want. With this spirit of temperance and moderation, they possessed all the concomitant virtues-intergrity in their commercial dealings, and a noble generosity in their general conduct. When a stranger appeared among them, their hospitality knew no bounds.

" The last war in India has occasioned, in some small degree, a relaxation of their morals. The volunteers of Bourbon and Mauritius distinguished themselves in its campaigns by their bravery: but the silks of Asia, and the military distinctions of France, have found an entrance into the island. The children having become more opulent than their fathers, required an higher degree of consideration; and have quitted their native home, and the repose of rural life, to seek those pleasures and honours which are to be found in Europe. As it is become a principal object of those who are fathers to advance the fortune of their sons, they send them to France, from whence they seldom return; so that there are now in this island five hundred marriageable women, who are growing old without any prospect of enjoying the comforts of the married state. $t$

- St. Pierre. 


\section{Observations on the Isle of Bourbon, by Admiral Kempenfelt, in the Year $175^{8 .}$}

" The Isle of Bourbon was inhabited some time before that of Mauritius, by the remains of the French, who had been expelled by the inhabitants of Madagascar from the settlement at Fort Dauphin. These were joined by the pirates who had infested those seas, and together, formed an establishment there under the protection of the French flag. They were composed of renegades of all nations, French, English, Irish, Scotch, Portugueze, \&c. ; and having married the black women of Madagascar, whom they had taken away with them, they soon had children, and thus augmented their new colony.

"The Isle of Bourbon is situated in the twenty-first degree of south latitude, and the fifty-fifth degree of east longitude from the meridian of London. It is about forty leagues west-south-west from the island of Mauritius.

"The inhabitants sowed corn and rice, and had planted coffee with great success; they had brought horned cattle as well as fowls from Madagascar, which soon multiplied, and served for their subsistence. In all their wants they had recourse to that island, with which they maintained a communication by means of their large canoes. Full Point, and the Island of St. Mary, on that coast, not being more than an hundred and forty-five leagues from Bourbon.

"About the year 1720, the pirates, who had been driven from Madagascar by the King's cruizers, took shelter in the Isle of Bourbon, and submitted themselves to the French government.

"The soil is extremely fertile, and the air wholesome, though there are two volcanoes which burn with great violence : their flames are seen in the night and their smoke in the day at a great distance.

"The want of a port or harbour, is the cause of its being less inhabited than the Isle of Mauritius. The necessaries of life are there in so great abundance, that they can supply the neighbouring island with provisions. The fine season lasts from the month of June to November; in the remaining part of the year there are terrible hurricanes, and particularly in February, March, and April; they frequently tear up the largest trees by the roots, overthrow the strongest buildings, and ravage the island from one end to the other. Many vessels have perished on this coast from these hurricanes, which come on so suddenly as to baffle every precaution; 
and many slaves are annually lost in their canoes, as they are employed in loading or unloading the larger vessels, or as they are employed in fishing at three or four leagues distance from the shore. I never saw any other kind of boats at St. Denis, or on the windward side of the isle. Some of them are so large, though made of a single tree, as to require ten or twelve oars. On the first appearance of the hurricane the French vessels cut their cables and stand out to sea, rather than go to the road of St. Paul, to the leeward of the island, though there is good anchorage, from thirty to thirty-five fathom water, at about two miles from the shore, and in a much less disturbed sea than that to the windward.

" The whole of the island is divided into ten parts or parishes; St. Denis is the principal of them, and the residence of the Governor; the others are St. Mary, St. Susanna, St. Benoit, St. Andrew, St. Peter, St. Paul, St. Giles, the River, and the Gulf.

"The small town of St. Denis, where I was, contains about an hundred wooden houses: the house of the Governor and a few others are built of stone. The town is agreeably situated on a small plain near the sea; the greater part of the houses have gardens behind them, and the residence of the Governor is large and convenient. At this time a very handsome building of two stories, with wings and an handsome front, is erecting as a college for the education of the youth of the two islands, and of the other French colonies in the East Indies. The houses here, as well as in the Isle of Mauritius, are covered with small planks which are not fit for other purposes, and are placed like our tiles. They form a light and lasting roof, and of a very pleasing appearance. There are also three batteries on the sea-side. But the most curious object in this place, and which merits particular attention, is the hanging bridge, contrived to project, as it were, into the sea, and by whose assistance goods may be embarked or disembarked with convenience and safety, in the most stormy weather, and when it is impossible to approach the shore from the violence with which the waves break against it. Before the construction of this curious bridge, it was not possible to disembark or unload, without great risk, in the finest weather.

" This bridge is principally formed of four large masts, which are fastened by large and heavy chains of iron; so that articles of merchandize may be elevated about thirty feet above the surface of the sea, and even still higher, in boisterous periods, by cords and pullies. A ladder of ropes is attached to its extremity for the 
purpose of ascending, \&c. It is the second bridge of this kind which has been constructed, as the first was carried away by an hurricane; but this is so securely fastened by strong chains to pieces of cannon and anchors buried in the earth, that there is no reason to apprehend a similar accident. It was constructed in the time of $\mathrm{M}$. de la Bourdonnais, and was formed on the model of a bridge in the island of Malta, supposed to be the only one of the kind in the world.

" The principal produce of this island for exportation is coffee, of which there are three annual harvests. The plantations are well kept and cultivated; and it is this article that reimburses the India Company for the expence which it is obliged to sustain for the support of these two islands. It received three large vessels every year laden with this commodity, at its own price, which was always the lowest, and did not exceed four sous of paper money per pound, or twenty livres per bag, containing an hundred weight; though it formerly paid a higher price, in order to encourage the planters : but in proportion as the plantations extended, and the quantity increased, the Company has diminished the price : and as the planters have no other channel of trade, they were obliged to receive whatever the Company choose to give them. It is said that the coffee is but little inferior to that of Moka; but the transport of it by sea is attended with a degree of risk peculiar to itself; the least humidity being sufficient to spoil an entire cargo. A bag, weighing an hundred pounds, put. on board at the island of Bourbon, generally produces an bundred and four or six pounds on its arrival in France. These bags are made of reeds which grow in the island, and were first formed into mats for this purpose by the slaves which were brought from Madagascar.

"Rats and mice make a most destructive havock in the plantations, but there are neither monkies or wild beasts.

"Besides coffee, the island produces corn, rice, maize, and manioc, with which they furnish the inhabitants of Mauritius, at certain prices fixed by the India Company, or the Governor General of the two islands. The corn, at nine livres the hundred weight; the rice, at one sous the pound, or five livres the hundred weight, unpicked; and maize, at four livres for the same quantity.

"Many of the inhabitants are rich, or at least very much at their ease. Their plantations are productive, and they extend in proportion as the grounds are cleared. Nevertheless, many of them are dissatisfied with the government beneath which they live, and are anxious to remove in to some other part of the world, where 
they might enjoy a greater degree of liberty. At the same time that they wish to get rid of their plantations, those of the Isle of Mauritius increase, from the number of the inhabitants, and the advantages of secure and spacious ports.

"Being in the possession of all the necessaries of life from their own plantations, which are, in general, very agreeably situated, they live at a very small expence in peace and tranquillity.

"Some of the planters in the Isle of Bourbon have from eight hundred to a thousand slaves on their plantations; and in that of M. de Forges, who has greatly improved and extended his possessions, there are at least fifteen hundred. He enjoys the post of Engineer of the Company, and is admirably qualified for his situation. $\mathrm{He}$ is the most opulent individual of the island, and has lately built a very noble house of the finest stone, which has the appearance of a palace rather than that of the habitation of a planter. It contains fourscore beds beneath its spacious. roof, and is surrounded with beautiful gardens, as well as a park embellished with herds of deer, and large pieces of water full of fish: he has also made, at a very great expence, a road from his house to the town, and is the only inhabitant of the island who keeps a coach.

"It has been already observed, that there is no port in this island, it being entirely surrounded with a steep shore, where the waves dash with great violence, especially on the windward side. The only place where a port might be formed, in which vessels might ride in safety, is at the mouth of a little river, at the place called St. Mary. Here it was that M. de la Bourdonnais thought it possible to make a port sufficiently large to contain three or four vessels : but to carry that design into execution, he demanded a million of livres of the Company; which has lost several of its vessels from the want of such an accommodation.

"When I was at the Isle of Bourbon, the Company lost a ship of eight hundred tons burthen, called La Paix, near the bay of St. Denis, in a violent hurricane. It lay there to receive a cargo of coffee for Europe.

"The inhabitants of this island are subject to the same danger and devastation as those of Mauritius, from the runaway slaves who inhabit the woods. They were, at a former period, estimated at the number of a thousand; but in consequence of considerable rewards offered to those who should kill or take them, they are now supposed to be reduced to two hundred. For each of them taken alive or dead, the Company gives a well-conditioned slave, who is generally valued at an hundred 
dollars. The captain of a ship, some time since, destroyed upwards of forty of them, by the following stratagem. As he knew that, from their abodes in the summit of the mountains, they could perceive every thing that passed in the road where his vessel lay, he ordered some biscuit, cheese, and several bottles of brandy: mixed with arsenic, to be put on board a canoe, and employed two of his sailors to take this treacherous cargo on shore, and to appear to enjoy the contents of it. Nor was it long before the wretched people, who were the objects of this perfidious design, came down with the utmost precipitation to seize the booty. The sailors then regained their boat with some apparent reluctance, and the Negroes, who thought that they had possessed themselves of a very valuable prize, instantly began to gratify themselves in the consumption of it. On the following morning twenty of them were found dead; and about the same number still living, who were so swelled from the quantity of water they had drank at a neighbouring spring, that they were incapable of quitting the spot. On the next day they also passed into the other world; where, it is probable, they found a more happy allotment than the captain will experience, when he has made the same voyage.

"Some of the inhabitants informed me that the vine would succeed in both these islands, but that the Company did not encourage the cultivation of it, from the apprehension that it might interfere with those objects which were more neces. sary and beneficial.

" The Company procured, at a "great expence, some young spice plants from the Dutch islands: but though some of them flourished, others degenerated; nevertheless, the cultivation of them is continued with great assiduity, and the hope of final success. Fresh and larger importations of these plants were afterwards made.

Observations on the Isle of Bourbon, in $176_{3}$, by an Officer in the Britisl Nary.

" This island is situated in about the twenty-first degree of south latitude, and fifty-four degrees thirty minutes east longitude, of the meridian of London, and is about eighty leagues from Madagascar. Its form inclines to an oval, and its greatest length is from north to south. Its circumference is about one hundred and fifty miles; and it is divided into eight parishes, of which St. Denis is the principal: each of them containing a church, with one or two officiating priests. The number of its inhabitants amounts to about twenty-five thousand, three fourths of which are 
slaves. The Portuguese discovered it, and gave it the name of Mascaregnas. They left some goats, and tortoises, or land turtles, there, ${ }^{*}$ which multiplied beyond all expectation; but the latter are now entirely destroyed. After the destruction of the settlement at Fort Dauphin, on the south side of Madagascar, the French, who were driven from the island about the year 1680 , took possession of this island, which they named the Isle of Bourbon. A small number of people also arrived there from France; and its population was also augmented by some English pirates, who came with Avery, England, Condon, and Pattison. After having acquired a considerable fortune in the Red Sea, and on the coasts of Arabia and Persia, they established themselves in this island. The King of France accordingly pardoned them; and some of them were still alive in ${ }_{17} 6_{3}$. Their descendants are very numerous in the island.

"The center of the island is very mountainous, and intersected with deep vallies; along which rapid rivers flow, and bear huge-stones along with them. During the

* In $1_{13}$, the Pearl, Capt. Castleton, visited this isle, when birds were its only inhabitants. $\mathrm{He}$ left some goats and hogs there, in order that they might multiply, and form supplies for those who might hereafter touch there. There are many fine springs of fresh water, and the flesh of the birds is excellent. John Thornton, p. 28.

- Purchas, vol. I. p. 331 , gives the following account :

March 27, 1613, twenty-one degrees latitude. We saw an island to the south-west, at the distance of five leagues, which appeared to be very elevated. At six in the evening we cast anchor on the east side of it, in ten fathom water, with a bottom of black sand, and about a mile from the land. We sent our boat on shore; and the people found an infinite number of land turtle, of a large size, and which were excellent food. The north-east point of this island is very high and steep ; and towards the south-east of this point there is a plain, which is watered by a fine stream that has the appearance of a river; and though a boat cannot enter there, it is an excellent place to take in water. The island had the appearance of a forest, and I accordingly called it the English Forest, though others denominated it the Isle of Pearls, from the name of our vessel. There are both land and sea birds, with pigeons and parroquets, in great numbers. There is also a species of large bird, about the size of a turkey, very fat, and whose wings are so short that it can scarce rise from the ground. They are white, and not having been terrified by fire-arms, discovered so little apprehension of our people that they knocked them down with sticks : ten men killed as many of them as would feed forty. In the interior of the island there was a pool, and another river, fre. quented by great numbers of ducks, wild geese, and abounding with large and as fine eels as any in the world : one of them, which appeared to me to be the largest I had ever seen, weighed twentyfive pounds. I consider this island as a most convenient place to obtain refreshments, thongh it is entirely unituhabited. 
rainy season it is very difficult to pass them. The precipices on either side are horrible; and the snow is seen on the mountains in the months of July and August. The road from St. Denis to St. Paul has been a work of great labour; it passes over five high mountains in various meanders : that which rises above St. Denis, and is by no means the highest, has twenty-two of these turnings before its summit is attained. Two other mountains form what is called the Grande Cbaloupe, from its sides, which resemble that of a boat. They are very elevated, and covered with small trees. There is between them a fine valley, and a river, which present at once a pleasing and fearful prospect.

" The country rises; with a regular ascent, from the shore to the middle of the mountains. It is agreeably varied by country-houses, corn fields, plantations of coffee, and water-falls : there are, nevertheless, both plains and mountains that advance almost to the sea. That part of the isle which belongs to the Creoles is ill cultivated : they are not in a condition to purchase slaves, and they are too proud to work themselves; nor is there any law to compel industry. The soil is in general fertile, though the vegetable earth is not more than two or two feet and an half in depth : beneath it is a bed of rock. It produces in great abundance, and with little culture, all the different grain of Europe, as well as rice, indian corn, the sugar cane, and a great variety of vegetables, roots, and esculent plants. The year yields two harvests; and the grain of Europe is sown in the winter months. There is also honey and wax of a superior kind. The fruits of India flourish there; but I do not remember that there are any European fruits, except the peach and the rasberry. The Talameba cinnamon* and the benzoin tree succeed there. The bark of the' first is very good, but the latter does not. yield any considerable quantity of gum. There is also the Chinese root, ipecacuanha, but inferior to that which grows in America, the larger kind of cardamum, and many other medicinal herbs. The inhabitants are also acquainted with plants which are excellent remedies in the dysentery and venereal complaints : they have excellent wood for building, which is very durable, and susceptible also of the finest polish; nor are they without timber trees which are calculated for the construction of vessels. But the principal production of the island is coffee, which was originally brought from Moka; it has, however, degenerated, in some small degree, though it is still superior to that of the

- The cinnamon may be propagated by planting the shoots. It grows very fast, and is but little inferior to that of Ceylon. 
West Indies. It is generally cultivated on the declivities of the mountains; rises to five or six feet, bears a white flower, and a fruit which resembles a cherry, that contains two grains inclosed in an husk: it is gathered in May and June, and is dried in the sun on platforms; it is then beat to disengage it from the husk, and is exported in sacks made of a double matting. The Company buy it of the inhabitants, at twenty French livres the hundred weight, and engage to take three millions of pounds, or fifteen hundred ton per annum; it is generally sold in the East at from seventy to eighty livres. The inhabitants have undertaken to make arrack, sugar, and indigo,* as well as to breed silk worms; but as the latter enterprize was not encouraged by the Company, it has proved unsuccessful, though it promised much in the beginning.

" They have great plenty of cattle, sheep, and goats, as well as hogs; with poultry of every kind, and,many species of wild fowl. They annually export a large quantity of grain and provisions to the Island of Mauritius, and all their vessels are victualled with these articles. They have a great number of horses, of a small size but very strong.

"This island is very much infested by snails, grasshoppers, and other insects; as well as by rats and small birds, which make a terrible havock in the harvests. They sometimes suffer also from the extreme drought of the season.

"The islanders are, in general, very healthy and robust; and as the air is wholesome, they often attain to a very advanced age. The most common disorders among them are those of the stomach, which are caused by worms and indigestion: convulsions, proceeding from colds, after taking emetics or purgative medicines, are not uncommon; and dẻath frequently follows from receiving wounds. Inflammatory fevers are not dangerous, and putrid fevers are, in a great measure, unknown: the tooth-ach is so common, that there are very few people at the age of twenty years who have not lost some of their teeth.

"The first inhabitants, by intermarrying with the black women of Madagascar, have transmitted some degree of that colour to their descendants, who retain a proportion of the original complexion of their female ancestors. Not a fiftieth part of the free natives are really white; and those which are the most remarkable in that particular, are the descendants of English pirates. The Creoles enjoy the privileges of the second order of French nobility.

"As they have but little or no commerce, the inhabitants live by the cultivation

- The indigo plant grows wild in this island, and mulberry trees are in great abundance. 
of coffee, corn, and rice, by breeding cattle and other animals, with which they supply their vessels and the Island of Mauritius. Their labour is performed by slaves, who are born in the island, or brought from Madagascar and the coast of Africa; whose principal sustenance is Indian corn, cassava root, and potatoes. The native slaves, and those which have been brought when they were very young from Madagascar or other places, are all Christians, and it must be acknowledged that the priests spare no pains in their instruction; nor are they permitted to speak any other language than that of France.

"The principal curiosities of this island are the volcano, the plain des Caffres, and the road from St. Denis to St. Paul. The volcano is in the southern part of the island; it often smokes, but seldom emits flames. The country is not habitable for many miles round it, and the islanders have named it the burnt country, because it is covered with cinders and volcanic matter, which has been vomited forth by the mountain. The plain des Caffres, is formed by the summits of mountains at a very. considerable elevation above the sea : it is said to be twenty miles in extent, and is very flat, and without stones. The access to it is very difficult in certain places, though it may be ascended on horseback. The air is very pure, but as cold as a winter's day in England. When the clouds pass over the surface of the plain, they have all the effect of a gentle rain. A brook runs through the middle of it, which is broad but shallow, has a sandy bottom, and freezes in the winter. To the northwest of the plain there is a lofty, barren, and naked rock, from whence the brook gushes forth. There are also several small mountains, about an hundred and fifty feet in lieight, with a very narrow base; they are called the Pins, by the inhabitants, from their resemblance to a set of nine-pins prepared for the game, On this elevated plain there are small trees, with broom, furze, a kind of wild oat, and fern, which. grows to the height of a shrub. There are also some curious birds, which never descend to the sea-side, and who are so little accustomed to, or alarmed at, the sight of man, that they suffer themselves to be killed by the stroke of a walking stick. It often rains on the sides of the mountains, while this predominating plain is enlivened with the finest weather.

"This island is subject to hurricanes from the middle of December to the first of April : they are often very violent, and prove extremely mischievous to the harvest : they throw down the houses, root up trees, and, as there is no port in the island, the vessels which are overtaken by them inevitably perish, if they do not gain the 
open sea : they, however, give sufficient warning of their arrival, and last generally twenty-four hours, during which time the winds blow from every quarter, but they are most violent in the point which appears to be their centre. They are not very extensive in their sweep, as it sometimes happens that the hurricanes in the Island of Mauritius are not known in the Isle of Bourbon but by the confusion and darkness of the clouds, and a kind of whispering sound in the air. There was an hurricane on the day of my arrival in the island. Having come to anchor off the town of St. Paul, a pilot came off at a very early hour in the morning, to persuade me to go ashore, as there was an appearance of an hurricane, though the night had been very fine, and the sky was clear and serene. Its approach is discoverable ten or twelve hours before its actual arrival by an hollow and whistling noise, which is heard in the mountains, and a particular motion of the leaves. A Creole had arrived at midnight to notify these circumstances to the Governor. Before we had quitted the vessel, the clouds began to gather on the tops of the mountains; they were black, and separating on a sudden, unfolded a clear and brilliant sky: they closed and opened several times, successively, in the same manner; the rain then commenced, and the wind began to blow with such violence, that in a few hours after we had got ashore our vessel was beaten to pieces.

"This island is about thirty-five leagues due west of the Island of Mauritius. All the outward-bound vessels from the latter touch at the former to take in provisions; they arrive off the eastern side of the island at about twelve leagues from St. Denis; the principal town, which is on the north side. From thence they keep along the coast, and at a small distance from the shore; in every part of which they may cast anchor, though the ground is not good. The shore is steep and covered with stones, and the swell is generally so great, that in many places it is very difficult to land. The anchorage is good at St. Denis, in about eighteen feet water, but the road is exposed to the south-east wind, which in these latitudes blows almost throughout the year. Vessels remain there but a short time: they go from thence to St. Paul, which is to the leeward of the island, where there is a good road-stead, and the shore is of sand mixed with small coral.

"St. Denis is situated in an extensive and beautiful plain, which is considerably elevated above the level of the sea: the houses are constructed chiefly of wood, and are very neat; but are necessarily low on account of the hurricanes. The residence of the Governor is a large and commodious stone building, which contains also the 
public offices and the magazines. To facilitate the debarkation of goods, there is a wooden bridge, the work of M. de la Bourdonnais, which is a masterpiece of art : it advances about fourscore feet into the sea, and is about twenty feet high and ten feet broad, with a wooden balustrade: it is supported by upright beams, which, being joined above, are fixed in the shore, and fastened there by strong chains of iron. It is so contrived as to possess an elasticity that preserves it from the violence of the hurricanes. The high mountain which is to the west of the town shades the plain from the sun in the afternoon, so that the evenings are very pleasant in every part of it.

" St. Paul is a large and populous town, and inferior only to that of St. Denis: there are six other places or villages, where there are magazines for coffee, in each of which resides one of the Company's agents.

"The French send every year from Bourbon and Mauritius to Madagascar, to purchase slaves, cattle, rice, and salt; * so that from April to December vessels may be always found on the eastern coast of Madagascar, between the island of St. Mary, which is, as I believe, in the 18 th degree of south latitude, and the Fort Dauphin, which is to the south. The principal places are Foulepointe, Matatan, and Fort Dauphin. They purchase their slaves with Spanish piastres, as well as fire-arms, powder and ball : each slave costs about twenty-five piastres.

"The civil government of the Island of Bourbon is composed of a Governor and seven Counsellors; who are, nevertheless, subject to the Governor of the Island of Mauritius: the other members amount to about thirty, consisting of merchants, factors, and writers: the commissions of the Counsellors are derived from the King. The Governor has a salary of twelve thousand livres of France per annum; besides various perquisites, which furnish the principal part of the expence of his table. The second in command has four thousand livres per annum; the Counsellors two thousand livres, and the inferior officers fourteen hundred livres: the Counsellors have also an allowance on the merchandize which is sold in their magazines, as well as what is exported, which is equal to their appointments. The commodities found in their magazines are sold to the officers and other inhabitants at about forty-five livres per cent. above the price of Europe. The officers are allowed a certain quantity of wine at the current price, while it is sold to the inhabitants at an hundred per cent.

" The currency of this island is that of Spain; but in the last war bills were issued, which became the only current money. They take the Spanish piastres at three

- There are at present salt pits in the Isle of France, near Port Louis. 
livres twelve sous, which are worth in France five livres five sous. During the war the credit of the Company was so low, that the Spanish piastre rose from three livres twelve sous, to fifteen livres, and the price of the various articles of provision and merchandize in the same proportion; so that, though during the time we were prisoners, we were allowed six livres fifteen sous each day in paper, the real value did not amount to more than two shillings and sixpence sterling. All commerce with Europe is prohibited; a limited trade with India and Madagascar is all that is permitted, upon which is levied a duty of two and an half per cent.

"Their ships generally set sail for Europe in the months of October and November, and those which return from thence, generally arrive at the Isle of Mauritius in May and June.

"I shall now proceed to make some remarks on the force of the island, such as it was during the last war, and at the close of the year 1763 .

"St. Denis, which has been already mentioned as the principal place, is situated in an extensive plain, considerably elevated above the level of the sea. The shore is very steep and covered with stones, so that no kind of boat can enter into the river on the western side: it is defended towards the sea by three batteries, one of which is of brick, with fifteen eighteen-pounders; another is formed of fascines, and contains twenty-four eighteen or twenty-four-pounders; the third is of less consequence, and has no more than twelve nine-pounders. On the other side there is a small plain, at the foot of a high mountain which commands the town, where a redoubt, with a small battery, has been constructed opposite to it ; as well as one with twelve cannon and four mortars, which commands the road: there are also some small batteries between this and St. Mary, on the eastern side, which have each of them from eight to ten cannon. The town of St. Paul is defended by a large battery of twenty-four eighteen-pounders : there are some small batteries also along the shore, and one or two on the side of the mountain, to guard the passage. These are all the strong places in the island; and though, from this detail, it has the appearance of possessing considerable strength, the inhabitants were not of that opinion during the last war: they thought themselves incapable of defence on the sea-side; though, by defending the mountains and defiles, they might be able to prevent the enemy from advancing into the country.

"I have already said, that there are about twenty-five thousand souls* in the Isle

* The population of Bourbon is now more than double. 
of Bourbon; of which near eighteen thousand are slaves; so that when the women, children, and old men are deducted, there will not remain more than six thousand men capable of bearing arms. They had seven or eight hundred militia, sixty dragoons, composed of the free inhabitants, two hundred European soldiers, and about fifty artillery men. Such was the whole force of the island; and as it was dispersed in six different districts; it does. not appear that in any one place two thousand men could be brought to oppose the descent of an enemy; particularly when it is considered, that there are a large body of runaway slaves, who would be ever ready to join an enemy; or to set fire to the plantations: so that a part of the militia must be employed to watch them and prevent their devastations, as well as to protect the women and children. When, therefore, the real force of the isle is considered, with the little confidence that could be placed in the slaves, and the terror, which the English arms inspired, it may be presumed, if our fleet under Admiral Cornish, which cruised in 1761 off Rodriguez, had received orders to attack the Isle of Bourbon, he would have experienced very lițtle resistance in obtaining that important conquest."; *

\section{Description of the Hurricanes in the Isles of Bourbon and France.}

" 1768 . The breeze, which comes always from the south-east, in the Isle of Bourbon, $t$ rises at six in the morning, and ceases at ten at night. In November it remains day and night, and with equal violence. On the 1 st of December; 1768 , the wind ceased on a sudden, and at high tide such a vast swell broke on the shore, as, by its violence, to drive the centinel from his post; the summits of the mountains were covered with thick clouds, that appeared to be stationary; the wind blew a little from the south-east, while the sea rolled in from the west: the heavy swells succeeded to each other, and they were disstinguished along shore like three rolling hills, throwing up a kind of regular spray, which had the appearance of hair; and, as they dashed on the shore, their foam was forced upwards to the height of fifty feet.

"It was difficult to breathe; the air was oppressive and the sky gloomy: at the same

* These reflections are very just; but the author did not reflect, that when the English had got possession of this island, they would have found themselves in the same difficulties which had facilitated the conquest; because, as there was no port where ships of war could remain to detend the approach, that power alone which is in jussession of the ports of the Isle of France, can be certain of maintaining itself in the Isle of Bourbon.

+ St. Pierre. 
time clouds of corbigeaux and pailleneus came from the main sea, and took refuge on the coast; the land birds and animals appeared in a state of disturbance; the inhabitants felt a secret apprehension, at the sight of a storm in the midst of a calm.

" On the $2 d$, in the morning, the wind sunk at once, and the sea increased; the swells augmented, and came from a greater distance. The shore, lashed by the waves, became white with foam, which had the appearance of balls of cotton: at the same time the vessels in the road strained on their cables.

" There now could be no longer any doubt of an approaching hurricane. The canoes, \&c, which were on the pebbles, were drawn on the land. Every one hastened to support their houses with cords and beams; and the whole shore was lined with people, attracted by the extraordinary spectacle of the sea, and the danger of the vessels.

"Towards noon there was a great change in the heavens, and the wind began to blow fresh from the south-east. It was then feared that it would turn to the west, and dash the vessels on the coast. A signal was given from the battery for the vessels to depart ; when they instantly cut their cables, and disappeared, in about two hours, in the midst of a very dark horizon, to the north-west.

" At three in the afternoon the hurricane declared itself with a most alarming noise : all the winds blew : the sea, raging and agitated, threw clouds of foam, sand, shells, and stones upon the land: and the boats which were repairing at fifty yards from the shore, were buried under the pebbles. The wind carried away a part of the church roof, and the portico of the government house. The hurricane lasted all night, and did not cease till three in the morning.

"On the 6th, the two vessels which returned to the anchoring ground were a small boat and a galliot: they brought an account from the Penthievre, which had lost its main-mast. The different vessels continued returning till the $1 \mathrm{gth}^{\text {th. }}$

\section{Account of an Hurricane in the Isle of France, in February, 1771, by $M$. Rochon.}

"It is absolutely necessary to have been an eye-witness of an hurricane, to form a just idea of such a formidable phænomenon. It is almost always accompanied with rain, thunder, and earthquakes : the atmosphere is on fire; and the wind blows with equal violence from every part of the horizon. An hurricane is a kind of 
water-spout, which seems to threaten the spot over which it hangs with an entire subversion, while vessels are actually becalmed at a small distance from its explosion. If the swiftness of the wind exceeds one hundred and fifty feet in a second, nothing can then resist its force : the largest trees are torn up by the roots; the most solid buildings are thrown down; nor can the weight of anchors, the strength of cables, nor the strongest hold of the ground, secure safety to vessels, which are dashed to pieces on the shore, unless they are thrown on a bed of mud.

"I saw the main-top-mast borne away from the Mars, of sixty-four guns, and shattered to pieces in the hurricane of 1771 ; and which was not so violent as that of the month of February in the same year. An extraordinary variation of the barometer, is the only sign of an approaching hurricane in the seas between the tropics.

" Previous to the hurricane in February, the sudden descent of the mercury filled me with alarm, as well as M. Poivre, who requested the Port Captain to come to his house. This officer, who had been an eye-witness of the hurricane in 1761 , was not equally surprised with us, at the variation of the barometer, and informed us that there were more certain indications. 'Twenty-four hours,' he said, 'before the hurricane, you will see the black clouds descend from the mountain, and declare the approaching storm; besides, the setting of the sun will decide the measures I shall employ on the occasion.' But neither the intreaties of M. Poivre, nor my observations, were capable of changing his opinions; and though the mercury continued to descend, as the sun set in great beauty and serenity, the Port Captain left us perfectly satisfied, and free from alarm as to any threatening danger. He had long served on board the Company's ships, and seemed to pity us for giving so much importance to the predictions of our barometer. It is very difficult indeed to soften the obstinacy of a man, who, knowing nothing but the practical part of his art, treats with disregard the instructions of theory.

"The burricane, however, declared itself at seven in the evening, which was an hour after sunset: before nine, all the ships were driven on shore except the Ambulante store-ship, and a small corvette, salled the Verd-Galand: but, in a violent gust of wind, the former was driven out to sea, and the latter was sunk.

"The Ambulante, without sails, helm, or provisions, and with a detachment of the Irish regiment de Clare, who were on board, was driven about for upwards of twelve hours at the mercy of the winds; and, after being carried by their variation 
round the island, was miraculously thrown upon the only place where, in such a violent tempest, it would have been possible for the persons on board to save themselves. The horror of these hurricanes is greatly aggravated by the total impossibility of affording or receiving assistance. The violence of the winds, and the force of the torrents, renders it impracticable for any one to quit the shelter he has sought, or the spot where be happens to be at the commencement of the storm.

"It lasted about eighteen hours without interruption, and with undeviating violence. Neither the heavy rain, thunder, or lightning, were in the least degree interrupted by the violence of the wind. But at three in the afternoon, the mercury, which had descended twenty-five lines, remained stationary some minutes, and then began to re-ascend; from thence the tornadoes ceased, the wind became more regular, and at six in the evening it was possible to give some assistance to those who were shipwrecked.

"From the ravages of this hurricane, the established communications between the different parts of the island were altogether interrupted by the fall of trees and the abundance of rain. Three weeks elapsed before any intelligence was received of the Ambulante, which had been shipwrecked at about the distance of six leagues from Port Louis, in the Isle of France. All the harvests were destroyed; and the vessels were in such a state as to require the utmost exertions to repair them: that important service was rendered by $\mathrm{M}$. de Tromelin to the colony and to commerce. These vessels were no sooner equipped, than they were dispatched to Madagascar to fetch provisions and necessaries of every kind. M. Poivre had, with his superior foresight and precaution, ordered several vessels to winter at the Cape of Good Hope, which were sent off with abundance of supplies, as soon as the disastrous state of the Isle of France had reached that government. This relief saved the colony; as it arrived immediately after the second hurricane, whose fresh devastations had sunk the hope and conquered the resolution of the unfortunate inhabitants.

"The damages sustained by the vessels in the port, by the violence of the waves and the force of the winds in the second hurricane, were much less than in the first. The variation of the barometer announced the danger, and every one employed the means he possessed for his security and preservation." 


\section{Description of an Hurricane in the Isle of France, April 10, 1773, by $M$. Brunel.}

"The storm made its appearance about nine at night, just as the moon began to appear in the horizon ; but its greatest violence was between eleven at night and one in the morning, when the blended noise of the wind and the thunder was terrible; while the lightnings, which gave a fiery appearance to the atmosphere, heightened the horror of the scene. The terror of the inhabitants did not begin to subside till towards five in the morning. They had all passed the night in an impatient state of alarm; but when the day began to appear, the spectacle was most horrible: upwards of three hundred houses in the town of Port Louis were destroyed, the roofs of all of them were carried away, and the principal church was reduced to an heap of ruins. Many of the inhabitants were buried in the rubbish; ; others, with bruised and broken limbs, solicited the help of their neighbours, who were not in a condition to succour them; while the streets were strewed with nails, timbers, and fragments of houses and furniture. All the vessels in the port, to the number of thirty-two, had been thrown on shore, and more or less injured; of many small boats nothing was seen but the keel; dead bodies were floating among the wrecks; while the seamen who were not yet exhausted, were exerting their remaining strength in useless efforts to gain the land. In short, all that presented itself to the view was consternation, disaster, and misery. The interior desolation was equally great : the maize, rice, and corn, were blown about and dispersed : the coffee and cotton plants, the sugar canes, and the cinnamon trees, were all torn up by the roots; the old timber trees were laid low by the violence of the wind; the shops and manufactories were destroyed; and the grass was parched and dried up, as if it had received the impression of fire. In one of the districts of the island, to the windward, the sea was driven to forty feet beyond its ordinary limits, and compelled the inhabitants to seek for refuge on the neighbouring heights; while it left every kind of fish on the land. This disaster occasioned so great a dearth of provisions, that bread was sold at eighteen pence a pound: in a short time however assistance of every kind arived from the coast of Coromandel, the Cape of Good Hope, the Island of Madagascar; and the Persian. Gulph." 
Abstract of Hurricanes and violent Winds in the Isle of Bourbon, from 1733 to 1754 ; taken from the Memoirs of the Academy of Sciences, 1754 .

"The Abbé de la Caille informs us, that he was at the Isle of Bourbon during the rainy season, when it is subject to violent hurricanes, of which he gives the following history.

" These hurricanes, which our seamen call violent gales, are also felt at the Isle of Mauritius, but generally with less force and mischief, because the volcano in the Isle of Bourbon augments their force; besides, the latter island is more elevated, and consists of a single mountain, which has but three openings, and is not composed of several chains, like the Isle of Mauritius. The torrents occasioned by the rains which follow the hurricanes cause very heavy devastations, as they are not separated by vallies; and consequently acquire a proportional rapidity in descending from one predominant height.

" The hurricanes seldom appear but between the month of December and the latter end of April; they are however more particularly formidable at the new and full moon. In this season the vessels never remain at anchor at the Isle of Bourbon, except during four or five days after the full moon, from the apprehension of being: overtaken in its vicinity by the dangers of those two periods. But this precaution is not always infallible, as will appear from the following succinct account of the different hurricanes which have attacked this island in the space of twenty years. It was given me by M. Bernier, Counsellor Commandant in the Isle of Bourbon, who kept an exact register of these events during his residence there. I have added to the dates of the hurricanes, the day and hour of the nearest phases of the moon, as well as that when it passed its aphelion and perihelion.

" 1733 . In the night between the 10 th and 11 th of December, there was a violent gale of wind from the north: the vessels which lay off St. Paul put to sea, and returned in a few days without receiving any damage: one remained at anchor, and did not sustain any injury. A vessel and a boat, which were off St. Denis, were driven on shore, and nine persons perished. It was new moon the 6 th, at 3 hours $3^{\circ}$ :minutes P. M. The first quarter was the $14^{\text {th }}, 12$ hours 30 minutes $A . M$. Its aphelion the $4^{\text {th. }}$.

"December 22. There was a very strong wind from the south. Full moon the 21st, at 3 hours 15 minutes A. M. Perihelion the 20 th. 
"1734. On the gth of January a violent wind arose from the east, which con-

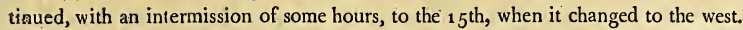
A vessel which lay off St. Denis put to sea. New moon the $5^{\text {th }}$, at $11 \mathrm{~A} . \mathrm{M}$. The first quarter the 12 th at 10 P. M. Perihelion the $14^{\text {th. }}$

"In the night between the $25^{\text {th }}$ and 26 th of January. The wind continued with

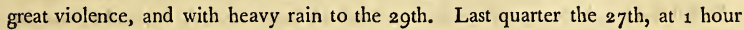
and 15 minutes A. M. Its aphelion the $29^{\text {th. }}$.

"The $13^{\text {th }}$ of March there was a strong gale in the offing, which was rather violent in the Isle of Mauritius. A vessel that lay off St. Paul put to sea. The first quarter 12 hours and 45 minutes P.M. Its perihelion the 11 th.

" 1735 . The 26 th of January a violent wind began in the west, at 4 hours P. M. It changed to the east, and blew all the $27^{\text {th }}$. New moon the $24^{\text {th }}$, at 6 hours $A . M$. Its aphelion the $22 \mathrm{~d}$.

" 1736 . On the $22 \mathrm{~d}$ of January there was a violent wind, which lasted till the

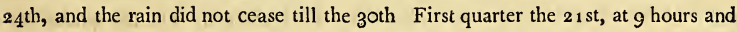
30 minutes A. M. The aphelion the $15^{\text {th }}$, the perihelion the $29^{\text {th }}$.

"February 5. Continual rain inclusively to the 10 th.

" - 7. A violent gale. The last quarter the $4^{\text {th }}$, at $\circ \mathrm{h} .15 \mathrm{~min} . \mathrm{A} . \mathrm{M}$. Its aphelion the 12 th.

"1737. January 28 . There was a very violent wind from noon to the following day, at 5 A. M. It blew from the south-west. New moon the $3^{1 \mathrm{st}}$, at 30 minutes A. M. Its perihelion the 2 oth.

"April 4. A strong gale at St. Paul, from 3 A. M. to the noon of the following day. It was felt on the east side of the isle from the first of the month. New moon the 31 st of March, at noon. First quarter the 8 th of April, at 11 hours 30 minutes A. M. The aphelion the 31 st of March.

" 1738 . February 13. A strong gale, which began in the south east, at $11 \mathrm{~A} . \mathrm{M}$. It changed to the south and south-west by north on the $14^{\text {th }}$ at noon. The last quarter the 11 th, at $8 \mathrm{P}$. M. Perihelion the 10 th.

" 1739. January.12. A partial gale of wind, from 8 P. M. to midnight. The wind was to the west. New moon the $2 g^{\text {th }}$ of January at 9 P. M. Perihelion the $7^{\text {th. }}$

"March 22. A strong gale to the northward: continual rain to the 26 th. Full moon the $25^{\text {th, at }} 8$ hours 45 minutes A. M. Perihelion the 3 th. 
" 174 o. January 21. A strong gale from the south to the north-east. It began at 3 A. M. and continued to the following day at noon. Last quarter the $22 \mathrm{~d}$, at 4 hours 45 minutes. Aphelion the 15 th.

" February 28. A gale at St. Denis, which was not perceived at St. Paul but by the swelling of the sea. New moon the $27^{\text {th }}$ at $10 \mathrm{~A}$. M. Perihelion the $25^{\text {th. }}$

"March 13. A strong gale to the south, which began at 8 A. M. and continued all the day and all the night. Full moon the $13^{\text {th }}$, at ${ }_{4}$ P. M. Aphelion the 9 th.

" 1742. January 10. A strong gale to the north, from 7 P. M. to 11 A. M. New moon the 7 th, at 1 hour 45 minutes A. M. Perihelion the 12 th.

" 1743 . March 8. A strong gale to the south at 8 P.M. to the following day at 4 P. M. It did more mischief at the Isle of Mauritius than the Isle of Bourbon. Full moon the 1 oth, at 2 P. M. Perihelion the 3 d. Aphelion the 17 th.

" 1744 . January 9. In the night between the 9 th and 1 oth a strong gale to the north. The 1 oth, at noon, the wind fortunately changed to the south; so that a vessel which was driving on the coast, gained the open sea. The last quarter the 6 th, at 10 P. M. Aphelion the $13^{\text {th. }}$

"6 1745. February 12. A strong gale to the north, from 3 P. M. and all the following day. The rain continued to the 19 th. First quarter the $g^{\text {th, at } 10 ~ P . M . ~}$ Perihelion and full moon the ${ }_{1} 6$ th.

16 1746 . January 19. Violent gale of wind, which began in the morning to the east, changed to the north, and continued during the whole night. After a short calm, it shifted suddenly and successively to the west, the east, and the south; and it did not finish till the evening of the $22 \mathrm{~d}$. New moon at $8 \mathrm{P}$. M. Aphelion the $2 \eta_{\text {th. }}$

"February 16. In the night between the 16 th and 17 th, a strong gale, which lasted only a short time, but did considerable damage to the harvest. New moon the 2oth, 45 minutes P. M.

"April 6. A terrible wind to the north, whose violence lasted from $6 \mathrm{~A}$. M. to 6 P. M. A Portuguese vessel, having lost its rudder and being reduced to one mast, was shipwrecked on the shore, and twelve lives were lost. The wind having changed to the south in the evening, the sea on a sudden became tranquil, and the vessel rested on the dry sands. Those who remained on board were saved. Full moon the 6 th, at 4 hours 45 minutes A. M. Perihelion the same day.

" 1747. January 11, at 7 P. M. A strong gale, which began towards the north- 
east, and continued the whole night, having passed to the south. New moon the 11 th, at 5 hours 15 minutes A. M. Perihelion the 6 th.

66 1748. A strong gale from ${ }_{4}$ P. M. and through the whole night. The last quarter the 23 d, at 3 hours 30 minutes P. M. Perihelion the $27^{\text {th. }}$.

" March 28. A very violent gale to the south. It began an hour P. M. and ceased after sunset. After a calm of about an hour, it rained very much this and the following day: during the rain the wind was sometimes heard. New moon the 21st, at 6 hours 30 minutes A. M.: Perihelion the $22 \mathrm{~d}$.

" 175 . January 31 . Strong gale of wind during the night which preceded the 1st of February: it was to the north, and very violent at St. Denis ; at St. Paul it was not so strong. Last quarter the 3 oth, at 8 hours 44 minutes A. M. Aphelion the 26 th.

"March 4. A partial gale of wind. New moon the 8th, at 11 A. M. Perihelion the 8 th P. M.

"March 18. A more violent gale than the preceding one: it lasted to the 20 th at 9 A. M. Full moon the 23 d, at 4 hours 30 minutes A. M. Aphelion the same day.

" 1751 . March 26 . In the night between the 26 th and the 27 th there was a more violent hurricane than any person on the island had witnessed. The wind was easterly, and occasioned very heavy devastations from the east to St. Paul. New moon the 27 th, at noon. Perihelion the 29 th.

" 1752. February 4. A gale of wind from the east-north-east, which was not

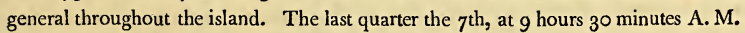
Aphelion the $9^{\text {th. }}$

"December 21. A gale from the north, with violent rain. Two boats were destroyed. Full moon the $21 \mathrm{st}$, at 4 hours A. M. Perihelion the $22 \mathrm{~d}$.

"1753. March 12. Gale from the north, which greatly damaged one of the Company's vessels. The last quarter the 12 th, at 7 P. M. Perihelion the $14^{\text {th. }}$

"March 26. A gale, which drove a vessel out to sea. Last quarter the 26 th, at 10 P. M. Aphelion the 28 th.

" 1754. January 10. A gale, which began at the north-east, passed from thence to the north-north-west, and then suddenly shifted to the south-west. Full moon the $g^{\text {th, at }} 6$ A. M. Perihelion the 11 th.

"April 19, 20, and 21. Gales and an hurricane, which laid waste the island. New moon the 22 d, at 6 hours 15 minutes P. M. Aphelion the 18 th." 
Extract of a Letter from Pondicherry, dated the 3 d of $\mathcal{F} u n e, 1787$; taken from a Fournal of the Isles of France and Bourbon; Vol. I. No. 3. Fuly, 1787 .

"We have suffered at Yanaon, and in all its environs, the same disaster which you have experienced at the Isle of France. We have had, during the night of the $1 \mathrm{gth}^{\mathrm{t}}$ and 20 th of May, a most violent hurricane. The sea rose to an extraordinary height; all the houses at Yanaon have been inundated and destroyed : the English and Dutch factories have suffered a similar destruction. A considerable number of Negroes have been drowned. The ship called Le Levrier, which had been sent to Yanaon to take in merchandize on account of the Company, and had actually taken in the greater part of her cargo in the road of Coringa, has been driven two leagues to the leeward, into a plain in the midst of palm trees. The ship the Heureux, which was in the river of Coringa, is lost, and five or six leagues of the country are inundated.

"Four days after the hurricane the waters still remained, as it had rained during that time without ceasing. The extent of our losses has not yet been ascertained; they must be very considerable to the Company, as well as several individuals of Pondicherry. The waters have carried away a large quantity of linens, not only from the grounds where they were bleaching, but from the warehouses; some of which, however, have been recovered, by drawing them out of the mud and sand with which they were covered. Such is the detail of this ruinous event." *

\section{Account of the Volcano in the Isle of Bourbon, by $M$. Rocbon.}

"This volcano, though its eruptions are frequent, has not occasioned any injury to the island since it has been inhabited. The colonists have very wisely kept at a distance from this gulph, whose vicinity is very much to be dreaded, according to the description given of it by $\mathrm{M}$. de Commerson, a very learned naturalist.

" M. de Cremont, at that time Intendant of the Isle of Bourbon, not only gave M. de Commerson all the assistance in his power, in order to facilitate his approach to the mouth of the volcano, and to examine its productions, but accompanied him in his researches.

" The approaches to the volcano of the Isle of Bourbon are very difficult: the country is entirely burnt up for six miles round it ; and very few of the inhabitants.

- Mr. Dalrymple-Oriental Repository, Vol. II. p. $2^{8}$. 
are acquainted with the way by which its summit is to be attained. Seven days are requisite to perform that journey. Heaps of cinders, lava, and vitrified earth, with rifts and precipices, render all access not only laborious but dangerous. The time must be very favourable, and without the appearance of a cloud, to allow of a visit to the crater; as a few drops of rain would be sufficient to provoke an eruption; when the imprudence of approaching it would cost the rash adventurer his life.

"The volcanic productions are very various; and sometimes there are found, at a great distance from the mountain, certain glassy filaments, of an exceeding fineness resembling hair. This kind of lava is not very common."

\section{The following Description of this Volcano is by $M$. Brunel.}

"It is situated almost at the summit of an hollow and detruncated mountain, whose base, falling down with a gentle inclination, rests upon a bed of calcined earth, at the distance of a league from the sea. Though the matter it contains is continually boiling, it never rises so high as to proceed from the crater. In the moment of an eruption, the lava is seen taking its course down the side of the mountain, in such a manner as to offer the appearance of a fiery cascade. The light, which is diffused to a great distance, as well on sea as land, is equal to that of the moon in its full splendour. According to the tradition of the country, it was this natural Pharos, that attracted the curiosity of the first Europeans who visited these coasts.

"The environs of the volcano are covered with sal ammoniac, sulphur, alum, and pumice stone. It is a remarkable circumstance, and very different from other volcanoes, that though its eruptions are frequent, they are never accompanied with earthquakes. The security of the inhabitants, therefore, is not endangered by the vicinity of such a phænomenon, as is known to be the case in every country afflicted by them: nor has it been observed that water is at any time thrown forth from this volcano; or has any warm mineral spring been discovered in this island.

"In the month of June, 1787 , this volcano was in a very remarkable state of eruption. The summit of the mountain was covered with thick vapours, of a black colour, which issued in clouds of a spiral form from the mouth of the ancient crater. On the $24^{\text {th }}$ the lava ran down as far as the sea; nine days after it had begun to flow, it extended in certain places to eighty fathom in breadth, and in others to forty. The liquid matter continued to run during a month, in great abundance, and formed a fiery current to the very sea, of about sixty fathom in breadth, and 
from ten to sixteen feet deep. The waves of the sea smoked at the distance of thirty fathom from the place where the lava precipitated itself into the waters, assuming a yellowish-green colour, and forming a broad line, to the leewrad, of the same hue.

"This current running parallel to anorher of a former period, which consists also of several beds of melted matter, formed a projection, whose base was volcanised sand, mixed with a kind of ferruginous foam. Eleven days after the lava had reached the sea, a solid crust was formed on its surface, which was sufficiently strong to admit of being ascended, to about fifteen paces from the place whence it issued. Indeed one might venture to walk without danger on a torrent of burning lava, if due precautions were taken. In the level parts it soon grows cool, and becomes hard as thick ice, while, through the crevices, the liquid matter might be seen flowing on without interruption. When, however, it meets with any obstacle, it forces its way through the external crust, and covers it with a new bed of boiling lava. On the 1 st of August the lava ceased to flow, but it diffused a considerable quantity of smoke, and appeared at the bottom to be red-hot for some time afterwards. It was believed that another crater was discovered at about a league from St. Denis, the capital of the island: clouds of smoke and a very strong heat issued from a ravine, which it was impracticable to approach during the space of a month. At the end, however, of that period, it appeared that this heat and the smoke that accompanied it, issued from a cavern, that was the hiding-place of some Maroon Negroes. A fire having been lighted in this place, either on purpose or by accident, was maintained by a large quantity of leaves, stalks, and other combustible materials, which were very slow in consuming, because the cavern admitted but a small portion of air. The remains of birds nests, which were found there, clearly proved that the cavern had not always been exposed to a similar degree of heat; and this circumstance, strengthened by other observations, quieted the alarms that this novel appearance had excited.

"The Isle of France, which is in the vicinity of the Isle of Bourbon, is considered as a country which has been exposed to the violent convulsions of nature. It abounds in caverns, precipices, waterfalls, subterraneous passages, iron mines, calcined stones, vitrifications, burnt sand, and pyrites, which are general indications of ancient volcanoes; but, on account of their antiquity, it is not possible at this time to determine their situation. The most lofty mountains in this island have not more than five hundred fathom of elevation, while, in the Isle of Bourbon, there are peaks 
which rise to upwards of fifteen hundred fathom. The two islands, which are more than thirty-five leagues distant from each other, were, without doubt, formerly united, but have been divided by some violent effort of nature: there is indeed every reason to believe that they are still connected, though the conjoining parts are covered by the sea, and that some subterraneous passage forms a communication between them.

"The earthquake which happened in the Isle of France on the $4^{\text {th of August, }}$ 1786, appeared to favour this conjecture. On that day, at thirty-five minutes past six in the morning, a calm succeeded to a strong east and east-south-east wind, which had prevailed during four days; a subterraneous noise, that terminated by a sudden explosion, like the discharge of a cannon, was heard in the south-east quarter, and at the same moment two violent shocks were felt, the one vertical, and the other horizontal: the barometer did not on this occasion indicate the least change in the atmosphere, and an east-south-east breeze commenced within a quarter of an hour, and continued till eleven on the following night. This strange phænomenon was not accompanied with any destructive circumstance in the Isle of France; but it appeared that, at the same moment, the volcano in the Isle of Bourbon had poured forth a greater quantity of lava than it had done on the preceding days.

"It is reasonable therefore to suppose, that the combustible matter in the Isle of France had fermented till it took fire, and having met with a resistance superior to its own force, occasioned the shocks which have been mentioned; when, being impelled in every direction, it found a passage, by a subterraneous gallery, to the 1 sle of Bourbon, and not meeting with any resistance, issued from the crater of the volcano."

\section{The succeeding Observations will enable our Readers to compare the Volcano of the Isle of Bourbon, with the two most celebrated Volcanoes of Europe.}

Mount Vesuvius is two leagues to the east of Naples, and about two thousand fathom from the sea ; the circumference of its base is about ten leagues, and its elevation above the level of the sea, or the Gulf of Naples, is five hundred and ninetyfive fathom. It divides at about two-thirds of its height, and its two summits are about five hundred fathom from each other: that towards the sea forms the volcano.

Its first eruption, as recorded in history, was during the reign of Titus, in the seventy-ninth year of the Christian era, and which was rendered remarkable by the 
death of Pliny the Naturalist, and the destruction of the cities of Herculaneum and Pompeii. Some authors however pretend, that this mountain had experienced seven eruptions previous to the reign of Augustus Cæsar.

According to a discourse of Silius Italicus, who lived before the time of Titus, it was very evident to ocular examination, that it had discharged volcanic matter previous to that period, though there was no tradition of such an event.

From the first known eruption to that which took place in the year 1754, there have been twenty-four; there have also been several since the latter period. That of April in 1694 , was one of the most considerable. The mountain then vomited forth flames during the greater part of the month, and the lava ran from the upper part of the volcano like a river, to the distance of three miles, destroying every thing which obstructed its passage.

In 1707 , while the Neapolitans were occupied in making rejoicings for the success of the Imperial forces, they were interrupted by a terrible eruption of Mount Vesuvius. The sky was entirely obscured in the middle of the day, by the quantity of cinders which issued from the volcano.

In the intervals of these eruptions the inhabitants are often alarmed by earthquakes, which, however, do not prevent them from cultivating and inhabiting the sides of this dangerous mountain. *

Mount Ætna is situated fifty miles south-west of Messina, and ten miles west of Catania, whose vicinity is filled with other towns, villages, vineyards, and plantations, which, as in the environs of Vesuvius, spring out of an abundant soil, that has been fertilized by the volcano. The mountain itself is enriched with trees almost to its summit, which is surrounded with a circle of snow.

The grand crater of Mount Etna is six miles in circumference. The base of the mountain occupies a circuit of twenty leagues, and its elevation rises to two thousand fathom.

On the eruption of this volcano in 1693 , the town of Catania was destroyed in a moment, and eighteen thousand persons perished in its ruins.

A learned and distinct description of Mount Etna, is to be found in a work entitled La Fyrologie de Bottoni de Leontini : that intrepid naturalist had the courage to ascend the summit of the mountain three different times, in 1540,1545 , and 1553 .

* See Sir William Hamilion on the eruptions of Mount Vesuvius. 
In 1537 , the wind bore the ashes, produced by the conflagration of the mountain, to upwards of an hundred leagues.

In $\mathrm{i}_{92}$ and 1693 , on the gth, 10 th, and $x 1$ th of January, there was an earthquake throughout Sicily, which not only overthrew the town of Catania, but also of Agousta, greatly damaged that of Syracuse, with many towns and villages, and buried in their ruins upwards of forty thousand persons. But, notwithstanding such disasters, these towns have been re-established, perhaps, to be again destroyed.

The destruction of Messina on the $5^{\text {th }}$ of February, 1783 , and the terrible phrnomenon which occasioned it, is well known; we shall, nevertheless, present to the attention of our readers, the following correct and curious account, by the learned M. Gallo, who was himself a witness of it.

" The preceding autumn had been rainy and cold; the winds varied between the south-west, the west, and the north-west; and if the south-east was at any time perceived, it was known to foretel a sudden storm and of short duration. Before the rising and setting of the sun, the horizon appeared to be charged with thick clouds, which displayed themselves between the east, the south-west, and the south. The beginning of the winter was dry and temperate: in the month of January it frequently rained; and the showers were not only violent, but accompanied with a stormy wind from the south-east and the south. The air was rather temperate than cold, because after the rain the rays of the sun were extremely hot. The winds continued to be stormy.

" At the extremity of the Strait of Charybdis, there appeared some irregularity in tide, an extraordinary boiling up of the waters, and at intervals a noise was heard; but these phænomena did not attract attention. On the $5^{\text {th }}$ of February, at fortyeight minutes past eleven in the morning, the earth experienced some light shocks, which soon became violent, and were accompanied with roarings and such irregular motions that the ground was seen-to undulate on all sides, while the walls of houses dashed against each other, and fell in large masses, with the floors' and roofs. Three or four successive shocks increased the horror of the moment. Houses, palaces, steeples, and churches, were shaken down. The earth sunk in some places, and opened in others, emitting flames from its burning chasms. The neighbouring mountains opened, the sea rose above its ordinary level, entered the mole, dashed its impetuous waves against the palace, and covered a considerable part of the maritime theatre, which is situated below the custom-house. In this scene of B b 
confusion and desolation, the inhabitants rushed into the larger streets and the fields; where, while consternation had seized their hearts, the earth shook under their feet, and the clouds poured forth hail and rain with resistless impetuosity on their heads. It was a varied and indescribable scene of ruin, distress, and death.

"6 The trepidation however of the earth continued with a concentrated murmur, like that of a bomb which bursts after it is buried in the earth. At three in the morning the shocks increased to such a degree, that those buildings which had resisted, from their massive strength, were thrown down, and the principal public edifices shaken into ruins. The sea also, by its violence and unusual rise, aided the general scene of devastation.

"On the $22 \mathrm{~d}$ of the same month at ten in the evening, the buildings which had: only crumbled in parts, fell at once, and Messina was destroyed. The very stones. appeared as if they had been pounded in a mortar.

From the $5^{\text {th }}$ of February to the $g^{\text {th }}$ of March inclusive, there were no less than one hundred and eighty commotions.

"It is not easy to determine the number of inhabitants which perished at Messina; they are not, however, supposed to have exceeded five hundred, as the shocks were preceded by certain notices which gave them an opportunity to escape: though of the number of those who survived, the fourth part was.dragged forth from the ruins. of the buildings in a wounded or maimed condition.

"The value of the public edifices and houses which were destroyed amounted: at least to fifteen millions of Roman crowns, and the loss of furniture, merchandize and gold and silver, was still more considerable."

\section{The Agriculture of the Isle of Bourbon, by $M$. Poivre.}

"The soil of the Isles of France and Bourbon is naturally as fertile as that of: Madagascar, and they enjoy a more favourable climate. The latter of these islands. has no port, and is not much frequented by shipping: but the manners of the inhabitants are simple, and its agriculture flourishes. The Isle of Bourbon produces wheat, rice, and maize, more than sufficient for its own consumption, as it affords a portion of those grains for the supply of the Isle of France. The same mode of cultivation is pursued as in the Island of Madagascar. The cattle and sheep which were transported from thence have also succeeded, more particularly as the grass called Fatak, which forms an excellent pasturage, was also brought with them, 
and naturalized in the Isle of Bourbon. But the principal object of culcivation is coffee. The first plants of this shrub was brought from Moka, and it is multiplied by its grains, which it sows itself. It is necessary to dress the ground round the young plant two or three times in the course of the first year, in order to destroy the weeds which might share in its subsistence, and it will then require no further care. Its branches, that extend horizontally and are very thick, suffocate, as it were, any other plants which might spring up about it. In about eighteen months the coffee tree begins to bear fruit, and in the third year it is in full bearing. The young shrubs are planted in squares, at the distance of about seven feet from each other, and they are kept down, by the pruning knife, to about two feet from thc earth.

"The coffee trce requires a light earth, and succeeds better in pure sand than in a rich earth. In the Isle of Bourbon, each tree produced, on an average, a pound of berries, and it ripens and is gathered in a dry season; a circumstance which gives it a very great advantage over the coffee of the American islands, that ripens and is gathered in rainy seasons. It is afterwards exposed to the sun during several days, till the berry is dry and contracted: it is then disembarrassed of its pulp.

" Cocoa trees flourish in the Isle of Bourbon, though they are no longer to be seen in the Isle of France:* they were probably destroyed by the first inhabitants. This tree is very useful, not only for its fruit, but as it supplies the principal wants of man; who derives from it not only food and drink, but wood for building his habitation, which is covered with its leaves, while its bark furnishes him with clothing and with fuel.

" This island also produces the tree from whence the benzoin is distilled, a resinous and sweet-smelling gum, which issues from the tree by incision, and whose qualities are well known. This tree is also a native of Siam, Sumatra, \&c. There are two kinds of benzoin, the one collected in drops, which is the best, and the other in large pieces.

"The first is clean, transparent, and of a reddish colour, speckled, as it were, with white spots, that resemble broken almonds. This circumstance has given it the name of Benzoinum Amygdalöides. It affords an aromatic and pleasant odour,

* There were cocoa trees at Mauritius when it was discovered, but their usefulness has proved their destruction. 
and is used by perfumers as well as by physicians. The flower of benzoin is an excellent pectoral medicine, and is used also to remove obstructions.

** We shall still have occasion to make frequent mention of the Isle of Bourbon in the accounts which will follow of the Isle of France, with whose history it is evidently connected, and particularly as they are both under the general jurisdiction of the same governors. The description of the Isle of France which has been already given, contains a chronological table of all its governors from its first discovery. As it furnishes but few interesting events till the arrival of M. de la Bourdonnais, and as the most authentic and instructive materials, since the commencement of his government, are to be found in the correspondence of Baron Grant, who was not only an eye witness of, but absolutely engaged in, that administration, during a period of eleven years; we shall proceed to give his letters in a regular series, which will communicate every thing that is to be known of the civil and military history of this island, with the manners and customs of the inhabitants, for the space of twenty years, without the least interruption. 


\section{GHAPTER VI.}

Letters of Baron Grant, respecting the Isle of France.-The following contains a short general Description, with an Account of the first Operations of M. de la Bourdonnais, Governor of that Island, to the Year 1744 .

\section{LETTER II.*}

Isle of France, 12th of February, 1741 .

$M_{Y}$ first letter contained an extract from the journal of my voyage, with some local descriptions of this island, as well as those of Rodriguez and Bourbon, both from my own observations, and the best information I could obtain from others : after having considered the soil and its productions, I shall proceed to describe the uses to which they are applied, by those whose culture has either produced or improved them for the public advantage. $t$

It will not appear surprising, that the far greater part of the military officers whom war has conducted to this island, should wish to fix their abode in it, when all the circumstances attached to it are faithfully enumerated: a delightful climate, a clear sky, and a soil which produces every thing that is useful and gratifying to man. While mountains, whose summits are never covered with snow, and whose declivities, bright with verdure, are contrasted with towering rocks, compose amphitheatres, which present a varied and picturesque scene of grandeur and beauty.

From the tops of the hills, small streams and rivers of a pure and limpid water gush forth, and, forming beautiful cascades as they fall, wind at length through the vallies which they fertilize and adorn, at once enriching the country, and refreshing the dwellings of the happy inhabitants.

- The first Letter was inserted in the Introduction.

+ Having assisted my father since his return to France, in arranging these letter's; (which were written by him, to his family in Normandy, during his residence at Mauritius), we have enriched them with observations, the fruits of subsequent inquiry and information. 
Africa and Asia dispute the property of this island, which nature has placed in the vast expanse of the Indian Ocean; but our modern geographers, better instructed than the Ptolomies and the Strabos, have assigned it to the first of these two ancient quarters of the globe; though it is altogether free from the dangerous animals with which those continents are infested.

Certain parts of the forests have been cleared, particularly in the neighbourhood of Port Louis, \&c. and plantations established.

There is but the difference of an hour between the longest and the shortest day.

I shall not mention in this place the violence of the winds, which has already been particularly detailed: at the same time $I$ shall just observe, that the rains form our happiness, not only because they refresh the air and are never of long duration, but as they are the first cause of the fertility which is our boast.

Hunting, which is pursued without difficulty, and with continual success, is one of our principal resources.

We have three kinds of partridge; none of which are the same as those of France, though some of them approach the red-legged species of our country. From the heat of the earth, they are compelled to perch on the trees. Guinea fowls are common in the woods, and there were plenty of white hares, whose flesh is indifferent, but they are now become very rare:

Monkies, parroquets, and bats, are in great abundance, and are pursued by the sportsman. The two latter are generally admitted to the tables of the inhabitants, notwithstanding the repugnance which the bat at first inspires as an article of food. The Portuguese alone add monkies to the number of comestible animals.

The number of plantations at this time established in the island amount to one hundred and fourteen, which are divided into four principal districts, or quarters.

The first, and which is nearest to the town, is that of la Montagne Longue, making a part of, or adjoining to Pamplemousses.

The second is on the left side of the port, diverging from the quarter of Flacq.

The third is three leagues from the town, in returning to the right, and is named by the Dutch, the plains of Willems.

The fourth, named Moka, is situated a league beyond the latter, and at the extremity of the mountains de la Ville.

There is also a fifth quarter, which received from M. de la Bourdonnais the name of Villebague, and is above that of Pamplemousses. 
There is still another small increasing quarter, called Flick, or Flacq.

The quarter of Port Bourbon, on the south-east, continues to be neglected.

The town of Port Louis, which is also called the Camp, because the Dutch, when they first visited the island, formed a camp there, is situated at the extremity of Port Louis, at the opening of a valley which is about three quarters of a league in depth, and four hundred fathoms in breadth, and is terminated by a circular chain of lofty mountains.

The sides of these mountains are covered with an high grass, which, in dry seasons, is commonly burned by the Maroon Negroes. This circumstance gives to the mountains a dreary aspect, and has occasioned some navigators, who have not landed on the island, to describe it as a barren country.

The highest part of the Mornes, or mountains which inclose the bottom of the valley, has been shattered; the most elevated of its parts is at its extremity, and is called Peterbotte. Its summit is terminated by a naked and insulated rock, called be Pouce, which is said to resemble the figure of a woman. There are a great number of trees in the vicinity of the Pouce; and a rivulet springs from it, which flows through the town.*

The following extract from the Romance of Paul and Virginia, by Bernardin St. Pierre, and which is the opening of it, is such a correct as well as interesting description, that we have no hesitation in offering it as an embellishment to this part of our History.

" $\mathrm{O}_{11}$ the eastern side of the mountain which rises above Port Louis, in the Isle of France, and in a spot that bears the marks of former cultivation, are seen the ruins of two huts. They are situated near the centre of a circular valley, formed by stupendous rocks, and which opens only to the north. On the left rises the mountain called the Morne de la Découverte, from whence signals are displayed to the ships which approach the island, and at the foot of it is the town of Port Louis. On the right is the road which leads from Port Louis to Pamplemousses, and beyond it the church lifts its head, surrounded by its avenues of bamboo; in the midst of a spacious plain : a forest then succeeds, which stretches on to the extremities of the island. This spot commands a view of the Bay $d u$ Tombeau; a little to the right is Cap.Malbeureux; and beyond is the expanded ocean, on the surface of which appear several uninhabited islands; and among the rest the Coin de Mire, which resembles a bastion in the midst of the waves.

"At the entrance of the valley, which displays a view of so many various objects, the echoes of the mountains incessantly repeat the hollow. noise. of the winds which agitate the neighbouring forests, and the hoarse murmur of the waves that break over the distant reefs; but near the ruined huts all is calm and still; and the objects which there meet the eye, are rude steep rocks, that rise like a surrounding rampart. Knots of trees grow at their base, in their rifted sides, and on their: 
The houses of which the town consists are built of wood, and covered with planks and the leaves of the palm tree. They do not rise above the ground floor, in consequence of the winds and the heat : they are separated from each other by the gardens that surround them : the streets are in a straight line, and trees should be planted to render them cool. It is indeed to be lamented, that those which covered the environs should have been destroyed, as they must have protected the town and port from the fury of the winds. The soil, as we have already observed, is sprinkled with rocks.

The island is watered with more than sixty rivulets, though some of them loose their water in the dry season; a circumstance which has become more prevalent, since so much of the wood has been destroyed.

There are a considerable number of pools in the interior parts, which, being in the midst of the woods, retain their water. Among others, there is a small lake near the mountain cailed the Piton, which is in the centre of the island. It is said that sea-fish are found in it, though I cannot confirm that account by my own experience: it is however but little known, from the remoteness of its situation.

There is frequently a great difference in the temperature of the air between two neight ouring plantations, according to the side of the mountains where they are respectively placed.

There is at present but a small quantity of cattle, as the inhabitants do not avail themselves of the rivulets to water the districts, which by such a contrivance would become excellent pasturage; so that the cows have no more milk than is necessary to maintain their young.

As there is no butter, we make use of hogs-lard and mantaigre, a kind of grease which is brought from India. It resembles the rank butter of Normandy, and its name indicates its quality. Grease is also furnished from the fat lumps which grow majestic summits, where the clouds seem to repose. The showers which their bold pinnacles attract, illuminate the dusky declivities with the colours of the rainbow, and feed the springs at their feet, which swell into the river of the Lataniers.

" In this seclusion reigns the most profound silence : the waters, the air, in short, every element is at peace. The echo scarce repeats the whispers of the palm trees, the points of whose bro:d leaves wave gently in the wind. A soft light beams on the bottom of this deep valley, which the sun does not reach till noon; but his earliest rays gild the summits of the rocks, whose sharp peaks, tising above the shadows of the mountain, are cloathed in tints of gold and purple, gleam. ing on the azure sky." 
above the shoulders of the cattle that are brought from Madagascar, and serve as a saddle to those who ride, on them. One of these lumps will weigh from thirty to forty pounds, and upwards. Its grease, however, is very unpalatable, and instantly coagulates: hence it is that we prefer hog's-lard and turtle oil, which never congeals.

The water of the rivers appeared at first to be unwholesome, as it gave the cramp to the young ducks, and brought on the bloody-flux in those persons who drank them: a quality natural to all waters which are shaded by woods from the influence of the sun. For though it is injudicious to strip an hot country of its wood, it is dangerous to inhabit it when entirely covered with forests, particularly in the vicinity of water.

"I The temperature of a country lately discovered, or newly inhabited, may be entirely changed by destroying the wood; though such a measure should be adopted with great consideration; according to the heat of the climate, and the nature of the soil. It would be necessary to leave the woods on the mountains, and a certain proportion of them on the plains, in order to attract the clouds, and to feed the sources of those streams, which, on quitting the shade, would be purified by the sun, before they! arrive in those parts, beneath the hills, which are generally preferred by new settlers for their habitations; they would then refresh the grounds which are prepared for pastures in the bottom of vallies. Meadow, as well as arable land, should be partially: decorated with masses of wood, inclosing lines, or single trees: they should also be left or planted in such a manner that the air may freely circulate through them; while at the same time they may protect the crops from destructive winds and parching heat.

The woods which are felled must, necessarily be burned; and their ashes will not only fertilize the soil, but purify it from reptiles and insects. This plan however will be adopted, with the exception of those trees which may be applied to useful purposes; and magazines of them must be formed, to prevent the future devastation of those parts where it may be necessary to preserve them.

On the first settlement of any country, a regular and general plan should be formed, by which all future operations should be governed; and when fire is employed to clear the ground, and a small number of settlers have no other means of performing such an operation, the axe must be used to direct its course, and check its expansion beyond the limits submitted to its fury. A neglect of such precautions caused the C $\mathrm{c}$ 
destruction of almost all the wood which covered the island of Madeira, on the first discovery of it. This conflagration, it is said, lasted seven years.

In the Isle of France, the banks of the rivers were no sooner deprived of their shade, than the water became wholesome; but the destruction of all the wood in the environs of Port Louis, was a fatal error, as it is now exposed to the violence of the winds, as well as to the heat of the sun, and several of the neighbouring rivulets have been dried up.*

At this moment (1740) an eighth part of the island is not yet cleared, so that it will be long before the population is equal to the extent.

If, however, we are not rich in cattle, we possess a great abundance of fowl, as well as both land and sea turtle, which are not only a great resource for the supply of our ordinary wants, but serve to barter with the crews of ships who put in here for refreshment in their voyage to India.

The time of my arrival, which was the month of August, is the winter season in this island; if I may employ such an expression in a country where the houses are built without chimnies, except for the purposes of the kitchen.

The summer is very dry, and the ground is in a state of aridity during that season. The warm rains then succeed, giving such vigour to vegetation, that the weeds frequently prevail over the regular crops, which are twofold in the course of the year. In this season is sown the maize, which serves as the food of the Negroes, as well as the rice, which the Creole ladies prefer to the finest bread, though simply boiled in water, and without the least seasoning: they however season their favourite dishes, which they call Caris and Plots, with the hottest spices.

In the months of May and June we sow our corn, which we reap at the end of September, as well as various kinds of beans, the greater part of which is sent to the magazines of the Company, to be ready for supplying the ships. Corn generally produces an hundred-fold.

When the grass springs up in the rainy seasons, it is necessary to take care that the cattle do not gorge themselves with it, which would be attended with fatal consequences. This year has been marked with sterility, and our island is menaced with dearth: indeed, it has happened that the Negroes and labourers have been necessarily sent to live by hunting in the woods, or the produce of the waters.

* These inconveniences however are fully counterbalanced, if it be true, that the cessation of hurricanes, since the year $178 \mathrm{~g}$, has been caused by the great diminution of the woods. 
The coasts abound in fish, which have been already described, as well as the enormous eels that are found in the rivers. I have frequently killed them with my gun in shallow waters. In the rainy and hurricane seasons these rivers become stupendous cataracts. Our venison, which is fat, is very good, and serves us instead of beef: but it must be got from the forests, where the deer are very numerous: on account of the heat and their fat, they are easily taken. It is however a circumstance to be lamented; that, from the temperature of the air, fresh meat cannot be kept longer than two days.

The birds very much diminish in the woods, as the monkies, which are in great numbers, devour their eggs. The parroquets however are still numerous, as they make their nests in the holes of the rocks, which the monkies cannot ascend.

The Governor's house and the Company's magazines, which are situated at the entrance of the port, are built entirely of stone: the latter are placed in front on each side of the former; and the intermediate space, which is considerable, is used as a place of arms. These edifices are erected in the Italian style, with flat roofs, which serve as terraces. This small town is the habitation of all those who are employed in the service of government; as well as of merchants and others who are not possessed of plantations.

The India Company reserves the commerce to itself: it makes advances to the inhabitants, and is reimbursed by the produce of their plantations. The money of France is not current here, except pieces of two sous, which do not pass for more than eighteen deniers, by which valuation we are considerable losers. Of these we have adequate supplies; but the seafaring people, who sell us certain contraband articles, insist on being paid in currency, on every piece of which they gain onefourth in France : hence it is that our coin is carried away.

We have Spanish piastres, which with us pass for four livres ten sous, and in France are taken for five livres two sous, and sometimes more. If we were permitted to engage in commerce, the profit would be certain, from the exchange in our favour. We have, besides, a paper currency, which is confined to the island: it consists of parchment bills, from ten to an hundred livres.

At the time of my arrival, M. de la Bourdonnais was Governor of the Isles of France and Bourbon, but he was gone to France, for reasons which will be hereafter explained; and M. St. Martin was Deputy Governor during his absence. M. de la Bourdonnais, who may be considered as the founder of this colony, acted 
so important a part in its establishment and administration, that $I$ should be guilty of an inexcusable omission, if I did not give a regular history of him and his transactions to the present moment.*

Account of the Administration of $M$. de la Bourdonnais, Governor General of the Isles of France and Bourbon.

1699 - - M. de la Bourdonnais was born at St. Malo in 1699, and from his earliest years manifested a decided preference to the naval profession, for which he was prepared by the instructions of the best masters. At the age of ten years he made his first voyage to the South Seas. In $17_{13}$, he made a second, with the rank of Ensign, to the East Indies and the Phillipine Islands : in this voyage he studied mathematics under a learned professor of the order of Jesuits.

1717. - In 1716 and 1717 , he made a third voyage, to the North Seas, and in 1718 a fourth voyage, to the Levant.

1719. - In 1719 he embarked, for the fourth time, in the service of the India Company, for Surat, with the rank of Second Lieutenant.

1723.- In 1723 he went in the same service, and with the rank of First Lieutenant, to India. In the course of this voyage he composed a treatise on the construction of ships. At the same time he rendered a signal service to the Company: a ship called the Bourbon was stranded, and there were no immediate means of saving her from destruction; when M. de la. Bourdonnais had the courage to venture in a common boat from the Isle of Bourbon to the Isle of France, from whence he brought a ship, which came in time to save the stranded vessel, and to enable her to return to Europe.

1724 . - No sooner. was $M$. de la Bourdonnais returned to: France, than he re-embarked in 1724 for the Indies, with the rank of Second Captain; and in the course of this voyage M. Didier, Engineer to the King, taught him the science of fortification and military tactics.

On his arrival in India, he found at Pondicherry several vessels belonging to the Company, ready to sail on an expedition to get possession of Mabé. The

- We shall proceed to give a detail of the operations of M. de la Bourdonnais, as well in the Isles as on the coast of India, to the end of the year 1744, before we resume the subsequent parts of the correspondence of Baron Grant, in order that no interruption might be given to the course of interesting events, in which M. de la Bourdonnais was so materially concerned. 
squadron appointed to this attack was commanded by M. de Pardaillan; and though M. de la Bourdonnais enjoyed no higher rank than that of Second Captain, he was entrusted, on this occasion, with the greater part of the warlike operations, as well as the regulation of the forces. He, at the same time, invented a new kind of raft to facilitate the descent, so that the troops accomplished that object without wetting their feet, and in complete order of battle. This war lasted till the following year, and finished by the capture of $M a b \dot{e}$, which was succeeded by a treaty of peace. At that period M. de la Bourdonnais had made effectual preparations to destroy the settlements of the enemy along the coast.

On the termination of the war, he gave himself up entirely to commercial enterprize, and remained in the Indies to fit out private armaments. He was, indeed, the first Frenchman who engaged in similar undertakings in these seas, in which he was so successful, as well as in his different voyages in every part of India, that he made a very ample fortune:

As he had acquired a consummate knowledge of India, and had gained the confidence of the nations with whom he had traded, he was thereby enabled to render some important services to the ships of the King of Portugal. He saved two of them; and was, besides, so fortunate as to conciliate the Arabs and the Portuguese, who were on the point of engaging in actual hostilities in the road of Moka: they were equally grateful to him for his beneficial interposition; and his conduct on this occasion induced the Viceroy: of Goa to invite him to enter into the service of the King of Portugal, as captain of a ship; and, as an inducement to accept the proposition, that officer presented him with the Order of Cbrist, and letters patent of nobility, which were accompanied with the title of Agent of his Portuguese Majesty on the coast of Coromandel. M. de la Bourdonnais accepted these offers, in order to gain a more perfect acquaintance with the resources and extent of the commerce of India, and he remained during two years in the service of the crown of Portugal. He was more particularly induced to enter into this engagement from the confidential communication of the Viceroy of Goa, respecting a projected attack on Mombaze, M. de la Bourdonnais was entrusted, under the orders of the Viceroy, with the siege of this place, which the Portuguese were anxious to retake; and he was animated with the hope of acquiring honour in this expedition: but when the design failed, from an alteration in the plans of the Portuguese government, he returned into France in 1733 . In the following year, after several conferences 
with the ministers on the state of the colonies and the commerce of India, the king was pleased to appoint him Governor General of the Isles of France and Bourbon.

1735.-Thus furnished with every necessary power, both from the government and the India Company, he embarked in the beginning of the year 1735 , and arrived at his government in the month of June. The object of the minister in appointing him to this important office, was the re-establishment of good order, in a country which was a scene of licentiousness, confusion, and anarchy.

To give an idea of the situation in which he found these islands when he arrived there, it must be observed, that the Isle of Bourbon was first peopled by certain Frenchmen who saved themselves from the massacre of Fort Daupbin, at Madagascar, and several handicraftsmen of different vessels, who were joined by other Europeans of various descriptions. With respect to the Isle of France, it was not inhabited till between the years 1712 and 1720 , and even then the number of persons settled on it were so few that, till 1730 , the India Company were doubtful whether they should keep, or abandon it. At length, however, these two islands have had their distinct destinations; the one to the culture of coffee, and the other to afford refreshment to ships employed in the India and China trade. The soil of the Isle of Bourbon being proper for plantations of coffee, they have succeeded there, and attracted a considerable number of inhabitants. The advantages of the Isle of France being of another kind, it became expedient to form a colony there, for the purpose of furnishing vessels with provisions and other necessary refreshments.

The most natural and efficacious means, therefore, was to make an advance of live and dead stock, necessary implements, and slaves, to the inhabitants; to put them in a condition to form a settlement with the views already mentioned: but the Company was disappointed in its expectations, from the injudicious manner in which these advances were made, to all kinds of people, without inquiring whether they had the industry or the talents necessary to ensure success. In short, till the arrival of $\mathrm{M}$. de la Bourdonnais, the Isle of France had been very burthensome to the Company, who, exhausted by the continual supplies which it required, had given very precise orders to $\mathrm{M}$. de la Bourdonnais, not only to withhold any future advances to the inhabitants, but also to exact reimbursements of all those which had been already made. It may be readily imagined, that the communication of these indispensable orders alienated the minds of the people; but this was not the only difficulty with which M. de la Bourdonnais had to contend, in the execution of his commission. 
The administration of justice, of the police, and of commerce, as well as the military and marine departments, were a source of still more painful occupations. $\mathrm{He}$ found justice administered by two Councils, one of which depended on the other: the Superior Council was in the Isle of Bourbon. Since the arrival of M. de la Bourdonnais, his Majesty issued letters patent, which conferred an equal power on the Council in the Isle of France, in whatever concerned the criminal law. With respect to the general administration, the Council where the Governor resided, was to be the superior. As may be supposed, these alterations were attended with very beneficial effects: $M$. de la Bourdonnais may boast that, during the eleven years of his government, there was but one law-suit in the Isle of France, as he accommodated all disputes by his own amiable interposition. It might also be added, that after his arrival those disputes, which had so often interrupted the harmony of the two councils, no longer prevailed.

The police was also a very interesting object; more particularly as the Maroon Negroes carried disorder and desolation into the very heart of the Isle of France. M. de la Bourdonnais discovered the secret of destroying them, by arming blacks against blacks, and in forming a marechaussée of the Negroes of Madagascar, who at length purged the island of the greater part of these marauders. As for commerce, there was no idea of it when M. de la Bourdonnais arrived in the islands. He first planted the sugar-cane there, and established manufactures of cotton and indigo.* The one finds a vent at Surat, Moka, and in Persia, and the others in Europe.

Agriculture was equally neglected in these islands; and such was the indolence of the inhabitants, that they did not avail themselves of the advantages with which the surrounding soil was ready to reward their labour. M. de la Bourdonnais, however, gave a new turn to their character, awakened a spirit of activity; and brought them to cultivate all the grain necessary for the subsistence of the two islands, in order that they might be no longer subject to that state of dearth which had been so frequent in them, and which had annually compelled the inhabitants to apply to hunting and fishing, to the native fruits and roots of the country, for their subsistence. With this view also M. de la Bourdonnais introduced, though not without considerable difficulty, the cultivation of the manioc, which he at length obtained from the island of St. Jago and the Brazils, He was, indeed, obliged to

- The sugar-works which M. de la Bourdonnais had established in the Isle of Franee produced, at this time $\left(175^{\circ}\right)$ a clear annual revenue of sixty thousand livres to the India Company. 
employ his authority to compel the people to cultivate this plant, though it was to prove an infallible resource against that scarcity which they had so ofien suffered. He published an ordinance, by which every inhabitant was obliged to plant five hundred feet of ground with manioc for every slave which he possessed. Nevertheless the greater part of them, attached to their old customs, and disposed to resist authority, spared no pains to discredit this branch of agriculture; and some of them even carried their aversion to it so far as to destroy the plantations, by secretly moistening them with boiling water. Sensible, at length, of the folly of their former prejudices, they now experience and acknowledge the utility of this plant, which secures the islands from the possibility of famine : when their harvests are laid waste by hurricanes, or destroyed by locusts, which frequently happens, the inhabitants find in the manioc the means of repairing their misfortunes.

Besides this root, which grows in great abundance, these islands produce at present from five to six hundred measures of corn; whereas, previous to the arrival of M. de la Bourdonnais, the quantity was very trifling, indeed, in the Isle of France, and still less in the Isle of Bourbon.

But it was not sufficient to provide for the subsistence of the inhabitants by the cultivation of the earth, it was also necessary to put the islands themselves in a state of security; for he found them without magazines, or fortifications, or hospitals ; nor had they any workmen, or troops, or marine force. To attain these objects M. de la Bourdonnais spared no exertions'; but they were attended with such difficulties and mortifications, from the actual state of things, as well as from the character of the inhabitants; that he had frequently determined to renounce the enterprize.

When he left France, he had been assured that he should find at the Isles several French engineers, not one of whom was there on his arrival; as there had been continual disputes between them and the members of the Council, and they were returned to France to complain of the treatment which they had received: so that he found the body of engineers reduced to a Mulatto, who superintended the construction of a small windmill, in an unfinished state : there was also a magazine, which had been building for four years, and was yet without a roof, and a very small house for the chief engineer. Such were the only public buildings which he found on his arrival in the Isle of France. The Isle of Bourbon could not boast a superior degree of preparation. 
As he was without any engineer or architect, he was under the necessity of assuming both those characters; and being well acquainted with mathematics, and the science of fortification, he formed such plans as were approved by the Company. In order to carry them into execution, he produced workmen of every kind, by putting a large number of Negroes into a state of apprenticeship, under the very few master workmen which he had with him : nor is it easy to conceive the difficulty he had to compel the one to afford instruction, and the others to receive it. At length, however, he found himself in possession of a sufficient number of workmen to carry his designs into execution. But the obstacles to them did not end here: to collect a sufficient quantity of materials, was a very arduous operation; trees were to be felled in the wood, stone to be hewn from the quarry, and carriages were to be constructed to convey them to their destination. Besides, there were no roads along which they could pass, or horses to draw them. Roads were therefore to be formed, and bullocks were to be broken in to the yoke; and all these various preparations were to be made by people whose indolence resisted all labour, and whose minds were insensible to the general good and the public interest. $M$. de la Bourdonnais however contrived, by a wise application of gentle means, and rigorous severity, as different occasions and characters required, to erect very considerable works, whose utility and advantage are now universally acknowledged.

But it is not the Company alone which has derived advantage from these labours: the colony has experienced infinite advantages, since, by the establishment of roads, the employment of carriages, and, above all, by the emulation that M. de la Bourdonnais had awakened among the inhabitants, he reduced the greater part of the necessary materials, such as wood, chalk, \&c. to a fifih part of their former value.

The only hospital in the Isle of France was a large hut, formed with stakes or pallisadoes, which would not contain more than thirty beds; when he ordered a commodious building to be erected for that purpose, in which from four to five hundred beds might be conveniently placed. The administration of the hospitals was attended with incredible trouble to $\mathrm{M}$. de la Bourdonnais; and, for one entire year, he found it absolutely necessary to pay them a daily visit; but even this painful attention could not preserve them from the bad effects of negligence, incapacity, knavery, and ingratitude.

It would be needless to enter into a detail of all the various buildings and works which M. de la Bourdonnais had caused to be erected in the course of his admi- 
nistration: it will be sufficient to observe, that they consisted not only of magazines, arsenals, batteries, fortifications, and barracks for the officers, \&c. but also mills, quays, offices, shops, canals, and aqueducts. The aqueduct in the Isle of France, which conveys fresh water to the port and the hospitals, is six thousand yards in length. This accommodation is attended with inexpressible advantages, both to the inhabitants, and the ships which arrive there for refreshment.

It is well known that the Governor General exerted himself with the same indefatigable spirit, in every thing which related to the marine in the port of the Isle of France. Before his arrival, the inhabitants were so ignorant of every thing that related to ship-building, that they were not qualified to make the slightest repairs of their own fishing boats; but were obliged to have recourse to the carpenters of ships who put into their harbours. He therefore did not delay to avail himself of the numerous advantages which the island possessed, to acquire some degree of maritime importance. He encouraged the inhabitants to support him in this patriotic undertaking; and, by their efforts, so large a quantity of wood had been cut down, fetched from the woods, and worked up into preparatory forms, that, in the course of two years, he found himself possessed of materials sufficient to commence his naval works.

1737. - He began by making pontoons to careen ships, as well as to load them, and lighters to carry water; he also built canoes and large boats, for the transport of materials and other daily service. In 1737 , he undertook to build a brig, which proved an excellent vessel. In the following year he built two other vessels; and put a ship of five hundred tons on the stocks. In short, from his persevering spirit and indefatigable skill, they now build and refit ships as well at the Isle of France, as in any port of the East : nay, in cousequence of certain machines, invented by M. de la Bourdonnais, ships are accommodated, particularly in obtaining water, with unrivalled expedition.

Previous to his arrival, the captains of the Company's ships had assumed a degree of independence, which by no means accorded with the good order and advantage of the service; nor could they conceal their dissatisfaction at being commanded by a man who was so lately their comrade. They were jealous also of the Croix de St. Louis, with which he had been honoured by his majesty. The service was in danger of suffering from these discontents, and required all the resolution as well as conciliating powers which $\mathrm{M}$. de la Bourdonnais possessed, to restore good order 
and discipline in its different departments. But though the officers of the Company did not venture to oppose themselves to his regulations, as they could not with any degree of justice refuse their assent to the necessity of them, they continued to entertain a secret resentment against him. In the first years of his government, from the natural state of the island, and afterwards, from an unfortunate mortality among the horned cattle, he was not enabled to furnish the Company's ships with their full complement of meat; the captains, therefore, though they appeared perfectly satisfied with his endeavours, and left him with every exterior approbation of his conduct, were no sooner arrived in.France, than they presented their complaints against him, for neglect in furnishing them with the necessary supplies for their homeward voyage: nor was it long before he was sensible that these representations had been received with a degree of credit which they did not deserve.

1740. - The death of his wife rendered it necessary for him to return to France; and on his arrival there, he found an unaccountable prejudice prevailed against him, not only in the minds of the ministers and the Company, but of the public at large.

In this unmerited situation he made his complaints to Cardinal Fleury; stated in the strongest terms his fidelity to the king, and his zeal for the Company, and demanded permission to offer his justification against the secret charges which had been made against him; declaring, at the same time, that he was ready to render an hundred fold to any one, who could prove that he had received the least injustice from him. Ile made the same application to the Count de Maurepas, and M. Ourry, Comptroller-general; when he was informed, that the accusations against him should undergo a very scrupulous examination.

At this time a publication appeared against him, containing a long detail of charges respecting his conduct, as governor of the Isles of France and Bourbon. But, conscious of his own rectitude, and despising the author of these calumnies, he let them pass away without any particular answer. At length, however, he thought it necessary to check the course of public prejudice, which ran with so much violence against him; and he completely effected it by the justification which he published. For the public not only received him to their former good opinion, but the ministers also expressed their approbation of his conduct.

He found, however, new subjects of chagrin and discontent, from the secret enemies which he now discovered in the Company. This circumstance very sensibly affected him; he perceived the difficulties that would unavoidably arise from being 
thwarted in his designs, which would inevitably happen, when, among those to whom he was accountable for the execution of his office, and who possessed the power to command the details, there were several who, from motives which they dared not to avow, were strongly disposed to trouble the repose, and disconcert the measures, of his government. He had, therefore, determined to resign his situation ; but the ministers to whom he communicated this resolution, would not permit him to execute it.

The wish to retire, however, still occupied his mind; when the preparations that were making in the several ports of France, announced a rupture with Great Britain and Holland. He accordingly formed a plan, to arm a certain number of ships to attack the commerce of those two countries; and his friends formed such sanguine expectations of his project, that, in order to facilitate its completion, they proposed to advance five millions of livres, on condition that he would take a tenth share in the armament. This proposition was no sooner made, than he hastened to Fontainbleau, to communicate his plan of operations to the Count de Maurepas, and to demand his permission to carry it into immediate execution.

His plan was as follows: To equip six vessels and two frigates, and to set sail for India. If war should be declared, he would be ready to attack the commerce of Great Britain, and to undertake expeditions against its colonies. He then engaged to apply whatever money he should take, to the service of the Company, which would render it unnecessary for them to send any specie out of the kingdom; and, in order that he might not interfere with their privileges, he would dispose of the merchandize which he might possess himself, in the South Seas. His next object would be to return to China; and having exchanged the money for which he had sold his cargoes, into gold, to touch at the Isles of France and Bourbon, in order to supply the Company with whatever funds it might require, and to bring the rest to France. If, however, war should not be declared, he then engaged to freight his ships for the benefit of the Company.

This project was highly approved by the ministers; and $\mathrm{M}$. de la Bourdonnais was informed, that the government would furnish him with two frigates, that the East India Company would add four vessels, and that the king would appoint him to the command of the squadron : at the same time he was ordered to execute for the Company, the plan he had formed for himself, with the assurance, that his Majesty would take care of him and his fortune. 
But flattered as M. de la Bourdonnais may be supposed to have been by these marks of confidence and favour, he was well aware of the opposition he should find from the Company, who, piqued at not having been consulted in a project, in which they were so materially concerned, would manifest their discontent by delaying the operations of the armament: nor did the promise of the minister, to advance him to a distinguished rank in the naval service of France, and thereby secure him from any vexatious proceedings on the part of the Company, satisfy his mind, or remove his apprehensions.

In short, the Company represented the proposed expedition as injurious to their interests, and that it could not produce any advantage to the state. They, consequently, indisposed the public mind against it, and its supposed projector. Accordingly M. de la Bourdonnais intreated the minister to discharge him from the service, and to employ some other person, who was better qualified than himself, to conciliate the confidence of the Company. But his remonstrances were not heard, and he was ordered to obey the commands of his sovereign. M. Ourry, the Comptroller of the Marine, however, undertook to dissipate his alarm, by making the Directors of the Company declare to M. de la Bourdonnais, in his presence, that they would afford him every assistance and support in their power.

1741.-M. de la Bourdonnais, therefore, left Paris in the month of February 1741 , with the general commission of captain of a frigate; and the particular commission to command the Mars, one of the king's ships of war.

He chose the Isle Grande, on the coast of Brazil, as a refreshing place, from its intermediate situation; and the Company's ships, from that time, followed his example. After passing twenty-two days there, to exercise and refresh his crews, he set sail from thence with the three largest vessels, and in fifty-six days he arrived at the Isle of France, August 14, 1741 . He left one of his ships at the Isle Grande, to wait for another which had not appeared when he quitted it.

He now learned that the Mahrattas threatened Pondicherry; and to prevent a seige of that place, or to maintain it against a beseiging enemy, the Isles of France and Bourbon had already transported their garrisons thither. This intelligence caused him no small disquietude; and he considered it to be of the last importance to proceed with all possible diligence to Pondicherry, after having put his islands in a state of security. To fulfil this two-fold object, he began by ordering a fort to be constructed upon one of the peninsulas which defends the port of 
the Isle of France; he then directed that the inhabitants should, on Sundays, be trained to the use of arms; he marked out their posts and places of rendezvous, with orders to repair there on the first alarm: and, lastly, he gave directions that the first vessel which might arrive, should be sent to Goa to fetch provisions. Having settled these various, necessary, and wise regulations, in the Isle of Bourbon, he set sail from it on the $22 \mathrm{~d}$ August, with the squadron, and arrived at Pondicherry the zoth September, which, to his great satisfaction, he found in a state of perfect tranquillity, from the excellent conduct of M. Dumas, the governor, who had found means to prevent the Mahrattas from undertaking the siege. The factory at Mahé, was, however, in great danger, having been blockaded for eighteen months by the people of the country; and, in consequence of the suggestions of the governor and council of Pondicherry, he set sail on the $22 \mathrm{~d}$ of October to the relief of that place.

During his voyage thither, he employed his utmost attention to exercise his forces, which were raw and undisciplined; and, notwithstanding the almost insuperable difficulties which presented themselves, he contrived by diligence, skill, and a perfect knowledge of the country, to fit his people for the service wherein they were to be employed.

The enemy, with whom he had to contend, occupied a mountainous country, intersected by ditches of fifteen feet in depth, which might be considered as so many slaughter-houses to the Europeans who should be so rash as to venture among them. These people, which are called Naires, are of a large size, of a copper colour, and active and vigorous. Their sole profession is that of arms, and they would be excellent soldiers, if they were in a state of discipline. $\Lambda$ s they fight without order, they take to flight whenever they are attacked by superior force; but if they find themselves pressed with vigour, and that they are in actual danger, they re-engage with desperate fury, and an unyielding resolution to conquer or to die.

The Naires which were encamped before Mabé, had determined to make an attack on the following day, when M. de la Bourdonnais arrived with two ships; and the disembarkment of his troops checked their design. As there was no kind of proportion between the numbers of the enemy, and the handful of men which he commanded, he did not venture to risk a general engagement. His knowledge and experience suggested to him, that he could alone insure success by opposing order 
and precaution, to men who knew no other rule of warfare but the impetuosity of the moment. He began, therefore, by opening a trench opposite one of the enemy's batteries which greatly annoyed the town; and the work was conducted with such expedition that, on the third day, it reached within thirty fathom of the outworks of that battery. Here, however, he met with a piece of marshy ground, which prevented him from advancing: he was therefore reduced to the necessity of making a parallel, to lodge a body of troops sufficient to sustain the head of the work, as it was his design to maintain that post till the arrival of the other ships, which he daily expected.

As soon as one of them arrived, he sent all the troops, as they landed, into the trenches, in order to accustom them to the fire of the enemy, which was incessant; and they soon acquired the resolution and habits of the military character.

In the night of the third of December, he ordered a battery to be constructed, which was attacked in the morning by the enemy. As he had foreseen this attack, he had the precaution to conduct eight hundred men thither, who repulsed the enemy with great bravery. He then made a general attack, which was supported with such spirit and activity, that the enemy, unable to sustain it, took to flight, and, having lost five hundred men, left the French masters of all their posts and intrenchments, with eight pieces of cannon. '

He now proceeded to negociate a peace for Mabc with the Naires, which was concluded in February, 1742 , and he then returned to the Isles of France and Bourbon, where his presence was essentially necessary. Here he waited for the intelligence which he daily expected, that war was declared between France and Great Britain.

By a letter, dated the 1 st of October, $174^{2}$, addressed to M. de la Bourdonnais, Cardinal Fleury communicated to him the high approbation of the King, and expressed his own eulogium of his services; at the same time he gave orders that letters of nobility should be expedited to him to the Isle of Bourbon.

As his ships arrived at the islands, he ordered them to be successively refitted; so that he had his fleet ready in the month of May, in a better state of equipment than when it left France. The hostilities of Mahé being terminated, and the islands not only cultivated, but sufficiently fortified to resist any attack, he waited for the information that war was declared, to engage in his premeditated expedition against the enemies of France in India. 
But this project, on which his hopes had so long rested, was doomed to end in disappointment; for at the moment when he was looking to the fame he should acquire, and the service he should render to his country, he received positive orders from the Company to disarm his squadron; and, to quench all representations on his part, he was expressly commarided to send every ship home, and let them return empty, rather than keep one of them at the islands. In this unexpected and mortifying conjuncture, he had no alternative but obedience. The French government, however, soon repented of this measure; and M. de la Bourdonnais, being persuaded that, in the circumstances wherein he was placed, it would be impossible for him to exert himself to any purpose of distinction or public advantage, at least equal to his hopes, demanded permission of the ministers to return to France. This request however was refused; as it was thought absolutely necessary for the welfare of India, that a person of his talents, local knowledge, and integrity, should remain there, for the interests of his country in that part of the globe.

1744.-M. de la Bourdonnais finding himself obliged to remain in his government, and that he must no longer indulge himself in military speculations, gave himself up entirely to œconomical arrangements. He employed himself in establishing sugar, indigo, and cotton works, which he had begun at his own expence, and had answered his utmost expectations. In these occupations he was busily engaged, when, on the 11 th of September, 1744 , he received the intelligence from Europe, that war had been declared between France and England. 


\section{GHAPTER VII.}

The Letters of Baron Grant continued.-Interior State and Condition of the Island. -Narrative of the Sbipvareck of the St. Geran.-An Account of the Grenville Family.-Interesting Circumstances relative to $M$. de Grenville Forval.

\section{LETTER III.}

Isle of France, ... 1742.

I INFORMED you in my second letter, of the reception I met with from the Deputy Governor and the Council, who have expressed a desire to keep me in this country, where I may at the same time continue in the service. I accordingly received a grant of a certain quantity of uncultivated ground, in a state to be immediately cleared, as well as six slaves, consisting of two Negro men, two women, with a boy and girl; the men at three hundred livres each, the women at two hundred, and the two others at one hundred and fifty, amounting all together to thirteen hundred livres; to be repaid from the produce of the ground, when it shall be advanced into a state of cultivation. This little troop were for some time employed in a plantation, where they learned to work, and gain their immediate subsistence, which consists of maize; though we begin to grow manioc as food for the slaves. The Captain of the Hercules, the ship which brought me here, received the first orders to take in manioc at the Portuguese island of St. Jago, and we put in there for that purpose.

My allotment of ground is situated between two rivers, which form its limits. One of these rivers falls in a cascade of upwards of three hundred feet, at a small distance from my situation; which, you will consequently perceive, is in the vicinity of the mountains. I soon cleared the ground, which is effected by destroying the wood; as the whole of this country, which is not in a state of cultivation, is one continued forest; and in attending to this object, I employed the time which was not engaged in military duties. These, however, are not very important in time of peace. The trees are cut down breast high, and burned: the ground is then prepared for seed, and the work of cultivation commences. I received considerable 
assistance in preparing my plantation, from the liberal and active kindness of my neighbours and their slaves, according to the usual custom of this island.

The labour of my slaves soon produced sufficient to indemnify me for their purchase; and my activity and attentions have procured me the encouraging approbation of all around me. I first employed my Negroes to erect huts for themselves, and when that necessary object was accomplished, I contrived a cottage for myself. My new occupations prove a source of infinite amusement to me; though the Negroes require a continual attention, and $I$ frequently rise in the night to see if they are in their huts. They are very fond of nocturnal excursions, either to gratify their gallantry, or to pilfer from their neighbours: indeed so strong is this disposition in them, that no severity seems equal to the correction of it.

The offices of religion are regularly performed to the Negroes morning and evening in every plantation, and they are married by a simple ceremony, suited to their understandings. We assort these matches in the best manner we are able, and endeavour to gratify their inclinations whenever it is in our power. The ceremony consists in nothing more than a short discourse, recommending mutual kindness and fidelity, accompanied with a menace of punishment to the party who shall be guilty of any misbehaviour or improper conduct. The whip is the instrument of justice employed on these occasions; and the person who is appointed to exercise it is called the Commander. This officer punishes the offences of the man; but if the wife should be guilty, the whip is consigned to the husband, who may correct her in the presence of the commander; though it often happens that he pardons her on the spot, and they depart perfectly reconciled. Notwithstanding their occasional disagreements, they are in general fond of each other, and discover the most tender affection for their children.

I sowed the ground which $I$ had cleared, with rice and maize; but the rainy season was not yet commenced, is being the early part of January; and the latter grain was exposed to the devastation of the rats; so that I sowed another crop when the rains came on, which may be considered as the manure of this soil : indeed no other is necessary, as each year yields a two-fold harvest. The corn, which is excellent, though its grain is small, remains but four months in the earth; and French-beans are equally rapid in their progress to maturity: but our harvests are infested by those very destructive enemies, the locusts, which fly like birds, and come no one knows from whence, in such clouds as to darken the sky. They eat the plants down to the 
very earth; they then lay their eggs, which are speedily hatched, and the ground is covered with them: they soon hop about, and would shortly rise upon the wing if they were not destroyed. The mode of attaining this very important object is as follows: small holes are made in the ground about the size and depth of the crown of an hat, into which the Negroes, with small brooms, sweep the young tribes, and having covered them with earth, they press it down with their feet. As the practice is universal over the island, this mischievous insect is at length destroyed.

The rats are very large, and issue from the woods during the night. In order to destroy them, the Negroes set traps along the border of the woods: they consist of wooden balls cut in half, the flat side being placed towards the ground; these are supported by three small pieces of wood, and some grains of maize are placed up them; so that when the rats seize on the bait, the semi-ball falls and crushes them.

The monkies, very fortunately for us, never quit their retreats but during the day. Negro boys are placed to make a noise about the woods, in order to frighten them; but these cunning animals will, if possible, discover some avenue which is not guarded, and carry off what they can find. Fowling-pieces and hounds are more effectual; but so great is their address and agility, that, though they are as large as a common spaniel, they contrive to hide themselves among the branches in such a manner, and leap from one tree to another with such rapidity, that it becomes a very difficult matter to destroy them. They have also a discipline, which I know not how to attribute to mere instinct; as, on their marauding parties, they have sentinels, who are placed in every necessary point, to give the signal of approaching danger. To these mischievous animals may be added, the hurricane and the dry seasons: the lightning is also very violent, and the thunder louder than is teard in other parts, from the position of the mountains. Torrents of rain and whirlwinds precede the hurricanes, which nothing can resist: but they are necessary evils, like our winters in France. We escaped them last year, and have been attacked by epidemical disorders. The small-pox still prevails. In China, that disease has been very fatal; and a ship coming from that country might readily infect our little Island. It is however worthy of observation, that the Isle of Bourbon has experienced the effects of four hurricanes, and we were not sensible of one of them.

This circumstance has been very favourable to the cultivation of the banana, which are in great abundance, as violent winds are fatal to them. The tree, or rather the plant that bears this fruit, is about ten feet in height, and it may be cut 
through with the stroke of a sabre as easily as a cabbage stock. Eggs sell for a sous, and chicken at one livre ten sous.

We now make wheaten bread of our own growth: the corn is ground by a small hand-mill, which gives rather a coarse flour, but the bread is of a very agreeable taste. This will prove very advantageous to the island, as the flour brought from Europe is often spoiled in the course of the voyage, and bread then becomes extravagantly dear,

Grant.

\section{LETTER IV.}

Isle of France, 1st of June, 1743.

I proceed to give you a detail of my present situation. You already know that the Council had granted me six slaves; but the strongest of them has already quitted me to join a party of runaway Negroes, who live on the fruits of nocturnal rapine. We consider them as obnoxious animals, and hunt them down in the same manner. My fugitive has accordingly suffered on one of his marauding expeditions, when he was shot. This black cost me three hundred livres; and since the return of the Governor, the slaves of his kind are sold for a thousand. This is a considerable loss in the first instance, besides the value of his labour; but I am consoled by the kind and ready assistance I receive from my friends and neighbours. I have since purchased a Negress, at a public auction, for three hundred and fifty livres, or an hundred piastres, which in France would amount to upwards of five hundred livres, to be paid in grain in the course of the year.

M. de la Bourdonnais has promised to let me have four blacks, on his return, at seven hundred and twenty livres each, one-third of which sum is to be paid in grain, on receiving them, and the rest in three years. He is now at the Isle of Bourbon; and as I have already delivered to the magazines, on his account, a quantity of maize, to the value of nine hundred and fifty livres of this country, $I$ shall receive my slaves as soon as he returns.

We however experience difficulties of many kinds : besides the augmentation in their price, disease, death, and flight, deprive us of our Negroes. We are also subject to the caprice of those in power, who change even the price of grain, notwithstanding the difficulty in conveying it to the port, which is at the distance of three leagues. The price of maize was fifty livres the millier, and after the succeeding 
harvest it was reduced to forty. We also raised beans, which were received at the magazines at an hundred livres the nillier; but the cultivation of that grain is now entirely suppressed, and the growth of wheat ordered in its stead; which does not exceed it in price, is a much less certain crop, and requires a fourfold proportion of time and labour.

There are not more at present than an hundred and fifteen plantations, divided into four districts or quarters, at the distance of about six leagues from each other : nevertheless, there is a difference of upwards of six weeks in their respective seeding times and harvests. In the plains of Willems we are but a league from Moka, where they do not enjoy an equal degree of warmth with us. This circumstance is occasioned by the mountains that separate us; we are on the sunny side of them, while their shade chills the environs of Moka, and retards their harvests. The port is inclosed by the mountains in the form of an horse-shoe towards the sun, which produces an extreme heat to the month of July, when the air acquires some degree of freshness. Clouds of stinging flies, gnats, and fleas, are extremely troublesome in that situation. The air having more activity in the plantations, these tormenting insects cannot live among them. The confined air of the port occasions diseases; but as I am only obliged to go there once a month to attend the review, and never remain there more than twenty-four hours, I have been so fortunate as to escape them. Indeed, a longer absence might be attended with very serious consequences, as the Negroes demand the most attentive vigilance, or very severe punishment. I choose to adopt the former; and, to declare my real sentiments, I think the rural occupations and enjoyment of my plantation, infinitely preferable to the busy scene of the port.

This island, with all its charms, has its inconveniences, but they are of a nature to be soon forgotten, amid the various advantages and pleasing circumstances which are enjoyed; and, after all, who would not wish to be the inhabitant of a spot where there are neither taxes or law-suits? As for myself, I have a few slaves, and a tract of ground to occupy them, with grain to sow it. My harvests have been successful, as well as those fruit trees which form a part of my revenue. We have standard peaches and apple trees from Normandy. Their fruit is ripe in January, when the ships arrive; and as the seamen are famished for fruit and vegetables, they are ready to pay a handsome price for them. The other fruits are figs, bananas, both green and yellow, the anana, dates, \&c. \&c. 
By the next arrivals from Europe, we shall be informed if it be peace or war. We are, at all events, making preparations to defend ourselves in case of an attack, and the Creoles are all soldiers. As for the rest of our population, it consists of an handful of people from every province in France; with whom, I must acknowledge, it would be indiscreet to form an intimate connection, without much preliminary precaution and experience.

Grant.

\section{LETTER V.}

Isle of France, 28 th of December, $1744^{\circ}$

It is now a year since we expected a large vessel, called the St. Geran, which was appointed to bring the necessary supplies to these islands, and it arrived only to be shipwrecked on this coast, off a small adjoining uninhabited island, called the Isle $d$ 'Ambre. The pilot, who had never been employed but in very small vessels, knew not how to guide so large a ship on this perilous coast; so that she was lost with all her cargo, and only seven of her crew escaped. We are destined to remain without those comforts and supplies with which this unfortunate vessel was laden, till - the Company, on being informed of the loss we have sustained, can make the necessary preparation to dispatch another cargo for our relief.*

- The following description of this shipwreck, is taken from the Romance of Paul and Virginia, by $M$. de St. Pierre; and as it is an accurate relation of this misfortune, we shall make no apology for giving it in the words of that admired and interesting work.

"On the 24th of December, 1744, at break of day, Paul, when he arose, perceived a white flag on the mountain De la Découverte, which was the signal of a vessel descried at sea. He flew to the town, in order to learn if this vessel brought any tidings of Virginia, and waited till the return of the plot, who was gone, as usual, to visit the ship. The pilot returned, with the information that the vessel was the St. Geran, of seven hundred tons, commanded by a captain of the name of Aubin; that the ship was four leagues out at sea, and would anchor at Port Louis the following afternoon, if the wind provad favourable; but it was then a calm. It was about ten at night, when, as I was about to extinguish my $1 \mathrm{mp}$ and retire to rest, I perceived, through the palisadoes of my hut, a light in the woods. I arose, and had just dressed myself, when Paul, half wild and panting for breath, sprang on my neck, exclaiming, 'Come along, Virginia is arrived ! Let us go to the port ; the vessel will anchor at breik of day.'

"We instantly departed; and as we traversed the woods of the sloping mountain, and were already on the road which leads from the Shaddock Grove to the Port, I heard some one walking 
Since this unpropitious event, some small vessels have arrived, which however brought us little more than accounts of the state of public affairs. The last of them indeed gave us the satisfactory intelligence, that the Company had dispatched several

behind us. When this person, who was a Negro, had overtaken us, he informed us that he came from that part of theisland called La Poudre d'Or, and was sent to the port to inform the Governor that a ship from France had anchored on the Isle of Ambre, and fired guns of distress, as the sea was very stormy. He then left us, and pursued his journey.- ' Let us go,' said I to Paul, ' towards that part of the island, and meet Virginia.' Accordingly we bent our course thither. The heat was suffocating, and the moon which had risen, was encompassed by three large, black circles. A disinal darkness shrouded the sky; but the frequent flakes of lightning discovered long chains of thick, gloomy clouds, rolling with great rapidity from the ocean, though we felt not a breath of wind on the land. As we walked along, we thought that we heard peals of thunder; but after listening more attentively, we found they were the sound of distant cannon repeated by the echoes. These sounds, joined to the tempestuous aspect of the heavens, made me shudder, and I had little doubt that they were signals of distress from a ship in danger. In half an hour the firing ceased, and I felt the silence more appaling than the dismal sounds which had preceded.

“We hastened on without uttering a word, or daring to communicate our apprehensions. At midnight we arrived on the sea-shore. The billows broke against the beach with an horrible noise, covering the rocks and the strand with their white and dazzling foam, blended with sparks of fire. By their phosphoric gleams we distinguished, dark as it was, the canoes of the fishermen, which they had drawn far on the sand. Near the shore, at the entrance of a wood, we saw a fire, round which several of the inhabitants were assembled: thither we repaired, in order to repose ourselves till the morning. One of this circle related, that in the afternoon he had seen a vessel driven towards the island by the currents, that the night had obscured it from his view, and that two hours after sunset he had heard the firing of guns, as signals of distress; but the sca being so tempestuotis, no boat could venture out : that a short time after he thought he perceived the glimmering of the watch-lights on board the ship, which he feared, by its having approached so near the coust, had steered between the min land and the small Is'e d'Ambre, mistaking it for the Coin de Mire, near which the vessels pass, in order to gain Port Louis; and if that were so, the ship, he apprehended, was in great danger. Another islander then informed us, that he had frequently crossed the channel which separates the Isle d'Ambre from the coast, and as he had sounded it, he knew the anchorage was good, and that the ship would there be in as great security as if it were in the harbour. A third islander declared it was impossible for the ship to enter the channel, which was scarcely navigable for a boat; he asserted, that he had seen the vessel at anchor beyond the Isle d'Ambre, so that if the wind sprung up in the morning, it could eithr put to sea, or gain the harbour. At break of day the weather was too hazy to admit of our distinguis ing any object at sea, which was covered with a fog. All we could descry was a dark cloud, which we were informed was the Isle d'Ambre, at the distance of a quarter of a league from the coast. We could only discern, on this gloomy morning, the point of the beach where we 
vessels laden with every thing necessary for the welfare of the island: but, if they should delay their arrival, we must be content to go bare-foot, like the Negroes, and to clothe ourselves in the skins of deer; though that animal, which furnishes

stood, and the peaks of some mountains in the interior part of the island, rising occasionally from admist the clouds which hung around them.

"At seven in the morning we heard the drums beat in the woods, and soon after the Governor, M. de la Bourdonnais, appeared on horseback, followed by a detachment of soldiers armed with muskets, and a great number of islanders and blacks. He ranged his soldiers upon the beach, and ordered them to make a general discharge, which was no sooner done than we perceived a glimmering light upon the water, that was instantly succeeded by the report of a gun; we therefore judged that the ship was at no great distance, and hastened towards that part where we had seen the light. We had discerned through the fog, the hulk and tackling of a large vessel; and notwithstanding the noise of the waves, we were near enough to hear the whistle of the boatswain at the helm, and the shouts of the mariners. As soon as the St. Geran perceived that we were near enough to give her assistance, she continued to fire guns successively every three minutes. M. de la Bourdonnais caused great fires to be lighted at certain distances upon the strand, and sent to all the inhabitants of that neighbourhood in search of provisions, planks, cables, and empty barrels. A crowd of people soon arrived, accompanied by their Negroes, loaded with provisions and rigging. One of the oldest planters at this time informed the Governor, that they heard, during the whole night, hoarse noises in the mountain, and in the forests: that the leaves of the trees were shaken, though there was no wind, and that the sea-birds had sought refuge on the land; all of which he considered as certain signs of an approaching hurricane. Every thing, indeed, seemed to denote its speedy arrival. The centre of the clouds in the zenith was of a dismal black, while their skirts were fringed with a copper hue. The air resounded with the cry of the frigate bird, and a multitude of sea fowl; who, notwithstanding the obscurity of the atmosphere, hastened from all points of the horizon, to seek for shelter in the island. Towards nine in the morning we heard, on the side of the ocean, the most terrific noises, as if torrents of water, accompanied by thunder, were rolling down the steeps of the mountains. A general exclamation followed of, ' There is the hurricane!' and, in one moment, a frightful whirlwind scattered the fog which had covered the Isle d'Ambre and its channel. The St. Geran then presented itself to our view; her gallery crowded with people, her yards and maintop-mast laid upon the deck, her flag shivered, with four cables at her head, and one, by which she was held, at the stern. She had anchored between the Isle d'Ambre and the main land, within that chain of breakers which encircles the island, and must have been driven over a bar that no vessel had ever passed before. She presented her head to the waves, which rolled from the open sea; and as each billow rushed into the straits, the ship heaved in such a manner that her keel was in the air, while at the same moment, her stert, plunging into the water, disappeared altogether, as if it were swallowed up by the billows. In this position, driven by the winds and waves towards the shore, it was equally impossible for her to return by the passage through which she had made her way, or, by cutting 
us with such excellent meat, begins to be less common than formerly in the forests: nor do the goats increase, whom I sometimes follow into their most difficult recesses. We must, however, be content to stay at home for the present, as the few handicraftsmen we had, are departed for the war in India, \&c.

GrANT.

\section{LETTER VI.}

Isle of France, 20 th of December, 1745 .

In this letter I shall change my former subject, and pass from the history of agriculture and the employments of a country life, to consider the occupations of the town. My uncle* has an house there, which we sometimes visit, particularly to enjoy the society of M. de Grenville and his interesting family. He has long been my uncle's intimate friend, and is become mine. It is from him and M. de la Bourdonnais, that I receive every information necessary for me to possess in this country.

her cables, to throw herself upon the beach, from which she was separated by sand.banks, mingled with breakers. Every billow which broke upon the coast advanced roaring to the bottom of the bay, and threw planks to the distance of fifty feet upon the land; then, rushing back, laid bare its sandy bed, from which it rolled immense stones with an hoarse and dismal noise. The sea, swelled by the violence of the wind, rose higher every moment ; and the channel between this island and the Isle d'Ambre, was one vast sheet of white foam, with yawning chasms of black, deep billows. The foam boiling in the gulph was more than six feet in height, and the winds which swept its surface, bore it over the steep coast more than half a league upon the land. The innumerable white flakes, driven horizontally as far as the foot of the mountain, appeared like snow issuing from the ocean, which was now confounded with the sky. Thick clouds of an horrible form, swept along the zenith with the swiftness of birds, while others appeared motionless as rocks. Not a spot of azure could be discerned in the firmament; only a pale yellow gleam - displayed the view of earth, sea, and skies. Fron the violent efforts of the ship, what we dreaded, happened. The cables at the head of the vessel were torn away; it was then held only by one anchor, and was instantly dashed upon the rocks at the distance of half a cable's length from the shore. A general cry of horror issued from the spectators. Sometimes the sea, in its irregular movements, had left the vessel almost dry, so that any one might have walked around it; but suddenly the waves advancing, with renovated fury, shrowded it beneath mountains of water, which then lifted it upright on its keel. At last every part of it yawned asunder, from the violent strokes of the billows; and the crew in despair threw themselves into the sea : of these, seven alone escaped; and the unfortunate Virginia was one of the victims. Such was this scene of horror."

* Mr. Grant d'Anelle, mentioned in the Introduction. 
M. de Grenville is of an ancient, noble, and illustrious family of Normandy, where there are several burghs and estates which bear his name; and a branch of which passed into England, with William the Conqueror, in 1066, where it now possesses very extensive possessions and high dignities. *

* Extracts relative to the House of Grainville, from the Peerage of England, and the histories of the noble families of France.

"Grenville, Grainville, Greinville, Greneville, Greneveile, Greenville, Granville, Greynville, Greinvill, Greinvyll, \&c.

" Earl of Temple, Marquis of Buckingham, Earl Nuguent in Ireland, and ancient Lords of Grainville, \&c. \&c. \&c. in Normandy.

" This name is written in all these various ways, both in Great Britain and Normandy, according to the British Peerage, by Collins, edir, 1756, Vol. IV. page 215, 216, 217; but the original way of writing this name in France is Grainville, as it is still written in Normandy, from whence Richard de Grainville, or Granville, passed with William the Conqueror, in 1066. This appears from the ancient deeds of the West, and those of Buckinghamshire.

" Robert de Grainville is one of the witnesses to the charter for building the Abbey of Nethe, which was begun by the aforesaid Richard de Grailville, anno 1129, 30 Henry I. and Ralph de Grainville, in the same reign, is among the witnesses to the charter of Roger Montgomery, Earl of Arundel and Salop, to the Abbey of Stephen (St. Etienne) at Caen, in Normandy ; likewise in that reign, Gerard de Greinville, \&c.

“The family of Grainville or Grenville, established several burghs or villages, which still retain their original name, in the environs of Caen and Rouen, in Normandy.

" The present representatives of this family in France are Messrs. M. de Grainville (the uncles, by the mother's side, of the Vicomte de Vaux), who were officers of rank in the service of the King of France.

"As to the difference between the arms of the French and English families of this name, they are very trifling; and it is well known to our antiquaries, that they were not generally settled till the reign of Edward $I$.

"The Grenvilles of England acknowledge that they descend from those of Normandy; while the latter consider it as an honour to proceed from the same root.

“ The Grainvilles of Normandy have, at all times, maintained themselves with honour, and their present representatives have served in the East Indies with great distinction.

"In La Rocque's Treatise on Nobility, edit. 1734, the following notices appear, p. 74. Ballivia de Caleto. (The Bailiwic of Calais.)

“ Foannes de Graeniville, miles, comparuit dicens dominum regem tenere, terram suam, et ad excercitum vadit; excusare se apud ipsum.

Idem. " Joannes Mallet, miles, comparuit se quintus de militibus nomina sunt hæc, Gulielmus de Queneville, foannes de Granvilla, Nicolaus de Sana, Gulielmus de Avenis, et idem dominus, milites.

Idem. (p. 77.) " Joannes de Grivelliis, miles, comparuit pro se. 
This gentleman is an old officer, who has served with honour both in France and India; and may, with great truth, be represented as superior to the generality of mankind, from his understanding, his knowledge, and the qualities of his character. He is distinguished here by the title of the Pbilosopber, and he deserves it; for in the most elevating sense of the expression, he is a lover of wisdom. In the early part of his life, the vivacity of his temper, heightened by the military spirit of that period, engaged him in frequent affairs of honour; and the last having taken place with a nobleman in the service of the court, in the garden of Versailles, and under the very windows of the king's apartment, it threatened the most serious consequences. But M. de Maupou, then in high office, to whom he was related, persuaded him to quit the kingdom, and procured him a commission in India, where he served with distinction.

If it were consistent with the objects of this work, it would be a delightful circumstance to dwell on the virtues and extraordinary qualities of this family. I must, however, confine myself to one of them, M. de Grenville de Forval, the second son of $\mathrm{M}$. de Grenville. Some events relative to him are so connected with the manners of these islands, and so remarkable in themselves, that they will at the same time heighten the interest, as well as add to the information of this work.

In these islands there is not a single example of a deformed or crooked shape, which must arise from the natural and unrestrained mode of education which prevails there. To these advantages, Forval united a martial air, blended with a slight appearance of severity, and an approved courage, to the most noble and generous sentiments that are found in the human breast.

The want of slaves in our colonies, renders expeditions necessary in order to procure them. Vessels, therefore, are equipped for the coasts of Africa and Madagascar, and a certain body of troops are sent with them, to favour or support the objects of these voyages.

Forval was ordered to command a detachment on a service of this nature, on the coast of Madagascar; and being arrived on the eastern side of it, he disembarked his people, and encamped them on the small island of St. Mary, called by the natives, Ibrahim, which is separated only from the principal island by a very narrow strait. Here the communications took place between the persons engaged in this expedition, and one of the petty princes of Madagascar, relative to the objects of the voyage.

\section{F f 2}


Forval, however, was so entirely convinced of the good disposition of the people with whom he treated, that he yielded to the friendly solicitations of the king, to remain among them, and accordingly ordered some tents, and a small number of soldiers, to remove from the little island, to the opposite coast. The king, who was called Adrian Baba, loaded him with caresses; and having shewn him his herd of cattle, demanded, in the pride of his heart, if the King of France was so great as him.

Forval, therefore, considered himself as in a perfect state of security; and having entered into his tent, in order to pass the night, he received an unexpected visit from a most beautiful woman, a native of the island, who, after a short compliment of apology for her intrusion, expressed her concern that so fine a white man as himself should be massacred.

Forval, who was astonished at the visit, could not help taking notice of the danger which seemed to have produced it. The sooty lady, who appeared to interest herself so much in his welfare, was the daughter of a king, and known by the title of Princess Betsy. On being questioned as to the cause of this visit, she asked him in her turn, if he would wish to sacrifice her life to save his own. "By no means," exclaimed Forval : "then," replied she, "I will inform you of a plot formed against your life, if you will promise to take me with you, and make me your wife. I will sacrifice for you the throne of my father, which is my inheritance; I will abandon my country, my friends, my customs, and that liberty which is so dear to me. My relations, who will consider me as dishonoured, will detest me; and if you leave me to their vengeance, I shall be reduced to slavery, which, to me, would be a thousand times worse than death. Promise to grant what $I$ have demanded; swear that your soldiers shall do no injury to my relations, and I will reveal what it is of the utmost importance for you to know?" Forval immediately engaged to grant her request, if the intelligence she announced, proved to be of the importance she had attached to it.

"Well then," said she, "at break of day my father will come here, under the pretext of a friendly visit; and if he breaks a stick which he will hold in his hand, that will be the signal of thy death: his guard will then enter with their hatchets, and will kill thee, and all thy people will be massacred with thee!"

Forval immediately conducted her to a place of safety. Nevertheless he was determined to wait till the morning, and ascertain the truth of her information. 
The princess had also added, that the signal the king would give for his attendants to retire, would ke to throw his hat towards them.

He accordingly ordered his soldiers to remain under arms during the night, and to keep within their tents. As for himself, he got his arms in readiness, placed a couple of pistols under the covering of his table, and dosed by the side of it, with his hand on the pistols.

At length the king arrived, and soon after, having broke his stick, the guard was advancing to the front of the tent; but the king, terrified at the pistol which Forval held to his throat, cast his hat towards his attendants, who immediately departed. The small party of soldiers which Forval had with him, were now drawn up in order of battle. All the Negroes had disappeared; the king alone remained as a prisoner; nor was he enlarged, till the princess was embarked with all the equipage, and Forval felt himself happy in departing from this perfidious coast. Nor was he ungrateful: he solemnly espoused the Princess Betsy, in spite of all the remonstrances of his friends, and he lives happily with her. Her colour was certainly displeasing to the white people, and her education did not qualify her to be a companion to such a man as her husband; but her figure was fine, her air noble, and all her actions partook of the dignity of one who was born to command.

She was a real Amazon, and the dress she chose was that which has since received a similar name. She never walked out but she was followed by a slave, and armed with a small fowling-piece, which she knew how to employ with great dexterity, and would defend herself with equal courage if she were attacked. She was nimble as a deer, though stately in her demeanour; but with her husband as gentle and submissive as the most affectionate of his slaves. She behaved to her inferiors with equal dignity and kindness; and she never went to the most distant part of the island, to pay visits to her family, but on foot; she nevertheless adopted the elegancies of behaviour with great facility, and her society is very pleasant and full of vivacity.

Some years after her marriage, the Princess Betsy, for she was seldom called Madame de Forval, gave her husband a new proof of her affection.

Her father at length died, the kingdom descended to her, and her people, who were ardently attached to the blood of their kings, anxiously wished to see her on the throne of her ancestors. As soon as she was informed of this event, she requested permission of her husband to visit her country.

Though such an unexpected request astonished Forval, he did not hesitate to 
comply with it; and as she did not unfold the reason of such a desire on her part, he felt his pride mortified at her conduct, though he kept his chagrin to his own bosom, of which it was a painful inmate.

The first sentiments of Forval, respecting his princess, had been instigated by honour and gratitude: but her demeanour towards him, her conduct towards others, and her personal charms, in which her colour was forgotten, had awakened in his heart the most faithful and tender affection.

The Queen Betsy, however, departed for her kingdom as soon as she had received the permission of her own sovereign; while Forval was totally unable to reconcile the step she had taken to her former sentiments and past conduct. He accordingly waited with the utmost impatience for the return of the vessel which had taken her away; when, to his great astonishment, his faithful wife returned in it, with an hundred and fifty slaves which she had brought him. "You had the generosity," she cried, on throwing herself into his arms, "to marry me, in opposition to the wishes of your friends, and the prejudices of your country, when I had nothing to offer you but my person, whose charms, whatever they might have been considered in my own country, were calculated rather to disgust, than to please you. You will therefore add another proof of your kindness, by assuring me of your pardon, for having raised a single doubt in your mind respecting the affection and duty you so entirely deserve from me: but it was my wish to avoid informing you of the project I had conceived on my father's death, till it was executed. It was not the little kingdom which that event transferred to me, nor even the largest empire, that would separate me from you; my sole design, in the step I have just taken, was to make you an offer of a small number of my subjects, which is the only part of my inheritance that I can bestow. I have, at the same time, complied with the wishes of my people, in resigning my litule sovereignty to the most worthy of my relations.'

Such a scene may be more easily conceived than described. Thus Forval found his wife worthy of all his affection; and the present she made him, is a sort of fortune in this country. 


\section{CHAPTER VIII.}

The Letters of Baron Grant continued; containing a furtber Account of the Operations of $M$. de la Bourdonnais.

\section{LETTER VII.}

Isle of France, 2oth of November, 1746.

IF M. de la Bourdonnais had not thought proper to entrust me with the defence of this island, I should have accompanied him on his expedition. His squadron was in danger of being lost in getting out of port. When it had refitted, it met with the English fleet in India : they cannonaded each other; and it is said that the English ships could not sustain our fire, and quitted the engagement as ill treated at least as we were, although one of our ships blew up, and eighty men perished.

Our squadron continued its course to Madras, a place of great importance to the English, two of whose ships lay at anchor at the entrance of the road. Our commander sent several vessels to engage them, when they defended themselves with great courage. The cannonade was very violent on both sides; but our ships being more shattered than those of the enemy, were obliged to retire.

Our brave warriors made a descent at six leagues from Madras, and carried the place, which was submitted to pillage; though the commander confined it to the country houses. He afterwards entered the place, where, for his courteous conduct, he received very rich presents and large quantities of gold. It is said that the capture was worth eleven millions of livres. The Governor of Pondicherry (M. Dupleix) opposed this undertaking, and the two commanders became so enraged at each other, that our troops were on the point of engaging those of Pondicherry. M. Dupleix claimed the superiority, as Governor General of India; and that, as such, he had a right to command. In short, this dispute continued so long, as to cause great loss and distress to the French fleet. *

* The future detail of the operations of M. de la Bourdonnais, which will be offered to the attention of the reader, will give a very correct description of these expeditions. 
During six months of the year it is impossible to approach this coast, on account of the hurricanes, which torment these seas, and destroy every thing. The remains of our brave troops and sailors are arrived under jury masts, having sustained a loss of eight hundred men, who were drowned.

Many of the inhabitants of this island are anxious to dispose of their plantations, being persuaded, that the change which has taken place in our government, will be attended with inevitable disadvantages to them. It will indeed be very difficult to find such a Governor as M. de la Bourdonnais. Nevertheless, from the manner in which M. David, our new Governor, speaks and acts, we shall derive considerable advantages from his administration. He says that the India Company, being now assured that the island produces plenty of provisions and refreshments for their ships, will order them all to stop at this port, which will be considered as a principal magazine for their commerce; at the same time every possible encouragement will be given to promote industry and advance cultivation.

The different undertakings for raising cotton and indigo have failed. One sugar plantation has, in some degree, succeeded, whose produce resembles the coarser honey of Europe: time and industry, however, will bring it to perfection. The more wealthy adventurers are absolutely starving, by being compelled to purchase the provisions necessary for themselves and their people. They have had the inconsiderate ambition to burthen themselves with large bodies of slaves, before they had provided the means to maintain them.

Our late Governor, M. de la Bourdonnais, will leave this island to return to France, in the month of March next : I shall avail myself of that opportunity to send you this letter, in which I shall inclose a continuation of his operations.

Grant. 
A furtber Account of the Operations of $M$. de la Bourdonnais.

1744.-The intelligence that war was declared between France and England, greatly distressed M. de la Bourdonnais, as it was accompanied with precise orders from the Company, dated $14^{\text {th }}$ of April, 1744 , which, on the idea of a neutrality between the Companies of the two kingdoms, forbade him to engage in any act of hostility whatever against the English. At the same time he was instructed to defend himself in case the English should commence hostilities; and he was authorised to keep one or two vessels with him : but what could M. de la Bourdonnais do with these merchant ships against four men of war, which had been dispatched from Great Britain for the Indies? Besides, since the Company thought proper to recall the squadron which had left France under the command of M. de la Bourdonnais, the incalculable advantage of arriving first with an armed force in India, was lost, all the projects of $\mathrm{M}$. de la Bourdonnais were overturned, the superiurity of the enemy was decided, and all his apprehensions that we should be beat and taken, in every part, confirmed.

In this mortifying conjuncture, he could do nothing more than send off a vessel to inform M. Dupleix, the Governor of Pondicherry, that war was declared between France and England, and to dispatch the Fiere to France, with letters for the Company; in which he repeated his efforts to undeceive them in their hopes of a neutrality. In the mean time, till he should receive fresh orders, he was obliged to let the enemy command in these seas. He did not, however, suffer any vessel to go out of port; he redoubled his efforts to finish a ship which he had laid on the stocks, and completely repaired the Bourbon, that had arrived from the Indies.

In the mean time, M. Dupleix, in obedience to the orders of the Company, negociated with the governments of the English East India Company to conclude a treaty of neutrality. The Council of Madras, however, would not render itself responsible for the conduct of his Britannic Majesty's ships of war, as M. de la Bourdonnais had foreseen; for it could not be imagined that any agreement made between the trading companies of two hostile nations, would influence the conduct of the ships of war of their respective sovcreigns.

To prove that the French risked every thing, and that the English hazarded nothing, in these treaties, it is sufficient to observe, that the latter had ships of war as well as merchantmen in the Indian seas, while the former had only commercial vessels: 
it is evident, therefore, that the French ships belonging to the Company would be taken by the English men of war, who are not to be influenced by any engagement made by the respective companies, to maintain a neutrality between them, as individual trading establishments.

At length the error, which had been committed by the French India Company, was discovered, but, like many other errors, when it is too late; and they acknowleged the misfortune of having despised the reiterated representations of M. de la Bourdonnais. On the $5^{\text {th }}$ of April they were informed by the Fleury, which arrived from India, of the capture of the Favori. That vessel was at anchor in the road of Acbem, with an English vessel, which it would have taken, if it had not received orders to the contrary from the company. Captain Peyton, who commanded the British vessel, did not act on the same principles, but seized an opportunity, on the following day, to board and take her. This French ship, the Fleury, which had been fitted out to attack some pirates, had also found herself before Cocbin with four English vessels, laden for Moka and Gedda; all of which she might have taken, had she not been restrained by the command of her superiors. At the same time all our merchantmen were taken, except that which was commanded by $M$. de la Villebague, who, suspecting the consequences of a declaration of war, changed his course, and arrived at Pondicherry. I shall not enter into a further detail of of our losses, but content myself with relating a singular circumstance, the truth of which is too well known. When Captain Barnet, who commanded an English ship of war, captured our merchant ships, he observed, that he only executed against the French trade, the design which $M$. de la Bourdonnais had projected against that of Great Britain.

Though M. de la Bourdonnais was extremely mortified, that the decisive stroke which he had so long meditated against the enemies of France should have been rendered abortive, he was not altogether discouraged; nor did he relax in his efforts, as will hereafter appear, to repair the misfortunes of his country: on the contrary, he made the same exertions, as if he had been the cause of them.

The letters, which he received by the Fleury, not only informed him of the arrival of the English ships of war in India, but made him acquainted also with the actual situation of Pondicherry : that settlement was represented as in a state of alarm; and the council communicated to him, in very strong terms, the dangers to which their commerce was exposed in the Indian seas. They entreated him to 
afford them all the assistance in his power; informing him, at the same time, that they could do nothing more, on their part, than send him by the first opportunity the crew of the Favori.

The necessity of affording some assistance to Pondicherry, determined M. de la Bourdonnais to keep the Neptune, of forty guns, which was ready to sail for Europe, and to dispatch the Charmante thither: he also retained the Bourbon, of forty-four guns, the Insulaire, of thirty, the Favourite, of twenty-six, the Renommee, of twentysix, and the Decouverte, of eighteen guns.

At the moment when M. de la Bourdonnais had determined, if possible, to equip these vessels for actual service, he was almost destitute of every thing necessary to carry his design into execution. An extraordinary drought had occasioned an alarming scarcity in the preceding year; the harvest of the current year had been ravaged by the locusts; the St. Geran, with a large cargo of stores and provisions from Europe, had been wrecked; and another vessel, which had been dispatched to India for rice, had returned without being able to execute its commission; in short, to complete the scene of distress, there was not more than five or six months provisions in the island: nor did be find a general disposition in the inhabitants to assist him at this critical moment. But notwithstanding all these discouraging obstacles, he employed his utmost activity and exertions in forwarding an armament, which appeared to him as the only means of protecting the ships which the Company must send from France to maintain its annual commerce.

M. de la Bourdonnais exhausied all his resources to collect men to form the crews of his ships, and procure stores for their support : but his endeavours were thwarted in every quarter. The inhabitants of the Isle of Bourbon were so alarmed at the shipwreck of the St. Geran, that those who had requested to be employed on board the armed ships, now refused to expose themselves to the dangers of the sea; at the same time, that island was also in such a state of dearth, as to require every assistance which he could afford it: he was, besides, under the necessity of victualling the Triton and the Heron, which were laden with merchandize for Europe, as well as to procure subsistence for their crews till their departure : he was also obliged to furnish daily supplies for the troops, the sailors in harbour, with the workmen, and, in general, for all those who did not possess plantations.

In this difficult situation he addressed himself to the Council; and proposed, that a strict account should be taken of the provisions in the possession of the inhabitants; 
and that, after leaving sufficient for their subsistence, they should be obliged to furnish the rest, at a fixed price, for the public service. It will be readily believed such propositions excited an universal discontent: they were, however, unanimously approved, and confirmed by the Council on the 8th of January, $\mathbf{1 7 4 5}$.

1745.-In order to procure men, he required every twentieth Negro in the Isle of Bourbon, on condition of paying his master thirteen livres per month for his service, and to return two hundred piastres for every one that might die in the expedition. He also urged the necessity of employing the authority of government against those who should refuse to accede to it. This measure was also approved by the Council, and increased the number of his enemies. He was, hewever, very fortunately relieved from the necessity of carrying it into execution, by the arrival of a vessel, freighted with Negroes, from the coast of Senegal, by certain merchants of France. As M. de la Bourdonnais had been permitted by the India Company to have a share in this adventure, and had full power to act for his commercial associates, he proposed to the Council to purchase two or three hundred of these Negroes for the service of the Company. This proposition was also accepted by the Council.

At length, by his activity and persevering resolution, he had the extreme satisfaction to see his armament complete, and in May, 1745 , it was in a state to receive his orders. It was, nevertheless, a point of some difficulty to settle the manner in which it should be employed: and it was matter of serious consideration, whether he should set sail immediately with a view to make prizes, which appeared to be very practicable, as the English squadron remained in the Straits; or whether he should wait for the arrival of the Company's ships from France, in order to conduct them to India. After much deliberation he determined to adopt the latter; as it would be the wisest measure to secure the commerce of the Company, before he employed any active means to annoy its enemies.

He had no sooner formed this plan, than a frigate arrived from France, which brought him the following orders, from the Minister of Marine, dated the $2 g^{\text {th }}$ of January, ${ }^{1} 745$.

" The Company has dispatched you a frigate, named the Expedition, which will be followed by the ships hereafter mentioned.

" The Achilles, of seventy guns, and four hundred and fifty men.

"The St. Louis, of fifty guns, and two hundred and fifty men. 
" The Lys, of forty guns, and two hundred and fifty men.

"The Phénix, of forty-four guns, and two hundred and fifty men.

" The Duc D'Orleans, of thirty-six guns, and an hundred and fifty men.

"These five vessels cannot depart for the East before the end of February; they are to proceed in company to Cadiz, and from thence to the Isle of France, where it is not supposed that they will arrive before the end of August.

"The king's intention is, that you take the command of these ships, as soon as they shall arrive at your island.

"The armament of these ships has two objects; - the first, to remit the funds with which they are charged, to the treasury of Pondicherry; and the second, to cruize against the enemies of the state in those parts of the Indian sea which shall, in your opinion, promise the greatest probability of success.

"The Company has assigned an hundred thousand marcs de piastres, which it has sent, this year to the Indies, to pay, in preference, the debts which the Councils of Pondicherry and Bengal have contracted, as it has very much at heart to satify all its engagements. Besides, as the vessels which will be charged with this money will not be able to leave Cadiz before the end of March or the beginning of April, they will not arrive at Pondicherry before October, ${ }^{*}$ when the season will be too much advanced to employ these funds in consignments of merchandize for France, both from Bengal and Pondicherry, for the year 1746. The Company, therefore, has confined itself to the exportation of such merchandize as the Council of Pondicherry alone will have been able to collect, since the departure of the vessels which had been expedited for Europe in the beginning of the present year.

"In order to employ to the greatest possible advantage the ships which you are appointed to command, you must make immediate preparations to embark, with any reinforcement of soldiers and sailors. which it is in your power to collect: and if any ship belonging to the India Company should be at the Isle of France, which may prove serviceable to your expedition, you will employ it in your squadron: you may also receive on board any number of your islanders, who may offer their services on the occasion.

"It is suggested to you to set sail about the latter end of September, and that two of your ships should proceed to the Coast of Malabar, and come to an anchor off - They did not arrive at the Isle of France till the month of January, 1746. 
Mabie, to obtain intelligence from the Coast of Coromandel, and receive answers to the lctters which you had forwarded to $M$. Dupleix, by the Expedition frigate. These vessels must not remain at Mahé a moment longer than is absolutely necessary; and I am of opinion, that it would be right for you to embark in one of them, and the rest of your squadron should receive orders to wait for you at Achem. It certainly would be impolitic for you to appear with your whole squadron off the Coast of Malabar, as that would spread an alarm throughout India; so that you would not meet a single vessel on the seas.

"Your rendeżvous, therefore, will then be at Achem, according to the plan already proposed. You must accordingly repair thither towards the end of October, or the beginning of November, to take in water, wood, and refreshments: from thence you will get up to the East, in order to cruize off the mouth of the Ganges before the eighteenth of December. You may remain there, with all your ships, till the fifteenth of January; you will then detach two of your vessels, to carry to Pondicherry the two hundred thousand marcśs de piastres, that you will have on board the squadron. They will exercise all possible diligence in taking in their cargoes, in order to proceed to the Isle of France; they will then complete their lading of coffee at the Isle of Bourbon, to be enabled to double the Cape of Good Hope at a favourable season, in Company with the three vessels from China, which will, I trust, be arrived there before them. The expedition to Pondicherry cannot take place, unless you have received intelligence that there are no English ships of war on the Coast of Coromandel. You may, however, continue to cruize off the mouth of the Ganges till you shall think it right to return to Pondicherry, stretching close in shore, in order to capture such of the enemy's ships which may be at Madras, or elsewhere. You will afterwards quit Pondicherry to cruize, for some time, either in the Straits of Malacca or Sunda, and any other part of the Indian seas which will, in your opinion, promote the objects of your expedition; ordering your course, nevertheless, in such a manner, that you may return to the Isle of France in June, to careen your ships there, that they may be in a state to return to France at the end of 1746 , or the beginning of 1747 .

"But though this plan appears to me well adapted to attain the object of the expedition, I have nevertheless that confidence in your zeal and abilities, which engages me to authorize you, to make any alteration which you may think conducive to the 
general good and the interests of the Company. You will communicate to $\mathrm{M}$. Dupleix the plan which you shall adopt, as I have given him strict orders to support you by every exertion in his power.

"If two of your ships touch at Mabé, you will there receive the necessary intelligence from the Coast of Coromandel; but if you should think it more suitable to your designs to repair at once to $A c b e m$, without suffering any of your squadron to appear on the Malabar coast, M. Dupleix may dispatch the Expedition frigate to Acbem, to convey the necessary communications to you, and to settle the time when you should arrive at Pondicherry.

"If, during your cruize off the mouth of the Ganges, in the month of January, you should make any prizes laden with merchandize suited to the European market, you will dispatch them at once to the Isle of France, and give the necessary orders, either to send the prizes to France, if they should be capable of making the voyage, or to transfer their most valuable part of their cargoes on board the vessels which shall be on their return from Pondicherry.

"By the next dispatches you shall be informed of the rendezvous, which I shall arrange with M. de Maurepas, that the vessels which shall sail from the the Isle of France in April, 1746, may return to France under the convoy of the King's ships, which shall be ordered thither for that purpose.

"If, on your return from this Expedition, you are of opinion that your presence is no longer necessary in the islands, I authorize you to embark on board any vessel. that may be on its voyage to France in the beginning of the year 1747; and you will nominate, per interim, as Governor and Commandant in the Isles of France and Bourbon, those whom you shall consider as the most capable of rendering service to the Company."

$$
\text { Signed, "ORRY." }
$$

1745.-M. de la Bourdonnais now submitted his plan of operations to the consideration of the Council, and when it had received their official confirmation, he prepared to carry it into execution. As the dearth, which had for some time threatened the island, began to be very sensibly felt, he dispatched his ships to take in provisions at Madagascar, with orders to wait for him there; at the same time he kept the Bourbon, on board which he resolved to embark on the first of August, to join his squadron, in order to proceed to India, if the ships promised him from 
France did not arrive. On the 28 th of July, the Expedition frigate brought him intelligence, that the Acbilles, the St. Louis, the Pbenix, the Lys, and Duc d'Orleans, would arrive at the Island in the month of October.

In consequence of these advices, $M$. de la Bourdonnais delayed his departure for India till the month of November; and, as the monsoon would not then permit him to pass by Madagascar, where he had determined to join the ships which he had sent there to victual, he dispatched orders for them to return to the Islands, that he might avail himself of the monsoon, to conduct them to Pondicherry. But, unfortunately, the ships which he expected from France in September or October, 1745, did not arrive till January, 1746 . This delay was attended with circumstances of extreme discouragement and difficulty.

In the first place, it left him too short a space of time to complete the repairs of his ships: nor was this the greatest obstacle. An epidemical disease had carried off the greatest part of his naval artisans: he was, therefore, compelled to form a new set of workmen to supply their place, from among those whose occupations had no connection whatever with the dock-yard. He accordingly employed housecarpenters to shape the ship-timbers, locksmiths to forge nails, and tailors to make sails. Nor would it have been possible for him to have succeeded, if he had not possessed a perfect acquaintance with the science of ship-building, and made a practical application of it to the necessities of the moment: he accordingly furnished models, regulated the admeasurements, and superintended every class of workmen, with unceasing activity and attention: he sometimes even assisted them in their manual operations. In short, his knowledge and activity supplied all his wants; and at length he surmounted those difficulties, which appeared to all but himself as altogether insurmountable.

But another, and still more alarming obstacle presented itself, in a general deficiency of provisions and equipments.

The ships which composed the first armament, had consumed their provisions in waiting for the arrival of those which were expected from Europe; and the latter, having been victualled only for fourteen months, had, after their long voyage, no more than four months provisions. It was therefore absolutely necessary to revictual both squadrons.

The crews, on their arrival, were also in a very bad state; and the Acbilles. alone was equipped as a ship of war: the others were armed only as merchantmen. 
It was requisite, therefore, to add to their force, and augment their crews; and this difficult task M. de la Bourdonnais contrived to accomplish. He formed soldiers by dividing the crews into companies, and incorporating Negroes and workmen with them: he taught them the use of arms, and the practice of military evolutions. He, himself, instructed them how to scale a wall, and to use a petard. He exercised them in firing at a target; and qualified the most dexterous among them to manage a machine, which he had himself invented, to throw fire grapnel to the distance of an hundred and eighty feet, by the means of mortars. Thus he formed soldiers capable of active service; though his success would have been more complete, if the officers of his squadron had seconded his zealous and indefatigable activity: but too many of them made his conduct the subject of murmur and disapprobation. Their personal interest, indeed, was the principal cause of their discontent; as, in order to change the merchantmen into ships of war, it was absolutely necessary to disburthen them of the packages which contained the ventures allowed by the Company to the officers; so that they risqued the loss of those advantages which they had expected to derive from the sale of them in India. They loudly complained of the deceit practised by the Company respecting them, and the injury they should sustain by being deprived of those privileges, which could alone remunerate them for the hazards of such a long and dangerous voyage.

These complaints, which were made in the most public manner, caused no small uneasiness and mortification to M. de la Bourdonnais; who could not but remark, that they tended to discourage the crews, more particularly as they were now reduced to half-allowance, and in a state of continual and laborious discipline. To assuage these discontents, he employed every ingratiating attention, and urged every persuasive argument; but while he gained several to enter into his views, there still remained those who did every thing in their power to thwart his designs.

As the vessels were successively equipped, he sent them to Madagascar to subsist and collect provisions, till he could join them. At the same time, as the ships which arrived from Europe would be subject to his orders, he directed M. de St. Martin, who remained in the isles as Deputy Governor, to detain a part of these vessels in port, and to employ their equipments to arm the others. These were destined to cruize off Bombay, to take such English ships as might be returning from Gedda, Moka, and Persia; and they were further ordered, after their cruize, to make the best of their way to $M a b \dot{e}$, in the beginning of September, where they would receive. 
further directions. In short, after having done every thing that depended on him for the good of the service, he prepared to depart for the coast of Malabar, where he reckoned upon meeting, some time in May, the English ships coming from Surat. Previous to his departure, he gave the following account of his situation and designs to the Company.

\section{Letter of M. de la Bourdonnais to the Directors of the East India Company.}

Gentlemen, Isle of France, ist March, 1746 .

"I have the honour to address this letter to you, dated the 1st of March, because, it being my design to leave the islands at the end of this month, it is necessary for me to prepare my communications to you at this time: whatever may happen subsequent to this date, I will add hereafter. I have given directions to the Council and M. de St. Martin, to transmit to you the current detail of the colony; it is enough for me to give you an history of the armaments; and as my former dispatches have been lost, I shall state to you every occurrence that has taken place, since the first intelligence that war had been declared between France and Great Britain.

"On the 11 th of September, 1744, arrived the Fiere: but though the monsoon for India was over, I dispatched a small vessel on the following day, to forward your letters and orders, which fortunately arrived at $\mathrm{Mab}$.

"The shipwreck of the St. Geran being attended with great distress to this colony, I sent back the Fiere to Europe, with the hope that she would arrive there in time for you to replace, in the following year, all those effects of which we were deprived by the loss of that vessel.

"You, in a very particular manner, instructed me by your letter of the $14^{\text {th }}$ April, 1744, not to commit any act of hostility against the English in India, in the hope that a neutrality would be observed there. If, however, that should not be the case, you authorized me to fall upon them wherever they may be found, as well as to keep one or two of your ships from Europe, which might appear to be the best adapted to such an object. I had already done myself the honour to communicate to you my opinion of this pretended neutrality; that it had not taken place but within the Ganges; and that the English in Europe, who were independent of their India Company, would not observe a treaty of neutrality, whenever they had an opportunity to violate it with advantage. I was still more confirmed in my opinion, by 
the arrival of a small vessel from Surat, which brought me the intelligence that four British ships of war had sailed for India. I did not doubt but we should feel the ill consequences of such an event ; and felt, more than ever, the necessity of possessing that squadron with which I left France. If I had been permitted to retain it, I should have gained all those advantages over the English, which they have obtained over us.

"As I foresaw the necessity of arming, I hastened the construction of the ship called the Insulaire, and made every possible preparation in the harbour, to receive the ships that might arrive. The first that appeared was the Bourbon, which we thought fit to unlcad, and to arm as a ship of war; though her captain gave us some trouble on the occasion, of which you have been already informed by the letters transmitted you by the council, as well as by those which I had the honour to address you. We transferred the cargo of this ship to the Heron and the Triton.

" In the month of February following, the Charmante arrived with dispatches from M. Dupleix, by which I was informed that he had agreed upon a neutrality with Madras, and, as he hoped, with Calcutta and Bombay. We accordingly discharged this vessel also of its cargo, with which we completed those of the Heron and the Triton; but prepared a loading of coffee for it, in case we should receive an authentic assurance that the neutrality was confirmed between the two nations.

"At the end of March arrived the Neptune from Bengal, commanded by M. de la Porte-Barré, who was to quit this port on the 6th of April, to return to France; when, on the $3^{\mathrm{d}}$ of the same month, the Fleury appeared, which had been dispatched from Mabé, to acquaint me that one of the Company's ships, called the Favori, had been taken by two English men of war in the road of Acbem. The Council of Pondicherry, at the same time, pressed me to afford them all possible assistance; and requested also, that I would not suffer any India ships to quit the islands without convoy.

"This was the first moment when I had a determined object before me. As we were now in that precise situation which, according to your orders, would justify hostilities on my part, we kept the Neptune, and embarked her cargo on board the Charmante, who set sail for France the 1oth of April, and by which I had the honour to transmit you the necessary details of these islands. We proceeded to complete, with 
all possible activity, the armament of the following vessels : the Neptune, the Bourbon, the Insulaire, the Renommée, and the Elizabeth, a small vessel from Surat, which appeared to be an excellent sailer, and was retained on that account, as she might prove very useful on the look-out service. I shall not trouble you with a description of all the various expedients which we were compelled to employ, in order to arm those vessels, at a moment when the loss of the St. Geran had left us, in a great measure, without resource; and an epidemical disorder had deprived us of almost every workman or artisan in our dock-yard. Nevertheless, I exerted all my diligence and activity in some degree to supply these wants: and our armament was considerably advanced when the Favourite arrived; and by your letter, dated the 22d September, which I received by that vessel, I gained no other intelligence, than that you proposed to answer my advices by the ships which you intended to send out, with no more than the usual preparations. I understood, also, that you had permitted M. Dupleix to expedite the homeward bound ships from Pondicherry and Bengal in the same manner.

"It appeared therefore to me, that the Company had an entire reliance on a neutrality, between the two belligerent powers, in India; and I found myself in a perplexing state of incertitude: but no sooner was I informed that the English had deciared open war in India, than I determined to stop all the ships belonging to the Company, in order to reinforce their respective equipments, and to convoy, with my squadron, the merchantmen bound to Pondicherry. It was now the month of June, and we were ready to set sail; but as your ships did not arrive from France, and the crews of the squadron were consuming the provisions of the island, I ordered the whole of them, except the Bourbon and the Elizabeth, to depart for Madagascar, and wait my arrival there. The month of July was now begun; and as the season was advancing, and no ships from France had yet appeared, I felt the absolute necessity of proceeding to the Indies : I accordingly fixed my departure for the 1 st of August; when, on the 28 th of July, the Expedition frigate arrived, by which I received advices from the Comptroller-general of Marine, who announced to me the five vessels that you had dispatched, which he ordered me to fit out as armed ships, and to add them to my squadron. He also informed me, that the object of this armament was to carry an hundred thousand marcs de piastres to Pondicherry; and, having executed that service, to annoy the enemy in those seas which were distinctly specified. The Minister, also, sent out an order 
from the King, which enjoined all the captains and officers of your ships to submit themselves to my command.

"On taking a view of the existing circumstances, I determined that the squadron should sail about the end of October, which would be a proper time to visit the coast of Malabar; where, as we should not be expected, we might make some prizes: but as the monsoon would not allow of our passing to India by way of: Madagascar, I dispatched the Elizabeth, to order the ships stationed there to return to this island, and then to continue its course to Mahé to remit your pacquets, from whence she was to return hither. On the arrival of the vessels from Madagascar, I immediately furnished them with what they wanted, and sent them to Bourbon to take in provisions, with orders to remain there till the 1 oth of October; they were then to proceed to Achem; and if I did not join them there by:the 1oth of January, they were to continue their course to Pondicherry by the road of Madras, in the hope that a part of the English squadron was gone to convoy the English China ships to Europe, when they would not encounter a superior force: and, in order that they might receive an account of the state of affairs in India, I dispatched the Expedition frigate to Mahe, to obtain it there, and proceed to Achem, and if no French ship was at the latter place, to continue its course to Pondicherry.

"These dispositions being made, on the $7^{\text {th }}$ of October the Neptune arrived from India, laden with Moka coffee, and came to seek the protection of our port, as the whole English squadron, reinforced by the Favori, which had been taken, was cruising from St. David's to Pondicherry. As I had every reason to suppose that this squadron was infinitely superior to the force which I had been able to collect, I gave orders to the vessels which I sent to Bourbon, to remain there till news arrived from Europe. The extraordinary delay of the squadron from France, made me apprehend that it had met with some accident; and I perceived, with extreme regret, that the provisions destined for our voyage to India, were consuming in a state of inaction; besides, if we did not receive some assistance, every one of our ships would soon be disabled from setting a sail: I therefore assembled the Council to consider our situation; when it was resolved to send a vessel to Pondicherry, to fetch provisions, cordage, tar, \&c. and to dispatch the Favourite frigate to France, to inform you of the distressing circumstances in which we were involved. 
"As the month of December is the critical situation for ships at the Isle of Bourbon, I sent out orders for those which were stationed there, to return hither; and they accordingly arrived at the end of that month, with a stock of provisions that would not last beyond the latter part of March: nor could we indulge any sanguine hopes of procuring a further supply; for we had no great dependance on the St. Pierre, which we had sent to Madagascar for that purpose, and was not yet returned. Besides, we had no article but powder, with which we could traffic with the inhabitants of that island; and the dry season in our own, had occasioned a considerable diminution in our corn harvest. In short, our utmost efforts did not promise the necessary subsistence for our people beyond the month of March. Such was our melancholy situation, when the first ship of the squadron from France appeared on the 28 th of January; and, on the 1 st of February, the whole of them arrived safe at anchor in this harbour.

"The first thing which naturally recurred to my reflection on this occasion, was the use I should make of this force, conformably to the season, the monsoons, and the orders which I had received. I had two courses to pursue; that of quiting the isles on the 1 st of March, and proceeding to India, so that I might reach Ceylon at the end of April or the beginning of May, where I might meet the English merchant ships from Surat; though it appeared to me to be impossible to unload and arm this squadron, as it required for this voyage, in the space of a month. Besides, I was fearful of remaining at sea for three months, with ships and crews who were just arrived from a voyage of nine months and upwards. The other course was, to pass to India by the north of Madagascar, which is one half shorter, with the advantage of taking in live stock, \&c. and the monsoon changes in March. All these reasons determined me to pursue the second; and I perceived it to be indispensable, the moment I reflected on the small quantity of provisions which was brought by these vessels from Europe, and which they were obliged to share with those they found here. In this distressed situation I issued orders, that the ships' companies should not touch the stock of their respective vessels; and I undertook, in some way or other, to subsist them from the island. But it was not the enemies of my country that I feared; nor the obstacles which were threatened by a scarcity of provisions, that alarmed me. I trusted that we might be able to contend with the one, and remedy the other: but $\mathbf{I}$ did not perceive a zeal for the service so prevalent as $I$ could wish, and had a right to expect, from men, who were bound by every tie of: 
honour, gratitude, and duty, to the Company. At length, I thought it necessary to explain the powers with which I was invested; and after having employed all the means of mild, but urgent persuasions, I found myself obliged to threaten the employment of force, to such as still continued to thwart the plans which. had been formed for the protection and defence of your commerce in India.

"Such is my situation, which will prevent me from undertaking any cruize; as. the utmost I can perform, will be to go directly for Pondicherry. Nor can I be insensible to the expectations which will be formed from my apparent force, and the impossibility, from its real state, of being able to gratify them. Besides, the anxiety I have suffered, the labour I have undergone, and the privations I have sustained, have greatly injured my health, and I have been a victim to the scurvy. But: neither the ill state of my health, nor the discouragements which have so long vexed and still continue to harass me, shall cause my zeal to slacken in the service of the Company, or lessen my sense of the honour which has been conferred upon me, by the appointment of the King, to command the naval service in the Indian seas. I well know the enemies which this confidence has procured me, and am aware of: the animosity which will be exercised against me. I am not ignorant that my administration in the islands has been the subject of severe animadversion: but that intelligence does not disturb my tranquillity. I am ready to meet my foes, and shall present myself to their accusations without fear : and with respect to the fortune I possess, I have no cause to blush at the means I employed to attain it. I am ready to deliver up my books, examined as they have been by the Council, year after year, into the hands of my enemies, and subject them to their malicious scrutiny. They will find in them an honest detail of my commercial concerns, and the origin of my fortune; but they will never be able to discover that the interests of the Company have been sacrificed to my own. I depart, therefore, under all the disadvantages which surround me, with the ardent hope, that I shall revenge myself of my: enemies by some signal service to my country, which will impose silence on them; and it will not be my fault if that hope is not gratified.

"In truth, the crews which you have sent me, are very unfit for the requisite service, and it is dire necessity alone that compels me to employ them. All the vessels which I command here, except the Acbilles, are incapable of carrying: a lower tier of guns; and I must content myself with placing twelve pounders on their decks. 
"The strength of the enemy, not including a ship of seventy guns, which is now on its way to join them, is as follows :

Two ships of sixty guns.

One ditto of fifty.

One ditto of twenty-four.

One ditto of thirty-six.

Two privateers of fifty guns, which took the St. Benoit.

Two ditto, which have certainly been dispatched from England to carry supplies of provisions and seamen.-In all, ten vessels.

" These, according to every appearance, will prove much stronger than us; but what does that signify? hunger will compel us to fight them with eight such ships, and so indifferently equipped, as ours. It is not arms or powder that we want, but men. I have therefore been obliged to augment the ships' crews with blacks, half of which belong to the Company, and the other I have been compelled to hire. I have also distributed the employments necessary for the good order, discipline, and accomodation of the squadron, to those whom $I$ believe to be the most capable of executing them with honour to themselves, and advantage to the service.

"I have made my arrangements to set sail about the end of March. After a short stay at Bourbon, I shall join the greater part of my squadron at the island of St. Mary, where I have sent them, in order to get fresh meat, as well as to relieve the colony, which_is in a very deplorable state. If I had not received authentic information of the force of the enemy, and consequently felt the necessity of making every possible exertion to augment our own, I should not have stripped it as I have done. I may surely deserve credit in this assertion, since I abandon my wife and my children: but there is no alternative. I have indeed every reason to believe that ships will soon arrive from Europe, and $I$ bave left orders to detain them for the safety and supply of the island.

"My plan on leaving the Isle of France, is as follows:

"I I shall use every effort to arrive off the coast of Malabar towards the tenth of May, in order to intercept the English vessels coming from Surat; which is the only success I have any reason to expect during the course of the present campaign. I propose to touch at $M a b \dot{e}$, in order to obtain intelligence of the enemy, who, as there was no French ship in India, in the course of last year, will naturally conjecture that some will be sent out from France, for the service of the present 
season, and we shall certainly meet them between Karical and Fort St. David. We shall then see who will remain masters of the coast. As I am in hope that I shall beat them, I shall then distribute our ships on various cruising services off Fort.St. David, Madras; and the Point des Palmiers, to the entrance of the Ganges; and on the presumption that we shall prove victoriou's, I have left orders here to dispatch, in July, all the ships which. shall have arrived from Europe, to cruise off Bombay: we shall thus embrace the whole coast, make an advantageous voyage, and, at the same time, be furnished with plenty of provisions from Pondicherry.: If fortune favours us, I shall return with all speed to the Isle of France, with what I may have taken in the Indies, and, having loaded our ships with coffee, return to give an account of my conduct; which, whatever may be the event of it, will not, I am confident, produce either shame or dishonour to me.

"I should rejoice at the arrival of the China ships before my departure for India. If I had a sufficient stock of provisions, I would fit out the Duc d'Orleans to go with them, but I shall now take her with me, in order to send her back as soon as possible, laden with supplies for the islands.

$$
\text { Signed, "MAHE' DE LA BOURDONNAIS。" }
$$

Isle of France, $2 \mathrm{~d}$ March, 1746.

" P. S. An express vessel from Bengal has just arrived in this port, by which I am informed, that the ship Cbarles, belonging to my brother, the Dupleix, and the Heureux, have been taken by the English squadron, which is very ill manned; and that notwithstanding its situation, the English have sent twenty merchantmen from Bengal. This intelligence has quickened my operations, and I propose to set sail the $23^{\mathrm{d}}$ of this month. As I have not time to complete all my dispatches, I shall transmit to the Comptroller-general, a copy of my instructions to M. de St. Martin, and request him to communicate them to you. With the blessing of God, I shall soon repair the losses which we have sustained.

$$
\text { Signed, "DE LA BOURDONNAIS." }
$$

M. de la Bourdonnais set sail from the Isle of France on the 24th of March, 1746 , his squadron being victualled only for sixty-five days.

On his arrival at Madagascar, he wrote to M. de St. Martin, Deputy Governor of the Isle of France, the following letter. 
- Sir,

Isle Marotte, on the Coast of Madagasear, 5 th May, 1746 .

" On my departure from the Isle of France, I proceeded to Bourbon, which I left on the $2 g^{\text {th }}$ of March. On the $4^{\text {th }}$ of April I arrived at Foule-pointe, in Madagascar, where the Parfaite waited for me. I was immediately informed that she had purchased about eighty milliers of rice, but no bullocks. M. Brusse came on board to acquaint me that the St. Pierre was lost on the coast, with five hundred milliers of rice, and eighty Negroes; and that the captain and a very few of the ships' company were the only persons who were saved. As the whole crew of the Parfaite were either sick or dead, I sent some people on board her to bring her up to us; and at the same time I ordered the Sieur le Riche to pass to Manivoul, to tell the Renommée, who was engaged in traffic there, to join us. As I had come to an anchor in a very critical moment, I ordered all the ships of the squadron to get under way at two o'clock, and to set every sail. The wind now increased, and the sea had a most terrible appearance, so that at eight o'clock we were under our courses, and doubtful whether we should be able to weather the Isle of Saint Mary. At ten o'clock, the Lys made a signal of distress: its fore mast was split as well as its bowsprit. In half an hour afterwards, our ship pitched in such a manner, that our fore mast broke off about twenty feet above the deck: soon after the main-top-mast fell; in a short time after, our mizen mast shared the same fate; and the bowsprit was broken: in short, the ship rolled so violently, and there was so much water in the hold, that towards eleven o'clock I gave up every thing for lost. However, by throwing over whatever could be moved, the vessel was consequently lightened, and towards the morning the water appeared to diminish in the hold; the storm also began to subside, and in a few hours we were out of danger. The only ship that remained in company with us was the Lys; but we saw the Neptune to leeward, with only two masts.

"In this deplorable state, we sometimes put to windward to endeavour to reach land, which was the Island of St. Mary, but we were at a great distance: and on the following day we found ourselves fortunately at the entrance of the Bay of Antongil, from whence I dispatched a pirogue, which I had taken at Bourbon, to go to St. Mary's, to tell the vessels which were there to join me at the Isle Marotte, where I anchored at ten at night, with the Lys. The Duc d'Orleans, which had not anchored at Foule-pointe, no more than the ship Neptune from France, arrived on the 11 th, with its bowsprit broken, and the other ships in succession. 
"I must now revert to the $9^{\text {th }}$ of April, the day when I landed on the Isle Marotte, to give you a brief detail of the circumstances connected with it.

" My first care was to prepare a place to receive the troops, a workshop of a sufficient size for shaping masts, and a rope yard. I therefore dispatched M. de Rostaing, with M. M. Sornay, Cere, and la Baume, to the main island, in search of wood fit for masts and yards. Their report was, that they had not been able to discover any pieces of wood from more than forty-five to fifty feet in length, but that the natives had assured them, that in advancing further up the country, they would find them from eighty to ninety feet, and upwards. With this expectation they returned up the river on the 12 th, with a body of carpenters and Negroes, in search of these trees, which they at length found and felled. I departed on the $1 \mathrm{gth}^{\mathrm{th}}$ with five hundred men to join the party, and to see myself the pieces which could be obtained. In effect, they appeared to be very fine trees; but I observed at the same time, with great concern, the almost insuperable difficulty of making roads in such deep marshes. It was however absolutely necessary to make the trial; and with wood and reeds this extraordinary labour was so far accomplished, that, on the $24^{\text {th }}$, we drew along the first piece of fifty feet. When this experiment had been made, I left a sufficient number of workmen with $M$. de Rostaing, to cut wood necessary for yards, with one large piece to mend the bowsprit, and returned on board.

"On my arrival I assembled a council, and after having received the opinion of every member of it in writing, I determined to take the principal masts, \&c. of the Bourbon, with one of the Lys, which I should leave here to be re-masted, with such pieces as we could procure from the country; or, after all, with the masts of the Neptune from India, if she were brought back, and immediately return to the Isle of France.

"When I had determined on this measure, I gave orders to all the vessels to advance as much as possible the changes that were to take place in the masts. I pushed forward this work with such vigour, that, in spite of all the obstacles I had to encounter, in the discontent of some, and the indifference of others, I at length attained my object. Here, as in the Isle of. France, I had, at each moment, new difficulties, and was obliged to attend night and day to the different workmen and artisans employed in the various operations; but heaven afforded me strength to bear it all; and amidst the fatigues I underwent, both in body and mind, I was so fortunate as to preserve my health without interruption. 
"The Insulaire arrived from the Point de Lare on the 28 th, with no more than fourscore bullocks; but as this provision was not by any means sufficient, I ordered her instantly to return and renew her traffic. On the $2 \mathrm{~d}$ of May she set sail, when the Parfaite returned with all the masts, rigging, and furniture of the Neptune, as well as the crew and passengers. I was also informed by M. Desjardins, that Bétandre* bad offered to provide us, at Manahar, with any quantity of bullocks and rice we might require. I made a signal therefore to the Insulaire to come to an anchor, and then ordered her to change her course for Manahar.

" It is a frequent and very just observation, that misfortune is sometimes a blessing in disguise; for it is certain, if the Neptune had not been lost, we should have been detained here for a long time, notwithstanding all my exertions. I should have been compelled to leave the Lys here, and to abandon the only ship which had remained with us in our distress; but the wreck of the Neptune has furnished us with the means of refitting her with masts and rigging, and putting her in a condition to follow the squadron. The surplus of cordage was serviceable to the Acbilles, as well as that which was made here by our ropemakers. At length I succeeded, by various means, and unremitting efforts, in putting the ships in as good condition as they were before the storm; and I hope in a few days to weigh anchor and proceed to the Indies. I propose to sail from hence on the 20 h, without fail.

"I dispatch the Parfaite to inform you of all these circumstances, and to acquaint you at the same time with the loss of two ships from India, the St. Pierre and the Neptune, in order that you may make such arrangements as you may judge necessary to remedy that misfortune.

"That which I have sustained, has made me lose the advantage which I should otherwise have had over the English ships, on their return from Surat to Europe, if I had arrived in India at the time I proposed; but I trust that I shall yet be in time to meet the ships of war of that nation.

" It is necessary also to inform you, that I was very much alarmed lest our blacks should desert during our stay at Madagascar. The manner of treating them on board the squadron is by no means harsh, so that we have lost but thirty by desertion; and by a bribe of gunpowder to the chief of Manahar, several of them have been restored to us.

"I must beg of you not to make any change in the arrangements I settled with

- One of the petty sovereigns of the country. 
you, to be informed of the arrival of any vessels from Europe at the isles, and the intelligence they bring you. Notwithstanding the length of time $I$ have remained at Madagascar, I shall always be within reach of your dispatches at the time and place which have been agreed upon between us. The measures that have been taken, respecting the destination of the ships for Europe, still subsist, and you will act in conformity to them. If, however, you cannot conveniently dispatch the Parfaite, employ some other vessel to impart to me any intelligence that you may receive; besides, you may rest assured that, in the month of September, I will expedite a vessel laden with provisions for the isles.

" I had promised, as I mentioned to you in my dispatch from St. Paul, the captain of the Portuguese vessel, to send the Neptune to Bourbon, to conduct his ship to the Isle of France; but the loss of the Neptune has unfortunately freed me from that engagement; nevertheless I beg of you to shew all possible regard to the captain, and to give him all the assistance in your power. It is absolutely necessary to afford every supply that your circumstances will admit, to his necessitous vessel, as I shall myself be obliged to have recourse to the Portuguese for many essential articles, which I can alone obtain at Goa,"

On quitting the Bay of Antongil, M. de la Bourdonnais had still nine vessels, with three thousand three hundred and forty-two men, comprising seven hundred and twenty blacks, and three or four hundred sick.

In passing before Mabé, he sent the Insulaire to get intelligence, and gave her the Isle of Ceylon for a rendezvous; where he afterwards learned that the English squadron was in expectation of meeting him.

M. de la Bourdonnais, at length, had the satisfaction to discover throughout the squadron, a general ardour to engage the English. He accordingly ordered the captains on board his ship, when it was determined, if they should have the wind of the enemy, to proceed, without any previous attack, to board at once. In short, on the 6th of July, on the Coast of Coromandel, the English squadron was discovered with the wind in their favour, and coming on with full sail. M. de la Bourdonnais ordered his ships to form a line, and wait for them : at noon the two squadrons were about two leagues distant from each other, and at half past four the engagement commenced.

The English force consisted of one ship of sixty-four guns, two of fifty-six, one of 
fifty, one of forty, and one of twenty guns. That of the French was composed of one ship of sixty guns, one of thirty-six, three of thirty-four, one of thirty, two of twentyeight, and one of twenty-six. The English ships were mounted with twenty-four pounders; while on our side the Achilles alone had eighteen pounders; and the rest were armed only with twelve and eight pounders. The combat soon became very violent, and the ship of $\mathrm{M}$. de la Bourdonnais sustained, during a quarter of an hour, the whole fire of the enemy. At length, dispirited by the powerful resistance of the French, at half past seven the English retired, and M. de la Bourdonnais passed the night in making preparations for renewing the action. On the next day, the wind remaining in the same quarter, he was obliged to wait for the enemy through the whole of it; but, as they had the advantage of the wind, they did not return to the conflict; nor could the French squadron, from the number of its sick and wounded, as well as the want of provisions, engage in the pursuit of them: it therefore made for Pondicherry, where it arrived in the evening of the 8 th of July, 1746.

The knowledge of India is absolutely essential for the due understanding of the subsequent events. The navigators, who frequently differ from the geographers, comprehend as India, that part of the globe which lies between the Cape of Good Hope and Japan, containing three or four times as much sea coast as Europe possesses from Lapland to Constantinople.

This vast continent comprehends from seven to eight thousand leagues of coast, and is occupied by a great number of sovereign princes, as well as the colonies of several European nations. I shall, however, pass by the settlements of the Portuguese and the Dutch, and confine myself to those of the English and the French. The former possess eight or ten establishments, distributed under the three principal governments of Calcutta, Madras, and Bombay, which are distant five or six hundred leagues from each other. France has also certain establishments, which form two principal governments, independent of each other: the one is Pondicherry, and the other the Isles of France and Bourbon.

The former of these comprehends the town of Pondicherry, where the Governor and supreme council reside; the three factories of Mahé on the coast of Malabar, of Karikal on the Coast of Coromandel, and Chandernagore on the Bengal river, are subject to it. This government contains in the whole about a league of coast, of seven or eight thousand of which India is composed. Such is the extent of the command intrusted to M. Dupleix. 
The government of the isles comprehends that of France, which is about forty leagues in circumference; and that of Bourbon, which is about the same extent. They have each of them a supreme council, similar to that of Pondicherry, and M. de la Bourdonnais presides over them both, in quality of Governor-general. These three councils, as well as the respective governors, are independent of each other.

In whatever manner these colonies were first established, whether by force of arms, or conventions formed with the sovereigns of the country; it is certain that they can subsist no longer than while they maintain a friendly intelligence with the nations on whose territories they are settled.

It is not less necessary to mention the nature of the monsoons, whose changes, which are well known to seamen, determine all the voyages and maritime enterprises that are undertaken in India. They are regular winds, which blow six months one way, and six months the other: their change takes place either a month before, or a month after, the equinox; and is announced by some remarkable variations, or a complete calm: they sometimes declare themselves by a violent gale. It is evident, therefore, that every season does not allow of navigating certain parts of the Indian seas; and that the navigation is practicable at one time, and impossible at another,

For example: On the Coast of Coromandel, on which Madras and Pondicherry

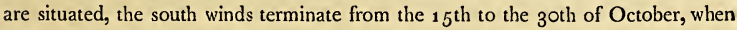
they are succeeded by those which blow from the north : it is necessary, therefore,

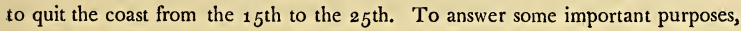
ships may risk wintering on the coast; as in the Indies, as well as elsewhere, the winters are sometimes calm, and at other times boisterous.

In the year $1741, M$. Dumas and $M$. de la Bourdonnais, with their respective squadrons, remained on the coast till the $22 \mathrm{~d}$ of October, without experiencing a gale of wind. In 1746 , the squadron of $M$. de la Bourdonnais suffered very severely from a violent gale. In 1747 and 1748 , the English squadrons remained on the coast, without suffering from the winds during the winter; and on the $24^{\text {th }}$ of April, 1749, there was on the same coast such a furious hurricane, that fifty or sixty vessels of different nations perished. It appears, therefore, to be an act of prudence, to quit the coast between the $15^{\text {th }}$ and 20 th of October.

The orders which $\mathrm{M}$. de la Bourdonnais had received, respecting the operations 
of the war, have already been detailed; but though they were, in a great measure, left to his discretion, they were subject to a verbal order, which the minister himself had personally given to him at the moment of his leaving France, "to make no attempt on the British settlements in India, but with a certainty of success, as it was the principal object of the Company to remain on the defensive, rather than engage in any active enterprizes against the enemy's settlements."

The secret orders which were given to $M$. de la Bourdonnais, in case he should make any conquests in India, were conceived in the following terms.

" Secret pacquet for M. de la Bourdonnais, which is not to be opened, unless war is declared between France and the maritime nations of Europe, and he has certain advices of it, or has experienced some act of hostility on their part."

"If the peace continues to subsist, he will bring back this pacquet without having opened it.

$$
\text { Signed, "ORRY." }
$$

"Instructions for M. de la Bourdonnais, Governor of the Isles of France and Bourbon, to which he is enjoined to conform his conduct, with the utmost exactitude.

"It is expressly forbidden for M. de la Bourdonnais, Governor of the Isles of France and Bourbon, to take any settlement or factory belonging to the enemy, with a view to keep possession of it.

$$
\text { Signed, }
$$

"OrRy."

This order, as will be seen hereafter, is of the last importance. We shall now proceed to give an account of the successive events which followed the arrival of the squadron at Pondicherry.

Without entering into a detail of the conduct of M. Dupleix, it may be necessary to observe, that his proceedings were not calculated to promote harmony between the garrison of Pondicherry and the troops belonging to the isles. M. de la Bourdonnais, however, contrived to preserve tranquillity; and applied himself to the arrangement of a plan of operations, which he communicated to M. Dupleix in the following letter. 
"Sir,

Pondicherry, 17 th July, 1746 .

"You are already informed, that I received orders from the Minister to arm five vessels coming from Europe, and to add to them all such as I could collect at the isles.

"In consequence of the intelligence which you communicated to me, of the first hostilities of the English, and in conformity to the orders of the Company, I detained the Bourbon and the Neptune; which, with the Insulaire and Renommée, altogether composed a squadron of nine ships. As you well know, it had three objects to accomplish.

"First; to convey to Pondicherry the funds of the Company.

"Secondly; to endeavour to destroy the enemy, in every way the most honourable to the nation, without forgetting the interests of the Company.

" Thirdly; to return with my squadron, laden with whatever merchandize you may have in a state of readiness for that purpose; and of all the coffee that I can collect at the isles.

"In order to fulfil these objects, I sailed from the isles on the $24^{\text {th }}$ of last March, in order to arrive in May on the Malabar coast, in the expectation of taking the Surat ships : but that hope was soon dissipated by a violent hurricane, in which I was on the very verge of destruction. After I had refitted my damaged ships as well as it was in my power, I continued my course to the Coast of Malabar. I ordered the Insulaire to touch at Mahé to get intelligence; when she brought me your letters announcing the union of all the English forces, consisting of one ship of sixty-four, one of fifty-four, two of fifty, one of forty, and one of twenty guns.

" Effectively on the 6th of July I met this squadron off the Coast of Coromandel, and after a very active engagement of three hours and an half, in which the enemy had the wind, the night separated us.

"The English squadron lay to during the night, and we did the same: in the morning we saw it to windward, coming down upon us, and I calmly waited the attack; but either from a want of wind or inclination, it never came within reach of our cannon.

"At four in the afternoon it lay to, and I followed the example. In short, the fear of missing Pondicherry; the specie I had to land there; and, above all, the want $\mathrm{K} \mathrm{k}$ 
of provisions, which, on board several of our ships, were within twenty-four hours of being consumed, convinced me of the alarming situation in which I should be, if I got to leeward of that port.

"I determined, therefore, to continue my course to Pondicherry, and I anchored in your road on the $g^{t h}$, when I remitted to you the funds of the Company:-thus was my first object accomplished.

"Before I enter upon a consideration of the second, I shall observe, that there is no apparent obstacle for the completion of the third, as you have engaged to furnish me with three cargoes, and I shall load the rest with coffee: the only difficulty appears to be in procuring provisions, as they are absolutely necessary for the ships on their passage from hence to the isles, and from the isles to Europe. I am commanded to address myself to you for the necessary supplies, and I request you to pay the utmost attention to them. I shall only occupy myself, at present, about what I think will be most useful to the Company, and honourable to the nation; but I shall not undertake any enterprize, without having consulted with you respecting our situation, and that of our enemies.

"The English squadron has not appeared since the engagement; and it is generally reported that, two of its ships having been very severely handled, it had put into the Bay of Trinquemalé, in the Island of Ceylon, in order to be repaired by the assistance of the Dutch : perhaps it will wait there for reinforcements from Bombay or from Europe.

"The English have, effectively, no other measure to pursue than to augment their squadron, in which consists their whole strength: if that were destroyed, we should be in a situation to attack their principal colonies.

"You well know, Sir, that since the year 1741, I had formed a design on Madras; having been encouraged by M. Dumas, to whom I had communicated my project: I also discovered it to you, when you came to take possession of your government, and you manifested your approbation of it, by making those preparations which a continuance of the peace rendered fruitless. As war is now declared, and $\mathbf{I}$ persist in my design, I have imparted it to you, entreating you to add to your former preparations, whatever may now tend to facilitate the success of it; nor can any thing be more certain than that conquest, if we should be able previously to destroy the naval force of the enemy: its destruction, therefore, is an indispensable preliminary, and must be attempted; for it would be absolutely dishonourable 
to leave three thousand men, capable of doing so much, in a state of inglorious inactivity.

"To employ the time in cruizes would be absolutely fruitless, because all the merchants' ships will remain in port; it would be also necessary to cruise with the whole squadron, lest we should be beat in detail : my object is to destroy, or disperse, if it be possible, the English squadron; and the capture of Madras would be the certain and immediate consequence of such an event. You have already informed me that it could be done, and without any reason to apprehend danger from the Moors.

"To succeed in this last point, it is necessary to conceal our design in such a manner, that none of the preparations may appear.

"In the first place, we must depend upon our weight of metal, as we cannot justify the hope of being able to board them : their ships are generally better sailers than ours, and those who conduct them are more skilful in manœuvering than we are. I therefore demand a supply of cannon, which will, at least, enable us to attack the enemy with equal force; and as it is absolutely necessary, to attain this very principal object of my duty, I demand it in the name of the King and the Company.

" My ships being thus armed, and furnished with proportionable stores and ammunition, all the forces which you can spare me, for the Madras expedition, must be embarked; but without discovering the objects of it. Thus provided, we will set sail in search of the English squadron : if we are so fortunate as to find and to beat it, we cannot hesitate as to what is to follow. I shall send you a vessel with all the wounded, and a requisition to assist me in a pretended descent to the south. You will then order the sepoys to be embarked, and every thing which you may think necessary for the expedition; and within two days after they shall be stationed in the road, I will pass before Pondicherry, and take them to about five leagues to the windward of Madras, from whence I will land my troops in the course of the night, who, by the break of day shall have invested the place; and, at the same time two armed ships shall seize on all the vessels at anchor off it: they will also cannonade and alarm the English, while I disembark the remainder of the troops destined to this expedition; and in three or four days the object will be attained.

"If I do not find the enemy's squadron in a place where I can bring it to an enagement, as it may have retired into some Dutch port, I will dispatch the ship as I have $\mathrm{K} \mathrm{k} 2$ 
already proposed, and we will proceed to carry our plan into execution before the enemy can be in a condition to prevent us. If fortune favours us, what ought we to do with Madras? My opinion is, to possess ourselves of whatever merchandize we shall find, embark it on board our vessels, and receive a ransom for the rest. For if we were to destroy the town, in the course of a year it would be rebuilt with additional strength. Let us be content with pillaging the inhabitants of Malabar, and the Armenians.

"I submit this plan, and the opinions on which it is founded, to your consideration. I hope to be favoured with your councils, and satisfactory answers to the different requisitions I have transmitted to you for stores, ammunition, \&c. on the attainment of which the success of my proposed enterprize will depend, \&c.

Signed,

"MAHé de La Bourdonnais.", 


\section{CHAPTER IX.}

\section{The Account of the Operations of $M$. de la Bourdonnais continued.}

$T_{\mathrm{HE}}$ requisitions made by $\mathrm{M}$. de la Bourdonnais, to $\mathrm{M}$. Dupleix, Governor of Pondicherry, for heavy cannon and proportionable ammunition, have been stated in the letter addressed by the former to the latter; but, instead of complying with them, M. Dupleix sent the following answer. "The prevailing idea is, that the actual force of the enemy will be strengthened, either from Bombay or from Europe; and if that opinion should be verified, you may be obliged to take refuge under this place; and what protection will it be able to afford you, if it should be dismantled of its heavy artillery?"

M. de la Bourdonnais, therefore, was obliged to set sail on the $4^{\text {th }}$ of August, without the artillery which he had requested, and a very inadequate proportion of military stores. The water with which the ships of the squadron had been furnished was so bad, as to produce the flux among the crews. M. de la Bourdonnais was very much afflicted with this debilitating malady; but his resolution appeared to surmount that, and every other obstacle; and he was impelled by no other impulse, than to destroy the English squadron, or render it incapable of future service. The wind was so contrary, that he employed thirteen days in getting to Negapatam; and as he was engaged in negociating with the Dutch respecting the surrender of a French prize, which had been bought of the English contrary to the faith of treaties, he was informed that six English vessels appeared to windward of that place: he accordingly returned in great haste to his ship, and found his squadron ready to weigh anchor, having first hoisted the Dutch flag, in order to deceive the enemy. In a short time the whole was under sail, and directing their course towards the English; but they were not the dupes of the Dutch colours; and availing themselves of the wind, soon put about. M. de la Bourdonnais pursued them through the whole day: and as it is necessary in these seas to bring up during the night, in order to wait for the land breeze, he hoped, on the following day, to surprize them 
at anchor; but they cut their cables, and the wind suddenly changing in their favour, they escaped a second time, and quitted the coast.

The time was then too precious to consume it in an unpromising pursuit; $\mathrm{M}$. de la Bourdonnais, therefore, returned to Pondicherry, where he came to an anchor on the twenty-third. As he was still weak, from the illness with which he was afflicted, so that he could not immediately disembark, he wrote to M. Dupleix, to propose, among other things, to leave his squadron under the cannon of Pondicherry, and proceed to besiege Madras by land. But in the conference which they held on the following day, so many difficulties suggested themselves, that it appeared to be impossible to carry that design into execution. On the other hand, M. de la Bourdonnais could not but be sensible, that, by conducting the squadron to Madras, the whole might be endangered, as the English ships might attack it with irresistible advantage, at the moment when the half of his troops and ships' companies would be engaged in besieging Madras by land. In short, the same reasons which had suggested the opinion that the English squadron must be destroyed, as a preliminary to the siege of Madras on the 2 oth of July, subsisted in all their force on the $23 \mathrm{~d}$ of August ; but the enemy's force, instead of being destroyed, was actually reinforced by two vessels from Europe, and the same number from Bombay.

M. de la Bourdonnais therefore, with all his zeal, would not take such an hazardous enterprize upon himself : besides, the orders of the Minister expressly signified, that no attempt whatever was to be made on any English settlement in India, but with the most encouraging prospect of success.

However, that nothing might appear like backwardness or disinclination on his part, to do whatever could be done for the service of the Company, and the honour of his country, he stated his sentiments in a letter to M. Dupleix, which he requested might be communicated to the Supreme Council of Pondicherry. It concluded in the following manner :

" $A$ fter a very serious deliberation, you resolved that it would be advantageous to the Company to make an attack on Madras, and I am ready to undertake it : nor shall the disorder with which I have been afflicted for a month past, deter me, whatever my sufferings may be. But this is a business of too delicate a nature for me to take upon myself; it is sufficient that I undertake to execute it, if it is commanded by others: I wait, therefore, for the deliberation of the Supreme Council; 
for without their formal declaration, that the siege of Madras is requisite for the interests of the Company, and the honour of the French flag, I will not undertake it."

The Council of Pondicherry returned an answer on the same day, the 26 th of August; in which, among other things, it was observed, that as they had not received any instruction either from the Minister or the Company, respecting the squadron, they could not take upon them to decide upon its operations, or offer any advice on the subject. They indeed suggested, that he ought either to besiege Madras, or attack the enemy's naval force; and added, that it would be very humiliating, and even disgraceful, if he did not do one or the other.

It is very evident that the Council of Pondicherry wished to increase the difficulties in which M. de la Bourdonnais was involved; and, however extraordinary it may appear, on the following day they called upon him, in the most formal manner, to adopt one or other of the measures which had been proposed to him, and declared him to be individually responsible for the consequences.

M. de la Bourdonnais could not be insensible to the insulting message of the Council, and he answered it in the following manner:

"I consulted the Council on the proposed attack of Madras, and on no other subject; and it depends on the Council, whether or no I shall engage in that enterprize. As to the destination of my squadron, that is not within the sphere of its commands. I well know what my duty requires of me, and my orders are already given to put to sea this evening.

Pondicherry, 27th August, 1746.

Signed, "MAHE' de La Bourdonnars."

Thus discouraged by these proceedings, and almost overcome by the violence of his disorder, he resolved, as he was not in a condition to sail himself, to send his ships to the road of Madras. His object was not only to seize the English vessels, which were then taking on board the valuable effects which the inhabitants of Madras were anxious to save, but also to obtain intelligence of the designs of the enemy: strange, however, as it may appear, at the very moment when M. Dupleix was informed of this design, he re-demanded of M. de la Bourdonnais the troops with which he had furnished him, on the pretext, that he could not thus weaken his garrison, without leaving the place in danger.

Very strong remonstrances were made to M. Dupleix on his conduct, but 
without the desired effect. When, therefore, M. de la Bourdonnais perceived that M. Dupleix was intirely influenced by passion, he sent back the troops, with a letter, which concluded in the following manner :

"I cannot give a more decided proof of my resolution to submit to controuling circumstances, than by resisting fifteen hours fever, giving orders to a squadron, and answering three such letters as yours, in one day : nor shall I forget to add, the lively emotions which the treatment I have received must necessarily excite."

The same day the squadron set sail, and left M. de la Bourdonnais in a condition which made it doubtful, whether he would live to see it again. His health, however, was soon re-established; and on the $5^{\text {th }}$ of September his squadron returned with two small prizes, estimated at two hundred thousand livres. This trifling success evidently proved, how little was to be expected from any enterprize which was not conducted by $\mathrm{M}$. de la Bourdonnais.

As he now had every reason to believe that his motions were not watched by the English squadron, he directed his whole attention to the preparations necessary for the siege of Madras: but at this moment, the Council of Pondicherry gave additional proofs of that counteracting spirit which animated them against him. In fact, they had spread reports of his maintaining an intelligence with the English, and that he had received a bribe of twenty thousand pagodas to forego the intended attack upon Madras. Nay, the various clauses of this imaginary treaty were circumstantially detailed, by his enemies. These malignant rumours, however, immediately subsided, when the necessary stores, \&c. for the siege, were embarked on board the squadron.

As he was too well acquainted with the characters of those with whom he was necessarily connected, he employed every possible precaution to check unfavourable suggestions concerning his conduct; and though he had appointed a Commissary for the squadron, he requested M. Dupleix also to name one from Pondicherry, that they might conjointly attend to the interests of the Company. M. Dupleix accordingly appointed M. Desprémesnil, his son-in-law, to be second Commissary. M. de la Bourdonnais also requested $M$. Dupleix to inform him, what conditions he should impose on the English, if they should express a desire to pay a sum of money to save Madras from bombardment. To this requisition he received the following answer :

"If the English should propose to buy off the bombardment of their town, and the attack of it by land, you should reclaim the ship Iman Sabeb, taken under its 
flag; the two French ships taken in the road of Belassor; the Favori, taken in the road of Achem; the vessel from Pondicherry, which was sunk; and a million of pagodas for the expence of your armament."

He then transmitted a note, which contained an estimation of the value of these prizes, amounting to $33^{2,1} 5^{2}$ pagodas; and proposed also, that a million of pagodas should be demanded for the Company.

It must also be observed, that in this letter M. Dupleix expressed himself in the following manner :

" As for the rest, I shall not pretend to regulate your conduct or operations; but you have asked my advice, and I have told you what I thought would be honourable to the nation: I know that the Minister has left you to be the master of your operations, and that I am only ordered to second your designs in every thing that depends upon me. I shall, therefore, keep within the bounds that are prescribed to me, and confine myself to such representations as circumstances may require that I should make to you."

At length M. de la Bourdonnais sailed from Pondicherry, on the $13^{\text {th }}$ of September, 1746, with nine ships and two bomb-ketches. He ordered the Saint Louis and Brillant to stand out to sea, and to get beyond Madras, in order to cut off the passage of any vessels that might try to save themselves from the road of that place, while the Neptune and the Bourbon received directions to sail directly for the road: the other vessels followed with the troops.

On the $14^{\text {th }}$ he was only four leagues from Madras, when he landed between five and six hundred men, with two field pieces; but not without apprehension that the enemy would dispute the descent, which is very hazardous, as it can only be accomplished by the boats of the country, conducted by natives, who are the greatest cowards in the world; for if one of them had been wounded, the rest would have instantly taken flight, and, consequently, the enterprize must have failed.

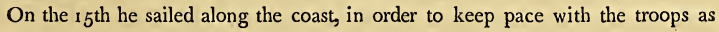
they advanced on the shore; and at noon on the same day he was within a long cannon shot of the town. The troops which he had disembarked were already within the enemy's district, when he landed with the rest of the soldiers appointed to carry on the siege. The whole consisted of a thousand or eleven hundred Europeans, comprehending the Creole volunteers, and the officers of the Isles of France and 
Bourbon; four hundred sepoys, and three or four hundred blacks of the isles There remained on board all the vessels, about seventeen hundred men.

As the troops of the first debarkation found themselves greatly fatigued, M. de la Bourdonnais ordered them to encamp near a pagoda, surrounded by country houses. As soon as he had given orders for the safety of the camp, he sent the Count de Restaing, Captain of Artillery and Engineer, with a detachment of an hundred men to reconnoitre; and during that time he descended to the sea coast, where he formed a small palisadoed camp, as a dêpot for the ammunition and provisions necessary for the siege. At length, on the report of the two officers who had examined the environs of the place, he transported himself to an height above the sea, which appeared to him the most proper situation for a battery of mortars, as from thence, the town might be battered, and the ships protected at the same time.

In the evening an Englishman arrived, of the name of Barnaval; and though he had no passport, M. de la Bourdonnais would not arrest him as a prisoner, because he was the son-in-law of M. Dupleix. This person brought a request from the English government, that the women might have permission to leave the town: this demand was granted to the wives of the Governor and M. Barnaval, but to no other; and those ladies refused to receive it on those conditions.

On the 16 th, approaches were made towards the town, and the camp was removed to a village which was within half a cannon shot of it. This whole day was employed to transport the artillery and form the batteries.

On the $17^{\text {th }}$, the sepoys, in the pay of the English, fired upon the latter camp; but they were so soon and so vigorously repulsed, that, instead of re-entering the town, they fled away into the country.

On the same day we took possession of the suburbs, and the Governor's country house, which was within musquet shot of the works.

On the following day the town was battered by twelve mortars on the land side, and at night, the three strongest vessels of the squadron began to cannonade it.

In the night $\mathrm{M}$. de la Bourdonnais received an express from M. Dupleix, which involved him in the greatest perplexity, as it informed him that ships had appeared off Pondicherry. He had therefore but one measure to pursue, on the supposition that the English squadron was approaching to relieve the place; and that was, to push the siege with the utmost vigour, so as to get possession of the town before 
its arrival: every necessary preparation, therefore, was made to attempt an assault. In short, the fire was continued with such vigour, that the English thought it necessary to make propositions; and towards eight o'clock, M. de la Bourdonnais received a letter from Madame Barnaval, the daughter of Madame Dupleix, to propose an accommodation.

Accordingly $M$. de la Bourdonnais, alarmed at the arrival of the enemy's squadron, with which he was menaced, eagerly embraced the opportunity to place his own in a state of security.

He immediately replied to Madame Barnaval, that if deputies were sent to him on the next day, her letter would serve as a passport, and the firing should cease from six o'clock in the morning till eight.

On the 2oth in the morning, Messieurs Monson and Hally-Burton, deputies from Madras, came to his camp, when he communicated to them the extent of his powers. They endeavoured at first to persuade him, that being on the territory of the Mogul, the town was privileged from any attack; but he represented to them, that he did nothing more than repel their hostilities; that they had taken the Favori in a neutral position; that they had burned the Pondicherry under the fortress of Tranquebar; and that they had sent detachments twenty leagues up the country, in search of French prisoners who had taken refuge there. These facts could not be denied, and the deputies threw the whole blame of these acts of hostility, on the ships of his Britannic Majesty. M. de la Bourdonnais replied, that it was to those ships he wished to address himself, but as he could not meet with them, Madras must answer for all. At length the deputies, understanding that the negociation must take a more serious turn, did not long delay to demand the nature and extent of the contribution which he would require, to induce him to retire from before their town. I do not traffic in honour, answered M. de la Bourdonnais; the French flag shall be planted on Madras, or I will die beneath its walls.

This proposition appeared to be very revolting to the deputies; who replied, that the object of their visit to him was to purchase the security of their town; and if all negociation on that point was refused them, they would defend it to the last extremity : as they should consider it less dishonourable to submit to the terms which a conqueror might impose upon them, than surrender themselves at once, and without a struggle, to his disposal. He then declared, that if they would surrender the town, and every thing which it contained, they might depend on 
his honour to restore it, with the reservation of a ransom. If, added he, you will trust to my word, in every thing that regards the personal interest of individuals, you will find my demands perfectly reasonable. He was then desired to explain his notions of what might be esteemed reasonable, under the immediate circumstances; when he took one of their hats, and observed, that, if it was worth six rupees, he must give three or four of it, and so for the rest. The deputies, however, were not sufficiently versed in the French language to comprehend this comparison, which appeared to decide the fate of the town : M. de Schonanville, therefore, another sonin-law of M. Dupleix, was desired to serve as interpreter on the occasion.

The deputies then proposed, that all the articles of commerce should have a price fixed on them, before the gates of the town were opened. This proposition, however, was considered as inadmissible; because such an arrangement would occasion considerable delay, and the enemy's squadron might arrive in the mean time, and change the face of affairs : besides, a report prevailed, that the beseiged had solicited the Nabob of Arcot to come to their assistance; and that prince, with fifteen or twenty thousand men, though but indifferent troops, might harass the handful of French forces which were before Madras, reduce them to act on the defensive, and compel them to regain their ships, that they might not be attacked on all sides.

M. de la Bourdonnais, therefore, on these considerations, demanded their immediate surrender of the town, or to take the consequences, which would prove its destruction. They answered, that if they did not receive an assurance from him, of being well treated, that they would defend themselves to the last drop of their blood. He replied, that it rested on them to choose between the alternatives which were proposed, and that they might depend on his maintaining his word in either of them.

The deputies, perceiving that he was immoveable, returned to Madras, to confer with the Governor on the propositions which had been made to them.

M. de la Bourdonnais took this opportunity to write a letter to the Governor, in which he drew a lively picture of the horrors that threatened Madras, and exhorted him, in very strong terms, not to render himself responsible, by a rash conduct which would not be successful, and every reflecting person must disapprove. At the same time he forwarded a dispatch to M. Dupleix, to inform him of his proceedings.

The bombardment was now recommenced and continued till three o'clock, when 
it subsided, according to stipulation, to give the deputies an opportunity to return. M. de la Bourdonnais took advantage of this interval to inform himself of the height of the walls, in order to proportion his ladders to them, and to mark the places where they might be scaled with the greatest advantage. In the mean time he sent to the ships, to invite such of the crews to join him who were willing to. assist in the assault, if he should be under the necessity of having recourse to that extremity ; and four hundred men disembarked, without hesitation, led on by their respective officers. Orders were now given to carry this design into execution on the night of the 21 st.

At about six in the evening a man, named Francisco Pereiro, arrived in the camp. He had formerly been a surgeon in the service of the Nabob of Arcot, and having an intimate acquaintance with the principal inhabitants of Madras, requested permission to enter the town, in order, as he said, to engage the Governor and council to an immediate compliance with the propositions which had been made to them. M. de la Bourdonnais assented to his requisition, on condition that he would give him an exact account of what was passing in the town. On his return, Pereiro presented himself as being commissioned by the Governor, to say, that nothing had yet been finally determined, and to request that a cessation of arms might take place during the night, in order that the beseiged might come to a final resolution as to their conduct: Pereiro added, that he had taken upon himself to assure them this request would be granted. M. de la Bourdonnais, equally astonished at the message, as well as at the choice of the person who brought it, who had neither title nor public character, reprimanded him with great severity for his presumption, and sent him back instantly with a letter to the Governor, informing him that the cannonade should cease on the following morning, from six to eight; and at the same time assured him, that if the deputies did not bring a clear and decisive determination on the part of the beseiged, he would not receive any future proposition.

At eight in the evening the fire was renewed with augmented fury, and was continued through the night, as well from the ships as the batteries.

The next day, being the $21 \mathrm{st}$, the deputies came a second time to the camp, and agreed to surrender the town on the conditions that had been proposed-of paying a ransom for it. Articles of capitulation were immediately drawn up, and Mr. Hally-Burton took them to the Governor, who returned them, with a repre- 
sentation that neither the Governor or the council should be considered as prisoners of war, during the time that the conditions of the ransom were settling. M. de la Bourdonnais, though he thought they should remain prisoners till the whole was completed, assured the deputies that the Governor and council should be at liberty, as soon as the articles of surrender were agreed upon. The capitulation was now signed by the Governor, and M. de la Bourdonnais entered the town, having already published a prohibition to his troops, on pain of death, to commit the least act of pillage or disorder.

Capitulation of Fort St. George, and the Town of Madras, September 21, 1746.

" The Fort St. George and the town of Madras, with its dependencies, shall be surrendered to M. de la Bourdonnais. All the garrison, officers, soldiers, with the council, and, in general, all the English which are in the fort, or the town, shall be prisoners of war; but all the council, civil officers, \&c. with those on the military staff, \&c. shall be on their parole, with full liberty to go where they please, even to Europe, on condition that they shall not bear arms against France till they are exchanged.

"To facilitate to the English the ransom of their place, and to give validity to the acts which may take place in concluding it, the Governor and his council shall cease to be prisoners of war, at the moment the negociation is commenced.

"The articles of capitulation being signed, those of the ransom of the place will be regulated in the most liberal manner by M. de la Bourdonnais; and the English Governor, or his deputies, will deliver up to the French; without the least reserve, all the effects, merchandize, books of accounts, warehouses, arsenals, ships, warlike stores, provisions, and whatever belongs to the English East India Company, as well as all articles in gold and silver, furniture, and whatever other effects are contained in the town, the fort, and the suburbs, to whomsoever they may belong.

"The garrison shall be conducted to Fort St. David; as prisoners of war; and if the town of Madras is ransomed, the English shall have liberty to recall the garrison to defend it against the people of the country; for which an adequate return of French prisoners shall be made.

"The sailors shall be sent to Gondelour. The exchange shall begin with those which are actually at Pondicherry, and the rest shall be sent into England; but 
they shall not bear arms against France till they have been exchanged, either in India or in Europe.

" On these conditions, the Watreguel-gate shall be delivered up to M. de la Bourdonnais at two in the afternoon; the different posts shall be relieved by his troops; and the mines, counter-mines, and other subterraneous places charged with powder, shall be discovered.

" Concluded in the French camp, the 21st September, 1746.--Signed, N. Morse, William Monson, J. Hally-Burton, Deputies.

"Acknowledged to be a true copy. Desprémesnil, Mabé de la Villebague, G. Desjardin."

When M. de la Bourdonnais had entered the town, he was informed by the Governor that a disorderly spirit reigned there; that the soldiers had been outrageous; and that many of them had declared they could be content to suffer death themselves, if they could but kill the French general. Accordingly twelve of his officers proposed to accompany him as his guard, which they effectually did, the rest of the day.

His first care was to insure the safety of his conquest, by posting guards round the place, with a general order not to suffer any effects whatever to be taken out of it.

Having employed these precautions, M. de la Bourdonnais repaired to the church of the Capuchins, where the ladies had taken refuge; and with great politeness desired them to return to their respective houses, and live there as they had been used to do, without the least apprehension of insult or ill treatment of any kind, as they might be assured of his protection.

M. de la Bourdonnais now proceeded to take possession of the government; and having assisted at a public Te Deum for the success of his arms, dispatched expresses to M. Dupleix, to inform him of his good fortune.

He remained at Madras to establish security, good order, and plenty; and it may be said, without the least fear of contradiction, that from the day after the entry of M. de la Bourdonnais, the police was as well observed as in any town of Europe. The inhabitants were disarmed, and the English soldiers and sailors were sent as prisoners on board the French ships. Having therefore discharged these preliminary cares, he proceeded on the following plan, to derive all possible advantage from his conquest, and to avail himself of the superiority which his squadron gave him in the Indies, 
As the monsoon obliged him to quit the coast about the middle of October, and as he could not, therefore, remain longer than twenty-five days at Madras, it was physically impossible to take away all the merchandize and effects which that town contained. He thought, indeed, that it would be sufficient for him to carry off what belonged to the English Company, with which he hoped to load three vessels; and he proposed to comprise the rest in the ransom. This was his first project : he determined therefore to send to the islands, the Neptune and the Princess Mary, laden with the effects of Madras; the Saint Louis and the Lys, laden at Pondicherry, with merchandize for Europe, with the Renommée and Sumatra, appointed to carry provisions. These six vessels would announce the arrival of M. de la Bourdonnais, and their crews would serve to defend the isles in case they should be attacked. During this time, M. de la Bourdonnais proposed to remain in India with seven large vessels, the Acbilles, the Pbonix, the Duke, and the Bourbon, together with the Centaur, the Mars, and the Brillant, which had been armed as ships of war at the isles, according to his orders, and actually arrived the 8th of October at Pondicherry, as will appear hereafter.

\section{Letter of $M$. Dupleix to $M$. de la Bourdonnais. \\ "Sir, \\ Pondicherry, 18th Sept. 1746:}

"6 I have received my letters from Mahé, which announce to me the arrival of the Centaur, of seventy-two guns, and six hundred and forty men; as well as of the Brillant and the Mars, of three hundred and sixty men each. The Captains were not come on shore. The Patmars were ordered to examine these ships; but it does not appear that they are to be followed by any others. I have not received any news from Europe; but M. de Leyrit informs me, that all the vessels which you expedited thither, have been taken at Louisbourg. A report to that effect had already prevailed in India, and it is now confirmed: these are heavy losses for our Company; and the success of your enterprise can alone indemnify them. The expectation of speedy succour will animate you to employ all your efforts to terminate it, \&c. \&c.

$$
\text { Signed, }
$$

"DUPLEIX."

M. de la Bourdonnais had also taken a vessel which could serve him on the look-out, so that he commanded a formidable squadron; and he proposed to quit the coast, about the middle of October, in search of the English: it was 
his design also to return thither in the month of January, in order to attack Fort St. David. In the mean time, he addressed the following letter to the Supreme Council of Pondicherry.

"Gentlemen, Madras, September 27,1746 .

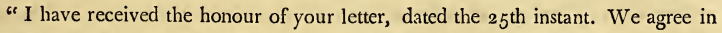
our opinion as to the necessity of quitting Madras, but we differ as to the manner in which I should conduct myself respecting that place. You think it ought to be entirely dismantled, while in my judgment it should be ransomed. What signify the walls of that town to the merchants, who inhabit the country twenty miles around it. You indulge the hope, that if those walls were demolished, these men would retire to Pondicherry : do you really imagine that such a circumstance would induce them to expatriate themselves? Ought it not rather to be presumed, that the English will continue their commerce; and that, to secure themselves from any future coup de main, they will erect others of a superior structure? I am certain that, in two years, the English will be stronger than they have ever been. I do not believe that the merchandize in Madras will produce more than from three to four lacks of rupees; and ought $I$ to sacrifice the surplus to a notion, that is at variance with the nature of things? For these hundred and fifty years, the vast commerce of the English has been the sole attraction of mercantile adventurers to Madras.

"If the whole body of these merchants were to take refuge in Pondicherry, would our commerce retain them there? I cannot therefore bring myself to sacrifice five or six millions which belong to the Company, and the crews of the ships, who have a decided claim upon them. But you will say, what assurance have I that the ransom will be paid? I answer, the solemn engagement of the English, which they will not forfeit. They also give you as hostages, the two children of their Governor, and two of the Council with their wives. Besides, the whole body of officers, and the principal inhabitants, have engaged themselves by a solemn oath to surrender their town to the Governor of Pondicherry, if the Company does not fulfil the terms of the ransom. But even if $\mathrm{I}$ had not these sureties, the law of nations demands the performance of similar engagements. Such is my opinion; nor do I entertain the shadow of a doubt that the English will pay the ransom."

After a particular account of the arrangement of his ships, he concludes his letter in the following manner: 
"I should be happy to raze Gondelour to its foundations: if I had finished here at an earlier period, I would have undertaken that service with the greatest satisfaction; but I must now refer it to January. As circumstances, however, may engage us elsewhere at that period, I have requested the English to grant me passports for two vessels, who may come to take those articles in January, which I could not carry away in October ; in such case, I could send two loaded vessels to Pondicherry. You must perceive, therefore, that $I$ shall be enabled to leave a number of ships in India, which will not, perhaps, be inferior to the English squadron. As for me, my purpose is determined: if fortune smiles on my designs, the Coast of Coromandel shall not be the only one to feel the effects of them, \&c. \&c.

$$
\text { Signed, “MAHE' DE LA Bourdonna1s." }
$$

Availing himself of the monsoon, M. de la Bourdonnais could in eight days have reached the Coast of Malabar, where, as there was no English force to resist him, he might have levied contributions on all their factories; and have then returned to Pondicherry, to take the cargoes destined for Europe under his protection. In October, 1747 , he would have been joined by the six laden merchantmen which waited for him at the isles; and before the close of the year 1748 , he would have arrived in France, with fourteen or fifteen ships, richly laden with the spoils of the English, to the amount of thirty or forty millions of livres.

Full of these ideas, M. de la Bourdonnais unfolded a part of them to M. Dupleix. The absolute necessity of secrecy, without which nothing could succeed, forbade him to discover the whole extent of his views. In short, the success of all his projects depended on one single point-the dispatch with which the business of Madras could be terminated. To this single object, therefore, was all the care and application of M. de la Bourdonnais directed; and it was with inexpressible pleasure that he beheld himself in a state to execute every thing which he proposed with his former armament. To accelerate, therefore, the conclusion of the treaty and the evacuation of the place, it was necessary to load the ships with the utmost expedition, and regulate, with the English, the price of the ransom, conformably to the capitulation. M. de la Bourdonnais proceeded in the following manner, to accomplish this two-fold effect.

The peculiar property of the English East India Company, consisted of gold and silver, of ammunition, and articles of merchandize.

The gold and silver were disposed in the Exchequer and the Treasury, of 
which Messieurs Bonneau and Desprémesnil, the Commissaries, kept the keys; and M. Laurent, principal writer, was charged with the office of making out the accounts.

The articles of merchandize, as well as military stores both for land and sea, and provisions, were lodged in magazines and warehouses, whose keys were in the hands of the Commissaries Desjardins and Villebague, who were charged with the embarkment of all the effects, \&c. \&c.

He had no sooner made this distribution, than he proposed to evacuate the place on the 11th of October, and to get all his ships in the road of Pondicherry on the following day.

It appears from the dispositions made by M. de la Bourdonnais, that, as soon as Madras was ransomed and evacuated, he proposed to conduct his squadron wherever the monsoons would prove favourable to him. M. Dupleix, on the contrary, resisted the evacuation of Madras, and contested that the ships should not depart from Pondicherry. His object was to break through the capitulation, and to keep Madras.

No sooner had M. de la Bourdonnais commenced the operations which have been already mentioned, than he proposed to enter into a negociation with the English, to regulate the articles of the ransom. He received, however, a letter from M. Dupleix, by which it appeared, that he did not approve of all these arrangements. In fact, by this letter, which was dated the 21 st of September, and arrived at Madras in the night of the $23 \mathrm{~d}$, he positively declared that he had promised the Nabob to give up that place to him, as soon as the French should become the masters of it ; and, as at the moment of writing this letter be was ignorant of the capture of the place, he added, that this circumstance should engage the besiegers to give new vigour to their attack, and to be deaf to all propositions that might be made to ransom it ; as the Nabob would otherwise be disposed to join our enemies.

M. de la Bourdonnais found this letter incomprehensible: he could not conceive that M. Dupleix would assume to himself the character of a sovereign; and give to one nation, those places which had been conquered from another. Nor could he comprehend his imprudence, in engaging to deliver up to the Nabob, a town of whose fate he was ignorant, and to which M. de le Bourdonnais might bave granted, 
as had happened, a capitulation incompatible with this disposition. Besides, this project was in such evident opposition to the interests of the state, and so far beyond the powers of M. Dupleix, or even of M. de la Bourdonnais, that it was very difficult to consider it as a serious proposition. In fact, it was nothing more than an attempt to deceive both the Nabob and M. de la Bourdonnais. The concealed object of it was as follows :

It cannot be denied that he had absolutely engaged to give up Madras to the Nabob; but if we may judge of his sincerity from the event, he had no intention whatever to fulfil his promise, as he did not carry it into execution when it was in his power. He accordingly deceived the Nabob, who afterwards revenged himself, by engaging in a war, which occasioned the loss of a considerable body of troops to the state, and of money to the Company. But the artifice he practised on the Asiatic prince, was merely to- give more certainty to the deceit he meditated on M. de la Bourdonnais; whom he hoped, by such a circumstance, to involve in the necessity of refusing whatever propositions, respecting a ransom, the Englith might offer: the consequence would be, that by rejecting the ransom, M. de la Bourdonnais would be compelled by the monsoon to quit the coast in the month of October, and leave to M. Dupleix the care of pillaging Madras. This was most anxiously desired by the Governor of Pondicherry, as will appear hereafter.

But however that may appear, at the time when M. Dupleix announced to M. de la Bourdonnais these political arrangements, the latter received the following letter from the Nabob.

"To the renowned French Commander, whom may God preserve from all evil, and give him prosperity.

"I know that thou art a great warrior, and that towns cannot resist thy power; but at the same time it has filled me with astonishment, that thou hast entered on my territories, without sending an officer, duly qualified, to notify thy designs. 'I pardon thy conduct; but on the receipt of this letter I order thee to embark with all thy forces, and cease to besiege Madras. If thou dost hesitate, I shall appear with my royal army, to compel thee to execute what I command. This being done, I wish that thy arms may prosper, and that thy happiness may be great as thy name." 
M. de la Bourdonnais wrote the following answer.

"To his Highness the Nabob, Marouz Kam.

"As the sovereignty of the town of Madras belongs to the English, the enemies of my nation, I presumed that, without invading the rights of any sovereign power, I might seek them in their own settlements, to execute vengeance on them for the mischief they have done us during the present war. They have made Frenchmen prisoners in your territories. It is the English, therefore, who have violated the respect which is due to you. As for me, although I am a seaman, and ignorant of your customs, since my troops have been landed I have exercised the most polite attention to your subjects. It is true that $I$ have pursued my enemies, and taken their town, according to the laws of war; which you cannot disapprove, since I have respected whatever belongs to you. As to the orders which you send me, to reimbark, I must answer them by observing to you, that I receive no commands but from the King, my master. If my conduct should induce you to fulfil your menace, I shall not forget that I am a Frenchman, and shall act accordingly, \&c.

$$
\text { Signed, }
$$

"Mahe' de La Bourdonnais."

The threats of the Nabob, and the singular projects of M. Dupleix, furnished M. de la Bourdonnais with new reasons to accelerate the conclusion of his treaty for the ransom, which was at length concluded the 26 th of September, after various conferences with the Governor and the English Council. It was fixed at eleven millions one hundred thousand pagodas, including the black town : of this arrangement M. de la Bourdonnais dispatched immediate information to M. Dupleix.

This settlement being completed, a deputation of the Supreme Council of Pondicherry, which had been already announced to him, arrived at Madras, under the pretext of complimenting $\mathrm{M}$. de la Bourdonnais on his conquest ; but nothing could exceed his astonishment, when the deputies informed him, that the object of their mission was, to form at Madras a Provincial Council, subordinate to the superior Council of Pondicherry; that they protested against any capitulation that he had made, or might hereafter make ; and that they opposed themselves in form, and in the name of the King and the Company, to the restoration of the town to the English. 
But the Deputies did not confine themselves to simple declarations; on the contrary, they employed every secret art to draw over to their party, the principal officers of the troops commanded by $\mathrm{M}$. de la Bourdonnais, many of whom communicated these circumstances to him. He accordingly addressed his complaints to the Supreme Council of Pondicherry, by a letter, dated the 27 th September, in which he stated the injustice, impolicy, and baseness of such a conduct, and which was justified, as proceeding from the orders of M. Dupleix.

From the 27 th to the 30 h, the time passed in disputes and protestations, as well on the part of the Supreme Council of Pondicherry, as of their Deputies; who insisted that they had a right to command in Madras, and to decide with sovereign power on the fate of that place. In the same interval, the greater part of the arrangements formed by $\mathrm{M}$. de la Bourdonnais ceased to be carried into execution. M. Desprémesnil, without any notice whatever, resigned the office of Commissary; and M. Bonneau quitted his functions in such an offensive manner, as to oblige M. de la Bourdonnais to put him under arrest : he contrived however to escape, and retired to Pondicherry, where his conduct received the most flattering approbation; while M. Dupleix, as a recompence for the zeal he had shewn for his interests, advanced him to a place in the Supreme Council.

M. de la Bourdonnais continued to remonstrate, in the strongest manner, against the conduct of M. Dupleix ; but the latter was so anxious to command in Madras, and to dispose of the riches contained in that place, that he would listen to no suggestions, but such as proceeded from his own avarice and ambition; and those passions dictated the violent means which he employed to establish his authority in the conquered settlement.

He prepared a new protest against the treaty, with letters patent for the establish. ment of a Provincial Council at Madras, and the commission of Commandant and Director of the town for M. Despremesnil. At the same time he transmitted to M. de Bury, Major-General, and to those who accompanied him, precise orders to exercise the most exemplary rigour against all those who should dare to support M. de la Bourdonnais; and to engage the troops which were at Madras to support, with all their power, the execution of these orders. He also wrote a circular letter to the principal officers, in which he excited them to revolt, in the following terms:

" Entreated and solicited by the whole colony, I cannot dispense with putting " an immediate conclusion to all the evil and dishonour, which must result from a 
" treaty ill conceived, and worse conducted. The reading of it will surprise you as " much as it has revolted the colony. All these considerations persuade me, that "you will be the first to give an example to all good Frenchmen, who are ever " disposed to take the side of reason, and manifest obedience to the orders of those " who employ them."

As this extraordinary project was really concerted with the deputies of Pondicherry, who were then at Madras, they retired to St. Thomas, the black town, at the distance of about a league, to wait the arrival of M. de Bury, M. de Paradis, M. Bruyeres, and the other emissaries from Pondicherry, commissioned to execute the orders of M. Dupleix. There these gentlemen held their councils, and after they had agreed upon the measures they were to pursue, returned to Madras. On the 2d of October, at eight in the morning, they entered the town with the design of gaining the troops over to their party; and as the soldiers were assembled to mount guard, they addressed them as follows: "Friends, it has been proposed by others " to give up Madras for paper; we are determined to prevent such a sacrifice, and " to give you an hundred thousand rupees : will not this content you?"-The proposition so astonished the soldiers that they did not utter a word. This unexpected silence caused no small degree of surprise to these gentlemen, who expected that such a proposal, so calculated to conciliate the soldiers, would have been received with warmth and gratitude. They however made no further attempt, but passed on to the State-house.

When they had entered the hall, they delivered to M. de la Bourdonnais the following letter from the Council: "Our answer to your letter of the 27 th, will be " delivered to you by M. de Bury, Major-General in India."

As soon as M. de la Bourdonnais had read this paper, the Register, who accompanied the Deputies opened the scene, by exclaiming aloud in his presence-" We " are come to announce the orders of the Commandant and the Supreme Council of "Pondicherry." This opening was not heard without emotion on the part of M. de la Bourdonnais, who immediately penetrated the whole of their designs. He nevertheless dissembled his resentment, and to prevent any disturbance, which might be attended with very disagreeable consequences, in a place filled with English and people of other nations, he politely invited the deputies to pass into his apartment, as they would there be more at liberty to explain themselves; but M. Paradis replied, 
in a very violent tone, "No, Sir, our communications must be public." The first emotion of M. de la Bourdonnais, at this rash reply, was to order them all to be put under arrest; but apprehensive that there might be found factious people to join them, in some act of sedition, he thought it would be more prudent to dissemble.

The Register immediately began to read the requisition presented by the inhabitants of Pondicherrry, which was succeeded by,

1st. The protest of the Council of Pondicherry, which signified to M. de la Bourdonnais and the English Council, that the treaty respecting the ransom was null and void.

2d. The commission, appointing M. Dupleix Governor of the French settlements in India.

3 d. The letters patent for establishing a Provincial Council at Madras, by the Supreme Council of Pondicherry.

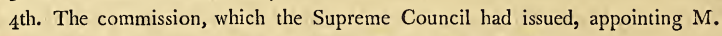
Desprésmenil Commandant and Director of Madras.

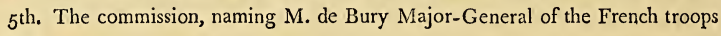
in India.

6th. The particular orders of M. de Bury.

The reading of these various instruments having excited an universal murmur in the hall of the State-house, which was now filled with people from every part of the town, M. de la Bourdonnais could with difficulty make himself heard. At length he requested the deputies to inform him what they proposed to do at Madras? - "To introduce good order in it," answered M. Barthelemy.- "That can be done," replied M. de la Bourdonnais, "without your assistance." In short, after much unpleasant altercation, during which the military officers repeatedly requested permission of $\mathrm{M}$. de la Bourdonnais to put the deputies under arrest; and after M. Paradis had treated the orders of the King and the Minister to M. de la Bourdonnais as so much waste paper, the English Council interposed, and appealed to the law of nations, which the Governor and Supreme Council of Pondicherry were attempting to violate in their persons. M. de la Bourdonnais therefore immediately ordered a council of war, to determine if the capitulation made with the English should be maintained and observed?-The result was as follows : 
"We are unanimously of opinion, that M. de la Bourdonnais is bound to keep " his word, and fulfil the engagements he has entered into, with the English."

Signed by all the officers.

The envoys from Pondicherry were very much disconcerted at this unanimous declaration, as they fully expected that they should have been joined, at least, by certain officers, who had avowed themselves to be personally discontented with M. de la Bourdonnais: on the contrary, there was not one among them, who did not lose all remembrance of private dissatisfaction in the anxiety to perform his public duty, and who was not both ready and willing to have arrested the whole of this pretended Provincial Council. But notwithstanding the heat and violence of the dispute that had takeñ place, M. de la Bourdonnais wished to give the deputies every opportunity, by his polite attentions, to recover from their confusion; they however refused his invitations, and retired from the hall one after the other, in order to conceal themselves as much as possible from public observation.

M. de la Bourdonnais however was well acquainted with their secret intrigues, and the efforts they were making to gain over the troops, as well as the means they were employing to ferment a civil war in Madras; he therefore employed all the precautions necessary to prevent such an evil, and, at the same time, ordered them in such a manner as to conceal their immediate object.

With this view he resolved to embark a part of his troops, and particularly those which had been detached from the garrison of Pondicherry; and he executed this project under the pretext of a report which prevailed, that certain large ships had appeared off the coast, though it was not known to what nation they belonged.

This news authorised him to send the troops on board, to strengthen the squadron in case of an attack. He accordingly ordered fifty men to be embarked on each vessel, and instructed his aids-de-camp to select the Pondicherry troops in preference. These orders were completely executed on the morning of the $4^{\text {th }}$ of October.

The discreet and cautious conduct of $\mathrm{M}$. de la Bourdonnais, greatly disconcerted the deputies from Pondicherry. They had depended with the utmost certainty on being firmly supported by all the troops that had been furnished towards the expedition against Madras, by M. Dupleix; and they flattered themselves also, that they should be able to gain over a part of the island forces: they hoped therefore to find themselves in equal force with M. de la Bourdonnais; and that they should be in a situation to sustain their pretended rights, with arms in their hands, if any opposition 
should be made to them. It was on the credit of these expectations, that M. Dupleix had ordered M. de Bury to put M. de la Bourdonnais, under arrest. But though the success had not answered their hopes, that officer could not, as he thought, dispense with putting the orders of M. Dupleix in execution; and on the same day, the 4 th of October, he presented himself to M. de la Bourdonnais, with two Captains, and put him under arrest, by a writing in the following terms :

\section{A. Monsieur de la Bourdonnais, Commander of the Frencb Squadron.}

"In consequence of the orders of M. Dupleix, Commander in Chief and Governor of Pondicherry, inserted in the letter of the 27 th of September, 1746 , which the members of the Council have just communicated to me, you will be pleased not to quit Madras, by land or by sea, with the French troops, under any pretext whatever, without a written permission from the said M. Dupleix. Dated Madras, $4^{\text {th }}$ of October, 1746 .

$$
\text { Signed, "DE BURY." }
$$

The effect that such a wretched attempt had on the mind of M. de la Bourdonnais, was less calculated to excite his indignation than his contempt; and it was rather to prevent any new scene of altercation, than from a spirit of resentment, that he ordered them under arrest. "I take upon me, gentlemen," said he, "to arrest you : leave your swords here, and demean yourselves in a peaceable manner towards the government, or I will make you." Nor did they hesitate to manifest a prompt obedience. The deputies having been informed of what had passed, detached the turbulent Paradis, to demand of M. de la Bourdonnais satisfaction for his conduct; but he had scarce opened his mouth, when the latter interrupted his speech, by putting him also under arrest. In the evening he dismissed them all, with an absolute prohibition to quit Madras without his permission.

The deputies finding all their measures rendered ineffectual, formed another project; which was to carry off M. de la Bourdonnais, and to conduct him as a prisoner to Pondicherry; but as it was necessary to employ the cavalry for this purpose, which was commanded by M. D'Auteuil, the brother-in-law of M. de la Bourdonnais, M. Dupleix ordered the former to repair immediately to Pondicherry.

It must be allowed that, in consequence of this strange conduct of the deputies, 
M. de la Bourdonnais was altogether dispensed from any precaution in his future conduct to them; nevertheless, the fear of interrupting the general welfare, and the little apprehension he entertained of any personal inconvenience to himself, determined him to write that very day to M. Dupleix. His letter was as follows:

"The scene which has passed this day at Madras, disorderly as it was, afflicts me much less with respect to myself, than as it is lumiliating to the whole nation. Since the capture of this place, I have done every thing in my power to preserve, among the English, that decorum which becomes the majesty of the King's arms, and the character of the officers whom I command. My commission, my orders, the wish of the minister, and the right of war, by placing me at the head of French warriors, oblige me to sustain the honour of their victorious flag. I entered Madras on the condition to treat for its ransom, in the most liberal manner, with the Governor and his Council. Whether I had a right or not to engage in the capitulation, is a question with which neither you or your Council have the least concern. The King alone commands here, whose orders I bear. I shall proceed to render to him an account of my conduct, to take back the ships with whose command he has entrusted me, and to carry him my head, which will be answerable for any ill I have done: but I rather expect from his Majesty the recompense of my zeal, than chastisement for involuntary errors, if I have committed them. I beg of you, therefore, to give me all the assistance which my situation requires: I ask it of you in the name of his Majesty and the Company: appoint proper commissaries to watch over the claims of the Company; but leave to the King, who is my master and yours, to punish me for the pretended crime which has been imputed to me. Inform me if you will receive the bales of cloth, the money, the artillery, the rigging, masts, \&c. the bills and the hostages, \&c. that I may know what arrangements to make. The time presses, and I shall be obliged to depart. If you will not undertake to act for the benefit of the Company, I cannot be answerable for your misconduct," \&c. \&c.

M. Dupleix did not answer this moderate letter, but by new traits of violent displeasure. All the representations, all the propositions of M. de la Bourdonnais, were offered in vain; M. Dupleix was absolutely determined to remain master of Madras : a resolution, in forming which he neither considered the interests of the Company, nor the dangers to which he exposed the colonies. As M. de la Bourdonnais had transmitted to him the articles of the treaty for the ransom, in their original form, he, on the following day dispatched, with all possible expedition, the 
five additional articles, which a new arrangement had obliged him to add to them. "I trust," said he to him, " that you will approve them in their present state: if you make the least alteration, I cannot answer that they will be accepted. It is then on condition that you do not attempt to alter them, that you may send your officers and your troops in the Centaur, and I will then deliver up Madras to you. I shall leave it with the greatest pleasure, as soon as you and your Council have signed the treaty, and the articles which have been added to it, which I now send you by express. As soon as I shall have received them, I shall get under way, and you will be the master," \&c. \&c.

When M. Dupleix and the Council of Pondicherry had left M. de la Bourdonnais to arrange the articles of the treaty of ransom as he thought proper, it was not in the common course of things to suppose that they would create new difficulties respecting these articles, especially at a critical time, when the least delay might expose the squadron to the greatest dangers. These reasons M. de la Bourdonnais urged in all his letters; the approach of the monsoon, the heavy lading of the vessels, and a variety of other important circumstances, were represented in his communications with them.

It seems as if $\mathrm{M}$. de la Bourdonnais foresaw the misfortune that was about to overtake him, and which he would have infalliably avoided; if he had not found so many obstacles and delays in the conduct of the Governor and Council of Pondicherry. This was, without doubt, the greatest loss which the Company had ever sustained. In short, though on the $13^{\text {th }}$ of October the weather was uncommonly fine, a violent hurricane arose in the night, which dispersed all the vessels, and shattered the greatest part of them. The Achilles was, at about a league from the shore, entirely dismasted, and driven towards the coast by an east wind, so that it was on the verge of perishing, with its whole equipage: the Bourbon was in still greater distress and danger: the Phonix never appeared again: the Marie Gertrude was wrecked, and only fourteen of her crew saved : the Duc d'Orleans went down with every thing on board, at about six leagues in the offing : the English prize named the Princess Mary, was entirely dismasted. In short, a long list of vessels belonging to various nations, strewed the coast with their wrecks. M. de la Bourdonnais, as may be naturally supposed, was very much affected by this afflicting spectacle; but his courage and constancy did not forsake him; and in the midst of his misfortunes, his only occupation was to find the means of repairing them. 
He accordingly collected some catamarans, ${ }^{*}$ which had weathered out the storm, and by dint of pecuniary rewards, he prevailed on a number of boatmen to venture out into the tempestuous sea, to convey his letters to the captains of those i essels which appeared in sight; and by these he exhorted them to struggle with the difficulties of their situation, and promised to send every succour in his power; but it was from M. Dupleix and the Supreme Council of Pondicherry, that he was to derive the means of affording the promised assistance to the crews of the ships.

The plan which M. de la Bourdonnais had conceived, in the present exigency, was as follows.

If the vessels which were in the road of Pondicherry were in the same situation as those of Madras, as there was too much reason to apprehend, he determined to send to the former place, and to leave there all the vessels which were rendered incapable of putting to sea, and to keep both at Madras and Pondicherry, such ships as were capable of being repaired under the cannon of these two places. In the mean time, the sailors belonging to them might join the respective garrisons; the troops would also be disembarked; and with them he proposed, during the winter, to undertake the siege of Gondelour. As the coast was impracticable at that season of the year, he could not fear any attack from the enemy's force by sea; and the Nabob feared him too much to give him any trouble by land; he therefore flattered himself that he should carry Gondelour in a few days, and ransom it, as he had done Madras.

When he was master of these two places, he proposed to evacuate them only on this condition-that the English would furnish him with six ships belonging to their company, the price of them to be deducted from the ransoms of the two towns. But this project vanished in a moment, when he received intelligence that the ships at Pondicherry had not sustained any damage; and he resumed his former project on the coast of Malabar ; in the full confidence, that he should be instantly relieved from his difficulties by ships which were subject to his command.

He accordingly wrote to M. Dupleix, to send them to him with all possible expedition; and, in the mean time, he was occupied night and day in conveying to the sea-shore whatever might be necessary to relieve the squadron, which had suffered so severely from the hurricane.

It has already been observed, that M. Dupleix and the Supreme Council of - A sort of boat used on the coast of India. 
Pondicherry had expressly engaged, by their letters, to execute the articles of the treaty, as they should be settled by M. de la Bourdonnais, whom they left the entire master to conduct the whole in the manner which he should judge most proper. It has also been observed that, in consequence of these engagements, M. de la Bourdonnais had framed the articles, and that he had sent a copy to the Council of Pondicherry, informing them at the same time, that if any alterations were made, he would not answer for their being accepted. But the 'gentlemen of Pondicherry forgot all their engagements, and returned the articles with alterations, which were not only inadmissible but impracticable.

For example: by the fifth article, they made themselves masters of the time when they should evacuate the place, by stipulating, but without fixing the term, that it should not be evacuated till the captured property was settled: but as that period might be lengthened at their pleasure, one of the conditions, solemnly agreed to by M. de la Bourdonnais, that the evacuation should take place in January, would be violated.

In this same article they inserted another condition, which was not less unjust: that the road of Madras should not be frequented by English vessels till after the evacuation. It was, in effect, to take from the English that freedom of commerce, which could alone put them in a condition to collect the funds necessary for the payment of the ransom. It was impossible for the English to accept of such a condition:

The seventh article was not less ridiculous. They thereby declared that they would receive neither bills nor hostages, and that M. de la Bourdonnais should take charge of them on board his vessels. But this proposition was impracticable, because the hostages and the bills could not be delivered but at the moment of evacuation, when M. de la Bourdonnais would not be at Madras to arrange the final settlement of it.

The eighth article, however, was that which gave the greatest offence. The Council determined to sign nothing with the English, and to enter into no engagement whatever, but with $\mathrm{M}$. de Ia Bourdonnais. The latter saw through all the finesse of that business; as the rulers of Pondicherry had no other object than to delay the final settlement of the treaty till $\mathrm{M}$. de la Bourdonnais should be obliged to quit Madras without signing it, and consequently leave the place to their discretion: but to render their projects abortive, M. de la Bourdonnais deter- 
mined to adhere to the capitulation, which he took with him, and would consequently guarantee the execution of the treaty. This was an important object with him, and was necessarily to be accomplished, by the engagements contained in the letters, \&c. written from Pondicherry, which are expressed in the following terms: "The Council engages and gives its word to maintain the articles, of which M. de "la Bourdonnais has sent the copy, so long as the English maintain theirs."

M. de la Bourdonnais, therefore, thought of nothing but to come to a final termination as soon as possible with the English. In short, there remained at this time but one article to settle, which was to postpone the evacuation of the place from October to January. The misfortune which had befallen the squadron commanded by M. de la Bourdonnais, rendered it impossible for him to fulfil this article of the capitulation, and the representations he made on the subject had their proper effect on the minds of the English. M. de la Bourdonnais therefore assembled the two nations at the State-house, on the 21 st of October, and having read it aloud in French and in English, he proposed it to their final ratification. This proposition was accepted by the unanimous voice of all present. The Council, the Magistrates, the military officers, and all the principal inhabitants, swore to preserve the treaty, in all its articles, inviolably. It was accordingly signed, as well as the letters of exchange on the English Company, amounting to five hundred thousand pagodas, and bills for eight hundred thousand pagodas, payable at certain periods, and to the order of the Council of Pondicherry.

On the same day he sent the treaty to the Council of Pondicherry, and observed to them, that they would be personally responsible for any infractions of it on the part of the French. The following letters accompanied it.

\section{A. M. Desforges Boucher.}

"Sir,

Madras, 17 th October, $174^{6}$.

"You will find three letters annexed, addressed to the Captains who are just arrived from Europe. I charge you, in the name of the King, to deliver them to the persons to whom they are respectively addressed, and to require them also, in the name of the King, to obey the orders which they contain.

$$
\text { Signed, "MAHE' DE La Bourdonnais." }
$$




\section{To M. M. of the Supreme Council of Pondicberry.}

"Gentlemen,

Madras, 18th October, 1746.

" The command of Madras has been hitherto the subject of much altercation; whether I am right, or whether I am wrong, I most willingly sacrifice my self love, to afford satisfaction at Pondicherry. To attain that object, I am about to give up the care of the town to $\mathrm{M}$. Desprémesnil, on the sole condition of maintaining the capitulation which I have granted to it. According to my opinion, it is perfectly well suited to our situation : if you think otherwise, you are the masters to act as you think proper. I have done every thing which depended on me, to merit the esteem of my friends and my enemies.

"While I thus submit to the state of public affairs, I cannot but express my surprise at what is passing at Pondicherry, under your eyes. You know that I have an order from the King, to command all the Company's ships in the East Indies, and I signified that order to the three Captains lately arrived from Europe : they however have replied, that, being under the command of the Council of Pondicherry, they could not obey me. I demand therefore to know, M. M. in the name of the King, if it is your intention to oppose his orders; if so, I shall abandon every thing to its fate, and leave you responsible for all the consequences of such a conduct. I shall embark in the first vessel for the isles, and take those measures which the treatment I have received, appears to demand. If you do not prevent these Captains from obeying me, order them to depart on the instant to come and save four vessels, which are in evident danger; and if I do not receive an answer in conformity to the will of the King, and such as I demand by this letter, your refusal is sufficient for me: I shall quit Madras on board the Achilles, dismasted as she is, and leave the rest in a similar situation, with their cargoes and equipages, to your care. I shall proceed to France, to give an account to the King and the minister, of the impossibility to which you have reduced me, of executing their orders.

$$
\text { Sighed, "MAHE' de La Bourdonnais." }
$$

At length, after having given all the necessary instructions to the Commissaries and Captains; after having delivered up all the accounts and papers relative to 
Madras to M. Desprémesnil, M. de la Bourdonnais ordered all the troops to be drawn up, and resigned them, October 23,1746 , to his command. As the apprehension of another hurricane had obliged his vessel to get into the offing, he threw himself into a catamaran, and joined her at the distance of four leagues, in a boisterous sea; when he sailed for Pondicherry, leaving his papers, baggage, and servants, to be dispatched after him on the following day, \&c.

Grant。 


\section{CHAPTER X.}

Letters of Baron Grant continued; with an Account of the furtber Operations of M. de la Bourdonnais, £̧c.

\section{LETTER VIII.}

Ioth March, 1748.

I SHALL not presume to give a definitive opinion on such important subjects, as the discussions which have taken place between M. de la Bourdonnais and M. Dupleix. 1 lament most sincerely, that men engaged in such important affairs, and at such an important moment, should be involved in a contest which may prove so injurious to the public interest: but to determine which is to blame in these discussions, we must wait for the termination of them. Both of them are men of superior merit in their respective situations: M. Dupleix is a great administrator, and it is not possible to maintain the honour of France with more dignity than he does.

M. de la Bourdonnais, with less dignity, is at the same time an intelligent governor, a skilful navigator, brave by land as by sea, and of an indefatigable activity.

The rapid successes of the latter, has elevated him very suddenly to a situation which threatened to interfere with the credit and established power of M. Dupleix, who may be supposed to have felt some uneasiness at the appearance of so formidable a rival. It is not improbable that the Minister and the Directors have not sufficiently understood each other respecting the orders given, and the powers transmitted to these two governors; but whatever may be the real cause of their difference, it is very evident, if they had maintained a good understanding with each other, very important services might have been rendered to their country.

M. de la Bourdonnais, during the time he remained in our isles, in the intervals of his operations on the coasts of Malabar and Coromandel, most certainly formed several very useful esablishments, both in the Isle of France and the Isle of Bourbon, though deprived, in a great measure, of the means essential to those objects: but calumny has not spared him; and if the government should conceive the same prejudice against him, as the public at present possesses, he will not very easily extricate_himself from his present difficulties. 
Though M. de la Bourdonnais has, by his knowledge and great activity, been of infinite service to these islands, he had, in the midst of his extraordinary undertakings, found such inadequate assistance, in the resources furnished by government or the Company, that he was under the necessity of employing his authority in obtaining it from the inhabitants. These measures, which have already been mentioned, raised up many enemies against him; as it is not every one who can or will discover, that future good must be frequently purchased at the price of immediate inconvenience.

$\mathrm{He}$ is now gone to France to defend his conduct, and demand the justice of government; and I shall delay the remaining part of his history in India, till we have received an account of his arrival in France.

Among the establishments of this island, a very considerable sugar-work has been formed by M. de la Bourdonnais, in a fine quarter called Villebague, which is the name of his brother, whom he placed at the head of it: but since his departure, it has been transferred to two other brothers, Messrs. le Vigoreux, of St. Malo, captains of ships in the service of the India Company; and they are pushing it forward at enormous expence.

As there is a great deal of fine wood in the island, which is calculated for every kind of construction, M. de la Bourdonnais began to build ships for the service of the Company. The first, named the Insulaire, was unfortunately lost. It was too long in finishing; a circumstance which cost the Company dear, and the lives of the whole equipage. She was commanded by $\mathrm{M}$. de la Baume, and perished on her first going out, in the Ganges.

At this time a frigate arrived to inform us of a war with England: M. de la Bourdonnais accordingly made every preparation for our defence, as well as to carry on his operations in the Indies.

He made us practise various manœuvres of attack and defence, on the principal batteries of the island: we made sham assaults on the forts with bamboo ladders. All our Creoles being thus disciplined and inured to military exercise, formed an excellent corps of volunteers, to join the European troops in the enterprize -which M. de la Bourdonnais meditated on Madras. These Creoles unite /great strength and activity, to an intrepidity that nothing can resist.

M. de la Bourdonnais having ordered all the troops under arms, he presented

$$
\text { O } 02
$$


himself, and commanded all those, whether officers or soldiers, who were willing to go on this expedition, to advance beyond the lines. Not a man remained behind them.

They arrived at Pondicherry, and performed those services to their country, which have been already reiated.

The narrative of the operations of $\mathrm{M}$. de la Bourdonnais has been continued to his return to the Isle of France, at the end of the year 1746; we shall now conduct him to France, and resume his history, at the moment when he quitted Pondicherry for the last time. *

\section{Third Epocba of the Operations of $M$. de la Bourdonnais.}

The Captains of the ships who were at Pondicherry not knowing whom to obey, the Council who retained them, or M. de la Bourdonnais who summoned them to his assistance, determined at length to join the latter. As soon as they were two leagues at sea, M. de la Bourdonnais ordered all the Captains on board his ship, and gave them their instructions, the principal of which was, to follow those which they had received from the Governor and Council of Pondicherry. At the same time, however, he thought it right to deliver his opinion on an article of these instructions, which appeared to him to be founded in extreme injustice.

The Council of Pondicherry, by the fifth article of the instructions which they had given to their Captains, commanded them to exact of the King of Achem, the restitution of the Favori, a French vessel, which the English had taken in his road; and they pretended that, by way of indemnification, he should be made to pay an bundred catis, which amount to two bundred thousand livres of our money. M. de la Bourdonnais considered this proposition as unjust, because the King of Achem not having sufficient force to prevent the English from taking the ship, the French could not, with any degree of reason, render him responsible for a violence in which he had no concern, and could not prevent or repress. The Council of Pondicherry

* We shall now, for the convenience of the reader, conduct $M$. de la Bourdonnais to the end of his career: we have not, it is true, proceeded further in the correspondence of Baron Grant than the year $174^{8}$, and this recital concludes in 1750; but we presumed that these details would be more interesting by being brought together, than by being presented in detached parts. 
well knew that the King of Achem was not in a condition to maintain the neutrality in his road : besides, by the first article of their instructions, they enjoined their Captains to fall on the English squadron, if they found them refitting in the road of Achem. According to their principles, therefore, the King of Achem, after having paid them the value of the Favori, taken from the French by the English, might be obliged to pay the value of the ships which should be taken in the same situation from the English by the French. The absurdity of such a consequence is sufficient to prove the error of the principle.

The Centaur, the Mars, the Brillant, and the St. Louis, soon lost sight of M. de la Bourdonnais, who, with his three wretched vessels, made many fruitless efforts to follow them. He was at length obliged to drive before the wind, which was unfavourable to him, and to make the best of his way to the isles, where he arrived on the ioth of December, in a very bad condition.

With respect to the four other vessels, they anchored at Achem the 8th of the same month, and fortunately for them did not find the English squadron commanded by Commodore Peyton, there, which had sailed for Bengal, nor the two ships commanded by Captain Griffin, who were gone to join that squadron. On their return from Achem to Pondicherry, the French vessels were to be laden with merchandize for the isles, from whence they would pass to Europe, as the Council of Pondicherry had assured M. de la Bourdonnais. The Captains had presented several requests to the Council to the same effect; but M. Dupleix preferred rather to disappoint the Company of the cargoes which they expected, than to send the vessels to the isles, where they would be under the command of M. de la Bourdonnais. He also suspected that the latter might arm them as ships of war, and signalize himself by some new enterprize. The project which he proposed in council was to send them into the Ganges to take Calcutta. Such a proposition equally revolted the Council and the sea officers; nor could they withhold their astonishment, as it was universally known that the Mogul caused the neutrality to be inviolably observed in the river of Bengal, and that any act of hostility there would bring on a war with the Mogul, who could in an instant rase our colonies with the ground, and drive us from Indostan for ever. This humiliating lessson given to M. Dupleix, by those who were not accustomed or disposed to contradict him, inflicted such a wound on his pride, that he indulged himself in expressions full of indignity and resentment. 
At length, however, he grew calm, abandoned his late senseless project, and even condescended to consult his Council, as to the manner in which these vessels should be employed. The Council replied, that there was no choice;-they must proceed to the isles. But M. Dupleix rejected this proposition; and, from an apprehension of attracting new invectives, the Council consented to send the ships to the coast of Malabar, where it was pretended that they would be in a state of security; as their principal object was to keep them out of the way of the English. Such conduct also formed a part of the instructions given to the Captains. They went therefore successively to Galle in the island of Ceylon, to Colche on the coast of Malabar, to Mahé and Goa, \&c. Thus did these ships, in going from road to road, and traversing the seas without any particular view or project, wear themselves out, diminish their equipages, and involve the Company in needless expences; while, under the command of an experienced officer, who would have brought the whole force of the Company to have acted together, it would have rivalled that of the enemy, made advantageous diversions, engaged in useful enterprizes, or, at least, have transported to Europe the cargoes necessary to sustain the credit of the Company. On the contrary, what has been the fate of the greater part of these vessels?-The St. Louis was forced to run ashore, the Princess Mary perished from the want of repairs, and the Neptune was burned under the cannon of Madras. With respect to the rest, they were preserved by the resolution of the Captains, who, after holding a council on their situation, and being satisfied of the impossibility that they could any longer keep the sea, determined, whatever might be the wishes of M. Dupleix, to proceed to the isles, where they repaired their ships and refreshe their crews. *

In the mean time the prediction of $\mathrm{M}$. de la Bourdonnais was accomplished; all the English force in India was united, and eight ships, among others, kept a regular cruize from Fort St. David to Madras; so that Pondicherry and Madras were entirely blocked by sea, while the Moors blockaded them by land.

It may be remembered that, in three of his letters to M. de la Bourdonnais, M. Dupleix had declared his absolute engagements to give up Madras to the Nabob. This promise was certainly inconsiderate; and it was to enforce the completion of it that the Moors had taken up arms. They had already marched a considerable

- These vessels afterwards afforded succour to Pondicherry, under the command of M. Bouvet. 
body of troops into the environs of Madras, before M. de la Bourdonnais had quitted it; but while he commanded in the place they did not venture to approach, or commit any act of hostility ; but no sooner was he embarked, than they began to blockade it. M. Desprémesnil, who commanded there, instantly dispatched deputies to the Nabob, to demand the reasons which induced him to threaten the French with an attack? His answer was, that M. Dupleix had promised to give up Madras to him, and that he was determined to possess himself of it, if that engagement was not immediately fulfilled. M. Desprémesnil replied, that he must acquaint the Governor and Council of the demands of the Nabob, and the difficult situation in which he found himself. These circumstances he thought proper to relate in his own person to M. Dupleix, and was removed from his command.

M. Barthelemy was appointed to succeed him, and, by some active sallies on the Moors, contrived to keep them at a distance, and restore liberty to the place: he was, indeed, assisted in his attacks on the enemy by a detachment sent to him from Pondicherry, under the command of M. Paradis. The latter possessed the first place in the confidence of M. Dupleix. He had been a surveyor in the isles; and M. de la Bourdonnais discovering that he had ambition, talent, and courage, was glad to employ him as an officer in the military service. At length, having asked some advancement, which $\mathrm{M}$. de la Bourdonnais could not grant, without manifest injustice to the senior officers of his troops, he took occasion to quarrel with him, and became his avowed enemy. He succeeded better with M. Dupleix, who preferred him to all his competitors; and he had no sooner received his appointments, than the project which M. Dupleix had so long meditated began to disclose itself. The following orders now arrived at Madras.

\section{Extract from the Register of the Deliberations of the Supreme Council, on the $7^{\text {th }}$ of November, 1746 .}

" The Council, in full assembly, having maturely deliberated on the representations made yesterday by the principal inhabitants of the colony and commanders of ships, declare to the English at Madras, that the treaty of ransom which they had made with M. de la Bourdonnais is null and void; and that the French nation now finds itself in the same relation towards them, as on the day when the town of Madras surrendered to the arms of his Majesty, \&c.

$$
\text { Signed, " "Dupleix, Desprémesnil," \&c. \&ci. }
$$


The orders of M. Dupleix were signified to the English on the $15^{\text {th }}$ of November, and published in Madras at the head of the troops, with a declaration, explaining the new conditions which it pleased the Council of Pondicherry to impose on them.

The declaration was to the following effect.

"1st. That the town of Madras stood in the same relation to the King and Company as on the day when it was surrendered.

" 2 d. That the English should be bound to give up all the keys of the magazines, that the French might take possession of the effects contained in them.

" 3 d. That the English should have liberty to take away their furniture and clothes, as also the wardrobes and jewels of the women: but with respect to merchandize, plate, horses, \&c. they shall remain at Madras, as the property of the French East India Company.

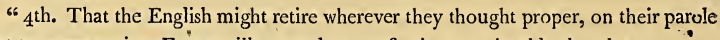
not to serve against France till an exchange of prisoners should take place.

" 5 th. That such as preferred to remain at Madras should take the oath of fidelity to the King, in the person of M. Paradis.

" 6 th. That the Governor and Council should bind themselves not to serve against France; and in case they should refuse to give their parole to that effect, they should be conducted prisoners to Pondicherry."

It is not possible to express the indignation which the publication of this act excited, nor the trouble and disorder which the execution of it produced. The greater part of the English officers escaped, during the night, with their wives and their families, and abandoned the greater part of their effects. Those who remained with the Governor, were conducted with him in triumph to Pondicherry, and presented as a spectacle to the people; at the head of whom appeared M. Dupleix, with the state of a sovereign and the éclat of a conqueror. The Jews and Arminians had the choice to see the pillage of their property, or to go and reside at Pondicherry : with respect to the natives of the country, they were compelled to fly, by the destruction of the Black Town which they inhabited, and was the centre of their commerce. In short, the politics of M. Dupleix were incomprehensible : for after having destroyed the Black Town, which was of the first importance on account of its trade, he engaged in an enormous expence to fortify the White Town, which was altogether an useless place, and not worth preserving when the Black Town was destroyed. 
We shall not enter into a detail of all the foolish enterprizes undertaken against Gondelour* by M. Dupleix, which failed in four distinct attempts; $\dagger$ it will be sufficient to mention, that the mortification he suffered, on his troops being continually beaten and repulsed by the Moors, led on by English officers, incited him to execute an act of vengeance, which cost the Company dear. He dispatched a large detachment from Madras to ravage the lands of the Moors; and the spirit of devastation was, on this occasion, carried to the utmost excess : fifteen Moorish villages were burned, with an immense quantity of grain and effects which they contained. Murder was also added to rapine and destruction; the French killed all they met, and accompanied this horrid enterprize with the most abominable and wanton. barbarity.

An expedition so cruel in itself, and so dangerous in its consequences, disgusted: all the French who were at Madras: the officer who commanded the detachment was. loaded with reproaches; and he had no other mode of excusing himself, but by distributing copies of the orders which he had received : as for the Moors, they meditated an ample vengeance. M. Dupleix, therefore, perceiving the danger that threatened him, found a resource in negotiations, and obtained a peace by dint of treasure; so that both the war and the peace were equally dishonourable to the nation, and ruinous to the Company.

Such a succession of misfortunes, occasioned by his own conduct, did not fail to mortify the vanity of M. Dupleix, who could not but perceive that comparisons were daily made between him and M. de la Bourdonnais, to his disadvantage; but such as ventured to express themselves aloud in favour of the latter, were sure to experience the resentment of the former: they had their place also in the libel fabricated by M. Paradis, to be sent to the Minister and the Company.

In order to continue the history of $\mathrm{M}$. de la Bourdonnais, we must return to the Isle of France, where we had left him, and from whence we shall attend him to the fatal moment that conducted him to the Bastile.

On his arrival at the Isle of France, M. de la Bourdonnais found his place occupied by M. David, whom the Company had named as his successor. The latter had received orders to make every possible inquiry, and obtain all possible

- Cuddalore.

+ The fourth attempt was made while the English were before Pondicherry. 
information, relative to the administration of his predecessor. He was at the same time ordered not to give up to him the command of the ships which were to return to Europe, if he had been guilty of any malversations.

M. David had acquitted himself of his commission before M. de la Bourdonnais arrived at the Isle of France, and was fully convinced, that all the complaints exhibited against him had proceeded from passion, and a spirit of mutiny. Besides, to give the fullest proof in his favour of the uprightness of his conduct to individuals, as well as of his zeal and fidelity to his King and the Company, M. de la Bourdonnais publicly called upon those who had been injured by him in any way whatever, in both the Isles of France and Bourbon, to come forward with their charge, that he might immediately do them justice, and make such restoration as they had a right to claim: but though he was now deprived of his government, and was not only a private, but in some measure a disgraced man; not a single complaint appeared against him. In short, so irreproachable in every particular did the conduct of M. de la Bourdonnais appear, that M. David did not hesitate to deliver to him the King's order to command the ships destined for Europe.

The repugnance with which $M$. de la Bourdonnais accepted the command, will be easily conceived. Mortified to the quick by these injurious inquiries into his conduct, his justification did not save him from the chagrin he experienced at having been suspected. However, that he might not be reproached for having refused to do his duty in this critical conjuncture, he undertook the command of the squadron of six ships, which were so weak, that the equipage of several of them did not amount to an hundred men. Nor was this all : he was to conduct these vessels to France, in the midst of English squadrons who possessed the sea; and, which naturally made a deep impression on his mind, his wife and children were to share his dangers with him.

In his passage to the Cape of Good Hope he encountered a tempest, which dispersed his six ships; and he thought the moment was arrived, when he and his family should perish together in the waves. The storm at length subsided, and he continued his voyage alone, as the whole of his squadron had disappeared. Three of his ships, however, having rejoined him, they arrived together at Angola, where he had orders to refresh. As to the other two vessels, he saw them no more; and 
he learned, after his arrival in France, that one, being almost a wreck, had taken refuge in the Bay of All Saints, where she was condemned, and that the other returned to the Isle of France.

While M. de la Bourdonnais was at Angola, he was informed of the appearance of two English ships; he accordingly dispatched one of his officers in a canoe, to discover if they were merchant vessels, or ships of war : they were found to be the latter, and another soon joined them. M. de la Bourdonnais, therefore, was convinced that the information he had received from Europe was too true, which stated, that a great number of English vessels were waiting for his squadron on all sides, having received notice of his return.

Determined as he was to defend himself, with his four ships, to the last extremity, he did not feel a sufficient degree of courage, or rather of insensibility, to expose his wife and four children to the dangers with which he was menaced; he therefore put them on board a small Portuguese vessel at Angola, to transport them to the coast of Brasil, from whence they were conducted to Lisbon on board a ship in the service of the King of Portugal; and from thence they proceeded to France. As. for him, he set sail for Martinico, according to the orders which he had reccived.

In the persuasion that he should meet with the enemy's squadrons, which would be very superior to his, he had conceived a manœuvre that no seaman had ever employed, to have saved the best of his ships, and, in general, all the crews; but he was so fortunate as to avoid the English throughout his course, so that he arrived. at Martinico without any interruption.

His ships being in safety in the port of that island, his next object was to take such measures as would secure their return to Europe. He had received orders. to remain at Martinico till the latter end of October, 1747 , in order to be convoyed by the King's ships; and to dispatch an officer, in the mean time, properly instructed, to give an account to the Court and the Company, of the situation. of the East India colonies. On the other hand, his squadron was not in a condition to put to sea, without an augmentation of stores and men, which Martinico was not in a condition to furnish. At length, he conceived a project which promised to indemnify the nation for all its losses; and M. de Caylus, Commandant of Martinico, considered the success of it as so certain, that he had associated bimself in it. It became necessary, therefore, to inform the ministers of this project, as appears by the letter of M. de Caylus, and M. de Ranche the Intendant, 
to M. de Maurepas. M. de la Bourdonnais accordingly left his squadron at Martinico, and, provided with passports and letters for the Dutch Governor, he set out to find at the Isle of St. Eustatius, some vessel on which he might embark for France.

On passing from Martinico to this island he assumed a feigned name, and ventured in a small boat, with M. Laurent his principal secretary, and a single domestic. In the passage he was chased by an English man of war, which forced him to deviate very much from his course; a circumstance that saved his life: for otherwise he would have arrived at St. Eustatius at the very moment when a tremendous hurricane was ravaging that coast, and whose violence was so great, that of forty vessels which were in the road of that island, not one was saved. This misfortune obliged him to remain forty-five days at St. Eustatius, to wait till a vessel could be refitted. It was a small Dutch ship, which was bound to Flushing.

As they approached Europe, they met an English vessel, who assured them that war was declared between France and Holland. This news rendered it necessary for the Dutch Captain to put into an English port, in order to procure a convoy. M. de la Bourdonnais was therefore taken into an enemy's country; and, though he had changed his name, he was not without apprehensions that he might be discovered; and they were too well founded: for as the intelligence had arrived in England, that he had embarked from St. Eustatius to get to Europe in a Dutch vessel, the ship was so strictly visited on its arrival at Falmouth, that he was discovered, and conducted to London as a prisoner of war.

There he was treated with every mark of regard and distinction; was received by the Ministers and Directors of the East India Company; and was favoured by very particular attentions from two gentlemen, who were members of the Council of Madras when that place was taken, and had since returned to England.

In short, to give an idea of the opinion which was entertained in England of M. de la Bourdonnais, it will be sufficient to observe, that on his request to return to France, the government refused any other security than his own word, and he quitted London on his parole the $22 \mathrm{~d}$ of February, 1748 . On the Sunday following he arrived at Paris, and he instantly set out for Versailles, where he had a conference with the minister. But the memorials from Pondicherry had excited an universal prejudice against him. In fact, these memorials, some of which appeared to be signed by ail the Council, and others by the whole colony, could not fail to 
impose very powerfully on the public opinion. It was not to be supposed that such united testimonies were founded in falsehood or misrepresentation. Besides, the facts charged in these libels were of a very serious nature, since he was accused of nothing less than holding intelligence with the enemies of the state, of disobedience to the orders of the King, and of misapplication of the funds and effects of the Company. It was not, therefore, possible for the minister to enter, of himself, into the examination of an affair which would probably require a very long discussion : on the other hand, it would not be prudent to leave a man in the enjoyment of his liberty, who was charged with so many capital offences. Thus M. de la Bourdonnais became the victim of state necessity, and no sooner appeared at Versailles, than he was arrested by order of the King, and conducted to the Bastile on the $2 \mathrm{~d}$ of March, $174^{8}$.

By letters patent of the $7^{\text {th }}$ of the same month, his Majesty named commissioners to examine the affair of $\mathrm{M}$. de la Bourdonnais; who, after he had languished twentysix months in prison, decreed that he should have permission to communicate with his council.

It has been said, that the interest of his wife alone, who was of the family of Auteuil, preserved him from being sacrificed: but, whether it was from chagrin, or some other cause, he did not long survive. *

M. de la Bourdonnais however was soon revenged. M. Dupleix was, in his turn, obliged to render an account of his conduct, and died in a state of penury, having lost the fruit of his labours.

\section{Continuation of the Letter, dated 10 th of Marcb, 1748.}

TH Is war, as you see, continues; and whole fleets, which were destined for our island, have been taken or destroyed; so that a few corvettes alone arrive here to announce these disasters, and they are very often in a crippled and dismasted condition.

We have been informed that fifteen ships have been dispatched from the East, laden with provisions for our islands; but unfortunately the English fell in with them, and, being superior in point of force, have taken them all, except a small vessel, which escaped to make us acquainted with our misfortunes. We live at present in a most wretched state of incertitude, in want of every thing; and, to complete

- It has been suspected that he was poisoned. 
our misery, afflicted with a continued drought, which has known no interval through. out the year, but from an hurricane that visited us during the last month. It ravaged every thing, and occasioned many fatal accidents. Several persons were killed and wounded during its continuance; and, to complete our distresses, it was succeeded by a cloud of locusts, which devoured whatever the hurricane had not laid waste. Such is our present situation, \&c. \&c.

Grant. 


\section{GHAPTER XI.}

Letters of Baron Grant continued.-Some Account of Animals in the 1sle of France, Hunting, छ̋c.-Circumstances respecting the Maroon Negroes, Slaves, छc.Arrival of M. David, wbo succeeded M. de la Bourdonnais as GovernorGeneral-bis Character and Conduct.-The Island tbreatened by an Englisb Squadron, छ̊. छ6.-ill Success of the latter.

\section{LETTER IX.}

Isle of France, June, 1749 .

$A_{s}$ the climate is very warm, I frequently remain for several successive days and nights in the forests and mountains, to enjoy the pleasure of the chase.

I most frequently hunt the stag,* and the cabri, a kind of wild goat, which is very active, runs among the mountains, leaps from rock to rock, and delights in ascending those narrow ledges and sharp points of the rocks, which are inaccessible to every other living creature. This mode of hunting is very dangerous, from the narrow and difficult ways we must necessarily pass in pursuit of our game.

We have had for some time a charming little animal in our woods, called the gazelle, or antelope. M. David brought it from Senegal; + but unfortunately the hunters of the island have, in a great measure, destroyed them. Different sorts of

* The stags (supposed to have been brought to Mauritius by the Portuguese) are smaller, and of a greyer colour than those of Europe.

t In Senegal and on the Gambia great herds of these little gazelles may be seen. It is, according to M. de Buffon, the cbevrotin, (tragulus, Brisson.)-cervus perpusillus, juvencus guincensis, cervus Africanus pilo rubro, Seba, \&c. "They are, (says Bosman,) the prettiest little creatures in the world; they are not much larger than a rabbit: the Negroes call them the little kings of the stags. Their legs are about the size of a goose quill; their horns are also very small, and of a bright black : they are so light that they seem to fly amongst the bushes; however, the Negroes catch them sometimes. These little animals are too delicate to be brought here, as they can only live in the hottest countries." 
antelopes are common in Africa, Asia, and the East Indies. The African antelopes resemble the roebuck in size and figure; their ears are large, and lined with a very black hair, which has the gloss of ebony : their horns are black, with fluted rings to half their length, and resemble the antique lyre. The outline of the horns of the female are less round and curvated than those of the male. At their root there is a tuft of hair, which is longer than that of the rest of the body. Their hoofs have the same polish as those of goats: the Arabs, indced, call them by the latter name.

The antelopes are gregarious, and chew the cud. Their large black eyes are so lively, and at the same time so tender, that the Eastern people think them a complimentary comparison for the eyes of a beautiful woman. The fore legs are not so long as the hinder ones, which, as in the hare, gives more facility in ascending than descending. As to their colour, the greater part are fallow on the upper parts of their body, and white under the belly, with a brown stripe which separates these two colours on the lower part of the flanks.

The wild antelopes are taken by means of a tame one, to whose horns a snare made of cords is curiously attached. When an herd is found, the tame animal is sent among them; when the wild males instantly advance to oppose him, and, in butting violently with their horns, are entangled in the noose. In this struggle they both fall to the ground, when the hunter arrives to kill the one and disengage the other.

We have as yet but a small quantity of wild boars, which we call Maroon hogs. They are the descendants of those which the Portuguese left behind them in the woods of these islands, when they made the discovery of them. Those which we breed for our domestic purposes, are of the small China kind. Our goats also have proceeded from those left here by the original discoverers.

The Maroon hogs are not so mischievous as our wild boars in Europe. They are very fat, as well as the deer; and the heat allays the fierceness of the one, as well as the running of the other.

When a stag is killed, an entertainment always follows, as the flesh will not keep more than two days: the neighbours are accordingly invited to partake of the feast; and though this island does not produce wine, rather from a defect in the knowledge of cultivating a vineyard, than any unfavourable qualities in 
the air or the soil, we contrive to enliven our festivals with the produce of Bourdeaux.

M. David, who has succeeded M. de la Bourdonnais as Governor, has published a general prohibition against hunting, to prevent the total destruction of the game, which, in case of dearth, would at all times prove an effectual resource; but, unfortunately, it is very difficult to compel the strict observation of this edict.

All the inhabitants are enchanted with the manners of M. David. He will not prove, perhaps, so enterprising as M. de la Bourdonnais, but mildness, humanity, and politeness, are, nevertheless, the least of his good qualities.

We have here a species of hunting which, as we are on that subject, I shall not omit to mention : it is indeed of a cruel kind in appearance, but absolutely necessary in point of policy. It consists in pursuing the Maroon Negroes, or deserters, in the woods and the mountains, where they are treated as wild beasts : they are shot whenever an opportunity offers, and this severity is absolutely necessary for our preservation. It is true, that, in general, they content themselves with pillaging what they want for their support; but they will sometimes accompany their plunder with fire and sword. The danger arising from the hostilities of these runaways, is increased by the perfect knowledge they possess of the plantations which they have deserted. Besides, their old comrades and mistresses will frequently give them information of the most convenient opportunities to descend on their pillaging parties, and second their designs; so that they may be said to keep us in a state of continual disquietude and hostility.

Our slaves, and particularly those which come from Madagascar, are insolent and idle, and consequently of little reliance. They have been more accustomed to war than to labour; and the hope of finding some means of returning to their country, employs all their thoughts. Though it is necessary, in order to catch the wind, to make a large circuit in coming from Madagascar to the Isle of France, they seem to have an instinctive knowledge, that the distance of their country is not in proportion to the length of the voyage: they will direct their hand to the point where it lies, and exclaim, in their corrupted French, "ça blanc là li beaucoup malin; " li couri beaucoup dans la mer la baut; mais Magascar li ld." This opinion incites them sometimes to undertake the most desperate actions; and they will make the most daring attempts to return to their home. They sometimes regard us with a ferocious aspect, as they have adopted the belief, since the affair of Fort 
Dauphin in their island, that the wine we drink is the blood of Negroes. They escape into the forest and mountains of the Isle of France; and whenever they find a canoe or other small boat along the coast, they endeavour to get possession of it, and discover not only uncommon courage, but address and agility in getting to sea. Sometimes they contrive to make a large pirogue or canoe of a single tree, some of which are very large in this island; and in one of these they will attempt a passage of an hundred leagues. It also happens that, when they are found to be too numerous for the canoe to contain them with safety, they will alternately embark and swim throughout the voyage. Though many of these adventurers are lost, some of them have been known to reach their native island.

We do not, however, go in pursuit of them, but when they have invaded the plantations, or committed some crime which calls for vengeance, as it once happened with respect both to my uncle and myself.

Bcing informed of my absence, eight of them entered, during the night, into his apartment. They deliberated for some time whether they should not murder him; but perceiving he was asleep, they contented themselves with robbing him as well as me; and, among other things, took my fire-arms and a barrel of powder.

Enraged, on my return, at this daring act of plunder, I took a small detachment of soldiers with me, and remained six weeks in the forests and mountains in pursuit of them. I killed the first who presented himself, and who was on the moment of employing my own arms against me. We took the most dangerous of them, who had been guilty of several murders, and they suffered the punishment they deserved. One of them had been my huntsman, and had rendered himself so formidable throughout the island, that it was dangerous to frequent the roads in the neighbourhood of the woods, from an apprehension of this man and his band of companions.

The arrival of our new Governor brought prosperity along with it: at the same time five ships arrived from Nantes, laden with flour, wine, and other necessary provisions for the island.

M. David* has already been Governor of Senegal : he is rich, and demonstrates

* M. David was a native of Provence, and the son of a Director of the East India Company. After he had made the pecessary arrangements for the welfare of the colony, he engaged in certain undertakings on his own account. One of these he formed on the sea shore, for the manufacture of lime, and placed seventy Negroes in it. This was a very necessary establishment, in order to carry on the public buildings of the Company. He also built an house for himself of stone, which 
the best possible intentions for the welfare of the colony. He has already built a very pretty frigate, which has been sent to France.

As we are now at war with England, it was natural to apprehend that our island would be attacked, and we have been employed in putting ourselves in a state of defence, which advances but slowly, though we have able engineers: but we trust too much to the natural advantages of the island, and the trifling success we have had on the attack which has lately been made on us.

In the month of July last, an English fleet of twenty-eight ships of war, commanded by Admiral Boscawen, arrived off this island, and advanced within cannon shot of it. Our port was full of vessels belonging to the Company, with one ship of war of sixty guns, named the Alcides, commanded by M. de Kersaint, who laid her across the entrance of the port.

The English came to an anchor, as they imagined the French squadron, bound for India, was still in the harbour. We worked all night, though with a great deal of confusion, to be in readiness for the following day.

The Count de Restaing, who had been commandant of our artillery, had, before his departure, examined the arsenal, and having found an old mortar, had placed it on the point that commands the entrance of the habour, before which the English fleet was at anchor.

At break of day, we found ourselves in a state to discharge a bomb at the nearest of the enemy's vessels, which, however, did not reach it : a second was thrown nearer to it; and the English Admiral thought proper to increase his distance, in a small degree, on the conjecture that we had a battery of mortars; and when he perceived that no more were discharged, he concluded that it arose from his being removed out of their reach, though the real cause proceeded from the impossibility of throwing another shell, as, by the second discharge, the mortar had been rendered useless.

The enemy remained off the island for several days, and from the frequent communication between the ships, the boats being continually passing from one to the other, we concluded that they held frequent councils respecting their future conduct.

On the sixth day, one of their largest vessels approached within cannon-shot of he named $L^{\prime}$ Epreuve, as it was the first of the kind which had been constructed in the island. He also formed plantations of cotton, and erected all the necessary magazines for cultivatil.g it with advantage and convenience. 
a place where they supposed that we had a masked battery: they cannonaded it from break of day, without the least return, as it was nothing more than a large heap of faggots, collected for a lime furnace, which their balls scattered about.

In the evening of the same day we saw a number of well armed sloops, escorted by a frigate, and ranging before the batteries, which, however, could not reach them. We concluded that their intention was to make a descent at a place called the Little River, which was not guarded, and where there was a small inlet, through which one boat alone could pass at a time. As I was attentive to guard the coast, I hastened to this point with some small pieces, and arrived there at an early period of the night. I saw the frigate and the sloops furling their sails opposite to me, while the latter appeared to be approaching the opening of the river. I immediately ordered my artillery to play, and, on the first discharge, the drums, which had scattered about in different places at some distance, with orders to come towards me, at that signal, came beating a march; which made the English suspect that my force was very considerable, and they accordingly retired from the shore. I however thought it necessary to pass the night under arms. At break of day the different vessels were returned to their former stations, and at eleven A. M. the whole flect was under sail.

Four of their ships, after having saluted the Admiral, passed to leeward towards Madagascar, while the rest held their course to windward, as if proceeding to India. It has been since said, that these four ships had several families on board, and a large quantity of every kind of utensil for the cultivation of the island, on the capture of which they had reckoned. The same report added, that we were all of us to have been sent to the Cape of Good Hope.

The enemy was certainly deceived by appearances, and concluded, from circumstances which were very fallacious, that we were in a state of defence very superior to our actual capacity. Or they might have imagined, that the time apparently necessary to take the island, would interfere with more important operations in India. But the English fleet was not more fortunate there, as our squadron was in a condition to meet them. Their campaign, indeed, was altogether fruitless, and they were glad to winter in their own settlements, \&c. \&c.

GRANT. 


\section{CHAPTER XII.}

Some Account of the Island of Madagascar, from the Observations of Admiral Kempenfelt.*-Letters of Baron Grant continued.-Curious History of a Princess of Russia, छ̈c.

$\mathrm{T}_{\mathrm{H} \mathrm{E}}$ Isles of France and Bourbon are so connected with that of Madagascar, by the continual commerce which is carried on between them, that the history of the latter is, in some degree, essential to the history of the former.

Madagascar is one of the largest isles in the world, and susceptible of many advantages; having an excellent soil, a fine climate, commodious bays, and navigable rivers. The only commercial objects which it produces are rice, cattle, and slaves. The natives are brave and honest, but extremely ignorant, though they are so often visited by European vessels. The French frequent the eastern side of the island; Saint Mary, Foule Point, Fort Dauphin, \&c. ; while the English principaliy visit the western side, in the Bay of Saint Augustine, \&cc. The French are actually establishing and fortifying a colony at Fort Saint Mary.

The subsequent communications, afforded by Admiral Kempenfelt, were originally received by him from $M$. Reglade, who had been in the service of the French East India Company for upwards of fifty years. He was on board the ship called la Paix, when it was wrecked on the Isle of Bourbon, and returned to France as a passenger, in the same ship with the Admiral.

"The King Massilige appears to be the most powerful prince in the island, and greatly favours the French in their commerce with him. He has a fort built of mud, in the European manner, in which there are from thirty to forty large cannon, and a numerous garrison of his own soldiers. M. Reglade had seen several thousand of them armed with musquets, and well disciplined.

"His palace is built in the European style, and has two stories; it contains a reserve

- As we lately mentioned the Negroes which are obtained from Madagascar for the service of the Isle of France, we have thought this a proper place to introduce the observations of Admiral Kempenfelt, on the former of these islands. 
of arms, and some articles of furniture brought from Europe; such as tables, chairs, and glasses of the first manufacture; with a palanquin very commodiously contrived and lined with crimson velvet. M. Reglade supposed that these things had been brought by the pirates, who formerly cruised off the coasts of this island, and infested the Indian seas.

"The King appeared to have absolute sway in his dominions; and if his subjects did any thing that was unjust or insulting to the French, he punished them with the greatest severity. The French found that the country produced both cotton and silk, of which they sent samples into France, that were approved; and people, properly qualified in those branches of manufacture, were sent to bring them to perfection. On ascending a river they came to a large rock of crystal, with which M. Reglade loaded several boats : he made presents of it to several persons of distinction, who set an high value upon it. In the bay; where there is excellent anchorage, there is also a small isle, which is very fertile and commodious for the refitting and repairing of ships; and in which the princes of the country have permitted the French to form an establishment. There are several Arab families settled among them, who construct small vessels, and trade from thence with Persia and the Red Sea, touching in their voyage at the Isles of Mohilla and Jounna for refreshments. Mr. Reglade was of opinion that the people of those islands send ships also to trade in different parts of Madagascar.

"The Arabs are the only inhabitants of the island who know how to navigate in the open sea; and they serve as pilots to the ships which are approaching to, or departing from the coast. The last French ship that was among them having taken one of these Arabs aboard, was run aground: the Captain, being alarmed for the safety of his vessel, in the first transport of his anger, declared he would complain to the king, and have his head cut off; whereupon the Arab drew his poniard, and killed the captain and one of his officers; he then leaped into the sea and was drowned. Those who remained in the ship, disengaged her, and returned to the Isle of Mauritius : since that event, the trade with Madagascar has ceased.

Port Dauphin, which was the first establishment that the French had formed at Madagascar, has long been abandoned, and the inhabitants of the island have driven them from another, which they had formed at Foule Point. This circumstance was occasioned rather by the bad conduct of those to whom the French Company had entrusted their affairs, and the indiscreet manner with which they treated the 
inhabitants, than by any perfidy or cruelty on the part of the latter, as they are, in general, found to be a civil and hospitable people; but they will not be insulted and treated as slaves in their own country: an error common to many European nations in those parts of India where they have settled and received encouragement. None have been more subject to this error than the French, which has already produced very disagreeable consequences, and will, it is to be feared, produce more.

"The King of this part of the island was called Tom Simcols, according to the French pronunciation, and as he and his sister both pronounce it. They were the children of an English pirate, and spoke the language of their father tolerably well; but from their commerce with the French, they spoke that language still better. The King treated the French established in his country with the greatest distinction: nay, they pretended that, before his death, he had settled his kingdom upon them; and when that event happened, they took possession of it, but were soon after driven by the natives from their presumptive claims.

"When M. de la Bourdonnais was dismasted by a violent gale of wind on this coast, he put into the Bay d'Antongil, in whose woods he found trees fit for masts, which enabled him, though with infinite difficulty, to complete his repairs.

"According to the relation of a French officer, the ships of that nation trade with the inhabitants on the coast of Madagascar in the following manner :

" A man or a woman from the age of $\left\{\begin{array}{l}\text { Two muskets; } \\ \text { Two cartouch boxes; } \\ \text { Ten flints; } \\ \text { Ten balls; or fifteen hundred balls, or } \\ \text { thirteen to forty }\end{array}\right.$
" For a bullock
"For an heifer
" For two heifers 
"A partridge, a turtle, or a quail $-\left\{\begin{array}{c}\text { Two or three balls, four or five flints, or } \\ \text { three needles. }\end{array}\right.$ "A pot containing three quarts _ $\quad$ Two knives, or twelve needles.

"Four measures of mead, or wine made?

"from honey - - - - $\}$ - $\quad$ - knife, or ten balls, or six flints.

"A pot of honey with the wax - $\quad$ "

"A pot containing three quarts of milk $\left\{\begin{array}{c}\text { Two pounds of powder, or six balls, or } \\ \text { eight flints, or eight needles. }\end{array}\right.$

"When the King pays his first visit to a French ship, he generally brings a present of two bullocks, one cow, three capons, two fowls, two baskets of rice, and some pots of honey with the wax.

" The King is well contented when they receive his present with pleasure, and that he receives in return, the usual acknowledgments of muskets, white and blue coarse linen, with looking glasses, flints, \&c.

"This is the best information I could obtain," continues Admiral Kempenfelt, "from the French officers: but as I have observed that the inhabitants of the west coast of Madagascar, in Saint Augustine Bay, where I have twice been within the last four years, make a considerable progress in commercial knowledge, and gradually advance the price of their merchandize, I have no doubt but it is the same on the eastern coast, and that the prices of mercantile articles vary there every year.

"I am of opinion, that the captains of India ships would not find it lost time, if they were to go in search of some other commodious port, on the coast of this island, where the inhabitants have not yet been instructed by their commerce with the nations of Europe.

"We have added but little for many years to our knowledge of foreign coasts; and we appear satisfied with the discoveries of our fathers, as if our charts had attained their utmost degree of perfection.*

"Captains who miss their passage by the Cape of Good Hope, and put into the Bay of Saint Augustine, where they sometimes remain for two or three months, without any employment, might employ their officers and principal boat in very useful objects, and without the least danger, if they had either a becoming ambition, or a laudable curiosity."

* It must be observed, that this account was written in the year $175^{8}$. 


\section{Tope History of a Princess of Russia, at Mauritius, Eंc.}

The Baron Grant, in his Letters X. and XI. written in the year $175^{\circ}$ and $175^{1}$, describes, in a very interesting manner, the scenes of domestic life in that country; but we shall content ourselves with extracting one of the principal facts mentioned in the first of these two letters, and in the secret memoirs of Mr. Duclos, concerning the curious history of the Princess Wolfenbuttel, who passed some years at the Isles of France and Bourbon, during the residence of Baron Grant there.

" Charlotte Christina Sophia de Wolfenbuttel, wife of Czarovitz Alexis, son of Peter the First, Czar of Muscovy, and sister of the Empress of Charles VI. was born the ${ }_{2} 5^{\text {th }}$ of August, ${ }_{1694}$. This princess, though possessed of beauty, grace, and virtue, in a very high degree, became an object of aversion to her husband, a man of a most ferocious and savage character. He had several times attempted to poison her, when she was saved by counteracting medicines.

"At length, he one day gave her such a violent kick on her belly, when she was eight months advanced in her pregnancy, that she fell senseless on the floor, which was soon encrimsoned with her blood. Peter the First was then engaged in one of his journies. His son, having every reason to believe that his unfortunate Princess would not recover, set off immediately for his country house.

"The Countess of Konismarck, mother of Marshal de Saxe, attended on the Princess when she was brought to bed of a dead child, and nursed her with unceasing care. Being sensible, however, if the Princess recovered, that she would perish, sooner or later, from the brutal nature of the Czarovitz, formed a plan to gain over the women belonging to the Princess, to declare that she and the infant were both dead. The Czarovitz accordingly ordered her to be interred without delay and without ceremony. Couriers were dispatched to the Czar to inform him of the event, and all the Courts of Europe put on mourning for the bundle of sticks which was interred.

"In the mean time the Princess, who had been removed to a retired spot, recovered her health and strength; when, possessed of some jewels, with a sum of money which the Countess of Konismarck had procured for her, and clothed in the dress of common life, she set off for Paris, accompanied by an old German domes¿ic, who passed for her father. She made but a short stay there, and having hired a female servant, proceeded to a sea-port, and embarked for Louisiana. 
"Her figure attracted the notice of the inhabitants, and an officer of the colony, named D'Auband, who had been in Russia, recollected her.

"It was however with some difficulty, that he could persuade himself of the reality of what he saw. Indeed it was scarce possible to believe that a woman in such a situation, could be the daughter-in-law of the Czar Peter. However, to ascertain the truth, he offered his services to the pretended father, and at length formed an intimate friendship with him; so that they agreed to furnish an house, and live together at their common expence.

"Some time afterwards, the gazettes which arrived in the colony announced the death of the Czarovitz. D'Auband then declared to the Princess his knowledge of her, and offered to abandon every thing in order to conduct her to Russia.

"But she, finding herself infinitely more happy than when she was within the verge of royalty, refused to sacrifice the tranquillity of her obscure situation, for all that ambition could offer her. She only exacted a promise from D'Auband to maintain the most inviolable secrecy, as well as conduct himself towards her as he had hitherto done.

" He made the most solemn declaration that he would obey her commands; and it became his interest to be faithful. The beauty, understanding, and virtues of the Princess had made a very deep impression on him, and habitual intercourse had served to strengthen it. He was amiable and young, and she was not insensible to his attentions. They continued, however, to live in their usual way, but became every day dearer to each other.

"The old domestic, who passed for the father of the Princess, at length died; and she could no longer, according to the rules of decorum, live with D'Auband as she had hitherto done, under the apparent authority and protection of a parent. In this delicate situation, D'Auband unfolded to her the dispositions and sentiments of his heart; and proposed to add a new veil to her real condition, by becoming her husband. She consented to his proposition; and this Princess, who had been destined to wear the crown of Russia, and whose sister actually wore that of the German empire, became the wife of a Lieutenant of Infantry. In the first year of her marriage she had a daughter, whom she nursed and educated herself, and instructed in the French and German languages.

" They had lived ten years in this happy state of mediocrity, when D'Auband was attacked by the fistula; and his wife, alarmed at the danger which generally 
accompanies the operation necessary for the cure of that disorder, insisted that it should be performed at Paris.

" They accordingly sold their habitation, and embarked on the first vessel that sailed for France. On their arrival at Paris, D'Auband was attended by the most skilful surgeons; and till his cure was completed, his wife never quitted him for a moment, nor suffered any other person to perform the tender offices which were necessary in his situation: she waited upon him throughout his illness with the most watchful and patient affection. On his recovery, D'Auband, in order to secure to her the little fortune which he possessed, solicited from the East India Company an employment in the Isle of Bourbon, where he was appointed Major.

"While he was engaged in soliciting this business, his wife sometimes went to take the air with her daughter, in the gardens of the Thuilleries. One day as she was sitting upon a bench, and talking with her daughter in German, that she might not be understood by those who were near her, Marshal de Saxe passed by, and hearing two ladies speak his own tongue, stopped to look at them. The mother lifting up her eyes and recollecting the Marshal, instantly threw them to the ground; when he, still more attracted by her embarrassment, suddenly exclaimed,- "Is it possible, Madam !'- She did not, however, permit him to finish the sentence, but rising from the seat, begged him to accompany her to a more retired part of the garden, where she acknowledged herself, and, after having requested his entire secrecy, invited him to see her at her own habitation, when she would inform him of every thing which concerned her.

"On the following day Marshal de Saxe paid her a visit, and heard the recital of her adventures, as well as the share which the Countess of Konismarck, his mother, had in them. She conjured him, at the same time, not to reveal any thing respecting her to the King, till a negociation which her husband was agitating was concluded, and which would be completed in three months. The Marshal solemnly promised to comply with her request, and paid his visits to her and her husband in the most secret manner.

" The three months being almost expired, the Marshal, on calling to see her, was informed, that she and her husband had quitted Paris two days before, and that M. D'Auband had been named to a Majority in the Isle of Bourbon.

"On this information, the Marshal went immediately to Versailles, to give an account to the King of every thing that related to the Princess; when his Majesty 
sent for the minister of marine, M. de Machault, and, without assigning any reason, ordered him to write to the Governor of the Isles of Mauritius and Bourbon, to treat M. D'Auband with every possible mark of distinction; which order was punctually executed, according to the report of Baron Grant, who had been a long time in her society; and remarks, as an extraordinary circumstance, that he had seen that Princess pregnant when she was upwards of fifty, about the year 1745 . The King also wrote to the Queen of Hungary, with whom he was then at war, to inform her' of the fortune and situation of her aunt. The Queen accompanied her letter of thanks to the King with one to the Princess, in which she invited her to come and reside with her; but on condition that she would quit her husband and daughter, for whom the King engaged to make a suitable provision. The Princess did not hesitate a moment to refuse these conditions, and remained with her husband till the year 1747 , when * he died.

" Being a widow, and without children, she returned to Paris, and took up her abode at the Hotel de Peru. Her design was to retire to a convent; but the Queen of Hungary offered to fix her at Brussels, with a pension of twenty thousand florins; but (adds M. Duclos,) I am altogether ignorant whether she went to reside there: but this I know, that within these six years she was at Vitry, where she lived in a very recluse manner, with no more than three servants, one of whom was a Negro. She was then called Madame de Moldack; but $I$ know not who M. de Moldack was, and when she married him. She is now a widow: I saw her as she was taking a walk, in the year $1768 . " *$

In the second of the two letters mentioned in this Chapter, and dated $175^{1}$, Baron Grant speaks of the arrival of the famous $M$. D'Apres at Mauritius, and gives an account of his first astronomical and nautical observations there, which, with some important additions, will be the subject of the following Chapter.

* This last account was written in 1771 . 


\section{CHAPTER XIII.}

Instructions for sailing to India by the Isles of France and Bourbon.-An Account of the Winds that prevail in the Eastern Ocean.-A Memoir on tbis Arcbipelago, and the Dangers to which Sbips are particularly subject, to the Nortb and North-East of Madagascar and Mauritius, by M. D'Apres de Mannevillette.

"VESELS which are bound to the Isle of France, after having doubled the Cape of Good Hope, must keep to the east, on the parallel of $35^{\circ}$ to $36^{\circ}$ of latitude, till by $55^{\circ}$ of east longitude; from thence they must take their course to the east-northeast, and then to the north-east. They will at length gain the parallel of $26^{\circ}$ of latitude, by $61^{\circ}$ of longitude; that is, north and south of the Island of Rodriguez.

"From this last position, they will make good their course to the north, to $20^{\circ}$ of latitude. In navigating in this manner, the great errors which have arisen from the reckoning of the longitude will be evident, and they will not fail to reach the object of their destination.

"An attentive observation to the variation of the compass, procures the same advantage in the Indian seas, as to the west of the Cape. Its variations appear to keep such a proportion between them, in going from the west to the east, or from the east to the west, that they may be considered as the means of discovering the same errors in the reckoning.

"The variation was about $20^{\circ}$ north-west at the Cape of Good Hope; it increases towards the east, as much as to $27^{\circ}$; and this, the greatest variation, is found almost north and south in the middle of the Mozambique Straits. It then lessens in going to the east; but I was not able to make such a succession of observations as to enable. me to form an instructive table. In the year $1757, \mathrm{I}$ observed that the variation was $11^{\circ} 15^{\prime}$ at the Island of Rodriguez; and I remarked that in this part of the Eastern ocean, the same line of variation extended almost from south-east to north-west.

" The bank, which I have traced upon my chart to the south of the straits of Mo-

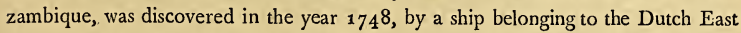
India Company, called the Van Capel, in going from the Cape to the Isle of France, in $37^{\circ} 20^{\prime}$ south latitude, and $20^{\circ} 20^{\prime}$ east from the Cape of Good Hope. This 
ship sailed along it one whole day, and remarked that it extended twenty-six leagues from east to west, and fourteen leagues from north to south. Although there has been no subsequent confirmation of the existence of this bank, it may, at all events, be prudent to entertain some apprehensions of it. I have passed to the north and to the south of it, but at such a distance, that I could not observe it. I remarked, however, as many other navigators have done, that in this part of our course the sea was agitated, and the waves very short.

"When you have got to $20^{\circ}$ of latitude, as has already been observed, you must make good your course to the west, till you are in sight of the Isle of France.

"The variation of the compass will determine, in a great measure, if you are to the east or the west of the Island of Rodriguez. In the first case, you will find it from $9^{\circ}$ to $10^{\circ}$, according to the distance; but if you observe it from $12^{\circ}$ to $13^{\circ}$, you will then be between the two islands. In short, if the difference in the reckoning of the longitude should be on the east, and Rodriguez should be in sight, you must bear away to the southward of it.

“ This island is situated in $19^{\circ} 40^{\prime}$ of south latitude, and in $60^{\circ} 52^{\prime}$ of east longitude, * according to the observations of $M$. Pingré, in ${ }^{1761}$. Its length is about six leagues from east to west, and its greatest breadth about two leagues and an half from north to south. It is very visible at sea, at the distance of from ten to twelve leagues; and appears from the offing, with the exception of some small elevations, to possess a level surface. This island is bounded to the north, the south, and the west, with chains of rocks nearly even with the water's edge, on which there are scattered several rocky islets. This bank extends a league and an half from the coast; and the north-east side is the least dangerous, as the reef recedes sufficiently from the bank to admit of ranging along the isle on that side. The most commodious part of its coast for landing, is to the north, opposite the settlement. There is also a channel between the reefs on the south side, but it is so winding, that it requires considerable practice to navigate it with safety.

"A guard house, with a few blacks, is maintained here to collect turtle, which are daily observed to diminish; indeed it is to be apprehended, that the rats and wild cats, who multiply considerably there, will soon destroy the species of this wholesome and nutritious animal.

"The vessels which wish to touch there, whether to obtain a provision of turtles, 
or to carry intelligence, will approach the island on the north-east side, at the distance of half a league; then ranging along the reefs, till the northern point of the isle appears to the south-west, you may either lay to, or make short boards, to wait for the chaloupe, which must be sent off in time, that it may not be exposed to fall to the leeward of the settlement.

"Those who would wish to anchor in the cove which is formed by the reefs, will range along the northern point, at the distance of a musket shot; and when the flag belonging to the settlement shall appear in a direct line with the south-west point of the compass, you must haul on the larboard tack, steering to south-west a quarter south, in order to pass to the leeward of several rocks which line the reef, and where there is anchorage in nine fathom, with a sandy bottom, at a pistol shot from it. From this position, the point of the reef which forms the cove on the eastern side, will be abcut the third of a league to the north-east : the flagstaff of the settlement, half a league south-west and by south; and the Isle of Diamonds, which is the nearest to the principal island, a league west by south, $5^{\circ}$ south : the Islet au Foux, which is the most distant, is west by north, $5^{\circ}$ north; and the point of the breakers on the starboard, is north-west by west, five quarters of a league.

"To the north, $5^{\circ}$ west of this place, at the distance of half a league, there are three or four small ledges of rocks, whose extent is about a quarter of a league from east to west, and the eighth part of a league from north to south. There is about eight or ten feet water in the shallowest parts.

"In setting sail from this anchorage, provided the vessel has not driven much in getting under way, it will be sufficient to stand on your course to the north, in order to pass the eastern extremity of these ledges, in ten or twelve fathom water, where the bottom may be clearly distinguished; but if you steer to the north-northeast, or north by north-east, you must hold the middle of the channel, between the rocks and the reefs.

"You may also pass it to the leeward; that is, between the rocks and the western reef, by steering immediately north-west by north, $3^{\circ}$ west, and then to the north; and when you are between them, you will pass about half a league over a bottom of rocks, which are very distinctly seen beneath at least eight fathoms water.

"It is reckoned that the Isle of Rodriguez is one hundred leagues from the Isle of France: when you have not seen the former, and the distance from the other is uncertain, you must attend to your course towards the latter, with continual precaution, 
lest you should come upon it suddenly during the night. The reefs which surround the east part of it, and advance almost into the offing, would render an unexpected arrival off it very dangerous.

" This island is seen at sea at the distance of fifteen or sixteen leagues, in fine weather; though the clouds and fogs will sometimes prevent its being discovered at this distance. Its surface has a very irregular appearance, from the mountains of different heigths and forms, which rise from it. When you make the island in $20^{\circ}$ of latitude, on the southern part of it is seen a groupe of mountains, which are called the mountains of Bamboo, rising above the south-east port; and on the northern side four islets are discovered, which are to the north-east of the northern point of the Isle of France. It is between these islands, that the common passage is made to the north-west port, which is the principal place in the Isle of France. *

"The Isle Ronde, which is the most advanced in the sea, is also the most remarkable on arriving from the east. It is visible at the distance of ten or twelve leagues. This islet, which does not exceed the third of a league in length, is in the shape of an hay-cock. On approaching it, another, but much smaller islet or barren rock appears, which is called the Isle au Serpent, which is to the north-north-east $5^{\circ}$ east of the Isle Ronde, and is not more than a quarter of a league distant from it.

"The Isle Ronde is situated in $19^{\circ} 50^{\prime}$ latitude; and when the Isle of France is made by this height, that island is more perceivable than the great isle, particularly when the sky is somewhat cloudy, and there is a misty horizon. On arriving from the south, the Isle Ronde appears less, though its whole extent is discovered. But whether you arrive from this side, or from that of the east, it is necessary to steer,

* " In the year 175 1, I determined, by several different observations, the latitude and longitude of the north-west port, or Port Louis in the Isle of France, and the result was, that I found its situation to be in $20^{\circ} 9^{\prime} 43^{\prime \prime}$ of south latitude, and of $3^{\text {h }} 40^{\prime} 30^{\prime \prime}$ more eastward than the Royal Observatory of Paris, which answers to $55^{\circ} 7^{\prime} 30^{\prime \prime}$ west longitude. Another person (l'Abbé de la Caille) having occasion to make the same observations in ${ }^{1} 753$, with larger instruments than those with which I was provided, has formed the same calculation within two seconds, that is, $20^{\circ} 9^{\prime} 45^{\prime \prime}$ south latitude; and $3^{\text {h }} 40^{\prime} 32^{\prime \prime}$ meridional difference.

"I had also deternined in 1740 , and verified in $175 \mathrm{I}$, the situation of the Isle of Bourbon, and I found the latitude of the town of St. Denis, to be $20^{\circ} 51^{\prime} 44^{\prime \prime}$, and its longitude $53^{\circ} 10^{\prime}$. I also found the latitude of the town of St. Paul, in the same isle, to be $20^{\circ} 59^{\prime} 44^{\prime \prime}$. The detail of these observations will be found in the memoirs presented to the Academy, Vol. IV.". 
so as to pass to the south of it, at half, or three quarters of a league distance; from thence you must direct your course to another islet, called the Coin de Mire, which is distant from it three leagues and two thirds south-west by west, $30^{\circ} 30^{\prime}$ west. As this islet is in the form of a wedge, it derived its name from such an appearance.

"About a league to the north-east of the Coin de Mire, and two leagues and an half to the south-west of the Isle Ronde, is the Isle Longue, or Plate, so called because the greater part of it is low ground. It is divided into two parts by a small arm of the sea, which affords a passage to the canoes. To the north is seen a large rock, which in its form resembles a tower: it appears to be separated from the 1sle Longue, though it is in fact joined to it by a chain of rocks that just appear above the water. The north-west end of the Isle Longue is high and steep towards the sea. The common passage for ships is between this islet and the Coin de Mire. Thus having doubled the Isle Ronde on the south side, you must steer towards the Coin de Mire, leaving it nevertheless a little to the larboard, in order to escape the rocks which are both above and below the water, and line its north side; the most advanced of which are not more than a musket shot from the shore.

"As soon as you have doubled the westernmost rock, you will approach the Coin de Mire, whose western part is the most elevated, and very perpendicular towards the sea. From this place you must direct your course so as to range along the Pointe des Canonniers, which is directly to the south-west, $2^{\circ}$ west of the most elevated part of the Coin de Mire, and giving at the same time a point to the breakers, which advance half a cannon shot into the sea.

"The currents or tides, whose high water is one hour, is generally very violent between these islands; and it has been observed that they run about a league an hour. The flood tide runs to the north-east, and sometimes to the east, and the ebb tide takes the contrary direction : it is necessary, therefore, to pay particular attention to these circumstances, and to take a little more of one side or the other, according as the particular situation of the ship may require.

"The Isle Longue forms a sandy cove opposite the Coin de Mire. At its southeast point there is a chain of rocks, which advance about a cannon shot into the sea. As this reef is dangerous, it is necessary to range nearer the Coin de Mire, or about mid-channel.

"The interval between the Coin de Mire, and the north part of the Isle of $\mathrm{S} s$ 
France, is full of shoal waters; it would therefore be very dangerous to attempt the passage, without being well acquainted with every circumstance of it.

"If a calm should come on when you are between these islands, the best mode of proceeding would be to moor with the ebb anchor, in fifteen or twenty fathom, the common bottom being gravel or coral; by which precaution you will avoid being thrown by the current on the reef which is joined to the Isle Longue, or carried away between it and the Isle Ronde, where there is a great deal of shoal water, as well as a chain of rocks, extending from the Isle Ronde near a league to the west-north-west. It never breaks, however, but when the sea is agitated; so that this channel is both narrow and dangerous. I have passed it, and could plainly distinguish the bottom at the point of the reef: but though I met with no accident, it appears to me to be a preferable course, when one is to the leeward of the Isle Ronde, to pass on the outside of the Isle Longue, to range along it at the distance of half a league, and to steer towards the Pointe des Canonniers.

" Having doubled the latter, you will continue your course in making free with the land, so as to range as near as possible to the point of the arm of the sea, which is about a league from it: you must then stretch out to the distance of a quarter of a league from the reefs which line the shore, taking care of those at the entrance of the Bay des Tortues, and before that of Tombeau, which advance the furthest into the sea. To avoid them, you must manœuvre so as to keep yourself in from thirteen to fourteen fathom water during the day, and in twenty fathom during the night.

"From the reef $d u$ Tombeau, the course must be taken a little more to the south; and you must keep on to the south-south-west, till you have got in the same line with the starboard point of the Great River, the mountain of the Guard-house, and a small hill. From this position, you will proceed to the south-west towards two buoys which are at the entrance of the port, at the end of the reef of the Isle aux Tonneliers, on which there are two small flags to serve as marks. You will continue this course till you open the most advanced point of the Isle aux Tonneliers, by the small mountain in the bottom of the bay; you will then anchor in fourteen or fifteen fathom, at the distance of a cable's length from the two small flags which have been already mentioned.

"If the winds blow from the north or north-west, as it sometimes happens, it 
would be useless to anchor without, when you can enter readily into the port. The channel is marked out with buoys, which carry also small flags. You steer southeast, and south-east by south, towards two points of the mountains, which are called Pieterbot, leaving them a little to the starboard. You will then get within the first point of the Isle of Tonneliers.

"When the Isle Ronde begins only to be visible in the evening, and the Coin de Mire cannot be doubled before night, as it is very dangerous to venture between the isles when the surrounding objects are but dimly seen, it would be much better to make small tacks off the Isle Ronde, but to take care not to get more than two leagues from it, by stretching towards the Isle of France, on account of the reefs that surround it : because this being a very low coast, a vessel might find itself on the rocks before it saw land. It would be very injudicious in this sea to heave to, or to drive under a main sail, on account of the tides.

"After having doubled the Isle Ronde, if the Coin de Mire and the Isle Longue are visible, which may happen in a moonlight night and fine weather, you may continue your course and pass between them. It will be sufficient to attend to the chain of rocks off the Isle Longue, as well as that off the Coin de Mire, which have been already mentioned; and when you have passed the last, and shall have got a league and an half farther to the west, you must steer to the west-south-west of the compass, to range along the reef of the Pointe des Canonniers. A fire is generally lighted on this point as soon as any vessels are discovered. When this fire is south-east about the distance of a league, you will have doubled the reef, and must continue to stretch along the coast, with the precaution of not quitting fifteen fathom water.

"Nevertheless, as it is difficult to reconnoitre the entrance of the port during the night, and as you may be easily deceived by the different fires on the mountains, it would be preferable, after having doubled the Pointe des Canonniers, to anchor in eighteen or twenty fathom water, and to wait till it is daylight, in order to come to moorings before the port.

"It would be dangerous, with a feeble wind or in a calm, either by day or night, to draw near the Pointe des Canonniers, on account of the eddies of the tides, which are very rapid there." 


\section{The Winds which prevail in the Eastern Seas.}

"In all the extent of sea between the Cape of Good Hope and the coast of New Holland, to the south of the parallel of $28^{\circ}$ of latitude, the winds are variable throughout the year. It is true that the west, north-west, and north winds, frequently prevail there, and that they sometimes pass to the north-east; but it may be said, in general, that the winds are never constant in this part of the Eastern Seas.

"From the parallel of $28^{\circ}$ latitude, in proceeding towards the north, at the east of Madagascar, the winds blow from south-east to east throughout the year: they are called general winds, not only because they prevail in the Eastern Ocean, but also in all the South Seas; with this exception, however, that in the latter, their region extends to about the Equinoctial line; whereas in the Eastern Ocean, it appears to be confined to between the parallel of $28^{\circ}$, and that of $8^{\circ}$ to $9^{\circ}$ in some places, and of $11^{\circ}$ to $12^{\circ}$ in others; particularly to the south of Java, and other islands to the east.

"This regulation of the winds, though tolerably constant, is nevertheless subject to variations, when the sun is in its southern district; that is, in the months of October, November, December, January, to the $15^{\text {th }}$ of April, when it may be said, in some degree, to change the state of the atmosphere. The winds then blow from the north-west, and sometimes from the west by south, particularly towards the change of the moon.*

"This disposition of the winds is principally known between the Island of Madagascar, and the Isles of Bourbon, France, and Rodriguez. It serves for vessels to go up from one island to another, in much less time than in the other months of the year. It is in this season also that hurricanes and tempests prevail in the region subject to the general winds.

"It is observed, that in the Indies there are four monsoons or seasons, during which the winds commonly blow six months one way and six the other.

"The south-west monsoon reigns to the north of the Equinoctial line, while that

- "Though I represent here, as well as throughout this memoir, the quarters, the full, and the springs of th.e moon, as producing the change in the winds, it must not be inferred from thence, that it is my opinion that they immediately depend on these phases, exclusively of every other concurrent circumstance. This expression is merely employed to conform to the general practice of seamen; being well aware that the observations on this point are neither sufficiently numerous or conclusive to decide the question." 
of the south-east blows on the southern side; and when the north-east monsoon succeeds that of the south-west, to the north of the line, a monsoon is observed to reign in the southern quarter, where the winds blow north-west by west, and in some places from south-west.

"The south-west monsoon lasts from the $15^{\text {th }}$ of April to the $15^{\text {th }}$ of October, in all the extent of the seas comprehended between the coasts of Africa, Arabia, and Japan.

"The north-east monsoon reigns in the same seas from the $15^{\text {th }}$ of October to the $15^{\text {th }}$ of April, with the exception of the Red Sea and the Gulf of Persia, which have their own particular winds.

" The Straits of Malacca might also be added, where the winds are almost always inconstant and variable; and where the monsoons are of short duration. Nevertheless, while the south-west and north-east winds are most violent without the Straits, it blows moderately from the same quarter within this of Malacca; that is, from the east in December and January, and the west quarter in June and July.

"The change of these monsoons is always gradual. The variable winds prevail in the interval between them; but these revolutions are generally followed and sometimes preceded by tempests and hurricanes, particularly when the north-east monsoon succeeds to that of the south-west; that is, in the months of October and November: those which happen in April are less frequent and impetuous.

"T The south-east and north-west monsoons, which blow to the south of the Equator, are confined to less extensive limits; since they are not perceived in the South Sea but from the Equinoctial line, to the 8 th or $9^{\text {th }}$ degree of latitude, and the 12 th or $13^{\text {th }}$ degree towards the Isles of Sunda, Timor, \&c. \&c. As to their western and eastern limits, it is observed that they do not blow but from the meridian, which passes near the north point of Madagascar, to the Molucca Islands.

"The winds during these two monsoons have, at the same time, a very different direction from those which prevail to the north of the Equator; for while they come on that side from the south-west, they blow on the opposite side from the south-east. When the monsoon of the north-west, which seldom begins till November on the south of the line, prevails from that part, the north-east winds blow from the northern side.

"As to their change, it is not accompanied with hurricane or tempest, as it happens with those that take place on the northern side; and though the weather 
may be bad, and the land and sea breezes more or less violent, the winds are never impetuous.

"Some authors, whose opinions appear to have been adopted without examination, confine the south-east and north-west monsoons to $2^{\circ}$ of south latitude: but notwithstanding all the researches which I have made on this subject, I could only discover, between the monsoons to the south and north of the line, a few variations, which were insufficient to determine the limits.

"In the space of sea which is situate to the south of the Equator, between the coast of Africa and the meridian that passes by the north-east point of Madagascar, the south-south-west winds are found to blow from April to October; but they incline more to the west on proceeding to the northward to get to the south-west monsoons, which blow to the north of the line.

"From the months of October or November to that of April, in the same space, the winds blow from north-north-east to the east; and near the coast they often come from the east-south-east to the south-east, to re-establish, probably, the equilibrium of the air rarified on the land by the great heats of the season."

\section{On the Archipelago of Isles, and the Dangers wbich attend the Navigation to the North and North-east of Madagascar.}

"Previous to the instructions which I shall offer to the navigator, relative to the different courses he may take to get to the East Indies; whether he goes from the Cape of Good Hope, or from the Isles of France and Bourbon, it is necessary to inform him of the isles and dangers which he may encounter, in order that he may be enabled to avoid them, and arrive in safety at the place of his destination.

" The Archipelago of the north-east of Madagascar, which contains a great number of isles, banks, and shoals, has been so imperfectly traced on the old charts, that it will be sufficient to compare them with that which I have formed, from a more recent and correct knowledge, to possess a very different idea of the situations and circumstances which have hitherto been so imperfectly described.

"When we consider the position of the Isles of France and Bourbon, the winds which prevail in this part of the Eastern Sea, as far as the Equinoctial line, and the different tracks which may be pursued to arrive in India, it may be presumed, that the knowledge of this Archipelago should be one of the first objects to be obtained by the commanding officers of the Company in these isles: but whether it was from 
too great a confidence in the authority of the old charts, or a want of precision in the orders given them, this undertaking was not commenced till a long time after our establishment. M. Mahe de la Bourdonnais, Governor of these isles, was the first projector of it, and in $174^{2}$ employed two small vessels in carrying it into execution. The war of 1744 occupied the Governor in a very different manner, and his recall to France put an end to the useful expeditions which he meditated.

"The track which Admiral Boscawen pursued in 1748 , with a fleet of twentysix ships, on leaving the Isle of France, which he was disposed to attack, to go to the Indies, and where he arrived in a very short time, by traversing this Archipelago, plainly proves that this course is preferable to the common one, that makes a northern part of Madagascar, as it shortens the passage upwards of three hundred leagues.

"I held, in a great measure, the same course as Admiral Boscawen, in a ship called the Monteran, in 1754 , without encountering either island or shoal. The snow Rubis, which also sailed through the Archipelago in $175^{8}$, perceived the island Agalega, and continued her passage to Negapatam, where she was taken by the English.

"Though the success of this attempt is, in some degree, a sufficient authority to engage navigators to abandon their ancient route, and to adopt one which is equally safe and much shorter, and particularly in circumstances requiring dispatch, our ships have not deviated from the track which they have pursued since the year 1722 . It may be necessary, therefore, in order to tranquillize the generality of navigators on the dangers which they have supposed in this passage, to enter into a connected examination of it.

" In ${ }_{17} 67$, the Chevalier Grenier was appointed to command a corvette, called L'Heure du Berger, in the King's service, destined for the Isles of France and Bourbon. He formed the project to make such discoveries as would be of the greatest importance to the navigation of these seas; and he accordingly associated with him the Abbé Rochon, of the Marine Academy, for the astronomical department.

"The minister favoured his views, and, in consequence of his protection, he was assisted by the Chevalier Desroches, Commandant of the Isles of France and Bourbon, and M. Poivre, Commissary-general, who, to the corvette L'Heure du Berger, joined the corvette Le Verd Galant, commanded by M. la Fontaine. His voyage to the Indies, as well as his return, was accompanied with many useful discoveries, which I shall relate in this memoir. With respect to the means which he proposed 
to shorten the passage from the Isles of France and Bourbon to India, they are similar to my own, and $\mathbf{I}$ shall hereafter give them a particular consideration.

“ M. du Roslan, seconded by the Chevalier D'Hercé, continued the progress of discovery after the Chevalier Grenier, and has fulfilled that object with equal care and correctness. His observations and remarks will be explained hereafter. I shall therefore pass at once to the discoveries successively made in this Archipelago.

"The Isle de Sable, ;situate to the north of the Isle of Bourbon, in the latitude of $15^{\circ} 5^{2}$, was discovered by the vessel called the Diana, in 1722 . The storeship the Utile was wrecked there the 31 st of July, 1761 , from having neglected to refer to its situation as laid down in my chart of 1753 , and having preferred another chart, which places it $25^{\prime}$ more to the south. This island is a flat bank of sand, of about seven hundred fathom in length, running north-north-west and south-southeast, and of three hundred and fifty in breadth, with a ridge of sand stretching six hundred fathom to the south-south-east. The crew saved themselves in a kind of flat-bottomed boat, made out of the wreck, and landed at Foule Point on the $27^{\text {th }}$ of September.

"The bank of Corgados Garayos was, in 1742, the first object of the researches made by the boat named the Charles, and the tartan the Elizabeth, dispatched from the Isle of France by order of M. Mahé de la Bourdonnais, at that time Governor of it. These two vessels having made it on the 27 th of August, anchored there, and traced a plan of it, by which it is represented in the form of an horse-shoe, and of six leagues in extent, running north-north-east and south-west. These two boats not having been on the north side, and, consequently, not having perceived the isles whicin lay off it, its small extent, and the affinity of its latitude and longitude with that of Saint Brandon, on which an English vessel, called the Hawk, (le Faucon) was stranded on her return from Surat to Europe, induced me to consider it as one and the same shoal.

"It was perceived in 1682 , by the ship $L_{a}$ Royale, in its passage from Surat to the Isle of Bourbon; and her course, till she came in sight of the Isle of France, then called Mauritius, was south-west by south, $4^{\circ}$ west.

" From the tracks of the two boats, I was induced to give it $5^{8^{\circ}} 7^{\prime}$ of longitude: nevertheless, as the course of M. le Chevalier Grenier is more direct, having taken a mean proportion between his own course, and that of the La Royale and the two boats, I have replaced it in $57^{\circ} 37^{\prime}$, that is $30^{\prime}$ more to the west. 
"By the plan which the Chevalier Grenier has given of the islets extending to the north-north-east, it appears that this shoal is Corgados Garayos, and not the Saint Brandon, where the Hawke ran on shore, and which I have placed in $60^{\circ} 10^{\prime}$ longitude; that is, $9^{\circ} 30^{\prime}$ west of the meridian of Surat, and in $16^{\circ} 3^{\prime}$, according to the track of the Hawke, as laid down in the charts of the Isle of France, to be found in the English Pilot.

" As to the two banks of Nazaretb, they must be found between the track of the pink la Digue and Corgados Garayos; as there is no reason to imagine, from the tracks of other vessels, that they are more to the west.

" The course of the boats the Charles and Elizabeth, from Corgados Garayos to Madagascar, make it apparent, that these two banks do not extend so much to the south as the old charts represent them. After having traversed the course of ticse two vessels, I made a proportionate correction of their extent towards the so th.

"These boats, on leaving Madagascar, proceeded on the $14^{\text {th }}$ of October to make further discoveries : on the 27 th, at nine, being in $10^{\circ}$ of latitude, and, according to estimation, in $50^{\circ} 30^{\prime}$ of longitude, they perceived a small triangular island, which they supposed to be Agalega, or the Isle Astove, and they ranged close along it, but without landing. This isle is probably that of the Assumption.

" On the $2 \mathrm{gth}$, in the morning, they discovered two islands, which were divided by a large bay, the opening of which lay east and west : but these appeared, nevertheless, to be closely joined together by several intervening islets.

"According to the track of the boats, these two islands, which they supposed to be those of $\mathcal{F}$ ean de Nove, were seventeen leagues to the north-west of the triangular island which they had perceived on the 27 th.

" The boats came to an anchor to the north-west of the northernmost island, and having sent a party to examine it, they found it very flat and marshy, and covered with small trees. They saw there' a great number of land turtles, much larger than those of Rodriguez, and abundance of game. As the anchorage where they were was not good, they quitted it on the 1 st of November, after having made a draught of the islands. It was in consequence of this discovery that I placed them upon my chart, as well as the little triangular isle, under the name of the Isle Astove.

"The two boats continued their course towards the east and the north east till the $19^{\text {th }}$, and being, according to their reckoning, in $60^{\circ} 30^{\prime}$ longitude, and $5^{\circ} 15^{\prime}$ latitude, they perceived an island with very high land, which appeared to be six 
or seven leagues in length from north to south. Having neared it, they anchored in a cove on the south-south-west side, which they examined; but as the season required their return to the Isle of France, they contented themselves with this imperfect knowledge of it.

"They renewed their course on the $27^{\text {th }}$, and sailed along the island on the east, when they perceived the isles which are to the north-east, and contented themselves with having seen them.

"It may be observed, that the two navigators charged with this expedition had not, by any means, the knowledge or experience necessary for such an important object; and though the difference they observed in the variation on this island, of $11^{\circ} 30^{\prime}$, and that which they found after, ought to have convinced them that there was a considerable error between them to the west, they counted upon their own reckoning of the longitude, and as it appeared on the chart of Pietergoos, and that of the Depôt de la Marine (edit. 1740), near the place which is distinguished by three small islets, called the Trois Freres; they therefore imagined that the island which they had approached, as well as all those which they had discovered, were these Trois Freres; and they accordingly took their departure, without any change in their opinion. They were, on their return, more fortunate than wise; for traversing this Archipelago, they made, on the $4^{\text {th }}$ of January, the island of Madagascar, when, according to their reckoning, they were thirty leagues to the east of the Isle of Rodriguez; so that the total error of their navigation was about three hundred leagues to the west. They. at length arrived in the Isle of France, on the 28 th of January, 1743.

" The report which they made of their discovery to M. de la Bourdonnais, determined that Governor (who judged that the supposed Trois Freres were rather some islands in the vicinity of the Amirantes, than those three islets), to send out again in the course of the same year, one of the two navigators, named Lazarus Picault, in the tartan Elizabeth; and he ordered a person to embark with him who was qualified to lay down a chart. M. Picault accordingly received instructions, on setting sail from the Isle of France, to take his course to the Malabar coast, in order to ascertain with precision the exact position of that isle.

"The journal of M. Picault having been communicated to me, as well as the draught which I now have in my possession, I had, from the knowledge which I acquired from the tracks of these navigators, placed that island in $52^{\circ} 30^{\prime}$ longitude from the meridian of Paris, and consequently $45^{\prime}$ more to the west than it is in fact, 
from the observation of the Abbe Rochon. I have, however, according to the latter, placed it in $53^{\circ} 15^{\prime}$.

" M. Picault having taken possession of these isles in the name of the King, denominated them the Isles de la Bourdonnais, and to the principal of them gave the appellation of Mabe, which I have preserved.

"In the year 1756, M. Magon, then Governor of the Isles of France and Bourbon, having been informed of the advantages which might be derived from the Isles de $M a b \dot{e}$, sent thither the Cerf frigate, under the command of M. Morphey, a very intelligent officer, who joined to the necessary qualities of a navigator, all the knowledge which would enable him to acquit himself with honour in this important mission. To this frigate was added the Saint Benôit schooner, commanded by M. Préjan, to second the objects of this expedition.

"As M. Morphey was determined, at the same time, to reconnoitre the Isles which the Charles and Elizabeth had discovered, he took his course, on quitting Bourbon, the $3^{1 \text { st }}$ of July, to fall in with the Isles Astove and Fean de Nove, according to the situation which I had given them on my chart.

"On the $9^{\text {th }}$ of August he discovered a reef, on which there were two small sandy islets, whose latitude by observation was $9^{\circ} 36^{\prime}$, and whose longitude, according to the dead reckoning, was $50^{\circ} 15^{\prime}$. Though they stood on their course to approach these islets, they soon lost sight of them from a violent current, which bore them away to the south-west; and notwithstanding every effort was made during the night to stand in for them, on the following morning they perceived a different island to the north, to which they bore up, and ranged along it at the distance of six hundred fathoms. Its latitude was determined by a correct observation to be in $9^{\circ} 2^{\prime}$, and M. Morphey sent a party to examine it.

" This island is no more than a bank of chalky rocks and white coral, which is about three leagues in circumference, and may be seen at the distance of five or six leagues. The small quantity of earth which is found there, appears to be nothing more than a mixture of decayed wood and leaves, and the loftiest trees are not more than ten feet high. There are water-fowl in great abundance, with many other birds, and a large kind of crab. The shore is very steep, and at half a cable's length from it no bottom is found at less than twenty fathom. M. Morphey not finding this isle marked on any chart, named it the Isle des Cerfs, though, according to all appearance, it was the Isle de St. Pierre, seen by many of our vessels in their passage to 
India. Hence it is, that $\mathrm{I}$ have marked it on my chart in $49^{\circ} 30^{\prime}$ longitude, relatively to the track of those who have fallen in with it on qutting Madagascar.

" On losing sight of this island, M. Morphey continued his course to the westward, and three days after, on the $13^{\text {th }}$ of August, they perceived several islets on a large reef, which they approached very fast, in consequence of a violent current, which was observed to run to the west. These isles consist of a kind of chalk stone covered with shrub-wood, and, according to the plan which I had traced from the rough draught and remarks of $\mathrm{M}$. Morphey, it appears that these are the islands known on the ancient charts under the name of Cosmoledo, situate to the northnorth-west of Cape d'Ambre.

"On the following day, being the $14^{\text {th }}$ of August, they saw a small triangular island, and on the $16 \mathrm{th}$, in the morning, they anchored there, and named it $L ' I s l s$ de l'Assumption. According to an observation, the middle of the island is in $9^{\circ} 47^{\prime}$ latitude. They landed on it, but found nothing worthy of remark : it is one chalky rock, full of caverns, with some sandy spots covered with shrubs. The access to this. island is very difficult.

"On the 17 th, in the evening, the vessels having driven, they set sail. It appears that this island is the same which the boats, the Charles and the Elizabeth, saw on the 27th of October, and which they took for Agalega, or the Isle Astove; although it appears that their observed latitude is $18^{\prime}$ more south. This difference is the less surprising, as the navigators on board those vessels,_-1st, Made use of an arrow ; 2d, They did not correct the declination; and ${ }_{3} \mathrm{~d}$, The sun was very near their zenith.

" On the 18 th of August, M. Morphey discovered another island, or rather two islands, joined together on the western side by intervening islets, and ranged along them close in shore. He determined their latitude between $9^{\circ} 24^{\prime}$ and $9^{\circ} 35^{\prime}$, and considered them to be the same which the boats, the Charles and Elizabeth, had visited, and named Fean de Nove. I have supported the same opinion; but in what degree of longitude am I to place them? According to the navigators in the boats, they should be in $49^{\circ} 30^{\prime}$; and according to M. Morphey, in $47^{\circ}$; and the result of this determination would be, that the islets of the Assumption and Cosmoledo would lay in the track of all our vessels going to the Indies, although they have never fallen in with them.

- Une flécbe, a sort of instrument, šometimes used for observation, called also un baton de facob̈. 
"To resolve a problem of this nature, I had recourse to the variations, of which there is a sensible progression in these seas, in steering from east to west: with this view I traced all the courses of the vessels, whose error, between their points of departure, which were correctly known, such as the Isles of France and Bourbon, and the land-fall on the coast of Malabar, were of little consequence. I took care to mark the variations which had been observed, and having drawn the lines of a considerable quantity of them, I discovered that these lines cut the meridians in an angle of from $31^{\circ}$ to $32^{\circ}$ from north to west.

" As I could rely on the exactness of the observations made by M. Morphey, I referred to them for the intersection of the variations which he had observed, with the parallel of latitude of those isles, and I found that the two last were in $49^{\circ} 30^{\prime}$, and answered, on the old charts, to Aldabra; the isle of the Assumption in $44^{\circ} 55^{\prime}$ longitude, and the middle of Cormoledo in $46^{\circ}$. I consequently traced them on my chart.

" The correctness of this operation was confirmed to me about four months after, and before my chart could possibly have reached the isles, by a letter from M. Grandmaison, who had fallen in with the isle Aldabra, three days after his departure from the Isle of Aijouan. The position, according to his reckoning, is precisely the same as that which $I$ had given to it.

"This method of determining the situation of the isles, and dangers of this Archipelago, by the variation, in default of astronomical observations, has appeared to me to be preferable to that of the track of vessels in this sea, where the currents are continually changing their direction.

"The Isle Natal, which is seen to the north of Aldabra, was observed by M. Barri, who commanded a ketch, in his passage to India, after having seen the Cape d'Ambre. The latitude is the same as is given in the Portuguese charts.

"The English ship the Atham, in $175^{8}$, discovered a sandy island, with several breakers, in $6^{\circ} 57^{\prime}$ south latitude, and thirteen leagues east from the Isle of $\mathrm{Zan}$ zihar. The ship ranged along the sandy island to the westward at the distance of a league.

"T The bank of Patram was seen in $175^{8}$ by the ship Pitt; when it was found to be in $4^{\circ} 30^{\prime}$ south latitude, and $50^{\prime}$ to the east of the meridian of the Isle of Commore.

"It is supposed also that there is a sand bank in $3^{\circ} 57^{\prime}$ of south latitude, and $2^{\circ} 5^{\prime}$ 
east of the meridian of St. Augustine's bay. This bank has been seen by two vessels, and may be a continuation of the preceding one, since it cannot be more than twenty leagues distant from it, to the north-east.

"The Panther man of war, commanded by Captain Affleck, in his passage from the island of Anjouan to India, made an observation on the 17 th of May 1760 at noon, when he was in $9^{\prime}$ of south latitude, and according to reckoning, $5^{\circ} 49^{\prime}$ to the east of the meridian of Anjouan, and at 2 P. M. saw the bank d'Ambre, which was to the east of him, $5^{\circ}$ or $6^{\circ}$ south, at the distance of about seven or eight miles; when he sounded without finding a bottom, with a thirty-five fathom line. At four P. M: he surveyed the extremities of the shoal, and found no bottom with an hundred fathom line. The variation was $12^{\circ} 20^{\prime} \mathrm{A}$. M. and $12^{\circ} 21^{\prime}$ P. M.

“ In the year $173^{\circ}$ the ship Le Lys, commanded by M. le Chevalier Pontevez, in its passage from the Isle of Bourbon to India, took the common course in order to make Madagascar : but not having seen that island, on the $25^{\text {th }}$ of June, at six P. M. he made good his course to the north-north-east, $3^{\circ} 30^{\prime}$ east, forty-five leagues and one-third, till the 26 th at noon; and afterwards to the north-north-east, $2^{\circ} 30^{\prime}$ north, till two P. M. of the same day, when he perceived land north-west by west, from four to five leagues. He observed that it consisted of two islands, which were separated by a small channel; and according to the latitude which he had observed, always allowing for the error of his fléche, the middle of this isle would be in $10^{\circ} 17^{\prime}$ latitude. As to its longitude, although $\mathrm{I}$ had determined it on my chart to be $49^{\circ}$, after having traced the courses of several ships which sailed from Madagascar, and had not seen this island in this longitude, and even more to the eastward, I thought it right to place it in $50^{\circ} 35^{\prime}$.

"The Lys, on losing sight of this island, made good her course north-north-east, when she perceived another island, that was named the Alphonse, which, according to the track of this ship, since she saw Fean de Nove, should be sixty-nine leagues to the north-north-east of it, and consequently in $7^{\circ}$ of latitude, and $52^{\circ} 2 \mathrm{O}^{\prime}$ of longitude.

"Eighteen leagues and an half to the north of the island Alpbonse, or rather to north by north-west, according to a more correct reduction of the courses of this ship, the Chevalier Pontevez saw another small island, to which he gave the name of Saint François.

" This island was seen on the 21 st of September, 1744, by a small vessel on its passage to Mabé. She ranged along the western coast of it, at the distance of a 
quarter of a league, where she was in eight fathom water, with a bottom of coral. She afterwards made a similar island, about three or four leagues east-north-east of the former: in the channel between them, there were thirty-five fathoms water, with a sandy bottom. The same day at noon, having made six leagues north-east by north, and being from an observation, in $5^{\circ} 59^{\prime}$ of latitude, a third isle was seen at a league to the west, when they had from thirty to thirty-five fathoms water.

" The frigate La Gloire, in 1756 , fell in with the Isle St. François in its passage to Pate.

M. du Roslan, who was dispatched in December, 1770, from the Isle of France, with the King's corvettes, L'Heure du Berger, and L'Etoile du Matin, to make discoveries in this Archipelago, made an island which he named the Isle Plate, whose latitude is $5^{\circ} 45^{\prime}$, and longitude $53^{\circ} 11^{\prime}$. It appeared to him to be about a league in circumference. There was a reef extending about a quarter of a league to the westward of it.

"Steering from the Isle Plate to the north-west, he saw a second island northwest by west, and he neared it without finding any bottom, till he got within half a cannon shot of the shore. He sent an officer to find a convenient anchoring place, and the following day he himself landed to examine the island, which he named the Isle du Berger. It is more elevated on the side of the north than that of the south: in the middle there is a cut or separation, which, at some distance, gives it the appearance of two islands. This cut is a bank of hard coral, covered with a thin coat of white sand, which the sea always overflows at high water; but, at low water, it is altogether dry, so as to form a passage from one part of the island to the other. It is about two leagues in circumference : the soil consists of a very hard coral, covered with sand; the trees are lofty, but their wood is of a spongy texture; there are also some small cocoa trees; and the whole island is surrounded with a reef at the distance of about a quarter of a league. There were a great variety of birds, and plenty of fish.

' This isle is in $5^{\circ} 45^{\prime}$ latitude, and $5^{\circ}{ }^{\circ} 8^{\prime}$ longitude. In coasting it, an opening was observed in the reef, where boats might enter to get to the island by a kind of causeway, formed by the contrivance of nature : the reef abounds in turtle, sharks, and many other kinds of fish. It appeared to possess no insect but a small red ant, some spiders, and numbers of Nerites : the sailors say they saw there Caymans and blue fowls. 
sc On leaving this island, and steering west by south-west, M. du Roslan perceived a third island, which he named the Isle de l'Etoile; he coasted along it at the distance of a league. In the bottom, betwcen the Isle du Berger and this, there are very perceptible inequalities. The lsle de l'Etoile is nothing more than a sand-bank, covered with brush-wood, and may be half a league in length; the reef which surrounds it extends on the southern side to about a quarter of a league.

"At six P. M. a fourth island was discovered, which was called Marie Louise. It appeared to be well wooded, was encircled with a reef, and of the same dimensions as the Isle Plate. Its latitude is in $6^{\circ} 12^{\prime}$, and its longitude $52^{\circ} 19^{\prime}$.

"On the $14^{\text {th }}$ of December, M. du Roslan saw a fifth island, two leagues to the west-south-west of Marie Louise, which he named the Isle des Noufs. At the distance of a league from it he found himself in nine fathom water, with a rocky bottom. It appeared to him to be smaller than the others, but equally woody. Its latitude is $6^{\circ} 15^{\prime}$, and its longitude $5^{2^{\circ}} \mathbf{1 2}^{\prime}$; the depth of water between these isles is from twenty-five to thirty fathoms; but on standing away in the least degree to the south, the bottom is instantly lost.

On the same day at noon a sixth island was discovered, distant about three leagues and one-third west by north-west of the Isle des Noeufs. It received the name of the Isle de la Boudeuse: it is a bank of sand, covered with brush-wood, like the Isle de l'Etoile.

"According to every appearance, these isles are those which are marked on the old maps under the name of the Amirantes, although their latitude is not so much to the south by $2^{\circ}$. M. du Roslan made a very exact survey of them, and in his passage from these to the Isle Mabé determined the longitude relatively to that of the latter; nor is there any reason to suppose his position to be erroneous.

"It appears, that the Isle des Noufs is that which was seen by M. de Pontevez, who commanded the Lys, in 1730 , and was denominated by him the Isle Saint François, which the ship la Gloire perceived in $175^{6}$; and that it was among those isles that the little vessel, which I have already mentioned, passed in its course to Pondicherry.

"To the north of these isles, and to the west-south-west, $5^{\circ}$ south of the Isle $M a b \dot{e}$, it is said that there are three or four similar islands. They have been seen by a small vessel on its passage to Bengal, which went to the Isles Praslins; it 
was commanded by M. du Chemin; but $I$ have never been able to obtain any particular account of them.

"The Twelve Islands were seen the 6th of June, $173^{2}$, by M. du Chemin, commanding the ship Saint Pierre, two days after he had lost sight of the north-east part of Madagascar; and as he perceived on the morning of the following day, another small island, to which he gave the name of his ship, the position of the one and the other is determined by his course, and the distance he was from them to the north-north-west.

The frigate Elizabeth, in its passage to Surat, after having made Madagascar, found itself on the 16 th of August, 1744 , at break of day, about a quarter of a league from the breakers that surround the Twelve Islands, which remained from north-west to north-east. At the same time there appeared from the north-west by north, to the north-north-west, three round islets, but little elevated above the sea; and to the north-east, a kind of flat island, which seemed to terminate the reef on that point. The winds blowing a stiff breeze from the south-south-east; and the agitated state of the sea, obliged the navigators to hold as close as possible to the wind to double this shoal, and, on approaching it, they perceived that it was formed of several others, all of which were mere banks of sand, covered with shrub-wood. At ten $A$. M. they surveyed the more northern islet to the west-south-west, four or five leagues; and, at noon, reckoning that they were seven or eight leagues to the north-north-east of the northernmost isle, as, from an observation they were in $9^{\circ} 42^{\prime}$ latitude, it was inferred that this mass of islands was in ten degrees.

"It is proper to observe, that when M. Morphey discovered the shoal Saint Laurent, he passed at such a distance to the north of the Twelve Isles, as not to be in a situation to perceive them.

"This same navigator had passed also to the south of the bank which extends to the south of the small Isle de la Providence, on which the crew of the Hereuse frigate, Captain M. Campis, was preserved. This frigate having sailed from the Isle of France on the 3 oth of August, 1769 , to go to Bengal, made the isle $\mathscr{F} e$ an de Nove on the $5^{\text {th }}$ of September, at from five to six leagues to the west. The following night she was wrecked on the south part of the reef, and the crew saved. themselves upon a dry bank of sand about a league within the reef, from whence they got to a small island at the distance of about seven leagues to the north, to which the reef is contiguous; and they named it the Isle de la Providence. 
" This island is a league in length from north to south, and about three hundred fathom broad towards the middle. The soil is a mixture of sand and white coral. The reef, with which it is surrounded, begins at its north point, and then runs off towards the south, so that the southern point of the isle is about half a league distant from it. The reef continues from six to seven leagues to the south, and its greatest breadth, which is near the middle of it, is about two leagues. The whole space which it contains is filled with banks of sand and coral, some of which are above the water; so that at low water a canoe could scarce navigate there; and even at high water there is considerable danger, which must be watched with great attention.

"The Isle de la Providence is covered with cocoa trees on the southern side, and to the north with a tree that resembles the fig-tree of Europe, and is of a very spongy texture. These trees are strait, and rise to about forty or fifty feet, having knots like the bamboo, at a regular distance of six feet. The fruit resembles small mangoes. * There is also a creeping kind of wood of a red colour, and very hard. It is a very singular circumstance, that the ashes of wood that has been burned here, having been wetted by rain, hardens in such a manner, that it is necessary to employ. an hammer to break the petrifaction: the inside is shining like the shells of a fish.

" There is great plenty of turtle, and a species of land crab, which is very large, and good to eat : some of them weighed six pounds. There are also great numbers of rats, which make their nests in the cocoa trees.

"The latitude of the island, according to four observations, two of which were made when the sun was on the north side of the island, and two when it was on the south side, was determined to be $9^{\circ} 7^{\prime}$; the variation according to observation, was $11^{\circ} 45^{\prime}$ north-west.

"After having exerted themselves during two months on the island, in endeavouring to lengthen their canoe six feet, and to refit it for sea, the shipwrecked crew embarked in her, to the number of thirty-five men, on the 8 th of November, and fortunately meeting with a north-east wind, they in four days after landed at Madagascar, at eight leagues south of Cape d'Ambre; from whence they proceeded to reach Foul Pointe, where they arrived in about a month. They continued their course in the canoe, and in their passage, between Cape d'Ambre and the Bay of Vobemare, they crossed three fine harbours, which appeared to them well worthy of attention. 
"The island Galeg $a$ was seen on the " 7 th of July, $175^{8}$, by the Ruby snow, in its passage from the Isle of France to India. As the course of this vessel appears to me nearly direct, I have placed this island in $54^{\circ} 55^{\prime}$ longitude, and in $10^{\circ} 30^{\prime}$ latitude.

"The frigate Le Cboiseul commanded by M. le Flock de la Carriere, in its passage from the Isle de Bourbon to Pondicherry, perceived this island on the $17^{\text {th }}$ of August, 1768 ; and although this navigator then reckoned that he was but five leagues more to the west, the soundings that he afterwards took, on the south-east part of the bank which surrounds the Isle Mabí, and others which are to the east of it, made him suspect that the Isle Galega is fifteen or twenty leagues more to the west than I had marked it. But as M. de la Carriere had no knowledge of the Isle Mabé, and that he was equally ignorant where the bank was situated which he had sounded, I have not thought proper to place it more than $35^{\prime}$ more to the west than my first determination, and in more than $10^{\circ} 27^{\prime}$ latitude.

"The Portuguese charts, on the faith of Alexo da Mota, places this isle in $9^{\circ} 30^{\prime}$, which is $57^{\prime}$ more to the north than its real position. Such are the errors of the old voyagers.

"During the night from the 18 th to the 19 th September, $177^{1}$, M. de Kerguelen, who commanded the store ships, la Fortune and le Gros Ventre, found himself over a bank in thirty fathom water, with a rocky bottom; in the succeeding moment he found but twenty fathom, and the bottom continuing to diminish, he anchored in sixteen fathom. On the return of light he saw no land; and having got under way, driving to the north-west, he found from thirteen to twenty-eight fathom; but after having made two leagues, he on a sudden got out of soundings. While he was at anchor, he remarked that the sea broke very much at the distance of a league to east-north-east; but such was the state of the weather, and the agitation of the sea, that he did not venture to send his canoe to take soundings. He reckons that this bank, which he named the bank de la Fortune, extended three leagues from south-east to north-west; and, according to his observation, it was situate in $7^{\circ} 30^{\prime}$ latitude, and in $54^{\circ} 5^{8^{\prime}}$ longitude.

"I have placed the bank of Saint Michel in $8^{\circ} 55^{\prime}$ latitude, according to the observation of the la Digue store-ship in 1768 , and in $57^{\circ} 30^{\prime}$ longitude, according to the reduction which $I$ have made of her track in going from the Isle of France to the Isle Mabé.

"The south part of Saya de Malba, is traced according to the navigation and $\mathrm{U}$ u 2 
observations of M. le Chevalier Grenier. As to the north side of the same bank, I have conformed myself to the following extract from a journal inserted in the English Pilot.

- The northernmost part of Saya de Malba is in $9^{\circ} 55^{\prime}$ south latitude, and in ' $11^{\circ} 4 \mathrm{O}^{\prime}$ to the west of the meridian of Bombay. I fell in with the western part of 'the northern point, where I found, on the first sounding, fifteen fathom water, with ' a bottom of coral, and on the second, no more than eight; which made me stand ' to the north, $3^{\circ}$ west; and though the breeze was light, every time I threw out the ' line the soundings increased from twelve to fifteen, twenty-two, twenty-five, thirty'two, sixty, and eighty-five fathoms, and then I lost soundings. I returned to the ' charge, and found as at first, fifteen fathom with a coral bottom, afterwards twelve, ' then ten; but apprehensive that I should run aground, I stood to the north-north' east, where I had eleven, twelve, thirteen, fourteen, seventeen, and twenty-two ' fathom; and after having sailed about a mile and a half, I lost all sounding. It ' is said that on the south part of this shoal there are several banks, which in some 'places are dry and visible. The variation was $16^{\circ} 40^{\prime}$ north-west.'

"I have found no other memoir on the Island Roquepiz to the south, but the Journal of Lancaster, who saw it in 1602 , and speaks highly of its appearance, without mentioning its longitude: it states merely that this Admiral having quitted the Bay of Antongil on the 6th of March, found himself in sight of Roquepiz on the 16 th of the same month, towards $10^{\circ} 3 \mathrm{o}^{\prime}$ south. I have placed it in this latitude, and in $62^{\circ}$. longitude, according to which position it could not have been seen either by the Cerf frigate, the gouelette the St. Benôit, or the Digue store-ship.

"In the memoirs which have been sent me from England, about five or six years ago, I have an extract from the journal of the two following ships, the Mary, Captain Mitcham, and the Prince George, Captain Lewis; who left the point of Galles, in the island of Ceylon, on the $15^{\text {th }}$ of June, 1755 , to proceed on their voyage to Bombay, and saw, on the $2 \mathrm{~d}$ of August, an island in $7^{\circ} 7^{\prime}$ south latitude, which they imagined to be that of Gratia, and reckoned to be $16^{\circ} 5^{6^{\prime}}$ to the west of the meridian of the point of Galles, answering to $60^{\circ} 49^{\prime}$ of our longitude; but according to a note inserted at the bottom of a small plan of it, which has been sent to me, it should be $20^{\circ} 47^{\prime}$ west of Galles; and in $56^{\circ} 5^{8^{\prime}}$ of our longitude.

"On the following day, having made an hundred and three miles to the north-west by north, these two ships struck on a reef, running off about five leagues to the south- 
west of a small island, which they saw in the morning, in $6^{\circ}$ of latitude, and which I should suppose was the north side of the Isle of Roquepiz, if the Portuguese Maritime Directory had not stated, that, to the south-west of it, and at the distance of six leagues, there were three small flat islets, with a few trees on them, and laying from east to west, which these ships had not seen. As they observed the variation in the environs, the uncertainty of their longitude engaged me to have recourse to it : and following the course of the lines of variation which I have already mentioned, the island which they imagined to be Gratia, and I had named the Isle St. George, (as Gratia, or Garcia, is more to the east,) should be in $5^{\circ} 35^{\prime}$, and Roquepi in $57^{\circ} 35^{\prime}$ longitude.

" There remains in this sea, the Isle of Sept Freres, on which I have seen no other memorial than that which is found in the Portuguese Maritime Directory, where it is mentioned as being in $4^{\circ}$ of south latitude.

"With respect to the islands that are to the eastward of this, they appear to me too well known, from having been so often seen by our own ships and those of the English, to require a particular description in this place.

"The island Diego Garcia, was seen on the $24^{\text {th }}$ of September, 1769 , by M. le Chevalier Grenier, who commanded the King's corvettes L'Heure du Berger and Le Verd Galant. M. l'A bbé Rochon determined its longitude țo be in $68^{\circ} 20^{\prime}$. M. la Fontaine, who commanded the Verd Galant, returned in the month of November, 1770 , to examine and take a plan of the very spacious bay, which this island, whose form resembles that of a serpent bent double, contains, as it were, within itself. A great number of vessels might anchor there in safety; but the principal object is wanting: for though it is covered with wood, it is not provided with fresh water. Its length is four leagues from north to south, and its greatest breadth is two leagues.

" This same island was perceived by an English ship, who, from sight of it, steering to the north, made two other islands and three islets, with a reef, distant about five leagues to the east-north-east. He passed between the reef and the islands, whose latitude he determined to be between $5^{\circ} 1^{\prime}$ and $5^{\circ} 23^{\prime}$. To the north-northeast of these islands, between $5^{\circ}$ and $4^{\circ} 35^{\prime}$, he found an unequal bottom of twentysix, seven, twenty-three, twenty-eight, nine, and twenty-three fathom.

"The island Diego Garcia was also made in January, ${ }^{7745}$, by, an English vessel called the Pelham, in its passage from the Cape of Good Hope to Bombay. 
He remarked its bay, as well as the islets which are at the entrance of it. This ship steered to the north-east and east-north-east, and afterwards to north-northeast, to the Equinoctial line, which it crossed in $73^{\circ} 20^{\prime}$ of our longitude : from thence taking a north-west course, on the 31 st of January, at ten A. M. and being, according to reckoning, in $1^{\circ} 55^{\prime}$ north latitude, and $71^{\circ} 4^{\prime}$ longitude, he saw the Maldive Islands north-north-west by west. He passed between them and arrived at Bombay.

" On leaving the Isle Praslin, which is to the north-east of the Isle Mabé, M. Roslan being anxious to know, on this side, the extent of the bank on which these isles are situated, found that it continued ten leagues to the north-east: from this position he steered to the east, running the parallel of $4^{\circ}$; on which the old charts mark the island of Sept Freres, and that of Trois Freres. Notwithstanding the difference caused by the accidental currents, which run sometimes towards the south, and at other times towards the north, the two corvettes maintained the supposed latitude of these islands, sufficiently to be assured that they are not on the parallel of $66^{\circ}$ of longitude. The course of M. Picault, on his passage to the Isle $M a b \dot{e}$, in 1744 , confirms this truth : if, on the other hand, it is considered that the Amirantes are placed on the old charts about $2^{\circ}$ more north than those which have been seen by M. du Roslan, it may be presumed that there is a similar difference respecting the Sept Freres and the Trois Freres.

"As his orders pressed his return to the Isle of France, he could not run the same latitude more to the east, and accordingly took his course south-east by south, and south-south-east, in order to make Diego Garcia. On the $2 \mathrm{~d}$ of March, he saw land at eleven P. M. at the distance of a league and an half; but without being able to find any soundings. Having manouvred during the whole night to keep the land in sight, they neared it at break of day, and perceived three islands, each of them encompassed with a chain of rocks, which extend about a quarter of a league off the coast. They are very low, but covered with very lofty cocoa-trees, and other wood of inferior height. The two first are about a league and one-third in circumference. The third, which appeared to consist of several islets separted from each other, but connected, as it were, by breakers, was supposed to be about two leagues in length; nor is there any reason to conjecture that the channels of these isles admit of a passage.

"As the sun was very near the zenith, M. du Roslan observed the meridian 
altitude of several stars, and from the result of his observations he concluded, that the latitude of the northernmost isle was $5^{\circ} 59^{\prime}$. The second, which is four leagues to the south-south-west of the first, is in $6^{\circ} 10^{\prime}$; and the third, being about three leagues south by south-west of the second, is in $6^{\circ} 20^{\prime}$. Two days after, having made Diego Garcia, whose longitude has been determined from the observations of M. l'Abbé Rochon, he inferred from thence that the longitude of these islands was $67^{\circ} 34^{\prime}$. The number of them induced me to suspect that they are those which former navigators named the Trois Freres.

"To the north-north-east, $5^{\circ}$ north of the island of Diego Garcia, and twelve leagues east-south-east of the islets discovered by the English vessel, which have been already mentioned, are the islets which M. Picault fell in with on the 16 th of April, 1744, in his passage from the island Rodriguez to the Isle Mabé. The direction. of his course leads to them; nor is it to be presumed that there has been any essential difference in this passage. On the preceding evening he found himself off a bank in $5^{\circ} 55^{\prime}$ latitude, where the depth was unequal, from forty-five to eleven, nine, twenty-five, and forty fathom. From thence having taken his course to the north, he found himself in the midst of twenty-two islets, and passed through them in $5^{\circ} 30^{\prime}$ latitude to proceed to the west. From the examination that was made of the islets, they were found covered with cocoa-trees, and their elevation was from twelve to fifteen feet above the level of the sea. The largest of them was about half a league in length : some of them were very small, and entirely surrounded with reefs. All the charts, in their representation of this little Archipelago, coincide with the plan given of them by M. Picault, under the name of Peros Banbos; but it is placed there a degree too much to the south.

" The island of Cbagas, as well as the shoal waters which are in its environs, was seen in the year $176_{3}$, by the ship Pitt, in $7^{\circ} 15^{\prime}$ latitude, and its longitude determined by an observation made by Mr. Stevens, of the mean distance of the sun and moon, in $71^{\circ}$ of our longitude, or $73^{\circ} 25^{\prime}$ east of Greenwich. He discovered also, eighteen leagues to the north-west of this island, in $6^{\circ} 40^{\prime}$ latitude, five or six little islets, which had been seen in the latter end of December, ${ }_{175} 6$, by M. de Surville, who commanded the ship the Duc d'Orleans; and about twenty leagues to the east, he found himself on shoal water, such as the ship Pitt had seen, according to a draught of it which has been communicated to me, in seven fathom, and three leagues to the south-south-east in ten fathom. 
" At forty-five leagues north by north-west of the island of Cbagas, between $4^{\circ} 39^{\prime}$ and $5^{\circ}$ latitude, there is a bank that was discovered by the English ship the Speaker, of which a draught has been sent to me. The depths were there found to be very unequal, from twenty-two, to twenty, five, six, and eight fathom. This vessel having anchored to the south, the longitude was calculated by observation of the mean distance of the sun and moon, and found to be $73^{\circ} 2^{\prime}$ east of Greenwich, which answers to $70^{\circ} 37^{\prime}$ east of Paris.

"As to the Isles $A d u$, the most recent information with respect to them proceeds from M. Moreau, who fell in with them in the boat the Favori, in 1757 . According to the latitude which he observed, these isles should be in $5^{\circ}$, but having remarked on his journal, by comparing the observations that he had made of the latitude of places well known, that the instrument which he employed gave them from $18^{\prime}$ to $20^{\prime}$ too much to the north; it would follow these isles must, in the same proportion, be too much to the south. And hence it is that M. le Chevalier Grenier, who followed in the King's corvettes the L'Heure du Berger and the Verd Galant, the parellel of $5^{\circ}$, did not perceive these isles, which are not discoverable but when you are close upon them. As to their longitude, I believe that it must be placed in $75^{\circ} 30^{\prime}$, and not in $73^{\circ}$, according to the reckoning of M. Grenier; as in pricking the course of M. Moreau, he should have passed in sight of the island of Cbagar, or over the shallows near it, though at the same time he had not seen it.

"The same day on which M. Moreau saw the Isles $A d u$, he discovered others to the south-south-east; which appear to be those that the ship London fell in with, in $5^{\circ} 39^{\prime}$ latitude, and $5^{\circ} 20^{\prime}$ to the west of the east part of the Isle of Ceylon, in $6^{\circ} 39^{\prime}$ latitude. A draught of them has been transmitted to me, as well as of the bank which extends to the south of these isles, which I believe to be those of Candu.

" M. Moreau was anxious to make himself acquainted with the $A d u$ isles, and accordingly sent a canoe, with an officer and eight men, to examine them; but he was compelled by the winds and currents to abandon his canoe and people, and pursue his course to India.

"In this situation, the officer and his men, after much difficulty and danger, landed on these islands on the 2gth of March, 1757. They are about twelve in number, and surrounded with reefs. The deserted seamen, however, found wherewithal to sustain them, by cocoa-nuts, which were in great abundance, and birds which they contrived to kill. They continued wandering about from one island to 
the other, in search of food, and in a state of uncommon misery and distress; nay, they were even on the point of losing their canoe, which was become their only resource.

"After having sojourned on these islands till the winds set in which would take them to India, and having constructed a catamaran, to carry the provision of cocoas requisite for their sustenance, as well as made the necessary cordage from the filaments of the cocoa, they departed from the isles on the $22 \mathrm{~d}$ of June, and took their course towards the coast of Malabar, without any guide but the sun and the stars, and their own maritime experience; as during their abode on the islands they had lost their compass.

" On the $24^{\text {th }}$, their catamaran overset, and they saw themselves reduced to the small provision of cocoa-nuts in the canoe, which lasted only till the 1oth of July, when they were actually without food. From that period they every day suffered from the weakness incident to their situation, and the painful consequences of hunger and thirst. At length, however, a period was put to their sufferings, and they landed at Cananore; from thence they proceeded to $M a b \dot{e}$, and so on to Pondicherry." 


\section{CHAPTER XIV.}

\section{The Course by the East of Madagascar, during the Period that the Soutb-west Monsoon prevails in India, extracted from $M$. d'Apres.}

"

If you should not choose to go to India by the channel of Mozambique, you may equally make your passage by the east of Madagascar. This track is better suited to ships which cannot reach the channel before the $15^{\text {th }}$ of August, on account of the feeble winds, calms, and variable weather which prevail there in that season, instead of the fresh winds that never fail to blow to the eastward. In case you should want to put into any port for water and refreshments, which long voyages render sometimes indispensable, they may be easily procured at Fort Daupbin, at Foul Pointe, and other places on the east coast of Madagascar.

" To make this passage, after having doubled the Cape of Good Hope, and being secure of your point from the view of the cape, or the soundings of the bank des Aiguilles, you will continue to get to the east, on the parallel which I have mentioned, as far as $44^{\circ}$ or $45^{\circ}$ of longitude. From thence steering to the north-east, and afterwards to the north-north-east, (an allowance being made for the variation and the drift) you will proceed to join the parallel from $26^{\circ}$ to $25^{\circ}$ of latitude by $50^{\circ}$ of longitude; and this precaution appears to me to be sufficient to prevent the errors of ordinary navigation.*

* "It were to be wished that those who have the command of vessels, or at least those who may contribute to the right direction of them, by their opinions, were qualified to determine the longitude at sea, by the distance of the moon from the sun or stars, which gives a sufficient approximation to perceive and avoid the errors of reckoning. The English Nautical Almanac, whose Ephemeris has given, since the year $\mathbf{1 7 7 4}$, an extract of every thing that is most essential for these observations, abridges, in a great degree, the labour of calculation, as well as many other books, which have been published in England on this subject, and render this method intelligible to well informed pilots. A considerable part of the English navigators, as well as many in France, use them at this time with success; and nothing can contribute more to the safety of navigation, particu. larly when the place of destination is already determined with exactness. The course, then, that $I$ 
"In this state of uncertainty, you must take care not to reach, during the night, the latitude of $25^{\circ} 45^{\prime}$, which is that of the south part of Madagascar: however that coast has no soundings off shore, but to the west of Cape Saint Mary.

"When it is designed to touch at Fort Dauphin, situated in $25^{\circ} 5^{\prime}$ latitude, it will be proper to near the land in $24^{\circ}$, or at least in $24^{\circ} 30^{\prime}$, in order not to miss it from the rapidity of the currents, which run towards the south, as much as $48^{\prime}$, or sixteen leagues in twenty-four hours. To avoid therefore the effects of it, during the night, on approaching Fort Dauphin, if the weather should be sufficiently favourable, and there should be a sandy bottom, the best way would be to cast anchor; but if the breeze is too strong, the ship must remain under sail.

"When you make the land in $24^{\circ}$, you will perceive a chain of very high mountains; and in $24^{\circ} 15^{\prime}$ to $18^{\prime}$, you will see a mountain in the form of a sugar-loaf, blended with lesser ones on the sea side. Then sailing along the shore at the distance of a league and an half, you will perceive, across the isles Saint Luce, some small rocky banks off the shore, situate between $24^{\circ} 35^{\prime}$ and $24^{\circ} 45^{\prime}$; and continuing to range along the coast at the same distance, you will perceive a point to the south-west by west, which will appear at first to be insulated, and represents two mountains more flat than round. Several navigators have erroneously taken it for the point d'Iiapere; that which succeeds, with summits also more flat than round, is not that object, but the third that is afterwards seen, whose pointed summits serve as distinctive landmarks, is the point d'Itapere.

"On approaching the second point, and sailing along the coast at the distance of a league, I perceived some shoals, the most distant of which appeared to me to be three quarters of a league from the shore; and to avoid them, it is necessary to keep at the distance of a league and an half.

"The rock d'Itapere, which is very discoverable by its breakers, is the most

give, will be susceptible of modification, since it will be sufficient to keep yourself from twenty to twenty-five leagues to windward of the places where you may wish to land, to prevent the greatest error of that approximation, and not eighty leagues, as I propose in this example.

"The success of marine clocks, or time pieces, which on the frigate la Flore, commanded by M. de Verdun de la Crenne, Lieutenant in the Royal Navy, have never failed to give the longitude with a precision altogether astonishing, encourages the expectation that the longitude will at length be discovered, by this method, which is the most expeditious, since the error has never exceeded $20^{\prime}$ in six weeks." 
certain mark to distinguish the point, from which it is distant about a third part of a league to the south : there is no passage between them.

"Two leagues to the west-south-west of this rock, is Fort Dauphin. The coast between the point d'Itapere, and that where the fort was placed, forms a cove, called Tolongbare by the natives, and Dauphin Cove by the French, who were formerly established there. The remains of their fort are still visible. It is in the small bay formed by the point, where the ships generally go.

"After having ranged for a quarter of a league along the rock d'Itapere, you must steer towards the point of Fort Dauphin. This point is surrounded with a reef at a cable's length, and within it is the best anchorage. The point $d$ 'Itapere should remain to the east, $5^{\circ}$ or $6^{\circ}$ south of the compass; the rock at east by southeast, and the extremity of the breakers, the nearest to the anchorage, south-east by east. The larboard anchor should be in the north-east in seven fathom, with a sandy bottom; that of the starboard at east-south-east in six fathom, having from twenty, to twenty-eight feet water under the ship. Another anchor should be carried astern, to the north-west.

"If there is not sufficient day-light to get into the road, you must first double the rock d'Itapere, and then anchor in the cove, if the weather will permit; at the same time paying the necessary attention to the nature of the bottom, which is not every where the same.

"Water may be found on the shore of the cove, by digging in the sand, which will be very good for cattle and culinary purposes; but to obtain better, it must be fetched by the blacks in barrels, from more distant springs.

" This country is under the government of several chiefs, of whom it is prudent to be aware; it is necessary therefore to be vigilant, and to maintain good order. This precaution is not only necessary at Fort Dauphin, but also in every other place in Madagascar, where the voyager puts in for refreshment.

"Foul Pointe being frequently preferred to Fort Dauphin, as it is more easy of approach, affords a better anchorage, and is inhabited by a better kind of pcople, it will be right, after having reached the parallel of $25^{\circ}$ of latitude, without seeing land, or any of those indications which announce a proximity to it, to steer to the northward during the day, and north-north-east during the night, to $18^{\circ} 10^{\prime}$ latitude, when it will be necessary to make the land, in order to reconnoitre the Isle aux Prunes. It is a small islet, situate in $18^{\circ} 7^{\prime}$ of latitude, two leagues to the 
north-north-east of Tamatave, and about two thirds of a league from the nearest part of the Madagascar shore. The trees with which it is covered are visible at the distance of five leagues.

"Three leagues to the north-north-east of the Isle aux Prunes, breakers are visible which are occasioned by a bank of rocks. A league and an half further on the same line, there is a shoal, with three fathom water; and another at a league to the north-north-east of the latter, in four fathom water, on which I have struck. These dangers are but a league from the coast.

"The land of Madagascar, from the Isle aux Prunes to Foul Pointe, is of a moderate height, very unequal, and covered with wood; it afterwards rises by small degrees, and in the interior part, double and triple high mountains are visible. The shore, which is of white sand, is bordered with a breaker at the distance of three cable's length. When the Isle aux Prunes is on the north-west point of the compass, at the distance of about two leagues, a small mountain is seen to the north, which approaches nearer than any other to the sea-shore, and forms two paps, which are called the Paps, or Mamelles de Natte, from a village of that name, where the natives sometimes hoist a white flag. Many vessels have taken this place for Foul Poinle, which is distant from it three leagues to the north. It is very easy, however, to avoid that error, on observing that, from the village of Natte, the Isle aux Prunes is always visible, whereas it ceases to be seen on approaching Foul Pointe.

"When you lose sight of the Isle aux Prunes, and that it rests upon the compass at $30^{\circ}$ south-west, then Foul Pointe is $15^{\circ}$ to the north-east.

"The cove of Foul Pointe, where the vessels anchor, is formed by a large reef, which begins at the third of a league below the village, and extends afterwards three quarters of a league to the north-north-east. You must approach it within a quarter of a league, and range along it, so as to double its northern point at a good cable's length. The breakers are very visible there, but they appear less at high water, and with a light breeze. From thence, keeping the wind, you will come to an anchor under shelter of the reef in six fathom, with a sandy bottom, mixed with mud. The northern point of the reef will remain to the east by north, and east-north-east ; the southern point of the cove south by west, $5^{\circ}$ west ; the village to the south-west the third of a league.* The northernmost land towards

“* By a course of observations of the sun and stars, I determined the latitude of the village of Foul Pointe to be in $17^{\circ} 41^{\prime} 20^{\prime \prime}$. I also observed during the night from the 3 oth to the 31 st 
Manivoul to the north by north-east, at the distance of six or seven leagues. Ships moor there east-north-east, and west south-west; when it is necessary to remain there some time, it will be proper to heave out a third anchor, on the north-west side.

"Within the reef of Foul Pointe there is a small cove, in which large ships may enter, the bottom being from six to seven fathom. The only difficulty is to stretch the cables in such a manner as not to rub against the rocks: to be there in perfect safety, iron chains are absolutely necessary, and the vessel must be secured with four hold-fasts, to prevent her from swinging.

" It is an easy matter to traffic for all the necessaries that may be wanting; at the same time the inhabitants are to be mistrusted. As the port is filled with banks, before you send the boat, it is proper to wait till high water. At all events, Foul Pointe should not be frequented but in the finer season of the year, as the reef is capable only of affording shelter in moderate weather. I pass on now to the description of the Island of Sainte Marie and Antongil Bay, where ships may also approach.

"Thirteen leagues and an half to the north-north-east, $5^{\circ}$ east of Foul Pointe road, is the south point of the isle of Sainte Marie, situate in $17^{\circ} 5^{\prime}$ latitude. This island, which the natives of the country call Nossi Hibrabim, or Isle d'Abrabam, extends north-east by north to $16^{\circ} 33^{\prime}$, which is the situation of its northern point. The channel that divides it from Madagascar is a very fine one, and ships of any size may pass through it. Its narrowest part, which is about the middle of the island, is a league and two thirds from the point de l'Ar'e in Madagascar, and the southern point of the cove of Lokinsin on the isle Sainie Maric. From the point de l'Arée, there extends' a bank to the east-north-east, about the third of a league in length, in from two to three fathom water. The point of Lokinsin is also surrounded by a reef, but in the midst of a channel, whose depth is from forty to forty-five fathom.

"The southern point of Sainte Marie is formed by a flat islet, which is separated by a channel, about a stone's throw in breadth. This islet is surrounded by a reef, which extends near half a league to the south; and all the eastern part of Sainte of July, 1757 , an eclipse of the moon, which was equally observed at Marseilles, Toulouse, Rouen, and Béziers, of which $I$ have received the correspondent observations; from whence I concluded that Foul Pointe was $3^{\mathrm{h}} 9^{\prime} 5^{\prime \prime}$ more to the east than Paris, and consequently in $47^{\circ} 16^{\prime} 15^{\prime \prime}$ east longitude." 
Marie is equally inclosed in breakers. In many places off the southern coast, there is eighteen or twenty fathom water.

"On the west side, at about two leagues from the southern point, there is a large cove, about a league in breadth, north-east and south-west, and at the extremity of it a small islet, named the Isle aux Cailles, under whose land small vessels may find shelter. We had formed a settlement there in 1750 , which the character of the inhabitants, joined to the unwholesomeness of the climate, compelled us to abandon. In order to anchor in the cove, you must range along the southern side of Sainte Marie, in from eighteen to twenty fathom; and after liaving doubled a large rock which is at the south-west point, you will cast anchor to the north of the Isle aux Cailles, in from eighteen to twenty fathom water. In this position the Pointe de l'Arée appears to the north, at the distance of four leagues.

"The Bay of Antongil, called by the natives Mangbabei, derives its former name from Antonio Gillo, a Portuguese Captain, who made the first discovery of it. It is thirteen or fourteen leagues in length, from north to south, and from seven to eight leagues in breadth, north-east by east $5^{\circ}$ north, and south-west by west $5^{\circ}$ south, between Cape Bellonnes and the Point Baldricbe. In order to enter it, you may range along either side, according to the direction of the breeze. The depth of the water, as well as the quality of the bottom, are the same in three parts of the bay, when the depth diminishes to thirty, twenty-five, twenty, and fifteen fathom.

"At the extremity of the bay there are several islets, the principal of which is called Maros, or Marotte, whose extent is not more than eight or nine hundred fathom, from north-east to south-west, and about a third of a league from the nearest part of the coast. It is in $15^{\circ} 25^{\prime}$ latititude.

"To the south of it are four others of smaller dimensions, the most distant of which is not more than two leagues from it. The common anchoring place is to the north of the islet Maros, at the distance of a gun-shot, and opposite two small coves formed by the sands, in from eleven to twelve fathom.

"Water and wood are obtained with great ease, and the tents are certainly more secure there than on the main land, where the traffic is carried on for provisions. The river is to the north-north-west of the islet Maros. Large boats may enter there, and the sea rises five feet at the new and full moon.

"In order to get to the north, on leaving the Bay of Antongil, you must range 
along the eastern side, availing yourself at the same time of the breezes and $\mathrm{ebb}$ tides, and stecring towards the Point Baldricbe. To the south of that point there is a small islet named Bebenter, to the south of which those vessels come to an anchor which carry on the traffic of this place. The coast which extends two leagues to the east, is lined by a reef about two-thirds of a league from it, to another islet called Mopatte, from whence the coast runs four leagues to the north-east by north, and afterwards north-north-east from $3^{\circ}$ to $4^{\circ}$ north, as far as the East Cape, which is situate in $15^{\circ} 15^{\prime}$ latitude. As it is also lined with reefs which advance, in many places, two-thirds of a league into the sea, it is necessary to keep at the distance of a league from it, in order to avoid all possible danger.

"From the East Cape, the coast takes a western direction, and runs only to the north by north-west $3^{\circ}$ west, to the Bay of Vobemare, situate in $13^{\circ} 26^{\prime}$ latitude; from whence it continues to extend, in the same line, to Cape $d^{\prime}$ Ambre, which is the northernmost point of Madagascar, and is in $12^{\circ} 5^{\prime}$ latitude.

"The Bay of Vobemare, or Boemaro, so called from the Portuguese Captain who made the discovery of it, is nothing more than a cove, lined by a reef on which there are several islets. It is supposed that between this bay and the Cape d'Ambre there are other bays, but I have never been able to procure any description of them.

"I must also observe, respecting the eastern coast of Madagascar, that Fort Dauphin is generally healthy, in all seasons; that from Foul Pointe, which is only so in the bad season, the country is unwholesome in proportion as it advances to the north; and to preserve the crew from the diseases which prevail there in the sickly season, after the end of November, care must be taken not to permit any one to sleep on shore, and that every one should return on board at the approach of night.

"When ships going to India do not put into Madagascar, and only pass to the east, it is necessary to take a view of it to rectify their course. Thus, after having reached, as I have already said, the parallel of $25^{\circ}$ of latitude, if, by making good the course to the north during the day, and the north-north-east during the night, you should get to $15^{\circ}$ of latitude, without seeing Madagascar, which would be the effect of a difference to the east, ${ }^{*}$ then you must steer to the west-north-west,

" $*$ I am sensible that these differences are rare, and that they are oftener found to the westward than the eastward. The example of the ship La Paix, in 1749 , which made the land to the south 
till you get a sight of it; and having neared the land at the distance of four leagues, you must stretch on till you see Cape d'Ambre.

"The currents at the opening of the cape, take their course with great rapidity towards the west, so that the ships which are bound to Querimbe or Mozambique, in passing to the north of Madagascar, must reckon on a difference towards the west, proportioned to the time employed in the passage. Many voyagers have found it twenty leagues in twenty-four hours. An inattention to this circumstance has indeed proved fatal to several vessels, who have run upon the coast of Africa during the night, when it was supposed that they were at a considerable distance from it.

"As to the vessels which proceed to India, after having made Cape d'Ambre, they must make good their course due north, and continue it till within $5^{\circ}$ of latitude: they must afterwards proceed to the north-east, as far as the Equinoctial line, when the course must be regulated according to the principles laid down in the beginning of this instruction."

of Mozambique, to the islet Mafémale, situate in $16^{\circ} 18^{\prime}$ latitude, and $37^{\circ} 30^{\prime}$ longitude, while its reckoning was in $46^{\circ} 30^{\prime}$ longitude, is singular in its kind; and whatever might be the cause of such an error; when, by an examination, in the journal of this ship, of the variations which were daily observed, even at the land-fall, it must appear very extraordinary, that it had not been discovered long before, that it had not got sufficiently to the eastward; and that it was in the Mozambique channel, rather than to the east of Madagascar." 


\section{CHAPTER XV.}

The Course, on leaving the Isles of France and Bourbon to proceed to India, during the South-west Monsoon.-The Course, from the Cape of Good Hope to India, during the South-west Monsoon, passing to the East, and in Sigbt of the Island Rodriguez.-Woyage to India during the Nortb-east Monsoon.

" $\mathrm{A}_{\mathrm{T}}$ the commencement of our navigation to India, the ships bound thither from the Isle of Bourbon, generally held the great course which passes to the east of the Isles, and avoided the dangers which are known to prevail in the Archipelago to the north-east of Madagascar. For that purpose it is necessary to leave the region of the general winds, in order to attain that of the variable ones, and to get afterwards to the east, so as to be able, with the general winds from the south-east to the east, to make the land of the Island of Ceylon. This course employs a very considerable portion of time, and generally occupies two months : some ships have indeed, though very seldom, made it in a shorter period.*

* "In the year 1719, the new East India Company having entrusted to my father, M. d'Après de Blangy, the command of the first ships which it sent to the Indies, with the title of Counselior in the Superior Council, he fitted out at Havre the ship le Solide, on board of which I made my first voyage, in the quality of Honorary Ensign.

"We departed from the road of Havre on the 14 th of December, and after having been obliged to put into Falmouth, on the English coast, from contrary winds, we continued our course. We crossed the Equinoctial line on the 18 th of February, $1720,19^{\circ}$ to the west of the mcridian of Paris; we doubled the Cape of Good Hope on the 17th of April, and on the 8th of May we arrived at the Isle of Bourbon. We remained there till the $2 g^{\text {th }}$ of the same month, when we sailed from the road of St. Paul, with such a favourable wind, that on the following day we passed six leagues to the south of the Isle of France, which was then known by the name of Mauritius. From thence, having during several days fresh gales from the north-west, to the west and south, which, as is well known, are very uncommon in that season, we got, without passing the tropic, sufficiently to the east, to get up afterwards to the northward; so that in the morning of the 27 th of June, we neared the south part of the Island of Ceylon, six or seven leagues to the west of the great shoal. On the sst of July, in the evening, we moored opposite Gondelour, and on the following day in the road of Pondicherry, after a passage of thirty days from the Isle of Bourbon. I do not know any example of so short a passage by the general course." 
"The ships the Lys and the Union, commanded by M. M. de Boisriou and Baudran, in 1723 , were the first who attempted a new course, on the report of some pirates who, having fled to, and being established under a general pardon at the Isle of Bourbon, offered to conduct them. One of them, whose name was Walkin, was chosen on this occasion.

" These two ships set sail from St. Paul, in the Isle of Bourbon, on the $22 \mathrm{~d}$ of August, and at six P. M. were from fourteen to fifteen leagues to the south-east by south of the middle of the island. On the 27 th they made Madagascar, in $13^{\circ}$ of latitude, and discovered that the north part of that island was marked on the chart of Pietergoos sixty leagues too much to the east. From this view, they first made good their course to the north, and afterwards to the north-north-east. They passed the Equinoctial line on the $4^{\text {th }}$ of September, in $49^{\circ}$ of east longitude, without seeing Fean de Nove, or any of the Amirantes, which they ought to have fallen in with, according to the ancient charts. On the 2oth of the same month they made the coast of Malabar. At length, on the 6th of October, these ships arrived at Pondicherry.

"From that time this track has been followed by all our ships. It is nevertheless to be remarked, that those, who have taken their point of departure too much to the south, where the coast of Madagascar projects towards the east, as well as those who took their course north by east, have either fallen in with the Twelve Islands, or the Isle Saint Pierre. It appears therefore that the northern track is indispensable.

"Although this track has always succeeded, as it requires a circuit of $8^{\circ}$ west longitude on quitting the Isle of France to go to Madagascar, and of $8^{\circ}$ to the east to regain the meridian of the place of departure, a more direct track would be preferable; and it would accordingly be better to cross this Archipelago from north to south, as it can be done without augmenting the risk of the passage. This was proposed by M. le Chevalier Grenier, who himself found it successful, as well as many other ships: and if to this course is added that of Admiral Boscawen, as well as that which I held on board the ship the Montaran, which take much more towards the east, it will appear, that this Archipelago is by no means such as it has been represented on the old charts. If there are the same number of islands, and the dangers are equal, their position, as well as their dimensions are very different. The very correct accounts which have, within these few years, been communicated by the voyages of M. le Chevalier Grenier, of M. du Roslan, and M. de Kerguelen, who were expressly 
employed to verify the possibility of this course, have afforded sufficient directions to navigate it in future with a greater degree of security. *

"It might be added, that on leaving the Isle of France, you will pass to the west of the Banks of Nazareth, if you make good a north course, without getting to the east, till within $10^{\circ} 30^{\prime}$ latitude, when you will make the Isle Agalega. On, taking a departure from the Isle of Bourbon, you should make good your course north by north-east.

" The Isle, or rather the Isles Agalega, as there are two, south-east and northwest from each other, and joined by a bank of sand or a reef, are situate in $10^{\circ} 25^{\prime}$, or $10^{\circ} 30^{\prime}$ latitude, and in $54^{\circ} 15^{\prime}$ longitude. They are low, but covered with wood; so that they may be easily distinguished at the distance of five leagues. The northernmost, which is the largest, may be about a league and an half in length from north to south, and its shore appears to be sand. The ancient charts, which mark these isles a degree of latitude too far north, represent them as being placed on a reef; but our ships not having approached them but at the distance of three leagues on the west side, the extent of the reef could not be determined, nor whether the islands are accessible.

"After making the heights of the Isles of Agalega, the course must be made good to the north by north-east till within $5^{\circ}$ of latitude. In proceeding to the north, there are tide-ways which run with great violence, and apparently towards the west-north-west. It may be conjectured that they are the waters which pass off from between the Banks of Nazareth and that of Saya de Maiba, which set to the westward; differences also are sometimes found on that side. .

" The Choiseul frigate, commanded by $\mathrm{M}$. le Floch de la Carriere, on losing sight of Agalega, having made good her course north by north-east $2^{\circ}$ east, struck soundings on the south-east side of the Isles of $M a b e$, in $5^{\circ} 49^{\prime}$ latitude: but as this bank does not contain any shoal in this part, if a bottom should be found there, it would be sufficient to steer east-north-east, in order to quit it. The only danger that may be encountered, on taking the course to the north-north-east, is the Bank de la Fortune, on which M. de Kerguelen moored, and where he thought he

* To these authorities should be added that of M. de Coetivy, Ensign in the King's fleet, and Commander of the ship the Isle de France, who was supported in a superior manner by M. d'Hercé, in his passage from the Isle de France to the Manillas; since, though he left the Isle of France in the month of June ( $577 \mathrm{I}$ ), he stood almost due north to the heights of the Isle of Mabi. 
saw the sea break; but though its extent is not clearly determined, as its latitude on the southernmost side is known to be $7^{\circ} 30^{\prime \prime}$, it will be proper, in order to avoid all danger, to pass it only in the day.

"When you have gained $5^{\circ}$ of latitude, you will take your course to the northeast, towards the Equinoctial line; and afterwards to the points of the wind, which will suit the place of your destination.

\section{Course from the Cape of Good Hope to India, $\$ 9 \mathrm{c}$.}

"In the instructions how to proceed from the Cape of Good Hope, or from the soundings of the Bank des Aiguilles, to the Isle of France, I have advised to get to the eastward on the parallel between $33^{\circ}$ and $36^{\circ}$ of latitude, till by $55^{\circ}$ of longitude, and not to gain the latitude of $27^{\circ}$, but under the meridian of the Isle Rodriguez, in order to prevent any great errors in the reckoning: but as in the present case the object is to make the latter, it is necessary to take precautions relative to its situation, in getting more to the east, and proceeding afterwards so as to get, according to the reckoning, eighty leagues to windward of that island.

"As a sight of Rodriguez is essential to the course that is here proposed, when you are at its height, and certain, from the variation, that you are to the east of it, you will steer to the west, in order to make it.

" On being five or six leagues to the east of this island, you will make good your course north by north-east, in order to pass to the east of Corgados Garayos, the shoal Saint Brandon, and the Bank of Saya de Malba. This course may then be continued to the Equinoctial line, and from thence, ordered in such a manner as the final destination of the voyage may require.

"In making this course, it is necessary to attend with great vigilance to the approach of the latitude of the islands, and the dangers that may be encountered, as, during the season of the south-east winds to the south of the line, the currents run towards the west, and frequently to the north-west. The island known in these seas is that of Roquepiz, situate in $10^{\circ} 30^{\prime}$ latitude; and the only memoir respecting it, is the account which John Davis has given of it, in the journal of James Lancaster, who commanded four English ships, in 1601 . He says, that having left the Bay of Autongil, on the 6th of March, and traversing this Archipelago, he found himself on the 16 th, in sight of the island of Roquepiz, of whose beauty and appearance he gives an animated description. The boats which were sent to discover an anchorage 
near this island, found the depths so great, that the ships did not attempt to come to an anchor off it.

"The Portuguese charts of Aleixo da Mota, mention another island of the same name, situate in $6^{\circ}$ of latitude. He says that he saw it: that it is small, low, and covered with wood; and that six leagues to the south-west there are three little islets, very flat, with a few trees on them, which lay from east to west. If the error in the latitude of these islets is the same as in those which we have seen, they would be 1 more southward. It is necessary, therefore, that those who may pass these seas, should take care not to fall in with them during the night.

"I shall observe in general, that in traversing this Archipelago, particular attention should be given, both in the morning and evening, to the flight of certain birds, which roost on the land, and who seldom fly far from it; as the goillettes grises and blancbes, the poules mauves, the foux, and the paille en cul, which are found there in great numbers. They are seen in the morning coming from the land, and in the evening returning to it : so that the direction of their flight indicates, in a great measure, its situation.

"The Portuguese have always paid great attention, as well to the flight of birds, as their kind, and even to the quality of the sea-weed, in order to determine the seas where they happened to be. Their charts are full of dissertations and remarks on those particulars; which, however, have not appeared sufficiently important to enter into a detail of them.

"The course which I have just considered and explained, appears to me to be preferable to the general track; because, in the first place, it does not require the ships to get two hundred and thirty leagues more to the east, in seas where the violence and variety of the winds, and the agitation of the waters, expose them to frequent accidents; and secondly, by getting up to the northward, the land-fall of the Isle of Rodriguez is a point of comparison correctly determined, which regulates the remaining part of the passage : whereas in the general track, there is no point to which the navigator can refer, and in which it has happened to many ships in this season to get among the Maldive Islands, or to the west of Ceylon, while they ought, on the contrary, to make the southern part of that island, when the southwest monsoon prevails in the Indian seas. 


\section{Voyage to India during the Nortb-east Monsoon.}

"Having considered the different courses that may be taken, while the south-west monsoon prevails in the Indian sea, it remains for me to point out those which should be preferred, when the north-east monsoon has succeeded to it, to get either to the Malabar coast, or that of Coromandel.

" On leaving the Cape of Good Hope, the general course, which I have described in the preceding article, must be kept as far as the tropic of Capricorn, from whence the course must be made good, north by north-east, in order to pass the Equinoctial line in $85^{\circ}$ longitude. From this position, if the winds should be north-east, you will be sufficiently to the windward to make the Isle of Ceylon; and stretching along this island towards the west, you will arrive at the place of your destination, whether it be to the coast of Malabar, Goa, Bombay, or Surat; according to the instruction which will be found in my Charts of India.

"If the season should be more advanced, so that the west winds blow to the south of the Equinoctial line about two hundred leagues to the east of Rodriguez, it will be sufficient to steer north-east by north; so that with the westerly winds, which always blow in $8^{\circ}$ or $9^{\circ}$ of latitude, the course may be so held as to cross the line as much to the east as may be necessary.

"Ships bound to the coast of Coromandel, which may be neared after the $25^{\text {th }}$ of December, must pass the line in $90^{\circ}$ or $92^{\circ}$ of longitude, to be able afterwards, with the north-east winds which prevail on the northern coast, to hold a course, so: as to fall in with the wind of the place to which they are destined.

"When ships leave the Isles of France and Bourbon, to proceed to the Indies in the latter season, that is, from the month of November to that of April, they generally take the common course; and for that purpose stretch away, with the assistance of the general winds, to the south, in order to gain the variable winds, with which they get sufficiently to the east; so as by getting up towards the north, to pass the Equinoctial enough to the east to reach the places of their destination.

"Such is the course which voyagers have hitherto pursued, without reflecting, probably, that the west winds which blow in the same season to the south of the Equator, would procure the means of shortening it from at least seven to eight hundred leagues. Perhaps, the sight of the isles, which the old charts suppose to be to the south of the Maldive Islands, might induce navigators to apprehend they should 
mcet with difficulties and dangers in crossing them; but whatever their reasons may have been, though a regular examination would have been sufficient to overturn them, they did not prevent M. le Chevalier Grenier from rendering this important service to navigation. He proposed this course, and executed it with success, in the King's frigate la Belle Poulc. Having got into $89^{\circ}$ of longitude, he passed the line on the twenty-eighth day of his departure.

"The ship le Castries, commanded by M. de Winslow, which left the Isle of France in December, did not occupy more than twenty-seven days in getting within sight of Ceylon. The ship the Bien-venu, Captain M. Violette, followed the same track, while another vessel, which took the general course, in the shortest way, employed two months in going to Pondicherry. These examples evidently prove that the new track ought to be preferred.

"For this purpose it is necessary, on taking departure from the Isle of France in the months of November, December, January, February, and even in the beginning of March, to follow the track which $I$ have marked out for the south-west monsoon, as far as $5^{\circ}$ of latitude ; to follow towards the east, the parallel between $4^{\circ}$ and $4^{\circ} 40^{\prime}$ latitude; and to get up sufficiently to the east, in order to cross the Equinoctial line, conformably to the final object of the voyage.

"The same course may be adopted in going from the Cape of Good Hope, when the season does not allow of reaching India but during the north-east monsoon, when you must make the Isle Rodriguez; from whence you will steer your course north by north-east, as far as the parallel between $4^{\circ}$ and $4^{\circ} 40^{\prime}$, which must be continued to the east, as $\mathbf{I}$ have already observed.

" Though I am persuaded that there is no danger between the parallel of $4^{\circ}$ and that of $3^{\circ}$, nevertheless, till my opinion is confirmed by actual experience, I shall not be peremptory in recommending voyagers to frequent it. Whenever an island is perceived, it should not be considered as attended with danger, if the latitude of its situation is known; and if the longitude of it be determined, it becomes even a necessary point of direction.

"I believe that it would be well, in following this course, not to approach the line in less than $2^{\circ}$ of latitude, to avoid the changes, storms, and calms, which must be occasioned by the different directions of the winds." 


\section{CHAPTER XVI.}

Extract from the Registers of the Royal Academy of Marine, Marcb 9, 1775.On the Arcbipelago to the North and Nortb-east of Madagascar.-Observations on the Chart of the Isles and the Dangers connected with them, to the Nortb-east of Madagascar, between tbe fourtb and eiglbtb Degree of Soutb Latitude, and the sixty-eighth and seventy-fifth of East Longitude. The two last Articles extracted from the Supplement of $M$. d'Après.

"M. D'APREs has divided his work into several Sections: the treatise on the Currents accompanies that of the Winds. After having acknowledged that the direction of the currents depends, in some measure, on the impulse of the winds, and consequently changes with the monsoon, M. d'Après remarks that their force is more perceivable in the vicinity of land, and that their direction is almost always subordinate to the position of the coasts, capes, and islands which they encounter. Hence he is led to describe what is most deserving of notice on this subject; and speaks of the monsoons and currents on the coast of Africa, Arabia, Persia, Hindostan, the Laquedive Isles, the Gulf of Manar, and the Island of Ceylon. He remarks, that the currents set into the Red Sea whenever they run out of the Gulf of Persia; and that, on the contrary, they set into the Gulf of Persia whenever they run out of the Red Sea.

" M. d'Après enters into a still more particular detail of what relates to the coast of Coromandel, and other places in the Gulf of Bengal; and has written some remarks on the navigation of this gulf, which are well worthy of attention: from thence he passes to the Gulf of Siam, the seas and coasts of China, and the Bornean, Phillipine, and Molucca Islands; when he points out the currents, monsoons, and some phænomena connected with them.

" This treatise on the winds which prevail in the Eastern Seas, is terminated by the signs of sea and land breezes, that are generally found near the coasts of which he has spoken, when the monsoon is towards its conclusion; and continue till the opposite monsoon succeeds, and has acquired sufficient strength to overcome them, and maintain its regular point. 
"There is also a memoir on the Archipelago of Isles, and their concomitant dangers, which extend along the north and north-east side of Madagascar. The remarks of M. d'Après on the position of the Isles of France and Bourbon, with respect to India, and the frequent necessity of dispatch in the communication between them, seemed to determine the advantage that would be derived from a knowledge of this Archipelago; nevertheless, no attempt was made to obtain it till the year $174^{2}$, by M. Mahé de la Bourdonnais, Governor of the Isles of France and Bourbon; but he was interrupted in his scheme by the war of $\mathbf{1 7 4 4}$, and his recall to France put an end to every thing which he had projected to forward that useful and important object.

" The danger of passing through this Archipelago to get to India was so generally believed, that the apprehensions of ordinary navigators on that subject were not removed even by the example which Admiral Boscawen gave in 1748 , when he got, by this course, in a very short time from the heights of the Isle of France to India, with a fleet of twenty-six ships. M. d'Après, however, renewed the track of the British commander in 1754, on board the Montaran; and in 1758, the snow Rubis also crossed this Archipelago, and followed the new course, which shortened the voyage upwards of three hundred leagues.

"The success of these attempts, which was surely a sufficient authority for adopting them, did not produce any immediate change in the general voyage to India; and the ships from Europe continued the same course as had been followed since the year 172.2 .

"At length, in the year 1767 , the Chevalier Grenier, who commanded the corvette l'Heure du Berger, being protected by the Minister, and assisted by the Chevalier des Roches, formed the project of making such discoveries in these seas, as to render them better known for the several purposes of navigation.

" The Chevalier Grenier associated with him the Abbé Rochon, to superintend the astronomical observations; and his voyage, which was crowned with success, has supplied a great deal of useful intelligence, which forms a part of the memoir of M. d'Après. After him M. du Roslan continued these discoveries, and fulfilled his object with great attention and correctness. His observations and remarks are also inserted in the same memoir; and his information respecting the Archipelago of Madagascar is so well established, as to leave no doubt of the advantage of that course to India.

" M. d'A près proceeds to describe the course from the Isles of France and Bourbon 
to India, during the south-west monsoon. He mentions, that at the commencement of the trade between France and the East Indies, the ships employed in it always took what has since been called the grand track: by which is understood, that they began to stand to the south, to get from the region of the general winds, into that of the variable ones, with which they would get sufficiently to the east, so as to be able, by stretching to the north, and re-entering the region of the general winds at south-east by east, to make the land of the Island of Ceylon.

"It was in 1723 , that the ships the Lys and the Union attempted a new course, on the report of certain freebooters, who, having received a pardon, were established in the Isle of Bourbon. These two ships left St.,Paul on the $22 \mathrm{~d}$ of August ; on the $27^{\text {th }}$ made Madagascar, in $13^{\circ}$ of latitude; crossed the line on the $4^{\text {th }}$ of September, in $49^{\circ}$ of longitude; fell in with the coast of Malabar on the 20 th of the same month; and, on the 6 th of October, arrived at Pondicherry. This was no inconsiderable advantage, since the passage by the great track generally occupied. two months. This course, therefore, has since been generally followed.

"M. d'Après, nevertheless, remarks, that this new course requires a circuit of $8^{\circ}$ of longitude towards the west, in order to near Isle of Madagascar, and consequently eight other degrees towards the east, to regain the meridian of the place of departure. It would therefore be much more advantageous to follow the more direct course, which has been already mentioned, by passing the Archipelago of Madagascar. It is the same which M. le Chevalier Grenier, Lieutenant in the Royal Navy, had proposed; and M. d'Après does not hesitate to declare, that the correct accounts which have, during some years past, been obtained by the voyages of M. Grenier, as weli as of M.M. du Roslan and de Kerguelen, who were also officers of marine, and expressly sent to verify the possibility of this course, form a body of instructions for the secure navigation of it.

"It is from their observations, that he has marked out the course which vessels may follow, in setting sail from the Isles of France or Bourbon, they must pass, first to the west of the Banks of Nazareth, and afterwards make the Isle of Agalega ; from thence they should steer north by north-east, as far as $5^{\circ}$ of south latitude, and afterwards stretch to the north-east, in order to cross the line, and then choose the course which suits the final object of the voyage.

" M. d'Après does not forget to mention a bank discovered by M. de Kerguelen, which may be encountered in this track; nor ought we to withhold our applause 
for his suggestions respecting the necessity of avoiding this bank, and the precaution he recommends of not getting into its latitude during the night, at least till its extent is known, and its position more correctly determined.

"In the last place, M. d'Après speaks of the voyage to India during the northeast monsoon; and this important article merits the utmost attention of navigators; particularly respecting a course which he explains, and by which seven or eight hundred leagues will be saved. For this abbreviated course, navigation is indebted to M. Grenier, who proposed and executed it in the King's frigate, la Belle Poule. Having got up to the east, as far as the eighty-ninth degree of longitude, he crossed the line the twenty-eighth day after his departure from the Isle of France. The ship the Castries, commanded by M. Winslow, which quitted the Isle of France in December, got in sight of Ceylon on the twenty-seventh day from its departure; and the ship the Bien-venu, commanded by M. Violette, followed the same track.

" M. d'Après, who suffered no opportunity to pass of adding to the utility of his work, has concluded his instructions, of which we have given some account, with the translation of a memoir of Mr. Dalrymple, upon a Chart of the Chinese seas, which makes a part of the Oriental Neptune. The perusal of this memoir will inspire a confidence in the Chart. And we take this opportunity of observing, that all those who form charts, or correct them, will deceive themselves if they suppose, that judicious and experienced voyagers will have any confidence in them, if they are not supported, justified, and confirmed by concomitant memoirs.

\section{On the Arcbipelago to the North, and Nortb-east of Madagascar.}

"I have suppressed in the corrected Chart, the two banks of Nazareth, which do not exist, according to the tracks of several ships who have endeavoured to discover them. The only bank they met with, is that which runs along to the north of the Isles of Corgados Garayos, and extends to the north, without presenting any danger, to $13^{\circ} 3^{\prime}$ latitude. According to the journal of M. Daniel Savari, second in command of the private ship the Esperance, in returning from the Isle Zanzibar to the Isle of France, in 1775, they sounded the bank of Saya de Malba, in the latitude of $9^{\circ} 26^{\prime}$, and passed along it going to the southward till they arrived in $11^{\circ} 34^{\prime}$ latitude, where no bottom could be found; and, continuing the same course, they did not come to soundings on the bank, which runs along to the north of Corgados Garayos, till they got into $13^{\circ} 3^{\prime}$. 
" M. Renault, captain of the Etoile, also fell in with this same bank of Saya de Malba, in 1775 , and, after having lost its soundings, made the Isles of Corgados Garayos. These authorities seemed to justify me in marking on my chart the soundings of these banks, of whose form I am altogether ignorant, as well as their extent from east to west, which I have given conformably to the old charts.

"I have traced the Isle of $\mathscr{F}$ ean de Nove, according to the plan which has been laid down by M. Margaro, who commanded the brig the Etoile, in 1776 . This navigator, on leaving $\mathcal{F}$ ean de Nove, fell in with the Isle de la Providence; and on losing sight of that island, he fell in with the Isle Alphonso, to the south-west of which, at the distance of five leagues, there are two islets, surrounded with a reef, stretching from east to west.

" M. Chotard, an officer on board the ship Pondicherry, says in his journal, that, in his voyage to India, they fell in with a small island, which he believes to be the Isle Sainte Pierre, in $9^{\circ} 25^{\prime}$ latitude; and about eight leagues to the east-north-east, they saw another island. He passed along the middle of the clannel between these two islands, without finding any bottom.

On the Chart of the Islands and Dangers situate to the North-east of Madagascar, between the fourth and eighth Degrees of South Latitude, and the sixty-eigbth and seventy-fiftb of East Longitude.

"From the examination which I have made of the course of several ships, and the journals that have been sent to me, since I have published my Neptune, I have discovered that the Islands of Chagas, and Diego Garcia are one and the same, and that the error proceeded from the observation which had been made there in 1769 , compared with that which had been made on board the ship the Pitt, in 1763 , I have thought it necessary, therefore, to lay down a new chart of the islands, and dangers, which make a part of the Archipelago to the north-east of Madagascar.

"For the construction of this Chart, I have availed myself of the position of six islands, whose longitude has been determined by the eclipse of the moon, which was observed on board the ship Egmont, the $22 \mathrm{~d}$ of November, 1760 , being about ten leagues to the west of the meridian of these isles: a correspondent observation was made at Paris; according to which, these isles are in $69^{\circ} 7^{\prime} 30^{\prime \prime}$ east longitude. Their latitude is in $6^{\circ} 34^{\prime}$ south. On board the same vessel, several other isles 
were seen at sunset, to the north-east, which other vessels have fallen in with, and in this chart are named the Trois Freres.

"In 1771, the corvettes, l'Heure du Berger and l'Etoile du Matin, fell in with six isles, as well as a part of the Trois Freres : the course that was taken when they lost sight of them, to the Isle of Diego Garcia, determines the position of the latter, which is confirmed by the almost direct track of the Bouffonne, in 1777. This corvette being off the southern point of the southernmost of the Trois Freres, the latitude was observed to be in $6^{\circ} 19^{\prime}$ south. Having continued its course to the south-south-east five leagues and an half, it neared the Six Islands in the latitude of $6^{\circ} 34^{\prime}$ south, and proceeding in the same track till $7^{\circ} 20^{\prime}$ south latitude, it stood to the east six or seven leagues. Land was then visible at about seven leagues distance; and at noon they surveyed the southern point of Diego Garcia to the east, and the point to the north-north-east by north, $3^{\circ}$ east, at the distance of about five leagues. They then steered to the north, and north by north-east, to get to the north of the Isle, and to enter the bay where they came to an anchor.

"In 1775, the ship the Calcutta, after having found a bottom, fell in with the Trois Freres, in the same latitude as the preceding ships. The longitude, on getting sight of these islands, by an observation made from the distance of the sun and moon, differs $33^{\prime}$ to the west, from that determined by the eclipse of the moon on the $22 \mathrm{~d}$ of November, 1760 .

"In 1747 , the ship the Kerkuyk saw the same islands.

" It appears by the latitude that was observed on board the Grantham, in 1728, that the islands which were surveyed to the west, and south-west, are the Trois Freres, and that standing to the north, they fell in with shoal water, in $5^{\circ} 4^{8^{\prime}}$ south.

" The Six Islands were also seen by the ships l'Aigle and Duc d'Orleans, in 1757. By the description given in the journal of the last ship, it cannot be doubted that they are the same which were fallen in with by the ships l'Egmont, l'Heure du Berger, l'Etoile du Matin, and la Bouffonne.

"In 1763, the ship Pitt fell in with the Six Islands, and Diego Garcia, or Cbagas. Though the longitude of this island on the chart, is not the same as that which is given to it by the observation made of the distance of the sun and moon on board this ship, the difference is no more than $46^{\prime}$ west. The difference which results from the observation made in 1769 by l'Heure du Berger, is more considerable, being 
$1^{\circ} 50^{\prime}$ east. The longitude which has been assigned in this chart to Diego Garcia, appears to be the most probable. For, first, it has been determined by an almost direct course of two ships, from the Six Islands, to this island. Secondly, in 1749, the ship the Griffin, having fallen in with Diego Garcia, steered to the north; when several islańds, which will be described hereafter, were seen to the west, in the latitude of $5^{\circ} 15^{\prime}$ south; and continuing its course to the northward, soundings were struck on the bank called the Speaker. Now, according to the construction of this chart, the $S$ peaker bank was found in $70^{\circ} 25^{\prime}$ longitude south of Paris ; and the observation of the distance of the sun and moon, made on board this ship, places the Speaker bank in $70^{\circ} 37^{\prime}$ longitude, in the same meridian. The difference of $12^{\prime}$, which results from this construction, is too inconsiderable to leave any doubt as to the position that has been given, as well to the Six Islands, and Diego Garcia, as to the Speaker bank.

"In 1775, the schooner the Cheval Marin, after having taken soundings on the Speaker bank, fell in with the same islands which the ship the Griffin found to the south-west of the Speaker bank. Its course was continued to the south, with the hope of falling in with Chagas, but without success. It is to be presumed, therefore, that when they were in its latitude, they had got more to the west than they had reckoned, which accounts for their not having seen it. They then steered their course to the west, in order to find Diego Garcia; and they run eighty leagues on this parallel without falling in with any land; which evidently proves that Diego Garcia, and Cbagas, are but one and the same island. Having missed Cbagas, they would have found Diego Garcia, if there had been two islands on this parallel.

"In 1776 , the ship Salomon, steering to the east in $5^{\circ} 6^{\prime}$ south latitude, fell in with the Isles Bourdé and Salomon, so called from the names of the ship, and the Captain, who took the bearings of it. Having made twelve leagues to the eastnorth-east, from the point where the bearings were taken, he found himself on the southern edge of the Speaker bank, in $4^{\circ} 55^{\prime}$ south latitude, from whence he continued his course to the east, without seeing any land. These islands, which the ship Salomon found in $5^{\circ} 6^{\prime}$ latitude, are the same which were seen to the southwest of the Speaker bank, by the Griffin, and the Cheval Marin.

" The Peros Banbos Islands are placed in this chart conformably to the track of the Elizabeth, in 1744 , and in the longitude that was taken on getting sight of 
these islands, which may be a continuation of the little Archipelago of the Islands Bourdé and Salomon.

"The latitude observed on descrying these islands, which the ship the Admiral Pocock fell in with in these seas in $176_{3}$, and the details found in its journals, induce us to presume that they are the Peros Banbos Isles, which had been already seén.

" The same opinion may be entertained respecting the island which was perceived by the ship Cornish, in 1762 , and was probably the southernmost of these islands.

"The corvettes l'Heure du Berger and the Verd Galant, in 1769 , and the ship Pelham, in 1745 , fell in also with Diego Garcia; but their tracks do not in any degree determine the position of that Island.

"In 1757, the bott* le Favori saw the $A d u$ islands to the north-north-west, and soon after the Candu Isles, to the south-south-east. The Captain being desirous of examining the former, dispatched a canoe, with an officer and eight men for that purpose ; but the winds and currents compelled him to abandon them, and to continue his course to India.

"The officer and his party landed on the islands, and remained there three months, during which time they were occupied in contriving the means of extricating themselves from their distressed situation. In the account which he gives of his abode on these islands, he observes that they are twelve in number, enclosed with reefs, and about six or seven leagues in circumference; and that in the middle of them there is a bank of a square form, whose circuit is about half a league.

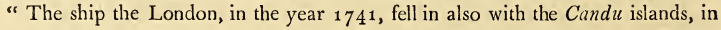
$74^{\circ} 10^{\prime}$ longitude east of Paris. It is in this longitude that they are placed on this Chart. They may be more to the east, but they certainly cannot be more to the west; for if that were so, the Favori would have fallen in either with the Six Islands, the shoal of Chagas, or Diego Garcia.

"The tracks of the ships the Stringers, in 1712, and the Terrible, afford but very uncertain conjectures."

* A Dutch-built vessel so called. 


\section{INTRODUCTION}

\section{To the following Chart of the Etbiopian Sea.}

As it is necessary, for the better understanding of the extracts I have given, to annex a Chart of that part of the Indian Ocean, which it has been my object to illustrate, I have selected, by preference, that of $M$. d'Après, on whose information I have principally depended for the Maritime part of this Work, and the Charts of the Isle of France. The Astronomical and Maritime Observations of the two celebrated French Academicians, M. l'Abbé de la Caille, and M. Le Gentil, which I add, with those of the Abbe Rochon, will still further illustrate those of M. d'Après, if recourse is also had to the learned Memoirs and Charts of $\mathrm{Mr}$. Dalrymple, and Major Rennell.

As I am not a navigator, and as my work is not designed particulatly to be a guide to pilots, history being its principal object, I do not consider myself as answerable for any errors that may be found in the Memoirs of the great men I have cited; if we can call error, what is merely want of more information, or of a complete knowledge of all the points and rocks dispersed on the surface of the universe. Such advantages can only be obtained by length of time, and by the indefatigable and successive exertions of such men, encouraged by their governments.

The following paragraph, taken from the introduction to the memoirs of $\mathrm{Mr}$. Dalrymple, will, I hope, enforce and explain this observation.

"I find many people, from inaccuracy of expression, too frequently call the "charts and plans published by me, му Сна тs :-to prevent the injustice which "would arise from such a conclusion, upon a comparison of the various plates " where the names of latitudes are discordant, it cannot be too strongly enforced, "t that such latitudes and names, are not what I have assigned, or supposed the true; " but what are in the originals, for which I am in no degree responsible, and they " must entirely rest on the authority of the author."

It will be perceived, among other corrections, that the Isle of Roquepiz, mensioned in this Chart, as being situate in $10^{\circ} 30^{\prime}$ latitude, \&c. according to the account of Davis, in Lancaster's Journal, is totally effaced from the modern charts; and 
$3^{62}$

that the Isle of Cbagas, represented as being in $7^{\circ} 15^{\prime}$ latitude, is now considered as one and the same with that of Diego Garcia, \&rc. \&c.

It is very much to be wished that $\mathrm{Mr}$. Dalrymple would give his latest Charts to the world. In the mean time, however, we learn with pleasure, that Mr. Arrowsmith is about to publish, upon a large scale, a general Chart of the Indian Ocean, according to the recent discoveries, and corrections, of the most distinguished navigators. 


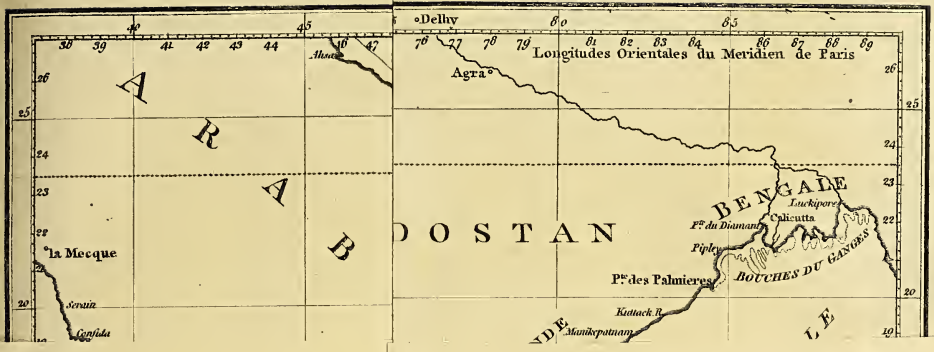






\section{CHAPTER XVII.}

Life of M. d'Après de Mannevillette, Knight of the Order of the King, Correspondent of the Royal Academy of Sciences, and Associate of the Royal Marine Academy.

"J он м Baptiste Nicolas Denis d'Après de Mannevillette, was born at Havre de Grace, on the 11 th of February, 1707 : his father was John Baptiste Claude d'Après, Esquire and Lord of the Manor of Blangy, Captain of a ship in the service of the East India Company: his mother was Mademoiselle Francoise Marion.

" M. d'Après de Blangy did not confide to a stranger, the important care of forming the mind of his son to science, and his heart to virtue: he was himself the preceptor of his child; and he fulfilled that office which affords the most sensible delight to a parent, as it is the most sacred of his duties.

"The young d'Après manifested, in his earliest years, a decided preference for the profession of his father, and his education was anxiously directed to that object. Nor was the parental care disappointed; for he was far advanced in the study of the mathematics, at an age when the generality of children can scarce stammer forth a dead language, which is of less utility to the marine, than any other profession. In short, never did sentiments of enthusiasm for a maritime life appear at an earlier hour, and with a more decided energy, than in the character of $M$. d'Après de Mannevillette.

"In 1719 , M. d'Après de Blangy was appointed to the command of the Solide, which the India Company had destined for Bengal. The early age of his son had determined him to leave the boy at Havre; but his earnest entreaties prevailed, and he was permitted at length to accompany his father; while an honorary commission of Ensign on board the ship was obtained for him.

" The Solide touched at the Isle of Bourbon for refreshment, and then proceeded to Pondicherry, where it arrived after a passage of twenty-seven days, having pursued the general track, and with a degree of celerity of which there is no other example. 
“ M. d'Après de Mannevillette employed every moment of his voyage in making practical applications of the knowledge he had already acquired. A new career of study presented itself to his genius, and new difficulties offered themselves to be surmounted by him. The theory of the young sailor was confirmed by, as it was consolidated with, progressive experience.

"On his return to France in $\mathbf{1 7 2 1}$, he hastened to Paris, in order to perfect himself in astronomy and geometry: his masters were M. M. De Lisle and Desplaces; and the rapid progress which he made in both those sciences, did equal honour to the dispositions of the scholar and the talents of his instructors. After having drawn from the works of the most eminent geometricians, and the society of learned men, all the knowledge necessary to a navigator, he departed in 1726 , with the rank of fourth officer on board the ship the Marechal d'Estrées, which the India Company had ordered to Senegal and the American islands.

"This voyage was not fortunate: the earthquake which alarmed those islands on the 2 oth of September, 1727 , was accompanied with a dreadful hurricane, which either sunk or greatly injured all the vessels in those seas. The Marechal d'Estrées, on setting sail from the Caye St. Louis, was attacked by the tempest: in a short time the rigging was rendered useless, and the masts gave way to the violence of the wind. It was perceived, at the same time, that the ship leaked; and while one part of the crew was employed at the pumps, the other was occupied in attempting to tow her to Cape François; where, after much fatigue and danger, she at length arrived. In this port every exertion was made to repair the damages she had sustained in the tempest; and she was no sooner refitted for sea, than the unlimited confidence of the Captain in the capacity of the pilot became more fatal than the storm. The ship had scarce cleared the port, than she was embarrassed by the rocks of $l a$ Caye. The young d'Après had foreseen and foretold the danger into which the Captain had brought himself, and pointed out, with modest confidence, the means of being extricated from it; but the ádvice of a young man of twenty years of age was rejected with disdain and reproach, for attempting to direct those who had grown old on the seas. The opinions of the latter were followed; and the ship having struck upon a rock, there was no resource for the crew to save themselves from instant death, but to cling to the upper part of the masts, as the ship itself had already sunk. Fortunately they had succeeded in getting out the long-boat and the barge, 
by which the greater part landed on the Great Caique, while the Captain and sixteen men pushed forward to gain the Port de Paix.

" M. d'Après de Mannevillette remained with those on the Caique, without shelter of any kind, and in danger of dying with hunger, as there was nothing to sustain him and his companions, but a small portion of provisions which the sailors had preserved from the fury of the waves. At length a boat arrived to save him and his associates in misfortune from the fate that threatened them.

"He now returned to France, and three years passed away without being able to obtain any employment from the Directors of the India Company; but as he was not formed for inactivity and repose, he, during that time, made two voyages to America on board mercantile vessels.

"In 1730 , he was appointed by the Company, second in command of the brig le Fier. The voyage he made on this vessel gave him an opportunity of observing the coast of Africa, from Cape Blanc to Bisseau. The remarks which he made in the course of it, formed the superstructure of that celebrated work with which he has enriched his country.

“ On his return to France in $\mathbf{1 7 3}^{2}$, M. d'Après remained some time at L'Orient, where he married Mademoiselle de Binard; but Love and Hymen did not quench his predominant passion, and he soon quitted the arms of his wife to follow M. de Tredillac to Cadiz, and from thence to the Madeiras: nor did he return to his country but to leave it again. M. Pocreau, Captain of the Galatée, had received orders from the India Company to set sail for Pondicherry, and in his way thither to pass through the Mozambique Straits. Such a voyage was precisely calculated to inflame the desires of $\mathrm{M}$. d'Apres; he accordingly solicited a situation on the Galatée, and obtained it.

" He returned in 1735 , and departed again in 1736 , on board the Prince de Conti, in the service of the India Company, of which he was appointed Second Lieutenant.

" In this voyage he employed Hadley's quadrant, which had hitherto been exclusively used by the English navigators; and on his return to France, his first care was to state, in a public print, his high estimation of that curious machine; and by thus procuring a reputation to this foreign invention in his country, he may be said to have added to its most valuable acquisitions.

"6 The trial that he made in 1740 , in another voyage to India, of a machine pre- 
sented to the Academy of Sciences, by M. Pitot, one of its members, was not so satisfactory. The object of this invention was to measure the track of ships; but it did not answer the end proposed by it, and gave only a favourable idea of the talents of the inventor.

“ In all his voyages $M$. d'A près was unceasingly employed on the important design which he had conceived of correcting the charts of the Indian Ocean, and of the eastern coasts of Africa and Asia.

'We may be assured,' says Fontenelle, 'that the charts of three quarters of the ' globe are but rough and imperfect sketches; and that even the charts of Europe, ' though so much labour has been employed on them, are far from being correct ' resemblances of the original.' "If, therefore, the charts of Europe received such an opinion of their inaccuracy from such a man, how much more subject to critical objection must be those of India? It was to remedy so many errors, and which have been so fatal to navigators, that $\mathrm{M}$. d'Après, with an indefatigable zeal, collected all the memoirs, charts, draughts, and journals, which he could obtain in the various countries where he had been; and, by comparing them with his own observations, he at length produced the Neptune Oriental, which holds the highest rank among the works that have been published on the important subject of maritime geography, and deserves the gratitude of every commercial nation.

" $M$. d'Après, who was as eager in the attainment of knowledge, as he was negligent in the acquisition of riches, had made his voyages rather as a philosopher than a merchant: his fortune therefore was not sufficient to bear the expences which the publication of his work required. He accordingly applied to the East India Company, who were ultimately to reap the fruit of his labour, for support and assistance. They, however, required the previous approbation of the Academy of Sciences, which being readily granted, the Neptune Oriental was engraved and printed at the expence of the Company. It appeared in the month of November, 1745, and the King permitted the Author to present the first copy to him.

"The eulogiums which this work received were not confined to France: all the navigators and learned men of other countries gave the Author the most flattering, testimonies of their regard. But $\mathrm{M}$. d'Après appeared to be more anxious to merit applause by a continuance of his exertions, than to sit down in the quiet enjoyment of it; he therefore received, in 1749 , from the East India Company, the command of the ship the Chevalier Marin, bound to Senegal. This expedition gave him an 
opportunity of pursuing fresh researches; and now it was that he first attempted to determine the longitude at sea, by the distance of the moon from the stars and sun; a very bold atiempt, which, from a want of proper instruments, was not so successful as it has since been. It appears that Appian was the first who conceived the idea of making the observations of the moon subservient to the determination of the longitude at sea. Gemma Frisicus, and Kepler, adopted his views: but it was reserved for the age in which we live to realize, by practice, the theories of these astronomers.

" M. Halley, convinced, from his own experience, of the insufficiency of the common methods einployed by seamen to find the longitude, proposed to determine it by the motions of the moon, and the occultation of the stars occasioned by that planet: but the honour of having first employed this method belongs solely to M. D'Après de Mannevillette.

"On the 2 st of October, 1750 , he departed again for India, on board the ship le Glorieux, to the command of which he had been appointed by the Company; by whom he was instructed to determine, in a more exact manner than had hitherto been done, the position of the Cape of Good Hope, and the Isles of France and Bourbon. He was also ordered to examine the eastern coast of Africa, from Laurent Bay to the Cape of Good Hope. He received on board his ship the celebrated Abbé de la Caille, whom the government sent to the Cape of Good Hope, to make observations of great importance to the improvement of astronomy, and to measure a degree of the meridian.

" M. d'A près put into Rio de Janeiro on the $25^{\text {th }}$ of January, 1751, and arrived at the Cape on the 3 oth of March following; from whence he proceeded to fulfil the object of his mission, and accordingly steered towards the Isles of France and Bourbon. He determined, with the utmost precision, the position and form of those islands; and he detected an error of about nine leagues in the extent of the Isle of France from north to south, which he fixed at eleven leagues two-thirds, while the old surveys had given it twenty-one.

" Two years after, the Abbé de la Caille received the orders of government to visit both these islands, and to repeat the same operations; and the calculations of the geometrician were in exact conformity to those of the navigator. M. d'Après, on examining in his turn the survey which the Abbé de la Caille had made of the 
Cape of Good Hope, discovered that he had not placed Cape False enough to the south.

"M. d'Après having executed his commission respecting the Isles of France and Bourbon, set sail in the ship the Treize Cantons, the Glorieux having been detained by the Governor of the Isle of France for the service of the colonies, to take a survey of Madagascar and the coast of Africa.

"In the year 1754, M. d'Après rendered a signal service to navigation. Till that period the French, in their passage from the Isles of France and Bourbon to India, had conceived an insuperable dread of the Archipelago which extends from the north to the north-east of Madagascar; nor had any of them attempted to pass it, though it would have shortened the voyage upwards of three hundred leagues: M. de la Bourdonnais had indeed, in the year ${ }_{174}{ }^{2}$, made some attempt to determine the possibility of this passage; but the war which took place soon after, obliged him to occupy himself with other objects.

"Admiral Boscawen, in 1748 , had the courage to attempt this passage with a fleet of twenty-six ships; but the French seamen were contented to admire his spirit, without following his example. M. d'Après was the first Frenchman who ventured to pursue the same course as the English Admiral. He also dissipated the apprehensions of navigators, by giving a description of the islands and dangers which are met with in that Archipelago.

" His health being exhausted by so many voyages, and such"a succession of laborious occupations, he stood in need of repose, and his sole occupation was in giving his work every improvement which subsequent experience and reflection enabled him to do. The instructions which he published in 1766 , by order of the Minister of Marine, for ships bound from Europe to the East Indies, was rewarded by the favour of the Court, and the riband of the Order of the King. In 1775, a new edition of the Neptune Oriental appeared under the auspices of his Majesty, who was pleased to permit it to be dedicated to him.

We shall content ourselves with transcribing what was written on the death of M. d'Après, by Mr. Dalrymple, so well known in this country, in Europe, and in India, for his superior knowledge of maritime geography.

' M. d'Après was not one of those men which are seen every day: Very few - indeed have advanced so far in that branch of science to which he devoted his 
- life. No maritime geographer, of any age or country, can be compared to him. ' His equal has never existed.'

"This illustrious navigator was employed in arranging materials which were to form a supplement to the second edition of the Neptune Oriental, when death deprived the world of this great man, on the 1 st of March, 1780 ; but M. d'Après de Blangy thought it a duty incumbent on him, for the public good, and for the honour of his brother, to publish this Supplement." 


\section{CHAPTER XVIII.}

Lettor of Baron Grant.- Fournal of $M$. l'Abbé de la Caille, during bis Voyage from the Cape of Good Hope to the Isle of France; and bis Operations there.

\section{LETTER XII.}

Isle of France, 15 th August, 1753.

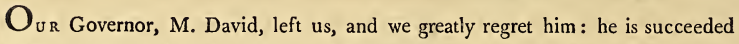
by his brother-in-law, M. Bouvet. I have given up my plantation in the Plains of Willems to M. de Ruviere, and am now in the quarter of Pamplemousses. The plantation which M. David procured for me is called L'Epreuve. I have there the best house in the island, and the only one built of hewn stone, ${ }^{*}$ except the magazines, and the Governor's residence at the port. It is not, however, stone that is wanting here; on the contrary, there is a superabundance of it; but we have few workmen, and no masons. Besides, the wood, which is very common, is more readily worked.

Heretofore I procured my provision of coffee from the Isle of Bourbon, at fifteen livres the bale; $\dagger$ at present it is worth thirty-two livres at the warehouse; but if I could obtain permission to embark a bale for France, I should not regard the price. We receive raw sugar from India, which costs us about six sous the pound; we think it very good here, but I believe you would not prefer the coffee which is sweetened with it: I use sugar-candy when I can procure it. The Dutch sometimes bring it at nine sous the pound; but with as much thread as sugar.

M. M. Vigoureux de St. Malo have established an handsome sugar work, but it is so ill conducted, that the sugar has the appearance of Norman honey: it costs two sous the pound, and is quite disgusting; but we entertain the hope that the manufacture will improve. This sugar is employed to cover houses in the Italian manner, and being incorporated with chalk, forms a kind of mastich; and, being spread on fine planks, becomes hard as a pavement. The Indians alone know how to make this composition.

* Since that time many other houses have been huilt of stone. $\quad$ An hundred pounds weight. 
Last year the Isle of Bourbon was in a state of absolute desolation. A small insect infested the coffee trees, destroyed the bud, and even some of the trees; at the same time the Company declared its intention to diminish the price that it had been accustomed to pay, which is five sous the pound. The inhabitants, however, have taken courage this year, and it is said that they have gathered two millions five hundred thousand pounds weight.

I informed you about two years ago, that we possessed M. d'Après in this island. He is this year returned to us, and has brought on board his ship the celebrated Abbé de la Caille, who is arrived from the Cape of Good Hope, where he ' has greatly enlarged the knowledge of astronomy towards the South Pole. He has already made some geometrical observations on our island, as M. d'Après had done before him. He possesses an indefatigable mind, and his labours will be of great importance to government, to these islands, and particularly to the voyagers who are obliged to visit them.

Grant.

Fournal of the Voyage of Abbe de la Caille, from the Cape of Good Hope to the Isle of France, and bis Operations there.

"March 4, 1753. The French ship the Duc de Parme, commanded by M. de la Crochay, came to her moorings at the Cape, and brought me a letter from $\mathrm{M}$. Trudaine, dated the 18 th of March, $175^{2}$, and two others from M. Duhamel and M. d'Après. That from $M$. Trudaine contains a permission from the Garde des Sceaux, to indulge in any expence that I may consider as necessary to the advancement of the sciences.

“ 8. At six in the morning I left the Cape, in the boat of M. de Ruyter, to embark on board the ship the Puissieux, for the Isles of France and Bourbon. At noon, the castle, batteries, and ships in the road, discharged a salute in honour of the birth-day of the Stadtholder. Soon after we got under way.

"April 5. Squalls and gales of wind in the morning, with an high sea. In the afternoon we saw a great number of birds, which flew round our ship, and having lighted on the ropes and rigging, suffered themselves to be taken by the hand. These birds are called Goilettes.* In the evening they were all gone.

* Or Querets, (Gulls) Larus, Brisson.

$3 \mathrm{~B}_{2}$ 
"April 16. In the morning we discovered the Isle Rodriguez.

" 18. In the morning we discovered the Isle Ronde, and afterwards the Iste of France: at four P. M. we anchored at the entrance of the port.

" 19. At half past eight I landed, and waited upon M. Bouvet, the Governor, who ordered me an apartment in the government house, and gave orders to prepare a place where I might fix my instruments.

"July 13. We set out to commence our operations. We were accompanied with a detachment of five soldiers, two corporals, and nine blacks, five from the coast of Malabar, and four from Guinea. WWe had a tent, and a pirogue to carry our effects, as well as to cross the arms of the sea, or the deep bays which are very common in these islands. We slept this night at the house of $M$. de Rostaing.

" 19. We employed the whole of this day in going to encamp at a place called la Poudre d'Or. The road is very difficult, and crossed by three arms of the sea. We passed one in the pirogue, and waded through the two others, the water being up to our middle, during the space of half a quarter of a league.

" 22. We went in the pirogue to the post of Fayette, where I made an observation. We afterwards encamped half a league further on. In the afternoon the pirogue was dragged on shore, to get it over land, within the reefs that line the coasts, for the space of half a league.

" 23. An heavy rain in the morning, which pierced through the tent. In the afternoon we launched the pirogue.

" 24. We went in the pirogue to observe the point of Flacq; and from thence to the Puits des Hollandois, where we encamped.

" 25. We went to make an observation at the Baraque a Farine, and from thence to the point of Quatre Cocos, where we encamped.

" 26 . We left our camp at Quatre Cocos, and went in the pirogue to the principal port, to examine the mountains which are in its vicinity. We arrived there at half past eleven in the morning.

" 27. We passed in a canoe to the Isle of Egrettes to take a view of the mountains, and left a signal there.

" 28 . M. Desny went to clear the summit of the mountain of Creoles, and to leave a signal on it. M. Godin and myself went to the Isle Marianne, and to the point $d u$ Diable: we sent for our people from Quatre Cocos.

" 30 . We left the principal port in a large canoe, and disembarked a little beyond 
the two Isles des Cocos. I made an observation at the point des Vaques, ${ }^{*}$ and we afterwards encamped beyond the arm of the sea called du Boucbon.

"July 31 . We encamped at the Baraque du Gouverneur. I went to make an observation at the point $d u$ Suffleur.

"August 1. We encamped between the river of the post, and the brook which is beyond it. In the afternoon we examined the savannah, in order to find a base.

" 2. We encamped on the river Dragan. We examined the remaining part of the savannah to find a base.

" 3 . I placed two signals to connect the operations with the base which we were to measure.

"4. We encamped on the rivulet called le Bain des Negresses. M. Desny, who found himself indisposed, returned to the great port. In the afternoon we endeavoured to find a square for the base.

" 5 . We squared the base; but finding it too short, we deferred to the following day the finding another line.

" 6 . We changed the line in the morning, and in the afternoon measured six hundred and seventy fathom of ground of unequal surface.

“ 7 . We measured about twelve hundred and fifty fathom of ground of an unequal surface, which was divided by an arm of the sea of two hundred and fifty fathom in breadth.

" 8. We compleated the measurement. M. Desny returned from the great port.

" 9 . We went to erect a signal, and to make an observation on the mountain of "the savannah. We arrived there after a walk of six hours and twenty minutes, through thick woods, and along the upper part of the lower mountains, which forms an uninterrupted chain. We were obliged to make a large fall of wood to form a signal, which was not finished till ten o'clock the following morning. It rained during the night and in the morning, so that it was with some difficulty that we were able to make a fire, from the humidity of the ground and the wood.

" 10. We made an observation at noon, and in about five hours returned to the Bain des Negresses.

" 11 . The rain continued throughout the day, so that we could not quit the tent.

66 12 . We set out to return to the great port: we endeavoured in vain to make 
an observation from two signals; as the cloudy weather and the rain obscured the mountains.

"August 13. We placed a signal on the mountain Cbaour; but the cloudy weather prevented any observation. We found at half past eleven, a canoe which came to take us to the arm of the sea called du Cbalan, and we arrived at the great port at half past two.

"14. We made observations on the mountain des Creoles.

" 15. After vespers we went in a canoe to the plantation de la Victoire, at the foot of the Bambou.

"16. We proceeded to make observations on the Bambou, and dispatched a canoe, with some of our people, to place a flag on the Quatre Cocos. The weather was very variable, but we were enabled to complete our observations, and to go to pass the night at the plantation de la Victoire.

" 17 . We returned on foot to the south-east port. The canoe arrived there in the afternoon.

" 18 . We went to make observations at the cocoa tree, on the point of the Deux Cocos.

"19. We embarked on the canoe at the south-east port; but the wind being contrary, we arrived rather late at Chalan; we proceeded nevertheless to take observations at the mountain Cbarou, and from thence to sleep at the Baraque al Gouverneur.

" 20. We went to make observations at the point de l'Arcade, and the eastern termination of the base, and from thence to sleep at the Buin des Negresses.

" 21. We proceeded to the western termination of the base, to the point . d'Ariembel, to that of the Mare aux Foncs; and from thence to pass the night at the post $\mathcal{F}$ acotet, where the tent was pitched, and a canoe ready for our service.

"22. We encamped in the field which is beyond Cape Brabant, after having passed this cape with great difficulty. It is a very lofty and steep bank of rocks, that projects into the sea, which must be scaled to get across it.

" 23. We encamped at the foot of the Morne Brabant. I visited the neighbouring plains, which present a pretty good space to be measured.

" 24. We formed a base at the foot of the Morne Brabant. M. Desny went to place a signal on the mountain of the Little Black River, and on the Morne of the Black River. 
"August 25. We measured the base, which we found to be one thousand nine hundred and fifty-six fathom.

" 26 . We observed the angles at the extremities of the base.

"27. I proceeded to the western termination of the base of la Savanne. The canoe conveyed me beyond Cape Brabant, where I placed a signal; from thence I passed to the post facotet, and slept at the western signal of this base.

" 28 . It rained throughout the day, and following night. In a momentary interval, I saw the signal that M. Desny had been to place on the Piton de Fouge. I slept at the post Facotet.

"29. I made observations at the point of the arm of the sea des Citroniers, at that of Suint Martin, and at the point du Corail; and I arrived at the tent under the Morne Brabant, after having passed the cape in a pirogue, and part of the remaining way in a canoe.

" 30 . I made observations at the hill of Fouge, and returned to the tent under the Morne Brabant.

" 3 . We encamped at the arm of the sea called Tamarin. We passed under an arch of stones, where the soldiers practise a kind of baptism on those who pass it for the first time. We arrived at the tent after a journey on foot, through very difficult ways, which occupied seven hours and a quarter.

"September 1. We passed over the plain of Flicq en Flacq, and measured a base there.

" 2. M. M. Godin and Desny squared the base. I returned in the pirogue to the north signal of the base of the Morne Brabant, from whence I could not see the extremity of that of Flicq en Flacq. I slept at the foot of the mountain of the Little Black River.

"3. M. Godin and Desny measured the base. I ascended the mountain of the Little Black River, where I suffered four hours constant rain. The weather becoming more clear, I observed my principal angles, and descended. It was eight in the evening before I had passed the woods, and arrived at the place where I had passed the preceding night.

" 4. I returned in the canoe to the tent at Tamarin. In the afternoon I made my observations at the two ends of the base at Flicq en Flacq.

" 5. I proceeded to make observations on the Morne of the Black River, from which I descended with great difficulty, from the slippery state of the herbage, and 
the small round pebbles with which the mountain is covered. I came to the point de Corail to take an observation there; and from thence I went to Tamarin. In the evening I made an observation at the southern termination of the base.

"September 6 . We went in the canoe to encamp at the Little River; through. out the day, the mountains were covered with clouds.

“ 7. We proceeded to make observations at the point des Caves, and that of the plain aux Sables; and in the afternoon at the southern entrance of the Little River.

" 8. In the morning we went to make observations at two points on the side of the river Belle Isle. In the afternoon we continued our way to pass the night at the foot of the mountain du Corps de Garde.

" 9 . In the morning we made an observation on the mountain. On descending from thence, we found horses prepared to take us back to Port Louis.

" 17. We made observations at the mountain du Pouce.

" 19. We departed to complete our operations, which had been interrupted, at the Coin de Mire. From thence we went on foot to pass the night with M. de Rostaing.

" 20. We went on horseback to the Trou aux Bicbes, and from thence on foot to Cape Malbereux, where we found our tent, and a large canoe.

" 21. We made observations at the Coin de Mire; and although it was very fine, and the sea smooth, $I$ was indisposed with sea sickness. We remained four or five hours on that islet, and from thence we went to our tent. In the evening I made an observation at Cape Malbereux.

" 22. At sunrise, I went to make observations at the signal of la Butte aux Sables; from thence we all embarked for the bay du Tombeau. WVe then proceeded to the western termination of our first base, and passed the night with M. Rostaing.

" 23. I went to make an observation at the Piton de la Decouverte, on account of the new flag-staff which had been placed there. I returned at half past ten to Pamplemousses, and from thence to the house of M. de Rostaing, where I was seized with the dysentery.

"24. I proceeded on horseback to the montagne Longue, and after having made an observation there, returned to the port, where in two days my bealth was re-established. 
“6 28 . I went to make observations at the flag placed at la Decouverte du Port, which was the last of our stations. *

"We shall interrupt our journal, at this place, in order to give a description of what is most remarkable in the Isle of France.

\section{Brief Description of the Isle of France.}

" The Isle of France, first discovered by the Portuguese, who probably carried thither the deer, goats, and monkies, which have since multiplied in it, was afterwards possessed by the Dutch, under the name of the Isle of Mauritius. The great number of establishments which that republic maintained in India, occasioned them to abandon it in 1712 : and the French, who had long occupied the Isle of Bourbon, which is not more than thirty-five or forty leagues from it, did not fail to possess themselves of it.

" According to my calculation, founded on the geometrical measurement which I have made, its outline is ninety thousand six hundred and sixty-eight toises. Its greatest diameter, which is nearly north and south, is thirty-one thousand eight hundred and ninety toises; and its greatest breadth, which is nearly east and west, is twenty-two thousand one hundred and twenty-four toises. Its figure is an irregular oval; and the surface contains four hundred and thirty-two thousand six hundred and eighty acres, at an hundred perches of twenty feet in length.

"This island has two very fine harbours. The least of them, which is called Port Louis, is situate towards the middle of the western coast ; and there is the principal establishment of the India Company. Ships must be towed into it, but they may sail out of it with the wind right aft.

"The other harbour, which is called the Great Port, or Port Bourbon, is situate towards the middle of the eastern coast of the island, and is very capacious and secure. Ships may enter it with a leading wind; but the departure from it is difficult, on account of the prevalence of the south-easterly winds, which blow directly into the principal of the two channels which form its openings. Here it was that the Dutch established their settlement, and built a fort, which they named Frederic Henry. Its foundations, and a part of the walls, still remained in 1753 , but they have since

* The result of all these observations, inserted in the Memoirs of the French Academy, anno 1754, P. 118, will be seen hereafter, and the Map of Mauritius, at the beginning of this Work, is reduced from it. 
been entirely removed, in order to erect a very handsome building for the reception of the commandant of the port and the garrison, as well as to contain the necessary magazines.

"The island is in general surrounded with rocks, and the bottom of the sea near the coast is covered with coral, madrepore, and shell-fish. There is very little real sand; and that which is found on the sea shore, is little more than the remains of shells. Its coast is lined with reefs, on which the waves break. These reefs sometimes extend upwards of a league into the sea, so that the circuit of the island may be made with great safety in a pirogue. It is only in the southern part that the sea breaks almost on the shore; this circumstance renders it inaccessible except in some places, where a canoe can be secured from the high sea.

" The Isle of France is almost entirely covered with woods, which are of an handsome appearance, particularly on the south-east side; but a passage through is rendered very difficult and troublesome, from the quantity of fern, and creeping plants.

" These plants, whose branches, like those of our ivy, wind about and interlace themselves. with the shrubs and dead wood, render the forests in a great measure impassable. Nor can a passage be obtained in any part of them but by circuitous ways, which are known to few. These forests are the refuge of the Maroon Negroes.

" The animals which are found in this island are deer, that resemble those of our own country, and whose flesh is excellent during the months of April, May, June, July, and August. There are no serpents in the Isle of France, and it is said that they cannot live there; while in the surrounding islets, called the Isle Ronde, the Isle Longue, and the Coin de Mire, there are both adders and serpents. I do not pretend to verify this opinion; and all I can say respecting it is, that in the Coin de Mire, I have seen lizards twelve inches long and one broad; and that in the Isle of France, I saw only a small species running about the walls, and of the same kind as those which we have in France. My knowledge of botany, is not sufficient to justify any attempt to describe the plants of this island.

"About the tenth part of the Isle of France is cleared and cultivated. Wheat, barley, oats, rice, maize, and millet, are the grains which compose its harvest. Certain portions of land are allotted to the cultivation of Manioc, which is the food of the Negroes. In some parts there are also plantations of sugar and cotton. 
" The air is wholesome, temperate, and even cold, particularly in the more elevated plantations. The heat is greater at Port Louis than elsewhere, as the neigh. bouring mountains protect it from the south-east wind, which prevails throughout the year. The sky is not equally serene in every part of the island. In the middle part it rains almost every day, so that the pools and rivers are constantly supplied with water; while in the north-western district, it rains regularly in the months of January, February, March, and April ; and sometimes in May, June, and July. The dry season prevails through the remaining part of the year. Thus the town and the environs of the port are rendered disagreeable and unpleasant, from the dried herbage, and the aridity of the mountains, which have no trees, and are sprinkled with stones. Even during the dry season the sky is seldom clear; clusters of clouds are continually coming from the middle of the island, where it rains almost every day, as has been already observed.

"The winds come generally from the south-east; and are much less violent than at the Cape of Good Hope. There are, however, variable winds from October to April. The barometer varied six lines during the time I remained on the island. In my observatory, which was not elevated more than four or five fathom above the level of the sea, it was at the highest on the $13^{\text {th }}$ of July, 1753 , when it was twenty-eight inches five lines and one-third; and on the 1 oth and 12 th of January, 1754, it was the lowest, at twenty-seven inches eleven lines and an half. On these two days there was an heavy rain and an hurricane, which was felt at the Isle of Bourbon. Throughout the year there was no sensible change in the mercury, except that it was a very small degree higher at noon than in the evening.

\section{Continuation of the Fournal.}

"January 16, 1754. I embarked at the Isle of France, on the ship the Bourbon, commanded by $\mathrm{M}$. Lesquelen, to go to the Isle of Bourbon. We got under way at eight in the morning, and the following day came to an anchor in the road of St. Denis, at one P. M. M. Brenier, who commanded in this island, provided me with a cottage near the government-house, and a black servant to attend me.*

"February 26. I embarked in the evening on board the Achilles, commanded by M. de Beau-briand to return to France. We got under way the $27^{\text {th }}$ at ten A. M."

* The Abbé de la Caille has given no account of this island, as he remained there only forty days. 


\section{CHAPTER XIX.}

Astronomical Observations made on the Isle of France, छc. छc. in the Year 1753, by the Abbé de la Caille. *-Determination of the Longitude of the Island of Madeira, by the Eclipses of the Satellites of $\mathcal{F}$ upiter, observed by M. Bory, Lieutenant in the Royal Navy of France, compared with those of the Abbe de la Caille, at the Isle of France, by M. de Lisle.

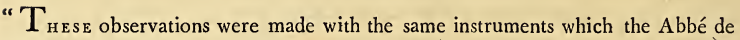
la Caille had employed at the Cape of Good Hope. The place where he fixed them in the Isle of France was expressly fitted for the purpose. Though the sky is generally clear in this island, it proved cloudy at the moment of the greater part of his most important observations; this circumstance proceeded, in a great measure, from the situation of the port, where the principal settlement of the island has been formed, which is surrounded with mountains almost always covered with clouds, which are dispersed by the winds, and successively cover the different parts of the sky.

"Article 1.-His first observation was made the $3 \mathrm{~d}$ of May, 1753 , on an eclipse of the Sun. Having regulated the pendulum by the corresponding heights of the Sun, he observed with the telesope of his sextant, which was seven feet in length, the phases of this eclipse. The largest phase was 8 digits 36 minutes.

"Art. 2.-He observed some eclipses of the satellites of Jupiter, with a telescope of fourteen feet in length, on the $25^{\text {th }}$ of April, at $5^{8^{\prime}} 3^{8^{\prime \prime}}$ past six in the evening. He repeated the same observation of these satellites the 16 th of October, at $36^{\prime} 12^{\prime \prime}$ past three in the morning; on the 1 st of November, at $54^{\prime} 4^{\prime \prime}$ past one in the morning; on the 1 st of December, at $3^{\mathrm{b}} 5^{1^{\prime}} 33^{\prime \prime}$; and on the $2 \mathrm{~d}$ of January, 1754 , at $0^{\text {h }} 7^{\prime} 48^{\prime \prime}$.

"Art. 3.-On the $5^{\text {th }}$ and 6 th of May he observed the transit of Mercury upon the Sun. On those days the weather was very variable; the intervening night was rainy, and it thundered; an uncommon circumstance in this island.

*xtracted from the Memoirs of the Royal Academy of Sciences. 
" At six in the morning, Mercury came forth from the clouds which hovered over the mountains, when it had attained an altitude of $7^{\circ} \frac{1}{2}$. He then observed, with a telescope of three feet in length, that it had but just entered on the Sun's disk, and was near a spot, when the sky became cloudy, and it rained copiously till $4 \mathrm{O}^{\prime}$ past eight.

"When the weather was cleared he made his observations with the horizontal and vertical lines, which form, in the focus of the glass of his quadrant, a radius of three feet. He had already verified their position by the horizon of the sea, as well as that of the line of collineation. The times which he gives in his tables are the true ones, and the altitudes are corrected only by the quantity with which the quadrant had increased them, \&c.

"Art. 4.-Opposition of Saturn to the Sun.

"Art. 5.-Passage of Mars through its nodes.

"Art. 6.-Opposition of Mars to the Sun.

"Art. 7.-Observations to ascertain the altitude of the Pole, and the obliquity of the Ecliptic.*

"I determined the elevation of the Pole from the place where I made the observation, by the mean of four stars which pass near the Zenith; and served at the same time to verify the position of the axis of the teleseope of the sextant, in regard to the first point of the division, and by the means of the distance of the two tropics from the Zenith. In June, ${ }^{1753}$, by five observations from $\gamma$ of the female Hydra, reduced to the 1st of January, $175 \circ$, I found its distance from the Zenith to be $1^{\circ} 39^{\prime} 3^{8^{\prime \prime}}, 8$, on one side, and by five others, reduced to the same, of $1^{\circ} 42^{\prime} 22^{\prime \prime}, 0$, on the other side of the first point of the division; from whence it follows, that the error of the position of the axis of the telesope was $x^{\prime} 2 \mathbf{1}^{\prime \prime}, 6$; that the real and corrected distance from the Zenith of $1^{\prime \prime}, 2$ of refraction, was $1^{\circ} 41^{\prime} 1^{\prime \prime}, 6$; and that, supposing the declination of this star on the 1 st of January, $175^{\circ}$, to be $21^{\circ} 5^{\prime} 43^{\prime \prime}, 8$ south, as in my catalogue, the elevation of the Pole was $20^{\circ} 9^{\prime} 4^{\prime \prime}, 2$.

"In the same month of June, the reduced distance of $\varepsilon$ of the Crow, from the Zenith, was, by four observations on one side, $1^{\circ} 5^{\prime} 22^{\prime \prime}, \mathrm{O}$, and by four on the other, $1^{\circ} 2^{\prime} 42^{\prime \prime}, 7$; the error of the sextant was therefore $1^{\prime} 19^{\prime \prime}, 7$ : and supposing $0^{\prime \prime}, 8$ of

- The following observations being very important to the cosmographic and maritime situation of the Isle of France, we have thought it necessary to insert them at large, as they have been related by the Abbé de la Caille. 
refraction, and $21^{\circ} 13^{\prime} 44^{\prime \prime}, 6$ for the declination of the star, the resulting elevation of the Pole is $20^{\circ} 9^{\prime} 42^{\prime \prime}, 4$.

"I also found in the same month, the distance of $\beta$ of the Crow from the Zenith by four observations, on one side to be $1^{\circ} 5^{\prime} \mathrm{2}^{\prime} 16^{\prime \prime}, 9$ and by three on the other, to be $1^{\circ} 49^{\prime} 37^{\prime \prime}, 5$, the whole reduced to the 1 st of January $175^{\circ}$. The error of the telescope, therefore, was $1^{\prime} 19^{\prime \prime}, 7$; allowing $1^{\prime \prime}, 3$ for the refraction, and taking the declination at $22^{\circ} O^{\prime} 40^{\prime \prime}, O$, there is for the elevation of the Pole, $2 O^{\prime} 9^{\prime} 41^{\prime \prime}, 5$.

"In December 1753, I found, by five observations, reduced to the 1 st of January $175^{\circ}$, the distance of $\beta$ from the Whale, to the Zenith, to be $0^{\circ} 46^{\prime} 27^{\prime \prime}, 9$ on one side, and by four others, $0^{\circ} 49^{\prime}{ }^{1} 5^{\prime \prime}, 7$ on the other; the error of the instrument, therefore, is $1^{\prime} 23^{\prime \prime}, 9$, and supposing the refraction to be $0^{\prime \prime}, 6$, and the declination of the star to be, $19^{\circ} 21^{\prime} 5^{1^{\prime \prime}}, 1$, the elevation of the Pole is $20^{\circ} 9^{\prime} 43^{\prime \prime}, 5$.

"On taking a medium between the four errors which have been found, it is evident, that the sextant makes the distances from the Zenith too small by $1^{\prime} 21^{\prime \prime}, 2$; and it is that error to which $I$ have attended in all the distances from the Zenith, which I have described in the preceding articles; nor shall I fail in doing the same with respect to those which I shall describe hereafter.

"I have also observed by the same sextant, and reduced to the 1st of January, 1750 , five distances from $\varepsilon$ of Orion to the Zenith; and they have given me, by a medium, $18^{\circ} 46^{\prime} 15^{\prime \prime}, 5$ : I have added $21^{\prime \prime}, 5$ of refraction, and the declination $1^{\circ} 23^{\prime} 3^{\prime \prime}, 3$, as it appears in the catalogue which I have cited; from whence I conclude the elevation of the Pole to be $20^{\circ} 9^{\prime} 40^{\prime \prime}, 3$. 
"I have arranged the following detail of observations and calculations respecting the distances of the Tropics from the Zenith.

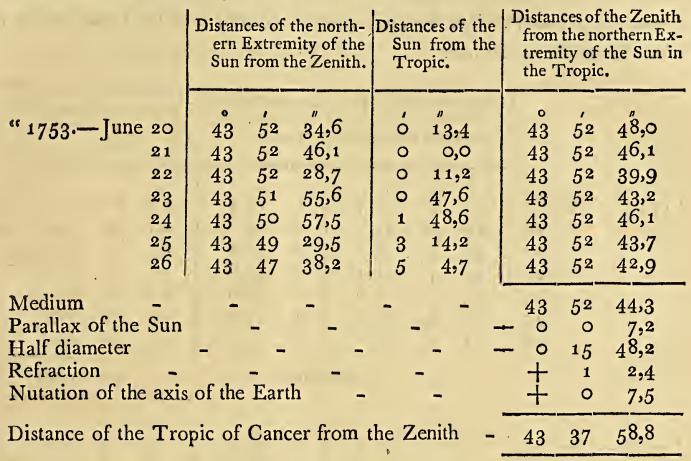

$$
\begin{array}{r|rrr|rr}
\text { 1753.-Dec. 15 } & \mathbf{2} & 52 & 48,3 & 9 & \mathbf{1 4 , 1} \\
\mathbf{1 6} & \mathbf{2} & 55 & \mathbf{2 6 , 7} & 6 & 31,5 \\
\mathbf{1 7} & \mathbf{2} & 57 & 41,7 & 4 & 16,8 \\
19 & 3 & 0 & 48,6 & \mathbf{1} & \mathbf{1 2 , 5} \\
\mathbf{2 1} & 3 & \mathbf{2} & \mathbf{1 , 0} & 0 & \mathbf{1 , 0} \\
\mathbf{2 2} & 3 & \mathbf{1} & 52,7 & 0 & 8,0
\end{array}
$$

\begin{tabular}{rrr}
3 & 2 & $\mathbf{2}, 4$ \\
3 & $\mathbf{1}$ & 58,2 \\
3 & $\mathbf{1}$ & 58,5 \\
3 & $\mathbf{2}$ & $\mathbf{1 , 1}$ \\
3 & $\mathbf{2}$ & 2,0 \\
3 & $\mathbf{2}$ & 0,7 \\
\hline
\end{tabular}

Medium

Parallax of the Sun

Half diameter

Refraction

Nutation of the axis

Distance of the Tropic of Capricorn from the Zenith

Adding the distance of the Tropic of Cancer

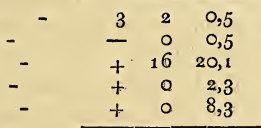

The distance of the Tropic is

\begin{tabular}{rrr}
\hline 3 & 18 & $30,7^{\circ}$ \\
\hline 43 & 37 & $5^{8,8}$ \\
46 & $5^{6}$ & 29,6 \\
\hline 23 & 28 & 14,8 \\
\hline 20 & 9 & 44,1 \\
\hline
\end{tabular}

Obliquity of the Ecliptic

The elevation of the Pole, therefore, is

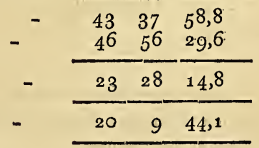


"The precise quantity of the obliquity of the Ecliptic being of the greatest importance in astronomy, I have observed the same solstical distances, with a sector of a radius of six feet, verified by the means of the stars $\beta$ of the Crow and of the Whale. These are as follows:

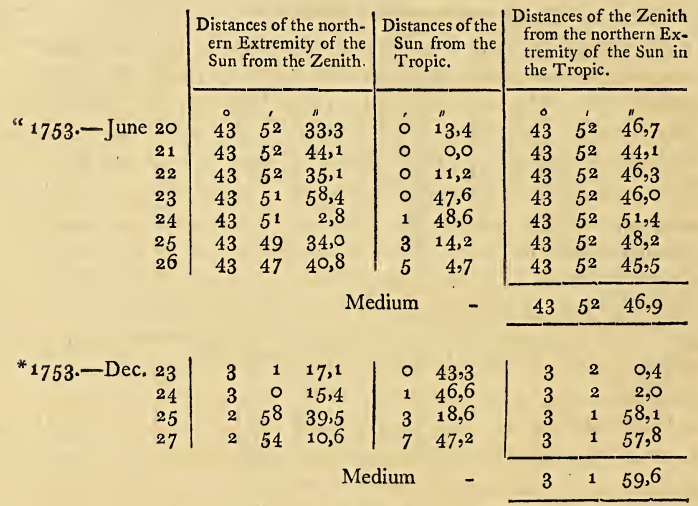

"Making the same reductions of these two distances as of the preceding ones, the obliquity of the Ecliptic is found to be $23^{\circ} 28^{\prime} 15^{\prime \prime}, 6$, and the elevation of the Pole $20^{\circ} 9^{\prime} 45^{\prime \prime}, 8$.

"The latitude of the place then which $I$ have observed, may be determined to be $20^{\circ} 9^{\prime} 42^{\prime \prime}, \frac{x}{2}$, and in referring it to the portal of the new parish church of Port Louis in the Isle of France, $20^{\circ} 9^{\prime} 45^{\prime \prime}$.

"Art. 8. Observations on the length of the pendulum with seconds, at the Isle of France."

- "The observations of the month of December were made in the negative part of the limb of every instrument, in order to get the interval of the Tropics; independently of the verification of the axes of the telescopes." 
Extracts of various Observations made by the Abbe de la Caille, during the Course of three different Passages, in bis Voyages to the Cape of Good Hope, and to the Isles of France and Bourbon.

"Article 2.-On the variation of the needle.

"The easterly and westerly variations are attentively observed on ships at sea, whenever there is an opportunity, as well to correct the courses, as to rectify the longitude. It is well known that there are many land-falls, which are ascertained by the variation of the compass; such as the Cape of Good Hope, and the Isles of Rodriguez, of France, and of Bourbon. It were to be wished that the variations observed in all ships which make long voyages, and particularly to the Indies, were collected and carefully registered: by this means, from time to time, for example, every ten years, a new edition might be given of the marine charts, where the curves of the variations might be marked, in the manner of M. Halley, as well for the year of the edition of the charts, as for an epocha of ten preceding years. These charts would be of great use in methodising the tracks, and, in many cases, they would give the longitude to land-falls with much greater certainty than by any observation of the moon made at sea. The proprietors of armed vessels should take care also to provide their ships with a good compass; and navigators should have somewhat less confidence in their reckoning, when they perceive that they do not agree with the variation. (See the tables of variation following this observation, pages 101, 102,103, \&c. of the Memoirs of the Academy, anno 1754.)

"Art. 5.-Observations made at the Isle of Bourbon.

" They were made at St. Denis, which contains the principal establishment of the India Company. There I employed my quadrant of three feet radius, a telescope of fourteen feet, and a good pendulum with seconds." 


\section{Observations on the Latitude.}

"As the Sun passed at noon too near the Zenith, I determined the latitude by the meridian altitude of six stars, three of which were on the north side, and three on the south.

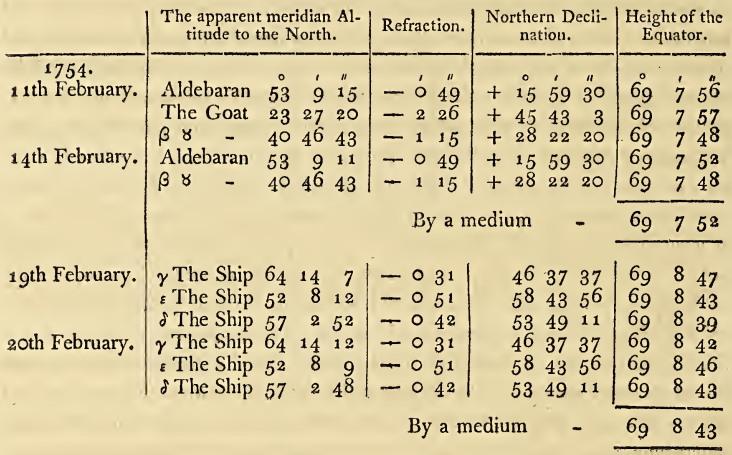

"It appears, therefore, that the real height of the Equator is $69^{\circ} 8^{\prime} 17^{\prime \prime}$, and consequently the elevation of the Pole $20^{\circ} 51^{\prime} 43^{\prime \prime}$. It is also evident that the quadrant made the altitudes appear too little by $26^{\prime \prime}$.

"The quarter of St. Denis being at the foot of Cape Bernard, which is the northernmost point of the Isle of Bourbon, the latitude of this Cape, which was due west of the place where I lived, at the distance of five or six hundred paces, may be determined to be $20^{\circ} 5^{1^{\prime}} 43^{\prime \prime}$.

\section{Observations on the Longitude.}

"February 9,1754 , at $12^{\mathrm{h}} 34^{\prime} 7^{\prime \prime}$ true time, the first satellite of Jupiter appeared to me to come forth from the shadow: it seemed rather to adhere to the body of the planet, which was in opposition to the Sun on the 1st of this month. 


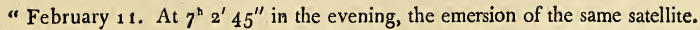

" 13 . At $15^{\mathrm{h}} 43^{\prime} 10^{\prime \prime}$, emersion of the third satellite. Jupiter is plunged in a thick mist.

" 16 . At $14^{\mathrm{b}} 28^{\prime} 12^{\prime \prime}$, emersion of the first satellite in fair weather.

" 25. At $10^{\text {h }} 52^{\prime} 16^{\prime \prime}$, emersion of the same.

" Not possessing the knowledge of all the observations which have been made, at the same time, in the different places of the world, I shall not discuss here the longitude which is to result from it. In the mean time, however, if we add to these observations, those which M. d'Après made in 1751, it may be supposed that, without any sensible error, the difference of the meridian of Paris, and of St. Denis in the Isle of Bourbon, or of Cape Bernard, is $3^{\mathrm{h}} 3^{\prime} \frac{1}{2}$, and consequently the eastern longitude $53^{\circ} 7^{\prime}$ or $8^{\prime}$.

Determination of the Longitude of the Island of Madeira, by the Eclipses of Jupiter's Satellites, observed by M. Bory, Licutenant in the Royal Navy, compared with those of M. l'Abbé de la Caille, in the Isle of France, by $M$. de Lisle.

"M. Bory having observed two immersions of the first satellite of Jupiter, and one of the third, at Funchal, the capital of the Island of Madeira, towards the end of the year 1753, and at the commencement of the year 1754, I compared them with those of the Abbé de la Caille, in the Isle of France, which are the only ones that $I$ have found to correspond with those of M. Bory.

"When I speak of corresponding observations, I understand not only those which have been made precisely at the same time, for such are not to be found; but it is well known, that in the use of the observations of the satellites of Jupiter for the longitudes; particularly those of the first, the observations, which were made after two or three revolutions, may be employed, when such as are simultaneous cannot be obtained. But, fortunately, the results that I have drawn from the three observations of M. Bory, agreed within a few seconds; which justifies the use that I have made of them, in comparing them with those of the Abbé e la Caille, with the difference of two or three revolutions. .

"In order to reduce to the meridian of Paris the difference which $I$ have found in the Isle of France and the Island of Madeira, I must suppose a known longitude $3 \mathrm{D} 2$ 
between the Isle of France and Paris; but I believe that I have sufficiently determined it, by taking the medium of twenty results, which $I$ have drawn from nine observations that M. l'Abbé de la Caille has made on the satellites of Jupiter in the Isle of France, I compared these nine observations of the Abbé de la Caille, with all the correspondent or approaching observations, made in different places, of which I have been able to obtain observations, and the longitude of which, with respect to Paris, was pretty well known. The resulting difference of longitude between the Isle of France and Paris, in taking a medium between these two determinations; was found to be $3^{\mathrm{h}} 4 \mathrm{O}^{\prime} 45^{\prime \prime}$.

"I also examined the result of seven observations of the satellites of Jupiter, made in the Isle of France, in the year 1751, by M. d'Après, and I formed nineteen results for the difference of longitude between that isle and Paris. The mean difference between these nineteen results is found to be $3^{\text {h }} 4 \mathrm{O}^{\prime} 22^{\prime \prime}$; so that taking a new medium between the observations of $M$. d'Après and those of M. l'Abbé de la Caille, the longitude between the Isle of Frsnce and Paris may be computed to be about $3^{\text {h }} 40^{\prime} 35^{\prime \prime}$; approaching somewhat nearer the results drawn from the observations of M. l'Abbé de la Caille, than those of $M$. d'Après.

"Supposing this longitude, the following is that of Funchal, as it results from the observations of M. Bory.

$$
\text { " } 1753 \text {-December } 28 .
$$

Immersion of the first satellite, observed at Funchal, by M. Bory ì 8 í Adding for two revolutions

The immersion should happen at Funchal 1st of January, 1754 It was was observed at the Isle of France 1st of January $\begin{array}{lll}7 & 10 & 1\end{array}$

Difference of Funchal and the Isle of France $3 ; 12 \quad 55 \quad 7$ Difference of the Isle of France and Paris

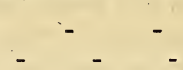

Difference, therefore, of Funchal and Paris 


\section{HISTORY OF MAURITIUS.}

"1754-January 1.

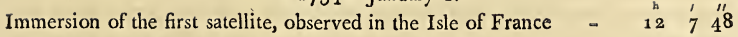
Adding for three revolutions $\quad$ - $\quad$ - $\quad$ - $\quad$ - $5 ; 72313$

The immersion should happen at the Isle of France, 6th of January $193^{1} 1$ It was observed at Funchal, by M. Bory - - $\quad 614.3319$

Difference of Funchal and the Isle of France _ _ - 45742 Difference of the Isle of France and Paris - $\quad$ - 34035

Difference of Funchal and Paris _ _ _ _ - 1177

Immersion of the third satellite, observed at the Isle of France in Jan. $1 ; 123^{2} 4^{6}$ Added for one revolution of that satellite

The immersion should happen at the Isle of France, 8th of January $16275^{8}$ It was observed at Funchal 8th of January - - $\quad 11300$

Difference of the Isle of France and Funchal - - $4575^{8}$ Difference of Paris and the Isle of France - - - - 34035 Difference of Funchal and Paris _ _ _ _ _ 1123

"The mean difference between these three determinations of longitude at Funchal and Paris, is $1^{\prime \prime} 17^{\prime} 14^{\prime \prime}$, or $19^{\circ} 18^{\prime} \frac{1}{2}$. If, therefore, the first meridian which passes over the Island of Ferro be just $20^{\circ}$ from Paris, as is generally conjectured, the town of Funchal should not be more distant from this first meridian towards the east than $0^{\circ} 41^{\prime} \frac{1}{2}$."

The continuation of these observations may be seen p. $55^{8}$, and the following pages, in the Memoirs of the French Academy, 1754 . 


\section{GHAPTER XX.}

\section{Life of M. l'Abbé de la Caille.}

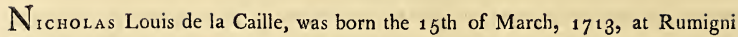
Bourgade, in the diocese of Rheims, situate two leagues from Rosoy, in Thiérache. His father was Nicholas Louis de la Caille, and his mother Barbe Rebuy; and he was allied to many ancient and distinguished families in the Laonois.

"His father, who had served in the Corps of Gens d:Armes, as well as in the Artillery, enjoyed, in 1713 , an handsome revenue, and led a retired life, which he varied by cultivating the sciences. He was an excellent mechanic, and invented several very ingenious machines.

" At a very early age, the Abbé de la Caille manifested those talents which promised that he would one day be an honour to his country; but a project in which M. de la Caille had engaged, and had absorbed, in a few years, the whole of his fortune, threatened to destroy the plan which he had formed for the education of his son.

"The late Duke du Maine, however, placed him at the head of an establishment which was about to be formed in one of the American islands. He accordingly repaired to Nantes, in $17^{2} 5$, by order of the Prince, with the design to embark for the place of his destination; but on a sudden that plan was set aside, and he again found himself without situation or employment. The late Dutchess du Maine, then, received him into her service at Anet; where he greatly improved the revenues of his benefactress. He now renewed his attentions to the education of his son, and soon after placed him with the principal of the college of Mante, on the river Seine, who was his friend. In the year ${ }^{1} 729$ he was entered as a boarder in the college of Liseux, where he greatly distinguished himself by his literary attainments.

"His inclinations appeared at this time to be directed towards the belles lettres, when he laid his hand by chance on the Elements of Euclid; and having made himself master of them, without any assistance or instruction, his reason was captivated 
by that study, and he at once devoted himself to mathematical pursuits. He soon after became the pupil of $\mathrm{M}$. Cassini, was settled at the observatory, and surpassed the most sanguine expectations of that renowned astronomer. The first observations of the Abbé de la Caille are in the month of May, 1737 .

" M. Cassini, proud of the assistant which he had gained, took every opportunity of declaring his rare and superior talents. M. Maraldi, who was a witness of the extraordinary capacity and progress of the young astronomer, became at once his admirer and his friend. Assisted by these two learned men, he proceeded in his career with the rapidity that might be expected from such a pupil of such masters. He unfortunately lost the former by an unforeseen accident; but the latter survived to continue his friendship and protection.

"In the month of May, ${ }^{17} 3^{8}$, he accompanied M. Maraldi who was employed to lay down the sea chart from Nantes to Bayonne; an operation in which he gave new proofs of his talents.

“ M. Dominic Cassini, M. de la Hyre, and M. Maraldi, uncle of the academi. cian of our day, had undertaken, in the year 1690 , to trace a meridian from the south to the north of France : this operation was completed in the year 1718 by M. M. Cassini and Maraldi ; but as the instruments of that period were less perfect than those which are in use in our time, certain errors were unavoidably blended with it, and twenty years passed away without any attempt being made to correct them. M. Cassini had indeed formed the design, and he now charged the Abbé de la Caille, and his son M. Thury, with the execution of it. This undertaking was also calculated to facilitate the execution of a geometrical description of France, which M. Cassini had been commissioned to undertake by M. Orry, Comptroller of the Finances; and which was necessarily to commence by a parallel of Paris, which M. Cassini had already begun.

"The new meridian was to be traced from Perpignan to Dunkirk. The Abbé de la Caille, therefore, set out for the former place with $M$. Thury, in the month of July, 1739, and he was no sooner arrived there, than he began that part of the operations particularly entrusted to him, which he continued to the end of October.

"In November he was recalled to Paris, to take possession of the Mathematical Chair in the Mazarin college ; and he then returned to Perpignan. The cold, which became excessive at the end of November, and throughout the following month, 
accompanied with snows, and other attendants on an inclement season, did not cool his ardour; he accordingly passed from Roussillon into Languedoc, and from thence into Auvergne, where, in the midst of snows, he continued his scientific labours. He arrived at Paris at the conclusion of the rude winter of 1740 .

" On his return to Paris, he assissted M. Cassini in ascertaining the base of M. Picard, and the direction of the meridian from Paris to Perpignan. In the month of July he took the road to Dunkirk, and suffered fresh fatigues. Occupied during the day in preparing his instruments, and fixing machines on the summits of mountains, he made his observations during the night, subject to the injuries of the open air, and frequently without the most common conveniences of life.

"In 1741, M. de Lisle, associate in ordinary to the Royal Academy of Sciences for the department of Astronomy, from the advanced period of his age, demanded his retreat; M. Fouchy passed from the place of assistant to that of associate, and the Abbé de la Caille was chosen by the Academy to replace M. de Fouchy. M. de la Caille was received in the month of May, and appeared for the first time with great eclat in that illustrious Society, by reading, at his introduction, a memoir on the calculation of the differences in spherical trigonometry; - a most profound and elaborate work.

" He presented the Academy the report of an eclipse of the moon, which he had observed at the Hermitage on the mountain of St. Victor, near Aix in Provence, the $13^{\text {th }}$ of January, 1740 . This report was received with great pleasure, as the eclipse had not been observed at Paris, on account of the cloudy weather.

" His admission into the Academy was the only recompence the Abbé de la Caille received for the part he took in forming the meridian; he did not obtain a pensionary gratification till after his return from the Cape.

" Before the end of 1741 , he published his Elements of Mathematics, and they are considered as a chef d'auvre of perspicuity and precision in the learned world. Various editions of them have appeared in France, and they have been translated into all the principal languages of Europe.

"In 1742, a comet appeared in the months of March, April, and May, and the Abbé de la Caille composed a memoir on its apparition and its course. In the same year he also formed another memoir, containing a method to find the place of the the Sun's apogee. 
" On quitting his apartment at the Observatory, he felt himself, as it were, expatriated, and he therefore constructed one at the Mazarin College.

" He made two kinds of observations, the one for his own particular inquiries, and the other for public instruction: in the second class we must comprehend those which he published in 1743 , on a comet that appeared in the month of $\mathrm{Fe}$ bruary; on the conjunction of Mars and Saturn; on the passage of the Sun in the parallel of Arcturus; on the conjunction of Mars and Jupiter; on the Sun in its apogeum; on the passage of the Sun in the parallel of Procyon; on the altitude of the upper extremity of the Sun in the tropic of Capricorn; on the planet Mercury in the Sun; on the Sun in its perigeum; with inquiries concerning the place of the apogeum of that luminary.

"In the same year he published his laborious process on the meridian; but would not suffer his name to appear in the frontispiece of the work, and abandoned all the honour to his associate, who did not fail, however, to make all due acknowledgement for the essential assistance which he received from $M$. de la Caille.

"At length he acquired, what he so well deserved, the character of a consummate astronomer; and having, by his immense labours, acquired a most profound knowledge of his science, he determined to convey to others an acquaintance with its principles. He accordingly composed his Elements of Astronomy, and published an octavo edition of them, with figures, \&c. which has been translated into the English, Spanish, and Latin languages.

" $\mathrm{He}$ also composed elementary Lessons of Mechanics, and the Elements of Optics and Perspective. Various other curious and admirable papers on astronomical subjects are to be found in the Memoirs of the Academy.

"In 1746 , he published the first part of his Ephemeris, which comprehends ten years. There is a kind of Supplement to it in the Chronological Table, which was placed at the head of the Art to verify Dates. This table reaches to the year 1800 . He composed the part that relates to the eclipses, which is the most important.

"In 1593, a comet had been observed at Zerbst, in the principality of Anhalt, from whose apparition new discoveries might be made in astronomy. M. de la Caille therefore gave the theory of it to the Academy in 1747, with the same accuracy as if he had himself observed it. Waltherus had, at the close of the fifteenth century, made observations at Nuremberg, and M. de la Caille, in 1749, communicated to the Academy his Memoir on Waltherus. 
"He continued his unremitted labours on various branches of astronomy, to the great illustration of that science, and the honour of his country, till the year $175^{\circ}$, when he proceeded to pursue his researches in the other hemisphere.

" On the 21 st of November, 1750, he embarked at L'Orient, on board the Glorieux, commanded by M. d'Après, and in three weeks arrived at the Cape de Verd Islands: on the $25^{\text {th }}$ of January, $175^{1}$, they put into Rio de Janeiro, on the coast of Brazil, where they remained, from some repairs necessary to a small vessel which attended them, upwards of a month. M. de la Caille, however, was not idle during his abode there, but made several important observations respecting the longitude, \&c. On the $25^{\text {th }}$ of February they set sail from thence, and on the 3 oth of March arrived in sight of the Cape of Good Hope, but did not enter the road till the $19^{\text {th }}$ of April.

"The astronomer was received at the Cape with all the honour due to his superior science and character. He began his observations on the 10th of May, 1751, with the parallax of the Moon, and continued them to the $25^{\text {th }}$ of February, $175^{2}$. He observed Venus from the $25^{\text {th }}$ of October to the $25^{\text {th }}$ of the following November; and the planet Mars from the $3^{1 \text { st }}$ of August to the $g^{\text {th }}$ of October. He renewed his operations on the parallax of the Moon in the month of March, and continued them till October. In the interval of his observations he gave his attention to geography and objects of natural philosophy. He sent the details of his first operations to the Academy before his return.

" Ptolemy, who lived in Egypt, gave a catalogue of the southern stars; but that catalogue was incomplete.

" The Portuguese navigators had traced the plan of several constellations, but in such a coarse way that astronomy did not derive any ádvantage from them.

"In $16_{77}$, M. Halley went to the Island of St. Helena, to form a celestial chart of the southern hemisphere, and he observed but three hundred and fifty stars.

"At the commencement of the present century, the Baron Krosick had charged Peter Kolbe, a. Prussian, with the same commission as that of M. de la Caille; but he did not answer the expectations of the German nobleman who employed him. Thus the descriptions of the southern hemisphere, when M. de la Caille arrived at the Cape, were nothing more than rough outlines.

" He began to observe the southern stars the 6th of August, 175 , and continued that labour till the same month in the following year. He beheld, in all their lustre, 
large stars which were not known to the astronomers of Europe but by their nebulous shapes.

"M. de la Caille had directed his first attentions only to the stars of the first, second, third, and fourth magnitude: having, however, a favourable opportunity, he determined to include within his calculation those of the fifth, sixth, and seventh magnitude.

"On the $1^{\text {th }}$ of February, a very thick and unwholesome fog arose at the Cape, and M. de la Caille was affected with all the disagreeable consequences of it. $\mathrm{He}$ however recovered in the same month of the year $175^{2}$, in which he died in the year 1762 .

"As soon as he had completed his catalogue of the southern stars, he compared it with the planisphere which had been laid down by M. Halley in 1677; and he found that he surpassed by $945^{\circ}$ stars that of the English astronomer.

"After having examined the planisphere of Halley, as well as those of Ptolemy, and the Portuguese pilots, M. de la Caille found place for fourteen new constellations, better furnished, and more exact than those of the ancients, which required a general reformation.

"On the 8th of March, 1753, he embarked on board the French ship the Puissieux, bound for China, and which was to touch at the Isles of France and Bourbon. During the passage from the Cape to the Isle of France, he made an experiment which has proved very useful to sailors, of a simple method of finding the longitude at sea. He has inserted it in his Ephemeris, as well as in another of his works, and it may be considered as one of the most important services which he has rendered to mankind. He arrived at the Isle of France the 18 th of April, forty days after his departure from the Cape.

"An account of his operations in the Isle of France are to be found in the Memoirs of the Academy of the year ${ }^{1754}$, and in his Historical Journal. $\mathrm{He}$ embarked the $15^{\text {th }}$ of January, 1754 , for the Isle of Bourbon, and arrived there the following day. After he had fulfilled the object of his mission, he embarked the 27 th of February following on board the Achilles, and returned to France.

"On the $15^{\text {th }}$ of April the ship came to an anchor before the Isle of Ascension. M. de la Caille remained there only five days, but he availed himself of the opportunity to determine the position of the place; a very important point for ships on

$$
3 \mathrm{E}_{2}
$$


their return from India to Europe. He re-embarked on the 2oth of April, and arrived at L'Orient on the $4^{\text {th }}$ of June, after a very fortunate voyage.

" On the 28 th of the same month he returned to Paris, after an absence of three years and eight months; when, his first care was to digest his observations, and compare them with those of his correspondents, in order to put the last hand to the great work of his mission. He first detached 1936 stars from his general catalogue, which the Academy placed in its Memoirs. He deferred giving his observations on it to the year 1760 , in order that nothing should be wanting which might advance their perfection. A great part of this important work was printed at the expence of the author, who had not, however, the satisfaction to see it finished.

" Besides the two parts of the relation of his voyages, M. de la Caille enriched the Memoirs of the Academy with many important pieces. In 1757 , he presented to the public his work entitled Astronomia Fundamenta; one of the most important that had ever appeared on that science, and which proves its author to have obtained a complete knowledge of the two celestial hemispheres. It consists of a quarto volume, which is followed with Observations on the Refraction of the Stars, and Solar Tables of the same author, which appeared in $175^{8}$.

"In 1759 , he presented various memoirs to the Academy on very important subjects of astronomy ; and in 1760 he formed the design to determine a certain number of zodiacal stars; and invented an instrument for the purpose of carrying it into execution. He observed six hundred zodiacal stars during the two years 1760 and 1761 .

"In the month of June in the same year, M. de la Caille had begun a great work, which occupied all his attention, when he was attacked by the disorder of which he died. It was a Course of Observations on all parts of the Heavens, relatively to each other; from whence a degree of certainty in operation would result, which must be of the utmost utility to astronomers.

" He maintained a constant correspondence with the most distinguished astronomers and mathematicians of every part of the world. His correspondent at Pekin was Father Benoit, his former pupil, who was become a resident in the palace of the Emperor of China, in that city:

" In 1761, he paid his academical tribute of five important memoirs; and he read before the assembled Academy, a Discourse on the Progress of Astronomy during the thirty preceding years. 
" He had long been solicited by his friends to augment the treasures of literature, by an history of astronomy, from its origin to his own improvements in that science; and he constantly resisted their entreaties, till the voice of the public demanded this important work at his hands: but death, which too often interrupts human projects, stifled this admirable design at the moment of its conception. What such a work would have been, may be conceived from the character of the man who had undertaken it; and that he did not live to complete it, must be regretted by all who are interested in the advancement of science, and the improvement of mankind.

"M. de la Caille had completed his forty-ninth year, when his constitution began to give way, and at the end of February, ${ }_{1762}$, he was attacked by the same disorder which he had suffered at the Cape in February, 1752; and on the 21st of March he departed this life, at the same age as his father, and in the same month in which he was born. It would be needless to describe the universal regret which followed the loss of a man equally dear to science and to virtue." 


\section{CHAPTER XXI.}

Extracts from the Observations of $M$. Le Gentil, Royal Academician, respecting the Soutbern Hemispbere, छc.; in a Series of Lelters to M. de la Nux, Correspondent of the Royal Academy of Sciences, at the Isle of Bourbon.

Isle of France, Feb. 6, 1761 .

**** " I Am occupied in calculating for Rodriguez, the transit of Venus over the Sun, on the same principles employed to calculate it for Paris. I have found that, at the moment of the entrance of Venus, the centre of the Sun should be elevated above the horizon of Rodriguez near $2^{\circ}$.

“ The calculation of M. de la Lande, founded upon somewhat different principles, affords me some encouragement; for this $A$ cademician has found it to be near $8^{\circ}$ : and as to the corrections that $\mathrm{M}$. de la Lande has made of the astronomical tables of M. M. Cassini and Halley, which you must have seen in the Ephemeris of 1761 , that I have sent you; do they appear to you to be well founded? In short, may I not at least suspend my judgment as to the preference which ought to be given to his calculation, or mine?

" Another cause renders the moment of the entrance of Venus very doubtful and uncertain at Rodriguez: you know, as well as me, that in the seas which surround your isles, the months of June, July, and August, form a season when strong gales from the south-cast to the east-south-east prevail, and which are seldom accompanied with a clear and serene sky; so that it very seldom happens that the Sun can be seen at its rising, and not often till it has attained a considerable degree of elevation; because these gales render the horizon misty, or form a range of clouds considerably above it. Such are my doubts respecting the Isle Rodriguez as a place to observe the entrance of Venus on the Sun; but it is very probable that I shall myself visit that island, as it is now the 6th of February, and I am without the hope of any other resource." 
Isle of France, June 23,1761 .

* * " I have found an observation on the departure of Venus, made by our friend M. de Seligny,* and I have made use of it to determine the meridian where I was when I observed Venus. This officer, who is a very good and zealous astronomer, has an excellent pendulum with seconds, and knows how to employ it."

\section{On the bigh Seas.}

"The ships which go to China having got to the $118 \mathrm{th}$ meridian of Teneriffe, on the $34^{\text {th }}$ or $35^{\text {th }}$ parallel, are then very near the land of New Holland, and consequently enough to the east not to be in a situation to miss the Strait of Sunda, but from ignorance or neglect. It is also at $118^{\circ}$ of longitude that these vessels begin to turn, by the aid of the south-east wind, towards the island of Java, and endeavour to stand in to the middle of it. This precaution is absolutely necessary, in order to get to the windward of the strait, for if a ship gets to the leeward, it is very improbable she would be able to enter it; the voyage would be lost; and the only resource that is left would be to proceed to the windward, in order to gain the Strait of Malacca, if the season should not be too much advanced.

"We entered into the line of the south-east winds, which we found towards $30^{\circ}$ of latitude. While we kept the latitudes of $34^{\circ}$ and $35^{\circ}$, we had very high seas; but if the waves were very high, they were at the same time so long, that their extremities were lost in the distance, in the same manner as those which are found on the other side of Africa when we have passed the tropic of Capricorn, to double the Cape of Good Hope. When we had got into the variable winds we had no. more of these long waves, but found in their place a short divided sea.

"The European seas are also very long, as well as all those which extend from this part of the world to the Cape of Good Hope. These long seas are not so dangerous as the short ones. Off the Cape of Good Hope the sea is almost always agitated by enormous waves, which encounter each other in two and sometimes three different directions; forming the highest seas as yet known in any part of the globe. Seamen who have passed Cape Horn in bad weather, and the Cape of Good Hope, have universally declared, that if the waves ran equally high at Cape Horn as they do at the Cape of Good Hope, the former would be absolutely impassable, because the wind blows there with greater force. When you have doubled the

* M. de Seligny was an officer in the sea service of the India Company. 
Cape of Good Hope, and have got up to $30^{\circ}$. of latitude, in the Ethiopic Ocean, you no longer meet with any of these long seas of Europe, and of the west of southern Africa. In this ocean the waves are short and divided. These seas frequently strain the ships much more than the long waves, particularly after a gale, as the wind increases the division of these waves, so as to give them the shape and size of sugar loaves, which proves always very distressing, and sometimes very injurious to ships.

"The reason why the sea is so high at the Cape of Good Hope, and that it is less so at Cape Horn, appears to me to be as follows: beyond the former cape, between the Tropics, and in the different parts of India, the sea forms, as it were, a kind of bay, sprinkled with isles and comprehended within coasts, which, though at a great distance from each other, are the cause, nevertheless, of the periodical winds which blow there. The sea, therefore, may be said to be confined between those parallels.

"When you are once got to the Cape of Good Hope, the waters appear to be no longer in a state of confinement, but are entirely free, and left, as it were, to themselves, through an immense space of latitude and longitude. The west winds are then at liberty to extend themselves, and to raise up the sea at the Cape, while the immense bank at the point of this Cape contributes, with the wind, to swell the waters of this part of the ocean.

\section{Birds.}

"I remarked that the Damiers quitted us at $30^{\circ}$ and some minutes of latitude, and that we found them also in the same degree; so that these birds do not go as far as the tropic. It appears that they delight in the west winds, and that the nature of the general winds drives them from their limits.

" The Paille en $\mathrm{Cul}$ is altogether different. It would be curious to know the precise latitude which forms, as it were, the boundary of these Damiers.

"We found ourselves on the $23^{\mathrm{d}}$ of June in the latitude of the Trialles, at $125^{\circ}$ of longitude; the charts place them in $119^{\circ}$. During the night, we run on short tacks in the offing, from the fear of falling in with them. We passed the whole of the $24^{\text {th }}$ without seeing any thing; and I thought it very singular that we did not even see any birds, which are certain indications of land or insulated rocks. We saw two Paille en Culs; but it is well known that these birds are frequently seen at 
fifty leagues from their habitation, and this distance does not prevent them from returning thither every evening: though they will sometimes pass the night on the upper yards of ships which they chance to meet."

\section{On the Voyage to Cbina.}

Pondicherry, October i, 1768 .

66 With respect to the supposed passage to China by the north-east, I shall consider two points:-The reality of the passage,-and the advantage which the commerce of Europe might derive from it.

"In the first place, I am firmly persuaded that no such passage exists; and I am of opinion that the Dutch have proved its non-existence, in their third voyage, particularly in the vicinity of the North Pole.

"With respect to the advantages that Europeans might derive from these voyages, I cannot discover any; and I think that voyages from France to Canton by the north-east, would be almost as long as they now are by the Cape of Good Hope.

"I will suppose, for a moment, that this passage exists during a month, or five weeks at most, in the year; that is to say, during a part of the months of July and August; with this restriction, nevertheless, that there would be certain years in which this passage would open and shut a little sooner or later.

" This being agreed, I do not hesitate to declare, that a ship which should make her voyage to Canton in China by this passage, and should return by the same, would employ seventeen or eighteen months.

"Now the voyages to China by the Cape of Good Hope, including the time which ships employ in different ports, are only from seventeen to eighteen months; nothing therefore would be gained by the supposed passage. We will endeavour to illustrate this idea.

"It is impossible to enter into the Chinese Seas from any quarter but by the assist. ance of the monsoons.

"These winds are regulated there, as they are in the Indian Seas; that is, they blow from west to south-west and by south from the middle of May to the middle of October, and during the rest of the year they blow from the north to the northeast by east. The times are ascertained when ships are to arrive in their respective regions. 
" The ships arrive in China in August and September, and depart from thence, at the latest, in the early part of February.

" This monsoon is not exclusively possessed by the Chinese Seas, but extends beyond the Island of Formosa to the Seas of Japan.

"The Dutch at Batavia, the only Europeans who send a ship to Japan, and consent to be insulted once a year by the Japanese, to be the exclusive possessors of its commerce, ${ }^{*}$ are very attentive in the middle of the west monsoon, in order to double the Cape Bajador in the Phillipine Islands, and to pass through the strait which is formed by them and the coast of China. This vessel returns to Batavia with the north-east monsoon.

"The Chinese junks, so ill calculated to resist strong gales, and which, of all the vessels in the Eastern seas, have the greatest occasion for regular winds, are very careful not to undertake a voyage against the monsoon. Several of these vessels go from Emouy to Manilla, where they arrive at the latest in April, and return from thence the latter end of August or the beginning of September. Without this precaution they would not be able to reach Emouy, whose position at the entrance of the channel is such, as to be inaccessible to all vessels coming from the Chinese Seas or Manilla, during the season of the north-east winds.

66 According to these certain and invariable rules, which no one acquainted with the subject will hesitate to admit, I will suppose that a ship has opened the north passage by the middle of August, it cannot, nevertheless, enter the Chinese seas by Cape Bajador before the month of September, when the west monsoon has not quite ceased, and the east monsoon has not begun to blow. When this ship is arrived at Canton, it will be obliged to remain there till the middle of May in the following year, at a great expence and charges; as it cannot leave that port to get

* The Dutch cannot come to an anchor on the coasts of Japan : their ship remains at a small island appropriated for that purpose, at the distance of some leagues from the continent. No sooner is the ship come to anchor than the Japanese go on board, take possession of the sails and helm, and carry them on shore. The Dutch then present the invoice of the cargo to certain commissioners, who set their own price on the articles it contains, as well as on those which are to be given in barter. The Dutch are entirely passive in this commerce: the Japanese unload their ship, and furnish it with a new cargo, according to their pleasure, without any observation being made as to the articles it contains, or the quality of them. The sails and helm are then returned, with an order for the ship to get under way as soon ais it can be refitted for that purpose. 
back to the seas in the vicinity of Japan till the return of the west monsoon. This vessel will have but two months at most to arrive at the entrance of the northern passage, and if unfortunately it should meet with any obstacles or delay during that period, it will risk the arriving too late at the passage, and find it shut.

"It appears indeed to me, that obstacles are not only possible, but probable; because beyond $40^{\circ}$ of latitude, whether northern or southern, the winds are variable, as is well known; and even blow oftener from the north-west to the south-west, than from any other point of the horizon. Now, the west or north-west winds, which are very good winds for the outward voyage, would oftentimes prove contrary on the return : but supposing a ship should meet with every favourable circumstance, she cannot clear the passage and get back to France before the end of September: thus, as she must have taken her departure, at the latest, in the first week of May in the preceding year, the voyage will last seventeen months, without even allowing not only for possible but even probable delays.

"' The French ships which sail to Canton by the Cape of Good Hope, take their departure in the beginning of January, and return about the end of June in the following year, which forms a period of eighteen months, including near two months stay at the Isle of France.

" They might also, instead of putting into the Cape, draw their refreshments from the Straits of Sunda; the ships might in that case leave France in the months of February or March, so that the voyage would not be more than fifteen or sixteen months, allowing for accidents. It appears, therefore, that the voyage by the northeast would be the longest by a month or six weeks.

"If it is objected to me, that the ship which I suppose to have gone to China by the north passage should return to France by the Cape of Good Hope, and consequently the voyage would not occupy more than fourteen months, and that so far from losing a month or six weeks, as I have supposed, that space of time, on the contrary, would be gained; I shall answer, that it is not certain, allowing the ship to arrive in China in the month of November, that it can complete its cargo for Europe before the middle of January, when it is absolutely necessary for her to leave China, (if she is to put in any where), in order to double the Cape of Good Hope: I will however suppose, that she may be able to sail from Canton, from the $15^{\text {th }}$ to the 2 oth of January, and that thereby the voyage, would be shortened a month or forty days; 
but I shall beg leave to ask, if the time thus gained would counterbalance the risks and dangers that are inevitable in the navigation by the north? and if it would be prudent to suffer two ships, worth upwards of three millions of livres, which is the value of the China cargoes, to return by that passage?

"The navigation by the Cape of Good Hope is so certain, that a common seaman is qualified to take a ship to China by that course, and bring her back to France in good condition.

"By the north, however, the most skilful and experienced seaman will find it a difficult undertaking to conduct a ship to China; but even if the voyage should be successful, it cannot be denied that it would be almost as long as that by the old course of the Cape of Good Hope."

\section{Navigation from the Isle of France to Cadiz}

* * * " Don Joseph de Cordova fitted up for me on board his frigate, a large chamber, which was equal in size to two of those which I had before occupied. We set sail from the Isle of France the 30 th of March, 1771 , having very fine weather, and constant winds from the south-east to the east, till we reached the Mozambique Strait.

"We had passed considerably to the south of the coast of Africa, where the tempests are much more frequent, being in the parallels of $37^{\circ}$ to $38^{\circ}$, than along the coast. I have been informed by very experienced seamen, that along the coast of Africa there is a strong current that runs to the west, at least, during this season, and that in $37^{\circ}$ or $3^{\circ}$, and beyond, the current runs to the east, that notwithstanding the violent winds which always blow from the western quarter, are in direct opposition to the current ; the current continues its course to the west, and enables ships to double the Cape in the teeth of the winds, while in $37^{\circ}$ and $38^{\circ}$ the wind and the current take the same direction.

"The ships which return from India, with a view of doubling the Cape in the winter, must not get to a great distance from the land. They may keep in the offing during the night, but in the day they must approach the shore, and, if possible, never lose sight of it; so that they may double it by the aid of the current: but if, on the contrary, from a mistaken apprehension of getting too near the coast, they drive away to the south as far as $37^{\circ}$ or $3^{8^{\circ}}$, these ships will have both winds and 
currents to encounter, and consequently risk a failure of their design to double the Cape.

"This manœuvre gives a probability to the voyages of the ancient Egyptians round Africa, as mentioned by Herodotus; for the smaller the size of the vessel, the greater is the facility of doubling the Cape, even in the most unfavourable season; because, from its drawing but little water, it can approach nearer the land, and take refuge from any violent gale, in some creek or bay; or shelter itself under some cape, as the winds never pass the south-east point of the compass, and calms never fail to succeed, and continue during three or four days, as it happened to us. During this interval the winds blow very faintly from the south-east to the north; they then get to the north, where they seem to recover their strength to prepare another tempest; but, in the interval, the little vessel quits its place of refuge, and takes advantage of the fair weather.

"M. de Flacour, in the last century, in order to get back from Madagascar, doubled the Cape of Good Hope in a small sailing boat. I have no doubt of the truth of this relation; and it was, probably, the same kinds of boats, or at least vessels of the same size, which the Egyptians employed; for it is not stated that they were governed by the seasons in these voyages.

"We had, as far as the Tropic, changeable winds, that varied from north-west to south-west.

"In this vast extent of seas I observed a very singular phænomenon; which I find very difficult to explain.

"We had some very blowing weather from the north to the west-north-west, which was always announced by an heavy sea, that, several previous days, appeared to come from the south-west quarter; and I have often remarked that the strength of the north-west wind was always in proportion to the swell of the south-west sea.

"I should not perhaps have given any attention to this fact, if M. de la Londe, an old officer in the naval service of the East India Company, had not first suggested it. He told me, when we were passengers together on board the Indian, that being at anchor at the Cape of Good Hope, a heavy swell from the south-west, which lasted two days, made him apprehend a violent gale from that part of the horizon; but, on the contrary, the gale proceeded with uncommon fury from the south-east.

"On the 31 st of July, at five P. M. we saw Cape St. Vincent, and in the evening of the following day we came to an anchor at Cadiz." 


\section{Inclination* of the Needle of the Compass.}

Although the inclination seems to be the first property of the magnet, the observations on that subject have been neglected, either because their utility have not been perceived, or for want of proper instruments.

" M. l'Abbé de la Caille being possessed of better instruments than any of his predecessors, and employing all that precision which is known to have accompanied his operations, found no inclination at $11 \frac{1}{2}^{\circ}$ south latitude. With the individual compass of M. l'Abbé de la Caille, eighteen years after him, I found no inclination in nearly the same situation, or at $10 \frac{1}{2}^{\circ}$. This fact, therefore, is incontestible.

"When M. l'Abbé de la Caille gave me his compass, he engaged me to repeat the observations which he had made; because, in presenting it alternatively to the north and the south, he found, to the south of the Line, an inequality in the inclination as far as $3^{\circ}$; and he did not believe that this difference arose, as M. Bernoulli thought, from any defect of equilibrium in the original construction of the instrument.

"On observing with the utmost care, and in repeated experiments, the inclination in the Isle of France, we determined the difference to be from $2^{\circ}$ to $3^{\circ}$.
"The fleur de lys to the north

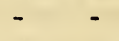
$53^{\circ} 37^{\prime}$

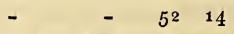

"That great astronomer observed the inclination in his voyages, but they are confined to the Isle of France. It appears that he entertained no idea of the inanner in which the compass is affected in the Ethiopic and Indian seas: nevertheless, he must have been surprised on finding the inclination of the compass at $52^{\circ}$; while he observed it to be about $20^{\circ}$ in the same latitude as the Isle of France, on this side of Africa.

M. de la Caille perhaps imagined, that this difference of $32^{\circ}$ might proceed, in some measure, from the difference in the longitude of the two places where he had made his respective observations, as that amounted to about seventeen hundred leagues.

"In the year ${ }^{1762,}$, when I was in the Bay of D'Antongil, in the Island of Madagascar, in $15^{\frac{10}{2}}$ of south latitude, I observed the inclination to be $46^{\circ}$, and consequently, that the needle could not be horizontal at the latitude of $11 \frac{1}{2}^{\circ}$, as M. de la Caille had seen it in nearly the same latitude, on the other side of Africa.

"In the year 1766, I repeated this observation, on board one of the King's ships,

- For the variation, see the Chart of the Ethiopian Archipelago, p. ${ }_{3} 62$. 
the Bon Conseil of sixty-four guns, bound to Manilla, when I was in the latitude of the Bay of Antongil, and found the inclination near $40^{\circ}$; which makes $7^{\circ}$, or $7 \frac{1}{2}^{\circ}$ of difference with that which I had observed in that Bay; but I was then near twelve hundred leagues to the east of it. It is certain, therefore, that the inclination of the compass cannot be of any use in finding the longitude; nevertheless, I soon perceived that the needle would not become horizontal till we had passed the line, and had even advanced a little into the northern hemisphere.

"I continued my attention to the needle till I saw it horizontal; I continued it also in the Straits of Sunda, where the sea being as smooth as a glass mirror, the deck of a ship is as steady a position as the earth itself; and there is every opportunity to repeat observations. Under the line, the inclination was about $15^{\circ}$; and the needle was horizontal at $8^{\circ}$ north latitude.

"Thus the loadstone has no inclination at $10 \frac{1}{2}^{\circ}$ of south latitude in our ocean, and at $8^{\circ}$ of north latitude in the Indian seas; that is to say, in the seas of Siam and Camboia. I have arranged a very comprehensive table of my observations, and in the margin I have marked, with the different degrees of latitude, my distance from the land at every observation.-The result of them is as follows.

"In returning from Manilla to Pondicherry, on board a Portuguese ship, by the Straits of Malacca, between $1 \frac{10}{2}$ and $4^{\circ}$ of north latitude, where the sea is smooth and tranquil, I traversed them with the compass in my hand, to Negapatam, in $11^{\circ}$ north latitude. From the observations which I made at this time, I found that the needle is horizontal in these seas, in $10 \frac{1}{2}^{\circ}$ of latitude near the Peninsula of India, nearly the same as it is on this side of Africa, in $10 \frac{1}{2}^{\circ}$ south latitude. This is about $2^{\circ}$ more to the north than I had seen it, in the Seas of Siam and Camboia, when I was on board the Bon Conseil.

"It was my intention to verify, on my return into these seas, when I should have got into $8 \frac{1}{2}^{\circ}$ of latitude, my observations on board the Bon Conseil, but that was not possible. We were driven onwards by the north-east monsoon, which is a very strong wind in these latitudes. The sea there runs very high, and we had the wind abaft. Besides, our ship was very heavy, and as it rolled, the water frequently dashed in through the gang-ways. I attempted to make some observations, but the motion of the ship was so violent, as to render every endeavour of that nature impracticable. 
"It was not till we had got into $4^{\circ}$ of latitude, that the sea would allow me to make the first observation on the inclination of the needle; we then approached the Strait, and were in a small archipelago, where the sea was more tranquil.

" My observations from that time, till we arrived at Negapatam, are very exact, and serve reciprocally to verify each other; for when we had once got out of the Gulf of China, my observations were confined between $4^{\circ}$ and $11^{\circ}$ of latitude : now, as the course of the ship was several times in the same latitude, I had frequent opportunities to verify my observations.

"When I passed from Pondicherry to the Isle ef France, on board the Company's ship the Dauphin, I continued to make my observatioas with the same care that I had given to those which had preceded them. The needle became horizontal at $8 \frac{1}{2}^{\circ}$ north latitude; very nearly the same as $I$ had seen it in the seas of Siam and Camboia; and it is to be remarked, that in these two positions, I was from fifty to sixty leagues from the great continent.

" On the coast of Coromandel I found no inclination in $10 \frac{1}{2}^{\circ}$ of latitude, and I was half a league at least from the coast: so that these $2^{\circ}$ of difference that I found in the Indian Sea, proceeds probably from the vicinity of the great continents.

"When we arrived at the line, in the same ship, the Dauphin, I found the inclination $18^{\circ}$; and at $15 \frac{1}{2}^{\circ}$. south latitude, which is that of the Bay of Antongil, I found the inclination $45^{\circ}$ I have observed already that it was $46 \frac{1}{4}^{\frac{10}{0}}$ in this Bay; but, on board the Dauphin, I was six hundred leagues to the east of it. The inclination, therefore, from the meridian of the Bay of Antongil from the place of my reckoning, was but $1 \frac{1}{4}^{\circ}$; then it is only $1_{4} \frac{10}{4}^{\circ}$ for six hundred leagues difference in longitude. The difference was much greater on board the ship of war, the Bon Conseil, it being about $6^{\circ}$ for eleven or twelve hundred leagues; but I was then very near the Isles of Sunda, which might in some degree, affect the inclination.

"It would be equally curious and interesting to know the effects in the South Sea, between the Philippine Islands and America, in the northern part of that vast ocean; where there are only a few small islands scattered here and there, in an extent of longitude of two thousand leagues. It appears by an observation of Father Fueillée, made at Lima, that the needle should be horizontal at about $8^{\circ}, 9^{\circ}$, or $10^{\circ}$ of north latitude. 
Fueillée, made at Lima, that the needle should be horizontal at about $8^{\circ}, 9^{\circ}$, or $10^{\circ}$ of north latitude.

“ M. de la Condamine found at Quito, in $0^{\circ} 13^{\prime}$ south latitude, that the variation was $15^{\circ}$ and $17^{\circ}$, which answers exactly to the observation that I made on the ships the Bon Conseil and the Dauphin, in the Indian Seas; from whence it follows, that the variation cannot subside but towards $8^{\circ}$ or $9^{\circ}$ of north latitude. It appears to me then probable, that in the whole of the South Sea, in an extent of two thousand leagues, which $\mathrm{I}$ have just mentioned, the needle is horizontal at about $9^{\circ}$ of north latitude.

"It is only then in our ocean, which is so straitened by Africa and America, in which the variation would subside in the southern part of the globe: it is therefore the two great continents of Africa and America which change the direction of the magnetic matter, so that there should be no variation somewhere under the Equator, in Africa and America." 


\section{CHAPTER XXII. \\ Extracts from a Letter of Baron Grant, relative to the Isle of France.- Observations on India.-Brief Account of Pondicberry, छ̈c.}

\section{LETTER XIII.}

Isle of France, October, 1754 .

**** I $\mathrm{F}$ it were not that we apprehend a war, and the sudden arrival of our enemies, it would be no common folly to leave so delightful a climate as this.

When I first arrived at Mauritius, I heard the inhabitants observe, that nothing was to be done by way of advancing one's fortune; and an ordinary maintenance was all that could be expected. My experience, however, is in direct opposition to such a declaration; and I perceive that every year the revenues of the inhabitants increase. If I had not a family and relations in France, whom I love and long to see again, I should be very well contented to finish my days here; but having had the misfortune this year to lose the most amiable of wives, * and my second son being dead lately of the small-pox; these cruel accidents determine me to prepare myself for my departure; and, in the mean time, to send my only son immediately to France.

We have received the pleasing assurances that $M$. David, our Governor, will return; he is impatiently expected here, and will be received with the sincerest pleasure by us all. I have no reason to complain of M. Bouvet, his brother-in-law, whom he appointed to occupy his situation till he should return, or a successor be named; on the contrary, I feel myself indebted to him for many acts of attention and civility. We understand there is a difference among the Directors respecting the return of M. David; we shall however know their decision by the ships whose arrival is now the object of our impatient expectation. The harvests have very generally failed throughout the island. I am this year the only fortunate cultivator in it: I sowed two thousand two hundred pounds of corn, and have gathered sixty-six thousand. ****\&c. +

Grant.

- She was a lady of the family of Grenville, whom Baron Grant married in the year 1746 .

+ We suppress, in the Letters of Baron Grant, many observations which would be no more than repetitions of the different authors cited in this Volume. 
Observations on India, in a relative View to the Isle of France.

Though the immediate object of this Work is the Isle of France, it is so connected with India, as well as the principal points on the various coasts of the Indian Ocean, that some account of the Peninsula of Hindostan seems to be necessary, in order to elucidate what has been already said, and will hereafter be mentioned. I shall therefore add, to the notes of my father, a brief detail of the principal events which have passed there, since the Isle of France may be supposed to have had any connection with it, from its subjection to the power of France.

Pondicherry being the principal establishment which the French possessed on the coast of Coromandel, and the centre of all those operations, I will first give a short account of the origin of that establishment.

\section{Pondicberry.}

The first project for a French East India Company was formed under Henry IV. by Gerard le Roi, a Flemish navigator, who had made some voyages to India in Dutch ships. The King, by letters patent in 1604 , granted to him and certain associates very encouraging privileges, and an exclusive trade for fifteen years: but this scheme was not carried into execution. Five years after he formed a new association, and obtained other letters patent, dated $2 \mathrm{~d}$ of March, 1611 . Four years however passed away without any enterprize being undertaken: some merchants of Rouen, therefore, solicited the transfer of these privileges to them, and engaged to fit out a certain number of ships for India in the course of the year 1615 . The associates of Gerard immediately opposed this demand; when the King, to conciliate the interests of these two Companies, united them by letters patent, dated $2 \mathrm{~d}$ of July, 1615 .

It is not known, with any degree of certainty, that their navigators reached India; but it can be ascertained that, in 1616 and 1619 , they set sail towards the southern coast of Africa; and it is probable that the French then landed for the first time in the islands of Madagascar and Mascaregnas, of the latter of which they took possession some years after.

In $164_{2}$, a new commercial company was formed under the auspices of the Cardinal de Richelieu, which took the name of the Company of Madagascar. It made some progress in that island, established a colony of an hundred French 
people, and built a fort there, in a place called Folonbaren, in $25^{\circ} 30^{\prime}$ south latitude. During the ten years, which was the period allotted by the patent to its exclusive privilege, the Company sent several vessels to Madagascar, and expended considerable sums of money, without deriving any advantage from it. Its funds being exhausted, the Marshal de la Meilleraie, and M. Fouquet, possessed themselves of the privileges of the Company. The first fitted out several armaments at his own expence; but his designs were interrupted by his death, in 1664 , though they proved of great utility to the new Company. Chamargou, Governor of the island for the Marshal de la Meilleraie, and from whom he held his commission, pushed on the conquests begun by Flacour, La Roche Saint André, and other navigators: he completed the submission of the whole country, and exacted tribute of two hundred thousand islanders, although his whole force did not exceed an hundred and sixty adventurers.

The inconsiderate zeal of a priest of the mission of Saint Lazarus, was attended with very unhappy consequences to the colony. An idolatrous Prince of the country, who had hitherto been a friend of the French, having refused to embrace the Christian religion, the missionary, instead of alarming him with the anger of heaven, threatened him with the vengeance of the French. The exasperated Prince immediately sacrificed the priest and a person who accompanied him; and forty French people were also massacred by a party of his soldiers, who had formed an ambuscade for that purpose. Those who escaped the same fate, were the victims of disease; and the establishment of Madagascar was menaced with approaching ruin.

The deplorable state of this colony induced M. Colbert to form a new Company, not only to re-establish the affairs of Madagascar, but to extend the commerce of France to the East Indies. Nine principal merchants, with a Secretary of the Council as their President, were charged with the direction of the Company in the capital, and other arrangements were made in the provinces. The King, in the edict of establishment, dated the month of August, 1664 , engaged to lend three millions of livres to the Company, without interest, or the reservation of any part of the profit during ten years; and at the same time charged himself with any loss that might be sustained during that interval. But the edict also exacted, that each of the proprietors of stock should furnish, at least, the sum of a thousand livres; 
and to render the Directors more attentive to their functions, those of Paris were obliged to subscribe at least twenty thousand livres, and those of provinces the moiety of that sum.

The first armament was completed in the month of March, $166_{5}$. It consisted of four vessels, which were sent to Madagascar, now named the Isle Daupbine. M. de Beausse, who went with the squadron, was appointed the Governor. Orders were also given to examine, in their way, the Isle Mascaregnas, as well as a neighbouring isle, of which the French had possessed themselves some years before, and had been named the Isle de Bourbon. Twenty passengers, whom the squadron now left there, laid the foundation of that establishment, which France has possessed from that period.

The differences that took place at Madagascar, between the officers of the new Company, and Chamargou, the agent of the house of Mazarin, prevented those advantages which might otherwise have been derived from this first expedition.

The following year the Company fitted out twelve merchant ships, which were escorted by four of the King's ships, commanded by the Marquis de Mondevergue, who was invested with the rank of Admiral and Lieutenant General in all places beyond the line. Caron and De Faye, two experienced merchants, were on board this fleet. Mondevergue arrived the 1 oth of May, 1667 , in sight of Madagascar, and came to moorings in the road of Fort Dauphin. Though the French had been upwards of twenty years established in this place, it was in such a miserable and neglected state, as at once to astonish and mortify the new Governor. De Faye and Caron were charged with the direction of all commercial concerns; but these new agents soon perceived, that the hopes which had been excited respecting the trade of Madagascar had no foundation whatever, and that this island could yield no advantage but as a magazine for the merchandize of India. The report from these persons was dispatched for the information and instructions of the Company; and, in the interval, the squadron set sail for Surat, and in 1668 the foundation was laid of the first factory that France possessed in India.

M. de la Haye succeeded to the Marquis Mondevergue, who had not conducted himself to the satisfaction of M. Colbert, and arrived in the road of Fort Dauphin, in 1670 , with a fleet of nine ships, which carried from thirty-four to fifty-six guns. He experienced the same obstacles that his predecessors had done, from Chamargou and the other colonists of the island, who were always caballing in opposition to the 
interests of the new Company. He therefore abandoned Madagascar, and passed with all the troops that he had brought from France, to the Isle of Bourbon. Although this last establishment had not been formed more than five years, there were already four plantations. This colony has continued to increase from that period: in 1717 , it contained two thousand inhabitants, of which eleven hundred were slaves. Their number has since doubled.

With respect to the Island of Madagascar, the Company, after a prodigious expence in maintaining their establishment there, were forced to abandon it. Chamargou, supported by De la Case, another famous adventurer, supported his authority during his life; but, after the death of these two brave men, the French colony was entirely ruined. Some have attributed its destruction to the Dutch, who, in a descent which they made at Fort Dauphin, towards the year 1672 , massacred the greatest part of its inhabitants; others pretend that the natives of the island prevailed on the slaves who cultivated the plantations of the French, to murder their masters.

After the French had abandoned Madagascar, Surat became the favourite establishment of the Company. They had however formed other factories in India: the principal ones were in the province of Bengal, on the banks of the Ganges; at Mirzeou, in the kingdom of Vizapour; at Balliepatan and Tilseri, in the country of Cananor; at Alicote, in the territory of Calicut; at Masulipatan, in the kingdom of Golconda; and, lastly, at Pondicberry. It was in 1670 , that the Company established this last factory, about the middle of the Coromandel coast, in a place which was formerly called Boudoutscberi; and here they determined to erect the principal entrepôt of their Indian commerce. The Governor of the country made a grant to them of some ground near the sea, where they first built a spacious edifice, which served as a factory. In 1676 he permitted them to fortify it, and even sent them three hundred Indian soldiers to augment their feeble garrison, which consisted only of sixty men. New buildings were now erected, and an offer of certain exemptions soon filled them with inhabitants; so that this settlement began to display a promising aspect. The first fortifications were planned by M. Martin, who had been sent out by the Company to take upon him the care of this establishment; but they were inconsiderable, as may be readily imagined when the expence of them did not exceed seven hundred écus.

In 1680 , the famous Sevagi, who was the sovereign of a part of Vizapour, having subjugated the province of Gingi, threatened the French factory with an 
irruption; but was diverted from his design by a present of five hundred pagodas, and engaged to grant to the colony scveral additional privileges; which were accompanied, however, with some exactions on his part, which he was afterwards induced to set aside. In 1686, M. Martin added two large warehouses built with bricks, as well as several other edifices. Two years after, he caused a strong wall to be erected on the western side, which has since been continued to the eastern side. This wall was flanked with four towers, on each of which was placed six pieces of ordnance.

The French had scarce begun to fortify themselves in this post, when the Dutch came to besiege them by land and sea, with such a superior force, that the town was obliged to capitulate on the 6th of September, 1693. It was however restored to the Company four years after, by an article in the Treaty of Ryswick. On the return of the French to it, they found the government house was finished, and the fortifications strengthened by six bastions. Sixteen thousand pagodas were paid to the Dutch to reimburse them for these expences. M. Martin, who was continued in the exercise of his former functions, added several new works to protect the government house from every possible attack ; and received a garrison of two hundred Frenchmen, to whom he joined three hundred Topases, or Indian soldiers : about the same time a Sovereign Council was established in the town.

Pondicherry now began to be a place of importance. M. Martin informed the Company, in 1699 , that he had added an hundred new houses to the town, for the purposes of receiving foreigners who might wish to establish themselves there; and in the beginning of the present century there were already from fifty to sixty thousand inhabitants.

From the year 1700 till the Regency, the commerce of the Company was in a very languishing state. Indeed, from the year 1686, the Farmers General had laid a most exorbitant duty on the linen and other Oriental merchandize which was imported into France. According to the edict of $166_{4}$, which was the work of M. Colbert, each piece of linen, consisting of ten ells, was to pay no more on its entrance than eighteen sous. The other articles of merchandize were subject to a moderate tax, and the highest imposts did not amount to three per cent.

After the death of $\mathrm{M}$. Colbert, the rates were so much advanced, that, independent of the old duties, six livres were exacted for every piece of cotton, twenty livres 
per ell for all stuffs embroidered with gold or silver, fifty sous for plain taffetas and satins, and thirty sous for stuffs made of the bark of trees. Afterwards the sale of this kind of merchandize was entirely prohibited in France, and, for some time, muslins even were refused entrance into the kingdom.

On the other hand, the government permitted several merchants in the maritime towns to engage in the trade to India, by means of the Company's ships, on paying a moderate freight, \&c. \&c. In short, the Company received so many severe blows, that the symptoms appeared of its approaching downfall : so that in 1708, being totally incapable of preparing any armed force, application was made to $\mathrm{M}$. Crozat to fit out two ships for India. The Company reserved fifteen per cent. on the sale of their merchandize, and two per cent. on the prizes that might be made. Four years after it engaged on the same conditions with the merchants of St. Malo, to whom it abandoned its trade. At this period it owed, in France and India, upwards of ten millions of livres; and its factory at Surat was so involved in debt, that no French ship would venture to anchor in the road, from an apprehension of being arrested for the debts of the nation. The Company nevertheless solicited, in 1714 , a renewal of its privilege, which was about to expire, and which it had enjoyed during a course of fifty years. It obtained a prorogation for ten years, and made no other use of it than to sell commissions and brevets to the best bidder. The French commerce to India, therefore, when carried on in this precarious manner, and oppressed as it was by very burthensome conditions, diminished from day to day, and could not support any degree of competition with foreign nations.

Two particular companies had obtained the privilege to carry on a maritime trade, the one at China, and the other at Senegal. The China Company had been established in 1660, and was renewed in 1698 ; but it was not more successful than the East India Company. The Senegal Company was more modern, and was occupied principally in the traffic of Negroes for the West India plantations.

In 1717 a new association appeared, to which that of Senegal was united, and assumed the name of the Western Company; because it proposed to confine its trade to the West Indies and America. Two years after, all the commercial societies of the kingdom were united, and formed but one Company, which still preserved the name of the India Company, as it was described under that title by the edict of its establishment. This edict declared, among other articles, that the 
new Company should have the exclusive privilege of trading in all the Indian and South Seas, and possess various other subordinate advantages, necessary for encouraging its trade and advancing its interests.

When the Western Company was first instituted, the fund of an hundred millions of livres had been created in shares of fifteen hundred livres each, bearing an interest of ten per cent. Previous to the publication of the Edict of Union, these funds became so popular, that they rose to an hundred and thirty per cent. These were not only preserved in the new project, but the India Company was permitted to increase these funds twenty-five millions of livres. Though they were not so advantageous as the others, subscriptions were offered to the amount of fifty millions.

In 1720 , bank-bills succeeded to the funds, and factitious riches multiplied. The Company enjoyed a moment of splendour, and dispatched for India three vessels laden with very valuable cargoes. The Directors at Pondicherry, who were ignorant of what had happened in France, were astonished, when their trade had been in such a languishing state, to receive so great an abundance of ammunition and merchandize, with a considerable quantity of gold and silver specie. The greatest part of these riches were employed to pay the debts that the old Company had contracted at Surat, Camboia, Bengal, and other parts of India. The returns, however, to these cargoes were but moderate.

The bank-bills, however, disappeared; several thousands of shares were burned; the resources and the hopes of the Company vanished together; and in the course of 1721 and 1722 , it was not in a condition to send a single cargo to the Indies. This interruption of its commerce excited the raillery of all Europe. At length, in 1723, two ships were fitted out for Pondicherry; and though their cargoes were not very valuable, the Directors of the several factories, and the people employed under them, were all paid, and the debts of the old Company were finally extinguished.

Though the French commerce was in an actual state of disgrace, in 1723, Pondicherry was strengthened by new fortifications, and the number of inhabitants was considerably increased. The walls, which were now begun on a design to inclose the town within them, were to be completed, in part, at the expence of the Company : the remainder was to be defrayed by the inhabitants, who submitted, for that purpose, to a poll tax of two sous per month.

In the course of the following year the India trade recovered itself, and was evidently gaining strength under the administration of M. Orry. M. Dumas, who 
was appointed Governor of Pondicherry in 1735 , obtained of the Mogul, permission to coin money in this town; and he struck every year, from 1736 to 1741 , when he returned to France, from five to six millions of rupees, by which the Company derived an annual gain of four hundred thousand livres.

In 1739 , a Nabob, named Sander Saib, put the French in possession of the town of Karikal, of the fort of Karcangeri, and some other domains in the principality of Tanjour. Karikal is two leagues from the Danish settlement of Tranquebar, and twenty-five from Pondicherry. It was an ancient town, and had been a very considerable place. It had five mosques, fourteen pagodas, and from five to six thousand inhabitants : it is situated on an arm of the great river Colsain, which is capable of receiving vessels of two or three hundred tons burthen. The fortress of Karcangeri is within cannon-shot of Karikal, and half a quarter of a league from the sea. The French, for their accommodation, destroyed a part of its fortifications, which consisted of eight large ancient towers. The domain of Karikal contains, in a circumference of five or six leagues, ten small towns; the most considerable of them is called Titoumale, which contained two thousand five hundred inhabitants when the French took possession of it. The country is excellent, and produces a great deal of rice, cotton, indigo, and various grain : its inhabitants fabricate a considerable quantity of stuffs, cotton, and painted linens. The revenue of this territory, comprehending the farm of tobacco and betel, with the duty on imports, amounts annually to ten thousand golden pagodas, which is equivalent to an hundred thousand French livres.

The war which was kindled on the Peninsula of India, between the Nabob of Arcot and the King of the Mahrattas, at the period when the French made the acquisition which has been just mentioned, gave them a very favourable opportunity of increasing the colony of Pondicherry. The Nabob of Arcot, the ancient ally of France, was conquered and killed in a bloody battle, on the 20 th of May, 1740 , and his country was laid waste by the Mahrattas. His widow, and all the women of his family, accompanied by their children, and a prodigious number of fugitives, came to seek an asylum at Pondicherry, whither they brought every thing which they had saved in gold and silver, in jewels, and valuable furniture. M. Dumas received them with all the attentions and respect due to their rank, their unfortunate situation, and the friendship which the late Nabob had always manifested to the French people. This humane, generous, and grateful regard, had like to have involved him in a 
war. The Mahratta General being informed of the place where the family of the Nabob had retired, addressed two threatening letters to the French government, demanding the payment of certain tribute, which he pretended that the French owed to the King his master; to pay, besides, five hundred thousand rupees, and to put into his hands the widow of the Nabob of Arcot, with the fugitives, and their treasure, their elephants, horses, and all their equipage.

M. Dumas having rejected these propositions, a detachment of fifteen or sixteen thousand Mahratta troops advanced as far as the large village of Archionac, which is but a league and an half from Pondicherry, and pillaged, in their passage, Porto Novo, the English factory at Gondelour, and other European habitations. The firmness which the French displayed, a diversion which the King of Golconda made in their favour, and other fortunate circumstances, saved Pondicherry. It is said that some bottles of liquor sent to the Mahratta General determined him to retreat.

The Court of Delhi, which protected the old Nabob of Arcot, was so well satisfied with the conduct of the French in this war, that Nisam-ul-Mulk, the first minister, wrote a letter of thanks on the occasion to the Governor of Pondicherry, and accompanied it with the present of a very costly robe, in the name of his master. Some time after, M. Dumas was advanced to the dignity of Nabob, which was also settled upon his children and family.

In the same year, $174^{1}$, the son of the Nabob of Arcot, as a mark of his gratitude for the very kind treatment which his mother, \&c. had received at Pondicherry, sent a Paravana to the French Governor, by which he ceded personally to him, and not to the colony, the Aldées of Archionac, of Tedouvana-tan, of Villamour, and some other districts, situate to the south of Pondicherry. These lands, which M. Dumas sold to the Company; considerably augmented its territorial dominion in this part of India.

The foreign commerce of France was carried, in 1742 , to the highest degree of importance that it ever attained. Seven ships were sent to India, with cargoes to the value of twenty-four millions of livres; so that to prevent the market from being overstocked, a large part of it was necessarily consigned to the magazines. A more powerful marine, at this time, would have fixed for ever the prosperity of the French East India Company, ${ }^{*}$ and, consequently, preserved them from the losses and disgrace which it has since sustained.

- See the accounts of M. de la Bourdonnais's operations, Chapter VI. p. 208, and following. 
Pondicherry* is situated near the middle of the Coromandel coast, in about $12^{\circ}$ of north latitude. According to the last enumeration, it contained an hundred and twenty thousand inhabitants, including Christians, Mahometans, and Gentoos. Its exterior form is square, and upwards of a league in circumference; its plan is regular, as the Governors have always marked out the ground to such persons as applied for permission to erect houses. Its streets are broad and straight, and its principal one, which runs from south to north, is a thousand fathom in length. The houses are contiguous to each other; those of the Europeans are built of brick, but do not rise above one story : this circumstance proceeds from two causes, the scarcity of timber, and the fear of hurricanes, which are not uncommon on this coast. Those of the Indians and the Moors are formed of clay baked in the sun, and covered with a kind of lime, made of calcined oyster shells: Their common length is eight fathom, by six in breadth, and each of them contains from fifteen to twenty persons. The courts are planted with palm and cocoa trees, beneath whose shade the weavers and other manufacturers fabricate those beautiful works which are imported into Europe from India. In these courts, or on the platforms on the tops of the houses, the Indians pass the night, on a single mat, and almost naked.

The Governor's house is a very handsome edifice, and equal to the finest hôtels of France. This officer is attended by twelve horse guards, and three hundred foot soldiers, which are called Pions. On days of ceremony he is carried by six men in a palanquin, whose canopy and pannels are adorned with a rich embroidery, and various ornaments in gold. This pomp is necessary in a country where the power of a nation is determined by the exterior splendour of those who represent it.

The Jesuits have a fine college in the town, where twelve or fifteen religious persons of that order are maintained at the expence of government, who teach reading, writing, and mathematics. The foreign missionaries and the capuchins have also an establishment there. The Gentoos have two pagodas, where they enjoy without restraint every indulgence their faith requires. They, indeed, create the wealth of the town and the country; are industrious and sober, of a mild demeanour, and submissive in the extreme, provided their laws, customs, or prejudices, are not opposed. Their best workmen do not receive more than two French sous per day, and with that moderate gain they maintain their families. Boiled rice and unleavened cakes baked in the ashes are their only nourishment. The first of these

- This account was written in the year $175^{6}$. 
nutritious articles is very common here, notwithstanding the drought of the country; and it is to the labour and industrious disposition of these people, that the country is indebted for its abundance. As rice does not grow but in water, they contrive, by artificial means, the result of their labour and ingenuity, to give the plantations all the moisture which they require.

Pondicherry possesses vast magazines and warehouses, six principal gates, a considerable citadel, thirteen small forts or bastions, with a formidable artillery, consisting of upwards of four hundred pieces of cannon.

It is to be lamented that so fine a town is without a port, and that the sea affords only a shallow road before it; so that it is absolutely necessary to send boats to the distance of a league, to receive and carry the various articles of merchandize. In every other respect its advantages are great and numerous, and its produce abundant as to the necessaries and luxuries of life. 


\section{GHAPTER XXIII.}

\section{Abstract of the Life of Haider-Aly-Kban, $\xi^{\circ}$.}

$A_{\text {воU }}$ the year 1728, Cuttulich Khan, Soubah or Governor General of the Decan, sent Termamond Khan, an officer of reputation, and a Patan by birth, to deprive the Nabob Abdoul Ressoul Khan of his government of Sirpi, which is a province on the frontiers of the kingdom of Maissour. That prince, determined to try the fortune of arms, assembled his troops, and went forth to meet his competitor; and, after a very bloody battle, the Nabob of Sirpi was defeated and slain. Among the dead was Fatty Naick, father of Haider Aly, an excellent warrior in the service of the Nabob.

In consequence of this victory, the Patan Termamond Khan was received in Sirpi, and acknowledged as Nabob of that country. Fatty Naick left two sons and a daughter; the eldest was named Saber Naick and afterwards Ismael Saib, and the other Haider Naick, who was at that time a child of ten years old. He was born at Divanelli, a fort situated between Oscota and Colar. They had an uncle, with whom the eldest entered into the service of the King of Maissour. As to Haider Naick, he was always kept in the vicinity of the districts where his brother and his uncle served. At this early age he was bold and enterprising, untractable, and overbearing; he could neither read or write, nor would he receive instructions from any one.

Carrasorri Nanderauz, brother-in-law of the King of Maissour, as well as his first Minister and General of his army, was one of those who had assembled the troops of their masters to join the Soubah Nazerzing, and enter with him into the Carnatic, in $175^{\circ}$, against Mustapha Jung, who designed to get possession of the Soubahship of the Carnatic, to which he laid claim under the will of the last Soubah, his uncle.

Haider Naick, who was now a robust young man of about twenty-five years of age, assumed the name of Haider Aly; and being tired of the idle life which he had led, collected fifty or sixty Pions, or fusileers, with five or six horsemen, and proceeded 
to offer his services to Nanderauz, by whom he was well received. In about four years, he had acquired sufficient credit to raise five hundred infantry, clothed and disciplined in the European manner, with two hundred cavalry, and a couple of field pieces.

In 1754, in an engagement between the troops of the English East India Company and those of the Nabob of Arcot, he displayed great judgment and spirit in a coup de main, by which he possessed himself of thirty-five of the enemy's waggons, loaded with arms, ammunition, and the baggage of the officers.

In 1755 , he was sent at the head of three thousand infantry and fifteen hundred cavalry, with four pieces of artillery, against the Polygars, or mountaineers of the country of Maissour, who had failed in the payment of their tribute. In this expedition his success exceeded his utmost expectations; though it was the fruits of his treachery rather than his military prowess. Under the pretext of engaging in a treaty, he got possession of several of their chiefs, and exacted from them about ten or twelve lacks of rupees; one half of which he sent to the King of Maissour, and the other he kept himself. The King, however, as well as his Minister, felt a considerable degree of resentment at the audacious conduct of Haider, and wished to find an opportunity to lessen the credit he had gained in the army, and to crush him before he should become more formidable.

As he had every reason to suspect the designs that were forming against him, he employed every means in his power to strengthen and increase his authority; and the money which he had amassed was equal to that object, more particularly as troubles were breaking out in the country of Maissour.

In 1760, Gopalsauz, a Mahratta chief, entered into Maissour with ten thousand infantry and twenty thousand cavalry, to lay siege to Bangalore, a very strong place, and well defended. The King of Maissour proposed to the Mahrattas to purchase their return to their own country, with fifty lacks of rupees. Haider Aly, however, whose views did not look to peace, persuaded the King to break off the negociation, and obtained permission of him to conduct his army against the Mahratta power.

The two armies met, but, after a partial engagement, the negociation was renewed, and the Mahrattas retired into their own country with fifteen lacks less than had been originally proposed by the King of Maissour, who rewarded the services of Haider Aly, by giving him the title of Bahader, and appointing him commander 
in chief of his army, in the place of Nanderauz, who took refuge in the fort of Maissour.

About six months after the late Minister and General had quitted Seringapatam, the old King, his brother-in-law, died; and Haider Aly employed every art to gain the affection and friendship of his young sovereign. His first object was to induce him to suspect his uncle; and, having succeeded in that particular, he obtained an order to put himself at the head of his troops to reduce the fort of Maissour, and, in a short time, invested it. This place, however, being strongly fortified and well defended, held out for three months, when Nanderauz agreed to give it up, on condition that he should receive in exchange the government of Carrour, which is a district at about twenty coss to the west of Seringapatam.

Haider having been hitherto so successful in his projects, and having contrived also to remove his adversary to such a distance from the court, began to enjoy all the authority that his rank as Minister and General gave him, as well as to indulge the belief, that in this situation he was superior to any reverse of fortune.

The young King however had, from various quarters, and particularly from his uncle, who maintained a secret correspondence with him, been informed of the ambitious designs of his Minister, and began to entertain serious apprehensions of a revolution. He accordingly won to his interest a very artful person, of the name of Canderon, who had been placed about his person as a spy; but having been offended at the insufferable haughtiness and tyrannic disposition of Haider Aly, assembled the guards by the order of the King, made himself master of a part of the ramparts, which were near Haider's residence, and fired upon it. The latter, astonished at this enterprize, of which he had not the least suspicion, and having every reason to apprehend that the troops which were in the town had been prevailed upon to take part against him, he instantly mounted his horse, and fled away with some of his friends and domestics, leaving his wife and family behind him, to find a refuge in the fort of Bangalore, of which Ibrahim Saib, his uncle, was Governor.

Previous to his being attacked as I have already mentioned, he had sent to Pondicherry, Mucktom Saib, his brother-in-law, a brave officer, with five thousand infantry and three thousand cavalry; but when he fled to Bangalore, he dispatched an express to Mucktom, to desire that he would join him with all possible expedition. The King had also sent a special messenger to the Rajah of Bunt-bing, a Mahratta chief, and whose residence was at no great distance from the route which 
Haider Aly's detachment must take, with a promise of fifteen lacks of rupees if he would intercept them. The Rajah accordingly began his march, with four thousand foot and seven thousand horse, to effect this purpose; and a short time after, he was joined by Canderon, whom the King, at the same time, had detached with three thousand foot and three thousand horse to effectuate the same design.

They soon met Mucktom Saib, who had advanced to the village of Auchitty Dungham, about twelve coss from Bangalore, where he threw up entrenchments, being resolved to defend himself to the last extremity: nor was he without hopes that his brother, Haider Aly, would make an effort to come to his assistance. Haider, however, who suspected what was passing, did not venture to quit Bangalore. He, nevertheless, accepted the offers of Mir Pharsula Khan, a very brave soldier, who proposed to conduct a convoy of provisions and ammunition to Mucktom; but, notwithstanding his courage, he lost the whole of it, and with difficulty rejoined Haider Aly.

A month had already elapsed under these circumstances, when the Mabratta chief received the news of the death of his king, Nanna, and consequently entertained some design of returning to his country. Haider, who had received notice of this circumstance, offered him three lacks of rupees to put that design in execution. He agreed to the proposition, and immediately set out on his march homewards.

Haider having succeeded in this important point, began by confirming his authority in Bangalore, and then set forwards with the few troops which he could collect, to attack his former friend and present enemy, Canderon; but the latter thought it prudent to retreat to Seringapatam, whither Haider and his brother, Mucktom Saib, attempted to follow him. The country however being against them, and refusing to supply them with provisions, they were obliged to abandon their enterprize.

It was in this critical circumstance that Haider Aly determined to execute a project that required all the courage which he possessed. He took ten confidential persons with him, and hastened to throw himself at the feet of Nanderauz, who was returned to court. He wept, acknowledged his offences, and demanded pardon. The good old man, won by his demeanour, and touched with his declarations of sorrow, was persuaded that he had no other view than to re-establish himself in his former post. Canderon, however, had put himself at the head of some troops, with a determination to maintain his new dignity; but was attacked and defeated by Haider, and with difficulty escaped to inform the King of the combination that had. 
been formed, by his uncle Nanderauz and Haider, against him, and the consequences that would result from it.

After this battle a part of the King's troops entered into the service of Haider Aly, by the persuasion of Nanderauz, who, at the same time, published a manifesto, addressed to the Bahadars of Maissour, assuring them that his friend, had no ill design against the government, nor any other views in collecting an armed force than to restore himself to the office of Duan, of which he had been unjustly deprived. In short, he was so blinded by the arts and flattery of Haider, as not to perceive the mischief he was doing, not only to himself, but the King, his nephew.

Haider, in consequence of these orders, which were so favourable to his designs, and having won over all the districts in the environs of the capital, which he had put under the direction of persons in his confidence, dismissed the old Nanderauz, who was no longer of any use to him, to his government of Carrour.

Haider now assembled his troops, paid them half of the money which was due to them, and promised them the rest as soon as he should be re-established in his post. The troops, therefore, who did not imagine that he had any other design than to get rid of his enemy, Canderon, marched to besiege the capital of their own country; which was soon blockaded in such a manner as to cut off all communication from without.

The place remained in a state of blockade during a month, when Haider Aly found means of assuring the King of his submission and fidelity : the latter, therefore, determined to open the gates to him, to receive him as Duan, and deliver up his enemy to his disposal. He was, however, no sooner admitted into the town, than he placed sentinels at the gates of the palace, of the magazines, \&c. made the King, in a manner his prisoner, and himself master of the treasure, with which he paid the troops, and made presents to the officers who had served him in his rebellion. He then shut up his enemy, Canderon, in a cage, and after exposing him for some days in the capital, sent him to close his life in that deplorable state at Bangalore. The cage with the bones are seen at this day, in the market-place of that town.

Haider Aly remained in the capital during six months, in order to regulate the affairs of the country, and to establish himself in his new government. These transactions took place in the year ${ }_{17} 6_{3}$.

Termamond Khan, who had been named the Nabob of Sirpi in 1728 , by Nizam 
el Muluch, dying in 1740 , the Mahrattas, whose districts bordered on the territory of Sirpi, raised some troops, and, after having reduced the whole couritry, invested the town of Sirpi, which is the capital of it. Delar Khan, the successor of the late Nabob, having neither the courage nor the means to defend it, gave up the place, and consented to retire into a small district near to Colar.

The conquest of Sirpi and all its dependencies by the Mahrattas, gave great uneasiness to the Soubah, who, in consequence of his alarm, sent his brother, Basaletzing, with an army, to drive them from Sirpi. As Ascotah, a frontier town of Maissour, was the first which he found upon his march, he accordingly invested it. Though the garrison did not consist of more than seven hundred men, armed after the manner of the country, the place resisted for two months the vigorous efforts of the Soubah's army.

Haider Aly, who was ever ready to profit of any opportunity which offered to aggrandize himself, dispatched Mir Phasula Khan to Basaletzing, brother of the Soubah, to offer him five lacks of rupees, if he would yield to him the government of Sirpi with its dependencies. He required the aid of the Mahratta troops to take the town, but he undertook to subdue the country with his own.

As soon as the treaty was signed, and the money paid, Haider set out with his troops to join the party with which Basaletzing had provided him. He renewed the attack on Ascotah, reduced the place in a few days to capitulate, garrisoned it with his own troops, and proceeded to besiege Sirpi, which surrendered in about a month. After this event the army of the Soubah returned to Adony.

Haider met with few obstacles in reducing the rest of the country to submission, except the Polygars, or mountaineers of Chinnabalaporam, who, in the space of two or three months, had killed at least a thousand of his people. As his expedition against them was not only attended with great loss, but also with considerable expence, and having been frequently attacked by the Mahrattas while he was before Chinnabalaporam, he proposed to Chinnapah, chief of the Polygars, to retire with his army, on condition of being paid five lacks of pagodas. These propositions were received, and he accordingly returned with his troops to Divanelly, about the distance of three coss, ${ }^{*}$ on the road to Maissour.

Morarou, one of the Mahratta chiefs, who had assisted in the defence of Chinna-

* The coss is an itinerary measure of India of about half a league, or thirteen hundred and thirty-five fathoms. 
balaporam, at the request of Chinnapah, left there about five hundred of his troops to strengthen the garrison, and departed for his own country with the rest of his troops. The Polygar clief also returned to Nanderauz, the place of his general residence.

Haider Aly, instructed in every thing that related to those people, returned by long marches to satisfy his desire of vengeance against the Mahrattas, and renewed the siege of Chinnabalaporam, which he took in ten days. The Polygar troops being returned into their own country, and the Mahratta chief being at too great a distance to afford any relief to the garrison; he mutilated a great number of them in order to terrify the rest, and facilitate his future enterprizes.

Having given the command of the place to one of his relations, he engaged in the pursuit of the Mahrattas, and, by forced marches, overtook them at Podgaconda; when, by a fierce and instant attack, he defeated their army, killed a considerable number of them, and made many of the principal officers prisoners. Morarou, after his defeat, retired to Gutty, his capital. Haider Aly, satisfied with having forced his enemy to a retreat, took possession of such part of his country as it was convenient for him to annex to his new acquisition of Sirpi, and were equal to the annual produce of three lacks of pagodas.

He had no sooner executed the project he had formed, to recover the ancient district of Sirpi, than he began his march against the Polygar chief of Chittercol Durgam, whom he soon reduced to submission, and not only compelled him to pay three lacks of rupees, but to furnish fifteen hundred cavalry and ten thousand infantry, to assist him in another enterprize which he had in view.

In order to render what follows more intelligible, it is necessary to revert for a moment to a former period.

The Rajah of Bednor, a fertile country, surrounded with lofty mountains and extensive forests, which render all access to it extremely difficult, had named his son, Chinavar Appiah, to be his successor; and, in consequence of this nomination, this child, who was no more than nine years of age, had been acknowledged as sovereign at the death of his father; so that every thing which regarded the government of the country was transacted in his name.

A year had passed away, and things remained in this situation, when the Queen meditated a design on the life of the young Prince, in order to place her brother on the throne. A friend of the young Rajah contrived to remove him to a 
distance from the Court, and sent him secretly to the Polygar chief of Chitticol Durgam. The young Prince had already been eight years under the care of the Polygar chief, when Haider attacked him. This circumstance suggested to Haider the idea of subjecting the country of Bednor; as he now could attain that object without difficulty, under the pretext of re-establishing the young Prince: and this ambitious project he finally effected, on condition of paying forty lacks of rupees to Mahaderon, and twenty to his Minister.

Haider now left the government of Bednor to the care of his son, Tippoo Saib, and established Lala Thean, who had espoused his sister, as governor of a fortified place in that neighbourhood. He sent also Mir Saib, whose sister he had married, to the government of Sirpi ; he gave the command of the fort and district of Maissour to Mir Pharsula Khan, and that of Seringapatam, the capital of the Maissour country, to Mucktom Saib. Ibraim Saib, his uncle, was continued in his government of Bangalore; and Amian Saib, his nephew, was employed to defend the valley of Burmal.

These arrangements being made, Haider Aly proceeded with a strong detachment towards the coast of Malabar, where he entered into a treaty of alliance with a petty prince named Ali Rajah, and, with the assistance which he received from him, he laid siege to Calicut, the capital and residence of the King of the Naires. This place held out during three months, and in the end obtained an honourable capitulation.

About the same time Mir Saib, the Governor of Sirpi, found means to make himself master of Chinnapah, chief of the Polygars; and, notwithstanding his most solemn engagements to the contrary, he sent him prisoner to Bangalore, where he died of a broken heart: while Haider, in order to secure his son, who was a young man, had him circumcised by force, and instructed in the principles of the Mahometan religion.

The King of Calicut was of the sect of the Bramins, and being very much attached to the principles of his religion, he could not permit himself to have any personal communication with the Mahometans. He therefore refused, but with the utmost civility, the visit that Haider Aly proposed to make him. He, however, sent a Bramin to demand the quantity of corn necessary for him to support his daily charities. The following day Haider sent him sufficient for five hundred persons; the next day a still less quantity, and continued to diminish the boon till it was reduced 
to nothing. The King, therefore, enraged at such inhuman treatment, assembled all his family, and, after having performed certain ceremonies with the principal Bramins, he ordered his palace to be set on fire in several different places; and it being constructed of wood, the unhappy Prince and all his family were immediately burned.

As soon as Haider Aly was informed of the death of the King he left a garrison of two hundred infantry and five hundred horse, and set out with the rest of his army, for the country of Coimboutour, which is about forty coss on the road from Calicut to Maissour. About two months after he had left Calicut, a brother of the King appeared before the place with an army of twenty thousand men; and having some intelligence with the inhabitants, took it by assault, and put all the garrison to the sword. Three hundred men alone escaped, by taking refuge in a pagoda.

When Haider received an account of this event, he immediately detached Assouff Khan with five thousand infantry and a thousand horse, with positive orders to engage the enemy; the brother of the King accordingly gave him battle, but having been defeated in two separate engagements, and fearing lest he should be shut up in the town, he quitted it during the night, with his whole army and all the inhabitants, and retired into the woods.

There he remained three months, without attempting any act of hostility ; and having lulled them by his conduct into a state of security, he appeared unexpectedly before the place, and retook it. He condemned Assouff Khan to lose his head, killed a great number of his soldiers, while the rest fled away to the territories of Haider to inform him of this disastrous event. He accordingly set out for Calicut, at the head of an army of six thousand infantry and two thousand horse; but, after two days march, he gave the command of his troops to Sevagée Rou, a Mahratta Bramin, who, on arriving before the place, was attacked by the King's brother; but having gained the battle, the latter retired, as he had already done, into the woods, and abandoned the place.

Haider Aly had quitted the command of his army to return in haste with his best troops to Seringapatam, when he received an account that Mahaderou, one of the Mahratta chiefs, was making preparations, and had, indeed, already put himself in motion to recover the domains which his predecessors had ceded to Haider in 1760. Though this circumstance was of great importance to him, he, nevertheless, determined to make his triumphant entry into Seringapatam. 
Mahaderou, who did not meet with any considerable opposition, took possession of all the districts as well as forts which have been already mentioned: he retook the country of Sirpi, Ascota, Chinnabalaporam, and all their dependencies.

In the months of January and February, ${ }_{17} 67$, the Soubah Nizam Ali and Basselat Jung his brother, whose army was strengthened by a detachment of the English Company's troops, left Hyderabad to join Mahaderou : but the Soubah, who amused himself with levying certain imposts in different districts on his march, did not join him till the month of April. During this interval, the Mahrattas did not remain in a state of inaction, and had already made themselves masters of Chinnaradurgam, of Davilradurgam, and of the strong citadel of Mugdeghenny. In this last place they found the young King of Bednor, with the old Queen and her brother. They afterwards took several important places, and levied very heavy contributions.

Haider, who perceived the storm that was collecting against him, fortified his principal forts, and having fully garrisoned and victualled them, gathered together all his troops and encamped before the walls of Seringapatam, where he entrenched himself to the best possible advantage. Being resolved to wait the event, he gave orders that all the grain and provisions within thirty miles of Seringapatam should be brought to the magazines of that city. This he considered as a certain measure to prevent the confederate army from approaching. In the mean time he entered into a secret correspondence with the Soubah; and he had also dispatched a Vaqueel to Mahaderou, the Mahratta chief, who agreed to restore all the places he had taken, for thirty lacks of rupees; which he had no sooner received, than he retreated to his own country, without giving to the Soubah the smallest portion of his bribe.

Though the English detachment had received considerable reinforcements, General Smith, who commanded it, perceiving the duplicity of the Soubah, withdrew his army to the frontiers of the Carnatic. About the middle of May, the Soubah set forward to join the army of Haider Aly; and about the $24^{\text {th }}$ of the same month, the English were informed that the object of their junction was to get possession of that country.

General Smith saw the danger that threatened him, and made continual requisitions to the Governor and Council of Madras to grant him the necessary supplies for the approaching campaign; but as they delayed their attention to his repeated remonstrances, Haider Aly and the Soubah entered with their armies into the valley of Burmal, and commenced hostilities. 
The troops of the Soubah consisted of thirty thousand horse, ten thousand Sepoys, and a vast body of irregular infantry, with sixty pieces of cannon. The army of Haider Aly was composed of twelve thousand well disciplined cavalry, eight thousand Mogul horse, with a troop of sixty European hussars, a very large body of infantry, armed with European musquets, and forty-five pieces of artillery.

As to the English army, it consisted of no more than two European regiments, amounting, at most, to eight hundred men; seven battalions of Sepoys, of about eight hundred men each, a body of artillery, and five hundred horse belonging to the Nabob; with a troop of European horse, which contained only thirty men, and was commanded by Lieutenant Robson.

Haider being convinced that he should more effectually distress the English army by cutting off all communication between their camp and the country, employed very large detachments of cavalry for that purpose, who continually relieved each other. Fortunately, however, for the English, the haughty humour of the Soubah and his officers was soon dissatisfied with this tiresome mode of making war, and reproached their ally with not having fulfilled his promise of cutting the English army in pieces.

At this time the English army, being in great distress from the want of rice and other provisions, began its march towards the defile of Singurpettah, to get out of the valley of Burmal, and to re-enter the Carnatic. The Indian chiefs, therefore, determined to attack them, and they executed their design on the $2 \mathrm{~d}$ of September, near the fort of Changaina. The contest was maintained with great courage on both sides, but the Eastern armies sustained very considerable loss, and the English remained masters of the field of battle. The latter, however, could not avail themselves of their advantage, from a deficiency of ammunition; so that the General thought it right to proceed the following night for Trincomally. Haider Aly soon learned that the English were on the march, and sent detachments to harass them; but though they were impeded by these manœuvres, they arrived at Trincomally, and were soon joined by the southern division under Colonel Wood. Having recovered from their late fatigues, the whole army encamped at a small distance from Trincomally; and the Eastern powers soon re-appeared, and fixed their camp in a very advantageous position; from whence Haider made an idle parade of his artillery, as he was at too great a distance to annoy his enemies. General Smith had frequently manœuvred to make Haider leave his advantageous situation, but in vain. 
At length, however, he succeeded, in consequence of a victory over the united army, on which occasion Haider and the Soubah lost twelve thousand men, besides those which were wounded; and the latter was compelled to leave bchind him thirty-scven brass cannon, fifteen and twenty pounders, which were said to have come from the foundries of France; but when the Soubah afterwards made peace with the English, they were all restored to him.

Some time previous to the battle which has just been mentioned, Haider Aly had sent his son Tippoo Saib, with a large detachment of cavalry, to the environs of Madras, with orders to carry pillage and destruction along with him. He was, however, prevented from obeying his father's orders, by the activity of Colonel Call, the principal engineer, who collected all the force that was to be found, and completely protected the Black Town from the menaced inroads of Tippoo. In the mean time, the Governor of Madras received an express from General Smith, to inform him that he had gained a complete victory over the armies of Haider Aly and the Soubah. A general discharge of the cannon at Madras announced this important event; and no sooner did it reach Tippoo Saib, than he retreated in great haste to rejoin his father and the Soubah, who had fallen back to Caveripatnam. As the rainy season approached, their armies went into cantonments, while the English forces took. up their quarters at Vellore, Wandewash, Conjeveram, \&c.

The rains having ceased, in the latter part of November, Haider Aly assembled his troops, and having entered the valley of Burmal, invested the two mud forts of Tripotore and Vaniambady, and as they did not contain more than five hundred Sepoys, they soon capitulated. Haider then proceeded to besiege the citadel of Ambour, a place of considerable importance, and situated on a rock, at the foot of which is the town, defended by a mud wall. The English commandant, perceiving that any effectual defence was impossible, retired with his troops into the fort, and dispatched an express to the Governor of Madras to inform him of his situation. The English army, therefore, received immediate orders to assemble, with all possible expedition, at Vellore, and it was soon enabled to march to the succour of Amboor. On their approach, Haider Aly raised the siege, and re-entered the valley. The Soubah followed him with his army, and proceeded to Caveripatnam, where he encamped; but Haider stopped at Vaniambady, where he chose a very advantageous post, being resolved to try the strength of his army alone against the English. 
On the 8th of December, the English appeared before Vaniambady, where they found Haider Aly; an engagement followed, in which he was worsted, but made his retreat in such good order, that the English did not think it prudent to follow him. He directed his route to Caveripatnam, where he joined the Soubah, and was again beaten by the English, with whom the Soubah, tired of the war, entered into a treaty of pacification.

Haider Aly, finding himself without allies, left a strong garrison at Caveripatnam, and led back his army into the Maissour country. Thus terminated the campaign of 1767 .

In January, 1768, the English began the campaign in two distinct parts. The division which directed its operations to the southward, was commanded by Colonel Wood, who received orders to march towards Davembarra, and from thence to Tingrocolat, Atour, and Selim.

The northern division, commanded by General Smith, advanced up the valley of Burmal, and sat down before Caveripatnam, which it soon reduced; he then invested and made himself master of the important fortress of Kitna Gurrey.

During this time, Colonel Wood obtained very signal advantages with the army which he commanded in the south.

The English at length determined to make a more serious attack on Haider Aly, by besieging his capital, Seringapatam, and Bangalore. They were confirmed in this design, on being informed that the government of Bombay had engaged in an enterprize against the possessions of Haider Aly, on the coast of Malabar, and had taken the forts of Mangalore and Onor, after having fortified the island of Bombay. This diversion favoured the views of the government of Madras. But Haider Aly was no sooner informed of this expedition, than he led the greater part of his army to the coast of Malabar; when the Bombay troops, being convinced that they were not in sufficient force to resist the Indian chief, whom they imagined to be at that time occupied with the army belonging to Madras, took to flight, and lost their artillery, with a considerable number of prisoners.

At the same time the divisions of the army of Madras, commanded by General Smith and Colonel Wood, though they had not received the heavy artillery which they expected from Madras, formed a junction on the 7 th of October, and set forward to meet Haider Aly, who returned triumphant from the coast of Malabar. They in vain strove to bring him to a general engagement, as be could always 
retreat with a degree of expedition which they could not adopt to follow him; and did not fail to employ his cavalry in harassing them without intermission. At length, however, he was reduced to such a situation, that he offered terms of peace to the government of Madras, which, unfortunately, were accepted the $4^{\text {th }}$ of April, 1769 ; as in the position in which he found himself at that time, he might have been driven out of the Carnatic, or been obliged to purchase peace on any terms that might have been dictated to him.

Haider Aly remained in a state of peace to the latter part of the year 1770 , and, during this interval, he applied himself to the government and domestic concerns of his country; but his repose was not suffered to be of long duration.

At the end of this year a vast Mahratta army appeared to attack him, which consisted of sixty thousand infantry, ten thousand cavalry, with some field-pieces; but they were indifferently served.

Haider, who had not a sufficient quantity of cavalry to oppose to such a torrent, contented himself with giving his army a very advantageous position, at some miles distance from Seringapatam. It was composed of eight thousand men, the flower of his cavalry, and thirteen thousand infantry, well armed with European muskets. His artillery also was served in a superior manner, and in several slight engagements, he had the advantage.

Morarou, an ancient Mahratta chicf, who, in the last war was an ally of the English, and whose camp had been forced by Haider Aly, still continued to preserve his former resentment. He had strengthened his army with that of another Mahratta prince, Trimbuch Mama, and offered the reward of a thousand rupees to any one who should bring the head of Haider.

Morarou counselled Trimbuch Mama to send some detachments on the side of Seringapatam, to deceive Haider, and draw him from his post, which he had maintained for eight months, and the stratagem succeeded. Haider Aly, forgetful of his former precaution, was led by degrees to a considerable distance from Seringapatam, from whence he drew all his supplies; and Trimbuch availed himself of the opportunity to place a large detachment between that city and Haider's army, so that the latter was reduced to the dangerous necessity of regaining his former position by open force; but in this attempt he was attacked by the Mahrattas, his army was totally routed, and he himself, with a few of his people, escaped with difficulty to his capital, 
This was a terrible misfortune for Haider, who found himself without an army, without resources, without friends, and without allies; but his courage never forsook him; and, though he was besieged by a powerful army, and his country ravaged by the enemy, he indulged the hope, that his former fortune would return. In fact, the Mahrattas, having no heavy artillery, were reduced to the necessity of turning what would have otherwise been an active siege, into a lingering blockade.

In the mean time, Trimbuch Mama wrote in the most pressing terms to the $\mathrm{Nabob}$ of the Carnatic, and to M. Dupree, then Governor of Madras, to obtain troops and cannon, in order to reduce the capital of Haider Aly. The Nabob was disposed to comply with the request, but the Council of Madras thought that they were bound to keep faith with Haider, and that they could not be justified in violating the pace of $176 \mathrm{~g}$.

Haider also, in his turn, applied to Governor Dupree for assistance, but the latter seemed determined not to interfere in the contest, and equally refused assistance to both parties.

The Mahrattas being, at length, in great distress for provisions of every kind, contented themselves with desolating Haider's country, and then retired to their own. Mahaderou died soon after his return; when a civil war took place among the chiefs, who contended for his succession; and to this discord, which lasted for several years, Haider Aly was indebted for his future glory.

The Mahrattas were no sooner departed, than Haider collected a small army, with which he attacked and retook all the forts that they had taken from him, and soon purged his country of those dangerous brigands. Thus he soon established tranquillity in his dominions, and, by the encouragements he held forth, induced the natives who had been driven away, to return and rebuild their villages, and resume the cultivation of their districts. He then employed his whole attention to the restoration of his army, and in a few years he had formed a body of troops, both as to numbers and discipline, which must give an extraordinary idea of his talents and perseverance. They were as follows :

Twenty thousand cavalry.

Thirty-eight thousand infantry.

Forty pieces of brass cannon.

Five hundred camels.

Two hundred elephants. 
Bullocks without number.

Upwards of twelve thousand troops dispersed in different garrisons.

Such was the amount of Haider Aly's army in 1775; and from that time to the year 1780 , he enjoyed an uninterrupted state of peace and tranquillity.

Towards the latter end of July, 1780 , he entered into the Carnatic, and, on the zgth of that month, sent a large detachment of troops to Porto Novo, which they reached by forced marches; when they surprised and pillaged that town, which had ever been considered as a free port for all nations. He made the Dutch and Danish Residents prisoners, and by such a measure manifested his intention to drive the Europeans out of that peninsula.

While Haider was ravaging the country, the English ordered their troops to assemble at Conjeveram, under the command of General Hector Monro. On the 8th of September that officer, having notice that Colonel Baily was pushing forward with the northern detachment, to form a junction with the main army ; and knowing, at the same time, that a large body of troops, commanded by Tippoo Saib was encamped near the route that Colonel Baily must take, dispatched Colonel Fletcher that very night, with a detachment to reinforce him; and these two detachments formed together a body of three thousand five hundred men. In the course of their march they were attacked by the united forces of Haider Aly and Tippoo Saib, and one of their tumbrels, laden with powder, blowing up during the engagement, that misfortune threw the column into disorder. Tippoo observing this circumstance, poured down his cavalry; and, though the English troops made a most obstinate resistance, the greater part of them were cut in pieces, and Colonel Baily, with all the surviving officers, taken prisoners, and sent to Seringapatam. Haider, immediately after this victory, sent a detachment of cavalry, commanded by a M. de Lally, to harass General Munro, who, on receiving the intelligence that Colonel Baily was defeated, retreated to Chinglepett. After this loss, the English army was no longer in a condition to resist Haider Aly, who now traversed, without opposition, the whole southern part of the Carnatic.

In the month of April, 1781, Haider invested the fortress of Tiagar, which, though impregnable from its situation, was obliged to surrender from the want of provisions. At length he entered the country of Tanjour, and not only destroyed all the villages he found in the course of his route, but even pillaged the temples of the Gentoos, which had hitherto been respected by every other sect and religion. 
The late alliance which Haider had formed with the French had contributed, in some degree, to the check which the English had received near Conjeveram; but the signal victory that was gained by Sir Eyre Coote, near Porto Novo, on the 3 oth of June in this same year, changed the posture of affairs.

This battle enabled the English to undertake, with their Admiral, Sir Edward Hughes, the siege of Negapatnam, which surrendered to their united forces on the 12 th of November.

In the month of December Haider Aly undertook the siege of Tellicherry, but was obliged to retreat from that enterprize with considerable loss.

In the mean time, the English army being reinforced by troops from Bengal, Sir Eyre Coote proceeded to Wandewash, which was besieged by Tippoo Saib, who, on the first intelligence of the approach, retreated towards Gingi, which he took with little opposition.

On the 2oth of August Sir Eyre Coote appeared before Tripassore, which capitulated, very fortunately for him, on the $23 \mathrm{~d}$, as the advanced guard of Haider Aly's. army appeared at the moment when the town surrendered, and the English had no more provisions remaining than for one day: as there was plenty in the town, Sir Eyre Coote immediately resolved to attack Haider, who retreated to the very place where he had defeated the small army of Colonel Baily; and, contrary to his usual practice, determined to wait for the English army, being influenced by a superstitious belief, that this situation would be fortunate to him : he did not, however, leave every thing to fortune, as he availed himself of every advantage which his position afforded him.

The battle, which continued from nine in the morning to sunset, was vigorously contested, but Sir Eyre Coote gained the victory. The English commander now determined to relieve Vellore, which was in a state of the utmost distress, as it had been for some time prevented by Haider Aly's cavalry from receiving the least supply of provisions. Haider, not altogether discouraged by his last defeat, hazarded another battle before that place, when his army was entirely put to the route, and Vellore effectually relieved.

While these events were taking place in the north, Colonel Braithwaite was not equally successful in the south: on the contrary, in an engagement with Tippoo Saib, near the village of Walletoole, in the Tanjour country, he suffered the same fate as Colonel Baily in the preceding year. 
At this time a squadron arrived from Europe, which brought reinforcements to the French troops, who landed at Porto Novo. Since the defeat of Colonel Braithwaite, the English were no longer formidable in the south, and Sir Eyre"Coote was too much occupied with Haider Aly, in the north, to be able to attack the French. The latter, therefore, advanced to Cuddalore, which they took in April, 1782, and sent a detachment to Haider Aly, who took possession of Permacoil.

No other event of importance took place, as the peace which had sheathed the swords of the belligerent powers in Europe, put an end to the war which had disturbed the Peninsula of India.

Haider Aly died in November, ${ }_{1782}$ : a cancer in his back, which had afflicted him for several years, finished the career of his bold and persevering ambition.

On the coast of Malabar the government of Bombay had levied a considerable body of troops, and given the command of them to Brigadier-General Mathews, who soon made himself master of Onor; and, on receiving the news that Haider was dead, proceeded to reduce Cundapore and Mangalore, the latter of which he took, after a feeble resistance. He then pushed on to the Bednor country, and possessed himself of the capital, which bears the same name.

The success of the English soon reached Tippoo Sultan, when he instantly quitted the Carnatic; and, on the $9^{\text {th }}$ of April, appeared before Bednor, with a very considerable army, a large train of artillery, and a thousand French troops. The English General, whose force did not exceed two thousand men, found himself obliged to retire into the fort, which, though it was commanded by the surrounding heights,

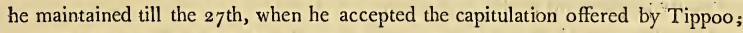
who, instead of adhering to the articles of it, exercised a degree of barbarity towards the English prisoners which has no example.

Bednor being restored to his power, Tippoo conducted his army towards the Malabar coast, to recover the places which the English had taken, and he accordingly appeared before Mangalore, which was garrisoned with three thousand men, commanded by Colonel Campbell, a valiant and experienced officer, who defended it with equal skill and courage for several months. At length, however, it was reduced to the greatest distress; when, fortunately for the brave garrison, they were relieved by a general peace. 


\section{GHAPTER XXIV.}

Extracts from the Correspondence of Baron Grant, during the Years 1755, 1756, 1757, 1758, 1759.-Extracts from Instructions to General Lally and Count $D^{\prime}$ 'Acbé, छ'c.-Firtber Extracts of the History of India during the seven Years War.

$\mathrm{T}_{\mathrm{HE}}$ large body of materials already inserted in this Work, and the importance of those which are to follow, renders it absolutely necessary to abridge this correspondence.

\section{LETTER XIV.}

Isle of France, December, 1755 .

Baron Grant having, in the preceding year, lost his wife* and his second son, it became an object of great importance to him to send his only remaining sont into the bosom of his family, at Vaux in Normandy : accordingly, in this letter, he enters into those details respecting him, which may be expected from such an excellent father as he was; and, at the same, recommends to his relations to make all the necessary preparations for his own return.

As his departure, however, did not take place till three years after, he enters into a detail of the works which he had erected, with M. David, the former Governor, in order to make lime from coral; as well as of his plantations of cotton, and the large forges established by M. David, in conjunction with the Count de Rostaing and M. Hermans, \&c. \&c. \&c.

" M. Bouvet, the successor of M. David, this year quitted the Isle of France, and was succeeded by M. Mago, who began his government, by giving a general permisson to cut wood, which threatened to injure that important object in the island,"

* Mademoiselle de Grenville.

† The Viscount de Vaux. 


\section{LETTER XV.}

In 1756 .

He continues to speak of the same objects, and certain preparations for war.

\section{LETTER XVI.}

Isle of France, 1757.

He announces the arrival of the French squadron at the Isle of France. The first vessels were commanded by $\mathrm{M}$. de Soupirs, and the main body of the squadron by the Count d'Aché, who conducted the Count de Lally to take upon him the government of the French establishments in the East Indies.

The principal part of the squadron, which was long and impatiently expected, at length arrived; and the principal articles of instruction for the two commanders in chief by sea and land are as follows:

\section{An Extract from General Lally's Instructions, given bim by the Frencb East India Company.*}

"The Sieur de Lally is authorised to destroy the fortifications of all maritime settlements which may be taken from the English; it may however be proper to except Vizagapatam, by reason of its being so nearly situated to Bemelipatana (a Dutch factory), which, in that case, would be enriched by the ruin of Vizagapatam: but as to that, as well as the demolishing all other places whatsoever, the Sieur de Lally is to consult the Governor and Superior Council of Pondicherry, and to have their opinion in writing: but notwithstanding, he is to destroy such places as he shall think proper, unless strong and sufficient arguments are made use of to the contrary: such, for example, as the Company's being apprehensive for some of their settlements, and that it would be then thought prudent and necessary to reserve the power of exchange, in case any of them should be lost. Nevertheless, if the Sieur de Lally should think it too hazardous to keep a place, or that he thought he could not do it without too much dividing or weakening his army; his Majesty then leaves it in his power to act as he may think proper for the good of the service.

"The Sieur de Lally is to allow of no English settlement being ransomed; as we

* The three following articles were given to the Author by one of the Directors of the English Eașt India Company. 
may well remember that after the taking Madras, last war, the English Company, in their Council of the $14^{\text {th }}$ of July, 1747, determined that all ransoms made in India should be anulled. In regard to the English troops, both officers and writers belonging to the Company, and to the inhabitants of that nation, the Sieur de Lally is to permit none of them to remain on the coast of Coromandel : he may, if he pleases, permit the inhabitants to go to England, and order them to be conducted in armed vessels to the Island of St. Helena. But as to the officers and writers belonging to the East India Company, as well as soldiers and sailors, he is to order them to be conducted as soon as possible to the Island of Bourbon, where it will be permitted for the soldiers and sailors to work for the inhabitants of that place, according to mutual agreement. Though the sending them to the French islands should be avoided as much as possible, to prevent their being acquainted with the coast, as well as the interior part of the island. It is by no means his Majesty's intention that the English officers, soldiers, and sailors should be ransomed, as none is to be delivered up but by exchange, man for man, according to their different ranks and stations.

"If the exchange of prisoners should be by chance settled at home, between the two nations, of which proper notice will be given to the Sieur de Lally, and that the islands of France and Bourbon should have more prisoners than it would be convenient to provide for ; in that case, it will be permitted to send a certain number to England, in a vessel armed for that purpose.

"No English officers, soldiers, \&c. are to be permitted to remain in a place after it is taken; neither are they to be suffered to retire to any other of their settlements. The Sieur de Lally is not in the least to deviate from the above instructions and regulations, unless there should be a capitulation which stipulates the contrary; in which case the Sieur de Lally is faithfully and honestly to adhere to the capitulation.

"The whole of what has been said before concerns only the natives of England; but as they have in their settlements merchants from all nations, such as Moors, Armenians, Jews, Pattaners, \&c. the Sieur de Lally is ordered to treat them with humanity, and to endeavour, by fair means, to engage them to retire to Pondicherry, or any other of the Company's acquisitions; assuring them at the same time, that * they will be protected, and that the same liberty and privileges which they before possessed among the English will be granted them.

" Among the recruits furnished to complete the regiments of Lorrain and Berry's, 
there are three hundred men from Fisher's recruits, lately raised, and as it is feared there will be considerable desertions among these new recruits, the Sieur de Lally may, if he pleases, leave them on the Isle of France, where they will be safe from desertion, and replace them from the troops of that island.

Remarks on a Memorial of the French East India Company, delivered to the Count D'Acbé, Cbief d'Escadre, and commanding the Squadron destined to the East, towards the latter End of the Year $175^{6 .}$

Article $4^{\text {th }}$ treats in general of dispositions to be made on the arrival of the ships at Mauritius; and observes, that there are two harbours, the one called Port Louis, or North-west, and the other South-east, Harbour. Port Louis is the principal, where the colony chiefly resides, and where the docks, magazines, and other conveniences for shipping are built; but the air of the south-east harbour is esteemed the most healthy, and on that account it is recommended to send all the sick sailors and soldiers on shore there, where it seems houses proper for hospitals are prepared. As soon as the sick shall be sufficiently recovered, it is recommended to let them march over land from the south-east harbour to the north-west, which is about fifty miles* direct across the island; so that apparently there must be a particular road, which indeed is reasonable to conclude, from the residence of many planters on the south-east side.

The south-east harbour has two channels, through either of which ships may easily enter, but the greatest difficulty is getting out : however, the instructions say, that the ship of each division which carries in the sick may easily get out again through the north-east or south-east channel.

It is also observed, that as the north-west harbour of Mauritius is not large enough to contain all the vessels that may arrive there, together with those there before, and as the islands may not be able to furnish fresh provisions for so many people, there will be a necessity for sending out the ships already there, to the island of Madagascar, where the general rendezvous is appointed to be, after leaving the Mauritius.

- There are no more than twenty-five miles between these two harbours, according to the exact observations of the Abbé de la Caille, made in the year 1753. This error proves that the French East India Company did not know at that time $(1756)$ the true extent of the island.

3 L 2 


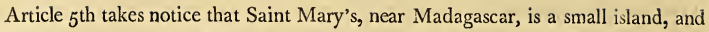
has one harbour, capable of containing seven or eight vessels : the French had sent thither a chief, an officer, and some soldiers, to get the necessary provisions for the sailors and troops.

Article $7^{\text {th }}$ remarks, that it is probable the English squadron may then be at Trinconomale Bay, either as a place of security against the French, or to careen. In either case the commander of the French squadron is instructed to declare to the Dutch, that it is against the rules of a strict neutrality to receive and protect in their port the enemies of France; and that he has orders to pursue and take, or burn the enemy's ships wherever he shall meet them, which order he must obey, in spite of their opposition.

Article 8th points out the places where it is probable the English squadron may take shelter, and advises the taking or burning it in any port of India, though belonging to neutral powers, as Trinconomale, Merguy, Acheen, or any other port, except in China or Bengal; where, they observe, it may not be prudent to commit any violence, lest their commerce suffer for infringing the protection the government may give to English ships.

Article 11 th proposes, that, in case they arrive too late at the islands, to be on the Coromandel coast time enough to undertake any enterprize before the monsoon of 1757 ; to project any other operation which may not interfere with, or delay the operations on the coast of Coromandel early in $175^{8}$. Some ships are particularly recommended to be sent to Bencoolen to take that place, and the other settlements on Sumatra, from whence all the English and slaves are to be carried off to the Island of Bourbon.

Article $13^{\text {th }}$ observes, that there is still in India a better understanding between the Dutch and English, than there is in Europe, to the prejudice of France; and, therefore, little regard ought to be paid to their flag, if any British subjects or effects are found with them.

In another Instruction for Count D'Acbé, sent by D. L'Aguille, on the 8th of December, 1757, it is said,

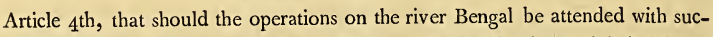
cess, the conquered place may either be kept, or the fortifications, civil buildings, and warehouses utterly destroyed. Should the latter plan be resolved on, not a 
factory ought to remain, nor an English inhabitant (even those born in the country) suffered to reside in the province. This resolution, they observe, is the most effectual means to establish their reputation on the Ganges. But they seem to recommend only the destruction of the new fort, and the preservation of old Calcutta, on condition of a ransom, and the observance of a strict neutrality in Bengal, for the future. This the French seem most desirous of, but insist on ready money for the ransom, and hostages for the performance of agreements, since the English have here publicly declared, they will abide by no treaty of ransom. His most Christian Majesty, in a letter of the $25^{\text {th }}$ of January, 1757 , to Count D'Aché, instructs him not to leave an Englishman in any place that shall be taken, but to send in cartel ships to St. Helena, or suffer to pass to England, all free merchants and inhabitants not in the Company's service : but to keep prisoners all civil servants, officers, and soldiers, and not set any at liberty, unless exchanged against those of equal rank. As to the prisoners, they are all to be sent to the Island of Bourbon, and there kept in deposit, till it may be thought proper to send them to France.

\section{Instructions given by the Directors of the East India Company to the Governor of the Isles of Mauritius and Bourbon, $24 t b$ of May, 1761.}

They first recommend the division of lands into small parcels among such as choose to become planters, and to let them each follow the bent of their genius, whether it be for tilling corn, breeding horses, bullocks, poultry, planting cotton or coffee trees: but for the advantage of refreshments for shipping, and to reduce the price of labour, they particularly recommend the breeding carriage and draught beasts of all kinds.

Their next attention is directed to cutting wood, which it seems was formerly supplied by contractors, who, on account of the easy conveyance, no doubt, cut that nearest the sea-shore. The Company considering this practice as prejudicial to the defence of the Island of Mauritius, whose shore is, in many places, guarded against descents by the woods, positively forbid the cutting any wood there in future, and say, "There are two places which require the most immediate attention; the first is the shore between the north-west bay and the Bay of the Tomb, (Bay du Tombealu), where it would be more preferable to abandon the making of lime, after the ancient custom, than to continue stripping the shore of wood in the neighbourhood of the port, which is defended by it. The second place is the country 
adjacent to the south-east bay, where there is a considerable yard and work-shop for cutting wood; it must be absolutely forbidden (if it is not too late) to strip the sea-shore of its wood in the neighbourhood of that port, that it may not be rendered as defenceless as the north-west harbour. If the evil is begun it must be stopped. M. David has in that place a large carpenter's yard, managed by the Sieur Rottier."

Speaking of barracks in one of the articles, the Company says,

"At any rate, but particularly in that light which we regard the Island of Mauritius, whether it be to make it a receptacle of all the Company's military forces in India, or to lodge the recruits there a year or two, which are destined for the garrisons in India, that they may be disciplined; that their health may be preserved by the shortness of the passage, that they may at first be landed in an wholesome and temperate climate, where they may recover the fatigues of the voyage, and accustom themselves by degrees to the heat, instead of transporting them at once into the burning, and often unhealthy, parts, of India ; or, lastly, with a view of having always at the Mauritius forces which may be sent to India on extraordinary occasions, when succour cannot be expedited from Europe, either through want of time to write for them, or prevention of their departure from France by enemies. It is certain, in all these points of view, equally favourable for the preservation of the settlements in India, and the good management of troops and money, that barracks are absolutely necessary at the Island of Mauritius. Frequent complaints have been made of the irregularities which the soldiers commit when dispersed, and at liberty in different houses: it is therefore impossible to prevent the licentiousness and unlucky accidents which happen, but by barracks. Hitherto we have had but a small garrison at the Island of Mauritius, when it becomes more numerous all the inconvenience attending licentious soldiers are more to be apprehended. It may be added, in favour of a numerous garrison at the Island of Mauritius, that it will be the readiest and cheapest method to people the island, and to form a militia on the spot, interested in its defence. At the end of a certain time, those who are willing to settle on the island may have their discharge, on condition that they shall form a company of militia, which shall assemble from time to time, and march when occasion requires. A good prison or guard-house is not less necessary to hold the Blacks, than barracks for the soldiers, in order to keep the Company's slaves under good management, shutting them up by night, and forming good posts on the sea-shore, and in the interior parts of the island. By means of a numerous garrison it is possible desertion may be 
prevented, and the attempts of the Madagascar Blacks, which are turned freebooters, may be guarded against : these slaves may then be bought without hazard, and all agree they can be had cheaper and better, and are more intelligent and laborious, and sooner trained to all kind of work than those procured elsewhere. The inconvenience of too great a quantity of grain, and a scarcity, has been successively experienced at the Island of Mauritius : to remedy it, instructions have been sent, concerning the manner of preserving corn in Italy and Africa, with the form and dimensions of the pits which are there used. The last works of the Sieur Du Hamel, relative to stores, ventilators, and the construction of granaries, have also been sent out; you must inform yourself whether any of his methods have been tried, and endeavour to introduce those best adapted to the nature of the grain necessary to be kept."

The Company, thinking the good of the service required that an entire jurisdiction over the Blacks should be established, wrote to the Council at the islands to employ such means as were necessary to engage the inhabitants to make detachments against the Blacks; they were promised one hundred and forty livres for every freebooter whom they destroyed; but that recompence not provinga sufficient encouragement, M. Bouvett determined to offer a slave, at the Companys price, for every freebooter killed, which the inhabitants approve and the Company have confirmed.

\section{LETTER XVII.}

From $M$. de Miran to Baron Grant.

Pondicherry, May 10, 1757 .

Contains an account of the loss of Chandernagore, which surrendered to the English by capitulation on the $24^{\text {th }}$ of March, in the same year.

\section{LETTER XVIII.}

\section{From Baron Grant.}

Isle of France, Feb. 16, $175^{8}$.

He announces his departure, which took place in the same month, on board a ship belonging to St. Malo, named the Emerald. 
Baron Grant was unfortunately taken prisoner in this voyage by three English ships, which took hin into Jamaica. On leaving that island for England, he suffered new misfortunes from being shipwrecked, and with great difficulty and danger, and in the greatest distress, reached the island which he had so lately left. At length, however, he arrived in England, where he remained six weeks, when he returned to his estates at Vaux, in Normandy.

\section{Furtber Extracts of the History of India, during the seven Years War.}

The descendants of Tamerlane and the Moguls continued from the time of that great conqueror to govern India, after having been driven from Tartary and Persia. Aurengzebe was the last monarch who inherited the talents of his predecessors; for after his death a general degeneracy followed, and, as it commonly happens in great monarchies, the provinces which were the most remote from the seat of government, became independent of the Mogul. Formerly the governors of these provinces, who are called Nabobs, practised more than a mere nominal subrission to the imperial authority, as such a conduct confirmed their power. One of these subordinate princes, the Nabob, or, as he is by some called, the Subah or Viceroy of Bengal, availed himself of some frivolous pretext, to besiege the English fort of Bengal. The place was bravely defended by Mr. Holwell; but on the 26 th of June, $175^{6}$, it was taken by the Nabob. The immediate consequences of which are too well known to require any description of them in this place. The horrors and sufferings of the Black Hole have been already described by the able pen of Mr. Holwell, who had his portion of them, and from whose works they have been translated into the principal tongues of Europe.

The English arms, however, in India, soon took their revenge, and repaired their losses. Admiral Watson, in the beginning of the year ${ }^{1756}$, attacked and destroyed the residence of Angria, the pirate, who had long been the declared enemy of the English. He then set sail from Madras with no more than three ships of the line, and having touched at the port of Balasore, entered the Ganges; where, by the capture of the fort of Busbudgia, he opened a passage to Calcutta, which he reduced in one day, as will as Huegly, another establishment above the Ganges. The Nabob assembled an army of ten thousand horse and twelve thousand infantry; but on the $5^{\text {th }}$ of February, 1757, they were defeated by an handful of English, and the Nabob was obliged to conclude a treaty of peace, by which the English East India 
Company was established in all its possessions and privileges, as well as an indemnification for every thing it had lost by the capture of Calcutta. As it was not supposed that this accommodation of the Nabob would last longer than it should suit his interests; and that he would break it as soon as he had concerted measures with the French for that purpose; the Admirals Watson and Pocock, with Colonel Clive, who commanded the land forces, attacked Chandernagore, the principal establishment of the French in this country, situated on the river, a little above Calcutta, which at length capitulated to their arms, on the $24^{\text {th }}$ of March. Five hundred Europeans and seven hundred Blacks surrendered prisoners of war, with an hundred and eighty-three pieces of cannon, a considerable sum of money, and a large quantity of merchandize. The ferocious manners of the Nabob had even disgusted his own subjects; and as success is the only title of these chiefs to their possessions, Jaffier Aly Cawn, at that time one of the principal officers of his army, and among those who pretended to have a legal claim to the rank of Nabob, put himself at the head of a confederation against him, and demanded succour from the English.

Without examining the rights of the rival Nabobs, it is sufficient for us to mention, that the English agreed to assist Jaffier, with whom they entered into a treaty: Colonel Clive accordingly opened the campaign in his favour, while the Admiral, in order to augment the land forces as much as possible, undertook to supply a garrison for Chandernagore, and sent him also fifty sailors to act as cannoneers : while a vessel of twenty guns was placed above Huegly, to preserve a communication between the land and sea forces. In the mean time the Surajah assembled an army of twenty thousand men, which was attacked by Colonel Clive on the $22 \mathrm{~d}$ of June, and entirely defeated. This event encouraged Jaffier Aly Cawn, who had remained inactive in the last battle, to make an open declaration of his pretensions to the character of Nabob; and, on the 26 th of the same month, the English and his party marched to Maxadavad, the capital of Bengal, where Colonel Clive placed him on the throne of the Nabobs, and he received, in the character of Subahdar, the distinct homage of Bengal, Bachar, and Orixa. As to the Surajah Dowla, his rival, when abandoned by his officers, he fled from the field of battle, and, being made prisoner, was put to death, as may be naturally supposed, by order of the conqueror.

Thus the English; in thirteen days, gave a master to one of the richest, most extensive, as well as most populous kingdoms of the world. The new Nabob thought 
that he could not give too ample marks of his gratitude to his friends, the English, he therefore concluded a perpetual alliance offensive and defensive with them. He augmented the limits of the Company's territory in India, and enlarged their privileges: he distributed six hundred thousand rupees to the soldiers and sailors, and at the same time indemnified the Company for the losses which they had sustained, by a payment of two millions sterling. Soon after these events Admiral Watson died, from the unwholesomeness of the climate. The French, in order to repair so many losses, equipped a new armament, under the command of M. D'Aché, officer of marine, and M. de Lally, who commanded the French land forces, which consisted of two thousand European troops. It appears to have been the opinion of the French, that this force would have been sufficient to have re-established their affairs, but they were mistaken; for though they took the fort and town of St. David, Admiral Pocock, who commanded the English squadron there, defeated them in two engagements, and cut off all communication between their army and ships. The truth is, that the French were not only discouraged and disunited, by their repeated disasters, but also wanted both provisions and money, as well as all military stores necessary for their operations.

As to the land forces, under the orders of M. Lally, their conduct was irregular to the last dègree. Not having money sufficient, as we have already observed, to continue his operations, he requested a loan from an Indian potentate, called the King of Tanjour, and his demand being rejected, he besieged the capital of that prince, but without success. He then endeavoured to repair this disaster by seizing a Dutch ship, where he found a sufficient quantity of money to enable him to undertake the siege of Madras, or Fort St. George. The place was defended by Colonel Draper and Major Brereton, and M. Lally was obliged to raise the siege, after having employed two months in that vain enterprize. The remonstrances which he sent into France, on that occasion, describe the horror and distraction of his mind, and the kind of intelligence that prevailed between him and those he commanded; while the English not only gained every advantage over him, but also reduced the rich town of Surat, on the western side of the Peninsula of India. On the 16 th of April, 1759 , the English army began the campaign, under the command of Major Brereton, who made himself master of the important town and fortress of Congeveram; and at the same time Major Ford took by assault the town of Masulipatam : thus a border of eight hundred miles in length, along a trading 
country, filled with manufactures, fell into the hands of the English; while the French commerce was confined to Pondicherry, and some places in that neighbourhood. The conquered country reached to the province of Bengal, from whence the French were entirely driven by Colonel Clive. These successes were in a small degree balanced by a failure of Major Brereton in endeavouring to dislodge $\mathbf{M}$. Lally and his confederates from a very strong post that they occupied. This check, which happened in September, 1759, cost the English between three and four hundred men, killed and wounded, and encouraged M. Lally to make preparations for the siege of Trichinopoly; but Colonel Coote, on the 3 oth of November following, took Wandewash, one of the most important forts of that coast, and made the garrison prisoners of war. Ten days after, he possessed himself of Cosangoly, which the garrison were obliged to evacuate. These successes determined M. Lally to risk a decisive engagement, in order to retake Wandewash, which he besieged with two thousand Europeans and nine or ten thousand native soldiers. Colonel Coote arrived there most fortunately with his army, consisting of about seventeen hundred European, and three thousand Black troops, at the moment when M. Lally was about to enter by a breach he had made in the place. A battle immediately ensued, in which the French were put to the rout, with the loss of a thousand men left on the field of battle: several of the principal officers were also killed, wounded, or taken prisoners, and M. Lally retired to Pondicherry with the remains of his army. The loss of the English was about two hundred, and unfortunately Major Brereton was of the number. Colonel Coote did not delay a moment in pursuing the advantages he had acquired, and marched directly against Chitiput, which he took: he then laid siege to Arcot on the 8th of February, which is the capital of a large province of the same name: This place surrendered to him on the 10 th, and he made three hundred Europeans prisoners of war.

The operations by sea in India were pursued with equal vigour, and crowned with equal success. On the $4^{\text {th }}$ of September, 1759, an engagement took place between M. D'Aché and Admiral Pocock; when the French commander was obliged to retire. The English Admiral then directed his course to Pondicherry, and was joined there by Admiral Cornish. On the 6th of April following the fortress Karical, as well as several other places of less importance, surrendered to the English; so that the far greater part of the French forces in India was shut up in Pondicherry. 
At length it was determined to lay siege to that place; and its garrison consisted of fifteen hundred Europeans, when it was invested by Colonel Coote on the land side, and Admiral Stevens by sea. It was surrounded by several forts, which had occasioned great difficulty in former sieges, but were now easily taken, as the adjacent country was in the hands of the English. The rainy season approaching, and the known bravery of $\mathrm{M}$. Lally rendered a regular siege impracticable; it was determined therefore to block the place by sea and land. This blockade was supported by certain batteries, which were very advantageously placed, and, while they continually harassed the garrison, were insensibly extended towards the town, notwithstanding the rains had commenced.

These operations̀ continued during seven months, the batteries being alternately destroyed and repaired : but amidst all these difficulties the English were encouraged by the distress of the garrison and inhabitants, who were reduced to feed on dogs, cats, elephants, and camels.

The French, in this situation, indulged the hope of relief from their fleet, and a violent storm on the 1 st of June, ${ }_{17} 6_{1}$, cherished their expectations, as it destroyed four English ships of the line, and obliged the others to quit the blockade. The hopes, however, that had been indulged by the French garrrison, and their brave commander, were of very short duration; for, in four days after the storm, and before any relief could have been administered to the town, Admiral Stevens re-appeared and renewed the blockade with eleven ships of the line and a frigate; at the same time a battery was erected within four hundred and fifty yards of the ramparts.

The garrison was now reduced to three days provision; but this miserable situation made no impression on the mind of General Lally: he persisted in holding out, and pretended that as the English had failed in their engagements to him, it was impossible for him to enter into a treaty with them. At length, however, a signal for a cessation of arms being made, the principal of the Jesuits, with two lawyers, but without any apparent authority from the governor, were sent to treat with the English, and after some previous and necessary arrangements, the latter took possession of the place. Soon after, the settlement at Mahé, on the coast of Malabar was reduced; so that the whole commerce of the vast Peninsula of India fell into the hands of the English.

We shall now proceed, before we finish the history of this war, to give an 
account of the internal revolution in that country, which threatened to deprive the English of the fruits of their astonishing successes.

The most ancient branch of the family of Tamerlane being extinct, another which, had been driven from Bucharie into Persia, passed at length into India, where the veneration of the inhabitants for a descendant of Timur-beg, or Tamerlane, was so great, that he ascended the throne of his ancestors, under the name of the Great Mogul, or great conqueror; and for a considerable period, both he and his posterity were entirely surrounded with Mogul guards, and established a most absolute despotism over his Indian subjects. Though no difficulties were thrown in the way of their succession, the emperors, nevertheless, who had reigned since Aurengzebe, have always thought it necessary to represent themselves as the descendants of Timur-beg.

At the time which is the object of our present consideration, the Mahrattas formed the military force of India, and having deposed the last Great Mogul, his son, Sha Zaddah, assumed that title; though his authority was disputed by several provinces: but being assisted by Mr. Law, who was nephew of the person so well known for the Mississippi scheme, with about two hundred fugitive French, he made considerable progress in confirming his title. At length Law persuaded him to put himself at the head of eighty thousand men, and to march against the English in Bengal. They were met by twenty thousand native troops and five hundred English, under the command of General Carnac, who entirely defeated them, and made the young Mogul and Mr. Law both prisoners, on the same day that Pondicherry surrendered.

Fortune was equally favourable to the English in other parts of India. Jaffier Aly Cawn, who had been raised, as we have already mentioned, to the rank of Nabob of Bengal, became intoxicated with his power, which deprived him of the protection of the English, who compelled him to resign his government in favour of his sonin-law. The new Nabob confirmed and even increased the privileges of the English in Bengal ; so that the Dutch became jealous of their power, and made a fruitless attempt to drive the English from that country.

During these events in India, Count D'Estaing, a French marine officer, with only two frigates, surpassed all his countrymen who were employed in the naval service in any other part of the globe. In October, 1759, he destroyed the English 
settlement of Benderabassy, in the Persian Gulf; he afterwards reduced Bencoolen, in the Island of Sumatra, where the English carried on a considerable trade, and destroyed all their forts and establishments. This enterprising seaman at last fell into the hands of the English : he was afterwards employed by the government of his country in various and important services. 


\section{GHAPTER XXV.}

Summary of the Life of Count de Lally.- Fournal of bis Expeditions in India.Report of the Conquest of Pondicherry.-An Account of the Condemination of M. Lally.

$T_{\text {H E }}$ Count de Lally was the son of a captain in the regiment of Dillon, who passed into France after the capitulation of Limerick, and a French lady of distinc. tion. Soon after his birth, which was in 1699 , he was entered, as was the custom in the French army, a private soldier in his company. He made very considerable progress in those sciences which formed a principal part of the education of the French nobility. Being the son of an officer of distinguished merit, it was natural for him to make military acquaintance; and being, by his mother's side, allied to some of the first families of France, he had more favourable opportunities than the generality of his companions, to form connections of the first class. These advantages, superadded to a fine person, advanced young Lally, at the age of nineteen years, to a company in the Irish brigade.

Though he was known to possess those qualities that form the soldier, he was equally qualified to succeed in civil employments; for at a period when young men are seldom more than equal to the inferior departments of the state, he was suddenly elevated to one of the most important situations that belong to political government. At the age of twenty-five he was sent by the court of France to negotiate some important affairs at the court of Russia, where his address and fidelity secured to him the confidence of the King his master, and won the esteem of the Czarina. On his return to France he was considered as one of the most distinguished men at Versailles, and was soon promoted to the rank of colonel of a regiment, in which he conducted himself with uncommon distinction wherever he was employed.

In the year 1745, when the young Pretender made a descent in Scotland, M. Lally came into England, under the pretext of claiming some lands which his father had possessed in Ireland, and to which he pretended to have a legal title: though, in fact, the real object of his errand was to serve the cause of the Pretender as a 
spy; to assist him with his counsels, and to excite malcontents in the southern parts of Great Britain, by promises of money and other inducements. It is even said that he had some success in these dangerous attempts, when his plans were discovered to the Duke of Cumberland, who gave immediate orders for his arrest: but M. Lally was, by the kind interposition of the Prince of Wales, preserved from a prison, and permitted to return to France, in direct opposition to the sentiments of the Duke.

Such, however, was the obstinacy of M. de Lally, that he quitted England with great reluctance, though, as the expedition of the Pretender entirely failed, he had every reason to be thankful to providence for his escape. From that time till he was promoted to the rank of lieutenant-general and commander in chief in the East Indies, his life does not offer any circumstance that merits particular attention. As to his history in that part of the world, to the period of his death, we shall refer our readers to the following papers.

Fournal of Expeditions in India, under the Command of Count Lally.

In the month of August, ${ }^{1756}$, Count de Lally was appointed to the command of an expedition in India, to support which the court had destined six millions of livres, six battalions of troops, and three ships of war, which were to be joined by such as the Company could prepare for the occasion.

The Chevalier des Soupirs, who was to command as major-general under him, set sail from L'Orient on the 3 oth of December following, with two millions of livres and two battalions.

On the 20th of February, 1757, the Count D'Aché set sail from Brest, with Count Lally, having two millions of livres, and two battalions, on board his squadron; but an accident which happened to one of their ships, in going out of the port, obliged him to return, and contrary winds detained him till the $2 \mathrm{~d}$ of May.

The Count D'Aché was near a year on his passage, a circumstance which gave Admiral Stevens sufficient time to reach the coast of Coromandel; though he did not leave England till three months after the French squadron set sail from France. The Chevalier des Soupirs waited some time at Mauritius, and disembarked at Pondicherry eight months before Count Lally arrived there. At this time the English could not bring a hundred men into the field, and he had two thousand. Madras was an open town, Fort St. David was in ruins, with a garrison of sixty invalids. Three weeks 
would have been sufficient to have taken both these places, but the Chevalier des Soupirs, who was entirely ignorant of the manner of carrying on war in that country, suffered himself to be influenced by $\mathrm{M}$. de Leyrit, the Company's governor of Pondicherry, who kept him all this time in a state of inactivity, and at the expense of all the money which he had brought from Europe.

Six months previous to his arrival in India the English had driven the Company from all its settlements in Bengal, which were the most valuable of their possessions.

On the $25^{\text {th }}$ of April, $175^{8}$, the Count D'Aché landed the Count de Lally af Pondicherry, with some of his principal officers, and several chests of money. On the following day, as he was preparing to cast anchor in the road of that place, he was surprised by the English squadron, and lost a vessel of 74 guns; but, availing himself of a favourable wind, he contrived to escape.

Within a few hours after he had disembarked, Count de Lally invested Cudalore, a place situated about five leagues from Pondicherry, and made himself master of it in three days : the garrison consisted of ten invalids. In a short time after he besieged Fort St. David, and entered into that place on the $2 \mathrm{~d}$ of June, after seventeen days of open trenches. On the 10th of the same month the Count returned to Pondicherry ; and, having determined to make an attack on Madras, he dispatched a vessel to Count D'A ché, who had retreated sixty leagues to the windward, with orders to return- M. de Leyrit at this time signified to Count de Lally, that he was not in a condition to subsist his troops for more than fifteen days, and that there was no other resource but to march them into the kingdom of Tanjore, which was about fifty leagues to the south of Pondicherry, to claim a debt due from the Rajah of that country. Thus he was obliged to seek for subsistence in Tanjore till the stormy season approached, which would oblige the two squadrons to take refuge in some distant ports.

The Rajah of Tanjore having refused the debt demanded of him, Count Lally marched towards his capital; and, in order to intimidate him, levelled five pieces of cannon against that place.

At this time he received an account that the English were marching, with a body of eight hundred men, against Pondicherry, and that the Chevalier des Soupirs, who had not an equal force, was preparing to abandon the surrounding country: he accordingly evacuated Tanjore, after having levied four hundred and forty thousand livres in money, and lived, during two months, at the expense of the inhabitants. 
On his approach to Pondicherry the English retired towards Madras. He now renewed his entreaties to Count D'Aché not to quit the coast; and, in order to induce him to remain there, made' him an offer of half his army to recruit his squadron; but the latter, deaf to his entreaties and arguments, set sail for Madagascar on the 1st of September, which was the day after M. de Lally's return to Pondicherry.

He had sent also for M. M. de Bussy and Moracin, with the troops that they commanded; the one in the Decan, and the other at Masulipatnam. These officers brought with them but one-third of their forces, and on their arrival demanded a reinforcement of a thousand men, \&c. But M. de Lally having received information that the English had made a descent in the neighbourhood of Masulipatnam, ordered M. Moracin to return thither, which he refused; and that place was afterwards surprised by the English.

M. de Lally, having remained at Arcot for five days, returned to Pondicherry, having refused the incredible offer of.M. de Bussy, to give him four hundred thousand livres in three hours, if he would let him return with a body of troops into the Decan. The army was at this time without pay, though M. de Bussy had informed M. de Lally that he had two hundred and forty thousand livres at the service of the Company, if he would be responsible for them, which he absolutely refused,-as he would have no commercial concern whatever with that body. M. de Lally, on his return to Pondicherry, renewed his design of attacking Madras during the absence of the English squadron; it was, however, opposed by M. de Leyrit, for want of funds to pay the army, and procure them subsistence: the other members of the council were of the same opinion; but four or five of them, with Count D'Estaing at their head, offered their plate, to the value of eighty thousand livres, as a contribution towards the enterprize. M. Bussy did not offer a single sol, and M. de Lally gave one hundred and forty thousand livres, which he had placed in the treasury.

In consequence of these aids he arrived in the plain of Madras on the 12th of December, $175^{8}$, and, after a few skirmishes, encamped there on the following day.

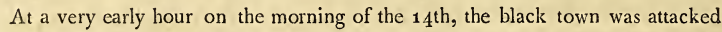
by $M$. de Rillon, at the head of his regiment : and, in a very few hours, he made himself master of it, with little loss.

M. de Lequille, who commanded a squadron, had in the mean time arrived at 
the Island of Mauritius with four ships of war, and three millions of livres, destined for the service of Pondicherry; and he was about to quit that island when, unfortunately, the Count D'Aché arrived there, and prevented him from proceeding. He also took upon himself to send to Pondicherry no more than one million of the money, by a small frigate, which anchored before that place on the 21 st of December, $175^{8}$.

On the arrival of this money Count Lally determined to besiege Madras in form. He paid both his European and black troops a portion of what was due to them, and opened the trenches on the 6th of January, 1759. He attacked the town with two thousand seven hundred Europeans, but the black troops were of little use in a siege. The garrison consisted of five thousand men, sixteen hundred of which were regular troops, four hundred servants of the English Company, and three thousand Sepoys. The English army, that was in possession of the country, made four different attempts to raise the siege, but was as often repulsed with loss. Count de Lally had already made a breach, and was preparing an assault, when six English vessels, laden with all kinds of refreshments, and six hundred men of Colonel Draper's regiment, came to an anchor in the road, and determined Lally to retreat to Arcot.

Six weeks after the siege of Madras had been raised the English received another reinforcement of six hundred men from Europe, and immediately took the field against the Chevalier des Soupirs, who abandoned to them the post of Conjeveram, and all the conquests that had been made on the left bank of the Paliar.

After an absence of thirteen months the Count D'Aché at length arrived at Pondicherry on the 17 th of September, 1759 , having had a third engagement with the English fleet, in which, as usual, he had been worsted. On that very day he wrote to M. de Lally, with an offer of four hundred thousand livres in piastres, and about as much more in diamonds, the produce of an English vessel which he had taken, in part of payment of the two millions he had stopped the year before at Mauritits, one of which would have secured the conquest of Madras. $\mathrm{He}$ also notified that he should set sail the following day for Madagascar. This unexpected message threw the whole colony into the greatest consternation. M. de Lally was so ill as not to be able to quit his house, but he sent a deputation of all his principal officers to engage him to suspend the execution of his design : nothing however that was said or done could avert his purpose. M. de Lally therefore assembled the council, who unanimously signed a protest against the sudden departure of 
Count D'Aché, rendering him alone responsible for the loss of Pondicherry, and threatening to appeal to the justice of the king against his conduct. This protest was unanimously signed in the hall of the council in Fort Lewis, in Pondicherry, the 17 th September, 1759 , as follows: Lally, Duval de Leyrit, Renaut, Barthelemy, Chevalier des Soupirs, Nichel Lally, Bussi, Du Bois, Cariere, Verdieres, Duré, Gaddeville, Du Passage, Beausset, Renaut, De la Selle, Guillart, Porcher, Pêre Dominique, capucin pretre de la paroisse de Nôtre Dame des Anges, F. S. Lavacer, superieur general des Jesuites Français dans les Indes, L. Rathon, superieur general des missions étrangères, Potier de Lorme, Duchatel, Audouart, Aimar, Combaut d'Autheuil, Goupil, Keisses, J. C. Bon, De Wilst, Banal, Rauly, Termelier, Saint Paul, J. B. Launay, Deshayes, Fischer, Du Laurent, Audoyer du Petit Val, D’Arcy, Medin, Dioré, Bertrand, Legris, Miran, Bourville, F. Nicolas, Du Plan, De Laval, Borée, De L'Arche, Boyelleau et Guellette.

M. D'Aché had already set sail, but the winds and currents, having driven him to the north, the protest overtook him at sea; in consequence of which he returned to Pondicherry, where he remained seven days, and once more departed for $\mathrm{Ma}$ dagascar ; promising, however, to return at a very early period of the following year; but from that time, which comprehends a space of sixteen months, nothing more was heard of him.

M. de Lally, who had now recovered his health and strength, daily expected the arrival of Bassuletzingue, brother of Salubetzingue, sovereign of the whole country, with a body of twelve thousand men. This prince was not more than thirty-five leagues from the French army when he demanded an officer of distinction, and a detachment of European troops, to facilitate their junction, and M. de Bussy was accordingly sent on that service. The army was now assembled under the walls of Arcot, from whence the Indian batallion was detached, as it began to foment a second revolt, on account of the pay due to the soldiers, from the not being able to dispose of the diamonds. The absence of $\mathrm{M}$. de Bussy, which did not require more than ten or twelve days, continued for two-and-forty; and the English, availing themselves of the impracticability of the French to begin the campaign without cavalry, made themselves masters of Wandewash.

Being disappointed of the arrival of Bassuletzingue, M. de Lally concluded, as soon as possible, in concert with M. de Leyrit, a treaty with a Mahratta chief, for a body of two thousand cavalry; which, joined to another of eighteen hundred 
blacks, belonging to M. de Bussy, and bearing his name, he encamped opposite the English, from whom he was separated only by the sandy bed of the Poliar, which was then entirely dry. Having got possession of some magazines which were in rear of the English, the latter were prevented from keeping the field for some days. The French, therefore, fell suddenly on Wandewash; but, on the appearance of the English to relieve it, M. de Lally found himself obliged to retreat to Pondicherry, or to hazard a battle, and he determined on the latter: he accordingly attacked them, but was repulsed and beaten, on the $22 \mathrm{~d}$ of January, ${ }_{1760}$. The loss was nearly equal on both sides, and the only officer of rank who was taken prisoner was M. de Bussy. M. de Lally, who was now reduced to the necessity of defending, as long as possible, the passage to Pondicherry, encamped with his army about four leagues from that place, on the road which the English must take in their approaches to attack it.

Admiral Cornish appeared on the coast with four ships of the line from Europe, in about a month after this battle: on the 28 th of February he came to an anchor in the road of Madras; and, on the 17 th of March he appeared with his squadron before Pondicherry. In the mean time the English army gradually approached nearer to that place, while M. de Lally, in order, at the same time, to protect it from the attack of the fleet, and obstruct the march of the army, necessarily retired from one position to another, till at length he occupied an advantageous post on the march of the English, and about the distance of two leagues from the town.

While the English army was occupied in possessing itself of the small French posts to the north of Pondicherry, the squadron of Admiral Cornish attacked Karical on the south, which was defended by the same officer, in the Company's service, who had given up Chandernagore, after a very short bombardment. He soon surrendered the place, which wanted nothing, and was the only European fortification which the French Company possessed in India. In a short time after this operation the English took Valdore. At the same time M. de Lally maintained his post during three months, and thereby gained time sufficient to victual Pondicherry for half a year.

While M. de Lally held the English in check, he concluded a treaty with the chief of Mysore. The object of this treaty was to supply Pondicherry with provisions; but he did not fulfil the conditions of it, and accordingly gave up the fort of Thiagar, which was the stipulated price. In a few days after the departure of the Mysore people, M. de Lally determined to strike a great stroke, by attacking the 
English on the night of the $2 \mathrm{~d}$ of September. This enterprize accordingly took place, and failed. At length, after a siege of two months, and a very gallant defence by $\mathrm{M}$. de Lally, Pondicherry surrendered to the English army, commanded by General Coote, on the 16 th of January, 1761 . M. de Lally requested to be sent to Cundalore, where he might have the advantage of being attended by French and English surgeons; but the Governor of Madras insisted on his being removed from that place, and sent his own palanquin to convey him thither.*

The English batteries were not opened but a few weeks before the reduction, and though they were served with great skill, and were employed with extraordinary effect, the want of every necessary of life within the town was the most important circumstance in favour of the besiegers. The inhabitants had for some time subsisted on elephants, camels, and horses. It is well known that a dog had been sold for twenty-four rupees; and of this wretched provision they had not more than would have sustained them for one day; when the place surrendered.

\section{Extract from the Report of the Condemnation and Execution of the Count de Lally.}

In consequence of the very weighty conclusions which the Procureur General had given against the Count de Lally, he was removed, during the night of Sunday, the $4^{\text {th }}$ of May, from the Bastille to the prison of the Conciergerie, which communicates by several staircases with the different apartments belonging to the Court of Parliament. Though it was but one o'clock in the morning when he arrived at the Conciergerie, he refused to go to bed; and about seven he appeared before his judges. They ordered him to be divested of his red riband and cross, to which he submitted with the most perfect indifference; and he was then placed on the stool

\section{* Extract of a Letter, dated Fort St. George, Feb. I, 1761.}

“ M. de Lally is arrived here; and, notwithstanding his melancholy condition, is as proud and haughty as ever. Genius, understanding, and military knowledge, obscured by very ferocious manners, and a perfect contempt for any one beneath the rank of a General, characterise this extraordinary man. When he quitted the citadel of Pondicherry, the officers and soldiers treated him with the most marked disapprobation and insult: while his Commissary, who attempted his justification, was instantly murdered; and the same fate would have awaited M. de Lally, if he had not retreated to the English camp. To have maintained, therefore, so long a siege amid the detestation of those whom he commanded, is a decided proof of his firmness, activity, and bravery." 
to undergo a course of interrogation. At this moment, clasping his hands and lifting up his eyes, he exclaimed, "Is this the reward for forty years faithful service?" The interrogatory lasted six hours. At three in the afternoon it recommenced, and the Marquis de Bussy and Count D'Aché were successively confronted with him. They remained but a short time in the Court, and were reconducted by officers of justice. The sitting lasted till nine at night, when the Count was taken back to the Bastille, surrounded by guards, and several companies of the city watch.

The following day, at six in the morning, the judges began to give their opinions, and they were not concluded till four in the afternoon, when they pronounced an arret, which contained only a simple recital of the proceedings against him, and other persons accused of abuses and crimes in the East Indies, with their acquittal or condemnation, but without specifying the facts or reasons on which they were respectively founded. The sentence stated, that he had been accused and convicted of having betrayed the interests of the King and the India Company; of abusing his authority, and of exactions, \&c. from the subjects of his Majesty, as well as the foreigners resident in Pondicherry; for the reparation of which, and other crimes, it was declared that he should be deprived of all his titles, honours, and dignities, and have his head separated from his body on a scaffold on the Place de Grève. His goods and property were also confiscated to the King, \&c. \&rc. and the arm of the public executioner terminated the career of the Count de Lally. 


\section{CHAPTER XXVI.}

Observations of Admiral Kempenfelt and $M$. de Rocbon on the Isle of France, in $175^{8}$.

Ir was not till the year 1730 that the value of this island was known to the French, and that it became an object of importance. Five years before, this colony had been so neglected that not a single French vessel ever touched at it: but ships, engineers, and workmen were now sent to assist the inhabitants, and to forward the designs that the India Company had formed. With this view, great encouragement had also been given to the inhabitants of the Isle of Bourbon, to engage them to remove to the Isle of France. M. de la Bourdonnais was sent from France as Governor of the two islands. He was a person in every respect qualified to fulfil the duties of that station. It is indeed to his talents, indefatigable industry, and enterprizing spirit, that the French India Company owes all the advantages it obtained from one of the most flourishing colonies and best harbours in India. The inhabitants which he found there had, till his arrival, lived in huts; they were ignorant, obstinate, and inured to idleness: those who came from the Island of Bourbon had been so long neglected by the Company, that they had thrown off all idea of dependance, and possessed those bad qualities that naturally result from such a situation. It required therefore great judgment and uncommon address in M. de la Bourdonnais to surmount these difficulties, by reducing these people to discipline and obedience, and introducing among them a spirit of industry, so necessary to the accomplishment of his designs. These rude people, debased by their indolent course of life, and banished, as it were, from their native country, murmured aloud when he ordered them to work, to cut down the wood, to cultivate the earth, to dig in the quarries, to saw planks, and to build houses. Nevertheless, the inhabitants increased, and though they had every reason to fear that they should be in want of subsistence, it was not without some difficulty that $\mathrm{M}$. de la Bourdonnais could engage them to dig the ground, and plant the manioc or the cassada root, to prevent that disaster; as many of the slaves whom they had brought from Madagascar were actually starved. 
The manioc is a root which grows on the banks of rivulets," and bears in the East Indies a large green leaf; it forms a very nutritious food for the slaves, but in a green state it is absolutely poison, and must be dried before it can be made into wholesome bread. M. de la Bourdonnais brought this root from Brazil, $\uparrow$ and obliged every planter, or inhabitant that possessed land, to cultivate five thousand square feet of manioc for every slave; but they were, unfortunately, so habituated to idleness, and so disgusted with his authority, that they did every thing in their power to discredit this root, and oftentimes during the night poured boiling water upon the plants, to check their vegetation. At length, however, for what will not perseverance, talent, and amiable manners accomplish, they were convinced of its utility, and it is this root which now nourishes all the slaves in the island, where they are very numerous, and perform the severest labours.

The Isle of France having never been cultivated, it was very difficult, in the beginning, to till the ground, so as to furnish a sufficient quantity of provisions for the support of its people, and to victual the ships which touched there. Nevertheless, M. de la Bourdonnais attained these important objects in granting to the inhabitants a certain quantity of ground, which had not been cleared, and a proportionable number of slaves at the Company's expense; so that they were enabled to cut down the woods, to cultivate the ground, and to build houses, mills, \&c. These various improvements, however, proceeded with a tardy pace; and, from a want of industry, or rather from a spirit of discontent in the people, it was some time before any sensible change took place in the face of the island.

M. de la Bourdonnais was the only person acquainted with the theory and practice of architecture; and having but very few workmen, he not only put a certain number of young people under their direction, but became himself their instructor; and as they advanced in this useful and necessary science, he put slaves under them, in the character of apprentices: but it is not to be conceived what trouble he had to compel the one to teach, and the other to learn: impeded, however, as he was with these and other difficulties, he contrived that wood should be cut, that stones should be dug and shaped; that houses should be built, that roads should be made, and that conveyances by water and wheel carriages should be

- This officer seems to confound the manioc with the yam of St. Helena, as the former grows in a dry soil, and the latter requires a moist situation.

† Others say from St. Jago. 
produced. He also imported horses, and taught oxen to submit to the yoke; he built a very convenient house for himself and his successors, magazines for the Company, an hospital of two stories, which contained five hundred beds, for the sick, and four windmills, with commodious granaries and quays. To these may be added an arsenal, batteries, barracks, shops for the different workmen employed in the canals, acqueducts, and a dockyard. In short, every thing is now seen in that island, which is calculated for the convenience and pleasure of the inhabitants.

The town and port on the north-west side of the island, which is the residence of the Governor and his Council, is situated in a valley surrounded with high mountains, and contains about five hundred houses. They are built of wood, which was in great plenty, as both the Islands of France and Bourbon were originally covered with it. These habitations are in general small, and have only one story with garrets; they are nevertheless disposed with great convenience: their foundation consists of rough stone and lime, about three feet above the surface of the earth, and serves as a platform for the upper part of the house; thus these dwellings are always dry, and as the wood never touches the ground, it is free from those inconveniences to which buildings are subject that are constructed with similar materials.

Wood, however, is now becoming rare, though there is still abundance of it, but as all the environs of the towns, villages, and plantations are in a state of culture, the forests may be said to have been removed to such a distance, that it would require great expense and immense labour to bring the timber from thence, and in many places it is altogether impracticable. The inhabitants, therefore, are already beginning to build with stone, which is in great plenty throughout the island; though it is very dear, as it requires a great number of slaves to dig, carry, and shape it; besides, as there are no European masons, except those who belong exclusively to the Company, who, being free men, demand from one to three dollars a day, stone buildings are very expensive.

The town is irregular, as it was originally begun without any settled plan, and every one was permitted to build according to the suggestions of his own fancy. The quays are very commodious, both for the loading and unloading of small vessels. The soft water, which comes from a river about a league from the town, is conducted thither by a canal to the foot of a high mountain, at the western extremity of the place, where the boats come under a large reservoir, and fill their barrels with the greatest facility. 
Towards the middle of the town, there is a large space surrounded with a strong high stone wall, which contains the buildings appropriated to the slaves of the Company, as well as the public stables, \&c. The inhabitants are not permitted to encroach upon this spot, as it is reserved by the Company for their future occasions.

The valley, in which the town is situated, is low and flat, covered with rocks and stones, which renders the streets and ways rough and uneven; but immediately round the buildings belonging to the Company, the ground is rendered very level. At the extremity of the valley, and at the foot of the mountains there is a considerable space of ground cleared of the stones, and covered with a grass plat: it is called the Field of Mars, as it is the place where the troops perform their exercise: it also contains a rope walk, and is the public promenade of the inhabitants.

The port is not large, and it has been rendered less by two ships which sunk almost in the middle of it.* It is, however, still sufficient for the purposes of the Company. The entrance of it is narrow, and defended by two batteries on two low points of land, almost opposite each other: they were begun after the fleet, commanded by Admiral Boscawen, had appeared off the island, and have proved very expensive works to the Company, though they are not finished. M. Cossini, who was the engineer there, from the nature of the ground, met with infinite diffculties in forming a solid foundation. The ships are moored at two guns shot from the quay, and the smaller vessels close to them. There are several pontoons for the purpose of careening the vessels, and the workshops of the carpenters, rope makers, armourers, coopers, shipwrights, \&c. are so near the port, that the artificers may be hailed from the ships.

In the harbour there are two rocks, or islets, on which are erected two stone windmills : there is also a small bason, or natural pond of salt water, where the turtles are kept which are brought from the Island of Rodriguez, about ninety leagues east south-east.

M. de la Bourdonnais had formed the design of a regular fortification on the most elevated part of the town, that is very well calculated for the purpose to which it would have been applied; but it was not completed. This spot is near the hospital, and commands the town, the high road, and a large and commodious bason, or small

* The carcasses of thirty-four vessels have been numbered, which have at different times foundered in this port and its environs. (See pages 11 and 12.) 
harbour, that communicates with the other, where inferior vessels might remain in perfect security ; and if it were not for a small chain of coral rocks, that appear above the water in the middle of it, and which M. de la Bourdonnais had determined to extirpate, it would have sufficient depth for vessels of the greatest burthen.

The lime employed in building is made of white coral, which is in great abundance throughout the whole circumference of the island, and is of an excellent quality, after the stone has been washed in fresh water to discharge the saline matter, with which it is naturally and strongly impregnated.

Among the many other improvements that M. de la Bourdonnais had made in this island, there is a machine of his invention, by means of which the chaloupes and long-boats are lifted out of the water, and put in a situation to be speedily repaired, with very little trouble and expense. A vessel of an hundred tons, having become very leaky and incapable of service, at a moment when there was a great want of vessels, was brought to this machine, where her leaks were stopped, her bottom cleaned and repaired, and she herself set afloat in the space of an hour.

There are several kinds of wood in this island, but from their great distance, and the rocks, mountains, and rivers that intervene, it is almost impossible to bring them to the inhabited parts. Ebony is very common, as well as many other kinds, which are extremely hard; one, in particular, is of a reddish colour, and of a very close grain, which is called nattes, and is the timber commonly employed in buildings. I have seen some of the trees from forty to fifty feet long. This wood, however, is in general too heavy to be employed in the construction of ships, as M. de la Bourdonnais experienced when he built a ship in this port, called l'Insulaire; though some vessels have since been built, and employed between these two Islands and Madagascar, Pondicherry, \&c.

About two or three miles to the west of the town, there is a considerable river, called La Grand Rivière, from whence the town and harbour are supplied with fresh water; and at the mouth of it a powder mill is at this time erecting. It would be very easy for an enemy to land at this place, as well as in others in different parts of the island. There are, indeed, some batteries with heavy cannon, and small magazines for ammunition near the shore, which, being almost covered with brushwood, are not perceptible by an enemy; nevertheless, from their great extent, and distance from the harbour, they would require a large body of troops to defend them. There is guard-house on the summit of an high, steep mountain, at the 
western extremity of the town, where a flag is hoisted when a vessel is discovered in the offing. There is another upon a still more elevated and distant point, which serves as a signal to the inhabitants of the country; so that by their means any intelligence is communicated to the whole island. When the island was menaced by the English admiral, previous to the siege of Pondicherry, M. de la Bourdonnais, with incredible difficulty, contrived to place some mortars on the first of these mountains.

There are scorpions in the Isle of France, but no wild beast of a dangerous nature. Its harbours, as well as the rivers and coasts, furnish abundance of fish, \&c.

The island contains four parishes, and as many churches, and as the inhabitants increase, other parishes are marked out, and places of worship erected. The principal church, when finished, will be the largest, as well as the best, piece of architecture in the island. The Governor, besides his town house, has a villa in the country, called the Reduit, in the middle of a wood, guarded with some pieces of cannon, where there is a curious garden under the direction of $\mathrm{M}$. Oblette, an experienced botanist. On the south-east coast of the island, there is another large harbour, which possesses a far more commodious entrance, but as the winds generally blow into it, it is seldom frequented from the difficulty of its outward passage: there is a small town near it, where the Company has a warehouse. The woods were formerly full of deer, but they have been so much destroyed, that their number at present is comparatively small, except in the impenetrable parts of the forest, where they retire for safety.

There are many high mountains, the most remarkable of which is called Peterbot, a name that was given it by the Dutch. It is of an extraordinary elevation, and its summit is generally covered with clouds. Many of the large rocks and stones, which are scattered about the country, are cleft in two at equal distances, from six to twelve inches, as if it had been the work of art, instead of some singular operation of nature. Beneath these rocks and stones rats are found in great numbers, which are very destructive to the plantations: however, the inhabitants are sufficiently encouraged in their labour, by constant demands for their productions, and the price that is paid for them. Hence it is, that the plantations are increasing in number, extent, and value; the wood is proportionably cleared, and the scene of cultivation enlarged and improved. The plantations require from thircy to two 
hundred slaves, according to their extent; they are in general pleasantly situated near a rivulet, and decorated with hedges. The houses are built with wood, and at a small distance from them are villages of huts, which form the residence of the slaves: many of the planters are rich, and are continually improving their situation. In proportion as the inhabitants increase, the price of their productions advances, and having more than sufficient in the island for their domestic consumption, in grain, cattle, fowl, fruits, \&c. they are able to supply the vessels which touch there, with refreshments.

The planters raise as large a quantity of live stock as they can, for which they have always a very beneficial sale. It is impossible for me to calculate the number of inhabitants with any degree of precision; but the island appeared to be very populous. The artisans and mechanics are very numerous; and when to these are added the sailors, who are continually coming and going, with the military forces, and the slaves, we may suppose a body of many thousand people. The slaves are brought from Gorée, an island on the coast of Guinea, from Madagascar, the eastern coast of Africa, and Bengal: the latter are generally preferred for home service. They are Gentoos, and of a docile character, therefore better qualified for domestic purposes than the others, who are of a robust form, and able to undergo the severer labours of tilling the ground. Many of these slaves are ingenious and easy to instruct, which their masters find it very advantageous, as they become artificers; some of whom are known to gain a dollar per day. In case of attack, many of these people may be armed without danger, particularly such as have 'been born in the island. When the fleet commanded by Admiral Boscawen threatened Pondicherry, a considerable body of them, natives of the Isles of France and Bourbon, voluntarily engaged in the public service, and were accordingly conveyed to Pondicherry, where they contributed very much to the preservation of that important fortress.

The women are handsome and very numerous, so that every artificer, workman, and soldier has a wife; they are very fruitful, which circumstance is imputed to the salubrity of the climate: they take a great deal of exercise, and are bold equestrians. The poorer classes of both sexes in the country, never have any covering to their feet.

The two most considerable establishments that M. de la Bourdonnais erected in this island, were the iron forges and sugar works; they cost very large sums, in mills, canals, and machines of various kinds, to advance them to that degree of 
perfection, which they have now attained, particularly in the manufacture of iron : the sugar works are at Vilbague, and produce at this time sufficient sugar for the consumption of the two islands, as well as to supply the vessels which arrive there: I found it to be of a fine grain, as well as clear and strong: it is sold in the shops of the island at five sous the pound.

M. de la Bourdonnais and the Count de Rostaing, principal engineer, discovered an iron mine in one of their plantations, or at least that kind of earth from which iron is extracted in Europe: some pieces of it were sent to the Company, which, on being assayed, were found to produce a greater quantity of ore than common mines. Under the encouragement, therefore, of the Company, the mine was opened, and works, with all the accessory machines, were constructed; workmen were also sent from Europe, and, after the usual obstacles which attend the commencement of great undertakings were surmounted, some bars of its manufacture were sent to France, to Mahé, Pondicherry, and Chandernagore, as samples, where they were very much approved. Some time after cannon and mortars were cast at these works, and I have seen some of them mounted on the ramparts of Pondicherry, and the batteries of the Isle of France, where they are considered by no means inferior to those which had been sent from Europe; but so great was the consumption of wood in these works, that there was not sufficient quantity of it, in their neighbourhood, to last more than eight or ten years. This, and other causes, occasioned the proprietors to relax in their enterprize, and at length to discontinue it. Thus M. de la Bourdonnais has transformed a desert island into a flourishing colony, and I have every reason to believe, that the port will give the French a decided advantage over us in India; the consequences of which, we do not appear to consider as they deserve. I sincerely wish that Admiral Boscawen had taken it, instead of making an unsuccessful attempt upon Pondicherry.* It would then have been a very easy conquest, as it did not possess its present strength, and many of the inhabitants were discontented, and secretly wished for a change in their government.

Both men and women are strong and well made : they breathe an wholesome air, are in continual exercise, and are distinguished for their moderation and temperance. The women are remarkable for the beauty and elegance of their shape, in which they surpass those of old France.

- Dr. Campbell represents the Isle of France, as one of the finest islands and most important places on the globe. 


\section{Observations on the Isle of France, by M. Rocbon.}

While the little French colony of the Isle of Bourbon enjoyed some degree of prosperity, that of the Dutch, established in the Isle of France, was in a state of distress and decay. I am at a loss to discover the reason, why the Dutch settled themselves in this island, which they named Mauritius; I only know, that they complained of the injury they had sustained, by the locusts and the rats, when they abandoned it, in 1712, to establish themselves at the Cape of Good Hope.

The inhabitants of the Isle of Bourbon, on the departure of the Dutch, were eager to possess themselves of the island they had left behind them, which is not more than thirty-four leagues from their own; the air is healthy, but though it is less fertile and extensive than the Isle of Bourbon, it possesses the advantage of having excellent ports, and of being to the windward.

In 1734, the French East India Company formed a resolution of establishing a considerable settlement in this island. The completion of this important object was intrusted to M. la Bourdonnais, who was born to command, because he knew how to insure obedience, and proved, in this remote part of the globe, that his skill and talents were equalled by the wisdom of his civil administration. To him, and him alone, the island is indebted for its aqueducts, its bridges, its hospitals, and principal magazines : in short, whatever exists at this day, in those islands, whether of public or private utility, may be considered as the work of that celebrated character. From his universal knowledge, persevering spirit, unerring judgment, and engaging manners, all his undertakings for the advantage of the colony, during an administration of twelve years, were attended with a prompt and successful issue.

It was to his sagacity, that the inhabitants are indebted for their principal settlement at the north-west port. A less enlightened understanding than his, would have preferred that to the south-east, because it is larger and more commodious, but this able navigator well knew the incalculable advantages of a port to the leeward.

The cultivation of grain is the most advantageous employment in the Isle of France; as the ground annually yields successive harvests of corn and maize. The manioc, a native of the Brazils, and naturalized by M. la Bourdonnais, is the principal food of the slaves. The continual demands of ships that put into the port of this island, have made the augmentation of cattle and sheep an important concern. The island produces an excellent grass, which springs up at the beginning of the 
rainy season, and attains its full growth in the space of three months: the inhabitants avail themselves of this period to pasture their flocks; but no sooner is the vegetation completed, than a straw succeeds, which is too hard for the nourishment of animals. The flocks and herds then quit the savannahs, and seek the food that the forests afford them. This straw is so dry that the least spark sets it in a flame, which is so rapid that it is impossible to stop its progress. These conflagrations have sometimes consumed the adjoining woods.

When the Portuguese discovered this island, it was covered with wood to the very summits of the mountains; in short, it was one vast forest of fine trees. In the early period of its settlement the ground was cleared by the means of fire, and it would then have been a wise measure to have left small districts of wood at short distances from each other. The rains, which in the hot countries are so necessary to the fertility of the earth, very seldom fall upon those spots that are entirely cleared of trees, as it is the forests which attract the clouds, and draw the humidity from them; besides the cultivated grounds have no protection against violent winds.

The high mountains which border on the harbour, and defend it from the violence of the winds, have been cleared to their very summits, which are burnt up, and the vegetable earth is precipitated into the vallies. The large trees have been cut down or burnt, which, when the island was first inhabited, prevented these dangerous removals of the surface; so that the anchorage of the vessels is no longer protected from the high sea, and violent winds. A temporary advantage induced the first colonists to deprive the port of that security which it formerly possessed.

M. de Tromelin, a French officer, undertook to find a remedy for this evil, by which the port should be protected from hurricanes: and, when he obtained the necessary permission, he began to form canals, to convey the torrents from the mountains to the sea behind the island of Tonnelier, into a part where they occasion no injury. This able and experienced officer extended his views still farther, and contrived, by the application of gunpowder, to force a passage through a bank of coral, by which ships might enter into the bason, known by the name of Trou-fanfaron. It is three hundred fathoms in length, by sixty in breadth, but its mean depth did not exceed ten feet; it was therefore necessary to increase it to twenty-five, in order. to render it capable of receiving vessels of large burden. 


\section{CHAPTER XXVII.}

An Account of the Arcbipelagos and Sand-banks between the Maldive Islands and the Isles of France and Bourbon, by M. Rochon.-Description of the Commora Isles by Spilberg, छ̈c.

$T_{H E}$ Isles of France and Bourbon, \&c. may be compared, for the beauty of the climate, and salubrity of the air, to the Fortunate Islands; but the former are separated from the Indian sea by an archipelago full of banks and rocks.

The ships which, on leaving the Isle of France for India, were forced, during the two monsoons, to take a long and indirect course, in order to avoid the archipelago to the northward of it; and, until it had been explored, it was dangerous for a squadron to attempt a more direct route. To the south of the Equinoctial line, from the eighth to the twenty-eighth degree of latitude, the winds are south-easterly throughout the year. From the eighth degree to the Line, the south-east monsoon begins in April, and continues till October, when the west monsoon succeeds it. To the north of the Line this arrangement of nature is reversed.

On leaving the Isle of France for India, in the fine season, the first place to be made is the most northerly point of Madagascar : and, proceeding from thence between the base of Patrum and the Amirantes, the Line is crossed in the fiftieth degree of longitude; and finding, on the northern side, the western monsoon, the Maldives are traversed between Kelloâ and Shullepar, where the vessel changes its course for Cochin : the rest of its navigation is along the coast.

Ships which set out from the Isle of France, in the bad season, for Pondicherry, are obliged to make a longer and much more indirect route; they bear away for the variable winds as far as the thirty-sixth degree of south latitude; and then direct their course so as to cross the Line in the eighty-fifth degree.

The principal points that M. Rochon has determined, are the Secheyles Isles, the base of Corgados, Salha de Mala, Diego Garcia Isle, and the Adu Isles.

Secheyles Isle has a very good harbour; it is situated in four degrees thirty-eight minutes south latitude, and fifty-three degrees fifteen minutes east longitude, from the meridian of Paris. 
This island is covered with wood to the very summit of the mountains, and abounds with land and sea-turtle, of three hundred pounds weight. On determining the situation of it in $176 \mathrm{~g}$, by M. Rochon, the adjacent islands appeared to be inhabited only by enormous crocodiles; but since that time a small settlement has been made there, and the nutmeg and clove cultivated. In one of these islands, called Palm Island, is to be seen the tree which bears that well known fruit called the cocoa of the Maldives, or the sea-cocoa.

The circuit of Diego Garcia is twelve leagues, and is in the form of an horseshoe; it is not a mile over in its broadest part, nevertheless the land is sufficiently elevated, so as to form a border and shelter to a bason capable of receiving the largest fleet : this bason is four leagues in length by one of mean width: this excellent harbour has two good entrances on the north side, and is situated in seven degrees fourteen minutes south latitude, and in sixty-eight degrees longitude, east of Paris.

Although this archipelago is covered with rocks, they are not as yet all known. The ancient maps of M. d'Après do not describe the whole of them. The collection of charts of the Isle of France are full of notes, written by M. Rochon, which shew that M. d'Après has confounded Artove with Agalega, and Corgados with St. Brandon, although there were among his papers the different plans of these islands and rocks, which contained many errors less obvious, but nevertheless of great importance.

The plan of Corgados had been taken by the boats Charles and Elizabeth, while that of St. Brandon is printed in the English pilot. These two dangerous rocks differ essentially both as to form and longitude; for they are fifty leagues distant from one another. Corgados is in the shape of a crescent, and St. Brandon forms an equilateral triangle; M. d'Après, confounding these two dangerous islets, has given them a mean position in his charts, because he had found them on the ancient charts in the same latitude; this position, however, is incorrect, and by no means ascertains the course that must be taken to avoid them. M. Rochon adds, on the memorable day when Venus passed over the sun's disk, in the month of June, 1769 , "I could not observe the passage of that star, important as it was, though the weather was clear and serene, as the vessel in which I was embarked was in danger of shipwreck off Corgados: if we could not have doubled the easternmost point of this frightful rock we must have perished; I am therefore justified in resisting the general opinion of the charts of M. d'Après." 
We cannot enter at present into a more minute detail of the archipelago which separates India from the Isle of France, though it is absolutely necessary to be well acquainted with it, in order to undertake the most dircet course during either of the monsoons.

The following events, that happened in these seas, afford the consolatory information, that any unfortunate shipwrecked navigator, thrown on the arid coast or barren isles, may find from the fish and animals which frequent the shores, a certain subsistence.

The ship named the Heureux left the Isle of France on the 3 oth of August, 1769 , being bound forBengal, and most unexpectedly fell in with the islands of Jean de Nove. The captain determined to pass them to leeward, and to avoid, by this manœuvre, the surrounding dangers. As soon as he had doubled them he took his course north-east by north, with a view of shortening his passage by some days: he perceived that he ought not to neglect any means of accelerating his arrival in Bengal, because the season was very far advanced: but in this passage the vessel was cast at midnight, upon two shallows, which gave the crew no hopes of saving themselves. These shallows were surrounded by a chain of breakers, which increased their alarm. All their manœuvres appeared useless, and the vessel was upon the point of going to the bottom, when the captain ordered the anchor to be cast, in such a manner as to give him some hope of the vessels being shipwrecked in shoalwater. This manœuvre succeeded, and the crew were enabled to pass the remainder of the night in the shrouds : day-break, however, did not free them from this dreadful situation, but at half past six in the morning they had some glimmering of hope, as they perceived at a distance a small sand-bank : all the crew passed over to it in the boat which the captain had taken the precaution to hoist overboard hefore the fatal moment when his vessel was wrecked. But this sand-bank was nothing more than a flat shore, left bare by the sea at low tide. In this cruel dilemma the captain saw no other resource than to send his boat to the coast of Africa for assistance. These unfortunate people, eight hours after their departure, met with a rock in their way, which they called Providence Isle : this rock was not entirely barren, for they found in it fresh water, sea turtles, and cocoas. Nine of the boat's crew remained there, whilst two strong rowers attempted to gain the sand-bank where the rest of the ship's crew had taken refuge, in the expectation of receiving succour. Their hope, however, was lessening, as they saw the fatal term approach- 
ing in which they would be swallowed up by the high tides. The boat was three days in getting there, and was too small to take them all on board; but this want was supplied by a raft from the wreck of the vessel. It possessed the dimensions requisite to contain the provisions and utensils which were necessary for the construction of a chaloupe. The raft was towed by the canoe to the Isle of Providence, and the shipwrecked people remained two months upon that rock, in order to construct a boat of five and-twenty feet in length, in which they had the good fortune to reach Madagascar without any further accident. The Isle of Providence is $9^{\circ} 5^{\prime}$ latitude, and $50^{\circ}$ longitude; and is north-north-west, and some degrees to the west of the Isle of France.

M. Moreau, Captain of the sloop Favori, dispatched from the Isle of France on the 9 th of February, 1757 , to Narrapore, on the 26 th of March following fell in with the Adu Isles: from his observation the latitude was $5^{\circ} 6^{\prime}$ south, and according to his reckoning, $76^{\circ}$ of longitude, to the east of Paris. He sent a boat on shore which he was obliged to abandon, being forced away by the currents. Six leagues to the south of these islands M. Moreau fell in with a bank, which had a good bottom. A narrative of what befel the party which were thus involuntarily deserted, and of their arrival at Cranganore, near Calicut, has already been given in a former part of this Volume.

The Isle de Sable was discovered in 1722 , by the ship la Diane, Captain M. de la Feuillée. It is flat; and is not a quarter of a league in circumference : however, at the northern and southern points of it fresh water is to be found, at the depth of fifteen feet. The ship l'Utile, Captain M. de la Fargue, was shipwrecked here in 1761 . The officers, and the ship's crew, which was for the most part composed of blacks, saved themselves upon this small island. They built, during their abode of six months there, a chaloupe out of the wreck of the vessel aboard of which the white people embarked. They fortunately reached the small island of St. Mary, near Madagascar, after a short passage. The blacks remained upon this rock in the fruitless expectation of receiving assistance from their companions; but they were left to perish there without a single attempt being made to rescue them from their melancholy situation. The corvette, the Dauphin, commanded by M. Tromelin, whose brother has been already mentioned with the distinction he deserves, on the $29^{\text {th }}$ of September, 1776 , fell in with the Isle de Sable, and, notwithstanding the dangers which threatened any approach to it, he bad 
the good fortune to take back to the Isle of France the sad remains of the crew of the Utile. Eighty Negroes, male and female, had perished from distress, or in attempting to save themselves on rafts, which they had constructed: seven Negro women had resisted, during fifteen years, all the rigours of the most cruel situation that imaginaton can form. The most elevated part of this shoal is fifteen feet above the level of the sea: it is six hundred fathom in length, and about three hundred in breadth. These deserted Negroes had constructed a hut with the remains of the vessel, and had covered it with the shells of turle; while the feathers of birds, ingeniously interwoven by the women, served them for clothing. This island is one scene of sterility; nor has it any shelter from the fury of the sea in the tempestuous seasons. One of the seven females who had escaped the united pressure of hunger and despair, became in this deplorable situation, the mother of a child, who perished with her. They related, that they had seen five vessels which had made many unsuccessful attempts to land on the place of their dire captivity.

\section{The Commora Islands.}

As these islands make a part of the great Ethiopian Archipelago, we conceive that this is the proper place to mention them: and before we give their particular description, we shall present an extract from the Voyages of Spilberg, which will inform us of the reception the Dutch met with, when they first touched at them. On his arrival at the first of the Commora Islands, Spilberg sent a boat on shore to ascertain the disposition of the islanders, which returned with various kinds of refreshments, and with the assurance that the place might be approached in safety. On the following day an interpreter, with some of the inhabitants, brought provisions, for which they were paid; and on the $22 \mathrm{~d}$ they came to an anchor in the road, where there was a good bottom in thirty fathom water.

Spilberg now ordered a large case of merchandize and some bars of iron to be carried into the house of the Prince, by way of security for the payment of what might be furnished for the service of the ships. In this island, which was named Mohilla, there was plenty of cattle but very little rice. "The Prince was a man of considerable experience, having travelled in Arabia and other places: he spoke the Portuguese language with great fluency, and was extremely fond of music; he took great delight in hearing the flourish of trumpets, and it appeared even that he had heard the harpsicord and the harp, as he enquired whether those instruments 
were on board any of the ships. His son paid a visit to Spilberg, with a great number of officers and two Turks, all superbly dressed in the Turkish fashion: he was received in a very respectful manner, and an handsome collation was prepared for him, but as it was a fast-day according to his religion, he declined partaking of it. The Admiral made him several presents for the Queen, his mother, as well as for himself, consisting of looking glasses, and necklaces of amber and crystal. The Queen immediately sent in return a bullock and several goats.

These mutual civilities inspired a mutual confidence, so that the Dutch visited the town at their ease, where they received the most hospitable attentions. They solicited their Admiral to comply with the desire of the King and the Queen, who had expressed an earnest wish to receive him on shore, as the latter had been induced to come from the furthest part of the island in the hope of seeing him. But the adventure of Rufisco was still in his mind, and made him deaf to their entreaties; though the King offered his son as an hostage : and to give him a further example of confidence, he proposed to pay him a visit on board his ship, and appointed the $5^{\text {th }}$ of March for that purpose. He was accompanied by a great number of his people, all dressed in the Turkish fashion; and his visit proved, to all appearance, extremely satisfactory to him. He was acquainted with navigation; and when a globe and charts were brought to him, he distinguished very readily the principal places in the East Indies. It appeared from his observations, that he lately frequented the Red Sea, of which he had perfect knowledge. As the season of fasting was not yet passed, there were no other means of entertaining him but by musical instruments, and the discharge of artillery: he declared the utmost satisfaction at the desire which had been manifested to please him; and it is not easy to determine if any treacherous design was lurking behind his exterior deportment.

Two days after, Spilberg went on shore without giving him any previous notice, and on his arrival at the city, he, by chance, met the High Priest of the island, who pressed him to pay a visit to the king: he again begged to be excused at present, on pretext of the fast not being over; the principal pleasure of visiting being to eat and drink. The season of fasting being completed, he was solicited more than ever to go on shore, and take part in the festivities of the town: he, however, made other pretexts for his refusal; but although the King voluntarily came on board to congratulate Captain Speck on his joining the fleet with his ship, neither this politeness nor the renewed invitations of the Prince, could 
overcome his resolution. In the meanwhile the ship's crew carried on their traffic without entertaining the least suspicion of any treachery : but, on the $3^{1 \text { st }}$ of March, the chaloupe and a canoe having been ordered out with eight-and-twenty men, to take in water, they did not return as was usual, at sunset. In vain were signals fired and repeated; and the night passed without receiving any news of them. Next day a white flag was hoisted, and all the necessary precautions were taken to prevent a sudden attack : no body, however, appeared upon the shore, neither did any canoe come off, nor was any signal made to answer those of the fleet. So strange an event excited the greater alarm in the Admiral, as, after such a diminution of his forces, the crew that remained, half of whom were sick, was not sufficient to give any hopes of succeeding by violence. Although he had lost his chaloupe and canoe he could have landed some of his men near a suburb of about two hundred houses, called the Fisber's Suburb, and at least demand the reason of an event that confounded him. Confidence and friendship had reigned without interruption throughout their intercourse : nor had there arisen the least dispute between the Dutch and the Islanders. It was, however, to be feared, that those who landed might be detained like the rest, which would necessarily produce some acts of hostilities; they therefore got under way, and having stood into the bay, they made fresh signals of their preparations to depart. At last Spilberg, discouraged at so many useless endeavours, resolved to sail for the Isle of Anjouan, where the Queen, then sovereign of the four Commora Islands, ordinarily held her court: with this design he weighed anchor; but his surprise and grief were much increased when, having stood off both Anjouan and Mayotta, he found in the inhabitants the same obstinacy in not shewing themselves, and refusing to answer his signals, although they formerly brought their refreshments freely on board the fleet: prudence, however, would not allow him to land on the two islands. At last the discontents of the sick, and the impossibility of freeing the prisoners, caused him to call those who were in a condition to hear him, to witness that he had no reason to reproach himself for what had happened, and that the interest of his masters obliged him to continue his voyage. This resolution was universally approved, and they immediately set sail. The eight-and-twenty men who were thus abandoned, and among whom was the Admiral's secretary, were the healthiest and strongest persons of the fleet. 


\section{Description of the Commora Islands.}

The Commora Islands, which are situated to the north-north-west of Madagascar, are five in number; the largest gives its name to all the rest, although the other four have each a particular name, which are Mohilla, Angaréja, Johanna and Mayotta.

Though the Island of Commora is the largest, it is, nevertheless, in every other respect, the least remarkable; it has no safe road for shipping, and the inhabitants are so barbarous and uncivilized, that Europeans have never ventured to make a long abode there: they are, in general, jealous of strangers, and have a particular aversion to the natives of Europe. It is said, that the cruelties which the Portuguese exercised the first time they landed there, are the cause of this suspicious disposition. The Island of Mohilla is of as little consequence as that of Commora ; it is very seldom visited, not only on account of the inhospitable disposition of its people, but also from there not being any convenient spot for shipping.

All the islands, however, are extremely fertile, well stocked with cattle, sheep, hogs, and birds of different kinds; they produce likewise sweet and sour oranges, citrons, bananas, honey, sugar-canes, rice, ginger, cocoa nuts, \&c.

The Isle of Angaréja is inhabited by Moors, who traffic with different parts of the continent, and several of the islands in the east, by means of their fruits and other productions of the island, bartering them for calicoes and other cotton manufactures. The bread used in these islands is made of the kernel of cocoa nuts, boiled or broiled, and covered with honey ; their drink is palm wine, and a juice extracted from the sugar-cane, which they leave to ferment, or the milk of the cocoa-nut. They never let strangers see their women without a permission from their chiefs, or an order brought by the stranger himself; many of them speak and write the Arabic language with facility; and some even understand the Portuguese tongue; this advantage they derive from their trade in the Mozambique Straits, which they carry on in vessels of about forty tons. They build their houses with stone and lime, made from calcined oyster shells, with which they cover their walls and roofs: their windows are shaded hy the leaves of the palm-tree, which protect them at the same time from the violence of the rain, and the excessive heat of the sun. The government of this isle is aristocratical; and is conducted by ten of its principal inhabitants-

The island of Mohilla is subject to a sultan, whose children share his authority as 
viceroys over different districts of the island : they all take the title of sultan, though subordinate to the authority of their father; and each of them has his guards, his crown, his sceptre, and all the other symbols of royalty, with a numerous court. The sultan never appears without being attended by twenty of the principal persons of the island : and, on these occasions, he is clad in a long robe of striped calico, which hangs from his shoulders to his feet, with a turban on his head. The people also generally wear long garments of a similar stuff; they continually chew the areka or beetle nut, like the Indians of the East, to whom they bear a great resemblance in their manners and actions.

The Island of Johanna is the most frequented by, and best known to, Europeans; who frequently touch there for refreshments, in their voyage to Bombay or the coast of Malabar. This island is in twelve degrees twenty minutes south latitude; is thirty miles in length, fifteen in breadth, and about fourscore in circumference; although certain parts of it are very mountainous, it is equally pleasant and fertile : the soil is naturally good, and its various rivers render it abundant in all the neecessaries of life.

To give an idea of the beauty of this island we shall relate the account of an excursion made into the interior parts of it by Mr. Grose. It it as follows:-

"We set out very early in the morning, with a design of penetrating about six miles into the country before the sun should incommode us, and it was no common undertaking, considering the mountainous surface that we had to pass. We had taken our fowling-pieces, in the hope of killing game if we could attain the summit of the mountains, whither they retire; but, notwithstanding our utmost efforts to climb up them on our hands and knees, we found it impossible, and were obliged to content ourselves with the small birds that we found in the vallies, and on the hills whose ascent we had accomplished. We breakfasted on pine-apples, and the milk of cocoa-nuts served to assuage our thirst. Towards noon we arrived at a fine lake, on whose banks we sat down to make another repast, and to enjoy the natural cascades which fell from the rocks, and, by blending their several noises from their respective distances, produced a soft and agreeable kind of water-music.

" The orange and lemon trees, bending beneath the weight of their fruit, dispersed a fragrance that embalmed the air: there were, also wild pine trees, which bore a fruit of thirteen inches in circumference, and of a more exquisite flavour than those I have since eaten in India : our guides also pointed out to us a great number of 
guava trees, and particularly a tree whose fruit resembles our damson, which leave an agreeable flavour on the palate several minutes after it has been eaten : they all grow without any regularity or order, and receive no advantage from cultivation: some cover the tops of the mountains, others shade the water-falls, or thicken in the vallies; the whole forming a terrestrial paradise, in comparison of which the finest gardens of France, with their statues and canals, their parterres and their fountains, exhibit but a poor and meagre scenery.

"We quitted with regret this charming spot, after having admired its beauties, and which still added more to our pleasure, having nothing to fear from wild beasts, or poisonous animals. We then returned to our tent, well rewarded for the fatigue we had undergone in our excursion."

This island produces several other kinds of fruit besides those already mentioned; among which there is a remarkable kind of sweet orange ; it is about the size of a common lemon, but of a much more delicious taste than those that grow in Portugal. The principal domestic animals are cattle, sheep, and hogs; the bullocks are of a moderate size, like those in the East Indies, and are remarkable for large fleshy excrescences on their backs : their flesh is very sweet, and the excrescence, when it has been well salted, eats like marrow: the natives prefer it to the tongue.

The woods abound with monkeys of different kinds, but there is no beast of prey, or venemous creatures: there are also two animals of the monkey kind, one is called the mongoo, and the other the mauaulo. The mongoo is of the size of a small cat, and its head resembles that of a fox; its eyes are black, with a yellow circle round the pupil; near the eyes the skin is black, and descends in a point to the nose, which is also black; but there is a small white space between the eyes and the nose, which continues from the face to the ears; the upper part of the head, the hinder parts, the tail, and the limbs, are of an ash colour, while the belly is white; the hair has a tendency to wool; the feet resemble those of a man, with flat nails, except one sharp talon on the hinder feet; the tail of this animal is long, and its hair is thick and soft; its actions resemble those of the monkey; it lives on fruits and herbs, but, in general, will eat any thing, not excepting fish. There are several kinds of these, but thèy do not appear to differ, except in their colour. It is gentle in its nature, and has no apparent means of defending itself.

The mauaulo is of the size of a common cat, but its body and limbs are much 
smaller; its tail is twice the length of that which nature has given to the cat; its snout is long, and resembles that of a fox: the iris of the eye is a brilliant yellow; its face and ears are white, but its nose is black; each eye is surrounded with a large circle of the same colour, and on the sides of the head and eyebrows there are long stiff hairs, resembling the whiskers of a cat, the crown and the hinder part of the head are of a dark ash colour, and the hair, in those parts, is longer than that of the face, but the hinder part and the sides have a slight tinge of red; the legs are of a light ash colour; the upper part of the feet is white; the fore feet resemble the human hand, with a thumb and flat nails, while the hinder ones are remarkable for the size of its principal toe, and the inside of them is covered with black hair: the skin in every part has the softness of velvet. This animal has two teats on the breast, which have the same position as in the monkey species: the tail is covered with fur, and decorated with large alternate rings of black and white: when it sleeps it rests its nose on its belly, brings all its feet together, as if it were sitting, and guards its head with its tail.

The black mauaulo is of the same size as that we have just described, is of the same gentle nature, and soon rendered familiar, though it has all the tricks and finesse of a monkey. Its head is like that of a fox, with a pointed snout; it eats in a sitting posture, and holds its food with its paws.

There are several species of fowl, and different kinds of game, but the inhabitants are so awkward in the use of nets and fowling-pieces, that they seldom kill any of them,

The sea abounds in different kinds of excellent fish, and the islanders are very skilful in taking them; they consist of the ray, the mullet, and a flat fish that resembles our turbot; but the most .remarkable species is the peroquet fish, so named from the resemblance of its snout to the beak of that bird: it is about a foot long, and of a greenish colour, spotted with yellow: its fins are blue; its eyes, which are very lively, are of the same colour, with a yellow iris; the scales are large, and it has two rows of teeth, with which it contrives to open the muscles and oysters : its flesh is very firm, and of an excellent flavour.

The natives of this island are, in general, tall, robust, and well made, but the women are inferior to the men: they have, all of them, long black hair, piercing eyes, and their colour is between olive and black. The poor people live in huts made 
with twigs, interwoven with, and covered by, a coat of strong grass: while the roof is protected by a kind of mat, made of the leaves of cocoa trees. The upper orders have houses built of stone, cemented with tempered clay.

Vegetables and milk form their principal food; but instead of oil and vinegar for their sallad, they use a liquor which they extract from the cocoa-nut. Persons of rank are distinguished by the nails of their fingers, which they suffer to grow to an immoderate length; they also paint them with the alkana, which produces an orange colour: this fruit is found on a particular kind of shrub, that grows in marshy places. They generally wear large knives attached to a belt which is fastened round their middle; the handles of some of them are of silver and agate.

The lower ranks have no other dress than a piece of coarse cloth tied round their loins, with a sort of cap upon the head, made of any kind of stuff they can procure. Those of the rank above them wear a shirt with large sleeves, which hangs down upon a pair of drawers, and covers a waistcoat made of a thick or light stuff, according to the season: the higher orders wear turbans.

The women are clad in a kind of jacket and petticoat, with a loose robe, and when they go out, their face is covered with a veil : they are very careful in adorning their legs, their arms, and their ears; they wear in the latter such a variety of baubles, in the form of pendants, that the lobes of them are drawn down to their shoulders; their arms and wrists are decorated with a number of bracelets, made of glass, of iron, of copper, of tin, or of silver, according to their rank and fortune. They suffer their children, both male and female, to be naked till the age of seven or eight years, a custom very general among the people of the East; they consider heat as more hurtful than cold, and are of opinion that a free access of air to every part of their bodies tends to strengthen them, and is much more favourable to their growth than if they were enveloped in clothes: thus, in their opinion, the infants and children are preserved from many maladies to which those are subject who are educated in a different manner. Health is the principal object with these people, and they have the good sense to consider it as the first blessing of life.

They are remarkable for their simplicity, obliging disposition, and hospitality, which often exceeds their means of indulging it : their manners preserve that natural appearance which proves that they have not yet been corrupted by the arts of the more civilized world.

The delightful temperature of their climate renders them indolent, and prone to 
amorous indulgence. They often avail themselves of the liberty which their laws allow them, to divorce their wives on the slightest pretences, and from the mere love of variety; though they generally have two or three wives, and as many concubines as they can maintain. They will ask freely for what will give them pleasure; but they are by no means addicted to theft : they treat the English, in particular, with the greatest cordiality, from a principle of gratitude, for the essential assistance which they formerly received from them in their wars with the people of Mohilla : at the same time they are extremely jealous of all other European nations, especially of the Portuguese, with whose usurpations on the shores of the continent they are well acquainted. They trust, for their defence, to the inaccessable mountains in the interior parts of the island, and consider them as the impenetrable barriers which nature has given them.

Their tongue is a corrupt Arabic, blended with the language of Zanguebar, a part of the continent opposite to them, and from whence, it is probable, that the Commora Isles were originally peopled. The white people among them, who are generally of an elevated rank, enjoy a superior degree of consideration. They derive their colour from a connection with the Arabs and Europeans, with whom they were formerly more connected than they are at present: they have, indeed, adopted the jealousy of the Arabs, as well as their religion and manners; their religion is, nevertheless, a gross kind of Mahometanism, corrupted by the remains of their own ancient superstitions. They hate and fear the devil to such a degree that they sometimes burn him in effigy, as a mark of their detestation for that common enemy of the human race: they also believe very much in ghosts, and their fear of them is equal to their faith in them. In general, the religion and manners of the inhabitants of these several islands bear a strong resemblance to each other, and only differ in certain usages and customs.

There are seventy-three villages in this island, besides the town of Johanna, where the king resides : the inhabitants are supposed to amount to one hundred and thirty thousand; the town of Johanna contains about two hundred houses, the greatest part of which are inhabited by the principal personages of the country; they are built of stone, but are very low, except the king's palace, which is high and spacious: strangers are permitted a free entrance into the anti-chamber, but the other apartments are reserved for the royal family.

The title of King is given to the chief of this island: in fact, he possesses an 
unlimited power over all his subjects, as well in religious as temporal concerns; he usually resides about nine miles from the town, and seldom comes there, excepting when European vessels arrive there; he is, on that occasion, accompanied by a numerous equipage, and seldom fails going on board, where he is entertained by the captain, and saluted at his arrival and departure by five guns. Of this circumstance he is very jealous, not only on account of the private satisfaction he receives from it, but moreover, because it is a mark of esteem and importance, which renders him the more respected by his subjects.

Every captain is obliged to obtain the king's permission before he can traffic with the inhabitants; to obtain which he has only to make him a small present of European manufactures.

"As soon as a vessel," says Mr. Grose, " has cast anchor in the road, it is immediately surrounded by a great number of canoes, which hasten to bring refreshments of all kinds. It is agreeable to see the confusion and eagerness of the rowers to get the first to the ship; when the sea is rather boisterous, it often happens that they are overset, but without danger of their lives, as they are excellent swimmers, and sustain no other loss than their small cargoes."

Some years ago the islanders, who used to come on board with refreshments for the crew, such as fresh cocoa-nuts, plantains, birds, fruits, \&c. bartered them for handkerchiefs and millinery articles, glass bottles, pieces of iron, and every kind of ready-made clothes, without caring for money; but at present they have learned to know the value of coin; nor are they any longer so eager after trifles as they were formerly : they now insist on being paid in money, fire-arms, gunpowder, \&c. for their goats and sheep.

Thus the most simple characters, when they come to communicate with the world, catch its habits, and learn its artifice.

The only private details we have of the isle of Mayotta, on which we can depend, is that of Commodore B. Francis Beaulieu, in an account of his expedition to the East Indies : he says, the island of Mayotta is low, cold, and damp; that it abounds with provisions and fruits, and is covered with verdure; but is not inhabited on the sea-shore. The tide, he says, carried him to the west, along the coast, to a spot where he perceived a vessel: he accordingly sent the long-boat, with ten marines, who brought back word that it was a vessel of forty tons, coming from La Mecca, and that the captain, taking them for Dutchmen, had sent all his merchandize ashore. 
The captain of the vessel shewed him two letters, one of an English commander, named Martin, and the other of Captain Banner, by which they inform their coun. trymen, that they found many refreshments here, particularly in fruit; but had not been able to meet with any fresh water; and that linen and paper were much sought after by the inhabitants; but that great care was to be taken not to indispose them, as, with all their friendly appearance, they might do much harm. "The road being surrounded with rocks, the Arab captain advised me," (continues Commodore Bealieu) " not to approach the island without a pilot, I accordingly sent my boat on shore with him, and he returned in the afternoon with two of the inhabitants, who, before sunset, brought the vessel to an anchor in a place of security. I then sent back the Arab captain to his vessel, with the strongest assurances that we had no bad intentions, and of our friendly disposition: I charged him at the same time with a letter, written in Spanish, containing the same assurances to the king of the island.

"Soon after the king sent some of his principal favourites to assure us of his friendship, and of his inclination to furnish us with all the productions of the island which we might stand in need of: on which I sent him, as a present, a dagger with a silver handle, two fine knives, a ream of paper, and a looking-glass, which he received with great satisfaction, and in return sent me a kid and some fruits. At the same time I begged the Arab captain, who was then on shore, to buy me some provisions, promising to send him the necessary merchandize to be given in exchange. He answered, that the inhabitants of the island have such strange ideas, that they would not conclude any bargain of the value of a single real in a day, nor would buy one single yard of linen, without calling in all their relations and neighbours to fix upon the price they were to give for it. I was likewise informed, that a Portuguese India ship having been cast upon this island about three years ago, the inhabitants had supplied themselves so abundantly with European goods, that they were no longer of any value.

"The following day, I observed two vessels of the country, and made the captains come on board, who informed me that they came from the island of Mayotta, that they were laden with rice and dried fish, bound for Mombza. The next day they furnished us with as much rice, peas, and hung beef, as would serve us four month, which gave the greater satisfaction, as we could not buy any thing from the inhabitants without a considerable delay; besides, I began to suspect their sincerity, 
for the day before, as we were employed in sounding, in order to cast anchor, some of them made us signs to come to a spot where we observed a long ridge of rocks; from whence I concluded that the profit they had gained by the shipwreck of the Portuguese India vessel, made them wish us to undergo the same fate. Finding afterwards, that the water was bad and brackish, we set sail again, and quitted this isłand.

We now return to the Isle of France.

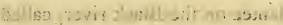
Nin..... If inisiog $\cos , 4$ 


\section{CHAPTER XXVIII.}

Excursion of M. St. Pierre in the Isle of France.-Description of the Cavern.A Tour round the Island, छc.-Account of an Hermit.-Its Commerce, Agriculture, and State of Defence.-Observations on the Island, by the Abbé Raynal, and M. Munro, \&c.

$A_{s}$ the following details will increase the local knowledge of the Isle of France, we think proper to insert them.

"I had been, a long time before, invited by a planter on the Black river, called M. de Messin, to pay him a visit: he lives about seven leagues from Port Louis, and availing myself of his pirogua, which came every week to the port, I embarked about midnight. The pirogua is a kind of boat, made out of one piece of wood, with oars and sails. We were about nine persons in it.

"About half past twelve at night we rowed out of the port: there was a strong swelling sea, which broke heavy upon the reefs; and we were often within the surf of the breakers, without perceiving it, as the night was very dark. The master informed me he could not continue his voyage before day-break; we therefore went on shore.

"We had probably run about a league and an half when we came to a mooring, somewhat below the Little river. The Blacks carried me on shore upon their shoulders; after which they took two pieces of wood, one of the velvet tree, the other of bamboo, and lighted a fire by rubbing them together. This method is very ancient, the Romans made use of it, and Pliny says, there is nothing better for that purpose than ivy rubbed against laurel.

"The men seated themselves round about the fire, smoking their pipes, which consisted of a kind of crucible, at the end of a thick reed : they passed them round to one another. I distributed some brandy among them, and laid myself down to sleep upon the sand, wrapped up in my cloke.

"They awoke me again at five o'clock, in order to re-embark. Daylight having appeared, I saw the summit of the mountains covered with thick clouds, passing 
rapidly along: the wind drove the thick fog into the vallies, the sea foamed, while the pirogua carried its two sails, and proceeded with great expedition.

"When we were upon that part of the coast called Flicq-en-flacq, about half a league from land, we were overtaken by a squall, which obliged us to strike our sails: we were to windward of the shore, which, being lined with rocks, it was impossible for us to approach. At length, however, after various difficulties, we got to the mouth of the Black river, where we disembarked, and were received by my friend with those attentions which indemnified me for the inconveniences I had suffered. His estate comprehends the whole of the valley which is watered by that river, and is very imperfectly represented on the chart of the Abbé de la Caille: he has omitted a branch of the mountain which is on the right bank, and is called the Morne du Tamarin; besides, the course of the river is not in a straight line: at a league from its mouth it turns to the left. That learned astronomer confined himself principally to the circuit of the island, and I have made some addition to the map, as laid down by him. The country about the Black river is abundant in every thing; game, deer, river and sea fish are in great plenty, the latter of which are easily taken : to these may be added, the land and sea turtle. This plantation is conducted with great order and regularity; the huts of the Negroes are ranged in a line, like the tents of a camp; and each of them has a little garden, in which he cultivates tobacco, \&c. Sheep and the domestic fowls, are in great number: grasshoppers do a great deal of mischief to the plantations; and it is very difficult to transport any weighty articles to the town, as the roads are almost impassible by land, and the wind ever contrary by sea. After-having reposed myself some days, I determined to return to the town by a circuitous way through the plains of Williams.

"I accordingly set off at two in the afternoon, in order to sleep at Palma, a plantation at the distance of three leagues, which belonged to M. Cossigni : the only way to it is along small paths among the rocks, I was consequently obliged to travel on foot. When $I$ had passed the chain of mountains that stretches along the Black river, I found myself in a vast forest, of which no part had been cleared. The path conducted me to the only plantation in this quarter, and it passed close to the house. The master of it was at his door, without any covering to his legs, and the sleeves of his shirt tucked up : he was amusing himself with rubbing a monkey over with red mulberries, and was himself bedaubed with their 
juice : he waş an European, and had enjoyed a considerable fortune in France, which he had dissipated.

"In about half an hour I arrived on the banks of the Tamarin river, whose waters run with great noise and rapidity over a bed of rock: The Negro, who accompanied me as a guide, found a ford, over which he carried me on his shoulders. I saw before me the very lofty mountains of the Trois Mamelles, on the other side of which lay the plantation of Palma. Here, however, we lost our way, and after a variety of difficulties, and suffering the extremity of fatigue and thirst, we arrived towards midnight at Palma, where, in the absence of the master; we received every kind of attention from the overseer of this plantation. : At an early hour in the morning I set forward to visit M. Jacob, who lived in the upper part of the plains of Williams. I passed along a large open road, and arrived, at an early hour, at the habitation of that gentleman.

"The air of this part of the island is much cooler than at the port, or the place which I had so lately quitted, and in the evening a fire was not unpleasant. This is the best cultivated quarter of the whole island; and is watered by several rivulets; some of which flow through ravines of a frightful depth. In my return to the town; I passed by one, called la rivière Profonde, the road being close to the brink; when I found myself in a state of elevation three hundred feet above its bed; the sides are covered by five or six stages of large trees.

"As I descended towards the town I perceived the heat gradually renew itself, and the herbage insensibly lose its verdure, till I arrived at the port; where an universal aridity prevails." .

\section{Description of the Cavern.}

Near the Great river there is a small establishment, consisting of an hospital and some magazines. There the aqueduct begins which brings' water to the town, and on the top of a small rising ground, in the form of a sugaruloaf, is a kind of fort which defends the bay.

In about three quarters of a league on' the other side of the river, to the westward, and in the midst of woods, is the mouth of the cavern. On entering the plain, it resembles the hole of a cellar, the vault of which is fallen in. Several roots of the. Mapou hang perpendicularly down, and close up one part of the entrance. b. is. if. 3 ? 
In order to descend into this abyss you must first provide yourself with wax lights and flambeaux: "when you have gone down a dozen steps on the rocks which form its mouth, you then find yourself in a vast subterranean place, the vaults of which are of black rock, in an elliptical form. It is about thirty feet wide, and twenty high; the bottom is very close, and is covered with a fine earth, which the rain-water has deposited there.

On each side of the cavern, round the upper part, is a kind of large bead and mouldings, which probably have been formed by the dripping of water in the rainy seasons, The natives think that it is the aperture of a volcano; it has, however, more the appearance of having been the bed of a subterraneous river. The vault is covered with a shining and dry varnish, formed by a kind of stony concretion which spreads itself over the projections, and in some parts of the floor : there is also ferruginous incrustations, which crackle beneath the feet like ice.

After a considerable length of passage, the ground becomes perfectly dry, except at about thrce bundred paces from the entrance, where the vault has fallen in, and the external water filters through the earth, and forms some humid spots.

From thence the vault continues lowering, till there is no proceeding but on the hands and feet : a stifling heat is found to prevail. There is a strange kind of plant found here, which is full of a milky juice: it resembles a root about the thickness of one's finger, and upwards of ten feet long, without branches or leaves, or the least appearance of having ever had any, although it is entire at the two extremities.

This cavern is capable of being formed into superb magazines, by building walls to prevent the water from entering into it. 


\section{Dimensions of the Cavern, according to the Measurement of the Marquis D'Albergati.}

The ground is very dry in all this part of it: there
re also several chinks which run along the whole are also several chinks which run along the whole
breadth; the entrance is east-north-east -

The subterraneous passage turns to the north-east one quarter east; the ground is dry, and throughout this part is a kind of causeway or parapet about two and a half high, \&c.

Fathom. Feet.

The first vault $\int_{\text {Height } 3}{ }_{2}$

from the en- $\{$ Breadth 50

trance - Length 22

o

The vault turns to the east-north-east, and two degrees thirty minutes north : at its extremity it has but four feet in height, but it rises again within a few fathoms: it is stony and damp, and some small petrefactions are observable in this part of it

The second vault $\int$ Height $2 \quad 5$ from the first Breadth 4 :

The parapets and mouldings continue on the sides; there is also a space of about fifty feet, filled with stones, detached from the vault ; the passage continues in a straight line turning - Length 68

It runs on to the north-west quarter north five degrees west

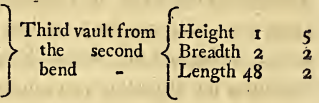

Fourth vault $\begin{cases}\text { Height } 3 & 0 \\ \text { Breadth } 4 & 3 \\ \text { Length } 58 & 2\end{cases}$

To the north-west quarter north two degrees thirty?

Fifth vault, third Height I 2

$\left\{\begin{array}{ll}\text { Fifth vault, third } \\ \text { bend }-\end{array} \begin{cases}\text { Breadth } 3 & 0 \\ \text { Length } 38-2 & 2\end{cases}\right.$ minutes

Sixth vault, Height I 4

fourth bend $\begin{cases}\text { Breadth } 3 & 3 \\ \text { Length } & \end{cases}$

To the west quarter north two degrees thirty mi- Seventh vault, $\begin{cases}\text { Height } & \text { I } \\ \text { Breadth } & 4\end{cases}$ nutes.

To the west quarter south-west two degrees thirty
minutes west

fifth bend

Length 26

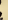

2

To the north-west quarter north two degrees thirty minutes north

\section{M. de St. Pierre penetrated no farther.}

To the north-west three degrees thirty minutes west, you are obliged, for one-third of this vault, to crawl upon the belly; it was formerly of easier access

At the end there are some moist places; and the vault threatens ruin in two or three parts

Eighth vault, Height I 5

Sixth bend $\{$ Breadth 3 o

Ninth vault, Height I I

Seventh bend $\{$ Breadth 5

Length 28

Tenth vault, $\begin{cases}\text { Height } 2 & 0 \\ \text { Breadth } 3 & 0 \\ \text { Length } 16 & 4\end{cases}$ Eleventh vault $\left\{\begin{array}{lll}\text { Height } & 0 & 2 \\ \text { Breadth } & \text { I } & 4 \\ \text { Length } & 6 & 0\end{array}\right.$ The whole length $\overline{342 \quad 2}$ 


\section{Description of a Tour round the Island.*}

"Standing along the coast, from Fort Blanc towards the left of the port, the sea opens upon a sandy low shore to the point of the battery aux Sables. The battery of Paulmi is also built there; it would be impossible to land upon this shore, because, at the distance of two musket-shots, nature has defended it by a ridge of rocks. From the battery of Paulmi, the coast is steep and perpendicular; the sea breaks upon it in such a manner, that it is impossible to land there. As to the plain, it is impracticable to cavalry and artillery, on account of the great number of stones with which it is covered. There are no trees here, but some mapus and velvet trees: the ruggedness finishes at the bay of the Little river, where there is a small battery.

" Near this spot is a cotton mill, invented by M. de Seligny, $t$ it is turned by water, and composed of a number of small metal cylinders placed parallel to one another: some children are employed to put the cotton between two of these cylinders, which passes and leaves the berry behind. This same mill likewise supplies a forge with wind, threshes the corn, and makes oil. Here M. de Seligny discovered a vein of pit-coal, the traces of an iron mine, and an earth proper for making crucibles: at the same time he perceived that the ashes of certain aquatic plants, where are a species of the nymphea, burned with coal; produce glass of different colours.

"By a pathway, which is only a gun-shot from the bank, you come to the river Belleisle, which is passed by a ford. At a quarter of a league from thence, the path leads through a wood to the plantation of $M$. de Chasal. This district, which is called the Plains of St. Pierre, is still more rocky than the rest of the journey.

"The whole coast is very steep, from the Little river to the Plains of St. Pierre: the soil is stony, but very well calculated for the culture of cotton: the coffee that grows there is of a good quality, because the ground is dry: it is more abundant in moist situations, but diminishes in flavour. The river Dragon, which succeeds, is fordable, as well as that of Gallet, which comes next. The coast now ceases to be steep, and it is commodious walking along the sea-side, in a large plain which leads

- The voyage of $M$. de St. Pierre in 1769 .

+ It was M. de Seligny who traced out a channel to the ship Neptune, which run aground in the hurricane of 1760 ; there were two iron rakes worked by two large wheels carried in boats, the effect of these wheels was increased by acting upon two levers supported by rafts. 
to Tamerin Cove, which is about a quarter of a league broad. Nothing grows there, though cocoa trees might be planted with success : to the right there is a brook of indifferent water, which runs through the woods.

"There are various places which are no longer covered by the sea : large shells and fossils prove, that it has receded from this coast. Where the sea displays itself, beyond the reefs in the offing, there is a kind of hollow bottom, or natural covered way. Cannon might be placed there with great effect; but above all, roads are necessary, and there are none.

"A About a league from the Black river, is the plantation of M. de Messino. From the Tamerin Cove to the rivière Noire, the sea beach is steep; and along the foot of the rocks there are abundance of crabs.

"The bottom of the Cove is sand, and vessels may land there. There is no battery on the sandy point to the right of the river Noire. Byl crossing the peninsula of the first Black river, which is covered with wood, stones; and long grass, you get to the shore; at low tide there are a great many oysters sticking to the rocks along the coast.

"After. having passed the two rivieres Noires, there is a brook that falls into the sea; facing a small island called Tamarin Islet. At low water it may be gained on foot, as well as the Islet of the Morne, where sometimes vessels ride during their quarantine.

" Here are blocks of ferruginous rock abounding in mineral; there is also a ridge of rocks which stretch out from the riviere. Noire, as far as Morne Brabant, which is the most windward point of the island: there is a passage behind the Islet of Tamarin. From thence you arrive at the plantations of $\mathrm{M}$. le Normand, situated on the sea-shore, and three leagues farther to Belle-ombre, in which M. Etienne has a concern, between which is the point of Corail. At the point du Corail, the sea enters the island between two chains of rocks formed into a peak: you must follow this chain, walking through broken paths, and clinging to the rocks. The most difficult is on the other side of the Cove, in doubling the point called the Cape: : in stormy weather this passage is impracticable; the sea is here engulfed, and breaks in a dreadful manner. In calm weather small vessels enter into the Cove, at the bottom of which they take in a lading of wood. On the left bank of the river des Cilronniers, vessels are built of about two hundred tons.

"From the plantation of M. le Normand, all this part is covered with a delightful 
verdure, it is a savannah entirely clear of rock, and lies between the sea and the woods, which are very fine towards the point of St. Martin.

"Before you pass the Cape, there is a large bank of coral that rises to the height of fifteen feet, and forms a kind of reef, which the sea has abandoned: at the bottom of it is a long pool of water, which might be converted into a bason for small vessels. From the Morne Brabant there is an inclosure of breakers, which admit of no passage but opposite the rivers.

"Between the reefs and the coast, the water is very clear, and admits of seeing a forest of madreporz of five or six feet high. They resemble trees, and some of them even bear flowers: different kinds of fish of every colour swim among the branches, and others are seen that inhabit the most beautiful shells.

" The post called Jacotet, is a place where the sea having penetrated inland, forms a round bay, in the middle of which is a triangular islet. This cove is surrounded with a hill which gives it the form of a bason, and it has no other opening but that towards the sea. At the extremity several rivulets pass over a fine sand into it, which come from a lake of fresh water that abounds with fish. Round the lake are several small hills, which rise behind each other in the form of an amphitheatre, and are crowned with tufts of trees in pyramidical and other pleasing shapes: behind and above them all, the palm trees rear their tufted heads. All this mass of verdure, which rises in the midst of the mossy ground, unites with the forest and a branch of the mountain which stretches on towards the Black river.

"There are sometimes troops of Maroon Negroes in the environs of Belle-ombre. In 1769 , there was from two to three hundred of them, who choose a chief, whom they obey, on pain of death. They are forbidden to touch any thing in the plantations of the neighbourhood, or to go along the frequented rivers in search of fish, \&c: In the night time, they descend to the sea in order to fish; in the day time, they hunt the deer in the interior of the forests, with dogs well trained for that purpose. When there is but one woman in the gang, she belongs to the chief; if there are several of them, they are in common: they put to death, it is said, the children that are born from them, in order that their cries may not discover them; they are occupied all the morning in casting lots to foretell the fate of the day.

"A very good port for small vessels might be formed at post Jacotet, by extracting some banks of coral from the bason. The arm of the sea near the savannah serves for embarking. The whole of this part is the finest portion of the island; 
nevertheless it is uncultivated, because it is difficult to keep up any communication with the principal place, both on account of the mountains in the interior, and the difficulty of returning by sea to windward of the port, by doubling Morne Brabant. "The left bank of the savannah is more rugged than that of the right. The river des Anguilles is somewhat dangerous: the bed is full of rocks, and the current rapid: some springs of a ferruginous nature fall into it, which covers its waters with an oil of the colour of a pigeon's neck.

"The river du Poste runs with great noise over rocks : its waters are very transparent in dry weather, and it is fordable about a cannon-shot from the mouth of it.

"All the coast from the arm of the sea, near the savannah, is rugged and unapproachable. The rivers which fall into it are very much inclosed; so that it would be impossible to proceed on horseback: the march of an enemy, therefore, might be easily arrested, each river being of a frightful depth. It is, at the same time, one of the finest districts of the island.

"After an hour's walk this fine mossy verdure, which begins at the Morne Brabant, is seen no more, and is succeeded by a very rocky country, like the rest of the island : its grass, however, is a fine sort of dog-grass, proper for pasturage. The arm of the sea of Chalan is fordable, on a bank of sand, and penetrates inland by so narrow a passage, that it might be inclosed with grates, and made a large receptacle for fish.

"The rivers de la Chaux and des Creoles are very deeply embanked; between them and the principal Port there are several plantations: the environs of this port, at about three quarters of a league from the river des Creoles, are covered with mango trees: the whole landscape is charming, as it is intersected by bills covered with plantations and groves of orange trees. The residence of the priests is about a league from the port, which is a kind of small town, containing about a dozen houses. The most remarkable edifices are a mill, in ruins, and the government house, which is not in a much better condition. Behind this little place is a large mountain, and before it is the sea, which forms a deep bay, two leagues in breadth, reckoning from the reefs which embrace its opening, and four leagues in length, from the point of the two Cocoas to that of the Diable: it very often requires a month for vessels to come thither from Port Louis. The south-east part was first inhabited by the Dutch, as we have already observed, and one of their ancient edifices still remains, 
which serves for a chapel. There are two entrances into this port, the one by the Point di Diable, and the other, which is the largest, on the side of an islet near the middle : there are batteries on these two places, and a third, called the Battery de la Reine, at the bottom of the bay. Whales frequently enter into this harbour, from the south, and might be easily harpooned. This coast is most abundant in fish, and the finest shells are collected on it. There are purple oysters at the mouth of the river de la Cballx, and a kind of crystallization in the bed of the river Sorbes, which is at no great distance from it.

" The air of the south-east port is of an agreeable freshness, the country beautiful and fertile, but the town is almost abandoned, the principal settlements being at Port Louis.

"The mouth of the Grande rivière is about four leagues from hence; it is somewhat larger than that which bears the same name near Port Louis. The shore is intersected with coves, where the mango trees flourish : it is probable that the seed of them was brought by the sea from some island more to windward. To the left there is a chain of high mountains covered with wood; while verdant hillocks are scattered over the face of the country. In this district a considerable number of cattle are bred; but though pleasing to the sight, it is fatiguing to the traveller.

"The Point $d u$ Diable is so named because the first navigators perceived, it is said, the needle to vary here, without being able to account for it. Two leagues from thence is a new house of stone, situated on a rising ground, and belonging to a rich planter, M. de la V-. The mouth of the Grand rivière is not navigable, on account of a: sand-bank that runs across it, and a cascade which it forms about half a league up it.

" There is a redoubt of earth built upon the left bank, at the beginning of the road which leads to Flacq; where you here enter a fine grove of orange trees, near to which there is a plantation. The whole length of the shore is scattered with rocks.

"A quarter of a league beyond the rivière Seche is a path on the right, which leads towards the sea-shore, and to a lake of fresh water, where there is a post of thirty men. There the shore begins to be practicable; and there is a small arm of the sea of considerable depth: here and there the sand is scattered with stones till you meet a long meadow covered with dog-grass. All this part is dry and barren, the woods low and thin, and stretching to the distant mountains. This plain is three leagues 
over, and does not wear the appearance of fertility: it spreads itself as far as a settlement called the four Cocoas, where there is no other water but that of a brackish well, dug in the rocks, which are full of iron ore.

" A path on the left leads to the woods, where the rocks re-appear. The river Flacq is crossed by planks, at about a quarter of a league from its mouth: the plantations here are numerous, and there is also a magazine situated on the left bank, and a post commanded by a captain.

"The quarter of Flacq is one of the best cultivated in the island, and produces large quantities of rice; there is a passage between the reefs which allow the gaulettes to take in their cargoes close to shore.

"Near the post de Fayette, almost the whole of the coast is covered with broken rocks and mango trees.

"The Cove des Aigrettes, a considerable arm of the sea, is fordable. At some distance from thence is the Cove aux Requins. Large beds of rock are seen here, pierced with a great number of round holes, a foot in diameter; some of which are of considerable depth. It may be presumed that the lava of some volcano, having formerly flowed down upon a part of the forest, had consumed the trees, and left the apertures empty which they had occupied.

" From the post of Fayette to the river du Rempart the flat country continues: this quarter is likewise well cultivated.

" Having passed the district and river called la Poudre d'Or, large woods succeed: the soil is good, but there is no water: beyond these is the river des Citronniers, and a plantation belonging to $\mathrm{M}$. Gole: there are then four leagues of uninhabited country before you arrive at the Pointe des Cannoniers. In the district of Pamplemousses the ground appears to be exhausted, nor can it well be otherwise, as it has been cultivated during a period of thirty years, without being restored by manure. In the dry seasons the rivers la Poudre dOr, la Secbe, and des Lataniers, are fordable; but there is always a running stream of fresh water in their respective channels.

"The island contains three churches: the first is at Port Louis, the second at the Soutb-east Port, and the third, which is the most commodious, is at Pamplemousses. A very handsome structure of this kind has been constructed at Port Louis, but it was raised to such an elevation that it was shaken by the hurricanes."

It was in the course of this tour that $M$. de St. Pierre met with an hermit, who gave the following account of his solitude. 
" Though I do not behold, from my hermitage, which is embosomed in a forest, that multitude of objects which present themselves from this elevated situation, it is not without circumstances peculiarly interesting to one who, like myself, looks, for his best satisfactions, into the secret recesses of his own mind. The river, which flows before my door, takes its course in an undeviating direction through the woods, presenting to my view a long canal shaded with.trees of every foliage. There are the ebony and cinnamon trees, with others of various name and figure, enriched and varied by tufts of palms, which rise above the rest, and whose tops resting, as it were, upon the summit of the wood, gives the appearance of one forest resting upon another. The creeping plants of divers kinds, form alternately arcades of flowers, and curtains of verdure. The groves dispense their aromatic odours; and, in the season of their flowers, the passenger bears on his garments their delightful perfume, long after he has quitted the shade of the trees on which they blow. At the close of summer, several kinds of foreign birds arrive, by an incomprehensible instinct, from distant and unknown regions, and over a vast extent of ocean, to collect the grain which is yielded by the vegetables of this island; while they enliven, by the splendour of their plumage, the foliage of the trees; which are embrowned by the sun. Among others, there are various kinds of parrots, and the blue pigeon, called here the Dutch pigeon. Monkies, which are the domiciliated inhabitants of the forest, amuse themselves among the dusky branches; sometimes.they are suspended by the tail, and balance themselves in the air; at other times, they are seen leaping from branch to branch; with their young ones in their arms. Here the murderous gun has never alarmed these peaceful children of nature: here nothing' is heard but the cries of joy, the warblings of birds, and the murmur of rivulets," \&c.

\section{Commerce, Agriculture, and Defence of the 1sland.}

This colony imports its plate from China, its linen and clothes from the Indies, its slaves and cattle from Madagascar, a part of its provisions from the Cape of Good Hope, its money from Cadiz, and its administration from France.

M. la Bourdonnais wished to make it an entrepôt for our commerce, and the bulwark of our settlements in India.

It has been supposed that the commodities, clotbs, linen, and manufactures of France, would have sufficed for the consumption of the island; and that the cottons of Normandy would be preferable to the linens of Bengal, for the slaves. It is cer- 
tain that money alone ought to be the circulating medium, and not paper, in which nobody puts any confidence.

Of all foreign countries, Madagascan is the most necessary to its commerce, on account of its slaves and cattle.

If it was seriously intended to place the commerce of this island in a flourishing situation, it would be necessary to clear Port Louis from a number of hulls of vessels which choak up the bason, and the more so, as they are forming themselves into a kind of reef by the growth of the madreporr; with which they are overloaded, and in some measure petrified.

They who have great property in lands which may be easily cleared, particularly

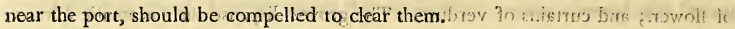

Beasts of burthen ought likewise to be increased, especially asses, so useful in mountainous countries; an ass carrying double the load of a Negro.

It would be likewise necessary for the administration to consult husbandmen, as to the properest mode of cultivating the island.

There are a great many soldiers, to whom lands might be given to clear and cultivate; it would also be a politic measure to marry them. Had this plan been pur-. sued, the whole island would have been in a connected state, and there would have been a nursery of Indian soldiers and sailors.

Nature has amply provided for the defence of the island, which is almost surrounded, at some distance from the shore, by a range of breakers: where this range is broken, the coast is formed of inaccessible rocks. In short, the island itself would be inaccessible were it not for some passages between the reefs, of which there are eleven, formed by the currents of the rivers, which are opposite to them.

The exterior defence of the island, therefore, consists in preventing all access to these openings: some might be shut up by floating chains, and others might be defended by batteries built on shore.

As a boat may be worked between the reefs and the shore, gun-boats might be used, to advance the fire when the passage is at too great a distance from the cannon on the coast.

Behind the reefs the shore is of easy access; but the accessible places might be rendered impracticable, as they are become at the extremity of the South-east Port: it is only necessary to plant mango trees to produce that effect. In those parts of the coast which is continually beaten by the waves, if there should be some beds of 
rock that might render them accessible, as they are not very extensive, they might be defended by common walls, chevaux de frise, \&c. - On any small sandy spot mango trees might be planted, whose roots and branches would interweave in such a manner as to prevent any boats from landing; at the same time it is necessary to use some/precaution in planting these trees, that they may not choak up places they were intended to preserve.

This isle is in a circular form, and each river coming from the centre may be considered as the rays of the circle. The banks on the side of the town might have their declivities increased by planting raquettes and bamboos, while the ground should be raised at the distance of three hundred fathom on the opposite side : thus the ground between the two rivulets would become a kind of fortification, and each of their channels would be a ditch not easily passed : an enemy would not be able to get to the town, but through a thousand difficulties. This system of defence is applicable to all islands of a small extent, where the streams always run from the centre to the circumference.

The two mountainous projections which embrace the town and Port Lous require no defence but towards the sea : a citadel might be constructed on the Isle of Tonnelliers, whose batteries, placed in covered ways, would discharge a level fire. Mortars, which are so destructive to ships, might also be placed there. To the right and left, as far as the mountains, the ground might be strengthened by the lines of a fortification. Nature has already saved a part of that expense, to the right, and the river des Lataniers protects the front.

At the extremity of the bason, and behind the town, is a large piece of ground, where all the inhabitants of the town, and their slaves, might be assembled. The other side of the mountain is inaccessible, or might be easily made so.

There is also another very singular advantage in the most elevated part of the mountain, behind the town; as at the spot called la Pouce, there is a considerable space covered with large trees, from whence two or three small streams of very fine water issue forth. It is impossible to attain that height but by a very difficult path : several attempts have indeed been made, by employing gunpowder, to gain a communication by it into the interior part of the island; but the opposite side of these mountains presents a most frightful declivity, which Negroes and monkies are alone capable of ascending. Four hundred men in this post, with a sufficient quantity of provisions, could never be reduced by force of arms, and the whole garrison 
might retreat to it. If to these natural means of defence are added, those which depend on government, such as a squadron of ships, and a body of land forces, an enemy would have the following obstacles to encounter.

First, a naval engagement. Secondly, supposing that the squadron should be beaten, it might nevertheless delay the conquerors in forcing them to the windward of the island. Thirdly, the difficulty of landing, as the coast cannot be attacked but on points, and never on an extensive front. Fourthly, the passage of every rivulet must produce a battle, with great disadvantage to the invader. Fifthly, the side on which the town can be besieged is of small extent, and, under a fire from the mountain that commands it, while the trenches must be opened in a rock. Sixthly, if the garrison were compelled to abandon the town, they would find on an height of the mountain, an impregnable redoubt, provided with water, where they might receive supplies and succour from the interior part of the island.

Observations on the Isle of France, by the Abbe Raynal.

"There are many mountains in the Isle of France, the highest of which has four hundred and twenty-four fathoms. Although the soil be, in all parts, covered with stones, of a greater or less size, so that it cannot be tilled with the plough, but must be worked with the spade, it is, nevertheless, fit for many purposes. Though more superficial, and less fertile than that of Bourbon, it is more generally susceptible of cultivation.

"This island for a long time engaged the speculation, rather than the industry, of its possessors: and they wasted their time in conjectures concerning the advantages which would be derived from it.

"Some were inclined to make a central mart of it for all Indian merchandize, which was to be brought thither on Indian bottoms, and then shipped on board French vessels, which were never to proceed farther. A twofold advantage evidently rose from this scheme: first, the expenses were lessened, as both the pay and the maintenance of Indian sailors is very trifling; and secondly, the ships crews were more effectually preserved, as they sometimes suffered greatly from the length of the voyage alone, and still more frequently from the climate, especially in Arabia and Bengal. This plan, however, met with no support; it was feared that the Company would fall into contempt, unless they displayed, in these distant latitudes, a naval force sufficient to ensure respect. 
"Others, agreeable to a new system which engaged their attention, were of opinion, that the inhabitants of the Isle of France should be allowed to trade to India, which they had never yet been suffered to do. The supporters of this system maintained, that the proposed freedom would prove an abundant source of wealth to the colony, and consequently to the mother-country. But the island was then in want of both vessels and specie; it had no article for exportation, nor any means of consumption. For all these reasons the experiment proved unsuccessful; and it was resolved that the island should be entirely confined to agriculture.

"This new regulation gave rise to fresh mistakes. Men were sent from the mother-country to the colony, who neither understood husbandry, nor were accustomed to labour. The lands were distributed at a venture, and without distinguishing what was to be cleared from that which was already in a state for cultivation. Money was advanced to the planters, not in proportion to their industry, but to the interest they could make with the government. The Company, who got cent. per cent. upon the commodities the colony drew from Europe, and fifty per cent. upon those that were sent in from India, required that the produce of the country should be delivered into their warehouses, at a very low price. To complete the misfortunes of the colony, the Company, who had kept all the power in their own hands, broke the engagements they had entered into with their subjects, or rather with their slaves.

"Under such an administration no improvements could be expected. Discouragement threw most of the colonists into a state of inaction; those who had some share of industry remaining, were either in want of the means that lead to prosperity, or were not supported by that strength of mind which enables men to surmount the difficulties which always attend on new settlements. Those who had an opportunity of seeing and observing the agriculture of the Isle of France, found it little better than what they had seen among the savages.

"In 1764 the government took the colony under its own immediate controul. From that period to 1776 a population has been successively formed there of six thousand three hundred and eighty-six white men, including two thousand nine hundred and fifty-five soldiers, eleven hundred and ninety-nine free Negroes, and twenty-five thousand one hundred and fifty four slaves. The cattle on the island have also been increased to twenty-five thousand three hundred and sixty-seven. 
"The coffee-tree has employed a considerable number of planters: but the hurricanes, that have succeeded each other with a fatal rapidity, have prevented, for some time, any advantage being derived from these plantations; and the government itself had endeavoured to check it, by the duties that have been laid on it at its going out of the island, and its entrance in France.

Three sugar-plantations have been established, and these are sufficient to supply the colony.

"No more than forty thousand weight of cotton has yet been gathered. This last commodity is of a good kind, and every thing promises an increase of it.

The camphire, the aloes, the cocoa-tree, the agallochum, the sago, the cardamom, the cinnamon tree, and many other vegetables, peculiar to Asia, have been naturalized in the island.

"Some iron mines had long been discovered, but it has been found necessary to abandon them, because they could not support the competition of those in Europe.

" It is well known that for these two hundred years, the Dutch have been enriching themselves by the sale of cloves and nutmegs: to secure to themselves the exclusive trade of these articles, they have destroyed or enslaved the nations that were in possession of those spices; and, lest the price of them should fall, even in their own hands, they have rooted up most of the trees, and have frequently burnt the fruit of those they had preserved.

"This barbarous avidity, which has so often excited the indignation of other nations, so strongly exasperated M. Poivre (who had travelled all over Asia as a naturalist and a philosopher), that he availed himself of the authority he was intrusted with in the Isle of France, and sent men into the least frequented parts of the Moluccas, to search for what avarice had for so long a time withholden from the rest of the world. The labours of those intrepid and sagacious navigators in whom he had confided, were crowned with success.

On the 27 th of June, 1770 , they brought to the Isle of France four hundred and fifty nutmeg and seventy clove trees, ten thousand nutmegs, either growing, or ready to grow, and a chest of cloves, several of which had shot forth. Two years after this another importation was made, much more considerable than the former. 
"Some of these precious plants were carried to the islands of Seychelles, of Bourbon, and of Cayenne; but the greater part of them remained in the Isle of France; and all those which were distributed among private persons perished.

" The care of the botanists, and their constant attention, preserved, at first, in the king's garden, only fifty-eight nutmeg, and thirty-eight clove trees. In the month of October, 1775 , two of the latter bore flowers, which were changed into fruit the next year.

" That which we have seen is small, dry, and meagre. If they are not improved by a long naturalization, the Dutch will only have had a false alarm, and will remain the masters of the spice trade.

"Sound policy has given another destination to the Isle of France. The quantity of corn there must be increased, and the crops of rice extended, by a more judicious distribution of the waters : it is equally important to attend to the multiplying of the cattle, and to the improvement of the breed.

"These objects, of the first necessity, were for a long time inconsiderable, although it was an easy matter to form pasturages, and the soil yielded twenty fold. Only a few years ago it was suggested to the government, to buy up, at a good price, all the grain which the planters might have to sell; and, at this period, the harvests were increased. If this plan be uninterruptedly followed, the colony will soon furnish provisions for its inhabitants, for the navigators that may frequent its roads, and for the armies and fleets which circumstances will, sooner or later, bring there. Then this island will be the bulwark of all the settlements which France possesses, or may one day acquire in the Indies: the centre of all military operations, offensive or defensive, which her interest will oblige her to undertake, or to sustain, in these distant regions.

"It is situated in the African sea, just at the entrance of the Indian ocean; and though very much elevated, its climate is temperate and wholesome. As it lies out of the common track, its expeditions can be carried on with greater secrecy. Those who wish it were nearer to our continent do not consider that if it were, it would be impossible to pass, in a short time, from its road, to the most distant gulfs of these regions, which is an inestimable advantage to a nation that has no sea-port in India.

" Great Britain sees, with a jealous eye, her rivals possessed of a settlement where the ruin of her property in Asia may be prepared. At the breaking out 
of a war her utmost efforts will certainly be exerted against a colony that threatens her richest treasures. What a misfortune for France, should she suffer herself to be deprived of it!

"Yet what have we not to fear, when we see that to this day no care has been taken for the defence of this island? that the means for this purpose have always been wanting, or misapplied; that the court of Versailles, from year to year, has waited for the dispatches of the directors, to come to a determination on this point, just as one would wait for the return of a courier from the frontiers; and that even at the time we are writing, there is still perhaps a dispute, respecting the kind of protection which it is most expedient to adopt for a settlement of this importance.

"It is the general opinion of seamen, that the security of the Isle of France must depend entirely on the naval forces : but they acknowledge that these forces cannot fulfil this intention, till they have been sheltered from those hurricanes, so frequent and so terrible, which prevail in these latitudes from the month of December to April. A great number of merchantmen have, indeed, been lost, and whole squadrons have received so much injury, even in Port Louis, the only one to which seamen at present resort, that too much labour cannot be bestowed in guarding against these dreadful events. For a long time the government paid little attention to this important object : it has, however, at length determined to dig a large harbour in this road, in the hope that ships, of all dimensions, may one day find a safe asylum there.

" This business cannot be advanced with too much expedition; but supposing it executed with every possible success, the maritime force would still be insufficient for the defence of the colony. The state will never subject itself to the expence of maintaining constantly a stationary squadron in these latitudes; and it is possible that the island may be attacked in the absence of the fleet, which -may also be destroyed by sickness or by a storm : let it be a strong or a weak one, it still runs the risk of being beaten; and even if it were victorious, an opportunity may have been seized of landing troops during the action. These troops would immediately march on to the port, and make themselves masters of it, as well as of the victorious ships, which might have taken shelter there, in order to refit.

" By this manœuvre, which is a very simple one, a valuable settlement would fall, without striking a blow, into the hands of an enterprising and skilful enemy. These apprehensions, which are well founded, argue the necessity of fortifications. 
"Some engineers have imagined, that batteries, judiciously disposed along the coast, would be sufficient to prevent the besiegers from landing; but it has been since ascertained, that the island is accessible to boats in the greatest part of its circumference, and that even, in several places, a descent could be effected by force, under the protection of the men of war; this plan, therefore, has been relinquished. It has been understood, that there would be an infinite number of posts to fortify; that the expences would be endless; that too many troops would be wanted; and that the distribution of them would leave every point exposed to the consequence of a landing, executed suddenly, or by surprise.

"The idea of a war of posts has not been thought a more fortunate one. The Isle of France, notwithstanding the advantage of posts, will never collect a sufficient body of troops to resist those which the enemy may bring there. The persons who have proposed this idea, have laid a stress upon the assistance to be obtained from the colonists and the slaves; but they have been obliged at length to acknowledge, that this multitude, which might possibly be of use behind good ramparts, could be of little or no service in the open field.

" The project of building and fortifying a town in the inland parts, has long since had its partizans. Such an establishment appeared to them to be calculated to keep the besiegers at a distance from the centre of the colony, and to force them, in time, to relinquish any advantage which they might have gained at first: they would not be convinced that, without any movement on the part of the enemy, who was already become master of the ports, and the coasts, the garrison, deprived of every external communication, would soon be reduced to the necessity of surrendering at discretion, or of perishing with famine; and, even if the enemy were to do nothing more than fill up the roads, and destroy the arsenals, magazines, and public edifices, would not their principal object be fulfilled? of what concern could it be then to them, that there should be a fortress and a garrison in the midst of an island, incapable of giving them any uneasiness, or of exciting their future jealousy?

"After so many various and uncertain opinions, the government begins to be convinced, that the only method of defending the colony is to provide for the security of its two ports; to establish an internal communication between them, that shall facilitate a ready distribution of the forces, according to the designs of the enemy, and make the succours which might arrive from without, by one or other of its roads, common to both parts. 
" Port Bourbon, where the Dutch had formed their settlement, and Port Louis, the only one to which the French resort, had not hitherto appeared capable of being fortified ; the first on account of its vast extent, the latter on account of the irregular heights which surround it. But the Chevalier d'Arçon has proposed a plan which has removed all these difficulties, and, after the fullest discussion, has obtained the approbation of those who are the best acquainted with the important art of defence. The expences attending the execution of this great project have been rigidly calculated, and it is affirmed that they will not be considerable.

"But what number of troops will be wanted to defend these fortifications? The skilful engineer usually requires but few. He is well aware, that if many were to be sent, they would soon become effeminate from the heat of the climate, be corrupted by the desire of gain, be ruined by debauchery, and enervated by idleness. Accordingly he has reduced them, in time of peace, to two thousand men, who will be easily restrained, exercised, and disciplined. This number appears to him sufficient to resist any sudden or unexpected attack that might fall on the colony. If it were threatened with extraordinary danger from great preparations, a minister, attentive to the storms that are gathering, would have time to send over the forces necessary to defend it, or to act in Indostan, according to circumstances.

"Some persons still disapprove of these views. The Isle of France is an annual expence to the state of eight millions of livres.* This expence, which will scarce admit of any reduction, excites the indignation of many good citizens. Their wish is that this settlement should be abandoned, as well as Bourbon, which is only a burthensome appendage to it.

" This, indeed, would be the scheme most expedient to be adopted, if we considered only the languishing trade now carried on by the French in India : but political speculations reach beyond this object. It is foreseen that if this resolution were adopted, the English would drive all foreign nations from the Asiatic seas; that they would appropriate to themselves all the riches of these extensive regions; and that so many powerful resources united in their hands, would give them a dangerous influence in Europe. These considerations ought still more fully to convince the court of Versailles of the necessity of fortifying the Isle of France; at the same time taking the most effectual precautions not to be imposed upon by the agents chosen to carry this point into execution."

$$
\text { * } \mathcal{L}_{0} .333,333 \text { 6s. } 8 d \text {. }
$$




\section{An Account of the Isle of France, by Captain Munro.}

" Our ship approached the Isle of France towards the south-east, so that before we arrived at Port Louis I had the satisfaction of coasting more than one half of the island, by which I had an opportunity of gaining a particular knowledge of the different bays through which we passed, and of forming some conjectures upon the defence of which this important island is susceptible. The French have judiciously chosen this settlement as the chief residence of their Eastern government, for it is to them what Batavia is to the Dutch. The Mauritius resembles, though it is somewhat longer than the Isle of Wight.* The middle of this island is formed of mountains of rocks, which, in proportion as they advance towards the sea, diminish in a very picturesque manner, leaving between them vallies of some extent, which are well watered, and covered with wood. A continual moisture reigns on the summit of the mountains, which, upon several of them, and particularly in the vallies, renders the verdure as fine as it is abundant. The northern quarter being much more level than the other parts, seems to be well inhabited. Here the wealthy inhabitants of Port Louis have their country houses: their cattle principally graze on the east coast, the water and pasturage being better there, and in greater abundance, than in any other quarter.

"Our ship, although with a fair wind, was twelve hours in its passage from Isle Rodriguez to the bay of Port Louis. $t$ Several small islands full of rocks run obliquely from north to west along the coast of Mauritius, at the distance of about from two to seven leagues from the main land, among which there are so many whales which were so bold, that I often expected some of them; as we ran along the coast, would leap on board.

"The Isle of France is far from appearing so impregnable as it is generally

- The Isle of France is five times more extensive than the Isle of Wight. 'This error, if it can be called so, in Captain Munro, is very excusable. It does not at first sight admit of that common geometrical measure. He did not live long enough in the island to perform such operations, and as a stranger, and particularly an Englishman, this verification must have. been impossible for him. I have only made this observation in order that the reader may not fall into any uncertainty or error. See the observations of M. de la Caille.

t Isle Rodriguez is one hundred leagues, or three hundred miles, distant from the Isle of France. 
reported to be. The shore, in many parts, is high and rocky, but there are several flats, very convenient for landing, along the coasts, and where the sea is deep enough to admit of the approach of frigates to cover a landing, although they are defended by strong batteries. Our ship, which carried six hundred tons, drew near enough to the shore to make her guns bear with advantage.

"Port Louis is situated at the bottom of a triangular bay. There is a good dock-yard here, and a port capable of containing two hundred vessels. The French practised the farce of sending a pilot to steer loaded vessels along the channel for the two last miles, between two rows of white flags, regularly placed, as if it were the only practicable spot of it: but I have seen vessels of a considerable burthen going within and without those flags at pleasure, and the wind frequently blowing in all directions.

" The town is large, and the houses, principally built of wood, form ône continued street, about a mile and a half long; it has more resemblance to an European town, than any other $I$ have seen on this side of the Cape, as well for its bustling commerce, as in the agreeable appearance of its inhabitants; while the women, who are very numerous, are remarkably handsome and engaging in their manners, and possess, as it is generally believed, all the gallantry of their mother-country. I was treated here with the greatest civility, and particularly by the Governor, who granted me permission to walk wherever I pleased.

"I think it is very much to be regretted that the British government, in the last war, did not direct its first efforts against this island : a well-directed blow against the root of the tree would have caused all its branches to fall. It would have been the most certain and quickest method of subduing the French power in this quarter of the globe. Had this measure been adopted, the English would not only have been able to overthrow Hyder Ali, but even to give a good account of the Dutch and Spanish settlements in the East Indies.

"The principal inhabitants of this island laugh at our not having sent, in the beginning of the war, Sir Edward Hughes's squadron to attack it on his way to Madras. One of the most respectable persons of the town frankly assured me they were much afraid of it, and that the island was in such a sad state of defence, that, anticipating this event, they had already begun to think of the articles of capitulation. The Isles of France and Bourbon would infallibly have fallen into our hands; for at this time scarcely any works of defence had been raised, and there were not 
beyond five hundred European regular troops in the two islands. I doubt not but the French will take care for the future not to be surprised in such a weak state.

"With all the deference due to those who formed the plan of the unsuccessful expedition under Commodore Johnstone, it will not be amiss to observe, that if the attack of the Isle of France had been the object of it, it might then have been conquered by an attack prudently directed; which would have been a surer source of glory for those who had undertaken it, and for the nation in general, than even the battle of Porta Praya, or the taking of the Cape of Good Hope. It may be considered as presumption in me to give my opinion on a subject of such importance; but as I write in the confidence of friendship, and after having attentively examined the matter, I think my observations will not be totally useless. I am at present so perfectly convinced of the inutility of any attempt to overthrow the French power in the Indies without first reducing the Isles of France and Bourbon, that were another war to break out between the two rival nations I should humbly and strongly recommend, to the government of Great Britain, not to lose time in making a vigorous attack upon these islands, as the most efficacious and quickest means in gaining our object; such an expedition would perhaps be accompanied with some loss, but it would fall far short of that which a lengthened and perhaps unfortunate war would occasion.

"It would not perhaps be a very difficult thing for some men of war and frigates stationed between the Isles of France, Bourbon, and Madagascar, with two cruizers fixed to the south-east, and two others to the south-west, or to windward of the island, to reduce Port Louis by famine in a short space of time; the troops to be sent should be Europeans, or Sepoys sent from Madras, or Europeans from England itself. I think that four thousand Europeans alone, or two thousand Europeans and four thousand Sepoys, with a just proportion of ships of war, would completely effectuate this enterprize.

"The works at the two extremities of the town of Port Louis being very open and extensive, the enemy's forces might be very much divided by landing an equal number of troops on each side of the port, who, however, ought to pay great attention to act in concert, by means of well-directed signals, as well by day as by night, in case of a projected attack or any other movement of the enemy. At the same time two men. of war, with several gun-boats or fire-ships, placed at the opening of the port, might hold themselves in readiness, if the enemy threatened a serious 
attack, to throw red-hot balls into the town; or if the wind happened to blow hard at the time from the north-west, to send a fire-ship among them, in which a kind of wooden mortars charged with bombs* might be made in such a manner as when the deck caught fire to cast the shells with a short fusee into the town. Some ships of war could lay at anchor at the distance of an hundred fathoms from the little island to the east of the port, called the Isle des Tonnelliers, at the east and west side of the town, covering two fordable rivers, the one called des Lataniers, and the other la Petite rivière, near Fort Blanc. Several brooks of this kind descend from the mountains in every direction, and the places, where they empty themselves into the sea, are the most convenient points to pass between the ridges of rocks which are said to guard the coasts; and when the boats have once passed them the water becomés perfectly calm in several parts of the shore. I was informed that vessels of two hundred tons were building in the river des Citronniers, at the south-east point of the island. At post $\mathcal{F}$ acotet, near this river, an arm of the sea enters in the land, and forms a large bason, where smaller vessels can approach the shore with the greatest security. Here I should propose the first descent to be made with two hundred Europeans and six hundred Sepoys, without artillery; this spot being the most retired of the island, as well as the most convenient for making a junction with the Maroon Negroes, who generally live in this neighbourhood. The end of April is the most suitable season, when the monsoons are over; the winds then become variable, and the winter provisions of the inhabitants are almost exhausted: the detachment, thus landed, should receive orders upon being reinforced by the Maroon Negroes, or by people on whose intelligence they could rely, to form into two divisions, and to advance towards Port Louis on each side of the coast; the interior parts being totally inaccessible, in order to carry off the cattle they might find in the vallies; whilst the rest of the troops and the ships should be formed also into two divisions, running to windward of the island with the utmost expedition, and effect a landing at each point of the town, as was before proposed : by this means the enemy's forces would be greatly divided, and their forage completely cut off; which, as is reasonable to suppose, would soon force the town to capitulate. But even if the island could not

* During the siege of Wandewash, Captain Flint, who made such a noble defence of the place, constructed mortars of wood surrounded with iron hoops, which perfectly answered his purpose. This excellent officer likewise invented grenades of dried potters' earth, which he filled and threw into the enemy's works with great effect.-Captain MuNRO. 
be effectually subdued; a fleet that should attack the Mauritius, on its way to the Indies, might cause essential injury to the French in that part of the world.

"This is all that can be said on a project, which, at the moment, may appear chimerical; but in the course of a future war, it may, perhaps, be thought worthy of attention, and lay the foundation of an important acquisition to the British crown." 


\section{CHAPTER XXIX.}

\section{Observations on the Isle of France, by M. de Cossigny.*}

"O approaching the Isle of France, you must keep to windward, because the port, which is frequented by the larger vessels, is to leeward : when the wind is not violent, the air is embalmed with the perfumes of flowers with which the trees of the island are covered. The same odours are perceived along the island of Ceylon, when the winds blow from the land. This effect was falsely attributed to the cinnamon tree, which forms a part of the forests of this island, as its flowers have a fetid smell. The effluvia from the land are carried by the winds very far to sea; and sometimes produce very sudden and unexpected effects. I saw one of this kind, which is not very uncommon. A German soldier, a passenger on board of our vessel, about seven or eight and twenty years old, died suddenly in sight of the little isle of Rodriguez, and about a hundred leagues distant from the Isle of France. He had some slight symptoms of the scurvy, but he was not on the sick list, nor did he appear to have any unfavourable symptoms.

"It belongs, in the first place, to the physician to inform us of the necessary preservative against such an attack ; but were an unprofessional person permitted to give his opinion in so important a matter, I should be inclined to think that a slight purge administered to such as were afflicted with the scurvy, some days before they come in sight of land: the daily use of smoking, of coffee, and a mucilaginous phtisan, sweetened with sugar or honey, with moderate use of spirits of geneva, fumigations, and general exercise, but repeated several times in the day, might prevent the effects of such a revolution in the human frame as has been just mentioned.

"6s The Isle of France, from its two ports, the one to windward, and the other to leeward, of the island, though they have hitherto been too much neglected, will become the mother of the colonies which France ought to establish in the East Indies, if she is anxious to increase her commerce and her power.

* M. de Cossigny was Governor of the Isle of France in the year 1791 ; and is a man full of knowledge and philanthropy. See his Voyage à Canton, printed at Paris in the year 1799.

VA $\boldsymbol{X}$. 
* This colony, which was originally settled in 1722 , is not yet arrived to that degree of strength to which there is every reason to presume that it will one day attain. Its soil, which is in general fertite and ferruginous, seems to have been formed from the ruins of a volcano, at a very remote period. Lava is to be met with almost every where, and I had, on my estate, a bed of volcanic ashes.*

"The whole land was covered with fine trees, among which there were many fit for building, in a profusion that proves the fertility of the soil. Two successive harvests in the course of the year, confirm its claim to that character.

"The most useful vegetables of the four quarters of the world, have been collected in the national garden, which, for these seven and twenty years past, have been under the direction of M. Céré. In doing justice to the zeal, intelligence, and activity of this excellent person, I do no more than repeat the merited eulogiums which the public voice has lavished on him.

"Among the valuable and most useful vegetables that are here cultivated, I shall. only mention the Sagoutier, and Rima, or bread-tree. The former is a very high and bushy palm, the fruit of which grows along several pending stems: nothing is collected from it, but as soon as the tree has borne its fruit it dies: then the sap, which is very abundant and mucilaginous, dries, and is formed into meal, that is easily separated from the wood, which is full of pores. But while the cultivation of the Sagoutier is confined to the national garden of the Isle of France, and to those of the curious, it will never be of any use to the colony. It would be necessary then to multiply them on the mountains, and in the forests of the island: the cultivation of it should likewise be encouraged in Madagascar, where it is indigenous. The inhabitants of the north and west call it Sagou; by those of the east, it is named Moufia and Rafia. With the leaves of this palm-tree, divided into very fine threads, the natives, shew their dexterity and skill in weaving the pagnes.

"The bread-tree, or Rima, which is cultivated in the Isle of France, bears a very prolific fruit, whose seeds rise into a rapid growth: they resemble the chesnut both in appearance and taste. But the bread-tree, which is the most esteemed, is that whose fruit is not prolific ; that is, which does not contain seed, but a fleshy pulp, proper for the nourishment of man. I know not whether this difference is the work

* The reader will here remark, that M. de Cossigny, in this respect, differs entirely in opinion with the Academician le Gentil. I will not take upon myself to decide the question.

VAUX. 
of nature, or of art. In the first case, it is probable, that, by multiplying the individuals of the Rima from its seeds, there may be some that bear unprolific fruits: they may therefore be multiplied by the suckers, slips, and grafts. Above all, the Rima should be transplanted and multiplied in Madagascar: the soil and temperature there agrees with it better than those of our two islands, and it would be a wise measure to form a botanical garden in this great island, as well for the utility of the inlabitants, as for the supply of those navigators that put in there, and consequently to increase the general purposes of commerce.

"The Isle of France was formerly exposed to the ravages of locusts. None of these noxious insects, however, have been seen here since the year 1770 . It is pretended, that the martins, a kind of bird brought here from India, and which have multiplied in a very extraordinary manner, have destroyed them. It is certain that these birds feed upon them with avidity, when they are just produced, and before they have wings.

66. This colony, considered as an anchoring place, is well situated for the commerce of the East Indies. It furnishes the ships with all kinds of refreshments and provisions, and the means of recovering their crews; the air is healthy and water excellent. Considered as a port, it furnishes a shelter for the ships, with every necessary accommodation to careen, refit, and equip them : it might, in this respect, become an entrepot for the commerce of the East Indies. This was the project of M. de la Bourdonnais. Considered in an agricultural view, it would furnish commerce with valuable objects of exportation, such as sugar, coffee, cotton, indigo, fine spices, \&c. As a military station, it can maintain in its bosom a large number of land and sea forces.

"As I do not propose to write the history of the Isle of France, which is not within the compass of my design, but merely to give a general idea of it, I shall conclude, by citing an extract from a work which was printed in the island in 1784 , in order to refute the false assertions of an ignorant author, who had, in his writing, attempted to depreciate the colony.*

"Fortunately for these islands, the dreams of a traveller, who saw and observed every thing without reflection; who examined nothing to the bottom; who sometimes contradicts himself; is almost always incorrect, and often false in his assertions, and erroneous in his reasoning, cannot have any weight with persons of

- M. de Cossigny speaks here of M. Saunerat. 
understanding and information. So far I have opposed facts, discussions, and authorities, to the assertions and decisions of the author whose opinions I have combated. It is, therefore, only left for me to draw those conclusions, which may be considered as so many opinions given, in direct opposition to his assertions.

"I accordingly declare it to be my opinion, that the Isle of France will one day astonish Europe and Asia by its riches, the variety and abundance of its productions, and the resources of its numerous population: in the course of time, it will have very great influence on the commeree of Europe in the Indies, and incalculably extend the advantages of the nation who possesses it, in that quarter of the globe. A colony whose soil is fertile, the air healthy, and whose position is so fortunate, both for the operations of commerce and the plans of policy, must necessarily arise from its present state of mediocrity. It has not as yet acquired all that a sagacious minister, a wise administration, a constant and well directed labour of the colonists, and time, the operations of which perfects every thing, may procure it. Nature had clothed its soil with extensive forests, but industry and patriotism have collected here the greatest part of the useful productions of hot countries, as well as many of the natives of temperate climates, which flourish with luxuriance; so that, at present, it has more useful plants collected than any other part of the known world. M. Saunerat misrepresented this isle, without being sufficiently acquainted with it, and has slandered its inhabitants without knowing them.

" M. de la Bourdonnais, that great man, whom history already mentions with the eulogiums which he so well deserves, that great general, mariner, administrator, merchant, and agriculturist, entertained very different opinions; his knowledge of it was the result of several years passed in the government of it, and to him it is indebted for the sources of its prosperity: he considered the Isle of France as the key of the Indian commerce of his nation, as the bulwark of its settlements in Asia, and as the means of future conquests : he did more,- - he proved the exactness of his last views, by keeping the English fleet from the coast of Coromandel, and by besieging and taking Madras. His object was to make the Isle of France the entrepôt of the Indian commerce of France, and as a place of arms for its land and sea forces. His idea was to make it an agricultural, commercial, and military settlement.

Let us add another respectable authority. "Were it not for the Isle of France," says the author of the Philosophical History, "the French settlements in India could not be protected." He also adds, "that the Isle of France will always be 
ready to give assistance to Pondicherry, or to act offensively, according as circumstances may require. Indeed every thing may be expected from the Isle of France, when it shall have gained that degree of prosperity to which it must one day arrive, when its cultivation shall be more extended, and its population more numerous.

"Although the colony has undergone, in 1792 and 1793 , for the fourth time since its foundation, the destructive scourge of the small-pox, which has retarded its progress and diminished its forces; although it has been, as it were, abandoned to itself since the revolution, the English have not thought proper to direct their attacks against it ; they preferred the conquests of the Dutch settlements : they, however, are deeply interested in rendering themselves masters of it, in order to secure the power in Indostan, their new conquests, and their commerce, which this island interrupted by its privateers.

"' ' Policy,' says the Abbé Raynal, ' foresees that if the Isle of France were abandoned, the English would drive all foreign nations out of the seas of Asia, and would possess themselves of all the riches of these vast countries.'

" $\Lambda$ sses of Mascate have been transported hither; they are of a very fine and large species, and extremely useful, both for draught and burthen.

" $\Lambda$ lthough the greatest part of the houses are of wood, and generally have but a ground floor, they are nevertheless convenient and agreeable. Almost all the streets are in a straight line, and many of them are planted with trees. The air here is very healthy, but is cooler in the country, which is cheerful, pleasant, and well cultivated. The forests are stocked with many kinds of very fine indigenous trees, the wood of which is employed for building and repairing of vessels, as well as for many necessary purposes.

"The ordinary coffee, known in Europe by the name of Bourbon coffee, is the only coffee cultivated, upon an extensive plan, in the two islands; some of the inhabitants, through curiosity, cultivate two kinds of coffee, to which they give the name of Eden or Ouden, the berry of which is exceeding small, though it is much superior to the other, and even to that of Moka; but the plant bears little, is very delicate, and subject to perish: I wished to form a plantation of it, but could not succeed. There are in the forests of the island, towards the quarter of Poudred'Or, Maroon coffee plants, so called because they are indigenous, and grow without care or cultivation; they are common in the forests of the Isle of Bourbon. the bean is longer than that of the ordinary coffee; it is pointed at one of the 
extremities, and appeared to me have as fine an odour as the cultivated coffee, but of a more bitter flavour.

"In other parts of the island there is a fourth kind of coffee, which is not generally known. The plant is indigenous, and grows as high as the forest trees: its stem is slender, its leaves are long, broad, thick, of a dark green above, and somewhat paler beneath; the flowers grow in bunches at the extremity of the branches; they are white, and without smell, with five petals, and a white cup divided into five parts. The fruit, which in its early state is green, is round, but inclined to an oval, somewhat less than the cherry of the ordinary coffee; it whitens as it ripens, and becomes brown in drying; the pulp, which is white, is doughy, and of a sweetish taste; it generally envelopes two very small hemispheric berries, which are covered with a brown pellicule, having a tough coat ; they are grey, and somewhat pointed at one of the extremities. I made several persons taste it, who all found it of an agreeable flavour. My design was to form some plantations of it, on the presumption that cultivation, the open air, and the sun, would impregnate it with new and better qualities; but circumstances having determined me to quit the colony, I did not execute my design. This kind of coffee is to be met with in the environs of Palma, and even in the neighbourhood of the Reduit.* I think it superior to that of Moka ; and my opinion was confirmed by all who tasted it.

"It is usual, in the Isles of France and Bourbon, to dry the coffee cherry, and afterwards pound it, in order to take away the envellopes of the bean, according to the method of the Arabs of Yemen.

"I caused a water-mill to be built upon my plantation, which turns one millstone over another that is immoveable. The coffee in the shell falls of itself from the loft, which is above, between two millstones, and the necessary process is performed without the labour of hands. Nothing more was to be done but to separate the berries by winnowing, and to take away those that were spoiled or bruised."

- The country-house of the Governor of Mauritius. 


\section{CHAPTER XXX.}

Conclusion.-Abstracts of Events that bave bappened at Mauritius, up to the Year 1800.

SINCE my father's correspondence with the islands came to a termination, I have been too much occupied with my own immediate concerns, to give a particular attention to the succeeding course of events connected with them, even when it was most in my power, during my residence at Paris ; the Revolution soon followed, and the means of communication, as may well be imagined, in a great measure, if not altogether, failed me. The memoirs which I shall now present to my readers are the fruits of my later collections and researcbes: they bring the history down to the time that is passing by us; and this Volume will, I trust, be, at length, found to contain every event and circumstance that is necessary to give the most perfect knowledge of the Isles of France and Bourbon. But before I resume the subject, it will not, I flatter myself, be considered as presumptuous in me, nor be altogether uninteresting to my readers, if I give a very brief account of the tranquil and exemplary manner in which Baron Grant passed the latter years of his valuable life.

Disinterested in all his proceedings, as he was unassuming in his nature, he engaged in those pursuits, as a liberal occupation and rational amusement, which so many others have followed to gratify their ambition, and feed their avarice. With the power of making a great fortune, he did not acquire, in the long progress of twenty years, the third part of what others have obtained in as many months. But he fulfilled his object, which was to remove himself far away from the misfortunes that had overwhelmed his family, with so many others, by the catastrophe of the famous Law, so well known throughout Europe. He, therefore, went in search of that tranquillity, and of those resources which he had a right to expect, by joining his father's brother, in the Isle of France ; that uncle, who, by too much confidence in others, and his own rigid integrity, had involved his brothers and nephews in his own misfortunes:* he who invited my father to come and reside with him, to console and

- I allude to those occasioned by the failure of Law, \&s. 
support his afflictions and disappointments, by affording him a quiet and secure asylum, as well as a share in that fortune which had been acquired by a part of what had been saved from their common ruin.

The Baron Grant was content to enjoy these advantages, at the same time that he continued in the service of his country; for the sale of his property on quitting the Isle of France, produced only a few thousand pounds sterling; one half of which was taken from him on his passage to France. "What he saved was employed by him to discharge the claims on the only estate which now remained of the ancient patrimony of his family.*

On his departure from France, being only of the second branch of his family, (as the head of the first lived as long as himself, and died, without issue, in the same year with him), and not being in possession of any estate, as his father was yet alive, he thought himself fortunate in obtaining one, such as it was, among the Antipodes. At the same time his marriage with Mademoiselle de Grenville, in 1746 , attached him to it. But notwithstanding the loss which he sustained, and the misfortunes that afflicted him in his residence in the Isle of France, and on his return to Europe, he was disposed to forget them all, on arriving in his native country, and returning to his native home, after all the dangers which he had risked, and the troubles that he had suffered.

Being at length settled on his own domain, he was truly sensible of the happiness that is to be found by living with persons who, by near relation and consanguinity, are formed to interest, in the tenderest manner, those minds which are susceptible of refined impressions. He accordingly occupied himself in the education of his children, as well as in cheering the age, and, as much as depended on him, in prolonging the life, of a most excellent mother, who died in his arms; at the very advanced age of ninety-two, twenty years after his return to France.

But his attentions and regard were not confined to his domestic concerns and the care of his family. He had learned, in the office of Justice of the Peace, which he had exercised in the Isle of France, how to conciliate the interests of men; and necessity, as well as humanity, had induced him to acquire a knowledge of medicine; so that he was equally qualified to assist his tenants, his neighbours, and his friends, in their moral and physical infirmities; nor did he ever hesitate to employ these venerable functions, or refuse the time and expence which they required of him.

* The estate of Vaux, in Normandy. 
These are not the vain eulogiums or empty flattery of a son, anxious to consecrate the memory of his father; on the contrary, he feels himself restrained, by the modesty that becomes him, from rendering all the justice that is due to his virtues and eminent qualities, and which all who knew him were ever anxious to applaud and testify.

Having passed the latter years of his life in these useful, virtuous, and respectable occupations, he resigned it, in religious confidence, to the Supreme Being, in the month of June, $17^{84}$, and in the seventy-fourth year of his age.

\section{Abstract of Events that bave bappened in the Isle of France, up to the Tear 1800.}

The succour which Admiral Suffrein had constantly received from the Isles of France and Bourbon, in repairing and victualling the ships of his squadron during the whole course of the American war, had fixed the attention of the French government; and on the peace of $178_{3}$, they were seriously occupied about these islands. The languid state in which they had remained during the time they had been under the dominion and protection of the French East India Company, served as a lesson for the Ministers of France: they availed themselves of it in order to preserve them from falling into the same state, when, in 1784 , they established a new East India Company.

These islands therefore enjoyed the advantage of receiving into their ports all the merchant ships of France, which were not allowed to proceed farther, on account of the rights of the Company, whilst they were allowed the privilege of trading to all parts of India, China alone excepted. The Company were also engaged to furnish directly and annually to these islands the merchandize of Europe necessary for their consumption.

By this order of things the Isle of France became the centre of that commerce which several French merchants carried on in the Indies, by establishing their factories in it, and the commerce of this colony accordingly became both active and of great extent. The population suddenly increased beyond its means of cultivation, and the Isle of France became a commercial entrepôt rather than an agricultural colony.

But the power which the governor and the Intendant of this colony enjoyed had been exercised in such an arbitrary manner, that several of its inhabitants became 
anxious to free themselves from it; and the distance of the mother-country increased their impatience to know the events of the French revolution, which began in 1789 . The colony was then governed by Lieutenant-general Conway. The Intendant, M. Dupuy, formerly couisellor of the Chatelet at Paris, amiable in his manners, and possessing a superior capacity, succeeded, by his mild conduct and vigorous policy, to conciliate the confidence and friendship of the colony; M. de Macnamara commanded the marines. In the last war he had gained, as he well deserved, the reputation of a brave and skilful officer, and was decidedly against the revolution.

A vessel which sailed from Bourdeaux at the end of October, 1789, and arrived at the Isle of France at the end of January following, brought the news of the great power the National Assembly had usurped to itself. The captain of the vessel, officers, and ship's crew wore the three-coloured cockade. On their landing with this revolutionary signal, and relating the late occurrences that had taken place in France, the flames of revolutionary conflagration instantly burst forth in all parts of the colony, and the cockade was very generally adopted. Some young men of the town, wishing to avail themselves of this moment of effervescence, posted up advertisements in the streets, inviting all the citizens to form themselves into primary assemblies, after the example of those which had taken place in all the communes of France, in order to draw up memorials of demands and complaints.

General Conway, the Governor, perceiving that the principles of the French revolution had infected the people, determined to oppose it by his authority. $\mathrm{He}$ accordingly sent some soldiers to arrest the young men who had posted up the advertisement, and went to the Intendant's house, to consult with him on the occasion. But the people had been collected in the square, and the young men whom the Governor-general had just caused to be arrested, happening to pass at that moment to prison, they were set at liberty by the multitude, who went immediately to the Intendant's house, and compelled $\mathrm{M}$. Conway himself to accept of the national cockade.

On the following day the inhabitants of the town united in a primary assembly, after the example of France, and established the different constituted authorities, to whom they confided the interior government of the colony.

1790. M. de Macnamara, Commandant of the French marine in the Indian seas, arriving at the Isle of France during this state of perturbation, could not 
conceal his aversion to their revolutionary proceedings. The soldiers of the 107 th and 108th regiments, who formed the garrison of the island, following the example of the army in France, had abandoned themselves to the cause of the revolutionists. M. de Macnamara, however, thought it his duty to give an account of it to the minister of marine, but he was betrayed; a copy of his letter was sent to the barracks, and incited the soldiers to threaten him with their vengeance. The grenadiers therefore collected themselves in a body to go to the port, in order to seize upon all the boats and canoes they might find there, that they might go on board M. de Macnamara's ship.

Being informed, however, of the preparations that were making to seize his person, he had made ready his cannon, but at the moment when the grenadiers presented themselves to mount on board, his sailors refused to defend him, and he was left to the discretion of these furious men, who conducted him on shore, and led him as their prisoner before the first constituted authority of the colony, then sitting in the church, and loudly demanded that he should be punished.

The fermentation of the soldiers had risen to such a pitch, that it was not possible to appease it ; so that the members of this constituted authority found it necessary to make M. de Macnamara undergo several interrogatories, and to send him to prison for his own security; with the hope that they should thereby appease the fury of the soldiers, who unfortunately resolved to conduct him thither. In his way to confinement, $M$. de Macnamara passing before the door of a watchmaker of his acquaintance, conceived some hopes of escaping from the midst of these furious people, that escorted him. With this design he rushed in at the door, which was open, flattering himself that by using his pistols which he had in his pocket, he should intimidate those that dared to follow him; but his threats only increased the rage of the soldiers, who threw themselves in a crowd upon him and murdered him, giving to the Isle of France an horrible example, the remembrance of which still makes them shudder with indignation. The inhabitants were distressed and humiliated at seeing their country, till then unspotted with any crime, stained with such a bloody outrage. It was, however, the only one that happened during the whole course of the revolution; whilst France itself and all its other colonies have been inundated with the blood of so many victims to democratic injustice and barbarity. 
1791. M. de Conway then resolved to set out for France, and was replaced in the interval by M. de Cossigny, who commanded at the Isle of Bourbon.

1792. M. de Malartic, named likewise by the King as Governor-general, arrived at the Isle of France in June, 1792. The colonies were then governed by their particular Colonial Assemblies, whose decrees had the force of law, when they had received the sanction of the governor, who represented the state.

He had, moreover, the command of the military force, and the regulation of the interior department.

The Intendant was charged with the administration of the finances.

1793. When the news of the power of the Jacobins in France was brought to this island, the Jacobin club was established, which was called the Chaumiere.

In 1794, the Chaumiere club soon rivalled the constituted authorities. The members of this club of the Isle of France forced M. de Malartic to grant them a sloop to convey one of their detachments of about one hundred men to the Isle of Bourbon, in order to arrest M. Duplessis Vigoureux, the Governor; M. Fayol, the Civil Commissary; and M. de St. Felix, formerly Commandant of the Marine, on the pretext that they corresponded with the English. They executed their design, and brought these three prisoners away on board the sloop. On their arrival at the Isle of France they were landed under an escort from this detachment, and were conducted to the Chaumiere. The president, who was formerly a police officer, said gravely to them, "the people accuse you, and the people will judge you." They were then conducted to the dungeon, where they were fettered, and they remained there about six months.

The Chaumiere, in the mean time, fixed up a guillotine in the public place, in expectation of making use of it against these victims of their suspicions.

The Colonial Assembly, better composed, succeeded in putting a stop to the effervescence of the Jacobins, by ordering that these prisoners should be judged only by a court martial, named by all the citizens of the colony, united in primary assemblies, each in its own district. This method occasioned a delay that gave them time to concert together, in order to contrive that the choice of members of the commission might fall upon upright persons, and this design was crowned with success.

At this moment an account arrived of the decree abolishing slavery in all the settlements of the French Republic. This news, which so deeply interested the inhabitants of the colony, operated a great change in their opinion concerning the 
revolution; and from that moment the Jacobins of the island were composed only of bad men, who had no other object than to disturb the government. The military commission nominated for judging the prisoners, found no difficulty in dissolving itself, by objecting to the mode of its institution.

The news of the downfal of Robespierre, and of the Jacobin clubs in France, being then brought to the colony, the Colonial Assembly, already strong from the change that had taken place in the public mind, freed itself from the yoke of the Chaumiere, by causing the different Jacobin leaders to be arrested, and shutting up the place of their meeting. The guillotine was taken away from the public square, and the prisoners were set at liberty without having undergone any trial, for which there were no solid grounds, in the general opinion of the colony.

The principal Jacobins, to the number of thirty, who had been arrested, were immediately sent to France.

1795. The information the colony had acquired respecting the decree that gave freedom to the Negroes, kept it in the greatest anxiety, on account of its attachment to France, as well as the certainty of the misfortunes which such a measure would occasion, the moment it was put in execution. The events of St. Domingo presented a most frightful picture of the consequences restilting from it.

The planters, who are the greatest proprietors of Negroes, were alarmed at their situation, as they well knew that their existence was but precarious while the decree remained disannulled; and perhaps they entertained the opinion that they should be happier if they belonged to a government that would protect their property. But they whose fortune depended upon commerce, and who had already formed to themselves exterior resources, as well as those who in time expected to form them, preserved a passive attachment to France; wishing, however, to retard as much as possible, but without compromising themselves in the business, the execution of this decree, if an official order should arrive to that effect, and particularly if it were supported by a power adequate to that object.

1796. Such was the state of opinions when, on the 18 th of July, a squadron of four frigates, under the command of Vice-Admiral Sercey, presented itself, having on board two agents of the Directory, named Baco and Burnel, sent out to take upon them the government of the colony. It being the Decad,* almost all the merchants of the town, according to custom, were gone to their country-houses, as well

- What the French, now, term Holiday. 
as several members of the Colonial Assembly. However, on a signal being given from the mountains, announcing the arrival of this French squadron, they all hastened to the port; but although some general measures had been taken to prevent the entrance of any one into the colony, without the permission of the Colonial Assembly, the division of $\Lambda$ dmiral Sercey was already anchored at the mouth of the harbour; and the agents, dressed in their directorial costume, had left the ship, followed by a company of grenadiers, belonging to the transport troops which they had on board, who were commanded by General Magalon.

The officer commanding the pinnace of the harbour remonstrated in vain witl the agents against their landing, until they had received permission from the Colonial Assembly, subscribed by the Governor-general.

No force being prepared to oppose the landing of the agents, they received no interruption, and the people, having assembled in crowds to meet them, flattering themselves that they brought orders favourable to the colony, they were conducted, with all possible respect and ceremony, to the Colonial Assembly, which had assembled in haste at the usual place of their session.

Being admitted as agents of the directory, their speeches on the occasion were most flattering for the colony, as they announced that they were charged with a commission from the Directory, which had no other object than the real happiness and prosperity of the colony. They were accordingly received in the most respectful manner. However one of the members of the Assembly, more courageous, and possessing more forethought than the rest, demanded if there was not also a commission named to receive from the agents the orders and instructions with which they were charged, and to give an account of them to the Assembly.

This question was evaded by the agents, who that very evening were installed in the government-house.

On the following day, 19th July, they reviewed the two regiments, the $107^{\text {th }}$ and 108th, which formed the old garrison, and caused the battalion, of about eight hundred men, and two companies of artillery, which they had brought with them, to be landed. At the review they flattered the soldiers, and seemed to blame the colony, on account of their receiving their pay in paper. Their discourse soon spread abroad, and began to confirm the fears of those who were alarmed at the arrival of persons, who, by their great powers, became the arbiters of their fate: they had, indeed, been already struck by the evasion of the agents to produce their 
instructions ; nor was it long before they were confirmed in these sentiments, as the agents, thinking themselves fixed in their situation, sought for a pretext to quarrel with the Governor Malartic, and even went so far as to threaten to have him hanged. They were likewise so imprudent as to menace, in the same manner, M. des Crozilles, the member of the Colonial Assembly, who had demanded that their instructions should be laid before them.

July 2oth. The agents reviewed the national guard of the port, and were astonished to find it about four thousand strong. In short, they were received with an appearance of mistrust, which became general. These fears were communicated to the inhabitants of the interior parts, who, having conferred together, came armed to the town.

During these two days the Colonial Assembly, particularly charged with the safety of the colony, had established a committee of nine members, to correspond with the agents, and endeavour to obtain some information of their future intentions.

The silence, in which they persisted, no longer left any doubt of their design of putting into execution the decree abolishing all slavery in the French colonies. The inhabitants therefore, being convinced of the imminent danger which threatened them, were influenced by one common determination to engage in the dismission of the agents; but as it was apprehended that the troops might support them, twenty young Creoless devoted themselves to the welfare of the colony, and vowed the death of these instruments of republican despotism.

In this morning, of the 21 st of July, almost all the inhabitants of the colony were assembled on the public place at the door of the government-house, where the agents continued to reside, although informed of the danger which threatened them.

The Governor-general Malartic was taken from his government, and carried in triumph to the Colonial Assembly. The agents then ordered General Magalon, who came with them, to cause the troops to take arms against the inhabitants: this order the general excused himself from obeying, by declaring that as he was under the command of General Malartic, he could receive none which had not his signature affixed to them. The agents in vain informed him that they deposed General Malartic, and appointed him as his successor.

In the mean while some young Creoles entered the government-house, by the windows, and announced to the agents that, being charged with orders that brought on 
the destruction of the colony, they deserved death; at the same moment one of the agents narrowly escaped being killed by the discharge of a pistol, and the other was preserved by the Commissioners of the Colonial Assembly, who at that instant were treating with them.

The inhabitants, informed of this event, and seeing the soldiers remain quiet in their quarters, contented themselves with insisting on the immediate re-embarkation of the agents, a requisition to which the members of the commission acceded: and, having persuaded the agents to submit, they accompanied them in person, in order to preserve them from the general indignation: and, in this manner, conducted them on board a sloop, which had been just ordered to receive and take them to the Phillippine islands. This destination had, without doubt, been preferred, as being one of the most remote places from France. This order had bcen obtained by the Colonial Assembly from General Malartic, who, during the whole of this tumult, was present with them.

The sloop; Le Moineau, having, in twelve hours, received all the necessary stores for its voyage, got under sail for its destination; but, on the morrow of their departure, having dressed themselves in their directorial costume, they harangued the crew, and soon induced them to mutiny against the captain, and consent to return to France, after having put in at Madagascar, to take in the stores necessary for so long a voyage.

The colony, thus freed from the presence of the agents, gave themselves up to transports of gratitude towards the military cliefs and troops who had refused to shed blood. Every one eagerly contributed voluntary gifts in favour of the soldiers, and good order was re-established under the administration of the constituted authorities. An advice was sent immediately to France, with an address of the Colonial Assembly, as well to the two Councils as to the Directory, giving an account of the dismissal of its agents, and representing it in a manner, as may be supposed, the most favourable to themselves.

The imminent dangers to which every one had been exposed, from the sudden emancipation of the slaves, with which they had been threatened, had, in a moment, rallied every one, as it were, to the common standard, and produced this union of the whole colony, for the immediate dismissal of its agents. Every one congratulated himself on such an happy event, and entertainments were given on the occasion throughout the colony: 
"But in a very short time a difference of interest rekindled discord, and some evil spirits, always active in fomenting mischief, conceived the hopes, by means of the soldiers in the garrison, of renewing the public disorder. The soldiers, to whom the colony continually gave proofs of its gratitude, in order to maintain peace, abused

- the kindness with which they wcre treated, and having given themselves up to licentiousness with the Negro women, formed a plan of freeing them from the servitude which retained them with their masters, by proclaiming their freedom.

1797. The Colonial Assembly, who watched without ceasing for the preservation of the island, being informed of the fresh dangers with which it was threatened, succeeded in obtaining from the Governor-general Malartic an order for sending to Batavia all the soldiers who came with the agents, under the division of Vice Admiral Sercey, which was executed towards the end of the year ${ }^{1} 797$, on pretext of assisting a colony, in alliance with them, and which was threatened by the common enemy.

1798. This is the epoch when two ambassadors from Tippoo Sultaun arrived at the Isle of France. The following is a copy of the proclamation, published on this occasion by the Governor-general Count de Malartic.

\section{MALARTIC'S PROCLAMATION.}

LIBERTY.

EQUAITX.

THE TRENCH REPUBLIC, ONE AND INDIVISIBLE.

PROCLAMATION,

By Anne Fosepb. Hyppolite Malartic, Commander in Cbief and Governor-general of the Isles of France and of Reunion, and of all the French Establisbments to the Eastward of the Cape of Good Hope.

\section{Citizens,}

HAving for scveral years known your zeal and attachment to the interests and the glory of our Republic, we are very anxious, and feel it a duty, to make you acquainted with all the propositions which have been made to us by Tippoo Sultaun, who has sent two ambassadors to us.

- A particular expression employed by the republicans, meanivg of the Isle of Bourbon. 
This prince has written particular letters to the Colonial Assembly, as well as to all the generals employed under this government, and has addressed a packet to us for the Executive Directory.

1. He desires to form an offensive and defensive alliance with the French, and proposes to maintain, at his charge, as long as the war shall last in India, the troops which may be sent to him.

2. He promises to furnish every necessary for carrying on the war, wine and brandy cxcepted, with which he is wholly unprovided.

3. He declares, that he has made every preparation to receive the succours which may be sent to him, and that, on the arrival of the troops, the commanders and officers will find every thing necessary for engaging in a war, to which Europeans are but little accustomed.

4. In a word, he only waits the moment when the French shall come to his assistance, to declare war against the English, whom he ardently desires to expel from India.

As it is impossible for us to reduce the number of the $107^{\text {th }}$ and 108 th regiments, and of the regular guard of the port of Fraternite, ${ }^{*}$ on account of the succours which we have furnished to our allies, the Dutch, we invite the citizens, who may be dis, posed to enter as volunteers, to enrol themselves in their respective municipalities, and to serve under the banners of Tippoo.

This prince desires also to be assisted by the free citizens of colour : we therefore invite all such who are willing to serve under his flag, to enrol themselves.

We can assure all the citizens who shall enrol themselves, that Tippoo will allow them an advantageous rate of pay, the terms of which will be fixed with his ambassadors, who will further engage, in the name of their sovereign, that all Frenchmen, who may enter into his armies, shall never be detained after they have expressed a wish to return to their own country.

Done at Port North-west, the 3 oth of January, $179^{8}$.

(Signed) MALARTIC。

- Meaning the Port Bourbon of Mauritius. 


\section{Malartic's Letters to Tippoo Sultaun's Ambassadors.}

\section{GeNTLEMEN,}

Isle of France, the 27 th of February, 1798, 6th Year of the Republic.

I am too sincere in my nature to suffer you to remain ignorant of the great dissatisfaction which your letter of this morning has given me. Your Sultaun deputed you to solicit our aid on such conditions as we might deem just, and not on those which you now prescribe to us.

The demands which I have proposed to you, within these few days past, were framed by General Dagincourt, who is particularly known to your Sultaun, under whose orders he served when a captain of grenadiers in the battalion of the regiment of the Isle of France, which made a campaign during the last war, under the Bahaudar and Tippoo Sultaun; I therefore persist in demanding, for all the officers and volunteers, the pay and provisions stipulated in the last statement which I transmitted to you.

The pay which was granted ten years ago, cannot be made a rule for the pay which ought to be given now.

Those who at that period received 150 rupees per month, now demand 600 .

As you do not choose to take surgeons; you shall not have them; but your naster will not be satisfied with your conduct on this article.

The officers and volunteers who are to accompany you, shall not make a journey of 500 leagues to ascertain what pay Tippoo Sultaun may choose to fix for them. I shall order them not to disembark, until Tippoo Sultaun shall have satisfied them that he will allow the pay and provisions which I propose to him.

We have not sought you, you came to solicit our aid: you ought, therefore, to submit to the conditions which I propose to you : they are just and reasonable.

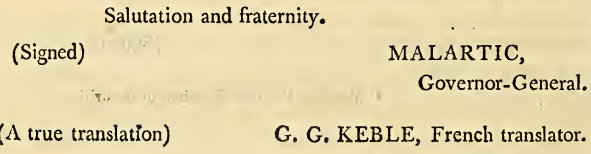




\section{Narrative of the Proceedings of Tippoo Sultaun's Ambassadors.}

The following Circumstances were taken down, as dictated by Ripaud, on board the

Vessel, on the 27 th of Zaukree, 1225, of Mabommed, answering to the 15 th of December, 1797 .

IT has been ordered by the sacred Presence, that (we) must bring thirty thousand horse and forty thousand infantry, one hundred guns and mortars, with their equipments and artillery men, to join the French force. Provisions, carriage, conveyance, and military stores, shall be furnished by the Khoodadaud Sirkar. This article was not brought forward.

That we should forward as great a number of Europeans as we can, together with twenty or thirty thousand men of colour, who know their exercise well, and commanded by experienced officers.

That the generals who may be sent on the part of the French be masters of their profession, such as General Magalon: and as our king is better versed in the systems of India, the French Generals must consult with him, and carry on operations against the enemy, in concert with him.

Whatever may be taken in this war from the enemies of our king and the republic, such as towns, forts, factories, effects, ships and vessels, money, \&c. or whatever cash or treasure be taken from nations in subjection to them; all these must be divided into two equal parts, one half for our king, and the other for the republic ; excepting the country of the Khoodadaud Sirkar, which the English formerly wrested by force of arms; such country will be retained by the Sirkar, and the French are to have no share in it.

Should the French republic be desirous of making peace with the English, they are not to conclude such peace without our king being comprehended therein; because, after the treaty of alliance, the enemies of the republic will be still the enemies of our king, and it would be inconsistent with ofriendship and justice not to include him in the peace.

Should any one in the service of the Khoodadaud Sirkar enter the French camp, and commit any outrage, let him be apprehended and sent to the Presence, in order that he may be punished according to the forms of the Khoodadaud Sirkar; and, in the same manner, should any one of the French army enter the camp of our king, 
and be guilty of any outrage and irregularity, he shall be immediately apprehended, and sent to the general of the French army, in order that he may punish him agreeably to his own customs. This article was not brought forward.

Should these propositions be approved by the republic, we request the leaders of the mother-republic to transmit speedy intelligence thercof to our king, by a small vessel, in order that his highness, in person, may set on foot a formidable and victorious army, to meet that of the French in the neighbourhood of Mirjaun, which place is near to Goa. Oh, French nation! with a view to the mutual interests of the parties, our king intended to'send several letters under his august seal and signature, with four sirdars of high rank, for the purpose of negotiating, in a ship belonging to the Khoodadaud Sirkar, to the chiefs of the mother-country : but the apprehensions of the enemy, and the unfavourableness of the season, prevented this design from being put in execution. A standard of the republic was, however, quickly prepared, and set up in the camp of Lally; which his majesty caused to be saluted with three thousand guns. *

Ripaud and Mons. de Bay can bear testimony to this fact: and whereas our king has declared, that he will thus support the standard of the republic : O French nation! if ye will but consent to these propositions, you need not hereafter fear your enemies. Tum your thoughts only to the protection of your island, for our king will keep the English so employed and embarassed, that they will be unable to turn their attention towards you. Further, Zemaun Shab, king of the $\mathrm{Afghauns,}$ and the greater part of the Indian powers, are united with our king for this purpose, and will not cease until they shall have driven the English out of India.

\section{O Protector! $\uparrow$}

\section{Supporter of the world-Health!}

- Here follow the names of various implements of war, probably meaning ordnance, muskets, and rockets; but the usual appellations being changed according to Tippoo Sultaun's system, it is not known what species are here designated. This alludes to the ceremony of consecrating the national flag, of which a detailed account is given in the journal of the sittings of a jacobin club, which had been established at Seringapatam, under the auspices of M. Ripaud. This curious paper, in which the Sultaun is styled le Citoyen Tippoo, was found in the palace at Seringapatam. + An invocation to the Deity. 
The particulars of our proccedings, from our first leaving Jemaul-abaud, until our arrival at the port of Cowriaul, Mangalore, in the Khoodadaud Sirkar, are as follow :

On Sunday, the 17 th of Zaukree, 1225 of the birth of Mahommed ( $5^{\text {th }}$ December, 1797), we embarked. Ripaud* occasioned the delay of a day or two in adjusting the equipments of the vessel, \&c. On the 19 th, we weighed anchor. After proceeding five or six coss tout to sea, Ripaud, accompanied by several persons, came to us in a very disorderly manner, desiring us to shew them the letters which had been entrusted to us for the Siŕdars, or chiefs, at Mauritius : we observed, that our orders from the Presence were, not to open the dispatches until our arrival there, and that it was not becoming in him, who had laid the foundation of the present expedition, and was acquainted with all circumstances, to take such a step. But our persuasions were of no avail ; for he took the dispatches from us by force, and, tearing open the leathern envelope, wanted to open the libereetabs $\neq$ also ; we told him that he would be disgraced, and his improper proceedings exposed to his whole nation; adding, that it was highly unbecoming in him to be guilty of such treachery and misconduct: that until our arrival at Mauritius, we respected these kbereetabs as our lives, and that we would sacrifice them in our endeavours to deliver these kbereetabs as we had been directed by the Presence. Upon this, he restored them to us. The next day he came to us, and desired that we would make over to him the money which had been given to us by the Presence, for him and his French associates, otherwise, said he, I will go to Umba'ee (meaning, perhaps, towards Bombay), and other parts, for plunder, and will

- Ripaud, who commanded a French privateer, was, by stress of weather, obliged to put into Mangalore, in the latter part of $179^{6}$. He was there apprehended, sent to Seringapatam, and confined. Ripaud (who is a violent republican), being interrogated by 'Tippoo Sultaun with respect to the disposition and ability of the French to co-operate in an attack against the English Company's possessions, encouraged the Sultaun to expect a powerful co-operation; and to effect his delivery, magnified the resources of his nation, and induced the Sultaun to believe, that a very considerable force was already assembled at the Isle of France, and only waited his sumnons. Tippoo therefore retained Ripaud as a vackeel, and sent him with his ambassadors to Mauritius.

+ A coss is usually reckoned equal to about two miles English.

$\ddagger$ Khereetahs are the bags or cases of tissue, or silk, in which letters addressed to persons of rank are usually enclosed. 
coast it for five or six months. We answered, "You know very well, that the money which his highness assigned for our expences was entrusted to us in your presence, by Shaik Ahmud, Mullik-oo-Toojar; it is, therefore, very unbecoming in you to make this request."

Refuge of the World, health! He assigned for our accommodation the part of the vessel appropriated to the Lascars, without any place for us to sleep or sit down; and our inconveniences increased daily: at last we desired Ripaud to allot some place for us to remain in until our arrival at the Mauritius; upon which he gave us a small doney (boat), which was on the vessel, to sleep and eat in, until our arrival at the island. From the day of our leaving Mangalore, until our arrival at Mauritius, he gave us no more water than he allowed to the Lascars, which only sufficed for drinking, and was not enough for cooking. In the course of the voyage, he took two vessels; when taking the cargo out, he released them. After ten or twelve days we steered directly for the Mauritius.-Ripaud sent a message to me,* proposing to recite to us the commands which your highness had entrusted to him, respecting the negotiations with the sirdars of the Mauritius; that we should take a translation of them, and make our representations accordingly, at the island. We replied, that the Shaik Ahmud, Mullik-oo-Toojar, had communicated to us in his (Ripaud's) presence, orders to this effect, that whatever he (Ripaud) should dictate to us, or tell us, we should make our representations accordingly to the sirdars above-mentioned, through the medium of Monsieur de Bay. Ripaud brought several papers to us, and dictating to de Bay, caused him to write several articles; which being done, he said, that they were in conformity to the orders of the Presence, and desired that we would regulate our negotiations by them. It is impossible to describe the distress we suffered from the rain and the motion of the waves. However, by the favour of God, and your majesty's auspices, we

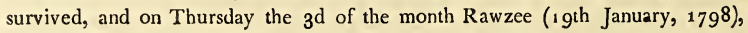
being arrived within two coss of the Mauritius, a pilot came off in a boat to learn the circumstances of the ship. He came on board, and Ripaud received him with a great deal of cordiality ; he told him that we were ambassadors sent by your highness to the sirdars of the Mauritius, and desired that he would send some one on shore to give the proper notification. The pilot immediately sent a Lascar, with a

- The vakeels are designated, throughout this paper, by the term ghoolaum, or slaves. Here the word is in the singular number, and is, perhaps, intended to apply to the writer only. 
verbal message, to the general: and in two or three hours *after, a physician came to ascertain the people's health on board the ship; he accordingly sent for all who were on board, and inquired into the state of every man's health : he then came up to us, and made a salam, or obeisance, and told us, that he would immediately send notice to the general, of our arrival: we desired him to allot some place for our accommodation on shore, and enable us to disembark, adding, that in a day or two after, we would commence our interviews with the sirdars; requesting that our arrival might not be made known.

The physician, after remaining an hour, returned to the sirdars, and before two hours had elapsed, sent four persons of rank with a verbal message, stating, that he was extremely happy at our arrival, and would send for us the next day; we replied, by requesting that he would send for us clandestinely, so that it should be known to no one; they replied, that they would make their report to the general, and act agreeably to such orders as he might give. They then departed. In the mean time, Ripaud carried the ship near land, and dropping anchor in the mouth of the river, immediately went to the general. At twelve o'clock at night he came on board again, and told us that he had represented every thing to the general : but before his return, five or six sirdars, and two aides-de-camp of General Malartic, came to us on board the vessel, and told us that they must conform to the custom of their nation, and that if they did not receive your highness's ambassadors with due respect and attention, they would be censured from home. We used every argument in our power to dissuade them from that intention, but to no purpose. The next day, the soldiers were drawn up in two lines, from the bank of the river to General Malartic's house, by his particular directions. He also sent several officers in his own boat to meet us, and conduct us to his house ; accordingly we went on shore in the boat, and immediately on our landing, near a hundred and fifty guns were fired; and we were conducted, with the utmost degree of respect, to the sirdars. When we arrived at General Malartic's house, the general himself, General Sercey, the members of the council, $t$ and other sirdars, met us at the door of the house. The general seated us on chairs at his right hand. We presented your highness's compliments to all the sirdars, and told them, that the object

* The hours in this paper must be understood to mean the Hindostany ghurry, consisting of about 23 or 24 minutes.

+ The Colonial Assembly. 
of our coming was to inquire after the health of your majesty's friends, as no news of them had reached the Presence for several years, and therefore your majesty had deputed i's to all the sirdars, that we might ascertain and return with an account of the welfare of your majesty's friends. I then took the kbereetabs, containing your majesty's letters, in my hands, rose from my seat, and addressing the sirciars, told them that they must take the royal letters with respect. Upon this, General Malartic arose, and taking off his hat, received the letters from my hands. In the same manner General Sercey rose from his place, and came up to me, and then I delivered to him his letter also. General Magalon was not then present, but General Malartic told us, that if we would deliver to him your highness's letter to General Magalon, he would take care to convey it to that officer, and obtain his receipt for it : we accordingly delivered the august letter into the hands of General Malartic. When I afterwards inquired who was the president of the council ; Malartic desired Monsieur des Combres to rise and take the letters. At the time of our landing, we desired Ripaud to accompany us, which, however, he did not ; but, in about one hour after our arrival, he came to the assembly, and holding his hat under his arm, stood at a distance. We told General Malartic that Monsieur de Bay had been sent from the Presence to be the interpreter between him and us, in any negociations which might take place between us; in consequence of which, he called de Bay, and observed to him, that in your highness's letter Yoosuf-Alli was mentioned, as the person deputed, whereas our names were Hussem-Alli and Shaik-Ibrahim, and desired to know the reason of this. This being explained to us by de Bay, I answered, that MeerYoosuf-Alli had been originally appointed, but being afflicted with illness, he had been set aside, and your highness had deputed us instead. We then told General Malartic that we had several points of a secret nature to communicate to him, and therefore if he would send for us in private, we would unfold to him what your highness had directed. General Malartic answered, "At three o'clock we will visit you at your place of residence ;" we then took our leave. General Malartic provided us both with palanquins, and directed the bearers to remain with us as long as we continued on the island, and he gave us a garden close to the city to reside in. At three o'clock all the sirdars came to visit us: we accordingly went to meet them as far as the garden gate, and conducted them into the house with all due ceremony and respect. We seated them on chairs, and addressed them to this effect: "The object of our king, in desiring to form an alliance with the 
"French republic, is to crush our already half-expiring enemy;-what do you wait "for? His majesty is ready to afford you succours; shew yourselves, therefore, in "India. The unbounded violence and oppression of the English have rendered all " the princes of India their enemies; they are enfeebled on every side, and from the " great extent of territory, which they have acquired by artifice, they are dispersed " in all quarters. Look upon the present time as a most fortunate opportunity; send a "large army, and an extensive train of artillery, to the assistance of our sovereign, and " after chastising our mutual enemies, drive them out of India. The English " tremble at the very name of our sovereign and of the French, and will not be " able to withstand his power, when it is supported by the aid of the French repub" lic, but will be defeated in every quarter. It is well known to the republic, that " both his late majesty, and our present sovereign, have at all times been the friends " and well-wishers of the French nation; have always sought their assistance and sup"port, and made common cause in the wars against their enemies. The wish of " of our sovereign is this, that, by affording assistance to the republic, the French " name may become as honoured and exalted in India, as it is through Europe and " among the Mussulmen."

The sirdars asked, if an auxiliary force should be furnished from Europe, would your highness supply them with provisions, military stores, conveyance, and carriage? We answered, that from the day of the landing of the French army in India, your highness would supply them with provisions; that is to say, rice, meat of every kind, and ghee (excepting, however, European liquors), military stores, conveyance, and carriage. They then told us, that, for the purpose of procuring a large military force, they would fit out two ships of war, which should be dispatched to France, with letters from themselves, together with your highness's letters addressed to them, which would be given in charge to two confidential persons of rank; and they desired that we would give them a memorandum of the provisions and carriage which we had promised them, in order that they might forward it to Europe, and speedily obtain the military succours required. We replied, that we would the next day furnish them with the account they requested. They then rose and went home. In the morning they sent the principal aid-de-camp and * __ Dewan, t to us; who said, that General Malartic sent his compliments, and desired him to mention, that he and the other three sirdars were about to write letters to the government in Europe, and

- It does not appear who the other was.

+ Supeiintendant of the finance, or revenue, 
therefore he requested that we would furnish him with the memorandum which we had promised, with respect to provisions and carriage. Having accordingly drawn up a memorandum with regard to provisions and carriage, we sent it by Mons. de Bay to General Malartic. Cherisher of the World, health!- These four sirdars have each written separate letters, to procure a large force for the assistance of the Sirkar; and have deputed two confidential persons, one Mons. _- , the principal aid-de-camp, the other Mons. Magon, a captain, in order to represent the excess of your highness's friendship and attachment, and charged with your highness's letters addressed to General Malartic, \&c.

Accordingly, on the 7 th of Rauzee, 1225, of the birth of Mahommed, (23 d of January, 1798), they were dispatched to Europe, on two ships of war, with the utmost caution. After two or three days, with a view to strengthen the foundations of friendship and attachment, we caused a paper to be drawn up by Monsieur de Bay, to the following purpose, and sent it to General Malartic; viz. that, in order to cement the basis of friendship and alliance, it was necessary that botb parties should bind themselves by oaths, in order that the system of harmony and friendship, subsisting between your majesty and the French nation, might be confirmed, and while the moon should keep its course, this alliance should remain unimpaired and unviolated. General Malartic returned for answer, that the ratification of the alliance by oath depended upon the government in Europe; that the friendship between the Khoodadaud Sirkar and the French nation was fully established; that there would never be any diminution of that friendship and union, as long as the moon retained her course; that the enemies of their state were the enemies of the French nation; that your highness would soon have an opportunity of seeing what the devotion and friendship of the French nation would effect, with the view of crushing the enemy; and that he was from his heart the devoted servant of your sirkar.

Refuge of the World! In consequence of the severity of a sea voyage, and unfavourableness of the climate, I was so much indisposed, that General Malartic's Dewan remarked it, and told the general that I was extremely ill; in consequence of that information, he immediately sent two of the first physicians to attend me, with a message, that on the next day, at three o'clock, he would come himself to visit me. The following day General Malartic came accordingly, and after making inquiries respecting my health, he said, that Ripaud had made an erroneous representation to your highness,

* Name illegible. 
which occasioned us to be deputed, that had we arrived four months before, he could have sent us back with one thousand Europeans, until the arrival of the army from Europe, but that those troops had now been dispatched to Batavia, to the assistance of the Dutch. Still, however, he would manifest his devotion in the best manner he could, and that he would not send us away empty-handed. He then asked in what places your highness had factories established, and what was the practice of the sirkar with respect to the establishment of factories? and desired us to send a memorandum upon the subject. The next day we caused de Bay to draw up a reply, to the following effect, which we sent to General Malartic; viz. "That your highness had " established factories at Muscat, at Kutch, at Bussora, and in other principal cities; " that two confidential persons were kept at each factory to buy and sell; and that if " he were willing that a factory, on the part of your highness, should be established "6 at the Mauritius, we could represent it to your highness, and that if you approved, " a factory should be established accordingly." Some days after, General Malartic sent for us, and told us, that he readily agreed to the establishment of the sirkar's factory at the Mauritius, adding, that he would appoint a dewan to superintend it, who would provide such articles as your highness required, at a favourable rate, and also that he would assign a house, belonging to the Company, for the purpose.

In the course of three days, I sent a note by Monsieur de Bay to General Malartic, requesting, that he would procure some plants of the nutmeg and cloves, some European fruit trees, fine coloured and sweet scented flowers, and filling some wooden boxes with earth, plant them therein, and send them carefully back with us, to be presented to your highness. The general immediately sent for the gardener, and directed him to prepare the plants in the boxes, with the utmost expedition. At three o'clock, we received a visit from General Sercey; we advanced to meet him, conducted him into the house, and seated him on a chair. General Sercey said to us, that, please God, some large succours would very soon arrive from Europe, and that it was his intention to accompany the troops to your highness. We then told him it would be very desirable, if he could send back with us, five or six experienced navigators, several ship-builders, and iron cannon founders; to which General Sercey agreed, promising to send them with us on our return. After sitting two hours, he rose. General Malartic, soon after, sent a message by his Dewan, inviting us, the following morning, to see the powder mills, gardens, and mortar-firing (adding, that he should be at the powder works before us. Early 
in the morning, accompanied by de Bay, we went to the powder works, and immediately on our alighting from our palanquins, at the gate, we were saluted with twenty-one guns, the soldiers were drawn out in two ranks, while several officers came out to meet us, and conducted us to General Malartic and General Sercey, who met us at the head of the stairs, and taking our hands, seated us upon chairs, and then proposed to shew us the works : we answered, that it was just as they pleased; their pleasure was ours. They immediately rose, and shewed us all the works. We then went without the gates, where they directed the artillery-men to fire the mortars at the targets, which they did fifteen times. They then requested that we would go and see the garden, with the plants of nutmegs and cloves, \&c. On our leaving the powder works, we were again saluted with twenty-one guns. We then proceeded to the garden, where we remained four hours, and then returned home. The next day, General Malartic sent to invite us to go and see some fire-works to be displayed that night; accordingly, an hour before the close of the day, we went to the place where the fire-works were to be exhibited. The second aid-de-camp, and five sirdars, came out to meet us, and conducted us to the upper story; at that time both the generals were not present. Having sat till nine o'clock at night, and seen the fire-works, we returned home. Two or three days afterwards, they invited us to go and see the arsenal, the moody-khauna*, and the iron manufactory, desiring that we would come for that purpose at four hours after daylight. We accordingly set out, and on our arrival at the gate of the arsenal, the sirdars belonging to the establishment, came out to meet us ; they shewed us the whole of the establishment of muskets, implements of war, balls, \&c. \&c. after which we took our leave. The next day, General Malartic sent a verbal message by — Dewan, inviting us to go, at three o'clock in the afternoon, to see the batteries and ordnance. The person in command of them, received directions to shew them to us; and we accordingly set out, accompanied by Monsieur de Bay; and when arrived at the batteries, the sirdars of that department came forward, and shewed us the batteries and ordnance : they caused several shots to be fired: After seeing them all, we took leave of those sirdars, and returned home. The next day, we were informed by des Combres and the Dewan, that General Malartic had sent a ship to Bourbon, to fetch men for the service of the sirkar; and that the general said he would not suffer us to take leave, until the return of the ship : we told them, that we were not 
come to carry away with us men to be enlisted for the service of the sirkar, (in other words, recruits), nor were such the orders we received from the Presence. Five or six days after, General Malartic informed us, that he had appointed some men for the service of the sirkar, whom he was about to send accordingly, and desired us to give it under our hands, that we would represent to the Presencc, and procure their entertainment at the rate of pay, which he should fix. We informed him, that we could not venture to make any such representation to the Presence. General Malartic replied, "Were I to write to the Presence, "would it not be agreed to?" We answered, that if he chose to write, it would be at your highness's option to agree to it or not, After this, we took leave. Being returned home, we wrote and sent a letter to General Malartic, by Monsieur de Bay, to this purport: "It is very well known to you, Sir, that the object of " our coming hither was, to carry with us the succour of a large and effective " body of troops. Persons of your nation, represented to the Presence, that a " considerable body of troops was actually ready at the Mauritius, for the assistance "of the sirkar; and that as soon as ambassadors should be sent to the sirdars of " the Mauritius, on the part of the Khoodadaud sirkar, an efficient body of men " should be sent back with them, whereby the common enemy would be chastised. "Had his highness been pleased to give us orders for raising French recruits, " his highness would not have sent us without settling their rate of pay and estab"lishment, agreeably to the custom of the sirkar. From a regard to the ancient " union and established friendship subsisting between the two states, you deem it " improper to send away the ambassadors of the Khoodadaud Sirkar empty handed, " and therefore propose to send a few men, whom you yourself have engaged for " the service of the sirkar; but the object of the sirkar will not be answered by " so small a number: neither are we instructed to carry with us recruits from " the Mauritius, nor indeed can this be done without money. Men of your " nation come to us every day (meaning for the purpose of being engaged), and "require to be furnished with money; but supposing they waved their demand for " money here, and voluntarily repaired to the Presence with us, mder your orders, " their pay must be fixed by the Presence; it would therefore be preferable to " depute two vakeels of your own with us, to negociate the matter. As soon as " such vakeels shall have arrived at the Presence, and his highness shall have stated "s to them the rate of pay and establishment, as allowed to Lally's force in the 
" service of the sirkar, should his highness be disposed to entertain them, agree" ably to the accustomed rate of our sirkar, his highness will send money with his " ambassadors: and then you may enlist men, and send them accordingly : in " the mean time, do us the favour to give us leave to return to the Presence."General Malartic wrote in answer, and also sent word by Monsieur des Combres, and —- dewan, that he proposed sending Messrs. Chapuis and Dubuc, with several other sirdars, to your highness, with this view; that until the arrival of the French succours from Europe, the former should reside at the Presence in quality of plenipotentiary; that the other Frenchmen might not, by telling falsities, like Ripaud, deceive your highness; and that Monsieur Dubuc might be deputed to France, together with your highness's ambassadors, at the opening of the season, to negociate on the part of your highness : as by his going, many points of great importance would be effected. For these reasons, he said, he proposed sending these persons to the Presence, that hereafter, should your highness approve of engaging Frenchmen for your service, they should be entertained at the rate, and according to the customs of the sirkar, and sent accordingly.

Refuge of theWorld! - After the lapse of eighteen days, the ship which had been sent to Bourbon, returned empty. It appeared, that a great many men wished to come, but were prevented by the want of means. On being informed of this, General Malartic sent word to us, that he proposed, in the course of five or six days, to send us to Bourbon; that we might carry to your highness as many men as were willing to accompany us. General Mangalon paying us a visit, we stated to him, that it would be very gratifying, if he would accompany the troops destined for the service of the state: to which he replied, that when a considerable force should arrive from Europe, for the purpose of subduing the enemy, he would accompany it to the Presence, and he desired that we would make that representation to your higness. After sitting two hours, he took leave. Four days after, General Malartic sent for us to his house, at three o'clock in the afternoon, and then proposed to us to embark the following morning at nine o'clock, adding, that he himself would accompany us on board of ship, to take leave.

On the next day, being Thursday the 21st of Rubbaunee, 1225, (8th March 1798), of the birth of Mahommed, we set out. When we arrived at the bank of the river, several sirdars accompanied us in the boat, and escorted us on board the ship, (the frigate la Preneuses, where they took leave. General Malartic, 
Monsieur Chapuis, and Monsieur Dubuc, followed us on board; when the former delivered to us the kbereetabs, containing the arzees to your highness's address, desiring that we would present his humble respects. He then gave orders for weighing anchor, and returned. As soon as General Malartic had got into the boat, the captain of the ship ordered the anchor to be hove; and in one day and a night, we arrived at Bourbon, where we anchored. Monsieur Chapuis and Dubuc, went on shore to visit the governor of Bourbon; and returned, bringing with them four persons, who were desirous of proceeding to the Presence. The captain continued here the whole day, and then weighing anchor, shaped his course for Mangalore, with about an hundred men.

Near the line we met with a storm, in which one of the masts of the ship was sprung, and during the whole of the night, the people despaired of their lives; but through the favour of God, and the royal auspices, in the morning the storm abated.

Prior to this, I had the honour to write to your highness, a full and accurate account of the engagement which took place off Tellicherry, ${ }^{*}$ together with the disembarkment of the Europeans, and their demands. Thus your highness will have been informed of those particulars.

Dated 8th of Tuckee, of the year Shadaub, 1226 of the birth of Mahommed, (23 May, 1798.)

\section{A true Translation.}

\section{N. B. EDMONSTONE,}

P. T. to Government.

Circular.-Copy of a Letter from the Secret Committee of Directors to the Government in India, dated the 26 th of November, $179^{8 .}$

Our letter to you of the 18 th of June last, inclosed a copy of our orders to the Governor-general in Council, of the same date, relative to the expedition from Toulon, under General Bonaparte, and directing your obedience thereto, so far as should respect your Presidency.

- This alludes to the capture of the Raymond and Woodcott Indiamen in Tellichery Road. 
Our subsequent advices of July and August will have informed you of the appointment of Mr. Jones to reside at the Court of the Pacha of Bagdat, as well as the object of his mission, and of the reinforcements already sent and now sending out to India.

Since the date of our letter of June last, above alluded to, the landing of Bonaparte in Egypt has been fully confirmed. By the glorious victory of Admiral Nel. son over the French fleet near Alexandria, and the opposition made to their progress through Egypt, by the Arabs, under the authority of the Porte, the designs of the French have been considerably impeded; yet if, contrary to our hopes and expectations, he should be able to establish himself in Egypt, we cannot but still be under apprehensions for the safety of our Indian possessions. These apprehensions are considerably increased in consequence of some hints lately suggested by the Right Honourable Henry Dundas, that if the French should be able to subdue Egypt, and to establish their authority in that country, it is likely their next progressive measure would be to secure the communication of the Red Sea with the Gulf of Cambay, at the narrow straits of Babelmandel; and, if in their power, to detach a sufficient force to take possession of the island of Perim, situate between the two points which include those straits.

The possession of this station will be of the greatest importance to the French, in securing the advantages they propose to themselves in the conquest of Egypt, and consequently it is well deserving the utmost vigilance and exertion on the part of Great Britain, to defeat any plan they may entertain to get it into their hands. If we should succeed in making ourselves masters of that island, it would be impossible, in the first instance, for any ships to pass the straits against a superior naval force stationed there. It may then be secured and fortified by the application of such materials as its situation may afford, for completing its permanent defence, and for effectually commanding the channels through which ships must pass to the Indian ocean.

We understand that the island of Perim is a low rocky substance, about five miles in length and two in breadth; that it possesses a good harbour; that the channel, which divides it from the African coast, though fourteen or fifteen miles across, is but little frequented, on account of the numerous rocks and shoals which obstruct it, insomuch as to render it necessary for vessels that do attempt it, to steer close under the western point of the island, and that the extreme breadth of the other channel 
is less than two leagues; and that this space cannot be navigable, nor the deep water every where at so great a distance from the island as to be out of the reach of its batteries, whether erected on the shore, or on artificial projections within the sea, if such should be found necessary to the entire command of the passage.

We have entered thus fully into detail, to shew the importance of taking possession of the island of Perim without delay; nor is dispatch alone necessary, but secrecy is equally indispensable, as it is not improbable that provisional measures have been taken by the French to assemble some vessels of burthen at the port of Suez, to cooperate in whatever way their services may be wanted, with the primary expedition; and if the design were known, they would detach a force, at all hazards, to secure the first possession of it.

Mr. Secretary Dundas has further informed us, that although the commanders of his majesty's fleets in India have already been directed to use every effort in their power to frustrate the designs of the French in the expedition under Bonaparte, yet special orders will be sent out to the commander in chief of his majesty's naval force in the Indian seas, as soon as possible, to detach to the Straits of Babelmandel such a force, as, according to the information he shall have received, he may judge sufficient for the service in the instructions to take possession of the island of Perim, by whatever power it may be occupied at the time.

The importance of the measure we have thus pointed out, will insure your most cordial endeavours in promoting the same by every means within your power. The security of our most valuable possessions in India, if not our very existence there, depends upon defeating the present formidable and inveterate design of the French against those possessions. 
The Originals of the following Translations from General Bonaparte, were communicated to Captain Wilson, at Mocba ; and the Translations were by bim transmitted to the Governor in Council at Bombay.

FRENCH REPUBLIC.

LIBERTY.

EQUALITY.

Bonaparte, Member of the National Convention, General in Cbief, to the most magnificent Sultaun, our greatest Friend, Tippoo Saib.

Head Quarters at Cairo, 7 th Pluvoise, 7 th Year of the Republic, one and indivisible.

"You have already been informed of my arrival on the borders of the Red Sea, with an innumerable and invincible army, full of the desire of relieving you from the iron yoke of England.

"I eagerly embrace this opportunity of testifying to you the desire I have of being informed by you, by the way of Muscat and Mocha, as to your political situation.

"I would even wish you could send some intelligent person to Suez or Cairo, possessing your confidence, with whom I may confer.

(Signed)

“ BONAPARTE."

(Seal.)

True Translation from the French.

(Signed)

FRANCIS WOPPERS, Translator.

Translation of a Letter from General Bonaparte to the Sheriff of Mecca, written in Arabic, witbout Date, and received at $\mathcal{J}$ udd a the 17 th of February, 1799.

"You will be fully informed by the Nocqueda of this Dow, how tranquil and quiet every thing is at Cairo and Suez, and between these places, and of the tranquillity which is established among the inhabitants. Not a single Mameluke oppressor remains in the country; and the inhabitants, without dread or fear, employ themselves in weaving, cultivating the ground, and in other trades, as formerly; and, by the blessing of God, this will be daily increasing, and the duties on merchandize and the taxes will be lessened. The duties on merchandize are now the same as they were prior to their being raised by the Mamelukes; the merchants have every assistance granted them, and the road between Suez and Cairo is open and safe; therefore 
do you assure the merchants of your country, that they may bring their goods to Suez, and sell them without dread or apprehension, and may purchase, in exchange for them, such articles as they may wish.

"I now send you a letter for our friend Tippoo Sultaun; oblige me by forwarding it to his countries."

A true Translation.

(Signed)

S. WILSON.

The Governor-general (Lord Mornington) orders the Army of Coromandel and Malabar to assemble, and bis Measures for improving the defensive Alliance.

The Governor-general, therefore, being decidedly of opinion, that it was necessary to assemble the armies on the coasts of Coromandel and Malabar, without delay, issued his final orders for this purpose, on the 2oth of June, 1798.

To assemble the army on both coasts, was an indispensable precaution, which his Lordship could not have been justified in omitting, from the moment he was apprised of Tippoo Sultaun's offensive engagements with the French, and of the landing of a French force at Mangalore; and if circumstances had been favourable for such an attempt, it was his fixed determination to have attacked the Sultaun instantly, for the purpose of defeating his hostile preparations, and of anticipating their declared object, His Lordship was concerned, however, to learn, from persons most conversant in military details at Fort St. George, that, notwithstanding the distinguished discipline of the army on the coast of Coromandel, and the eminent valour, activity, and skill of its officers, its dispersed state, joined to certain radical defects in its establishments, would render the assembling a force, equal to offensive movements against Tippoo Sultaun, a much more tedious and difficult operation than he had apprehended.

The necessarily dispersed state of the troops would have been of less importance, but for those radical defects, which have in a certain degree, at all times existed. These proceed from a system of economy, which precludes the expence of establishing depots of grain in different parts of our possessions, and of maintaining a fixed establishment of draught and carriage cattle; without which, no portion of the Madras army, however amply it might have been supplied with every other requisite for field operation, was in a condition to act with promptitude and effect. 
At the time M. Malartic's proclamation appeared in Bengal, it happened that he condition of the several native powers in India, both with relation to each other, and the British interests, was far more favourable to the success of French intrigue, than it had been at any period, since the peace of Seringapatam. The French faction at Hyderabad, had risen to a dangerous height. Seindeah had lately placed the Boigne's corps in the hands of Frenchmen. Tippoo had manifested a disposition to admit French officers and privates, to an unlimited extent, into his service; and the distractions in the Marhatta empire, and the policy of the several actors, in that intricate scene of reciprocal distrust and irreconcileable interests, left little hope of deriving any advantage whatever, from their alliance, in the event of a war with Tippoo Sultaun.

The danger, however, the most to be apprehended, was from the French party at Hyderabad. The corps, commanded by French officers, in the service of the Nizam, which, during the last war with Mysore, amounted to no more than fifteen hundred men, was at that period so defective, in point of discipline, as to be rather an object of contempt, than of jealousy, to the governments in India : it had gradually augmented its numbers, and improved its discipline, under the command of the late Monsieur Raymond, until the period of the Marquis Wellesley's arrival in India, when it had nearly reached the number of fourteen thousand men; and had attained a degree of discipline, superior, in every respect, to that of any native infantry in India, excepting the seapoys entertained in the Company's service.

On the $13^{\text {th }}$ of July, the Governor-general sent orders to the government of Fort St. George, to assemble such a force in the Guntoor Circar, as might enable him to fulfil the subsidiary engagements of the Company, under the new treaty, at the earliest possible period, subsequent to his concluson. This measure was executed with the utmost degree of promptitude and alacrity by Lieutenant-general Harris, (at that time uniting in his person the offices of Governor of Fort St. George, and Commander in Chief; to whose zeal, public spirit, and prompt obedience, the Governor-general, on this and many other occasions, bore public testimony.

The British detachment was placed under the command of Lieutenant-colonel Roberts. It reached Hyderabad on the 1oth of October, and on the $22 \mathrm{~d}$ of the same month, under the orders of his highness the Nizam, and with the co-operation of a body of his cavalry, it surrounded the camp of the French army, disarmed all 
the seapoys, and secured the persons of all the French officers then in camp. This operation was happily effected without bloodshed, and without contest. A mutiny having broken out in the French camp on the preceding day, and the seapoys having imprisoned their officers, the Resident at Hyderabad, and Lieutenant-colonel Roberts, with the consent of the Nizam, judiciously availed themselves of this favourable opportunity, to execute the important measure entrusted to him, without difficulty or danger.

The amount of the French force disarmed on this occasion, was about eleven thousand men. The remainder of the corps, having been sent on detachments, at some distance from Hyderabad, was soon after secured and disbanded.

The. French officers were treated with every practicable degree of attention and humanity.

The season for negotiation, through the pacific channels, so often offered, was now elapsed. After mature deliberation, on the grounds already stated, the Governor-general directed the advance of the army into the territory of the Sultaun, and signified to the allies his determination to proceed to hostilities.

A change of circumstances, and of season, might enable the Sultaun to avail himself of the assistance of France. This conclusion was at that period, confirmed by the knowledge of the actual embarkation of M. Dubuc, and two native vakeels, on an embassy from Tippoo to the Executive Directory of France, an event which took place at Tranquebar, on the 7 th of February, 1799.

It would be superfluous to give a detailed account of the march of the army in this campaign, as it has already been very correctly given by Colonel Beatson, \&c. The issue of it will be seen in the following letters.

Copy of a Letter from Lieutenant-general George Harris, to the Chairman of the Court of Directors, dated Seringapatam, 6th May, 1799.

The Chairman of the Hon. Court of Directors of the United East-India Sir, Company, \&c. \&c.

I have the honour of congratulating you and the Honourable Court, on the prosperous expedition committed to my charge, by the Right Hon. the Earl of Mornington. 
Seringapatam was carried by storm at mid-day of the $4^{\text {th instant; Tippoo Sul. }}$ taun killed, with many of his principal officers, and thousands of his adherents: his family, with the families of his chief sirdars, are in our possession.

My attention is now directed to secure my position, and maintain our advan. tages, until I can receive further instructions from the Right Hon. the Governorgeneral.

I have the honour to be, Sir, \&c. \&c.

Head Quarters, Seringapatam, 6th May, 1799.

GEORGE HARRIS.

Capture of Seringapatam-Deatb of Tippoo-Conduct of bis Sons-Interment of the Sultaun-British Commander's Attention to the Sultana-Her Cbaracter-Cursory Remarks, Ėc.

The capture of Seringpatam and death of Tippoo, being but slightly mentioned in the British Commander's letters, it is necessary here to resume the history, and give a full detail of this interesting business. The papers of Lord Mornington sufficiently evinced the necessity of crushing Tippoo's power, and disappointing his ambitious views.

General Harris, according to orders, proceeded for Seringapatam where he arrived April 4, 1799. The English troops were, during the first few days after their arrival, employed in collecting the necessary materials : after which they had repeated skirmishes, when they took some out-posts, \&c. so that their breaching batteries did not open till about the termination of the month. Several Polygars and Zemandars of Mysore, had now attached themselves to our allies, and rendered considerable service.

The fire of the batteries, which began to batter in breach on the thirtieth of April, had on the evening of May 2, so greatly injured the walls, against which it was directed, that the arrangement was then made for assaulting the place on the following day, when the breach was reported practicable.

May 3. Early this morning the troops intended to be employed, were stationed in the trenches, that no extraordinary movement might lead the enemy to suspect the assault, which was determined to be made in the heat of the day. These flank companies of Europeans, taken from those regiments necessarily left to guard the camps and out-posts, followed by the 12 th, $33^{\mathrm{d}}, 73^{\mathrm{d}}$, and $74^{\text {th }}$ regiments; and 
three corps of grenadier seapoys, taken from the troops of three presidencies, with 200 of his Highness the Nizam's troops, formed the party for the assault, accompanied by 100 of he artillery, and the corps of pioneers, and supported in the trenches by the battalion companies of the regiment de Meuron, and four battalions of Madras sepoys. Colonel Sherbrooke, and Lieutenant-colonels Dunlop, Dalrymple, Gardiner, and Mignan; commanded the several flank troops, and Major-general Baird was entrusted with the direction of this important service.

The troops moved at one o'clock from the trenches, recrossed the rocky bed of the Cavery, under an extremely heavy fire, passed the glacis and ditch, and ascended the breaches in the fausse braye, and rampart of the fort, surmounting in the most gallant manner, every obstacle which the difficulty of the passage, and the resistance of the enemy, presented, to oppose their progress. Major-general Baird had divided his force, for the purpose of clearing the ramparts to the right and left. One division was commanded by Colonel Sherbrooke, the other by Lieutenant-colonel Dunlop; the latter was disabled in the breach, but both corps, though strongly opposed, were completely successful. Resistance had been made from the palace of Tippoo, some time after all firing had ceased from the works.

General Harris only gave Tippoo twenty-four hours to consider the propositions which it was deemed expedient to make to him, respecting our operations against the fort of Seringpatam. These were transmitted by a vakeel, April 28, but Tippoo returned no answer, obstinately persevering in his determination of defending his capital to the last.

May 4. The breach being now practicable, it was resolved to commence the attack, and at three o'clock in the morning, the flank companies of every corps in the field, besides two or three European regiments complete, moved down to the trenches, where they sat for some time, in anxious expectation of the signal, during which time they kept up an incessant fire. The storming party, under the command of General Baird, began to move on, covered by a constant fire from the batteries, and suffering a very galling one of grape from the fort. Great anxiety pervaded the English troops for a quarter of an hour, till they saw their colours hoisted on the ramparts. Loud acclamations of joy then resounded from all parts, and the breast of every British soldier was fired with enthusiasm. The enemy soon abandoned the ramparts, after the English had reached them; in about half an 
hour, the fire in the fort had entirely ceased, and the British flag was triumphantly displayed in every part of it.

Soon after the storm, 300 grenadiers rushed into the palace, and were about to plunder it, when they were called off. Those within it immediately shut the gates, and the $33 \mathrm{~d}$ regiment, and a native corps drew up in front. At this critical time, Tippoo Sultaun, with his Sultana, sons, treasure, \&c. were all in the palace. A little before the attack, Tippoo had been making merry with his family; and by the cheerfulness of his countenance, seemed to bid defiance to his adversaries. Major Allan now came up with a flag of truce from General Baird, and after explaining to those who were in the balcony, that no violence should be offered, desired the Sultaun to be called. They replied, that he was wounded; that they did not know whether he was in the palace or not, but that they would look for him. After much delay, it was suspected that this was only a pretence to give him time to make his escape, upon which the general ordered a six-pounder to be brought in front of the gate, and told them if the Sultaun did not immediately make his appearance, he would burst it open. They then positively declared, he was not in the palace, but that his sons would come out immediately. They waited again for some time, but the sons not making their appearance, Major Allan, carrying the flag of truce, and accompanied by two other officers, went in, and returned in about half an hour, with the two princes, who, though they seemed to hide their depression of spirits, could not but manifest that they felt their situation. Being asked what servants should attend them to the camp, they very nobly replied, " that they had now no right to order:" and when the general told them that they had only to name the persons whom they wished for, and that they should accompany them, the younger said, with a tear starting in his eye, "We could have called for many this morning, but now, I fear, there are but few remaining."

General Baird, who behaved to them with much kindness, gave them in charge to Major Agnew, who conveyed them in palanquins to head-quarters.

It being now near sun-set, every one was desirous to secure, if possible, the Mysorean chief. After much inquiry, they found a person, who seemed to be a man of consequence, but his name was unknown. He said, that Tippoo Sultaun had been killed in endeavouring to escape. This man was immediately seized, and threatened with immediate death, if he did not show the place. Accordingly, he led the way to 
a kind of gateway, leading to a bridge across the ditch: there, in a place about four feet wide and twelve feet long, were upwards of seventy dead bodies, and Tippoo's palanquin appeared in the midst of them. Immediate search was then made for his body, but so numerous were the slain, that it was a full hour before he was disco. vered. The unfortunate Tippoo had received a shot in his arm at the time of the storm, for he was himself on the ramparts: after this, in endeavouring to make his escape, he was met by a party of Europeans, who wounded him in the side with a bayonet; he had also received a shot in the temple, which put an end to his existence. The body was recognised by his relatives, and some of the palanquin-boys, and was still warm when discovered. He had his sabre clenched fast in his hand.

The Nizam's troops discovered great pleasure, indeed savage satisfaction, when the body was exposed to view; but the English observed the utmost order and decorum. Such a speedy termination to the war not being expected, the former cried with exulting voices, "Seringapatam is taken-the tyrant is dead-his sons and family are prisoners, and all his treasure is at our disposal." General Harris issued orders to suppress their impetuosity.

The surrender of this strong fort, at such a critical time, was particularly fortunate; for the army had only three days grain remaining. When the news was announced at Madras, it was celebrated by a general and brilliant illumination.

Two days prior to the capture of Seringapatam, Tippoo held a durbar (or council), attended by all his chiefs, who advised him to cede more territory to his besiegers, and the payment of a large sum of money; but Tippoo seeing that his adversaries had already one half of his dominions, strenuously opposed the measure, and dismissed the council.

Tippoo Sultaun was rather above the middle size, stout, corpulent, and well made. He dressed rather plain, and his head was shaved close. He was in his $\mathbf{5 1}^{1 \text { st }}$ year when killed, and was interred, agreeable to the supplication of his family, on the left side of his father, in Laul Baug, with all the ceremonies and honours of the place.

His will, and the treaty concluded between him and the French Directory, were found in the palace: the latter was inclosed in an elegant little box, which was very remarkable, as it discovered the sanguine hopes entertained by the deceased chief of his hostile plans against the British government. 
Many of Tippoo's chiefs were slain, particularly Syed Saheb, Meer Saduc, Syed Kofar, \&c. His brother Kerim Saheb sought refuge with Meer Allum Bahauder.

Tippoo's sons, though suspected at first of dissimulation, behaved with the utmost candour and sincerity. They did not know of their father's death, and were absolutely in search of him, as they had declared. They made no hesitation in surrendering themselves to General Harris, though their resistance, at first, was vigorous. Recollecting the kind treatment they had experienced from Lord Cornwallis, they doubted not but they should now meet with equal civility. The two first captive sons sent to their three brothers, and strictly enjoined them to follow their example.

The news of Tippoo's death filled all the ladies of the Zenanna with the utmost consternation; not on account of any partiality for the chief, but through an apprehension of what frequently attends conquests in these countries; for the natives of India, in all their victories, never pay that respect which is due to the female sex. These apprehensions were; however, soon removed by the politeness of the British commander, who sent a flag, immediately after the surrender of the place, to assure them of his protection. His attention to the Sultana, whose sorrow on this occasion was truly sincere, does him equal honour.

This lady is delicately formed, and the lines of her face so regular and placid, that a physiognomist would have had little difficulty to pronounce her of a tranquil and amiable temper; her dress was generally a robe of white muslin, spotted with silver, and round her neck rows of beautiful pearls, from which hung a pastagon, consisting of an emerald and a ruby of considerable size, surrounded with a profusion of brilliants. She is about twenty years of age, and for a complete form and captivating appearance, rivalled all Mysore.

Among the poor prisoners who had suffered long confinement in a dark dungeon, was a descendant of the Hindoo King of Mysore, whom Hyder Ally dethroned. There were several British officers, supposed dead, who were found still living in these horrid prisons.

General Baird, who had now taken an active part in defeating the tyrant, had formerly suffered three years confinement in this prison, during which time he was loaded with irons and experienced the most cruel treatment.

Considering the magnitude of this enterprise, our loss was inconsiderable, but that 
of the enemy was very great. Upwards of three millions of treasure were found in the palace.

Mangalore is to be added to the British territory in India; a circumstance not more important in the benefit it will render to our commerce and marine, than in depriving the enemy of a port in which they found protection and relief.

The partition of the treasures and other spoils of Seringapatam is thus arranged: the arms and military stores are to be given to the king; one clear moiety of all the other produce to the besieging troops, and the other moiety to the East India Company. In Lord Cornwallis's expedition against the Mysore country, the Company ceded their portion of the booty to the brave captors; but so great are the spoils at present, that it is thought the allotted share will amply compensate their services, though eminent in the greatest degree.

The standard of Mysore was sent by General Harris to Fort William : it is of light green silk, with a red hand represented in the middle, and was never hoisted but on the palace in Seringapatam.

This history cannot be concluded better than by quoting the singular and just catastrophe which was predicted of this tyrant by an eminent writer:- "He would continue to advance till he came to a point from which there was no receding, and then, like a stag at bay, he would terminate his career of despotism, cruelty, and oppression."

We now resume our account of the Isle of France, up to the period when the Ambassadors of Tippoo had left it, in March, 1798.

\section{A Continuation of the late Events wbich took place in the Isle of France, until 1800 .}

1798. There only remained in the Isle of France the skeletons of the two old regiments of the Isle of France and Bourbon. The Colonial Assembly, by diminishing the number of the soldiers in the colony, flattered themselves that they should more easily retain them in their duty; and, in fact, until May, 1798, the tranquillity of the island was not disturbed: but, at this epoch, these two regiments having also formed the same project of proclaiming liberty to the slaves, the Colonial $A$ ssembly obtained an order from General Malartic for the two companies of grenadiers to embark on board the frigate la Seine, then ready to sail on a cruize. The grenadies 
companies may be said to be the soul, and to contain the energy, of the French regiments, whether good or bad. Those, therefore, who wished to excite trouble in the colony, perceiving, by the embarkation of the two companies of grenadiers, that all their plots would be disconcerted, thought it absolutely necessary to execute the plan of insurrection which they had been, so long fomenting. 'They accordingly represented to these grenadiers, that the order for their embarkation on the Seine frigate had been obtained from General Malartic by surprise, and that, instead of going upon a cruize, they were to be sent to Tippoo Sultaun, with whose cruelty and despotism they were well acquainted : that this project had been formed by the Colonial Assembly, for their destruction, as might be proved by the destination of their comrades to Batavia, a colony remarkable for the unhealthiness of its climate.

The grenadiers were easily persuaded by these insinuations, and refused to obey the order for their embarkation. General Malartic represented to them their crime in not obeying, and condescended so far as to assure them, that they were not to be landed in the states of Tippoo Sultaun, but were only to reinforce the crew of the Seine, that was too weak, and to go on a cruize, which would give them an opportunity of making rich captures, and consequently, of having good shares in the prizes: this, however, did not satisfy the grenadiers.

General Malartic then threatened to force them to obey his orders; but they insolently answered him, that he would find it a difficult undertaking; and in spite of the entreaties of the greatest part of their officers, on the $24^{\text {th }}$ of $A$ pril, in the afternoon, they caused all their comrades in the other companies of their regiments to mutiny, and take arms. They got possession of eight field-pieces, which were in their quarter, and broke open the doors of the armoury, where the cartouches and cartridges were kept. Fortunately the officers of these regiments, the most part of whom were still of the ancient government, and almost all of them attached to the colony, as well by the ties of blood, as by their possessions, succeeded in preventing the soldiers from coming out of their quarters in arms (as they several times wanted to do), by remaining there, in order to keep them, if it were possible, from any act of violence.

Thus the night passed, the soldiers remaining through the whole of it under arms in their quarters. The news of this insurrection of the garrison was soon spread in every quarter of the island, and orders had been sent to all parts of it, for every man capable of bearing arms to come to the town in the course of the night. 
At day-break, the $25^{\text {th }}$ of April, the alarm was beat in the town by the drummers of the national guard; and every one eagerly flew to the post that had been assigned him; confident that this day would decide the fate of the colony.

In the course of the night, every means had been prepared to attack the soldiers, who, fortunately, had remained in their quarters. In a moment, the whole national guard of the colony was assembled; a battery of four pieces of cannon and two howitzers, were planted upon a hill which commanded the court of the barracks, where the soldiers were still in arms. Twelve field-pieces, served by the young people of the colony, who had been particularly instructed in this service, and four columns of the national guard, advanced each on different sides to attack the quarters. The companies of this national guard, in which there were some Sans-culottes, were posted so as to be kept in awc. All these dispositions having been executed with the greatest celerity, General Malartic, accompanied by the members of the Committee of Public Safety of the Colonial Assembly, and at the head of the national guard, summoned the mutinous companies of the grenadiers, to embark immediately on board the Seine frigate, to go on a cruize ; informing them, at the same time, that if they persisted in their refusal, he would employ the force which he possessed. The matches were lighted on both sides, and cartridges distributed; the muskets were loaded, and every thing announced the disastrous consequences of such a combat. The grenadiers, however, persisted in their refusal, when providence, who watched over the colony, suggested to the members of the Committee of Public Safety of the Colonial Assembly, to cause an order to be given by General Malartic, to the two regiments to embark for France; to which they should be carried by the Seine frigate and by another large merchant vessel; which would be prepared for them; granting them till noon, to make up their knapsacks, collect their linen, and depart. The soldiers, after much hesitation, accepted of this order or proposal, and the same day at noon, April 25, 1798, the Isle of France was freed from 800 armed stipendiaries of the French republic, who had conspired its overthrow, but which the good conduct of their officers, the greatest part of whom remained behind in the colony, added to the courage and reuniting of the inhabitants, preserved from the destruction that threatened it. *

The Isle of France being, as it were, miraculously delivered from the two agents whom the Directory had sent there, with about a thousand soldiers inflamed with

- This frigate, La Seine, was taken off the coast of France, and carried to England. 
enthusiasm for the republic, who accompanied them, and having likewise freed themselves by their courage, from an equal number of soldiers, who, seconded by the discontented subjects of the colony, had conspired its ruin, by manifesting open rebellion to the orders of their chief, looked forward with confidence to a state of tranquiltlity. It no longer contained in its bosom any individual, who would not be interested in its preservation, being fortunately governed by a general, who, although lolding his place under the French government, had no other wish than that of the Colonial Assembly. This Assembly, renewed every year, by the nomination of the citizens of the colony, could have no other interest, nor any other design, than its happiness and prosperity.

But the power of the governor was now become entirely dependant on the will of individuals, and discord soon arose among them, respecting the laws about to be established for the re-payment of debts contracted in paper currency; the depreciation of which had increased in such a proportion, that it at length represented but a thousandth part of the nominal sum it expressed. The depreciation of this paper currency, issued in the colony by the administrators, in the name of the French Republic, unfortunately was not settled, till it was fallen to that point of debasement, by a deposit of merchandize in the magazines of the general commune; certain quantities of which, fixed by the law in this respect, were given to every bearer of paper currency, who wished to exchange it.

As soon as intelligence reached the Isle of France repecting the laws, which the two governing Councils of France had decreed, relative to the payment of these debts, contracted at the time of the paper currency, the creditors, who were greatly favoured by them, demanded the execution of it. The debtors, on the other hand, represented with force and truth, that the circumstance in general, under which the different contracts had been made in the colony, being different from those which had taken place in France, it would be evidently unjust to apply the same laws, when there was an apparent difference, both in the manner, situation, and contracts of the colony. In this shock of discordant interests, the Colonial Assembly being directed alone by past circumstances, adopted a mode of payment founded on the principles of justice; and this unpleasant business was on the point of being finally arranged, when the creditors excited a conspiracy, in order to dissolve the Assembly, and obtain colonial laws more favourable to their interests.

Blinded by their views of personal interest, and without reflecting on the conse- 
quences of their conduct, they associated themselves with all the discontented people and Sans-culottes of the colony, who were ever ready to take a part with those who wanted to excite insurrection and disorder.

It was in the afternoon of the $4^{\text {th }}$ of November, 1799, when the conspiracy burst forth in the town of the North-west Port, at three o'clock; an hour, when the greatest part of the most respectable inhabitants are accustomed to retire to rest, during the sultry part of the day. The conspirators caused the alarm to be beat at the top of the great street, a kind of suburb, where they principally resided. The Governor-general Malartic, hearing the alarm beat without his orders, sent immediately one of his aides-du-camp, to be informed of the cause of this alarm, and take the necessary measures to put an end to it. The municipality also repaired to its post, and sent likewise one of its officers to support the orders of the general; but neither the aid-de-camp, nor the municipal officer were listened to by the conspirators, who assembled in arms, and formed themselves in a body near the drummers. The aid-de-camp and the municipal officer, not being able, by their representations, to hinder them from continuing to beat the alarm, endeavoured to snatch the drumsticks from the drummers; but they were prevented, and a pistol was fired at both of them, but fortunately without effect. The drummers continuing to beat, the conspirators continued to increase, till they amounted to about six hundred. They then hastened to the parade, to get possession of the field-pieces in the court of the municipality, These field-pieces belonged to the company of flying artillery, which was composed of chosen young men, all of them addicted to good order, and zealous for the honour of their corps. The alarm was no sooner heard by these young men, than they hurried to their post; but their cannon were already in the hands of the conspirators. Impelled, however, by their courageous spirit, and without reflecting that they had only their sabres to defend themselves against men armed with loaded muskets and bayonets, they rushed upon them to retake their cannon; but notwithstanding their courage, they were necessarily repulsed by the fire of the conspirators, who were superior in number. Several of them fell the victims of their rashness, and the rest were obliged to retreat. The conspirators, being now in possession of the parade, the field-pieces and magazines, placed sentinels every where, to prevent the other inkrabitants from assembling; and loudly demanded of General Malartic to dissolve the Colonial Assembly. 
The different members of that Assembly, although informed of the dangers that threatened them, hastily collected in one of the halls of Justice which looked on the parade, in order the better to take their resolutions, according to the events which might take place before them.

General Malartic, during the tumult, came into the hall where the Colonial Assembly was collected. The conspirators entered in arms, threatening the General and the Assembly with great fury, if it did not immediately dissolve itself. Citizen Journel was then president, who, by the bravery and steadiness he had shewn, in all the critical occasions in which the Assembly had found itself, had acquired the esteem of the whole colony. This moment of terror and threats brought with it new honour to him. His answer to the conspirators, who only waited for the signal to tear him to pieces, was as firm and courageous, as if he had presided at a moment of the greatest tranquillity. "Citizens," said he to them, "neither your threats, nor the sight of your bayonets, pointed against our breasts, will induce the Assembly to dissolve itself, if it does not believe it necessary for the tranquillity of the colony. It is your duty to withdraw, and leave it to examine at leisure, and with wisdom, the decision it may make in regard to your demands."

The cries of fury were redoubled at this answer. The conspirators then addressed themselves to General Malartic, as the representative of the metropolis; and this respectable old man, thinking, by his condescension, to prevent greater mischiefs, pronounced the dissolution of the Colonial Assembly, which was succeeded by his intercession to save the most distinguished members from being murdered, several of the wretches having rushed forwards, and obliged them to escape by the back doors.

The consternation was general among all the respectable inhabitants of the town, who sought an instant refuge in the country, and availed themselves of the darkness of the night, to withdraw from the designs which the chief of the conspirators had planned against them. Nay, to such an height did they carry their insolence, that they made General Malartic sign an order to imprison twelve different members of the Assembly.

The town presented nothing but the aspect of a civil war. The Sans-culottes, supported by the creditors, who had likewise armed themselves, in order to dissolve the Colonial Assembly, were masters of all the posts in town: cannon were pointed, and fires lighted on all sides, least the inhabitants in the country 
should unite.with the people of the town who had flown to them, and march against it. The country people, informed of the events in town, reflected maturely upon the re-establishment of good order, not wishing to compromise the fate of the colony, upon which their existence depended, by too hasty a movement of vengeance. The different districts consulted together, and agreed to march from their respective situations, against the town, on the morning of the 6th of November. This delay had already caused a great change in the minds of the conspirators, who had united to destroy the Colonial Assembly. Many of them who had been induced, without reflection, to wish for the dissolution of the Colonial Assembly, to prevent the passing of the law which it was preparing, for the reimbursement of the debts contracted during the course of depreciation of the paper currency, soon began to be alarmed at such an association, and to dread the misfortunes which their conduct was about to bring upon the colony. From that moment they refused to concur in the means which the Sans-culottes wanted to take, to prevent the country people from coming to re-establish order in the town. Terrified at being thus abandoned, and perceiving that their number was so small with that collected against them, they accordingly did not oppose any resistance, and suffered the different detachments from the country to enter quietly into the town, which accordingly took possession of all the posts, and formed a kind of camp on the parade.

Some very grievous enormities had been committed, and it was, perhaps, even imprudent not to punish them as they deserved. The colony, however, thought proper to be satisfied with the expulsion of the principal criminals, in order to avoid the spilling of blood, which had hitherto been avoided, in spite of all the storms of the French revolution; the murder of Macnamara not being imputable to it, since it had been committed by the soldiers, from whom it had afterwards delivered itself.

This resolution of the generality of the inhabitants, who were collected in the town, was submitted to the deliberation of the Directory representing the general commune of the colony, and of the municipality of the town of Port Louis, assembled together likewise, under the direction of General Malartic. A vessel, named the Hyppolite, was provided to carry the disturbers of the tranquillity of the colony to France, and on the $15^{\text {th }}$ of November they set sail.

The Isle of France being thus freed from the principal ringleaders of this conspiracy, so fortunately terminated, found itself without a Colonial Assembly, which had been formally dissolved. The general opinion was, that it was necessary to 
avail themselves of the present moment, to discover the best means of composing this first constituted authority, which the colony considered as the centre of its safety, now so difficult to preserve, in the critical situation in which it found itself with respect to France. It had dismissed its agents, driven out its soldiers, and persisted in its refusal to adopt the decree of abolishing slavery; at the same time it wished to remain a French colony, though acquainted with the dispositions of the French Directory, and the majority of the two councils to punish it. It -was then resolved by the Governor-general Malartic, according to the desire of a committee, which was given him for a council, that the primary assemblies of the colony should name fifteen commissaries, eight for the country, and seven for town, to decide upon a better constitution to be given to the Colonial Assembly, which, till that time, had been composed of fifty-one members, who had been found too numerous; since in each shock the colony had undergone, several members of its Assembly had been the principal instigators, so that many of them had been actually proscribed, and exiled from it.

The conduct of the Colonial Committee was conformable to the general wish; and the number of its assembly was limited to twenty-one members, of whom fourteen were of the country, and seven of the town, who were to be named by the primary assemblies of each canton of the colony. This resolution was sanctioned by General Malartic, and carried into immediate execution. Such is the actual and definitive state of the Isle of France.

\section{Population and Military Force of the Isles of France and Bourbon in 1799.*}

Isle of Bourbon.

Isle of France.

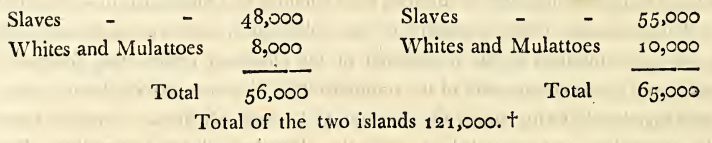

- All the cannon of the Isle aux Tonneliers and Fort Blanc, which defend the entrance of Port.Louis, may at present be worked with red-hot balls, by forming reverberating furnaces. The cannon of l'Isle de la Passe, which defend the entrance of Port Bourbon, may also be worked with red-hot balls.

+ The population of Port Louis (or du Port du Nord-ouest), is esteemed to be three-fifths of that of the whole Isle of France. 
Armed Force of the Isle of France.

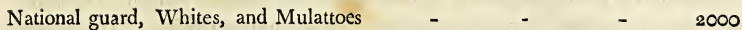

Black and Mulatto slaves to be armed as chasseurrs, or to serve the artillery 3000

Total of the armed force 5000

N. B. It is only since the year 1798 , that the taxes have sufficed for the interior expences of the Isle of France, as the Colonial Assembly then established a customhouse, to receive a tax on importation from five to ten per cent. on all merchandise brought to the colony by neutral ships. This tax was reduced to two-thirds for French vessels.

Expence of the Isle of France in 1798, to be clarged to the French Republic.

N. B. In 1798 , there were but 800 regular troops, who were driven out of the Isle of France this same year.

For 800 regular troops, the staff and extraordinaries $299,302+$

Fortification

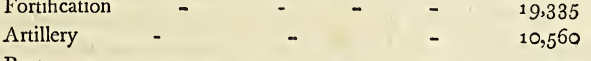

Port - - $\quad$ - $\quad$ - $\quad$ - $\quad 33,297$

Hospital - $\quad$ - $\quad$ - $\quad 53,89^{2}$

Administration - $\quad$ - $\quad$ - $\quad 27,216$

Marine of the Port and Cayenne (prison ship) 10,163

Six hundred rationaires _ _ _ _ $\quad 28,75^{8}$

Support of the Blacks of the Republic - $\quad 27,63_{2}$

Pensions granted to several persons _ _ _ $\quad \mathbf{1 , 2 2 9}$

$\begin{array}{llll}\text { Divers minute expences } & - & - & \end{array}$

Garden of the Republic (M. Séré) - $\quad$ - $\quad 927$

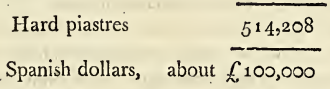

* The piastre is almost five shillings English.

+ All this expence was to be suppressed after the inhabitants dismissed the regular troops, consequently, the expence for the preservation of the isle, does not cost 200,000 piastres, or $£ 40,000$. sterling, and they find the means of levying this sum upon the exterior commerce of the island. 
By a law of the Colonial Assembly, passed in 1799, the corn of the country was received in the public magazines, at four piastres the hundred weight. The price of foreign rice varies from one to four piastres the hundred weight. That of the country, as it is better and fresher, is never under two piastres the hundred weight.

The present State of Agriculture in the Isle of France, as given by an Inbabitant of that Island, who arrived in London in 1800.

The soil of this island is very diversified. Although, by its climate, it is adapted for all colonial productions, it has not equally answered to all the different kinds of cultivation which the inhabitants have endeavoured to naturalize.* The plantations of coffee, being of the most simple culture, and requiring less expence and establishments, were the first which they adopted; but other objects of culture, such as cotton, having appeared more profitable, coffee has not become so general as it would otherwise have been. The cotton, which had promised such advantageous returns, has likewise been neglected in its turn, for the same reason; because the cultivation of indigo was become the most popular; but the great profit which the first sugar plantations afforded, has induced them to establish some wherever they could procure a quantity of water above the level of the earth, sufficient to work a sugar mill. Several sugar plantations have already proved successful, and many others are expected equally to succeed. Unfortunately, the mountains, though covered with fine trees, have been found, in certain spots, to have a white stone or rock too near the mould, + but those who have suffered from this inconvenience have indemnified themselves, for the present, by felling woods.

- The inhabitants complain that the soil is not sufficiently fertile, although it is very rich in natural productions; but the fact is, that they continually exhaust it, never letting it remain fallow, nor supplying it with the necessary manure.

+ It is not astonishing that the mould on the brows of the mountains should become dry, or be carried away by the runuing waters, when the trees have been cut down which preserved and defended it from the sun, winds, and waters; and, when no expence is made to defend it against these natural inconveniences: on the contrary, the soil is exhausted by two harvests in the year. Had not the soil been originally excellent, it would not have produced such fine trees as are found upon it, and which are continually felled without regularity or measure.

I 'This felling of the woods ought to be observed and controuled by the administration; as the inhabitants, to accelcrate their fortunes, will soon have laid waste the whole island; so that it will 
Colonial Commodities which the Isle of France may produce in 1800.

Price during the present war,

Coffee, - 6000 bales, of 100 pounds French, from 8 to 20 piastres the bale.

Indigo, - 300,000 pounds weight, good year, from 2 to 8 shillings per $\mathrm{lb}$.

Cotton, - 2000 bales of 250 pounds, - from 8 pence to 2 shillings per $1 \mathrm{lb}$.

Raw sugar, 20,000,000 pounds weight, - from 4 to ten piastres the quintal.

Cloves, - 20,000 pounds, _ _ _ from $\frac{\mathrm{I}}{3}$ to 1 piastre per $\mathrm{lb}$.

The Isle of Bourbon, at present called Réunion.

Coffee, about 60,000 bales.

Cotton, 2,000 bales.

Two or three sugar plantations for the consumption of the island.

Cloves, $60,000 \mathrm{lb}$.

\section{New Division of the Isle of France.*}

No. 1. Municipality of the North-west Port, extends from the river des Lataniers, the boundary of the Municipality of Moka, to the Grande rivière.

No. 2. Municipality of Pamplemousses-from the river des Lataniers, the limits of the municipality of Moka, of the Three Islets, and of the riviere du Rempart, as far as the Great Bay.

No. 3. Municipality du Rempart-from the Grande Baie, the boundary of the municipality des Pamplemousses, and of the Three Islets, as far as the French river.

No. 4. Municipality of Flack-from the French river, the boundary of the municipality of the Three Islets, to the rivière Seche.

No. 5. Municipality of the Three Islets-from la rivière Secbe, the boundary of the municipality of Flack, of the Rempart, of Pamplemousses, and of Moka, to the Deep river, or Great river of the Great Port.

then become uninhahitable. It is high time to remedy it. There is still more than half the island covered with most beautiful woods, and it would be very impolitic to let one of the finest and most productive spots of the globe be destroyed, blest as it is with an healthy climate and magnificent harbours. Finally, the greatest advantages might be derived from it were the inhabitants richer, or less eager to make rapid fortunes.

* This new division is marked on the Map of the Isle of France, placed at the beginning of the Volume. 
No. 6. Municipality of the Great Port Bourbon (at present called the Port of Fraternity) - from the Great river, the boundary of the municipality of the Three Islets, of Moka, and of the Plains of Willhems, to the river du Poste.

No. 7. Municipality of the Savannah-from the River $d u$ Poste, the boundary of the Plains of Willhems, to the Bay of the Cape.

No. 8. Municipality of the Plains of St. Pierre and Black river-from the Bay of the Cape, the boundary of the Savannah, and of the Plains of Willhems, to the Little river.

No. 9. Municipality of the Plains of Willhems-from the Little river, the boundary of the municipality of the Black river, of the Savannah, of the Great Port, and of Moka, to the Great river of Port North-west.

No. 10. The municipality of Moka-comprised between those of the North-west Port, of the Plains of Willhems, of the Great Port, of the Three Islets, and of Pamplemousses.

Actual State of the Price of the Commodities in 1800.

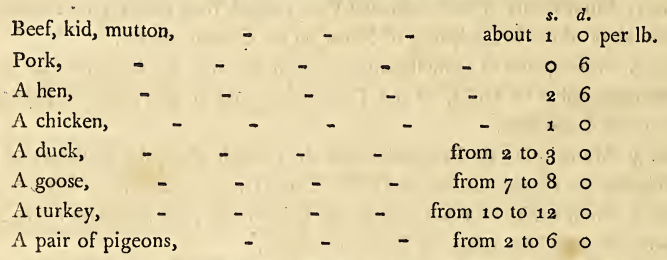

Bread and wine fluctuate, according to the commerce in time of war.

Wine, from the price of Europe, to eight times higher.

Bread, from the price of Europe, to four times higher.

$N$. B. All the inhabitants having commodities to dispose of, and seldom buying any, it is their interest to sell them dear to foreigners, who come hither for the purposes of commerce.

In the Isle of France a plantation entirely cleared, may be bought for $f_{1} 1500$. (6000 piastres) with about thirty slaves of both sexes, reckoned, on an average, at about $f .3$ o. each. This plantation would produce sufficient to support a family in great comfort. Only half of the purchase-money must be paid down. 


\section{Remarks on the Isle of France, in 1800.}

First. The Isle of France imports from Europe almost all its necessaries and objects of consumption, except linen, cotton, and stuffs, which it obtains from the coasts of Coromandel and Bengal ; China ware and silk from China; its corn is partly of its own growth, and of the Isle of Bourbon; the surplus consumption of its bread and biscuit is imported in flour from Europe and New England. It imports its rice, (besides what it grows itself, from Madagascar and other ports of India; its slaves, for the most part, are brought from the coast of Africa, and Madagascar.

Second. In 1779, all the business was solely carried on in the commodities of the colony, or in piastres (a Spanish coin, value about five shillings English). There was still in circulation the paper currency issued by the administrators in the name of the French republic; but as it was constantly diminishing in value, the Colonial Assembly settled it irrevocably in $179^{8}$, by a depôt of merchandize destined for the payment of the paper currency then in circulation; the value of which to money was only in proportion of one to a thousand: so that a stamp paper currency or note for ten thousand francs was then only worth ten francs in commerce. On this basis the redemption of the paper currency was ultimately fixed.

Third. The plan of forming the Isle of France into a general entrepôt has not been followed up; 1 st, Because it is more advantageous to obtain all articles of merchan dize from the place itself, which produces or manufactures them. 2d, Because, although the Indian sailors have much less pay than those of Europe, this point alone does not render the navigation of vessels in India more economical, or more advantageous, than the navigation of European vessels; as the latter navigate them better, and a crew of European sailors does not amount to one-third of those required by the vessels of India.*

* The principal advantage which the Isie of France derives from its ports and situation, is that of its being a military depôt. On this account it would be necessary that its mother-country should have the superiority by sea. A commercial entrepôt would then be the natural consequence.

THE END.

Printed by W. Bulmer and Co. Russel-

court, Cleveland-row St. James's. 



